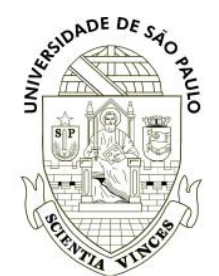

UNIVERSIDADE DE SÃO PAULO

FACULDADE DE FILOSOFIA, LETRAS

E CIÊNCIAS HUMANAS

DEPARTAMENTO DE LETRAS MODERNAS

Programa De estudos linguísticos, LITERÁRIOS E TRADUTOLÓGICOS EM

FRANCÊS

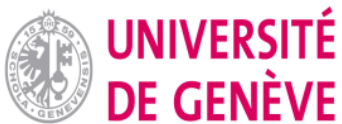

UNIVERSITÉ DE GENÈVE

FACULTÉ DES LETTRES

DÉPARTEMENT DE LANGUE ET

DE LITTÉRATURE FRANÇAISES MODERNES

\title{
Imagens de Roland Barthes no Brasil
}

V. 1

SÃO PAULO, GENÈVE

2013 


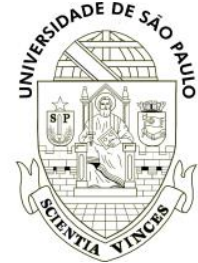

UNIVERSIDADE DE SÃO PAULO

FACULDADE DE FILOSOFIA, LETRAS

E CIÊNCIAS HUMANAS

DEPARTAMENTO DE LETRAS MODERNAS

PROGRAMA DE ESTUdOS LINGUÍSTICOS, LITERÁRIOS E TRADUTOLÓGICOS EM

FRANCÊS
UNIVERSITÉ DE GENÈVE

UNIVERSITÉ DE GENÈVE

FACULTÉ DES LETTRES

DÉPARTEMENT DE LANGUE ET

DE LITTÉRATURE FRANÇAISES

MODERNES

\section{Imagens de Roland Barthes}

\section{no Brasil}

\section{LAURA TADDEI BRANDINI}

Tese apresentada ao Programa de Estudos Linguísticos, Literários e Tradutológicos em Francês do Departamento de Letras Modernas da Faculdade de Filosofia, Letras e Ciências Humanas da Universidade de São Paulo e ao Département de Langue et Littérature Françaises Modernes de la Faculté des Lettres de l'Université de Genève, para obtenção do título de Doutor em Letras.

Orientadora: Profa. Dra. Maria Cecília Queiroz de Moraes Pinto Co-Orientadora: Profa. Dra. Patrizia Lombardo. 


\section{Resumo:}

Imagens de Roland Barthes no Brasil

Roland Barthes nunca colocou os pés em território brasileiro. O que não quer dizer que ele nunca tenha estado no Brasil: seus escritos, carregados com suas ideias, suas noções, seus paradoxos e suas idas e vindas, trataram de assegurar sua presença na história da crítica literária brasileira do século $\mathrm{XX}$. As relações entre Barthes e os intelectuais constituem o tema deste trabalho, que tem por objetivo encontrar, descrever e problematizar as imagens do escritor francês, produtos de sua recepção no Brasil, de 1953, data da publicação do primeiro livro de Barthes, Le Degré zéro de l'écriture, até o momento atual. Efeitos de um processo de refração, tais imagens não se limitam a reproduzir a dinâmica do pensamento barthesiano, mas também evidenciam as particularidades do contexto e dos intelectuais que delas se apropriaram. Pois a periodização estudada compreende um momento de transição na história da crítica brasileira que a recepção à obra do escritor torna evidente: a consolidação das instituições universitárias, nos anos 50 e 60, abriu um novo espaço para os debates literários, antes limitados aos jornais. A crítica literária e as discussões teóricas, até esse momento, dominadas por críticos de formação autodidata, passaram a, paulatinamente, constituir uma preocupação dos professores universitários. A proposta deste trabalho é examinar como o pensamento de Barthes foi integrado nesse contexto, tendo como fio condutor e corpus principal o jornal $O$ Estado de S. Paulo, complementado pela revista universitária Lingua e Literatura. Tendo sido primeiro comentado pela crítica jornalística para, em seguida, tornar-se objeto de uma crítica universitária, o pensamento barthesiano transparece sob a forma de imagens parciais que, ao final do percurso investigatório, compõem um mosaico heterogêneo e complexo. Incompreendido, mestre estruturalista da nouvelle critique, semiólogo e guru nas universidades, hedonista, subversivo: em cada imagem pulsa uma faceta de Barthes, num movimento constante, engendrando novas leituras e a escrita de novos textos, e assim circulando, viva.

Palavras-chave: Roland Barthes; Relações Brasil-França; Crítica literária; Estudos de recepção; Literatura comparada. 


\begin{abstract}
:
The images of Roland Barthes in Brazil

Roland Barthes never placed his feet on Brazilian territory. Which is not to say that he has never been in Brazil: his writings, full of his ideas, his concepts, his paradoxes and his comings and goings, treated to ensure his presence in the history of Brazilian literary criticism of the twentieth century. The relations between Barthes and intellectuals are the subject of this work, which aims to find, describe and discuss the images of the French writer, products of his reception in Brazil, from 1953, the publication date of Barthes' first book, Le Degré zéro de l'écriture, until the present time. Effects of a refraction process, such images do not merely reproduce the dynamics of Barthesian thought, but also highlight the particularities of the context and intellectuals who have appropriated of them. As the periodization studied comprises a transition moment in the history of Brazilian criticism that the reception to the work of the writer becomes evident: the consolidation of the university institutions in the 50s and 60s opened a new space for literary debates, once limited to newspapers. Literary criticism and theoretical discussions, so far dominated by self-taught critical, began, gradually, a concern of academics. The proposition of this thesis is to examine how Barthes' thoughts were integrated in this context, having as a guiding thread, and the main corpus, the newspaper $O$ Estado de São Paulo, complemented by the university journal Língua e Literatura. Having first been discussed by the journalistic critics and later becoming a subject of academic criticism, Barthesian thought emerges in the form of partial images that, at the end of the investigative path, composes a heterogeneous and complex mosaic. Misunderstood, struturalist master of nouvelle critique, semiotician and guru in universities, hedonistic, subversive: in each image pulsates a facet of Barthes in a steady movement, engendering new readings and the writing of new texts, and thus circulating, alive.
\end{abstract}

Keywords: Roland Barthes; Brazil-France relations; Literary criticism; Reception studies; Comparative literature. 


\section{Résumé:}

\section{Images de Roland Barthes au Brésil}

Roland Barthes n'a jamais mis les pieds dans le territoire brésilien. Ce qui ne veut pas dire qu'il n'ait jamais été au Brésil: ses écrits, chargés de ses idées, de ses notions, de ses paradoxes et de ses allers et retours, ont assuré sa présence dans l'histoire de la critique littéraire brésilienne au $\mathrm{XX}^{\text {ème }}$ siècle. Les rapports entre Barthes et les intellectuels constituent le sujet de ce travail, qui a pour but de trouver, décrire et problématiser les images de l'écrivain français, celles-ci étant des produits de sa réception au Brésil, de 1953, date de parution du premier livre de Barthes, Le Degré zéro de l'écriture, jusqu'au moment actuel. Effets d'un processus de réfraction, de telles images ne se bornent pas à reproduire la dynamique de la pensée barthesienne, d'autant plus qu'elles mettent en évidence les particularités du contexte et des intellectuels qui les ont appropriées. Car la périodisation étudiée comprend un moment de transition dans l'histoire de la critique brésilienne que la réception de l'œuvre de l'écrivain rend évident: la consolidation des institutions universitaires, dans les années 50 et 60, ouvra un nouvel espace pour les débats littéraires, auparavant limités dans les journaux. La critique littéraire et les discussions théoriques, jusque là dominées par des critiques de formation autodidacte, devinrent, graduellement, une préoccupation des professeurs universitaires. Le but de cette thèse est d'examiner comment la pensée de Barthes a été intégrée dans ce contexte, ayant comme fil conducteur et corpus principal le journal $O$ Estado de $S$. Paulo, aussi bien que la revue universitaire Língua e Literatura. D'abord commentée par la critique journalistique pour, ensuite, devenir l'objet de la critique universitaire, la pensée barthesienne transparaît sous la forme des images partielles qui, à la fin du parcours de la recherche, composent une mosaïque hétérogène et complexe. Mal compris, maître structuraliste de la nouvelle critique, sémiologue et gourou dans les universités, hédoniste, subversif: une facette différente de Barthes bat dans chaque image, dans un constant mouvement, entraînant de nouvelles lectures et l'écriture de nouveaux textes, et ainsi circulant, vivante.

Mots-clés: Roland Barthes; Les rapports entre le Brésil et la France; Critique littéraire; Études de réception; Littérature comparée. 


\section{Agradecimentos}

Sempre gostei de ler os agradecimentos de livros e trabalhos universitários. Cheguei a passar tardes na biblioteca lendo somente essa parte de dissertações de mestrado e teses de doutorado, quando cursava minha graduação. Imaginava as histórias por trás de cada nome citado: colegas de trabalho, alunos, funcionários, familiares, gente que efetivamente contribuiu para o trabalho, gente que simplesmente esteve ao lado do autor durante a caminhada até o ponto final.

Procurava a dimensão humana por trás daqueles volumes pesados, que se oferecia pelas citações de frases de empregadas domésticas ao lado de nomes de grandes professores, declarações de amor apaixonadas, por vezes com visada poética, desculpas aos filhos pelo tempo passado longe deles, menções àqueles que não foram mencionados "por esquecimento". E me perguntava: como será que vou escrever os meus agradecimentos, quando a hora chegar?

A maneira que encontrei responde à questão que me empurrava para as estantes do fundo da biblioteca: associar os nomes às histórias que os trazem para esta parte da tese. Em atenção à brevidade do espaço, separo-os pelos lugares por que passei em meu percurso doutoral.

Inicio agradecendo a minhas duas orientadoras, Maria Cecília Queiroz de Moraes Pinto e Patrizia Lombardo, onde a história desta tese começa. Ambas foram cúmplices de meu projeto de doutorado em co-tutela, o primeiro firmado entre as universidades de São Paulo e de Genebra e, por isso, tão difícil de ser implantado e de ser levado a termo. Durante todas as etapas do processo, minhas orientadoras tiveram enorme paciência com a burocracia imposta pelas duas universidades e, nos momentos em que eu já não aguentava mais lidar com as exigências de um ou do outro sistema de pós-graduação, Maria Cecília e Patrizia sempre estiveram ao alcance de um telefonema, de uma ligação via Skype ou de um e-mail, prontamente respondido. Nelas, invariavelmente encontrei a palavra amiga, que acalma, ou a escuta atenta do desabafo, que conforta. Na tranquilidade de Maria Cecília e na eletricidade de Patrizia, sempre contei com a amizade que tornou a empreitada da tese mais leve e prazerosa.

No Arquivo Público do Estado de São Paulo realizei a pesquisa de corpus durante dois anos, aproximadamente. Agradeço aos funcionários que me atenderam com eficiência e gentileza: Aparecido Oliveira da Silva, Geovane de Souza Silva, Anatércia Araújo dos Santos, Maira Oliveira Santos, Tárcio Sandro Nascimento Silva, Márcio Borges, José Aparecido Barros Corrêa, Gileade Estevam, Ricardo, Kepler, Marli e "Seu” Félix. 
Tendo viajado algumas vezes para tratar de assuntos referentes à tese e para realizar pesquisa, agradeço, em Genebra e em Paris, aos amigos Midori Nakamura, Chiara Gambacorti, Frédéric Martin-Achard, Valérie Bucheli, Amy Heneveld, Matthieu Vernet, Yuji Murakami, Teppei Asama e Klara Koutnikova. Também agradeço ao professor da Universidade de Genebra, Jenaro Talens Carmona, integrante da banca de qualificação, por sua leitura e suas sugestões para o desenvolvimento do trabalho. E menciono os atenciosos Olivier Frutiger e Annik Baumgartner, responsáveis por questões práticas referentes à co-tutela.

$\mathrm{Na}$ Universidade de São Paulo, sou grata a todos os docentes do Programa de Estudos Linguísticos, Literários e Tradutológicos em Francês, em especial aos amigos Cláudia Amigo Pino, Alexandre Bebiano de Almeida e Cristina Casadei Pietraróia. Meu reconhecimento especial aos professores Verónica Galíndez Jorge e Gilberto Pinheiro Passos, por terem integrado minha banca de qualificação, contribuindo com questionamentos fecundos para a continuidade da escrita da tese. E não deixo de registrar meu muito obrigada às secretárias Edite e Regina, por toda a assistência extra-acadêmica de que precisei.

Em Londrina, agradeço aos amigos Miguel Vieira, Jacicarla Souza da Silva, Telma Maciel da Silva, Américo Grisotto, Camila Emídio, Bárbara Marques, Maria Carolina Godoy, Cláudia Rio Doce, Tacel Leal, Eduardo Araújo, Ana Lúcia e Paulo Almeida Campos, pelo apoio constante. E a meus orientandos nos projetos de pesquisa e nos trabalhos de conclusão de curso sobre Barthes: Anderson Braga do Carmo, Taciane Marques, Amanda Ferreira, Carla Coelho, Mariana Killner, Nádia Lima, Eduardo Ferreira, Letícia Carnio, Rafael da Silva e Eduardo Pimentel, bem como a todos os demais alunos do Bacharelado em Língua e Cultura Francesas, que tiveram de resenhar textos de Barthes nos cursos de literatura que ministrei, permitindo-me ler, reler e debater seus escritos de forma constante nos últimos quatro anos.

Em todos os lugares, meu agradecimento vai àqueles que estão sempre a meu lado: Nádia Battella Gotlib, Valter Pinheiro, Henrique Codato, Célia e Lua Fahy, Eliane Lousada, Arnaldo Franco Júnior, Cilza Bignotto e Mirko Lerotic Filho, Clorinda Mingone (que fez a revisão cuidadosa do texto), tia Dida, pai, mãe e família.

Agradeço ainda a Leyla Perrone-Moisés, por tudo o que escreveu sobre Barthes, inspirando este trabalho.

Recebi bolsa de pesquisa do CNPq durante os meses de abril e maio de 2011.

Contei com financiamento da Pró-Reitoria de Pós-Graduação da Universidade de São Paulo para participar de reuniões de pesquisa na Universidade de Genebra, em setembro de 2012. 
Écrire, c'est ébranler le sens du monde, y disposer une interrogation indirecte, à laquelle l'écrivain, par un dernier suspens, s'abstient de répondre. La réponse, c'est chacun de nous qui la donne, y apportant son histoire, son langage, sa liberté; mais comme histoire, langage et liberté changent infiniment, la réponse du monde à l'écrivain est infinie: on ne cesse jamais de répondre à ce qui a été écrit hors de toute réponse: affirmés, puis mis en rivalité, puis remplacés, les sens passent, la question demeure.

Roland Barthes, “Avant-propos”, Sur Racine, 1963.

Não há dúvida que os ferozes antagonismos são bem reais. Mas enquanto as manifestações destes não tardam a perder o ilusório interesse que por vezes dá às suas expressões polêmicas o talento dos contendores, as manifestações da vontade comum de renovação conservam para além das circunstâncias, mesmo quando expressas polemicamente, um valor duradouro que thes vem da importância dos problemas trazidos à discussão.

Adolfo Casais Monteiro, "Divagação sociológico-literária", O Estado de S. Paulo, 27/03/60. 


\section{Sumário}

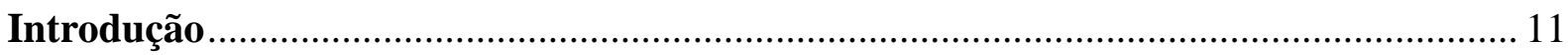

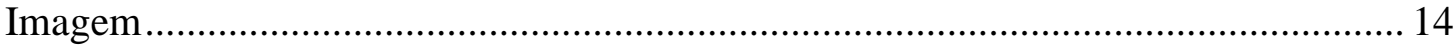

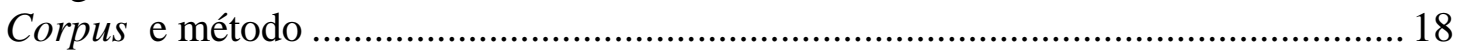

Estética da recepção e imagem............................................................................... 24

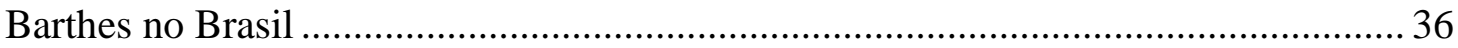

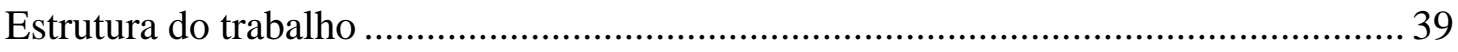

Corpus/ Corpo

Da Província ao Estadão, passando pela Universidade .............................................. 47

Procurando agulhas em um palheiro ......................................................................... 55

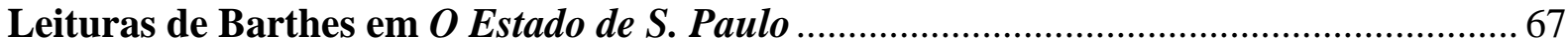

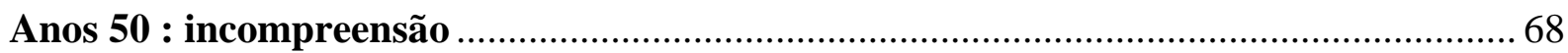

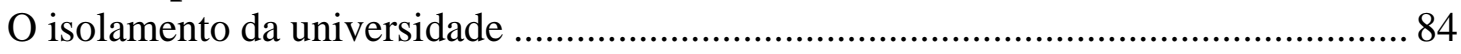

A querela da crítica............................................................................................... 88

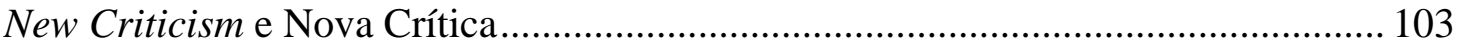

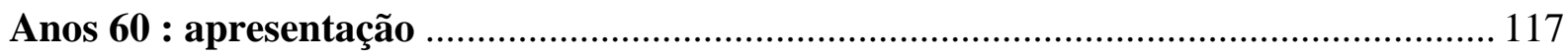

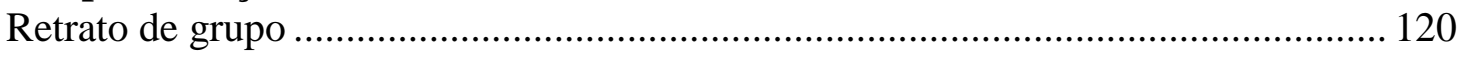

A querela francesa e seus ecos no Brasil................................................................. 129

O estruturalismo é um humanismo e um anti-humanismo .......................................... 136

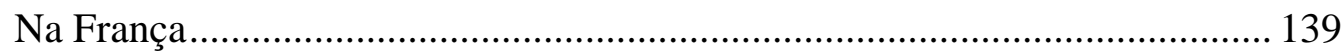

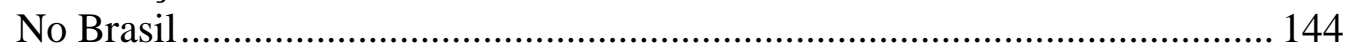

O Jean-Paul Sartre do Brasil e o estruturalismo ……………………………... 146

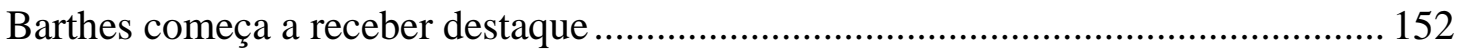

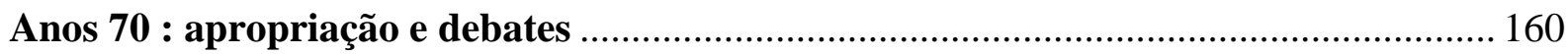

Pau para toda obra, teoria para toda pesquisa..................................................... 162

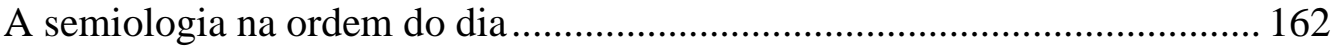

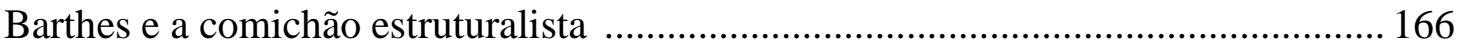

A comichão estruturalista no Brasil............................................................... 166

A querela do estruturalismo e a "tradição do impasse"................................. 170

Terrorismo terminológico ................................................................................ 173

O estruturalismo coloca a literatura em perigo ………………….................... 183

Barthes no front estruturalista.................................................................. 192

A polêmica das ignorâncias altamente especializadas...................................... 196

À margem das querelas : Barthes em discussão …………………………………..... 203

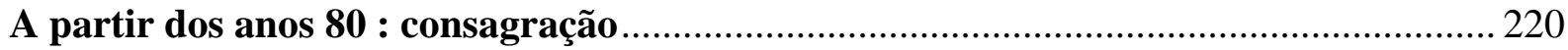

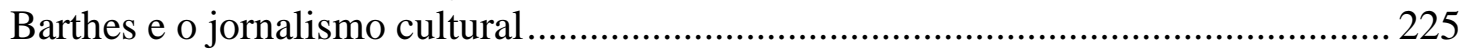

Fragmentos de um discurso amoroso, a peça teatral .............................................. 231

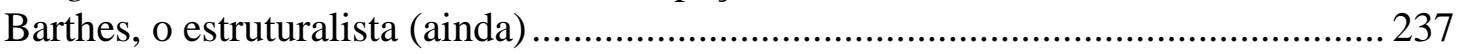

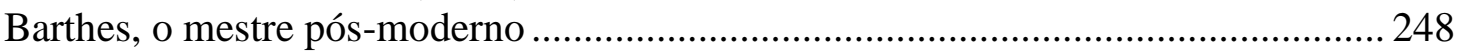




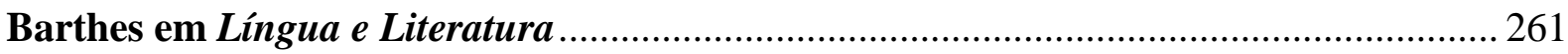

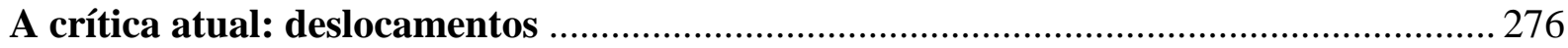

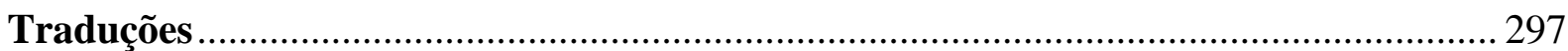

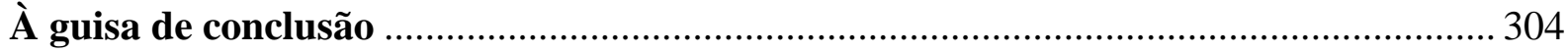

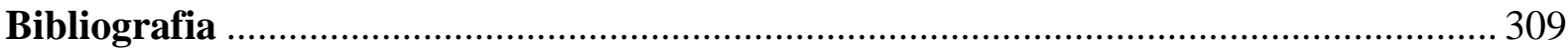

Anexo 


\section{Introdução}

Le langage (des autres) me transforme en image, comme la pomme de terre brute est transformée en frite. ${ }^{1}$

Roland Barthes

Roland Barthes não gostava de ser transformado em imagem, o que se torna evidente em sua comparação com a batata frita, na epígrafe. Relutou em aceitar que fosse organizado um colóquio sobre ele, e só concordou quando foi resolvido que não seria o tema do evento, mas somente seu pretexto - informação explícita no título: "Prétexte: Roland Barthes". Não queria criar a imagem "de celui-qui-refuse-les-colloques-sur-son-nom" 2 .

Apesar de preocupado com as imagens de si mesmo, Barthes não pôde, contudo, impedir que se falasse dele - que fosse transformado em imagem pela linguagem dos outros. Isso o conduziu a escrever uma comunicação entitulada "L'image", em que reflete sobre a opressão da linguagem exercida por meio de "figuras de sistema", ou da criação de uma imagem.

Nesse texto, Barthes, primeiramente, estabelece uma oposição entre "Acolouthia" e "Machè". Por um lado, a "Acolouthia" compreende a conciliação e a convivência natural. Por outro, a "Machè" traz em si as ideias de combate, ruptura e disputa, e tem na linguagem seu lugar privilegiado: nela encontram-se tanto a Bobagem (Bêtise), presença opaca que se impõe na linguagem, quanto o texto ilisível, que provoca um embate com o leitor, ou ainda as "figuras de sistema", que aprisionam os argumentos, cerceando o espaço da linguagem. Em uma palavra, a "Machè reúne situações de linguagem conflituosas, que funcionam dentro da lógica da imposição e da sujeição. São "intimidations de langage" 3 .

A Imagem, que no texto passa a ser grafada com letra maiúscula, é vista como uma situação conflituosa de linguagem. Como uma ventosa, ela "cola" no corpo e lhe inflige uma violência, uma vez que o transforma: "Combat des systèmes de langage: métaphore de la ventouse. Revenons maintenant au combat des Images ('image': ce que je crois que l'autre pense de moi) ; comment une

\footnotetext{
1 "L’image ", texto apresentado por Barthes no Colóquio "Prétexte: Roland Barthes", realizado em junho de 1977 no Centro Cultural Internacional de Cerisy-La-Salle, sob a direção de Antoine Compagnon. In Roland Barthes, Oeuvres complètes, nova edição organizada por Éric Marty, Paris, Seuil, 2002, v. 5, p. 517. Todas as citações de Barthes serão extraídas da edição mencionada de suas Obras Completas, doravante $O C$, acrescidas do número do volume, salvo referência contrária.

2 "Conclusions", $O C$ v. 5, p. 520.

3 "L'image", $O C$ v. 5, p. 514.
} 
image de moi 'prend'-elle au point que j'en sois blessé ?" 4 A imagem se apodera e deforma o indivíduo assim como o óleo quente se apodera e deforma a batata crua, transformando-a em batata frita. Ou seja, um sistema externo ao objeto o cerca, envolve-o, transforma-se com esse contato, transformando o objeto. A Imagem, portanto, violenta o corpo ao qual ela se liga, transformando-o contra a sua vontade. Trata-se, em suma, de uma imposição.

Para Barthes, além de imposição, a Imagem é também uma violência muitas vezes inevitável, pois é o produto de uma reação entre a linguagem e um objeto, surgindo a cada momento em que a linguagem é empregada para tratar de um tema, um autor, uma obra, um conceito, uma ideia. Ou seja, a Imagem existe em cada texto que tem como referente um objeto exterior a ele - no termo de Barthes, um texto produzido por um écrivant ${ }^{5}$. Nesse tipo de texto a linguagem é utilizada para se apropriar de seu referente, envolvendo-o com adjetivos, definições, indagações, julgamentos, moldando-o conforme seu interesse, fazendo dele um outro. Logo, cada texto escrito sobre Barthes renova nele a consciência da violência de que ele é objeto. Que o escritor aceita, resignado: "Rien à faire, je dois passer par l'Image; l'image est une sorte de service militaire social: je ne puis m'en faire exempter; je ne puis me faire réformer, déserter, etc. Je vois l'homme malade d'Images, malade de son Image" 6 . Conformado com esse tipo de submissão social - uma forma da doxa -, Barthes ainda previne qualquer tentativa de insubordinação, de controle da própria imagem: “Connaître son Image devient une recherche éperdue, épuisante (on n'y arrive jamais), analogue à l'entêtement de quelqu'un qui veut savoir s'il a raison d'être jaloux (...)" 7 .

A comparação da procura de um sujeito por sua própria Imagem com a procura do ciumento pela confirmação de suas desconfianças, conduz a um jogo de gato e rato em que os ratos são infinitos. É impossível encontrar sua Imagem, pois ela nunca é única, mas são muitas e tão infindáveis quanto as razões que o ciumento encontra para desconfiar do amor do outro. As buscas do sujeito por sua Imagem e as do ciumento pelas razões de seu ciúme não se situam no domínio do conhecimento, mas no domínio da posse: possuir tanto sua Imagem quanto possuir o outro significa controlá-los, dominá-los. Aquele que se sujeita - às Imagens criadas pelos outros e às dúvidas geradas pelo amor - também deseja sujeitar.

\footnotetext{
${ }_{5}^{4}$ Ibid., p. 516.

5 Aqui menciono o conceito barthesiano de écrivant, escrevente, que se opõe ao de écrivain, escritor. Para Barthes, o écrivant é aquele que escreve algo, com um objetivo, diferente do écrivain, que escreve, e só. Para o écrivant a escrita é uma atividade transitiva, ao passo que para o écrivain, ela é intransitiva, um fim em si. Cf. "Écrivains et écrivants", $O C$ v. 2, pp. 403-410.

6 "L'image", $O C$ v. 5, p. 517.

${ }^{7}$ Ibidem.
} 
A única maneira de escapar a esse sistema de imposições é evitando a Imagem. Para tanto, em “L’Image”, Barthes define a "Epochè", “suspensão do julgamento”, “suspensão de Imagens” 8 , como algo diferente de sua negação, a qual geraria uma nova Imagem. E sugere uma forma de se suspender essa criação ilimitada: “Un moyen de déjouer l'Image, c'est peut-être de corrompre les langages, les vocabulaires; la preuve qu'on y parvient c'est de susciter l'indignation, la réprobation des puristes, des spécialistes. Je cite les autres, en acceptant de les déformer: je fais glisser le sens des mots (...)" ${ }^{9}$. Ou seja, Barthes propõe deformar a linguagem antes que ela deforme o objeto: criar neologismos, inventar novos sentidos para as palavras, desvirtuar noções e conceitos e, assim, arrancá-la da zona de conforto, do lugar comum e gerar uma nova linguagem, provocante e libertadora.

Ao atacar o agente criador da Imagem, isto é, a linguagem, Barthes acredita poder se defender da imposição: propõe que se "corrompa" a linguagem antes que ela "transforme" seu objeto em Imagem. Essa “corrupção” visa à criação: o objeto primeiro é, pois, preservado, tornandose apenas o ponto de partida para a elaboração de um novo. Barthes, portanto, apresenta como alternativa à imposição da Imagem a invenção de um objeto de linguagem, ou seja, de um novo texto ${ }^{10}$. Seria essa, pois, a diferença entre um colóquio sobre Roland Barthes, que o transformaria em Imagem, e o colóquio de que Roland Barthes é o pretexto, o ponto de partida para a elaboração de novos textos.

Tal alternativa, contudo, só prevê a ação daquele que cria uma Imagem, não daquele que é transformado nela, situação em que se encontrava Barthes no Colóquio de Cerisy. A esse respeito, durante a discussão que se seguiu à leitura de "L’image", Barthes desabafa:

Tous ces problèmes d'image, pour moi, sont sérieux; j'en parle aujourd'hui d'une façon apparemment pacifiée; puisque j'en ai fait un exposé, c'est que cela va assez bien; mais très souvent, dans la vie plus solitaire, plus secrète, qui sépare les moments publics, d'autres choses plus graves, plus dramatiques peuvent se passer en moi; mon débat avec les images est un débat réel; à certains moments, je me dis: je ne pourrais jamais résoudre ce problème; pour pouvoir résoudre ce problème, il faudrait que je renonce à écrire, car si j'écris, si je publie, par là même je m'expose aux images; il faut donc que je choisisse: ou bien des images, ou bien ne plus écrire. ${ }^{11}$

\footnotetext{
${ }^{8}$ Ibid., p. 518.

${ }^{9}$ Ibid., p. 519.

${ }^{10}$ Alguns meses antes, face ao poder exercido pela língua, Barthes apontava a mesma solução: em sua Aula Inaugural no Collège de France, proferida em 7 de janeiro de 1977, ele propunha: "Mais à nous, qui ne sommes ni des chevaliers de la foi ni des surhommes, il ne reste, si je puis dire, qu'à tricher avec la langue, qu'à tricher la langue. Cette tricherie salutaire, cette esquive, ce leurre magnifique, qui permet d'entendre la langue hors-pouvoir, dans la splendeur d'une révolution permanente du langage, je l'appelle pour ma part : littérature" (Leçon, in OC v. 5, p. 433).

${ }^{11}$ In Antoine Compagnon (dir.), Prétexte: Roland Barthes, Paris, Union Générale d'Éditions, 1978, p. 319.
} 
Felizmente o escritor escolheu suportar as imagens e continuar a escrever. E ao fazer isso, permitiu que as linguagens dos outros o envolvessem e que mais e mais imagens dele fossem geradas. Barthes, que já era muitos, foi multiplicado ainda mais por tudo o que se disse dele e de suas obras. É sobre imagens de Barthes criadas no Brasil, com ênfase em São Paulo, que este trabalho se debruça.

\section{Imagem}

A imagologia, estudo do elemento estrangeiro em determinado contexto por meio das imagens, no âmbito da literatura comparada, no qual este trabalho se insere, pressupõe relações complexas entre duas culturas, muito além das relações estritamente literárias. As imagens do estrangeiro, veiculadas em textos, por vezes revelam mais sobre a cultura local do que sobre a estrangeira. Em Da Literatura comparada à teoria da literatura, obra que estuda o papel da imagologia para os estudos comparados, Álvaro Manuel Machado e Daniel-Henri Pageaux afirmam: "Estudar este elemento estrangeiro [através das imagens], é reler a literatura nacional" 12 . Essa releitura deve ser estrábica, no sentido concebido por Ricardo Piglia ao cunhar a expressão mirada estrábica, um olhar característico da relação entre os intelectuais latino-americanos e as culturas europeias: um olho no próprio país e o outro no país estrangeiro ${ }^{13}$. Mas não só: tal releitura deve ser estrábica, também, por convocar múltiplos saberes - e não somente os literários - sem perder de vista o estrangeiro, a fim de construir sua imagem. Nas palavras de Machado e Pageaux,

Assim concebida, a imagem literária pode ser definida como sendo um conjunto de ideias sobre o estrangeiro incluídas num processo de literalização e também de socialização, quer dizer, como elemento cultural que remete à sociedade. Esta nova perspectiva obriga o investigador a ter em conta não só os textos literários em si, mas também as condições da sua produção e da sua difusão, bem como de todo o material cultural com o qual se escreve, pensa e vive ${ }^{14}$.

A imagem, portanto, nasce da conjunção de dois processos diferentes: o de natureza literária e o de natureza social. Trata-se de ver a imagem, ao mesmo tempo, por dois prismas: por um deles, como uma narrativa, portadora de uma temporalidade própria, ou, em outras palavras, de uma historicidade própria, com suas características se desenvolvendo nos espaços em que circula isto é, uma história da imagem centrada sobre ela e sobre as relações que ela cria. Pelo outro prisma, como "a representação de uma realidade cultural estrangeira através da qual o indivíduo ou o grupo

\footnotetext{
${ }^{12}$ In Da Literatura comparada à teoria da literatura, Lisboa, Edições 70, 1988, p. 20.

${ }^{13}$ In "Memoria y tradición", Anais do II Congresso Internacional da ABRALIC, Belo Horizonte, UFMG, 1991, v. 2, pp. 60-66.

${ }^{14}$ In Da Literatura comparada à teoria da literatura, op. cit., p. 57.
} 
que a elaboraram (ou que a partilham ou que a propagam) revelam e traduzem o espaço ideológico no qual se situam" 15 .

Em suma, as duas faces da imagem compõem uma realidade dupla, em parte válida por si só, em parte válida por seu papel de testemunho das crenças e dos fantasmas de um dado grupo social, situado em um momento histórico. Neste trabalho, portanto, o conceito de imagem ultrapassa os limites de uma mera correlação com a realidade: eu a concebo como uma refração.

Esse fenômeno ótico se dá quando a luz passa de um meio para outro e, nessa passagem, tem sua velocidade de propagação e direção alteradas. Ora, também quando o pensamento de um escritor estrangeiro começa a ser conhecido em um país, ele se propaga em um outro meio que não o de sua origem, respeitando o tempo e as particularidades do novo contexto e, consequentemente, gerando uma imagem refratada. As alterações por ela sofridas, em relação a seu ponto de partida, criam um Outro, com características do próprio Eu:

Eu "olho" o Outro - mas a imagem do Outro veicula também uma certa imagem de mim mesmo. (...) Queremos dizer "o Outro" (por imperiosas e complexas razões, quase sempre) e, ao dizer "o Outro" negamo-lo e dizemo-nos a nós próprios. De certo modo, dizemos também o mundo que nos rodeia, dizemos o lugar de onde partiu o "olhar", o juízo sobre o Outro: a imagem do Outro revela as relações que estabelecemos entre o mundo (espaço original e estranho) e eu próprio. A imagem do Outro surge como uma língua segunda, paralela à língua que falamos, coexistindo com ela, sendo, de certo modo, a sua dupla, para dizer outra coisa ${ }^{16}$.

E mais adiante, sintetiza: "A imagem é, na verdade, uma língua segunda, uma linguagem" $"$. As imagens do escritor estrangeiro, Barthes, neste trabalho, enquanto linguagens, são compostas por diversas vozes, o que acentua o fenômeno de refração por elas sofrido. Pois cada uma dessas imagens refratadas contém traços tanto dos intelectuais que escreveram sobre o escritor francês, quanto dos momentos históricos em que o fizeram, no Brasil. Interesso-me pelas distorções que as imagens de Barthes apresentam, pois é nelas que enxergo as projeções feitas sobre o estrangeiro, as apropriações e assimilações do estrangeiro e suas implicações para a cultura local. Essas distorções, as particularidades das leituras brasileiras de Barthes, serão colocadas em evidência e analisadas, década a década, em meu trabalho.

\footnotetext{
${ }^{15}$ Ibid., p. 58.

${ }^{16}$ Ibid., p. 61.

${ }^{17}$ Ibidem.
} 
Para que um estudo contemple a multiplicidade de informações veiculadas pela imagem do estrangeiro, Machado e Pageaux sugerem atenção a três elementos: a palavra, a relação hierárquica entre as duas culturas em questão e o scénario ${ }^{18}$.

Por "palavra" os autores compreendem a análise dos campos lexicais em que a imagem figura, para que se possa determinar a que temáticas elas são associadas e se são caracterizadas positiva ou negativamente. Levei em conta essa sugestão no momento de selecionar os textos que constituíram o corpus deste trabalho, onde efetivamente encontrei menções a Barthes e elementos dos quais me servi para reconstruir as imagens do escritor francês. Busquei textos que contivessem algumas "palavras-chave" que potencialmente pudessem se relacionar com Barthes, direta ou indiretamente, tais como: crítica, semiologia, linguística, estruturalismo, universidade, nouveau roman, nova crítica, bem como qualquer possível alusão a títulos de suas obras ou a conceitos, como os de écriture e neutro.

Entender o tipo de relação hierárquica existente entre as culturas local e estrangeira no período estudado oferece uma visão mais ampla do contexto em que as imagens se inserem: é relevante saber se há uma idolatria acrítica pela cultura estrangeira, pois isso caracteriza a mania; se a cultura estrangeira é vista como inferior ou negativa, existe a fobia; se não há desnível entre as duas culturas, possibilitando um diálogo entre elas, tem-se um caso de filia; por fim, se não há juízo de valor declarado entre as culturas, se impera um pretenso cosmopolitismo, os autores admitem que nesses casos pode-se identificar a mania ou a filia ${ }^{19}$.

O período estudado, a segunda metade do século XX, é caracterizado pela decadência da influência francesa na cultura brasileira e pela ascensão da estadunidense. Trata-se, portanto, de um momento de transição, pois nele ocorre, paulatinamente, uma troca de modelo cultural. A língua francesa é substituída, no ensino regular, pela inglesa, em função do crescente poderio econômico dos Estados Unidos. Ademais, desde o final da Segunda Guerra, o American Way of Life é popularizado pelo cinema e pela música. Nesse momento de substituição do modelo, as duas culturas, francesa e estadunidense, coexistem no Brasil, não mais existindo galomania, e nem havendo motivos sócio-históricos para galofobia. Há, sim, uma espécie de cosmopolitismo que, no entanto, supõe valores distintos associados a cada uma das culturas envolvidas: a francesa representando o passado e a formação da geração de intelectuais tradicionais; a estadunidense apontando para o futuro, para o qual estão voltados os olhos dos intelectuais mais jovens; e a

\footnotetext{
${ }^{18}$ Ibid., p. 62.

${ }^{19}$ Ibid., pp. 73-77.
} 
brasileira colhendo e adaptando elementos dessas duas culturas estrangeiras em função de suas necessidades e interesses.

No que concerne especificamente aos autores franceses e às modas literárias parisienses, constato a existência de um diálogo entre eles e os intelectuais brasileiros que, segundo a classificação de Machado e Pageaux, caracteriza um longo momento de galofilia, que dura até o momento presente, embora restrito a grupos de intelectuais. A recepção a Barthes reflete bem as conversas, muitas vezes desencontradas, entre os autores e críticos brasileiros e suas leituras à vol d'oiseau ou minuciosas da obra do escritor francês. Na maior parte da periodização, entre as décadas de 50 e de 70, predomina uma visão crítica dos conceitos barthesianos e de seus livros. No último momento, dos anos 80 até a atualidade, cessam as discussões e o escritor francês é visto, sobretudo, como uma referência e um ponto de partida para novas reflexões.

O terceiro elemento e último nível analítico a ser levado em conta, num estudo de imagem, é o scénario. Segundo os autores: "A partir de palavras, de relações hierarquizadas, a imagem desenvolve-se até se tornar tema, sequência, cena, no duplo sentido, narrativo e dramatúrgico" ${ }^{20}$. É em sua leitura que Machado e Pageaux reconhecem a capacidade da imagem de sustentar sua própria temporalidade: "Não deixa de ter interesse fazer notar que a palavra scénario em francês, praticamente intraduzível em toda a sua ambiguidade para português (simultaneamente intriga e cenário), remete, de fato, para um dos elementos principais do mito: sequência duma história que se conta" 21 .

A história que pretendo contar, a da presença de Barthes no Brasil, por meio de suas imagens, não se restringe a um único protagonista, o escritor francês. Indiretamente, ela também reflete questões, anseios e concepções daqueles que forneceram suas vozes para criar as imagens do escritor, na esteira da própria compreensão barthesiana de imagem, criada pela linguagem dos outros, tal como a epígrafe da Introdução enuncia. E, mais do que isso,

(...) Torna-se decididamente necessário convencermo-nos duma evidência: o texto imagológico serve a algo na e para a sociedade, de que é a expressão fugitiva e parcelar. É que a imagem do Outro serve para escrever, para pensar, para sonhar de outra maneira. Ou seja: no interior duma sociedade e duma cultura estudadas em termos sistemáticos, o escritor escreve, escolhe o seu discurso sobre o Outro, por vezes em contradição total com a realidade política do momento. A rêverie sobre o Outro torna-se um trabalho de investimento simbólico contínuo. Se, no plano individual, escrever sobre o Outro pode levar à auto-definição, no plano coletivo, dizer o

\footnotetext{
${ }^{20}$ Ibid., p. 70.

${ }^{21}$ Ibid., p. 71.
} 
Outro pode servir os défoulements ou as compensações, justificar as miragens ou os fantasmas duma sociedade ${ }^{22}$.

Distinguir os "défoulements", as "compensações", as "miragens" e os "fantasmas" a que as imagens de Barthes serviram fará parte da intriga de sua história no Brasil, chegando até mesmo a roubar a cena do escritor em alguns momentos. Apesar de certos desvios de percurso, o fio condutor de minha narrativa crítica será a trajetória de Barthes, o Outro para os intelectuais brasileiros, que se alimentará e dividirá a cena com os vários Eus que se aventuraram - com ou sem propriedade - a escrever sobre ele. As imagens do escritor, portanto, terão voz e serão vistas também como testemunhos de alguns momentos-chaves da história da crítica brasileira.

\section{Corpus e método}

As imagens de Barthes criadas pelos intelectuais brasileiros, desde 1953, ano do lançamento de Le Degré zéro de l'écriture, primeiro livro do escritor francês, foram tantas quanto o número de textos publicados sobre ele e sobre suas obras. Este trabalho lida, portanto, com uma pluralidade de imagens, constituída, por sua vez, por uma pluralidade de vozes. E é uma parcela dessa multiplicidade que pretendo mostrar, descrever e analisar, a fim de montar parte do quebracabeça da recepção do escritor no Brasil.

O próprio Barthes pensava nas leituras que suas obras poderiam suscitar. Por ocasião da reedição de Essais critiques (1964), em 1971, o autor revê sua coletânea de ensaios e reflete sobre o futuro de seus textos:

Et puis, s'il est une chose, précisément, que le "structuralisme" nous a apprise, c'est que la lecture présente (et future) fait partie du livre passé: on peut espérer que ces textes seront déformés par le regard nouveau que d'autres pourront porter sur eux; que, d'une façon encore plus précise, ils se prêteront à ce que l'on pourrait appeler une collusion de langages; que le langage de la dernière avant-garde pourra leur donner un sens nouveau, qui, de toute façon (par simple vocation plurielle), était déjà le leur, en un mot, qu'ils pourront être pris dans un mouvement de traduction (le signe n'est rien d'autre que traductible). ${ }^{23}$

Partindo do pressuposto de que a atividade crítica é um processo de apropriação que, através da leitura, presentifica o texto analisado, ela, ao mesmo tempo, "deforma-o", tal qual a batata frita, por meio da linguagem que lhe sobrepõe. Nesse sentido, a crítica pode ser compreendida como um tipo de "tradução", onde o crítico reproduz com outras palavras o texto analisado,

\footnotetext{
${ }^{22}$ Ibid., p. 72.

23 “Avant-propos 1971", Essais critiques, in $O C$ v. 2, p. 272.
} 
problematizando-o ou tornando claro o que não é explícito. Os críticos brasileiros produziram uma "collusion de langages" que envolveu a obra de Barthes. A grande maioria criou imagens reproduzindo valores que ao mesmo tempo são pessoais e refletem características de certos grupos, dentro de um determinado momento histórico. Alguns, porém, valeram-se dos conceitos e das ideias barthesianos para criar novas obras. Todos, de uma maneira ou de outra, colocaram em evidência facetas de Barthes, inevitavelmente construindo imagens do escritor francês dentro das cenas literárias brasileiras.

A fim de evidenciar algumas dessas imagens, bem como as relações delas com seus autores e os contextos em que foram produzidas, foi necessário delimitar um corpus de pesquisa abrangente e capaz de abarcar diferentes momentos da crítica literária brasileira.

Primeiramente, escolhi o Estado de São Paulo como campo cultural privilegiado no trabalho. Tal seleção não foi fortuita, pois além deste acolher, em seus jornais, alguns dos primeiros ecos das obras de Barthes, suas instituições universitárias estão entre as primeiras a abrir as portas às ideias do escritor francês.

Esses espaços de discussão - os jornais e as universidades - marcam dois momentos distintos da crítica literária brasileira, que na segunda metade do século vinte, aproximadamente entre os anos 50 e o final dos anos 70, encontrava-se num período de transição. A crítica que se fazia, quase exclusivamente, nos jornais durante os anos 50 e 60, ganhou um novo local de ação com o desenvolvimento das universidades brasileiras e a consolidação dos departamentos de letras ${ }^{24}$. Assim, se as reflexões sobre a literatura viam seu espaço diminuir na imprensa de divulgação de massa, as salas de aula, as defesas de tese, os ensaios e os artigos das revistas acadêmicas, então nascentes, relançavam apaixonadamente o debate literário.

\footnotetext{
${ }^{24}$ A Faculdade de Filosofia, Ciências e Letras, um dos núcleos centrais da Universidade de São Paulo, tornou-se, em 1970, Faculdade de Filosofia, Letras e Ciências Humanas, pois as ciências exatas e biológicas, que antes faziam parte da Faculdade, foram desmembradas em diversos institutos e faculdades. Consequentemente, as Humanidades reafirmaram sua independência no seio da universidade, e os então três departamentos de Letras, nos anos 80 e 90, expandiram-se, dividindo-se em cinco: Departamento de Letras Clássicas e Vernáculas, Departamento de Letras Modernas, Departamento de Linguística, Departamento de Letras Orientais, Departamento de Teoria Literária e Literatura Comparada. A Universidade de Campinas, fundada em 1966, criou, dez anos mais tarde, o Instituto de Estudos da Linguagem, dedicado aos estudos linguísticos e literários, originário do Departamento de Linguística do Instituto de Filosofia e Ciências Humanas. A Universidade Estadual Paulista, criada em 1976, absorveu faculdades e institutos de ensino superior de cidades no interior do Estado, dentre os quais a antiga Faculdade de Filosofia, Ciências e Letras, de Assis, que se tornou Faculdade de Ciências e Letras de Assis, importante centro de estudos literários. A Pontifícia Universidade Católica de São Paulo, fundada em 1948, em 1971 implantou um ciclo básico para as Humanidades, integrando os diversos cursos de ciências humanas, como o de Letras, que existia desde 1937, na antiga Faculdade de Filosofia, Ciências e Letras de São Bento, incorporada à universidade. Portanto, na década de 70, todas as grandes universidades do Estado de São Paulo viram o espaço destinado às Letras - e consequentemente aos estudos literários expandir-se e tornar-se independente das ciências.
} 
A crítica praticada nos jornais por escritores ou por intelectuais autodidatas foi gradualmente substituída pelas análises dos professores universitários. Estas frequentemente se pautavam nas teorias literárias em voga, cuja grande arena de discussão, durante os anos 60, encontrava-se na França, onde Roland Barthes era um dos protagonistas.

O estudo de Barthes centrado em São Paulo, portanto, contemplará tanto as imagens do escritor criadas no seio de um veículo de divulgação de massa, o jornal, quanto o aproveitamento de seus conceitos na universidade, que pode ser aferido, sobretudo, com a análise de textos publicados em revistas acadêmicas e em coletâneas de ensaios. O primeiro Barthes, cujo reflexo foi mostrado exclusivamente no jornal pelos críticos tradicionais, ainda nos anos 50, e os Barthes dos anos subsequentes, partilhado pelo jornal e pela universidade, teriam algo em comum? Quais teriam sido as imagens de Barthes veiculadas pela imprensa de massa, e quais teriam sido os conceitos barthesianos assimilados nas universidades? Esses Barthes tocar-se-iam em algum momento?

O primeiro desafio de um trabalho que procura responder a tais questões reside no estabelecimento do corpus de pesquisa, pois a recepção de Barthes no Brasil se estende por um terreno ao mesmo tempo vasto e plural.

O terreno é vasto porque a periodização escolhida, entre 1953 e o momento presente, encobre temporalmente toda a recepção à obra barthesiana. O corpus é vasto também em termos de volume de material, uma vez que privilegia pesquisas em jornal e em revista, documentos seriados normalmente bastante numerosos.

O terreno por onde se espalha o corpus deste trabalho é plural, pois é constituído de textos publicados na imprensa de massa e de ensaios acadêmicos. Como a maioria do material pesquisado encontra-se dispersa, uma coletânea dos textos mais significativos sobre Barthes, publicados na imprensa, integrará este trabalho, bem como a bibliografia das publicações sobre o escritor francês no Brasil, em volume e no jornal pesquisado.

A fim de tratar dos dois momentos da crítica brasileira - jornalística e universitária - foram escolhidos como corpus da pesquisa um jornal, O Estado de S. Paulo, e uma revista universitária, Língua e Literatura, de responsabilidade dos departamentos de Letras da Faculdade de Filosofia, Letras e Ciências Humanas, da Universidade de São Paulo.

A preferência pelo jornal $O$ Estado de $S$. Paulo deu-se por se tratar de um dos mais importantes cotidianos de São Paulo, ao lado do jornal Folha de São Paulo. Sobretudo, o Estado foi escolhido em detrimento da Folha por duas razões: por um lado, somente o Estado contempla toda a periodização definida pelo tema da tese. O jornal foi fundado em 1875 e nunca teve sua circulação interrompida. Já a Folha só foi criada em janeiro de 1960, a partir da fusão dos três jornais do grupo: 
Folha da Noite (fundada em fevereiro de 1921), Folha da Manhã (fundada em julho de 1925) e Folha da Tarde (fundada em 1945), não cobrindo, portanto, toda a periodização da tese em um único cotidiano.

Por outro lado, a família Mesquita, proprietária de $O$ Estado, esteve diretamente implicada na criação da Universidade de São Paulo, primeira universidade brasileira e pólo aglutinador de grande parte dos críticos universitários de São Paulo. Desde os anos 20, Júlio de Mesquita Filho iniciou, em $O$ Estado, uma campanha em favor da criação da universidade, sustentada por alentado estudo sobre a realidade da educação no Brasil, assinado por Fernando de Azevedo. Em 25 de janeiro de 1934, o então interventor de São Paulo, Armando de Salles Oliveira, genro de Júlio Mesquita e um dos nove acionistas de $O$ Estado, assinou o decreto que oficialmente fundou a Universidade de São Paulo. Júlio de Mesquita Filho foi incumbido do recrutamento de professores estrangeiros, que comporiam o primeiro corpo docente da Faculdade de Filosofia, Ciências e Letras, um dos núcleos centrais da universidade. Então proprietário de $O$ Estado, Mesquita Filho foi, portanto, um dos responsáveis não só pela criação dessa instituição, como também pela presença dos professores estrangeiros, notadamente franceses para as cadeiras de Humanidades, que formaram parte da primeira geração de críticos universitários do Brasil.

Tendo-se em vista que tanto a crítica literária veiculada nos jornais quanto a crítica universitária integram este trabalho, foi essencial eleger como um dos eixos do corpus um jornal não só adequado à periodização, como também intimamente ligado à criação da principal universidade brasileira.

A pesquisa de textos realizada em $O$ Estado acrescenta mais uma justificativa à exclusão da Folha como corpus da tese: ao longo da periodização que este trabalho recobre, houve muitas mudanças na imprensa brasileira: os jornais, nos anos 50, eram mais sisudos, continham menos rubricas e cadernos do que nos anos 70 e 80, por exemplo. Os textos de crítica e de reflexões sobre problemas literários eram abundantes nos anos 50, 60, até meados dos anos 70. Nesta década, no entanto, aos poucos eles foram sendo substituídos por reportagens culturais, textos mais curtos e meramente informativos, sem o caráter crítico e reflexivo que caracterizava seus predecessores. Tais mutações, comuns à imprensa do mundo todo, foram verificadas tanto em $O$ Estado quanto na Folha, jornais que acompanharam o desenvolvimento da imprensa mundial. Por conseguinte, estudar a recepção de Barthes em um jornal como no outro implicaria no embate com os mesmos tipos de textos: mais analíticos e realmente críticos no início da periodização e meramente informativos ao final dela. Certamente os intelectuais que escreviam para um ou para outro jornal não eram os mesmos, e nem eram os mesmos o tom empregado, os temas preferencialmente 
abordados, os autores e as obras mais comentados. No entanto, ater-se a tais elementos diferenciais entre esses jornais faria do estudo das imagens de Barthes o fio condutor para um trabalho comparativo de ordem discursiva sobre os dois jornais, o que não é a proposta da tese. Esta tem por foco as imagens de Barthes obtidas por meio de sua recepção e arregimenta um corpus capaz de dar conta dos dois momentos da crítica brasileira durante os quais as obras do escritor francês foram publicadas.

Os textos encontrados em $O$ Estado são vistos, portanto, como uma parte significativa de um corpus idealmente constituído por tudo o que já se publicou sobre Barthes no Brasil, com ênfase para a produção paulista. Tais textos, em número de 621, valem não só por seus conteúdos, pelas opiniões e reflexões de seus autores, mas também constituem uma amostra dos diferentes tratamentos que Barthes recebeu por parte de intelectuais brasileiros. Para além de escolhas pessoais, de princípios adotados por grupos e de possíveis orientações impostas por redatores, a acolhida de Barthes em São Paulo foi marcada pela transição entre a crítica impressionista praticada nos jornais e a crítica universitária, ensaística, veiculada pelas revistas acadêmicas e por ensaios publicados em livros.

A crítica universitária integra o corpus da tese por meio dos textos publicados em diversos livros e revistas acadêmicas e pelos artigos de Língua e Literatura, a revista dos departamentos de Letras da Faculdade de Filosofia, Letras e Ciências Humanas da Universidade de São Paulo. Criada em 1972 e tendo como principais responsáveis os professores Erwin Theodor Rosenthal, Isaac Nicolau Salum e Segismundo Spina, foi o primeiro periódico acadêmico da Universidade de São Paulo dedicado aos estudos linguístico-literários. Assim, a revista nasceu para divulgar os trabalhos dos docentes dos departamentos de Letras, à época, apenas três - Departamento de Letras Clássicas e Vernáculas, Departamento de Letras Modernas e Departamento de Linguística e Letras Orientais. Posteriormente foram criados o Departamento de Letras Orientais (1986), que se separou do Departamento de Linguística, e o Departamento de Teoria Literária e Literatura Comparada (1990). Inicialmente anual, a revista contou com alguns números temáticos e, com o tempo, sua periodicidade tornou-se irregular. Depois de nove anos de eclipse (de 2000 a 2009), e recentemente retomada, Língua e Literatura credencia-se como amostra de crítica universitária por ter sido criada no momento de consolidação dos estudos linguísticos e literários no Brasil. Naquela época, por serem ainda raros os espaços dedicados exclusivamente à produção acadêmica - até então, a única revista universitária paulista existente na área de Letras era a Revista de Letras da Unesp -, Língua e Literatura oferece uma rica amostra da produção científica dos docentes da Universidade de São Paulo, com 25 artigos que citam Barthes. 
Embora totalmente distintos nos propósitos e, portanto, em seus conteúdos, $O$ Estado de $S$. Paulo e Língua e Literatura, veículos representantes da crítica jornalística e da crítica universitária, tocam-se em sua ligação com a história da Universidade de São Paulo. Por essa razão, além das já elencadas, foram escolhidos para compor o corpus da tese, numa tentativa de fornecer ao material selecionado uma coerência que o justifique.

Com o objetivo de traçar os perfis de Barthes na imprensa de massa e na universidade, destacando suas obras e seus conceitos mais comentados, discutidos, rechassados e enfim assimilados, serão adotadas duas visadas: uma histórica e uma analítica.

A visada histórica presidirá a elaboração de uma cartografia da presença de Barthes no Brasil, com ênfase em São Paulo, em função do corpus escolhido. Os diferentes momentos da recepção das obras e dos conceitos do escritor serão organizados cronologicamente para que sua dinâmica transpareça. No jornal, quem ataca Barthes? Quem o defende? Em que momentos e com quais argumentos? $\mathrm{Na}$ universidade, as questões se colocam menos em termos de ataques e de defesas, e mais em relação ao aproveitamento de teorias e de conceitos. Quais Barthes foram incorporados às análises literárias universitárias? Em que momentos? Um trabalho de contextualização, feito sob o ponto de vista da história cultural, contribuirá para a compreensão das reações brasileiras às obras do escritor.

A visada analítica guardará estreitas ligações com o contexto histórico em que se insere o corpus: ao mesmo tempo em que as análises destacarão as nuanças da recepção do pensamento de Barthes, presentes em cada texto selecionado, elas também apontarão quais obras e conceitos foram os mais discutidos. A partir das análises, serão aventadas hipóteses que justifiquem o interesse despertado por Barthes, fundamentadas nas particularidades do contexto brasileiro, assim como serão colocadas em evidência as imagens do escritor fixadas em cada período.

Este estudo será, portanto, voltado para o passado e para o presente. Por um lado, existe nele a preocupação em constituir uma coletânea de documentos sobre a presença de Roland Barthes no Brasil, notadamente a partir do corpus selecionado, com a finalidade de tornar disponível a outros pesquisadores o acesso a textos hoje esquecidos nos arquivos públicos. Por outro lado, buscar-se-á determinar quais são as principais contribuições do pensamento do escritor francês para os estudos literários desenvolvidos nos meios universitários. Sem negligenciar as etapas de construção da imagem de Barthes hoje reinante na universidade, isto é, a de um autor “difícil”. 


\section{Estética da recepção e imagem}

Não se pode aspirar a detectar imagens de um escritor, em um determinado contexto, sem se destacar e problematizar o papel de seus leitores, ou seja, aqueles que constroem tais imagens. Seu processo de concepção está diretamente relacionado às interpretações que os leitores fazem da obra do escritor. Ora, para Barthes, “Interpréter un texte, ce n'est pas lui donner un sens (plus ou moins fondé, plus ou moins libre), c'est au contraire apprécier de quel pluriel il est fait." ${ }^{25}$ Em outras palavras, o real sentido da interpretação não é fechar o texto em uma significação pessoal, mas abri-lo a todas as possibilidades de compreensão. Prática essa que Barthes exercita em sua leitura de Sarrasine, de Balzac, em $S / Z$, livro no qual ele explicita sua concepção do "texto ideal" sob o signo da pluralidade:

Dans ce texte idéal, les réseaux sont multiples et jouent entre eux, sans qu'aucun puisse coiffer les autres; ce texte est une galaxie de signifiants, non une structure de signifiés; il n'a pas de commencement; il est réversible; on y accède par plusieurs entrées dont aucune ne peut être à coup sûr déclarée principale; les codes qu'il mobilise se profilent à perte de vue, ils sont indécidables (le sens n'y est jamais soumis à un principe de décision, sinon par coup de dés); de ce texte absolument pluriel, les systèmes de sens peuvent s'emparer, mais leur nombre n'est jamais clos, ayant pour mesure l'infini du langage. ${ }^{26}$

Enquanto "galáxia de significantes", o texto permanece pulsando de sentidos infinitamente, o que faz com que ele não pare de significar através do tempo. Esse eterno movimento se completa em cada leitor e por cada um é revelado, através das escolhas - determinadas ou deliberadas - que levam às mais diferentes interpretações. Devido a essa instabilidade dinâmica de sentidos e, portanto, de imagens, que, como em um caleidoscópio, transforma-se a cada leve movimento, sua apreensão nunca será mais do que o retrato feito por um certo grupo, ou mesmo por um único indivíduo, em um dado momento.

A porção de relatividade intrínseca a todo trabalho dedicado às imagens, em literatura, demanda, portanto, um recorte temporal e espacial, voltado para as particularidades tanto do contexto sócio-cultural, no qual o objeto de estudo transita, quanto do perfil dos leitores do autor e/ou da obra em questão, ambos cruciais para a construção imagética. Esses elementos fazem parte da essência dos estudos de recepção, ou, nos Estados Unidos, os audience-oriented studies. Susan R. Suleiman, estudiosa de longa data dessa vertente crítica, é uma das organizadoras da coletânea The reader in the text. Essays on Audience and Interpretation (1980), obra que reúne artigos de

\footnotetext{
${ }^{25}$ In $S / Z$. In $O C$ v. 3, p. 123.

${ }^{26}$ Ibidem.
} 
pesquisadores dos estudos literários, vistos pelo prisma das teorias da leitura e dos leitores. No texto introdutório ao volume, Suleiman passa em revista os principais ramos do audience-oriented criticism, também abertos a múltiplas abordagens: "Audience-oriented criticism is not one field but many, not a single widely trodden path but a multiplicity of crisscrossing, often divergent tracks that cover a vast area of the critical landscape in a pattern whose complexity dismays the brave and confounds the faint of heart." 27

Longe de lamentar tal variedade de opções dentro de um mesmo terreno, a autora ainda acrescenta: "The vitality of audience-oriented criticism depends precisely on the realization that various dimensions of analysis or interpretation are possible, and that a combination of approaches is not a negative eclecticism but a positive necessity." $28 \mathrm{Ou}$ seja, respeitando reais incompatibilidades de princípios, diferentes olhares sobre a leitura e o leitor podem se encontrar na análise da obra literária à luz das teorias da recepção e dos audience-oriented studies.

Percorrendo as trilhas demarcadas por Suleiman em seu artigo, passo pela crítica retórica de Wayne Booth, que vê o texto como uma forma de comunicação e busca nele valores implícitos, o que caracterizaria o implied author, na nomenclatura do autor estadunidense; pelas análises descritivas propostas pelo estruturalismo de Gérard Genette, Algirdas Greimas, Michel Riffaterre e do próprio Barthes, dentre outros, nas quais o leitor crítico tem o papel semelhante ao do relojoeiro que desmonta e monta novamente sua obra; pela fenomenologia, centrada na percepção estética do leitor e cuja teoria Wolfgang Iser desenvolveu em The Implied Reader: Patterns of Communication in Prose Fiction from Bunyan to Beckett (1974); pela crítica psicanalítica de David Bleich e Norman Holland, que se interessa pela influência da personalidade do leitor na interpretação literária; pela hermenêutica no sentido tradicional, de Schleiermacher, e moderno, da teoria da interpretação, que se consolida com o $S / Z$ barthesiano e com as interpretive communities, de Stanley Fish; até chegar aos domínios da sociologia e da história, com Ian Watt e Lucien Goldmann, encontrando a estética da recepção de Hans Robert Jauss. Sobre essa corrente, a autora escreve:

The attempt to account both for the dialectic of production and reception of literary works in a given culture at a given time, and for historical continuities and discontinuities in the reception of individual works or authors, is what characterizes the work of the group of contemporary German critics loosely united under the banner of Rezeptionsgeschichte or Rezeptionsästhetik. ${ }^{29}$

\footnotetext{
27 "Introduction: Varieties of Audience-Oriented Criticism". In Inge Crosman, Susan R. Suleiman (org.), The Reader in the Text. Essays on Audience and Interpretation, Princeton (New Jersey), Princeton University Press, 1980, p. 6.

${ }^{28}$ Ibid., p. 7.

${ }^{29}$ Ibid., p. 35.
} 
Traço de união entre a sociologia e a história literárias, a estética da recepção teve suas bases estabelecidas no ensaio “L'Histoire de la littérature: un défi à la théorie littéraire” (1970), de Jauss. Nele, o autor, primeiramente, examina a situação da história da literatura em seu tempo para constatar seu total descrédito no século XX. Pois seu valor, enquanto ciência, repousa no já distante século XIX da consolidação dos estados-nação, quando a enumeração de autores considerados modelos e de obras tidas como representativas, bem como seu agrupamento em escolas literárias, ilustravam os valores dos povos. O autor também demonstra a falta de interesse da história literária para a crítica do presente, uma vez que a visão histórica não se propõe a fazer julgamentos sobre as obras que examina. Em suma, nas palavras de Jauss,

En dehors de l'enseignement, on ne trouve plus guère d'histoires de la littérature que, peutêtre, dans la bibliothèque des bourgeois cultivés, qui les consultent surtout pour y trouver la réponse aux questions d'érudition littéraire posées par les jeux télévisés - faute de disposer d'un dictionnaire technique plus approprié. ${ }^{30}$

Associados à decrepitude e até mesmo à futilidade das histórias da literatura estão a escola e o comportamento pequeno-burguês diante da procura pelo conhecimento - com a finalidade de vencer jogos de perguntas e respostas que até hoje fazem sucesso. Para que o estudo da literatura, pelo viés histórico, chegasse a esse ponto, foi preciso que sua importância decrescesse à medida que diminuía a necessidade de afirmação das nações, ao longo do século XIX. Como tábua de salvação, a história da literatura se apoderou do positivismo e aplicou os princípios dessa filosofia a seu método analítico, tentando recuperar seu prestígio por meio da objetividade científica que passou a presidir suas leituras. No entanto, esse tipo de estudo não dava conta da individualidade das obras, requisitada pelos métodos de análise imanentes, e foi então posto em questão pelo marxismo e pelo formalismo, segundo o autor.

O marxismo, enquanto instrumento de leitura de obras literárias, em linhas gerais, deixouse envolver pela compreensão do realismo artístico como mero reflexo de uma dada condição social. Suas análises literárias pendiam para um determinismo que mais uma vez obliterava as particularidades das obras. Em outra frente, que em muitas interpretações flertou com o marxismo, o formalismo, de um modo geral, estabeleceu seus fundamentos no caráter estético da literatura, como uma reação à função social a ela exclusivamente atribuída por correntes críticas no século XIX. O que fazia de cada obra literária única era obstinadamente buscado em cada análise, que examinava

\footnotetext{
${ }^{30}$ In Hans Robert Jauss, Pour une esthétique de la réception, traduzido do alemão por Claude Maillard, Paris, Gallimard, 1978, pp. 23-24.
} 
com precisão os elementos constituintes de seu sistema de significados. Ora, tal compreensão, de tão voltada às minudências do texto, rechaçava a historicidade da literatura, tirando-a de seu tempo e fazendo a balança pender demasiadamente para o lado oposto ao das leituras marxistas. Pois a história, no formalismo, até pode existir, mas sempre limitada por quadros, recortes, como se fosse um sistema de momentos que se sucedem e dentro dos quais as obras existem.

Nem puro reflexo da sociedade, nem objeto único alheio a seu tempo, a literatura, para Jauss, mantém suas especificidades estéticas sem deixar de lado as relações com a história. Em 1970, momento ainda de furor estruturalista, que era o herdeiro dileto do formalismo do início do século XX, o autor tentava restabelecer o lugar da história nos estudos literários sem abandonar a conquista da imanência da obra literária, perguntando-se:

Si l'on peut interpréter d'une part l'évolution littéraire comme une succession perpétuelle de systèmes et d'autre part l'histoire générale, l'histoire de la praxis humaine, comme l'enchaînement continu des états successifs de la société, ne doit-il pas être possible aussi d'établir entre la "série littéraire" et la "série non littéraire" une relation qui circonscrive les rapports entre l'histoire et la littérature sans dépouiller celle-ci de sa spécificité esthétique et la confiner dans une pure et simple fonction de reflet? ${ }^{31}$

A resposta se encontra numa parte do sistema literário sem grande importância para o marxismo e o formalismo: o leitor. Pois, para Jauss, "Si l'on considère ainsi l'histoire de la littérature, sous l'angle de cette continuité que crée le dialogue entre l'oeuvre et le public, on dépasse aussi la dichotomie de l'aspect esthétique et de l'aspect historique, et l'on rétablit le lien rompu par l'historisme entre les oeuvres du passé et l'expérience littéraire aujourd'hui". ${ }^{32} \mathrm{O}$ estudo da primeira recepção de uma obra já fornece dados relevantes para o julgamento de seu valor estético segundo um certo padrão de aceitação e o conjunto das sucessivas recepções ao longo do tempo, que Jauss chama de chaîne de réceptions, poderá se constituir como termômetro de sua importância histórica.

Ora, essa visão que relaciona o valor da literatura à história por meio do estudo de sua recepção me parece fecunda para uma análise do papel de um escritor estrangeiro em uma dada cultura e, por essa razão, foi escolhida como fio condutor de minhas leituras da presença de Barthes - por meio de suas imagens - no Brasil. Contudo, diferentemente de Jauss, que fala na primeira recepção da obra como aquela que ocorre em seu próprio contexto de produção, não é foco de interesse deste trabalho o impacto causado pelos textos de Barthes na França, mas somente no

\footnotetext{
${ }^{31}$ Ibid., p. 47.

${ }^{32}$ Ibid., p. 49.
} 
Brasil, sendo, aqui, sua primeira recepção, a da década de 50. Desde esse momento, através do estudo da chaîne de réceptions, tentei esboçar os perfis do escritor francês nos períodos em que sua obra foi lida no país. A estética da recepção de Jauss, portanto, configura-se como inspiração teórico-metodológica deste estudo. Inspiração por não ser vista como uma forma a partir da qual moldei o corpus, mas na acepção aérea do termo, como uma teoria por vezes respirada, incorporada, e por vezes expirada, expurgada, numa dinâmica dialógica.

No centro da tentativa de Jauss de restituir o papel da história aos estudos literários encontra-se o conceito de horizon d'attente, definido como as referências em vigor no contexto em que a obra é publicada. Essas referências dizem respeito às experiências prévias dos leitores com o gênero ao qual ela pertence, com sua forma e com a relação que ela estabelece com a realidade do leitor. Pois, quando surge,

(...) Elle [a obra] évoque des choses déjà lues, met le lecteur dans telle ou telle disposition émotionnelle, et dès son début crée une certaine attente de la "suite", du "milieu" et de la "fin" du récit (Aristote), attente qui peut, à mesure que la lecture avance, être entretenue, modulée, réorientée, rompue par l'ironie, selon des règles de jeu consacrées par la poétique explicite ou implicite des genres et des styles. ${ }^{33}$

A teoria de Jauss foi criada para as obras literárias no sentido mais restrito do termo, ou seja, ficcionais e poéticas. As menções à sua estrutura segundo Aristóteles o atestam. No entanto, ela pode ser proveitosa para o estudo da recepção de obras não-ficcionais, como as de Barthes, pois muitos dos seus postulados são amplos o suficiente para abarcá-las. Por exemplo, o próprio conceito de horizon d'attente, que, enquanto sistema de referências em que a obra é lançada, constitui-se importante fonte de informações sobre a própria obra, o que esta reflete ou com o que ela tenta romper. Nas palavras do autor, “(...) Le texte nouveau évoque pour le lecteur (ou l'auditeur) tout un ensemble d'attente et de règles du jeu avec lesquelles les textes antérieurs l'ont familiarisé et qui, au fil de la lecture, peuvent être modulées, corrigées, modifiées ou simplement reproduites." ${ }^{34}$ Isto é, a obra dialoga com o horizon d'attente, podendo, até mesmo, modificá-lo.

Tal compreensão dinâmica é muito cara a este trabalho, que examina as recepções de Barthes ao longo de seis décadas. Lido, portanto, com várias recepções, separadas, não muito claramente, é verdade, por momentos históricos e horizons d'attente diferentes. Estes mudam em função das próprias obras de Barthes: livros como Le Degré zéro de l'écriture, Mythologies e Essais critiques preparam os leitores de teoria e crítica literárias para os posteriores $S / Z$, Le Plaisir du texte,

\footnotetext{
${ }^{33}$ Ibid., p. 55.

${ }^{34}$ Ibid., p. 56.
} 
Roland Barthes par Roland Barthes e o sucesso estrondoso de Fragments d'un discours amoureux. O leitor que estranhou as primeiras obras do escritor pôde se adaptar às ideias e à linguagem barthesianas - graças, também, a outras leituras - para consagrar seus últimos livros.

A reconstituição, portanto, do chão histórico no qual Barthes aterrissava a cada lançamento de novo livro, corresponde à busca do possível horizon d'attente de seus leitores brasileiros, ainda que apenas delineado. Seu estudo detalhado não seria possível a partir de um espectro tão vasto de autores, como o que compõe o corpus deste trabalho. Aliás, Jauss, em seu ensaio, não especula sobre como delimitar um universo de leitores, a fim de estabelecer com precisão um horizon d'attente, mas imagina-se que este seja reduzido, para que se investiguem, a contento, os hábitos de leitura e os padrões estéticos e formais de uma fatia do público receptor de determinada obra. Por ter optado pela escolha de uma gama ampla e variada de leitores, abri mão de uma leitura mais precisa do horizon d'attente, a fim de obter um máximo de informações com a finalidade de compor algumas imagens de Barthes. $\mathrm{O}$ estudo de sua recepção, nesse sentido, não se constitui um método de análise e julgamento da obra do escritor francês, mas, executado de modo enviesado, segundo o interesse da pesquisa e não estritamente de acordo com os preceitos de Jauss, configura-se como uma ferramenta rentável de aproximação de meu objeto: uma lente de aumento para se enxergar os vários Barthes da crítica brasileira.

Associado ao horizon d'attente está o conceito de écart esthétique, a distância entre as expectativas dos leitores e a concretização da obra. Jauss lança mão dessa diferença como medida do valor estético da obra literária: quanto maior a diferença, maior a ruptura em relação aos padrões vigentes e, consequentemente, maior o valor da obra. No sentido inverso, se a diferença é pequena ou não existe, o valor, ou sua ausência, encontra-se em um dos dois extremos: ou a obra não tem valor, está estacionada na mediocridade, não acrescentando nada de novo ao sistema, ou ela atinge o valor máximo, sendo reconhecida como uma obra-prima, embora também paralisada, imóvel, no nível dos clássicos. ${ }^{35}$

Dentro dessa perspectiva, é sempre mais interessante não o clássico, mas a obra de ruptura, pois integra uma dinâmica do devir. Essa obra está em ação, propulsionada pelo diálogo que trava constantemente com os leitores: quase sempre áspero, movido a desconfianças, a considerações apriorísticas, a preconceitos, a suposições, a leituras apressadas ou mesmo a leituras parciais, a discordâncias e, por vezes, a simpatias, tal diálogo movimenta o espaço literário, tira o pó das estantes do pensamento e acrescenta, ao menos, mais convicção às velhas certezas, quando não traz

${ }^{35}$ Ibid., pp. 58-59. 
novas dúvidas aos leitores críticos. Em minhas análises, procurei colocar em relevo amostras do burburinho que certas obras de Barthes provocaram, sem, para tanto, deixar de lado as imperfeições das críticas, que tornam sua recepção tão rica.

A respeito dessa dinâmica entre obra e horizon d'attente que transforma textos atacados impiedosamente em clássicos incontestáveis, Jauss escreve:

$\mathrm{Si}$, au contraire, le caractère proprement artistique d'une oeuvre se mesure à l'écart esthétique qui la sépare, à son apparition, de l'attente de son premier public, il s'ensuit de là que cet écart, qui, impliquant une nouvelle manière de voir, est éprouvé d'abord comme source de plaisir ou d'étonnement et de perplexité peut s'effacer pour les lecteurs ultérieurs à mesure que la négativité originelle de l'oeuvre s'est changée en évidence et, devenue objet familier de l'attente, s'est intégrée à son tour à l'horizon de l'expérience esthétique à venir. C'est de ce deuxième changement d'horizon que relève notamment le classicisme de ce qu'on appelle les chefs-d'oeuvre (...). ${ }^{36}$

Essa metamorfose, no caso de Barthes, da recepção ambígua, quando não francamente negativa, de Le Degré zéro, ao sucesso dos Fragments, não só resultou na grande vendagem de seu livro de 1977, como também consagrou a figura de seu autor como um dos grandes mestres da pósmodernidade. O caráter clássico e incontestável dos escritos de Barthes contaminou sua própria figura, e, no século XXI, ele se tornou fiador de todo tipo de subversão no terreno literário ${ }^{37}$.

O espaço de tempo que separa duas realidades de recepção tão distintas comprova o caráter histórico da relação entre a obra e seu horizon d'attente. No caso deste estudo, cada obra de Barthes foi concebida como resposta a certas expectativas do meio a que seu autor pertencia, segundo sua percepção e necessidades - ou desejos - pessoais. Ou seja, seus textos foram escritos tendo em vista o contexto francês. Suas obras, portanto, não tinham qualquer relação com a situação dos estudos literários brasileiros, aumentando, assim, a distância entre elas e o horizon d'attente de seu público e potencializando seu écart esthétique. Por conseguinte, conclui-se que toda obra estrangeira tem sempre, potencialmente, maior probabilidade de obter um elevado quociente de écart esthétique, pelo simples fato de ter sido criada dentro de um sistema de referências diferente daquele de sua recepção. Isso não se traduz necessariamente em valor estético, o que me parece, assim como a Susan Suleiman, o grande problema da teoria de Jauss: a associação quase mecânica entre o valor estético de uma obra e seu écart esthétique. Nas palavras da autora,

\footnotetext{
${ }^{36}$ Ibid., p. 59.

${ }^{37}$ Prova disso é o dossiê da revista brasileira Cult dedicado ao escritor em março de 2006, cujo título é "Roland Barthes, subversivo e sedutor".
} 
The idea that a work's artistic value is directly proportional to its "negativity" with respect to the expectations of its first readers is especially appealing to modern theorists. It is not at all certain, however, that the rule holds in every case, and surely it does not hold with the mathematical precision that Jauss attributes to it. (...) It seems especially difficult to make such a claim without considering the possibility of different horizons of expectations co-existing among different publics in any one society. ${ }^{38}$

Dos diferentes horizons d'attente resultam diferentes julgamentos estéticos das obras, o que torna impossível que estes sejam incontestáveis. Penso, portanto, que as obras clássicas só devem ser consideradas enquanto tais tendo em vista seu público e o momento em que o julgamento é feito - quando e para quem um determinado livro é clássico?

Sendo relativo, o clássico é resultante do encontro entre as expectativas de seu público e a realização que o texto lhe oferece. Como Jauss enxerga que nos clássicos, mesmo quando ainda não elevados a essa categoria, existe em germe os elementos capazes de satisfazer plenamente as exigências para se atingir o Olimpo literário, ser ou não ser clássico torna-se, na maioria das vezes, uma mera questão de reconhecimento:

(...) il [o "julgamento dos séculos"] résulte du déploiement à travers le temps d'un potentiel de signification, immanent à l'oeuvre dès l'origine, qui s'actualise dans la succession des stades historiques de sa réception et qui se révèle au jugement compréhensif dans la mesure où celui-ci accomplit de façon scientifiquement contrôlée, dans sa reencontre avec la tradition, la "fusion des horizons" 39 .

A onda libertária do momento pós-estrutural estadunidense, que alimentou e alimenta os Cultural Studies, fez com que os leitores de Barthes dos anos 80 em diante lessem Le Plaisir du texte, Fragments d'un discours amoureux e La Chambre claire como manifestos pela emancipação da subjetividade individual contra o jugo técnico-científico da moda literária precedente. Barthes foi então canonizado. Mas esse fenômeno não se restringiu a seu horizon d'attente nos Estados Unidos. Com as facilidades de hoje, quando se pode obter, via internet, um livro lançado em qualquer parte do mundo em no máximo três meses, ou em poucos minutos, em formato digital, a definição de horizon d'attente se torna muito mais complexa e problematiza o conceito de obra clássica, tal como compreendida por Jauss. Por um lado, ela se torna mais homogênea, sendo partilhada por um número maior de pessoas, pois os leitores têm mais acesso a todos os livros; por outro, ela se enriquece na medida em que cada público continua tendo suas raízes próprias ao contexto em que se insere e dentro do qual faz perguntas e busca respostas.

\footnotetext{
${ }^{38}$ In "Introduction: Varieties of Audience-Oriented Criticism". Inge Crosman, Susan R. Suleiman (org.), The Reader in the Text. Essays on Audience and Interpretation, op. cit., p. 37.

${ }^{39}$ In Hans Robert Jauss, Pour une esthétique de la réception, op. cit., pp. 66-67.
} 
Tendo em vista as peculiaridades do momento presente, a obra clássica, entendo, é clássica para um público mais vasto, mas por razões diferentes. A multiplicidade de leituras que ela contém fala a diversas culturas e sua extensão não mais é essencialmente temporal, no sentido de permitir várias leituras ao longo dos séculos, mas também é espacial, pois chega a um número mais amplo de leitores, espalhados pelos cinco continentes. Assim, Barthes é conhecido como um dos pais da pósmodernidade literária em todo o mundo, mas, acredito, cada grupo de leitores o elege por uma razão diferente, pois cada grupo valoriza um aspecto de sua obra, construindo uma imagem diferente do escritor. Não só seus escritos são "galáxias de significantes" cujos sentidos se desvelam aqui e ali, cada um a seu tempo, em um lugar diferente, como as estrelas aparecem no céu ao anoitecer, mas também sua própria figura enquanto intelectual adquire contornos que acentuam um ou outro olhar, uma ou outra careta, um ou outro trejeito.

O conceito de horizon d'attente, que permite todas essas reflexões sobre a dinâmica da recepção - da recusa de uma obra a sua consagração como obra-prima -, tem nas interpretive communities, do intelectual estadunidense Stanley Fish, parentes próximos. No ensaio introdutório de seu livro Is There a text in this class? The Authority of interpretive communities ${ }^{40}$ (1980), o autor analisa seu próprio percurso de questionamentos sobre a origem do sentido nas obras literárias e de propostas de respostas centradas na figura do leitor. Deixando para trás o monopólio do autor sobre o significado, Fish revê o poder do texto, espalhado por suas estruturas linguísticas conforme postulou Barthes em 1968, em "La Mort de l'auteur" - e situa no leitor a construção de sentidos, mais precisamente no ato interpretativo. Este faz da literatura uma "categoria aberta" ${ }^{41}$, na qual cabe qualquer leitura que se faça, de qualquer obra, independentemente de critérios de verdade ou de pertinência. A rigor, cada leitor é livre para fazer as interpretações que quiser dos textos literários.

Vista dessa maneira, a literatura se torna um produto de seus leitores: são as interpretações que os leitores fazem das obras literárias que determinam o que elas são, seu valor, seu interesse, seu sucesso e seu fracasso. Contudo, tais leituras não são fruto apenas de individualidades e, portanto, meras opiniões pessoais e subjetivas. Elas integram interpretive communities, definidas por Fish como segue: "Interpretive communities are made up of those who share interpretive strategies not for reading but for writing texts, for constituting their properties. In other words these strategies

\footnotetext{
${ }^{40}$ Cambridge (Massachusetts), Londres, Harvard University Press.

${ }^{41}$ In "Introduction, or How I stopped worrying and learned to love interpretation", Is There a text in this class? The Authority of interpretive communities, op. cit, p. 11.
} 
exist prior to the act of reading and therefore determine the shape of what is read rather than, as is usually assumed, the other way around." 42

Como os horizon d'attente, que conduzem, em maior ou menor grau, as leituras que são feitas das obras literárias, as interpretive communities também são responsáveis por direcionar os modos segundo os quais são compreendidos os textos. Mais do que isso, para o autor, "rather, it [o ato de reconhecimento da literatura] proceeds from a collective decision as to what will count as literature, a decision that will be in force only so long as a community or readers or believers continues to abide by it." ${ }^{43}$ Definindo a literatura pela via da interpretação, os leitores, agrupados nas interpretive communities, acabam por criar imagens daquilo que leem. E é muito em função dessas imagens, distintas segundo cada community ou cada horizon d'attente, que acontecem as discussões entre os intelectuais ${ }^{44}$, cada grupo procurando impor sua visão de determinado livro, autor ou conceito. Barthes muitas vezes participou de verdadeiras querelas brasileiras sem o saber: sua imagem de mestre do estruturalismo e da nouvelle critique foi frequentemente oposta à de crítico de vanguarda nas décadas de 60 e 70, por exemplo. Fruto de duas percepções diferentes, de duas interpretive commuties ou de dois horizons d'attente, ambas as imagens são verdadeiras e não são inconciliáveis. Mas esse ponto de vista só é possível hoje, tendo em vista toda a trajetória intelectual de Barthes.

As afinidades entre o horizon d'attente de Jauss e as interpretive communities de Fish ratificam o papel essencial do contexto, em seu sentido amplo, de formação e de padrões vigentes, na recepção literária criadora de imagens. A história literária, vista do ângulo do leitor, passa a ser um conjunto de criações coletivas e o historiador, posição na qual me incluo, um contador de histórias, fundamentadas em diversas verdades. Não por acaso, as partes finais do ensaio-programa de Jauss são dedicadas à nova concepção de história literária nascente da estética da recepção. A tônica recai sobre a oposição entre a concepção formalista de história literária, movida por rupturas e, por isso, fragmentada, e a volta a uma concepção mais orgânica, na qual o autor enxerga laços entre o padrão estabelecido e a novidade, bem como entre esta e a vida prática do público leitor. Dentro dessa compreensão, o horizon d'attente tem papel central, uma vez que é ele que garante a coesão entre os momentos de calmaria e os sobressaltos estéticos na história literária. Jauss lança mão de uma metáfora astronômica para desenvolver essa ideia:

\footnotetext{
${ }^{42}$ Ibid., p. 14.

${ }^{43}$ Ibid., p. 11.

${ }^{44}$ Ibid., p. 15.
} 
Car si les livres qui sont produits simultanément se divisent - du point de vue de la production - en une multiplicité hétérogène, en réalité non simultanée, c'est-à-dire s'ils sont marqués par des moments différents du shaped time, de l'évolution du genre auquel ils appartiennent (de même que l'apparente simultanéité des étoiles dans le ciel d'aujourd'hui se décompose pour l'astronome en une immense diversité dans l'éloignement temporel), cette multiplicité des phénomènes littéraires, vus sous l'angle de la réception, ne s'en recompose pas moins, pour le public qui la perçoit comme la production de son temps et établit des rapports entre ces oeuvres diverses, en l'unité d'un horizon commun, fait d'attentes, de souvenirs, d'anticipations et qui determine la signification des oeuvres ${ }^{45}$.

Segundo essa linha de raciocínio, as obras só adquirem significados dentro das redes de expectativas, lembranças e antecipações que compõem os horizons d'attente. O que não está explícito no texto de Jauss é que nem todas as obras significam em determinados momentos e para determinados públicos, assim como nem todas as estrelas podem ser vistas a olho nu. Por isso, são somente determinadas obras, as de brilho mais intenso, que se constituem como balizas para uma nova configuração do horizon d'attente, à maneira como os astrônomos desenham as constelações, traçando linhas entre as estrelas principais. Pensando sempre na rede de relações de que a história literária é feita, a seus olhos, o autor escreve:

Mais la dimension historique de la littérature, sa continuité événementielle vivante qui échappe aussi bien au traditionalisme qu'au positivisme littéraires ne saurait être ressaisie que si l'historien découvre des points de coupe et met en relief des oeuvres qui permettent d'articuler de façon pertinente le cours de l'“évolution littéraire", de distinguer ses temps forts, ses césures décisives. Mais cette articulation de l'histoire littéraire ne peut être fixée ni par la statistique ni par l'arbitraire subjectif de l'historien: c'est l'effet historique des oeuvres qui en décide, l'histoire de leur réception: "ce qui est résulté de l'événement" et qui constitue, au regard de l'observateur actuel, la continuité organique de la littérature dans le passé, dont résulte sa physionomie d'aujourd'hui'" ${ }^{46}$.

No universo de Barthes no Brasil, algumas obras não brilharam o suficiente a ponto de compor o rol de estrelas que modificaram o horizon d'attente de certos grupos de intelectuais. Menções a Michelet, ao Empire des signes e a Sade, Fourier, Loyola, por exemplo, são raríssimas e suas traduções brasileiras tardias certamente contribuíram para isso. Outras obras como $S / Z$ e Roland Barthes par Roland Barthes tiveram alguma acolhida, mas pouca, se comparada ao conceito de écriture - e não a Le Degré zéro, o conceito tendo muito mais sucesso do que o próprio livro -, aos Éléments de sémiologie, à polêmica da nova crítica, a Le Plaisir du texte, à Leçon e aos Fragments. Por se tratar de um estudo de imagens, e aqui me distanciando da teoria de Jauss, não me limitei a reunir informações somente sobre as obras do escritor, mas também sobre conceitos e

\footnotetext{
${ }^{45}$ Ibid., pp. 77-78.

${ }^{46}$ Ibid., p. 79.
} 
situações em que esteve envolvido. Em alguns momentos, o brilho do líder da nouvelle critique francesa duelando com Raymond Picard ofuscou argumentações revolucionárias desenvolvidas nos Essais critiques ou em Critique et vérité. Em outros, a relação do escritor com sua mãe ocupou o lugar das reflexões sobre a morte e a memória na fotografia, presentes na Chambre Claire.

Retomando Jauss, este conclui seu ensaio com uma bonita defesa da literatura como ferramenta de conhecimento do mundo:

L'expérience de la lecture peut le [o leitor] libérer de l'adaptation sociale, des préjugés et des contraintes de sa vie réelle, en le contraignant à renouveler sa perception des choses. L'horizon d'attente propre à la littérature se distingue de celui de la praxis historique de la vie en ce que non seulement il conserve la trace des expériences faites, mais encore il anticipe des possibilités non encore réalisées, il élargit les limites du comportement social en suscitant des aspirations, des exigences et des buts nouveaux, et ouvre ainsi les voies de l'expérience à venir. ${ }^{47}$

Para o autor, mais uma vez seu conceito-chave, o de horizon d'attente, é essencial, desta vez ao processo de aquisição de conhecimento através da literatura. Por meio da compreensão de que a literatura torna o homem melhor, que data pelo menos de Montaigne, Jauss procura unir literatura e vida prática sem abrir mão da historicidade da primeira, uma vez que o processo de aprendizado não se manifesta unicamente nas mudanças de padrão de julgamento estético, mas também de moral e de comportamento, registrados nos diferentes horizons d'attente. Exemplo maior de que tais mudanças podem ter por estopim uma revolução estética é Madame Bovary (1857), obra em que o emprego sistemático do discurso indireto livre suscitou enormes discussões de fundo moral e ético, inclusive no âmbito de um processo jurídico. Por essa razão, comprovada por fatos históricos, Jauss depreende que os leitores franceses do século XIX passaram a repensar ou a ver de outra maneira as normas sociais relacionadas ao adultério.

Embora um pouco otimista demais, exagerando sobre o poder da literatura, o grande ensaio de Jauss sobre a estética da recepção não deixa de oferecer a mais completa teoria sobre as relações entre a literatura, o leitor e a história literária. Para meu trabalho de cunho histórico sobre as imagens de Barthes no Brasil, muitos procedimentos propostos pelo crítico alemão foram seguidos, outros foram adaptados às particularidades e objetivos deste estudo, conforme pontuei ao longo de minha leitura de “L'Histoire de la littérature: un défi à la théorie littéraire”. Não se trata, portanto, de uma aplicação da teoria de Jauss, ou de qualquer outra, a um determinado corpus, mas, ao contrário, da leitura desse corpus com a ajuda de pressupostos da estética da recepção de Jauss: para mim, o

${ }^{47}$ Ibid., p. 83. 
corpus é o protagonista e a teoria, a coadjuvante, ambos direcionados para o delineamento das imagens de Barthes.

\section{Barthes no Brasil}

$\mathrm{O}$ interesse pelo legado de Barthes foi explicitamente manifestado por ocasião de dois colóquios internacionais, realizados em 2003: "Roland Barthes, o saber com sabor" (de 29 de setembro a $1^{\circ}$ de outubro) na Universidade de São Paulo (USP) e "Colóquio Roland Barthes" (3 de outubro) na Universidade Federal Fluminense (UFF), com a participação de especialistas da obra de Barthes, a saber, Leyla Perrone-Moisés, uma das organizadoras dos eventos e principal divulgadora da obra de Barthes no Brasil, Antoine Compagnon e Philippe Roger. Esses colóquios foram os primeiros eventos internacionais dedicados a Barthes realizados no Brasil e, por conseguinte, momentos de revisão dos aportes de sua obra no país.

A memória desses acontecimentos acadêmicos ficou registrada na coletânea dos trabalhos apresentados, organizada por Leyla Perrone-Moisés e Maria Elizabeth Chaves de Mello, entitulada De volta a Roland Barthes (Niteroi (RJ), EdUFF, 2005). Tal como o título do livro sugere, os colóquios e a publicação - bem como eventos na França e nos Estados Unidos, a exposição de 20022003 dedicada a Barthes no Centre Georges Pompidou, em Paris, e a publicação de seus cursos no Collège de France e de suas obras completas - marcariam um retorno à obra do escritor francês, “depois de um período de relativo esquecimento, purgatório habitual por que passam os famosos recém-falecidos (...)" ${ }^{48}$. Mas será que, no contexto brasileiro, Barthes se enquadra nesse perfil de um autor que, depois de morto, caiu no esquecimento para, passados alguns anos, voltar à moda?

O texto de apresentação do volume, assinado por suas duas organizadoras, oferece um breve histórico da recepção de Barthes: "Aqui no Brasil, Barthes tem sido referido na imprensa desde o fim dos anos 60 e editado desde 1970, quando foram traduzidos Crítica e verdade e uma seleção dos Ensaios críticos, por Leyla Perrone-Moisés." ${ }^{49}$ De fato, sua presença na imprensa se tornou maior no final da década de 60, mas já em 1953, Le Degré zéro de l'écriture, primeira obra de Barthes, lançada no mesmo ano, foi objeto de um comentário crítico em O Estado de S. Paulo, assinado por Sérgio Milliet. Ao longo dos anos 50, outras menções a Barthes foram feitas em notas, artigos e rodapés jornalísticos. O mesmo se deu na década seguinte, desde seu início, citado, por exemplo, pela própria Leyla Perrone-Moisés, no mesmo jornal, ainda em 1964, portanto não exatamente no final da década, seguido por mais um artigo em 1965 (de Willy Lewin), quatro em

\footnotetext{
${ }^{48}$ De volta a Roland Barthes, “Apresentação", op. cit., p. 7.

${ }^{49}$ Ibid., p. 8.
} 
1966 (de Lívio Xavier, Álvaro Lorencini e Leyla Perrone-Moisés), etc., num movimento crescente até o final dos anos 70 .

As autoras ainda afirmam que "Depois disso, num ritmo ininterrupto, todos os seus livros foram traduzidos e publicados por diversas editoras" 50, o que contribuiu para deixar Barthes constantemente em evidência nos jornais, por meio de resenhas de suas obras e de debates que elas reacendiam ou geravam. A presença de Barthes no mercado editorial brasileiro - que ganhou fôlego com as novas edições e traduções de suas obras pela editora Martins Fontes, em coleção coordenada por Leyla Perrone-Moisés, no começo dos anos 2000 - é sinal do interesse suscitado por suas ideias, que se traduz na vendagem dos livros para o público acadêmico ligado às Humanidades, seus leitores desde os anos 50.

Como se constata que Barthes nunca deixou de ser publicado no Brasil - porque suas obras nunca deixaram de ser traduzidas, retraduzidas, reeditadas e comentadas -, ele nunca deixou de ser lido. E justamente pelos intelectuais que, no início, faziam-se presentes nos jornais para, posteriormente, migrarem para as universidades, deixando em seu lugar na grande imprensa os repórteres culturais. Estes, por sua vez, também são produtos da universidade leitora de Barthes, o que explica a presença do escritor nos jornais durante os anos 80, 90 e 2000, embora de uma maneira diferente: menos como um autor cujas ideias deveriam ser debatidas, como nos anos 50, 60 e 70, que como uma referência canonizada, parte da formação das novas gerações de intelectuais, um escritor que se lê e se discute... nas salas de aula das universidades.

O texto de apresentação a De volta a Roland Barthes ainda menciona a grande quantidade de estudantes brasileiros que se instalou em Paris durante as décadas de 60 e 70, como consequência da ditadura militar e das perseguições políticas no Brasil. Muitos desses estudantes tiveram contato com as ideias de Barthes graças à frequentação das instituições universitárias francesas e, voltando às terras brasileiras, nos anos 80 , tornaram-se professores universitários. Esse dado testemunhal ${ }^{51}$ também explica a presença de Barthes nos programas dos cursos universitários brasileiros até a atualidade.

Em que pese essa informação histórica, as autoras fazem uma constatação um pouco diferente:

\footnotetext{
${ }^{50}$ Ibidem.

51 Leyla Perrone-Moisés já fazia alusão à mesma informação de ordem histórica quando tratou da repercussão do estruturalismo no Brasil, em seu ensaio "Pós-estruturalismo e desconstrução nas Américas", publicado no livro por ela organizado, Do positivismo à desconstrução: ideias francesas na América, São Paulo, Editora da Universidade de São Paulo, 2004, p. 214.
} 
Na década de 1980, aquele Barthes estruturalista e semiológico foi rejeitado pela academia, como já havia sido abandonado por ele mesmo. As referências a ele nos trabalhos universitários tornaram-se mais raras. Em compensação, ele continuou a ser descoberto e lido pelas gerações mais jovens, independentemente das bibliografias universitárias. ${ }^{52}$

Embora os livros de cunho estruturalista de Barthes não tenham mais atraído o interesse da comunidade acadêmica nos anos 80 , suas obras desde Le Plaisir du texte continuaram a arrebanhar leitores: fora das salas de aula, como prova o estrondoso sucesso da peça Fragmentos de um discurso amoroso, em cartaz no Brasil de 1988 a 1989, segundo as próprias autoras ${ }^{53}$; mas também dentro das salas de aula, o que os artigos de Língua e Literatura evidenciam. O que mudou, nessa época, e em função da mudança de foco das obras de Barthes, foi o proveito que os intelectuais fizeram de suas ideias. Antes instrumental teórico-analítico, sua obra passou então a ser vista como um modelo contestatório aplicado contra as diversas formas do poder - não por acaso por uma geração de professores universitários que viveu os horrores de uma ditadura militar.

As autoras estão certas em apontar que os anos 80 não foram pródigos em textos sobre Barthes - em parte porque a profunda crise econômica colocava o preço do papel nas alturas e fazia com que o número de páginas dos jornais diminuísse, notadamente nos cadernos culturais, sem mencionar o encarecimento dos livros e edições de revistas acadêmicas. No entanto, passado o momento mais agudo da crise, já na década de 90, ensaios sobre Barthes voltaram a ser publicados, evidenciando o novo perfil do escritor que seus leitores construíam, o contestador de doxas.

Hoje, ainda se fala de Barthes, ainda se escreve sobre ele, tanto nos jornais como nas universidades. Seu nome é referência frequente em estudos de diversas áreas das Humanidades - no último congresso internacional da Associação Brasileira de Literatura Comparada, que congrega doutores e doutorandos em diversas especialidades, oriundos de universidades de todo o país e do exterior, realizado em julho de 2011, seu nome foi citado em nada menos do que 29 resumos de comunicações, num universo de 955, ao lado de Michel Foucault (presente em 27 resumos) e Derrida (20 resumos) ${ }^{54}$. Barthes, portanto, integra uma seleta constelação de autores atualmente tidos como canônicos na universidade brasileira.

Então, se Barthes nunca deixou a cena intelectual brasileira, como demonstrei, pode-se falar em uma "volta a Roland Barthes"? Talvez nos anos 80 e 90 não tenham sido publicados muitos estudos monográficos sobre ele, mas isso não configura um momento da crítica sobre Barthes, mas uma constante. Como foi explicitado, Barthes nunca deixou de ser referência tanto na imprensa

\footnotetext{
52 Op. cit, p. 9.

${ }^{53}$ Ibid., p 8.

${ }^{54}$ Informação obtida a partir de pesquisa realizada no caderno completo da programação do evento.
} 
cultural quanto nas universidades, nas áreas de Letras e em outras áreas. Por essa razão, talvez a expressão "volta a Roland Barthes” não seja a mais adequada de um ponto de vista histórico. Mas ela é pertinente em um sentido absoluto, como uma revisitação de sua obra, uma volta ao passado em forma de espiral, imagem emprestada de Vico e tão cara a Barthes, que a explica da seguinte maneira:

L'histoire marche en spirale, selon l'image de Vico, des choses anciennes reviennent, mais évidemment elles ne reviennent pas à la même place; par conséquent, il y a des goûts, des valeurs, des conduites, des "écritures" du passé qui peuvent revenir mais à une place très moderne. ${ }^{55}$

De volta a Roland Barthes, assim como todos os livros, todas as teses, todos os ensaios que na atualidade tratam do escritor francês, propõe-se a revisitar sua obra, trazendo à tona partes dela vistas através de um olhar renovado. O passado se presentifica e, graças a essas novas leituras, passa a ocupar um lugar importante na modernidade, pois traz em seu bojo o olhar crítico sobre o passado e a perspectiva de novas visões do presente. É nesse rol de leituras que incluo meu trabalho.

\section{Estrutura do trabalho}

O presente estudo se organiza como um percurso de leitura da recepção às obras de Barthes, buscando as imagens por ela criadas, e tendo como espinha dorsal o jornal $O$ Estado de $S$. Paulo. Tal leitura foi feita em ordem cronológica e dividida por decênios, em razão da extensão da periodização e do grande volume de textos encontrado. Essa prática se reflete na divisão dos capítulos, como segue:

O primeiro capítulo, entitulado "Corpus/ Corpo", trata do jornal O Estado de S. Paulo, compreendendo sua apresentação, a descrição do método de pesquisa empregado e os critérios que nortearam o recolhimento dos textos que compõem o corpus. Evidentemente trata-se de um capítulo teórico, mas de um espaço dedicado ao elemento central de minha pesquisa, o material estudado. Substituo, portanto, a revisão e análise de teorias de interesse para a tese por uma longa exposição do corpus, por entender que este deva ser auscultado cuidadosamente em suas vontades e peculiaridades, uma vez que será dele que sairão as imagens que pretendo elencar e discutir. Esse capítulo dá início ao estudo das imagens de Barthes dentro de seu contexto primeiro de recepção, fornecendo o panorama histórico-cultural que fundamentou as leituras do pensamento barthesiano

\footnotetext{
${ }^{55}$ Entrevista de Barthes a Jacques Henric, maio de 1977. “Entretien”, $O C$ v. 5, p. 399.
} 
pelos intelectuais brasileiros. Sua função, portanto, é a de estabelecer as bases metodológica e histórica sobre as quais a pesquisa foi desenvolvida.

O segundo capítulo inaugura a análise do corpus propriamente, sob o prisma da história cultural, situando a recepção de Barthes no contexto brasileiro. "Leituras: O Estado de S. Paulo" desmembra-se em outros quatro capítulos, sendo que cada um deles privilegia um momento da recepção de Barthes no jornal. O primeiro, “Anos 50: incompreensão”, é introduzido por análises de uma seleção de textos que citam Barthes na década de 50. Minhas leituras evidenciam o desconhecimento dos intelectuais que empregam o nome do escritor francês em seus textos, exercendo, então, uma função discursiva que prescinde de seu significado. Ao mesmo tempo, nesses anos, ocorrem as primeiras alusões ao conceito de écriture, adequadas ao contexto em que figuram. A esse quadro geral segue uma análise do comentário crítico de Sérgio Milliet sobre Le Degré zéro de l'écriture, primeiro texto dedicado a Barthes no Brasil, a partir do qual coloco em relevo a imagem do escritor, num momento em que suas obras começaram a chamar a atenção dos intelectuais brasileiros. Devido a seu caráter inaugural, estudo esse texto minuciosamente, procurando mostrar como Milliet desvia as proposições do escritor francês em função tanto da percepção do momento histórico-literário em que vive, como de suas convicções literárias pessoais. Em outras palavras, o comentário crítico de Milliet permite enxergar as duas lentes dos óculos a partir dos quais um objeto é visto em uma cultura estrangeira: o contexto histórico e os interesses de ordem pessoal. O fenômeno de refração sofrido por Le Degré zéro repete-se ano após ano, artigo após artigo, razão pela qual não me ocupo tão detalhadamente das demais análises dos textos selecionados. Ao invés de fazê-lo, procuro me ater às formas como Barthes figura nesses textos, aos temas aos quais ele é associado e às possíveis razões que conduzem os intelectuais brasileiros a ler suas obras de maneira mais ou menos enviesada. Em suma, minhas leituras buscam detectar o grau de refração sofrido pela imagem de Barthes ao chegar ao Brasil e suas causas, e não todas as minúcias desse "processo ótico", já observadas a título de exemplo no texto de Milliet.

Além dos estudos dos primeiros textos que citam Barthes e dessa análise pontual do comentário crítico, apresento outros textos jornalísticos da época que permitem estabelecer relações com a leitura inaugural de Milliet. A reconstituição da conturbada cena cultural e literária dos anos 50, com base em documentos históricos, ajuda a lançar luzes sobre a recepção de Barthes não somente naquele momento, mas também na década seguinte: o complexo universo de dualismos no qual Le Degré zéro aterrissa - universidade x sociedade, crítica tradicional x crítica universitária ecoa nos anos 60 e assume novas formas. 
No segundo capítulo analítico, que tem por título "Anos 60: apresentação”, pontuo, de início, textos em que Barthes aparece associado a grupos e formulo hipóteses para tentar explicar cada uma das etiquetas que os intelectuais brasileiros lhe colaram. Trato, em seguida, da querela da crítica francesa que, chegando ao Brasil, dá novo fôlego à continuidade dos debates da década precedente e reaviva a disputa dos anos 50 entre as críticas tradicional e universitária, sob nova roupagem: crítica tradicional x crítica estruturalista, à qual Barthes foi identificado. Dentro das discussões suscitadas pelo estruturalismo, destaca-se seu anti-humanismo, que teve ampla repercussão na imprensa brasileira. Nesse quadro, a visita de Sartre e de Simone de Beauvoir ao Brasil, em 1960, reforçou as fileiras dos “críticos humanistas” que então já denunciavam a tendência anti-humanista da moderna crítica universitária francesa. Concluo com a análise de alguns dos primeiros textos inteiramente dedicados a Barthes, que apresentam uma leitura bastante diferente da de Milliet, de 1953.

O terceiro capítulo de análise do corpus jornalístico, "Anos 70: apropriação e debates", detém-se sobre um momento em que, graças às primeiras traduções das obras de Barthes, seus livros, conceitos e ideias começaram a circular no Brasil. Como consequência, exponho dois tipos de reações por parte dos intelectuais brasileiros: por um lado, a assimilação da semiologia barthesiana e seu emprego como ferramenta analítica dos mais variados objetos; por outro, a discussão de suas obras e conceitos, pela primeira vez debatidos e não simplesmente atacados com argumentos frequentemente errôneos ou inadequados. No seio de tais discussões, mais um round da luta travada por numerosos intelectuais brasileiros contra o estruturalismo. Só que, nesse momento, envolvendo questões mais complexas, de ordem sócio-histórica, e não a simples defesa da subjetividade contra a objetividade analítica em nome de um humanismo nacionalista, recrudescido pelo pós-guerra. Separadamente, analiso também os textos consagrados exclusivamente a Barthes e a suas obras nesse momento, evidenciando quais livros e ensaios provocaram reações em seus leitores brasileiros.

O último capítulo em que estudo os textos jornalísticos sobre Barthes contempla a década de 80 em diante e tem por título "Anos 80: consagração". Nele, aponto os derradeiros suspiros dos debates literários no jornal e sua gradual substituição pela divulgação cultural. O intelectual diletante ou universitário que até então tomava da pena ou da máquina de escrever para levantar questionamentos ou participar de polêmicas literárias perdia espaço para os jornalistas recém-saídos das universidades ${ }^{56}$. O que acarretou o gradual desaparecimento dos artigos de opinião e análise e o

\footnotetext{
56 O Decreto-lei 972, de 17 de outubro de 1969, que institui a obrigatoriedade do diploma de curso superior de jornalismo para se exercer a profissão fez com que crescesse enormemente a oferta de cursos de graduação nessa área
} 
preenchimento de seu espaço por textos superficiais. Nesse contexto, Barthes, que já havia penetrado os muros das universidades brasileiras, era um autor conhecido dos professores, que integrava as bibliografias dos cursos e, portanto, era uma referência para os jovens profissionais que entravam no mercado de trabalho do jornalismo. Sua entronização nas universidades, reforçada pela canonização que a pós-modernidade dos anos 90 em diante lhe impôs, transformou o escritor francês num argumento de autoridade. $\mathrm{O}$ resultado foi o congelamento de sua imagem num retrato frio e chapado, esvaziado de sua complexidade e de sua riqueza maior: seu potencial provocador.

Como contraponto à fixidez em que o jornal aprisionou Barthes em seu post mortem, exploro o universo irrequieto dos ensaios acadêmicos, publicados na revista universitária Língua $e$ Literatura no mesmo período, no capítulo "Barthes em Língua e Literatura", a fim de colocar em relevo seu retrato mais recente, dinâmico e vivo, que reside nas universidades.

Esse último retrato é complementado pelo capítulo "A crítica atual: deslocamentos", em que faço um balanço das leituras da obra do escritor francês dos anos 90 até o presente. Para tanto, fundamento-me somente na crítica universitária, recolhida em diversas revistas cientíticas, coletâneas de artigos e obras dedicadas a Barthes, pois é na universidade que ele é discutido, e são, portanto, os universitários - professores e pós-graduandos - que delineiam sua imagem hoje. Essa imagem tem uma mesma cor, herdeira dos anos 80 e 90 pós-modernos, mas apresenta gradações diferentes, que evidencio, exploro, disseco, até chegar a um perfil, que defendo como a imagem atual do escritor no Brasil.

Por fim, meu trabalho apresenta um curto capítulo dedicado às traduções das obras de Barthes no país. Muitas vezes sendo pretexto para a publicação de artigos nos jornais, as traduções são por excelência o veículo de divulgação das ideias de todo autor em um país estrangeiro. Porém, por não se tratar de um estudo específico das traduções - o que, aliás, seria bastante fecundo, pois o conceito de écriture foi traduzido no Brasil tanto como escritura quanto como escrita, por exemplo -, mas de um estudo interessado nas imagens do escritor, as traduções integram um capítulo constituído por uma análise dos dados referentes aos anos das publicações das obras de Barthes. Esses dados são fornecidos em sua íntegra no anexo deste trabalho.

A documentação que fundamenta meu estudo é formada quase totalmente por textos inéditos em livro, e, portanto, de difícil acesso. Mesmo com a digitalização dos arquivos de $O$ Estado de S. Paulo, o acesso à íntegra dos textos permanece restrito aos assinantes do jornal. A fim

nas décadas seguintes. Os novos cursos lançaram no mercado profissionais que, não mais intelectuais de vasta erudição - autodidata ou universitária, oriunda de cursos de letras, sociologia, antropologia, história e outros domínios das Humanidades -, eram meros jornalistas culturais.

Fonte: http://www.planalto.gov.br/ccivil_03/decreto-lei/del0972.htm (consultado em 31/5/2013). 
de torná-los disponíveis a outros pesquisadores, completa o trabalho um volume anexo composto por uma seleção de textos dentre a vasta massa que compõe o corpus da pesquisa. 


\section{Corpus/ Corpo}

Le corpus: quelle belle idée! A condition que l'on veuille bien lire dans le corpus le corps: soit que dans l'ensemble des textes retenus pour l'étude (et qui forme le corpus), on recherche, non plus seulement la structure, mais les figures de l'énonciation; soit qu'on ait avec cet ensemble quelque rapport amoureux (faute de quoi le corpus n'est qu'un imaginaire scientifique). ${ }^{57}$

Roland Barthes

Em Roland Barthes par Roland Barthes, o enunciador, que é "un personnage de roman", como avisa a primeira frase do livro ${ }^{58}$, em um momento - leia-se fragmento - reflete sobre a "indifférence de la science", sua pretensa imparcialidade, sua circunspecção face ao objeto de estudo $^{59}$. O enunciador busca "dramatiser la science", ou seja, conferir-lhe um pathos a fim de individualizá-la, torná-la complexa e interessante. E localiza na ausência de arrebatamento a causa da perda de força da semiologia: “elle [a ciência semiológica] n'était souvent qu'un murmure de travaux indifférents, dont chacun indifférenciait l'objet, le texte, le corps." 60

A solução seria projetar um pathos sobre o corpus de trabalho, lendo-o como um corpo, como o enunciador de Roland Barthes par Roland Barthes sugere no fragmento citado como epígrafe a este capítulo. O corpo, então, passa a não mais ser um mero conjunto de textos e torna-se objeto de desejo, como o Outro dentro de uma relação amorosa.

O corpo desejado de Roland Barthes par Roland Barthes coincide com o do enunciador quando este utiliza a primeira pessoa do singular. Mas, por vezes, o enunciador se descola de seu objeto e emprega a terceira pessoa do singular para falar dele. Institui-se, portanto, um jogo de aproximação e distanciamento entre o enunciador e o objeto, ou o enunciador e o corpo, sujeito do texto. Tal sujeito, nomeado Roland Barthes pelo título do livro, é o corpo que se oferece ao leitor lentamente, provocando seu desejo, via fragmentos de imagens - fotografias - e fragmentos de texto - parágrafos curtos, num movimento sensual de desvelamento, como num striptease.

\footnotetext{
${ }^{57}$ Roland Barthes par Roland Barthes, OC v. 4, p. 735.

58 "Tout ceci doit être considéré comme dit par un personnage de roman". Ibid., p. 577.

${ }^{59}$ Ibid. pp. 733-735.

${ }^{60}$ Ibid. p. 733.
} 
Assim como em Roland Barthes par Roland Barthes, a imagem de Barthes construída por seus leitores brasileiros, ou melhor, seu corpo, desejado por seus leitores brasileiros, dá-se a ver aos poucos, por meio da combinação de fragmentos de origens diferentes. Esses fragmentos, textos de diversos autores e momentos, artigos, ensaios e livros, que compõem o corpus deste trabalho, serão analisados tendo-se em vista suas particularidades e suas diferenças; serão lidos como um corpo desejado, que será revelado por partes, jamais em sua íntegra. Porque a totalidade só se concretiza na fantasia.

Por suas características “corpóreas", o lugar dos textos selecionados não será meramente o de objetos de análise sobre os quais será sobreposta a visão do autor; eles desempenharão o papel de enunciadores, pois seus discursos terão espaço no trabalho. A proposta de meu trabalho é, portanto, dar voz à massa textual selecionada, ouvindo as discussões, as críticas, os elogios, as dúvidas, os comentários longínquos ou próximos proferidos pelos intelectuais brasileiros, movidos pelos mais diferentes pathos, a fim de promover uma conversa impossível e passional entre eles e Barthes. Para tanto, não renunciarei a exercer meu papel de autora, uma vez que não só selecionarei as vozes a auscultar dentro da massa ruidosa de textos que li, como as que dialogarão com as obras barthesianas e estas, apreendidas por meu olhar, particular a uma leitora brasileira no início do século XXI. Como uma ventríloqua, falarei com as vozes de outros, sem, no entanto, deixar de manifestar as paixões despertadas pelos autores e pelas polêmicas de que fizeram parte, sem deixar de expressar meus pontos de vista datados de hoje e amadurecidos dentro de uma formação historico-literária com foco nas relações entre as literaturas francesa e brasileira. Serão sujeitos da enunciação, portanto, o corpo deste trabalho e as obras de Barthes, secundados pelo contexto histórico-cultural. Tudo orquestrado pela autora, presente nas suas escolhas - estas, guiadas pela atenção à clareza da exposição e ao interesse das discussões - e sob a forma da primeira pessoa do singular.

Constituirão o corpo deste trabalho artigos jornalísticos e críticas, ensaios acadêmicos e reportagens culturais, pois este estudo não se limita a um único grupo de intelectuais, dada sua extensão temporal. Não procuro uma imagem una e nítida, mas a riqueza do múltiplo, a imagem vista no espelho quebrado.

O ecumenismo que reúne textos tão diferentes se mostra interessante para o trabalho não somente por sua abrangência, mas também por permitir o cotejo de dois universos intelectuais bastante distintos: o universo da crítica jornalística e o universo da crítica universitária. O primeiro, menos compromissado com a análise e mais interessado no debate de pontos de vista. O segundo, mais preocupado em apreender e discutir conceitos e ideias e menos interessado em divulgação. 
Ambos os universos abrigam textos de grande interesse para este estudo, não somente pelas ideias neles contidas, mas também pelo lugar e pelo momento em que esses textos são publicados.

No presente trabalho, o contexto é ferramenta importante para as análises do corpus barthesiano brasileiro e o olhar que lançarei sobre ele acabará por se sobrepor à figura de Barthes em proveito das situações dentro das quais o escritor francês foi lido: o caráter histórico deste estudo conduz ao exame das reflexões de Barthes sobre as relações entre a história e a literatura, levadas a cabo com maior desenvoltura no ensaio "Histoire ou littérature ?”, publicado em Sur Racine (1963). Ao analisar a crítica raciniana de seu tempo, apontando para a força da figura do autor e sua biografia, que oblitera a leitura da obra, Barthes resume: "De ce bilan numériquement modeste, saisissons tout de suite le vice: l'extrême difficulté d'atteindre la généralité d'un milieu à travers une oeuvre ou une vie; dès que l'on demande au groupe étudié une certaine consistance, l'individu recule (...)" 61 . Nas páginas seguintes deste capítulo, Barthes sairá de cena, momentaneamente, para dar lugar a um panorama historico-intelectual, sobre o qual se deu sua recepção no Brasil. Mas ele retornará, fragmentado, a cada momento em que for objeto de um discurso.

Tendo em mãos um corpo de textos cujas principais características são a heterogeneidade e a fragmentação, como nele encontrar a imagem de Barthes? Do mesmo modo como se monta um quebra-cabeça: primeiramente, é preciso espalhar todas as peças sobre uma mesa, a fim de que se possa estudá-las, uma a uma, para, em seguida, agrupá-las segundo seus pontos comuns. Feito isso, tem início a etapa de montagem que, no caso do quebra-cabeça da recepção de Barthes no Brasil, não é usual: não há uma imagem a se reproduzir encaixando-se as peças, uma vez que cada uma delas reflete uma faceta do escritor francês. Todavia, há imagens que serão construídas quando as peças forem todas encaixadas, refletindo, como um espelho quebrado, as imagens do escritor, particulares aos leitores brasileiros. O resultado será apenas uma tentativa de apreensão de Barthes, cujo legado ultrapassa as limitações de um estudo universitário. Mas ao menos - assim espero - será um perfil válido ${ }^{62}$ de um autor e de uma obra.

Antes de começar a montar esse quebra-cabeça de espelhos, foi preciso recolher e selecionar as peças. Dentro das limitações do presente trabalho, elas foram pesquisadas exclusivamente no jornal $O$ Estado de S. Paulo, dentro da periodização estabelecida (1953-2012),

\footnotetext{
${ }^{61}$ In $O C$ v. 2, p. 180. No mesmo texto, Barthes enfatiza: "Autrement dit, l'histoire littéraire n'est possible que si ele se fait sociologique, si ele s'intéresse aux activités et aux institutions, non aux individus" (p. 185). Discordo parcialmente do escritor pois entendo que, ao abandoná-lo em alguns momentos para tentar apreender o meio em que é citado, estarei me aproximando dos Barthes brasileiros, à maneira de Perseu, como se estivesse caminhando de costas em direção à Medusa, sem olhar diretamente para ela, mas não tirando os olhos de seu reflexo.

${ }^{62}$ Emprego o termo "válido", tradução de valide, que Barthes utiliza para caracterizar a atividade crítica, uma atividade de metalinguagem, que tem a função de construir camadas de linguagem sobre o objeto literário. In "Qu'est-ce que la critique ?", $O C$ v. 2, p.505.
} 
tendo como critério único de seleção a presença do nome de Barthes. Também foram recolhidos textos que não citam o escritor, mas que apresentam temáticas importantes para o estudo do contexto cultural em que as leituras das obras do escritor se inserem. Tratarei dos critérios de seleção dos textos ao final deste capítulo.

\section{Da Província ao Estadão, passando pela Universidade}

O Estado de S. Paulo é o mais antigo jornal em circulação no Estado de São Paulo e, atualmente, o quarto em número de exemplares no Brasil ${ }^{63}$. Sua história, que é também a história da família Mesquita, proprietária do jornal desde seus primeiros anos de existência até os dias atuais, demonstra que seu papel nunca se resumiu a relatar os acontecimentos relevantes para o Estado de São Paulo e para o país. Além de exercer a função de veículo de informações, $O$ Estado com frequência conduziu campanhas junto à sociedade e foi de encontro a interesses governamentais. Tais tomadas de posição, que refletiam os ideais e os interesses de seus proprietários, em muitas ocasiões custaram caro ao jornal.

Em 4 de janeiro 1875 publicou-se o primeiro número do jornal A Província de S. Paulo, sociedade de cotas arregimentada por Américo Brasiliense e por Manuel Ferraz de Campos Salles, com os redatores Francisco Rangel Pestana e Américo de Campos, então sócios majoritários. O jornal divulgava os ideais republicanos e abolicionistas de seus cotistas e chamou a atenção de nomes importantes das letras brasileiras que passaram a utlizá-lo como tribuna para defender a República e o fim da escravidão ${ }^{64}$.

Em janeiro de 1890, o jornal passou a se chamar O Estado de S. Paulo, em consonância com o novo vocabulário em vigor no país: com a proclamação da República em 15 de novembro de 1889, as antigas "províncias" brasileiras tornaram-se "estados". Doze anos mais tarde, um dos cotistas, Júlio Mesquita, redator do jornal desde 1885, tornou-se o único proprietário de $O$ Estado, ligando o nome de sua família a um dos periódicos mais longevos e influentes do Brasil.

Durante a chamada República Velha (1889-1930), Júlio Mesquita não deixou de assinalar, nos editoriais de $O$ Estado, sua oposição à "política dos governadores", que então dominava a vida pública brasileira. Tal "política", que na realidade era um acordo, consistia no apoio do governo federal às candidaturas dos grupos hegemônicos locais ao governo dos estados, em troca do auxílio

\footnotetext{
${ }^{63}$ Fonte : levantamento feito pela Associação Nacional de Jornais e disponível em seu sítio na internet: $\underline{\text { www.anj.org.br }}$ (consultado em 2 de maio de 2013).

${ }^{64}$ Dentre os escritores que colaboraram para $O$ Estado, destaca-se Euclides da Cunha, que, a pedido do jornal, acompanhou uma das expedições federais contra Canudos, enviando ao jornal reportagens sobre a guerra. Tais reportagens foram o laboratório para a criação do grande clássico da literatura brasileira, Os Sertões (1902).
} 
destes aos candidatos do governo federal a postos do Legislativo. Essa conjuntura, de que fazia parte toda sorte de fraude eleitoral, impossibilitava a alternância de grupos políticos no poder, nas esferas federal e estadual. Assegurava, portanto, o domínio das oligarquias agrárias nos Estados, em São Paulo, representadas pelo Partido Republicano Paulista (PRP).

O então proprietário de $O$ Estado, em conformidade com seu ideário liberal, posicionava-se contra esse sistema político, segundo textos autobiográficos e alguns historiadores ${ }^{65}$. Mas é preciso não esquecer que, filho de imigrantes portugueses, Júlio Mesquita não pertencia à oligarquia cafeeira paulista e, portanto, não tinha nenhum interesse na continuidade do sistema político praticado na época, uma vez que este não o beneficiava. Tendo na imprensa seu ramo de atividade, a ele importava, sobretudo, o crescimento da massa letrada na capital, o que não era apanágio dos governos brasileiros e paulistas da República Velha. Por essa razão, o ideário da família Mesquita, veiculado nos editoriais de $O$ Estado, representava a nova ordem social do Brasil do final do século XIX e início do XX, dos primeiros anos da República, presente maciçamente nos centros mais desenvolvidos, como São Paulo: o ideário liberal de uma elite urbana e industrial, cujo capital dependia diretamente do desenvolvimento social e tecnológico do país, em oposição à elite agrária e tradicionalista, cujo poder repousava na produção agrícola voltada para a exportação.

O descontentamento de segmentos da elite urbana com a política de privilégios favorável às oligarquias cresceu ao longo da República Velha, e grupos de oposição ao sistema vigente foram se organizando na capital paulista. Em 1926, foi fundado o Partido Democrático (PD), imbuído dos ideais liberais que marcaram malogradas tentativas anteriores de oposição aos governos, e que, em suma, lutava por grandes reformas: a adoção do voto secreto e de mecanismos que evitassem as fraudes eleitorais, a autonomia do poder judiciário em relação a interesses do governo e de setores da sociedade, uma ampla reforma do sistema de educação, assegurando a toda a população o acesso à instrução ${ }^{66}$.

Júlio Mesquita apoiava o PD, mas nem ele, e nem seu filho, Júlio de Mesquita Filho, entraram oficialmente para os quadros do partido, visando assegurar a independência de $O$ Estado diante de toda e qualquer organização política. Segundo Roberto Salone, “Ainda assim, os principais

\footnotetext{
${ }^{65}$ Essa é também a posição de Roberto Salone, biógrafo de Júlio de Mesquita Filho, e que em seu alentado estudo trata, em alguns momentos, de Júlio Mesquita, reproduzindo interessante bibliografia sobre ele. Ver Irredutivelmente liberal : política e cultura na trajetória de Júlio de Mesquita Filho, São Paulo, Albatroz Editora, 2009.

${ }^{66}$ In Maria Lígia Coelho Prado, A democracia ilustrada - o Partido Democrático de São Paulo, 1926-1934, São Paulo, Editora Ática, 1986, pp. 10-11, apud Roberto SALONE, op. cit., p. 117.
} 
diretores do jornal encontravam-se entre os fundadores do Partido Democrático e, por meio das páginas editoriais do diário, aplaudiam a criação de uma alternativa às práticas viciadas do PRP” 67 .

Fazendo frente ao PRP, por ocasião da eleição presidencial de 1930, formalizou-se a candidatura do gaúcho Getúlio Vargas, compondo a Aliança Liberal, sustentada em São Paulo pelo PD e por $O$ Estado. Tal candidatura só foi possível graças ao apoio de parte das oligarquias brasileiras, que, há anos, estavam descontentes com a política do governo federal de valorização do preço do café. $\mathrm{O}$ ápice desse descontentamento e a consequente mudança de posição das oligarquias estaduais deram-se em 1929, com a quebra da bolsa de Nova Iorque. Face à imensa crise de exportação que então se desenhava, o presidente Washington Luís, grande cafeicultor de São Paulo, na tentativa de preservar os privilégios da classe de que fazia parte - e de salvaguardar seu patrimônio -, indicou à presidência um paulista, Júlio Prestes. Com isso, desrespeitou a "política do café com leite", um acordo entre as oligarquias paulista e mineira, segundo o qual um presidente paulista deveria sempre indicar ao cargo um sucessor mineiro e vice-versa. O rompimento da influente oligarquia mineira com o governo federal garantiu à candidatura da oposição um importante aliado, que arregimentou outros grupos tradicionais descontentes com o governo de Washington Luís.

Vargas perdeu as eleições - que foram flagrantemente adulteradas - para o candidato do governo, Júlio Prestes. A fraude eleitoral foi amplamente denunciada no jornal dos Mesquita, sem nenhuma consequência prática. Mais uma vez era adiada a tão esperada revolução política, de que dependiam as demais revoluções, sobretudo a educacional. Firmava-se, no seio do PD e junto a grupos aliados, em especial militares, a ideia de uma revolução armada.

Embora profundamente legalistas, os Mesquita se posicionaram a favor da Revolução quando esta irrompeu, a 3 de abril de 1930. Em apenas alguns dias foram depostos pelo movimento, fortemente apoiado por quase todos os setores militares, presidentes de Estados nordestinos e o presidente da república, Washington Luís, assumindo seu lugar o então candidato derrotado, Getúlio Vargas. Este, no entanto, traiu os ideais e parte dos grupos que o levaram ao poder e não nomeou, para São Paulo, o interventor indicado pela coalizão. Designou um militar que, com a anuência de Vargas, infligiu a São Paulo uma política truculenta de censura e de prisão de antigos aliados democráticos. Face a tal situação, de acordo com Salone, "Em maio de 1931, O Estado de S. Paulo iniciava, em seus editoriais, a campanha pela constitucionalização do país, em resposta a Getúlio Vargas, que naquele momento considerava prematuro convocar uma Assembleia Constituinte" 68.

\footnotetext{
${ }^{67}$ Irredutivelmente liberal: política e cultura na trajetória de Júlio de Mesquita Filho, op. cit., p. 119.

${ }^{68}$ Ibid., p. 134.
} 
No começo de 1932 a indignação de São Paulo - que se manifestava em todas as classes sociais - frente ao governo provisório atingiu um marco importante: segundo notícia de $O$ Estado de S. Paulo, em 25 de janeiro, aniversário da cidade, mais de 100 mil pessoas fizeram uma passeata em apoio às reivindicações do Estado ${ }^{69}$, isto é: a nomeação de um interventor civil e paulista para São Paulo e a convocação de uma Assembleia Constituinte. A multidão parou diante da redação de $O$ Estado, de cuja sacada Júlio de Mesquita Filho discursou em prol da resistência à "ditadura" e da luta pela irradiação por todo o país do "Estado de direito, da paz e da ordem social" 70 .

O movimento armado contra Vargas organizava-se, e tinha em Júlio de Mesquita Filho um de seus principais articuladores. Ao então proprietário de $O$ Estado - seu pai, Júlio Mesquita, falecera em 1927 -, cabia coordenar a preparação militar da revolta. Seu papel era tão central na Revolução de 1932 que, em 7 de junho, Vargas, devidamente informado sobre a movimentação em São Paulo, convocou Júlio de Mesquita Filho, Waldemar Ferreira e Francisco Morato, alguns dos líderes do movimento, para uma conversa sobre a situação do Estado diante do governo federal. O então presidente propôs medidas visando apaziguar os ânimos dos paulistas que, no entanto, nunca foram concretizadas.

Deflagrada a Revolução em 9 de julho, a família Mesquita partiu para a frente de batalha: nas páginas de $O$ Estado, o apoio ao movimento era irrestrito. Júlio de Mesquita Filho lutou na cidade de Cruzeiro (situada na fronteira entre Minas Gerais e Rio de Janeiro) e seus irmãos, Francisco e Alfredo Mesquita, incorporaram-se ao grupo armado que atuou em Vila Queimada, no Vale do Paraíba ${ }^{71}$.

O esperado apoio de batalhões de Mato Grosso e do Rio Grande do Sul nunca chegou. Ao cabo de mais de três meses de guerra, a Revolução foi contida pelo governo federal, e seus líderes foram presos e exilados. Em depoimento à polícia política, cujos extratos Roberto Salone reproduz em seu livro, Júlio de Mesquita Filho assume a responsabilidade pelo movimento ${ }^{72}$. Em outubro de 1932 os prisioneiros foram enviados para a Europa, Júlio de Mesquita Filho e sua família partiram para a Itália. Durante o período de exílio europeu dos Mesquita, O Estado foi dirigido por Nestor Rangel Pestana e por Plínio Barreto, seus homens de confiança no jornal.

Embora tenha perdido a Revolução nas armas, São Paulo teve suas reivindicações atendidas em 1933. Vargas nomeou o tão esperado interventor civil e paulista: Armando de Salles Oliveira, então presidente da Sociedade Anônima O Estado de S. Paulo e cunhado de Júlio de Mesquita Filho.

\footnotetext{
${ }^{69}$ Apud Roberto Salone, op. cit., p. 138.

${ }^{70}$ Roberto Salone, op. cit., pp. 138-139.

${ }^{71}$ Ibid., p. 151.

${ }^{72}$ Ibid., pp. 153-154.
} 
Todos os expatriados foram anistiados e, em agosto do mesmo ano, a família desembarcou de volta ao Brasil. Júlio de Mesquita Filho estava obcecado pela " 'luta transformada': a criação da Universidade de São Paulo" ${ }^{73}$, seu antigo sonho.

Em 1925, Júlio de Mesquita Filho publicara A crise nacional - reflexões em torno de uma data (1925), em que colocava a educação como mola motora do desenvolvimento do Brasil ${ }^{74}$. No ano seguinte, encomendou ao educador Fernando de Azevedo uma pesquisa sobre o sistema educacional paulista, publicada ao longo de quatro meses em $O$ Estado com o título de "Inquérito sobre a instrução pública em São Paulo". Os resultados dessa pesquisa apontavam para a ausência de políticas educacionais no Estado de São Paulo e para a necessidade de um planejamento educacional com vistas à formação de uma elite esclarecida, destinada a conduzir não só São Paulo, mas todo o país, rumo a um ideal civilizador.

Por esses tempos, precisamente em 1927, São Paulo contava com 570 mil habitantes, mais da metade constituída por analfabetos. O Estado era então uma "publicação de importância nacional, feita no maior parque gráfico ao sul do Equador e com uma tiragem que chegava aos $60 \mathrm{mil}$ exemplares diários ${ }^{75}$. Ou seja, num universo de cerca de 270 mil habitantes alfabetizados, quase uma pessoa a cada quatro lia $O$ Estado, o que dá a medida da influência do jornal. Mais do que o livro de Júlio de Mesquita Filho, a pesquisa de Fernando de Azevedo, estampada nas páginas do jornal, jogou luzes sobre o problema da educação em São Paulo e no Brasil.

Com o fim da Revolução de 32, ainda sopravam ventos de desconfiança em São Paulo. A criação da universidade, além de um sonho antigo acalentado pelo grupo que estava no poder - o chamado "Grupo de $O$ Estado", em alusão ao jornal -, representado por Armando de Salles Oliveira, era também uma forma de afirmação da independência intelectual dos paulistas frente ao governo federal ${ }^{76}$. Nesse contexto, a 25 de janeiro de 1934, assinou-se o decreto que criava a Universidade de São Paulo, primeira universidade brasileira.

Até então, poucas eram as instituições de ensino superior no Brasil, todas voltadas para suprir os interesses de um país que fora colônia, durante três séculos e depois, sede de Império (1822) e da república (1889), num intervalo de apenas 67 anos. Havia, sobretudo, faculdades

\footnotetext{
${ }^{73}$ Ibid., p. 159.

${ }^{74}$ Ibid., pp. 97-111.

${ }^{75}$ Jorge Caldeira, "80 anos sem Julio Mesquita" in O Estado de S. Paulo, 15 de março de 2007, p. A20, apud Roberto Salone, op. cit., p. 120. Três anos mais tarde, em 1930, a tiragem do jornal atingia o marco dos 100 mil exemplares diários, para uma população de 887.810 mil habitantes em São Paulo, segundo o sítio internet do jornal: http://www.estadao.com.br/historico/resumo/conti4.htm (consultado em 2 de maio de 2013).

${ }^{76}$ A tese da criação da Universidade de São Paulo como passo fundamental para a concretização de um projeto de poder arquitetado por uma parte da elite paulista é desenvolvida por Irene R. Cardoso em A Universidade da comunhão paulista, São Paulo, Cortez Editora, 1992.
} 
voltadas à formação de médicos, farmacêuticos, dentistas, engenheiros e advogados, profissões essenciais para garantir o funcionamento do Estado. Nunca houvera, portanto, nenhuma preocupação institucionalizada em formar professores e muito menos em desenvolver um pensamento brasileiro.

Foi com esse intuito, de formar professores capacitados e de banir o amadorismo das escolas, bem como de fomentar o desenvolvimento de um pensamento sobre o país em seus múltiplos aspectos - geográfico, histórico, sociológico, político, antropológico, filosófico, linguístico, etc. - que a alma da universidade foi colocada na Faculdade de Filosofia, Ciências e Letras. A essa faculdade foram incorporadas a Faculdade de Direito, a Faculdade de Medicina, a Faculdade de Farmácia e Odontologia, a Escola Politécnica, o Instituto de Educação, o Instituto de Ciências Econômicas e Comerciais, a Escola de Medicina Veterinária, a Escola Superior de Agricultura "Luiz de Queiroz" (situada na cidade de Piracicaba) e a Escola de Belas Artes, além de todas as outras instituições de caráter técnico e científico do Estado ${ }^{77}$.

A Júlio de Mesquita Filho coube recrutar professores para a futura Faculdade de Filosofia, Ciências e Letras. Devido à carência, no Brasil, de profissionais suficientemente capacitados para desempenhar as funções de docência e pesquisa universitárias, Júlio de Mesquita Filho buscou na Europa os primeiros professores do núcleo central da universidade ${ }^{78}$. E ele os procurou, principalmente, na França, segundo Salone, por esta ser, à época, um exemplo de país liberal - pois o liberalismo foi a filosofia pela qual Mesquita se guiou por toda a sua vida. Mas não se pode negar que, em 1934, e durante todo o século XIX até a metade do século XX, a França era e seria o grande centro irradiador de cultura, berço no qual as elites brasileiras - agrárias e urbanas - haviam se formado e ainda se formariam. Portanto, menos por convicção ideológica que por formação, era natural que Júlio de Mesquita Filho procurasse em Paris os futuros professores para os cursos de Humanidades da Universidade de São Paulo.

Por intermédio de Georges Dumas, professor da faculdade de psicologia da Universidade de Paris e conhecido de Júlio de Mesquita Filho, foram contratados incialmente Fernand Braudel, para a cátedra de História; Paul Arbousse-Bastide e Claude Lévi-Strauss, Sociologia; Pierre Monbeig, Geografia; Jean Maugüé, Filosofia; e Pierre Hourcade, Literatura Francesa. Nos anos que se seguiram, em função de términos de contratos e de interesses pessoais dos professores, alguns foram substituídos, sempre por colegas franceses. Dentro desse quadro, lecionaram também, nos

\footnotetext{
${ }^{77}$ Informações obtidas no sítio internet da Universidade de São Paulo: http://www.usp.br/75anos/?idpag=35 (consultado em 7 de agosto de 2010).

${ }^{78}$ Roberto Salone, op. cit., p. 172.
} 
primeiros anos de funcionamento da universidade, Roger Bastide (Sociologia), Jean Gagé (História), René Courtin (Literatura Francesa) e Alfred Bonzon (Língua e Literatura Francesas), este último formou parte da geração de docentes que atuaram na área até os anos $80{ }^{79}$.

Às vésperas da formatura da primeira turma de licenciados pela Faculdade de Filosofia, Ciências e Letras, de que Júlio de Mesquita Filho foi o paraninfo, Getúlio Vargas, apoiado pelos militares e por setores conservadores da sociedade, deu o golpe de estado que inaugurou o período ditatorial conhecido como Estado Novo (1937-1945). Vargas antecipou-se às eleições presidenciais que ocorreriam em 1938, justificando sua permanência no poder como uma reação ao Plano Cohen, factóide forjado pelos militares que previa a implantação de um Estado comunista no Brasil. Tendo dissolvido o Senado e a Câmara dos Deputados, Vargas impôs uma nova constituição que reforçava consideravelmente o poder executivo.

Desde a primeira hora, $O$ Estado posicionou-se contra a ditadura de Vargas, e por isso sofreu forte censura. Júlio de Mesquita Filho, assim como o então governador de São Paulo, Armando de Salles Oliveira, foi preso e novamente exilado na Europa. Francisco Mesquita continuou à frente do jornal, desafiando o regime com denúncias constantes sobre os abusos cometidos pela ditadura Vargas. Em 1940, O Estado foi encampado pela ditadura, seus diretores foram presos e o jornal passou a circular sob a direção de Abner Mourão, indicado pelo Conselho Nacional de Imprensa. Até o término do Estado Novo, em 1945, O Estado permaneceu nas mãos da ditadura Vargas. Esses anos de publicação sob intervenção, por iniciativa da família Mesquita, são desconsiderados na história do jornal.

Com a deposição de Vargas pelos militares em 1945 e o restabelecimento dos direitos civis, O Estado voltou às mãos da família Mesquita. Os anos de redemocratização que se seguiram (19461964), para a direção do jornal, foram marcados politicamente pelos temores pela volta do varguismo e pela propaganda anticomunista, entre apoios e oposições a presidentes eleitos. Nesses anos, sobretudo, o jornal passou por profundas reformulações em sua estrutura física e nos seus quadros. Em 1950 inaugurou-se a nova sede do jornal, em um prédio especialmente construído para esse fim, na Rua Major Quedinho, e modernas rotativas foram compradas para sua impressão. Desde essa época conhecido como Estadão, dado o grande volume de páginas que comportava - o elevado número de páginas de anúncios justificava os investimentos em equipamentos novos que permitissem maior precisão e economia na diagramação do jornal. Também na década de 1950,

\footnotetext{
${ }^{79}$ A lista completa dos docentes franceses pode ser consultada no interessante estudo de Jean-Paul Lefebvre, "Les professeurs français des missions universitaires au Brésil (1934-1944)". Cahiers du Brésil Contemporain n 12, 1990, também disponível na internet no sítio :

http://www.revues.msh-paris.fr/vernumpub/8-J.P\%20Lefebvre.pdf (consultado em 2 de maio de 2013).
} 
houve uma grande renovação no corpo de colaboradores: os jornalistas de formação autodidata, autores de textos predominantemente subjetivos e de linguagem rebuscada, foram gradativamente substituídos por jovens licenciados pela Universidade de São Paulo, de formação acadêmica, comprometidos com a fundamentação teórica e a objetividade do texto. Nesse espírito de renovação fundou-se o Suplemento Literário, caderno cultural que revolucionou o espaço destinado à cultura nos jornais brasileiros, e de que tratarei mais adiante.

No início dos anos 1960, o panorama político brasileiro recomeçou a dar sinais de instabilidade. A renúncia, em agosto de 1961, do presidente eleito em 1960, Jânio Quadros, criou um impasse: pela Constituição, deveria assumir o cargo o vice-presidente, João Goulart, próximo do Partido Comunista Brasileiro e de lideranças de esquerda. Setores das Forças Armadas, deputados e uma parcela da sociedade civil - incluindo $O$ Estado - posicionaram-se contra a posse de Goulart, temendo grandes reformas sociais e a instituição de um governo comunista. Por fim, Goulart assumiu a presidência do país em setembro de 1961 e seu governo foi marcado pela forte oposição a seu plano de reformas. Num contexto de crise econômica e inflação descontrolada, sem apoio e defendendo medidas que desagradavam às elites, em 31 de março de 1964 Goulart foi vítima de um golpe orquestrado pelos militares e sustentado por setores sociais tradicionais, dentre os quais a direção de $O$ Estado.

Num primeiro momento Júlio de Mesquita Filho saudou o golpe, pois viu na junta militar que se instituiria o governo de transição necessário para restituir o equilíbrio político do país. Tal como pensara em 1930, quando apoiou o golpe militar que colocou Vargas na presidência... E tal como em 1930, decepcionou-se também em 1964, quando percebeu que os presidentes militares não iriam restabelecer a democracia em pouco tempo, como se esperava.

O Marechal Castelo Branco assumiu a presidência e passou a governar por meio de Atos Institucionais (AI), uma maneira de validar juridicamente medidas inconstitucionais, como o cerceamento de liberdades individuais e a censura dos meios de expressão. O Estado oficialmente passou à oposição em 1965, quando foi instituído o AI-2, que extinguia os partidos políticos e determinava eleição indireta para a presidência da república. Durante quase todo o período ditatorial (1964-1985), o jornal sofreu forte censura dos governos militares. Como forma de denúncia, publicava poemas de Manuel Bandeira, de Cecília Meireles e trechos de Os Lusíadas, de Camões, em lugar das matérias censuradas.

Júlio de Mesquita Filho faleceu em 1969, mesmo ano da morte de seu irmão e braço direito no jornal, Francisco Mesquita. Seus filhos assumiram os cargos de chefia nas empresas do grupo (além de O Estado, a Rádio Eldorado (1958) e o Jornal da Tarde (1966)); hoje, O Estado é dirigido 
por Ruy Mesquita. Além dos dois jornais e da rádio, o Grupo Estado é composto pela maior agência de notícias do país, a Agência Estado (1970), pela OESP Mídia (1984), a OESP Gráfica (1988) e pela TV Eldorado, do Maranhão, com retransmissoras em São Paulo, São José dos Campos, Campinas e Mogi das Cruzes ${ }^{80}$.

A partir deste breve panorama histórico, ficam evidentes as relações entre $O$ Estado de $S$. Paulo, da família Mesquita, a criação e o desenvolvimento da Universidade de São Paulo e a história do Brasil, do final do século XIX ao início do século XXI. Houve maior ênfase nos momentos que envolveram a universidade, antigo sonho de Júlio de Mesquita Filho e consequência direta da Revolução Constitucionalista de 1932, devido ao papel decisivo que essa instituição teria mais adiante: a partir dos anos 1950, a Faculdade de Filosofia, Ciências e Letras passou a ser o principal centro formador dos críticos literários paulistas, muitos deles colaborando em $O$ Estado e escrevendo sobre Barthes, além de integrar os quadros docentes da Universidade de São Paulo.

\section{Procurando agulhas em um palheiro}

As pesquisas para elaboração deste trabalho iniciaram-se em junho de 2008, após aprovação do projeto de tese na Universidade de Genebra. A primeira etapa consistiu na seleção e no recolhimento, por meio fotográfico, dos textos publicados em $O$ Estado e durou quase dois anos, pois, naquele momento, o trabalho só poderia ser feito no Arquivo Público do Estado de São Paulo, na cidade de São Paulo, consultando-se rolos de microfilmes e exemplares do jornal organizados em grossos volumes.

Porém, em 10 de maio de 2011, o Grupo Estado disponibilizou na internet, na íntegra, todo o acervo do jornal, seguindo a tendência mundial de digitalização de arquivos antes somente acessíveis para pesquisas in loco. Portanto, a descrição de meu trabalho de pesquisa, neste capítulo, faz parte de uma outra era, quando luvas e máscaras eram necessárias para se consultar fontes primárias.

Se, por um lado, o tempo que dispendi consultando o acervo foi muito maior do que teria sido se o jornal já estivesse digitalizado, no início do trabalho, por outro, o contato físico com $O$ Estado me permitiu atentar para elementos que a pesquisa via internet não evidencia. A começar pela composição do jornal: se a consulta on line conduz o pesquisador diretamente ao texto em que se encontra a palavra-chave buscada, a pesquisa manual permite que se folheie a publicação toda, oferecendo uma visão completa. Essa visão fornece informações tanto sobre os focos de interesse da

80 Informações fornecidas por Roberto Salone, op. cit., p. 307 e no sítio internet do jornal: http://www.estadao.com.br/historico/index.htm (consultado em 2 de maio de 2013). 
publicação e de seu público leitor, quanto do entorno do texto selecionado, o que é importante para um estudo de recepção: dentro de um jornal, o lugar em que determinado texto é publicado denuncia o tipo de leitor que esse texto terá. Por exemplo, a publicação de um artigo sobre literatura ao lado da coluna social tem uma significação muito diferente do mesmo estampado em um suplemento literário. Valho-me desse tipo de informação quando trato do primeiro texto sobre Barthes publicado em $O$ Estado.

Outra informação relevante para os estudos de recepção, favorecida pela pesquisa manual e que pode desaparecer com a ferramenta de busca do sítio do acervo na internet, é a compreensão da dinâmica do jornal, quando pesquisado em uma longa periodização, como no caso deste trabalho. Exemplo disso é a constatação que fiz a respeito da existência ou não de cadernos destinados às reflexões artístico-literárias: sua presença catalisa textos mais densos, enquanto sua ausência os dispersa, quando não os elimina por completo. Claro que por trás de um caderno literário está sempre um corpo de intelectuais engajados em captar textos de interesse. Mas não se deve esquecer que o próprio espaço no jornal estimula em seus leitores a reflexão e o debate, engendrando a elaboração de novos textos que são, por sua vez, oferecidos aos editores. Da mesma maneira, o perfil do caderno artístico-literário influencia o tipo de texto nele publicado: científico, reflexivo ou meramente divulgador, cada um deles demanda uma abordagem diferente dos temas e, consequentemente, espelha uma recepção diferente de Barthes. Descrevo as várias fases de $O$ Estado e suas relações com os tipos de publicações que encontrei, mais adiante, ainda neste capítulo.

Para não me limitar ao exercício de ilustração da pesquisa à moda antiga, destaco as vantagens da ferramenta de busca do acervo digitalizado de O Estado: a praticidade de consultá-lo de onde quer que se esteja e a precisão da informação pesquisada. $O$ trabalho que realizei manualmente, fiando-me exclusivamente em meus olhos, à procura dos textos que mencionavam o nome de Barthes, foi completado pela pesquisa via internet, revelando-me textos que minhas limitações, bem como as do próprio acervo, com edições faltantes, incompletas ou em mau estado de conservação, haviam deixado de lado ${ }^{81}$.

Pelo trabalho já realizado manualmente quando da digitalização do acervo de $O$ Estado, e tendo em vista as informações essenciais que ele me ofereceu, mantenho sua descrição na tese, também um pouco à guisa de homenagem aos últimos registros desse tipo de pesquisa.

\footnotetext{
${ }^{81}$ Contudo, descobri que o acervo digital de $O$ Estado contém problemas que induzem o pesquisador ao erro: não raro as páginas do jornal estão duplicadas, sobretudo a partir da década de 80 , falseando o número de ocorrências do termo pesquisado. Também há algumas páginas defeituosas que não podem ser abertas. E ainda acabei por descobrir que o instrumento de pesquisa via internet não cobre todas as ocorrências do termo "Barthes", uma vez que, na pesquisa in $l o c o$, encontrei e fotografei alguns textos que não aparecem quando da pesquisa digital.
} 
Em uma fonte de documentos tão vasta e heterogênea como o é $O$ Estado, procurar textos sobre Barthes é o mesmo que procurar agulhas em um palheiro. Dentro da periodização estudada (1953-2012), o jornal naturalmente sofreu muitas transformações em sua estrutura e organização, em consonância com os desenvolvimentos técnicos que tanto mudaram a imprensa mundial ao longo da segunda metade do século XX. De janeiro de 1953 a dezembro de 2012, O Estado passou de jornal que dificilmente contava com mais de 90 páginas aos domingos, às mais de 250 páginas dominicais (desde os anos 1970); do jornal que não circulava às segundas-feiras e nem depois de feriados, ao cotidiano publicado sete dias por semana (desde outubro de 1991); do jornal exclusivamente em preto e branco, às grandes fotografias coloridas presentes em todos os cadernos (desde outubro de 1991); do jornal que não tinha mais do que três grandes cadernos, sem títulos e identificados apenas por números ordinais, aos mais de quinze cadernos existentes na atualidade (aumentando progressivamente desde o final dos anos 1960); do jornal contendo o acanhado caderno Literatura e Arte, perdido entre as intermináveis páginas de anúncios, publicado exclusivamente aos domingos, ao Caderno 2 diário (desde abril de 1986), ao Caderno 2/ Cultura dos domingos (de junho de 1986 a março de 2010) e ao Sabático (de março de 2010 a abril de 2013), sem esquecer o já lendário Suplemento Literário dos sábados (de 1956 a 1974).

Tendo-se em vista que este trabalho se debruça sobre as imagens geradas pela recepção de um escritor, espera-se que, em um jornal, os ecos sobre suas obras e suas ideias sejam veiculados predominantemente nos cadernos culturais. Por essa razão, faz-se necessária uma apresentação da estrutura interna de $O$ Estado, dentro do período estudado, com ênfase na sucessão de seus cadernos culturais.

No início dos anos 50, o layout das páginas do jornal lembrava o de um livro tradicional: os textos eram escritos com fontes pequenas, distribuídos em linhas apertadas e divididos em colunas separadas por barras. As imagens eram raras e os anúncios, embora numerosos, tinham um design bastante primário. Naquele momento, o jornal ainda não refletia em sua estrutura a variedade de perfis de seu público leitor que, com o passar dos anos, aumentou significativamente, acompanhando o incremento da tiragem diária de $O$ Estado. Com poucos cadernos, na década de 50, textos sobre temas diferentes muitas vezes dividiam a mesma página do jornal. Tal fato era particularmente frequente em textos sobre as artes e a cultura, que só dispunham do espaço dominical proporcionado por Literatura e Arte, caderno que habitualmente tinha uma única página ou, no máximo, duas. O espaço exíguo destinado aos textos sobre as artes e a cultura fazia com que eles fossem publicados em qualquer parte do jornal: ao lado dos editoriais, em meio a reflexões 
sobre política nacional e internacional, junto a notícias sobre cidades do interior e, principalmente, na página da coluna social, entitulada "A Sociedade".

A constatação de que, no mais importante jornal da capital paulista, durante os anos 50, os textos sobre as artes e a cultura eram, com frequência, publicados em meio às notícias sociais mostra que, à moda do século XIX e início do século XX no Brasil, as discussões sobre as artes ainda eram privilégio das elites letradas. Artigos sobre obras de escritores brasileiros e estrangeiros eram publicados ao lado da crônica cotidiana e dos acontecimentos sociais da cidade, entre eles, as exposições de artes visuais, os concertos de música erudita, os espetáculos teatrais, as conferências com destaque para os ciclos de palestras sobre literatura francesa organizados pela Casa de Cultura Francesa - Aliança Francesa. A alta sociedade paulistana lia a página 4 ou a página 6 de $O$ Estado, onde era publicada "A Sociedade", para saber quais personalidades aniversariavam no dia ou haviam aderido ao jantar em homenagem a alguma eminente figura social. E, de quebra, podiam encontrar, ao lado, a análise de uma obra literária.

Mais importante do que indagar se todos os leitores de "A Sociedade" dispunham de cabedal teórico e crítico para compreender alguns dos artigos sobre literatura, publicados nessa mesma página, é constatar que elite social, mundanismo e reflexões sobre questões artísticas muitas vezes ainda andavam juntos, no Brasil da metade do século XX.

Literatura e Arte não dando conta da vazão dos textos propostos, em abril de 1956 fez-se uma primeira tentativa para organizar, ao menos, os textos literários. Surge, assim, o "Jornal Literário", uma coluna diária dentro de "A Sociedade" 82 . O espaço mostrou-se ainda insuficiente e, nesse mesmo ano, criou-se o Suplemento Literário, hoje considerado o divisor de águas do jornalismo brasileiro em matéria de cultura.

Como já visto, a década de 50 foi marcada por grandes mudanças em $O$ Estado, com a entrada dos filhos de Júlio de Mesquita Filho e de Francisco Mesquita na direção do jornal. Renovou-se não só sua estrutura física, como seu corpo de colaboradores, cujos nomes mais importantes e atuantes no Suplemento Literário, acabavam de sair da universidade.

Nessa época, a Universidade de São Paulo começava a dar seus primeiros frutos: de maio de 1941 a novembro de 1944 foi publicada a revista Clima, dedicada, sobretudo, às artes e à cultura, sob a responsabilidade de jovens talentos recém-formados na Faculdade de Filosofia, Ciências e Letras: Antonio Candido de Mello e Souza, Décio de Almeida Prado, Gilda de Moraes Rocha, posteriormente de Mello e Souza, Lourival Gomes Machado, Paulo Emílio Sales Gomes e Ruy

\footnotetext{
${ }^{82}$ O "Jornal Literário" foi, primeiramente, uma coluna fixa publicada dentro de Literatura e Arte.
} 
Coelho. O grupo propunha refletir sobre a cultura brasileira com rigor acadêmico, o que destoava do diletantismo até então dominante; por conseguinte, sua postura causava estranhamento, sobretudo aos mais velhos. Por exemplo, o poeta Oswald de Andrade, um dos líderes do modernismo brasileiro dos anos 20, não se cansava de provocar os tão jovens e já tão circunspectos membros do "Grupo Clima", fazendo piada com a erudição e o sólido arcabouço teórico que fundamentavam suas reflexões e análises. Sinal claro de mudança do paradigma crítico: a geração de modernistas das décadas de 20 e 30 era constituída, essencialmente, por intelectuais e artistas autodidatas, impressionistas, amadores, que pertenciam a um tempo em que o conhecimento se construía com a prática. Entre os modernistas e os jovens de Clima, havia, portanto, um abismo de conhecimento teórico, aberto pela criação da Universidade de São Paulo.

Numa resposta às piadas de Oswald de Andrade, Antonio Candido dizia:

(...) É preciso compreender que o surto dessa tendência para o estudo corresponde em nós a uma imposição da necessidade social de crítica. É a necessidade de pensar as coisas e as obras, inclusive as que você e seus companheiros fizeram, sem compreender bem o que estavam fazendo, como é de praxe. ${ }^{83}$

Antonio Candido falava de uma "necessidade social de crítica", como se a crítica, nos anos 40, fosse imprescindível à sociedade. Mais adiante, em depoimento, reproduzido por Heloísa Pontes em sua obra Destinos mistos: os críticos do Grupo Clima em São Paulo (1940-1968), Ruy Coelho esclarecia a postura do grupo:

Nós não revelamos grandes talentos de ficção e de poesia. As boas coisas que existiam de ficção, de poesia, eram de pessoas que já estavam formadas. Mas, do ponto de vista da crítica, uma crítica que se pretendia filosófica ou sociológica, uma crítica que visava ser mais científica, nós tivemos influência. Eu creio que em relação às revistas anteriores, no panorama da literatura brasileira, a parte principal de Clima é esta noção de crítica. Nós éramos muito universitários. Com todos os pedantismos e vícios que tem uma posição universitária. Isto marca uma certa diferença. (...) Quer dizer, nós não tínhamos muita liberdade de pilhéria, de espírito. Não havia como dentro do modernismo a frase de espírito, a exploração da veia cômica, que era uma coisa essencial. Nós éramos, como dizia Oswald de Andrade, os chato-boys. ${ }^{84}$

Assim como Antonio Candido, Ruy Coelho também situava na maneira de se fazer crítica o principal diferencial entre o "Grupo Clima" e as gerações de intelectuais que o antecederam, em

\footnotetext{
${ }^{83}$ In Mário Neme (org.), Plataforma da nova geração, Porto Alegre, 1945, p. 33. Apud Heloísa Pontes, Destinos mistos: os críticos do Grupo Clima em São Paulo (1940-1968), São Paulo, Companhia das Letras, 1998, p. 59.

${ }^{84}$ In Maria Neuma Cavalcante, Clima: contribuição para o estudo do modernismo. Dissertação de mestrado defendida na Faculdade de Filosofia, Letras e Ciências Humanas da Universidade de São Paulo, 1978, p. 202. Apud Heloísa Pontes, op. cit., pp. 98-99.
} 
especial as gerações dos modernistas. Coelho mencionava a fundamentação "filosófica ou sociológica" da crítica que o grupo praticava, o que, além de ressaltar a formação acadêmica de seus adeptos, permite hoje situar a atividade crítica dentro do sistema cultural brasileiro, como uma ferramenta para compreendê-lo. A crítica, então, começava a ser vista como uma prática cultural relevante socialmente e sua função, aos poucos, deixava de ser a da conversa por escrito entre amadores de arte, para se tornar um exercício analítico, fundamentado em teorias, principalmente, de base sociológica, visando à compreensão da sociedade brasileira. Levando em conta a diferença de instrumental teórico, Antonio Candido não via afinidades importantes entre a sua geração e a geração modernista. Para ele, essas gerações só eram ligadas pela continuidade histórica ${ }^{85}$.

Apesar da novidade que a formação universitária trazia aos jovens críticos e do consequente novo estatuto da crítica, as gerações modernistas - da fase "heróica", nos anos 20, e da fase "social", nos anos $30^{86}$ - e a geração de Clima constituíam uma linha contínua não só por uma questão de sucessão histórica, mas por terem um horizonte comum: contribuir para a construção de um país melhor, por meio da arte e da cultura. No modernismo "heróico", artistas e intelectuais voltavam seus esforços para a construção de uma arte nacional, incorporando às obras as cores e os falares do povo, buscando no folclore e nas lendas indígenas inspiração artística. Na fase "social”, buscava-se conhecer o homem brasileiro, e a literatura descobria regiões do país até então pouco lembradas.

No mesmo sentido, os intelectuais da geração de 40 tinham na crítica sua principal ferramenta de trabalho e, armados com as teorias aprendidas na universidade, estudavam com método a cultura brasileira, buscando sistematizar um pensamento crítico nacional. Portanto, em seu trabalho havia também uma preocupação de ordem construtiva, estreitamente ligada ao conhecimento da sociedade brasileira. A obra máxima dessa geração é Formação da Literatura Brasileira (1959), de Antonio Candido, segundo a qual é somente a partir da existência de uma literatura própria - a literatura brasileira - que se pode falar em identidade nacional. Essa obra se sustenta pela tese de que uma literatura só existe dentro de um sistema literário, constituído pela tríade autor-obra-público, realidade inexistente no contexto brasileiro até o século XVIII. Independentemente de toda a polêmica gerada por Formação..., que desconsidera a literatura barroca, indubitavelmente essa obra constitui-se como um marco no pensamento crítico brasileiro, pois é a primeira tentativa de fundação de uma teoria literária nacional.

\footnotetext{
${ }^{85}$ In Mário Neme, op. cit., p. 35. Apud Heloísa Pontes, op.cit., p. 59.

${ }^{86}$ João Luiz Lafetá estabelece essa nomenclatura em sua obra 1930: a crítica e o Modernismo, São Paulo, Duas Cidades/ Editora 34, 2000.
} 
A criação de uma teoria literária brasileira articula-se com a definição da identidade nacional, tema obsessivo para os modernistas e, antes ainda, para os românticos brasileiros. A geração de Clima, portanto, não rompe propriamente com a tradição brasileira de se procurar definir a identidade cultural nacional, aliás, natural para um país que obteve sua independência política somente em 1822. Essa geração rompe com as gerações precedentes num plano diferente, erigindo o rigor científico como ferramenta de análise e instituindo a crítica literária e o ensaísmo como formas de desenvolvimento de um pensamento crítico.

Em 1955, em contato com Júlio de Mesquita Filho, Antonio Candido propôs a criação de um caderno literário em $O$ Estado. Incumbido pelos Mesquita, formulou um projeto, que foi aprovado, e o Suplemento Literário entrou em circulação em 6 de outubro de 1956, sob a direção de Décio de Almeida Prado, crítico de teatro do jornal desde 1946.

O Suplemento Literário inovou por ser o primeiro caderno de cultura da imprensa brasileira, dirigido por um grupo de intelectuais com total independência, em relação ao jornal de que fazia parte. Tratava-se de um suplemento dedicado às artes com fonte e layout próprios, colunas fixas e um corpo de colaboradores composto, em sua maioria, por universitários ou exuniversitários. Nele predominava a crítica, havendo também espaço para lançamentos de livros e de discos, resenhas de obras recém-lançadas, publicação de contos e poemas inéditos, bem como desenhos e gravuras especialmente criados para a publicação.

Pela primeira vez um grande jornal dedicava tão amplo espaço à cultura - o Suplemento Literário, quando começou a circular, era composto por 8 páginas. Criou-se, com ele, um lugar perene de debates que estimulava reflexões teórico-críticas e permitia a troca de ideias e a divulgação de informações sobre arte e cultura. E tudo isso ao alcance da classe média, que a essa altura já havia entrado para o rol de leitores de $O$ Estado. O ideal modernista de disseminação da cultura a toda a população brasileira, que havia recebido um impulso fundamental com a criação da universidade, ganhava novo fôlego com a criação do Suplemento Literário, pois cultura e arte não mais eram privilégio exclusivo da elite letrada.

O nascimento do Suplemento Literário, com circulação aos sábados, não implicou na extinção imediata do apagado Literatura e Arte, que continuou ser publicado aos domingos, até novembro de 1959, conforme minha pesquisa atestou. Nesse momento, ele foi substituído pelo $7^{\circ}$ Caderno, ou pelo $4^{\circ}$ Caderno, ou ainda pelo $5^{\circ}$ Caderno, sempre aos domingos, dedicados à literatura e às artes, nos mesmos moldes de seu antecessor. Durante vários anos, houve, portanto, um caderno cultural dirigido pelos redatores de $O$ Estado e o Suplemento Literário, dirigido pelo grupo de Clima, no mesmo jornal. 
Em dezembro de 1966, Décio de Almeida Prado abandonou a direção do Suplemento Literário para assumir integralmente suas atividades de docente na Universidade de São Paulo. Em seu lugar ficou Nilo Scalzo, que explicou a Elisabeth Lorenzotti:

(...) as seções continuaram como antes, mas os colaboradores mudaram com o tempo, e foram tentadas novas fórmulas, como a das traduções. Também a direção do jornal, que antes não tomava conhecimento do Suplemento, passou a intervir, embora não de forma ostensiva, e mostrou interesse em fazer uma publicação mais jornalística ${ }^{87}$.

As críticas dentro da redação de $O$ Estado ao "regime privilegiado" de que gozava o Suplemento - alta remuneração para os colaboradores, textos assinados, quando essa não era a prática no jornal, baixíssima renda advinda dos poucos anunciantes e emprego de uma linguagem acadêmica - fizeram com que, finda a gestão direta do grupo de Clima, que tinha carta branca, a direção do jornal revisse seu caderno mais prestigiado intelectualmente, buscando dinamizá-lo e integrá-lo melhor em $O$ Estado.

No final de 1970, mais precisamente no mês de dezembro, o Suplemento Literário passou a circular aos domingos, tornando-se, a partir daí, o único espaço consagrado à cultura no jornal. Extinto o caderno sobre literatura e arte comandado por um núcleo de $O$ Estado, o caderno criado pelos intelectuais universitários deixou de ser "intocável” e começou a seguir as mesmas normas do resto do jornal. Essa nova realidade incluía atender às exigências de rentabilidade, o que pressupunha uma reforma profunda no teor e na linguagem dos textos nele veiculados, abandonando a reflexão em prol de uma vulgarização do conhecimento.

Dezembro de 1974 marca o último número do Suplemento Literário e de janeiro de 1975 a abril de 1976, em seu lugar, publicou-se, semanalmente, o Suplemento do Centenário, contendo textos de cunho histórico que homenageavam o centenário do jornal. De maio a setembro de 1976 não houve caderno cultural em $O$ Estado e, os poucos textos sobre cultura, mais uma vez foram publicados sem lugar fixo, majoritariamente aos domingos. Até que, em outubro desse ano, foi lançado o Suplemento Cultural, circulando exclusivamente aos domingos. Diferentemente do artístico e analítico Suplemento Literário, o novo caderno era mais voltado para a divulgação cultural e por isso também publicava muitos ensaios e artigos sobre física, química, biologia, filosofia e sociologia, além dos textos sobre música, literatura, artes visuais e cinema.

\footnotetext{
${ }^{87}$ In Suplemento Literário, que falta ele faz!: 1956-1974 do artístico ao jornalístico: vida e morte de um caderno cultural. São Paulo, Imprensa Oficial do Estado de São Paulo, 2007, p.63.
} 
Em junho de 1980 desapareceu o Suplemento Cultural e em seu lugar criou-se o Cultura, caderno que tentou retomar a tradição ensaística do Suplemento Literário. O Cultura, assim como os demais cadernos culturais, sofreu alterações em seu número de páginas seguindo a saúde financeira de $O$ Estado. Chegou a circular com apenas quatro páginas, nos duros anos de recessão econômica da década de 80 , um quarto do número que continha no momento de seu lançamento. Mas nunca deixou de ser publicado. Em maio de 1986, lançou-se o Caderno 2, de circulação diária, uma expansão da antiga coluna "A Sociedade" e da rubrica "Artes e Espetáculos", uma vez que, com o crescimento vertiginoso de São Paulo, multiplicaram-se também os teatros, os museus, as salas de cinema e de concertos e as galerias de arte, fundaram-se institutos culturais e o volume de eventos culturais da cidade há muito não cabia na única página que lhe era dedicada.

O Caderno 2, que circula até os dias de hoje, é, portanto, a versão moderna de "A Sociedade" e noticia os acontecimentos artísticos de São Paulo, totalmente diferente do Cultura, o caderno cultural, ensaístico e reflexivo do jornal. Em setembro de 1991 o Cultura trocou de formato: deixou de ser uma "revista" horizontal, encarte do jornal, e passou a acompanhar o formato vertical de $O$ Estado, agora um encarte do Caderno 2 aos sábados, com o nome Caderno 2/ Cultura. Mais uma vez, vida social e reflexão intelectual associavam-se, ainda que preservados seus respectivos espaços. Em novembro de 1993 aparece o Caderno 2 Especial Domingo, mais uma releitura expandida da coluna social e dos eventos artísticos da cidade. E em novembro de 1996, nasceu o Caderno 2 Fim de Semana, propondo, toda sexta-feira, programas artísticos para o final de semana. Essa configuração de cadernos culturais se manteve até 2010, quando o Caderno 2/ Cultura foi extinto e substituído pelo Sabático, caderno ensaístico publicado aos sábados, e o Caderno 2 Especial Domingo, rebatizado como Caderno 2 Domingo. Também nesse ano começou a circular aos sábados o Caderno 2 + música. Por fim, desde 22 de abril de 2013, O Estado foi comprimido em apenas três grandes cadernos, extinguindo o Sabático e o Caderno 2 + música, dentre outros, nem nada propor em seu lugar.

De 1953 a 2013, portanto, o Estado teve sete cadernos exclusivamente dedicados à cultura, a saber: Literatura e Arte (até 1959), 4 Caderno, $5^{\circ}$ Caderno e $7^{\circ}$ Caderno (1959-1970), Suplemento Literário (1956-1974), Suplemento Cultural (1976-1980), Cultura (1980-1991), Caderno 2/ Cultura (1991-2010) e Sabático (2010-2013) ${ }^{88}$. Independentemente das particularidades de cada caderno,

\footnotetext{
${ }^{88}$ Elizabeth Lorenzotti, em sua obra dedicada ao Suplemento Literário, estabelece uma cronologia dos cadernos culturais de $O$ Estado de S. Paulo que engloba o Suplemento do Centenário e o Caderno 2 (In Suplemento Literário, que falta ele faz!: 1956-1974 do artístico ao jornalístico: vida e morte de um caderno cultural, São Paulo, Imprensa Oficial do Estado de São Paulo, 2007, p. 12). Minha concepção de "caderno cultural" não se coaduna com a da referida autora, não compreendendo um suplemento de natureza comemorativa e nem um caderno voltado predominantemente para as
} 
com o passar dos anos os perfis dos colaboradores e dos leitores interessados em cultura mudaram, tendo mudado, também, os tipos de textos publicados nesses espaços.

Na década de 50, em Literatura e Arte, bem como nos textos publicados sem lugar fixo no jornal, predomina a crítica impressionista, os "comentários críticos", como Sérgio Milliet, um dos representantes dessa geração em $O$ Estado, referia-se a seus próprios textos. Nos anos 60, em grande parte graças ao Suplemento Literário, o perfil do colaborador cultural começa a mudar, com a publicação cada vez mais frequente de ensaios de professores universitários. Os textos, então, ganham em densidade e em embasamento teórico, e aparecem no jornal as primeiras notas de rodapé com referências bibliográficas. O crítico não mais faz sua apreciação da obra, expondo suas opiniões e sentimentos, mas analisa-a a partir de leituras teóricas às quais ele faz referência. Nesse momento, o rigor científico substitui as impressões. Nos anos 70 o panorama começa a mudar novamente: o mercado consumidor se segmenta e novas categorias de leitores são atraídas para o jornal, provocando a proliferação de cadernos cada vez mais especializados. A diversificação dos leitores incide não só sobre a estrutura do jornal, mas também sobre seu conteúdo, de que o Suplemento Cultural é uma prova: nessa época, interessam menos os profundos debates sobre questões teóricas do que a divulgação científica, acessível a um público mais numeroso e menos especializado. O ensaísmo perde espaço no jornal e, a partir dos anos 80, os colaboradores universitários são gradativamente substituídos por repórteres culturais, que hoje em dia predominam nos cadernos culturais. A reflexão cede espaço à notícia e, quando muito, à análise feita à vol d'oiseau.

A recepção à obra de Barthes em $O$ Estado muito oscilou em função das mutações do jornal e do contexto sócio-cultural brasileiro. Nos anos 50, o escritor quase passou despercebido, tendo sido encontrado apenas um texto sobre sua obra, um "comentário crítico" assinado por Sérgio Milliet sobre Le Degré zéro de l'écriture. Já a década de 60 foi marcada pela apresentação de Barthes aos intelectuais brasileiros, sobretudo pelas mãos de Leyla Perrone-Moisés. O escritor francês, nesse momento, foi mais citado do que propriamente analisado. Suas obras ainda não haviam chegado ao país - os primeiros livros de Barthes publicados no Brasil são Critique et vérité e uma coletânea dos Essais critiques, traduzidos e apresentados por Leyla Perrone-Moisés e publicados em um mesmo volume em 1970 - e o acesso a elas ainda era bastante restrito. Nesse momento, o parco conhecimento das obras do escritor francês limitava-se, essencialmente, aos professores universitários brasileiros que, como Leyla Perrone-Moisés, estiveram em Paris nos anos

notícias artísticas. "Caderno cultural” é, portanto, compreendido neste trabalho como um caderno dedicado à análise dos fenômenos culturais e às reflexões que eles suscitam, quaisquer que sejam os graus de profundidade das leituras nele publicadas. Nessa perspectiva, são cadernos culturais de $O$ Estado de S. Paulo, dentro da periodização estudada, aqueles citados. 
60, muitos, exilados por conta da ditadura de 1964-1985 ${ }^{89}$. Assim, somente na década seguinte (1970) Barthes passou a ser objeto de discussão no jornal: outras obras suas foram sendo paulatinamente traduzidas e suas ideias e conceitos começaram a arregimentar detratores e defensores. Nesses anos, ainda havia espaço no jornal para o debate sobre teoria da literatura, promovido pelos colaboradores universitários. No entanto, a partir da década de 80, Barthes foi progressivamente deixando de ser tema de discussões no jornal. A substituição de colaboradores universitários por repórteres culturais, por um lado, tornou $O$ Estado mais profissional, com o aparecimento de cargos com funções específicas: o jornalista esportivo, o jornalista internacional, o jornalista político, o jornalista econômico, o jornalista cultural. Por outro lado, o jornal perdeu seu papel de arena de debates, já que os repórteres culturais com formação apenas para trabalhar com "cultura", não se especializavam em nenhum assunto a ponto de poder discuti-lo seriamente, como o faziam os colaboradores universitários. Desde os anos 80, Barthes, portanto, não mais foi discutido, mas simplesmente citado, como uma referência da qual, bem ou mal, todos já haviam ouvido falar.

Diante de uma fonte de documentos tão vasta e heterogênea, portanto bastante arisca à manipulação, algumas questões sobre o método de pesquisa adotado impõem-se. A primeira questão seria onde, no jornal, deve-se procurar os textos sobre Barthes? A resposta já foi dada na reconstituição histórica dos cadernos culturais de $O$ Estado: em determinados momentos, procureios por todo o jornal, página por página; mas na maior parte da periodização, ative-me aos cadernos culturais e sociais. A complementação da pesquisa por meio do acervo digital de $O$ Estado confirmou essa hipótese, tendo encontrado poucas citações ao escritor em outras partes do jornal.

A outra pergunta que o trabalho suscita refere-se aos critérios que regem a seleção dos textos constitutivos do corpus proveniente do jornal. Estabeleci dois critérios, um objetivo e um subjetivo. O critério objetivo presidiu a escolha dos textos que compõem a espinha dorsal do corpus, os textos que citam Barthes: o fato de mencionar o nome do escritor francês foi suficiente para que o texto em questão fosse integrado ao corpus da pesquisa. A partir dos anos 80, encontrei alguns textos nos quais o nome de Barthes não está presente, mas nos quais há alusões claras a algumas de suas obras, e estes também foram incorporados à tese.

O critério subjetivo foi empregado na seleção de textos complementares aos que citam Barthes: textos que não mencionam o nome do escritor e nem suas obras e ideias, mas abordam assuntos pertencentes a campos temáticos que, de alguma maneira, interferiram na recepção de

\footnotetext{
${ }^{89}$ Leyla Perrone-Moisés, no relato de sua última conversa com Barthes, em fevereiro de 1979, menciona o interesse e a preocupação do escritor em relação aos estudantes e professores universitários brasileiros exilados em Paris. Na ocasião, Barthes pede-lhe notícias dos ex-alunos brasileiros e da situação política do país. In Roland Barthes, o saber com sabor, São Paulo, Editora Brasiliense, 1985, p. 99.
} 
Barthes. Esses textos foram agrupados sob os seguintes campos temáticos: "Tendências da crítica brasileira”, “A universidade no Brasil”, “A recepção à Nova Crítica no Brasill", "Estruturalismo”, "Cultura francesa no Brasil", "Pós-modernidade". Foram recolhidos 96 textos, selecionados de forma subjetiva, de acordo com a abordagem dos assuntos citados. Sua função é a de fornecer às análises subsídios de ordem contextual, que contribuam à compreensão das leituras feitas das obras e ideias do escritor. Para recompor os contextos teórico-críticos em que a recepção de Barthes acontece, acrescentei aos textos recolhidos uma seleção bibliográfica sobre os assuntos privilegiados pelos campos temáticos. 


\section{Leituras de Barthes em $O$ Estado de S. Paulo}

A análise do corpus permitiu-me distinguir quatro momentos dentro da recepção de Barthes no jornal, a saber:

- Anos 50: incompreensão;

- Anos 60: apresentação;

- Anos 70: apropriaçãoo e debates;

- A partir dos anos 80: consagração.

Esta divisão fundamenta-se não somente em balizas cronológicas, mas leva em conta as características gerais dos textos que compõem o corpus deste trabalho. A recepção a Barthes deu-se no ritmo não só em que suas obras se fizeram conhecer pelos intelectuais brasileiros, como também em função do crescente interesse despertado pelas pesquisas desenvolvidas à luz da linguística, desde os anos 60. Por essa razão, se nos anos 50 Barthes quase não foi notado pela crítica brasileira, esta começava a manifestar-se sobre o new criticism, cujos ecos, ainda longínquos, aos poucos se faziam ouvir no Brasil, e preparariam a recepção à nouvelle critique. Nas duas décadas seguintes, o incremento dos estudos linguísticos nas universidades brasileiras e a tradução sistemática de obras sobre o assunto, tiveram papel fundamental na recepção a Barthes, conduzindo-o a um lugar de destaque na onda de estudos geralmente classificados como "estruturalistas". O jornal, nessa época, ainda caminhava junto à universidade e constituía um espaço de discussões acadêmicas. Dos anos 80 em diante, o hiato entre jornal e universidade foi definitivamente estabelecido e sobre Barthes, em $O$ Estado, restaram a referência ao intelectual ímpar e os ecos do sucesso de Fragments d'un discours amoureux (1977), traduzido pela primeira vez no Brasil em $1981^{90}$ e encenado em $1988^{91}$.

\footnotetext{
${ }^{90}$ Em 2003 a editora Martins Fontes (SP) publicou uma nova tradução, feita por Márcia Valéria Martinez de Aguiar.

${ }^{91}$ A peça de teatro Fragmentos de um discurso amoroso alcançou grande sucesso e ficou em cartaz em São Paulo de março a agosto de 1988.
} 


\section{Anos 50: incompreensão}

Não se censure ao crítico a desconversa. Vivemos uma época difícil e bem ousado me parece quem desde já possa apontar uma verdade qualquer na confusão e contradições reinantes. ${ }^{92}$

Sérgio Milliet

Na década de 1950 foram encontrados em O Estado de S. Paulo 10 textos que citam Barthes, mas somente o primeiro é dedicado ao escritor francês: bastante precoce, publicado no final de 1953, por Sérgio Milliet, é entitulado "O Grau zero da escrita”. Tratarei em especial desse texto posteriormente, pois a leitura que Milliet faz de Barthes reflete questões que vão muito além de uma visão pessoal do primeiro livro do escritor francês, apontando para problemas mais amplos que tomavam conta do contexto brasileiro da época.

Os demais textos em que Barthes aparece foram publicados principalmente no Suplemento Literário ${ }^{93}$ e não apresentam mais do que a breve citação do nome do escritor francês, acompanhado de informação pontual, a maioria sem grande importância para o desenvolvimento do texto. Por exemplo, em "Crise do teatro francês", nota de Sábato Magaldi para a coluna de teatro do Suplemento Literário, publicada em 1956, o autor noticia a crise de espectadores vivida pelos teatros franceses na época, elencando explicações de dramaturgos. Para Ionesco, grande referência em matéria de teatro moderno naquele momento, a crise é motivada por um certo "terror" que se instaurou no teatro francês e que se apresentava sob duas formas: a da rotina, como repúdio às experimentações, e a do "fanatismo doutrinário", defendida "por dois ou três Barthes, redatores da revista Théâtre Populaire, teólogos brechtólogos" 94.

O Barthes redator da Théâtre Populaire também é citado em curta nota na coluna de teatro do jornal, não mais no Suplemento Literário, mas na página que concentrava as notícias sociais e culturais, dentro do Primeiro Caderno. Em texto de 1958, que informa a publicação dos Cadernos de Teatro, do grupo O Tablado, o autor, anônimo, cita o sumário da revista, que compreende um "comentário de Barthes sobre a temporada de Jean Vilar" 95 . Esse comentário pode ser tanto o texto entitulado "Le Faiseur", como "Le Mariage de Figaro", ambos publicados por Barthes em Théâtre

\footnotetext{
${ }_{92}^{92}$ Sérgio Milliet, "O grau zero da escrita”, Primeiro Caderno, 17 de novembro de 1953, p. 8.

${ }^{93}$ A lista completa de textos em que Barthes é citado se encontra na Bibliografia deste trabalho.

${ }^{94}$ Suplemento Literário, 6 de outubro de 1956, p. 5.

${ }^{95}$ Primeiro Caderno, 24 de maio de 1958, p. 7.
} 
Populaire, em 1957, sobre as peças de Balzac encenadas por Jean Vilar, no Théâtre National Populaire, à época, em Paris.

Outra faceta de Barthes que vagamente aparece no jornal nesses primeiros anos é a do mitólogo, que já aponta para a do semiólogo. Em "Madame Solario: um sucesso anônimo", Willy Lewin resenha para o Suplemento Literário, na coluna "Letras Anglo-Americanas", de junho de 1957, esse romance de sucesso na Europa, publicado em 1956 anonimamente e por isso bastante comentado. Depois de apresentar seu enredo e, brevemente, discutir questões como a da aferição de valor a uma obra literária, o autor da crítica sinaliza, com sua simpatia pelo livro, ao dizer, perto da conclusão:

(...)Madame Solario é um best-seller rico de qualidades, um exemplar interessante e sugestivo da novelística "burguesa" cuja característica substancial (estendida também a outros gêneros), segundo o francês Roland Barthes no seu recentíssimo Mythologies, é essencialmente sinalética, isto é, impõe, transmite menos a emoção em si mesma do que os seus signos ${ }^{96}$.

No elogio de Lewin ao livro do momento aparece a menção a Barthes e a sua obra de 1957, Mythologies, sintetizada pela leitura da temática burguesa por meio dos signos. Sem maiores explicações sobre como o escritor francês articula sua crítica à sociedade francesa, aos signos que ela tenta impor como naturais, a referência a Barthes parece um toque de contemporaneidade anedótica, uma alusão meramente decorativa, com a única função de significar que o autor está atento às novidades literárias do momento.

Procedendo da mesma maneira, Antonio Dacosta, em sua coluna "De Paris...”, publicada na página social de $O$ Estado, em agosto de 1957, escreve "Simbolismo", que nada tem a ver com o movimento estético do final do século XIX, mas com... o striptease. O autor também cita brevemente Barthes para demonstrar que está a par de sua mitologia sobre o assunto, entitulada "Strip-tease", antes de nele entrar propriamente: "Referimo-nos, bem entendido, ao [striptease] de expressão parisiense, porque do outro, que o precedeu e parece obedecer, como diria R. Barthes, a outras necessidades mistificadoras, não sabemos nada" ${ }^{97}$. A menção ao escritor francês é tão breve que quem não leu Mythologies, ou seja, a grande maioria dos leitores de Dacosta, fica sem entender o que ele quer dizer: só se sabe qual é o "outro" striptease quando se lê a mitologia barthesiana, que estabelece como contraponto ao parisiense, o striptease estadunidense. Sobre as "outras

\footnotetext{
${ }^{96}$ Suplemento Literário, 15 de junho de 1957, p. 1.

${ }^{97}$ Primeiro Caderno, 9 de agosto de 1957, p. 6.
} 
necessidades mistificadoras", o leitor também não tem informação alguma, pois o texto cala sobre Barthes logo em seguida, passando a considerações da lavra de Dacosta sobre a dança sensual.

A citação de Barthes, portanto, não tem função outra dentro do texto senão a de significar o conhecimento de textos e autores contemporâneos. Ou seja, de significar o real, de Dacosta, mesmo que este não contribua para o desenvolvimento do texto. Sua função assemelha-se à da notation insignifiante presente nas narrativas realistas que Barthes analisa em "L'Effet de réel" 98 . Para ele, trata-se de resíduos descritivos cuja única função é ancorar o texto em uma certa realidade, mesmo que vazia de significação:

(...) La "représentation" pure et simple du "réel", la relation nue de "ce qui est" (ou a été) apparaît ainsi comme une résistance au sens; cette résistance confirme la grande opposition mythique du vécu (du vivant) et de l'intelligible; il suffit de rappeler que, dans l'idéologie de notre temps, la référence obsessionnelle au "concret" (dans ce que l'on demande rhétoriquement aux sciences humaines, à la littérature, aux conduites) est toujours armée comme une machine de guerre contre le sens, comme si, par une exclusion de droit, ce qui vit ne pouvait signifier - et réciproquement" ${ }^{99}$.

Adaptando a leitura de Barthes sobre a narrativa realista para as breves notas e os artigos jornalísticos que o citam na década de 50, encontro a mesma justificativa para a presença de seu nome e do comentário sobre algumas de suas ideias, um tema ou livro recém-publicado: assinalar uma certa "realidade" do autor que o cita, uma "realidade" de atualidade, mesmo que seja um corpo estranho à organicidade do texto. Pois, como Barthes observa, “(...) le 'réel concret' devient la justification suffisante du dire" ${ }^{100}$, apesar de não ser um "real" partilhado pelos leitores nos artigos citados. Essa "realidade" auto-suficiente torna-se autista do ponto de vista da interação com os leitores de jornal, o que tem por consequência principal a obscuridade que tais citações trazem aos textos em que figuram, ao invés de aclarar ideias ou de ilustrar pontos de vista.

Configura-se, portanto, o uso do nome de Barthes como um suposto argumento de autoridade, num momento em que ele ainda não detém essa autoridade no Brasil, por ser quase desconhecido. Talvez sua autoridade resida, paradoxalmente, em seu relativo anonimato, o autor que o cita podendo ganhar pontos frente a seus colegas por apresentar uma "figurinha nova" ao contexto brasileiro. Contudo, do ponto de vista do leitor, as citações de Barthes se constituem unicamente como pontos cegos do texto.

\footnotetext{
${ }^{98}$ In $O C$ v. 3, pp. 25-32.

${ }^{99}$ Ibid., p. 30.

${ }^{100}$ Ibidem.
} 
Diferentemente desse tipo de citação, frequente na época, dois autores fazem uso de concepções barthesianas em seus textos de maneira mais fecunda, com o objetivo de complementar uma ideia. Temístocles Linhares, em "Uma obra diferente”, publicado no caderno Literatura e Arte, em 1957, discorre longamente sobre A Palavra escrita (1957), último livro de Wilson Martins, reconhecendo nessa obra um trabalho muito distinto da atividade habitual do crítico literário. Tratase de um estudo histórico sobre a escrita, o livro e as bibliotecas, que desperta o interesse de Linhares não só pela erudição e utilidade, mas sobretudo por reconhecer no tema árido o escritor que é Martins:

Não vou ao extremo de afirmar que a leitura foi gostosa, mas fiquei satisfeito por ver a presença do escritor, que não é nenhum escrivinhador comum, transparecer logo nas primeiras páginas e prosseguir airoso e expedito nas subsequentes, para mostrar como é possível aliar o gosto da erudição ao bom gosto literário ${ }^{101}$.

Jogando com as diversas facetas do autor, tema que subjaz à resenha de A Palavra escrita, Linhares fala também do crítico, do professor, do historiador e do erudito. Fixa-se nos três últimos para elogiar o livro e imagina como seria a abordagem do tema se o crítico Wilson Martins tivesse se sobreposto:

Na própria escolha do título da obra, o autor parece ter agido como professor e historiador. Se agisse como crítico, o título talvez pudesse ser A Linguagem escrita em vez de A Palavra escrita. É exato que o livro é aberto com um capítulo sobre a linguagem, mas a linguagem vista do prisma histórico. Insistindo, contudo, nesse termo, ele não fugiria aos comentários críticos, logo pressuporia a existência de alguma coisa diferente de seu conteúdo e de sua forma individual, falaria nessa ordem sacral dos sinais, a que se refere Roland Barthes, que se impõe mais como literatura ${ }^{102}$.

Ao citar Barthes em suas conjecturas sobre o uso do termo "linguagem" ao invés de "palavra", o autor demonstra ter algum conhecimento da obra do escritor francês, e faz pensar em Le Degré zéro de l'écriture, pelo conceito de écriture que se fundamenta na linguagem e substitui a ideia tradicional de literatura. A alusão a Barthes confere paternidade à ideia de que os "sinais" 103 substituem a velha concepção de forma e conteúdo. Mesmo que o leitor da época quisesse mais explicações, o que seria provável dada a novidade do conceito de "sinal", a função da citação de Barthes, no texto de Linhares, não permitiria maiores delongas, pois ele aí figura somente como

\footnotetext{
${ }^{101}$ Literatura e Arte, 16 de junho de 1957, p. 80.

${ }^{102}$ Ibidem.

103 A palavra "signo" ainda não era corrente no Brasil da época, signe sendo frequentemente traduzido por "sinal" ou "símbolo".
} 
autor de uma nova concepção que imbrica literatura e linguagem, informação que é perfeitamente compreensível ao leitor do texto, mesmo que este não conheça Le Degré zéro.

Referência semelhante a Barthes faz o próprio Wilson Martins, em rodapé entitulado “Ingleses”, publicado na coluna "Últimos Livros”, do Suplemento Literário, em dezembro de 1957. Nesse texto, ele resenha $O$ Americano tranquilo (1955) de Graham Greene e Entre o sonho e a realidade (1951) de Howard Spring, ambas as obras recém-traduzidas para o português à época. Martins classifica os dois escritores como "epígonos" de grandes romancistas e seu texto se detém sobre as características do romance vitoriano que os dois autores executam com esmero sem, no entanto, alcançar um resultado maior, uma obra de excelência.

Sem muito desmerecer Spring e Greene, apenas relegando-lhes seu lugar de autores secundários no sistema literário britânico do momento, o resenhista destaca a maior qualidade de seus romances, a saber, o espírito vitoriano, refletindo sobre os conceitos de linguagem e estilo à luz de Roland Barthes:

(...) [o romance inglês é, em sua maior parte, vitoriano] Não porque os ficcionistas britânicos manifestem reconhecida preferência pela "saga" (como diria, como disse, Galsworthy) industrial e urbana do século 19, mas porque também os seus romances ainda carregam o perfume, o "estilo" daquela época. Seria o caso de lembrar aqui a distinção de Roland Barthes, para quem, ao lado da "língua" e do "estilo" existe, em literatura, uma terceira realidade, que é a "escrita". A "escrita" seria essa coisa ainda mal definida que identifica, sobre as divergências ou as diferenças ocasionais e pessoais, os escritores de um país, de um partido, de uma crença, de uma época. Há, dizia o ensaísta francês, uma "escrita" inconfundível dos escritores comunistas, quaisquer que sejam as suas características pessoais de estilo e de língua; da mesma maneira, pode-se dizer que há uma "escrita" do romance vitoriano ${ }^{104}$.

Sem mencionar Le Degré zéro, Martins demonstra conhecer pelo menos o primeiro capítulo desse livro, "Qu'est-ce que l'écriture?", pelo emprego exato do conceito de écriture, ainda não claramente definido nessa obra, mas cujas características Barthes amplamente descreve. Sobretudo, o crítico brasileiro vai além de seu colega Temístocles Linhares e não cita o escritor francês somente como o autor de uma ideia, mas como o autor de um conceito que é utilizado no desenvolvimento da resenha. Pois Martins continua seu texto detalhando as particularidades da "escrita" do romance vitoriano e como elas estão presentes nas obras de Spring e Greene. Mesmo que um pouco timidamente, o crítico antecipa um procedimento de recepção que só se tornará comum no Brasil na década de 70, quando os intelectuais terão acesso às obras de Barthes e incorporarão suas ideias,

${ }^{104}$ Suplemento Literário, 21 de dezembro de 1957, p. 2. 
seus conceitos e suas reflexões aos textos. Até lá, esse tipo de apropriação será restrito a um pequeno número de críticos brasileiros.

Redator da revista Théâtre populaire e, portanto, brechtólogo; semiólogo, por considerar os tais "sinais" como elementos de base da linguagem e esta como a essência da literatura; um pouco mitólogo, crítico da sociedade burguesa; e, com mais propriedade, autor do conceito de écriture, ainda que mal apreendido, embora já incorporado de maneira operatória ao texto: eis como Barthes aparece aqui e ali, de maneira despretensiosa e sem alarde, nas poucas críticas dos anos 50, cujos autores ousam citá-lo.

Essa presença, mesmo que restrita e ainda bastante discreta, deve muito a Sérgio Milliet, então referência crítica na imprensa brasileira pelos longos anos de militância nas fileiras das artes visuais e da literatura. Seu texto "O Grau zero da escrita" é um dos primeiros inteiramente dedicados a Barthes publicados no Brasil. É o primeiro em O Estado, precedendo a todos os textos já analisados nesta parte de meu trabalho e, por isso, Magaldi, Dacosta, Linhares, Lewin, Martins e outros autores, cujos textos não selecionei por não serem muito significativos, são devedores ao texto de Milliet.

“O Grau zero da escrita” na verdade é um comentário, faz eco à repercussão que Le Degré zéro de l'écriture obteve por ocasião de seu lançamento na França, no início do mesmo ano, e demonstra o quão atento aos debates literários estava o crítico modernista brasileiro. Esse texto, portanto, confirma o papel de Milliet como importante intermediário entre as culturas francesa e brasileira nas décadas de 20,30,40, chegando até aos anos 50. Seu mérito em, de imediato, detectar em Barthes um autor a ser debatido, só faz aumentar quando se tem em mente que Milliet foi um escritor modernista de primeira hora, depois defensor da literatura regionalista e de concepções literárias muito distantes das do escritor francês. Ele soube reconhecer o papel importante de Barthes no cenário literário francês e brasileiro quase vinte anos antes dos críticos universitários, grupo no qual as ideias barthesianas foram discutidas e pelo qual foram assimiladas: a primeira tradução brasileira de Le Degré zéro foi publicada somente em $1971^{105}$.

"Grau zero da escrita" apareceu em "Vida Intelectual", última coluna que Milliet assinou em $O$ Estado, interrompida em 1966 pela morte do crítico. Trata-se de um espaço em que o autor ora comentava obras literárias recém-lançadas, escritores e obras do passado, ora tratava de acontecimentos da vida cultural paulista, ora publicava uma crônica de cunho literário. Ou seja, "Vida Intelectual" não tinha um tema propriamente delimitado e, por essa razão, lembrava os velhos

${ }^{105}$ O grau zero da escritura. Tradução de Anne Arnichand e Álvaro Lorencini. São Paulo, Cultrix/ Conselho Estadual de Cultura, 1971. 
rodapés de jornal escritos por intelectuais - embora o texto fosse disposto na vertical. Ainda que à época o jornal contasse com o caderno Literatura e Arte, que saía exclusivamente aos domingos, reunindo textos sobre temas culturais, "Vida Intelectual" era publicada habitualmente no primeiro caderno, sem página e nem dia fixos, quase diariamente.

A coluna de Milliet, assinada "S.M.”, tinha por vizinha "A Sociedade”, que posteriormente viria a se chamar "Vida Social", figurando em meio a notas sobre personalidades da alta sociedade paulista e acontecimentos artísticos. Em 17 de novembro de 1953, por exemplo, enquadrando os comentários sobre Le Degré zéro havia anúncios dos Móveis Artex, dos adubos para jardim Manaflor, de "Massagista para Senhoras", da joalheria Casa Bento Loeb, de um colecionador particular vendendo uma "pequena coleção de quadros de um pintor holandês: Willem Vanduerf", dentre outros. Havia também a programação dos museus e galerias de arte de São Paulo, uma nota divulgando concerto da Orquestra Sinfônica Municipal, os nomes das personalidades paulistas aniversariantes do dia, bem como a enorme lista de nomes daqueles que já haviam aderido ao jantar em homenagem ao ex-vereador da UDN Pedro Pedreschi.

Tais informações sobre o entorno da coluna de Milliet não são fortuitas, pois fornecem pistas sobre o público leitor de "Vida Intelectual", o mesmo da coluna social. Em tempos em que os cadernos culturais eram raros e consistiam em páginas sem projeto definido que simplesmente reuniam artigos sobre artes e filosofia, textos de cunho reflexivo sobre cultura eram frequentemente encontrados junto às programações de teatro, cinema, museus, concertos de música erudita, conferências e demais acontecimentos sociais, todos assuntos do interesse da alta sociedade que se queria culta e refinada. Não era, portanto, de se estranhar que a coluna fosse publicada nesse meio. E ela aí permaneceu mesmo após o surgimento do Suplemento Literário, em 1956. Fato esse que permite inferir que "Vida Intelectual" talvez fosse leve demais para integrar o Suplemento, uma vez que Milliet também nele publicou textos, mas artigos densos e analíticos, deixando os comentários para a coluna. Em resumo, mesmo que o colaborador fosse o mesmo, os textos publicados no Suplemento Literário eram mais sisudos e seguiam um certo padrão de rigor, não exigido para a publicação em outras partes do jornal.

Apesar de a coluna não aparentar ser o local ideal para a leitura de obra tão complexa e profunda quanto Le Degré zéro - por figurar na página social do jornal e por essa obra não se constituir como mais um assunto leve, característico de "Vida Intelectual" -, nela o crítico brasileiro comenta o livro, resumindo sua tese e discutindo os argumentos de Barthes. 
O Estado de S. Paulo, Primeiro Caderno, terça-feira, 17 de novembro de 1953, p. 8. 
A introdução do texto já permite ao leitor vislumbrar o tom dos comentários de Milliet, cético em relação às propostas de Barthes: “Observa um comentarista da Revue de Paris que, na atualidade, se preocupa mais a crítica em encontrar um trampolim para inesperadas hipóteses do que estudar em profundidade determinado assunto" ${ }^{106}$. Milliet, em seguida, justifica tal tendência da crítica aludindo ao momento histórico de então de maneira vaga, caracterizando-o como "difícil”. Parece-lhe natural, "coisa de seu tempo", portanto, que a crítica, negligenciando a exegese, encare sua atividade como um exercício de criação desvinculado da obra analisada. Essa percepção será partilhada por muitos intelectuais brasileiros nos anos 50 e 60 e fundamentará grande parte dos ataques dirigidos à nova crítica, grupo ao qual o nome do escritor francês será associado no Brasil.

Milliet inicia o comentário sobre o livro, não sem antes afirmar que Barthes pratica o tipo de crítica descrito na introdução, ou seja, uma crítica sem vínculos com a realidade e que não discute assunto nenhum, ocupa-se apenas com devaneios intelectuais. O crítico brasileiro avisa que Le Degré zéro de l'écriture é um livro "que está sendo discutidíssimo na Europa”, informação que estrategicamente precede seu resumo da obra, procurando manter a atenção do leitor no assunto tão comentado no velho continente.

O crítico resume sucintamente a tese contida no livro: “O que caracteriza a literatura não é a lógica, nem o estilo: é a escrita (écriture).” Empregando uma exclusão para introduzir a definição de Barthes, Milliet denuncia de antemão as bases sobre as quais repousa sua própria definição de literatura, veiculada, desde a década de 30, em suas colunas e artigos de jornal. Grande parte dos escritos do autor encontra-se publicada nos dez volumes que compõem seu Diário Crítico (São Paulo, Martins e Editora da Universidade de São Paulo, 1981-1982), abrangendo uma seleção de textos publicados entre 1940 e 1956, em que não figura o texto sobre Le Degré zéro. A razão dessa exclusão, a meu ver, reside no fato de Milliet ter selecionado publicar em volume notadamente textos sobre obras brasileiras e debates diretamente relacionados a questões artísticas e literárias que se impunham na época, o que não era o caso do comentário sobre o livro de Barthes, que toca em tais questões de maneira enviesada. A leitura do Diário Crítico permite depreender que, por "lógica", nesse contexto, Milliet se refere à coerência interna da obra literária. E por "estilo", ele entende o equilíbrio entre a forma e o conteúdo, partes constituintes de toda obra, na visão do crítico $^{107}$.

\footnotetext{
${ }^{106}$ Primeiro Caderno, 17 de novembro de 1953, p. 8.

${ }^{107}$ Tal concepção de estilo está presente, por exemplo, na leitura de Milliet das obras O Quinze, João Miguel e Caminho de Pedras, de Rachel de Queiroz, comentadas em 12 de agosto de 1948. Elogiando a "sobriedade de estilo" da autora, Milliet escreve: "Em todas essas obras de criação e mais nas crônicas ora reunidas em volume, revela-se Rachel de Queiroz uma escritora em plena posse de seu instrumento de trabalho. E isso merece um aplauso especial, nestes tempos
} 
Em seguida, Milliet escreve: "Tudo isso é claro e ao mesmo tempo confuso. Claro no enunciado das ideias, obscuro pelo significado um tanto esotérico dado ao vocabulário que emprega." Aqui, é importante salientar que "esotérico" é um adjetivo frequentemente empregado pelo crítico para caracterizar obras que ele considera herméticas ${ }^{108}$. Com esse comentário, Milliet anuncia uma crítica que se mostrará comum às obras de Barthes e às dos críticos universitários: o vocabulário visto como demasiado técnico ou simplesmente inusitado, sempre digno de nota por seus opositores.

Diante da dificuldade em apreender o conteúdo do livro, o crítico procura as definições de Barthes de "língua", "estilo" e "escrita", elementos que lhe parecem essenciais a todo conceito de literatura. Milliet reproduz a concepção de Barthes de que a língua não é peculiar à literatura pois a língua engloba a literatura, bem como outros tipos de discurso. Essa definiçãa encontra-se no início do ensaio “Qu'est-ce que l'écriture?”:

Cela veut dire que la langue est comme une Nature qui passe entièrement à travers la parole de l'écrivain, sans pourtant lui donner aucune forme, sans même la nourrir (...). Elle enferme toute la création littéraire à peu près comme le ciel, le sol et leur jonction dessinent pour l'homme un habitat familier. ${ }^{109}$

Não sendo o uso da língua a matéria-prima que caracteriza a literatura, o crítico examina então o conceito de estilo. Milliet relata que Barthes também exclui o estilo do cerne da definição de literatura, pois ele pode igualmente ser encontrado em outras artes. O crítico brasileiro, contudo, não se furta ao prazer de suscitar no leitor uma certa estranheza em relação à obra de Barthes, escrevendo displicentemente que "[o estilo] não passa de um fenômeno biológico de ordem germinativa" para o escritor francês. De fato, o segundo parágrafo de "Qu'est-ce que l'écriture?" contém a definição de estilo e, a certa altura, Barthes afirma: "Le style est proprement un phénomène d'ordre germinatif, il est la transmutation d'une Humeur" ${ }^{110}$. Milliet retoma a expressão “d'ordre germinatif” empregada por Barthes sem, no entanto, contextualizá-la, o que reforça a surpresa causada pelo uso de uma imagem biológica na definição de um termo literário. Pois a conclusão do escritor francês pelo "fenômeno biológico de ordem germinativa" se dá dentro do

de soltura estilística. Nas crônicas, sobretudo, o domínio da língua e a justeza de expressão se evidenciam nitidamente. Há páginas que são perfeitas pela adequação exata da forma ao fundo”. In Diário Crítico vol. VI, p. 155.

108 Milliet emprega o termo "esotérico", por exemplo, em texto de 5 de março de 1945, ao caracterizar a obra de início de carreira de Oswald de Andrade, mostrando que o poeta, pouco a pouco, abandonou o hermetismo formal em proveito de uma obra acessível ao leitor: "Ela [a poesia de Oswald de Andrade] parte do esotérico, do estanque e atinge o exotérico, a comunhão. Quase torre de marfim no princípio, vai-se tornando, após dura e longa relutância e toda uma série de sacrifícios retóricos, largamente participante". In Diário Crítico vol. IV, p. 61.

${ }^{109}$ In $O C$ v 1, p. 177.

${ }^{110}$ Ibid., p. 178. 
desenvolvimento de uma argumentação que prepara o leitor para a eclosão da imagem destacada pelo crítico: Barthes afirma que o estilo faz parte da natureza pessoal do escritor, tornando-se autônomo e inevitavelmente presente, e encadeia definições que, progressivamente, conduzem à imagem citada por Milliet.

Primeiramente, Barthes ressalta o caráter bruto do estilo, mostrando que "[o estilo] est une forme sans destination, il est le produit d'une poussée, non d'une intention, il est comme une dimension verticale et solitaire de la pensée" ${ }^{111}$. Tal explicação já remete à imagem de uma planta que nasce com um impulso, um empurrão para fora da semente para, então, crescer de forma vertical e solitária. O autor em seguida explicita sua alusão: "Ses références [do estilo] sont au niveau d'une biologie ou d'un passé, non d'une Histoire" ${ }^{112}$. A palavra "biologie" insere definitivamente o leitor de Le Degré zéro no universo da botânica, pertinente, para o autor, para melhor esclarecer sua compreensão de estilo. E a metáfora não mais é sugerida, mas nomeada, quando Barthes escreve: "il [o estilo] fonctionne à la façon d'une Nécessité, comme si, dans cette espèce de poussée florale, le style n'était que le terme d'une métamorphose aveugle et obstinée (...)" ${ }^{113}$. No impulso necessário ao nascimento de uma flor, expresso pela expressão "poussée florale", o autor reconhece o estilo de um escritor, e conclui que este é um fenômeno de ordem germinativa. Portanto, o leitor de “Qu'estce que l'écriture?" não é apresentado a essa definição sem antes ter passado por várias alusões, imagens e metáforas preparatórias, denotando a construção de um significado linguístico-literário com o emprego do vocabulário da botânica. Diferentemente do que acontece ao leitor de Milliet, que é confrontado com a imagem floral sem maiores explicações, o que, naturalmente, causa grande estranhamento. Graças a esse subterfúgio, o crítico brasileiro corrobora sua afirmação sobre o vocabulário "esotérico" do escritor francês, e sustenta sua tese segundo a qual muitos dos críticos de seu tempo preocupam-se mais com ideias originais do que com a objetividade de suas análises.

Refutados a língua e o estilo como elementos caracterizadores da literatura, resta a écriture, a escrita, como a traduz o crítico, conclusão a que ele chega por exclusão. Milliet procura compreender o conceito de écriture de Barthes, e conclui com as seguintes palavras: "O tom, explica-nos Roland Barthes, o tom, a maneira de dizer (le débit), a naturalidade da fala, o objetivo, a moral" 114. Tais elementos são empregados ainda em “Qu'est-ce que l'écriture?" para mostrar a diferença entre as écritures de uma série de escritores que partilhavam praticamente o mesmo contexto socio-linguístico, no intuito de demonstrar que esse conceito independe de fatores de

${ }^{111}$ Ibidem.

112 Ibidem.

${ }^{113}$ Ibidem.

${ }^{114}$ Primeiro Caderno, 17 de novembro de 1953, p. 8. 
ordem histórica. Barthes afirma que Mérimée e Lautréamont, Mallarmé e Céline, Gide e Queneau, Claudel e Camus, por exemplo, embora quase contemporâneos, praticaram écritures muito distintas. Em suas palavras, “tout les sépare, le ton, le débit, la fin, la morale, le naturel de leur parole (...)"115. Milliet reproduz os termos empregados por Barthes ressaltando o tom, mencionando-o duas vezes. Em seguida, julga: “Arbitrária é a definição, como se vê, e nos mergulha na mais profunda perplexidade" ${ }^{116}$. Milliet taxa a definição de écriture de "arbitrária", acrescida da expressão "como se vê", que, pelo emprego do índice de indeterminação do sujeito, mascara a opinião do crítico e convoca o leitor a testemunhar em seu favor, pela proximidade evocada com o uso da expressão coloquial. O crítico, que até então empregara principalmente expressões impessoais e eventualmente as primeiras pessoas do singular e do plural, volta momentaneamente à primeira pessoa do plural, via pronome oblíquo "nos". Hábil manipulador das palavras, Milliet discretamente recruta o leitor para, a seu lado, julgar a definição de Barthes espantosa, estranha, por meio do emprego de uma primeira pessoa do plural no limiar entre o "nós" de polidez, forma de primeira pessoa do singular esfumaçada, camuflada pela primeira pessoa do plural, e o "nós" significando "eu e o leitor”. E, em linguagem oral, esclarece sua concepção, ainda dentro desse regime híbrido, manifestada pelo uso do verbo "imaginar" na primeira pessoa do plural: "Sim, porque à exceção do objetivo e da moral, o resto sempre imaginamos constituísse o estilo" ${ }^{117}$.

Em seguida, o próprio crítico esclarece a causa de peculiar definição, apontando a diferença estabelecida por Barthes entre o elemento de ordem psicológica ou biológica, logo, individual, como o estilo, e fenômenos de ordem social que impõem ao escritor certas regras de expressão, mencionadas por Milliet sob a forma da "ação coercitiva do grupo". De fato, o escritor francês estabelece tal distinção, mas com o objetivo de congregar esses dois aspectos na definição de écriture: 'l'écriture est donc essentiellement la morale de la forme, c'est le choix de l'aire sociale au sein de laquelle l'écrivain décide de situer la Nature de son langage" ${ }^{118}$. O que parece espantar o crítico é a instabilidade da definição de écriture, estabelecida não sobre um único elemento, mas sobre uma ambiguidade, como Barthes afirma em outro ensaio que integra Le Degré zéro, "Écritures politiques": "On trouvera donc dans toute écriture l'ambiguïté d'un objet qui est à la fois langage et coercition (...)" $)^{119}$.

\footnotetext{
${ }^{115}$ In $O C$ v 1, p. 180.

${ }^{116}$ Primeiro Caderno, 17 de novembro de 1953, p. 8.

${ }^{117}$ Ibidem.

${ }_{118}^{118}$ In $O C$ v 1, p. 180.

${ }^{119}$ Ibid., p. 183.
} 
Milliet deixa de lado o conceito de écriture para destacar a relação desta com a História, afirmando que cada momento histórico teria a sua própria écriture, mas que, à medida em que os escritores questionam as normas de seu tempo, "vão se criando escritas antagônicas, a refletirem, no mundo atual, as contradições da civilização burguesa" ${ }^{120}$. Tal reflexão se encontra na Introdução de Le Degré zéro, mas não exatamente como Milliet a reporta. O crítico cita o exemplo dado por Barthes da relação entre os escritores e suas écritures nas épocas de apogeu da burguesia, durante o Classicismo e o Romantismo, não havendo, portanto, nenhuma relação com o "mundo atual", dos anos de 1950. Milliet desloca temporalmente a afirmação de Barthes, que remete aos séculos XVII, XVIII e XIX, inserindo-a no século XX, para sutilmente defender sua tese: para ele, as formas literárias, a partir da segunda metade do século XIX, criaram um abismo entre os escritores e o público, que lê cada vez menos. Ora, nenhuma dessas ideias está presente na obra de Barthes.

O crítico continua resumindo as ideias do escritor francês, porém distanciando-se ainda mais do texto original, ao depreender da leitura da Introdução de Le Degré zéro que "O escritor deixaria então de ser 'testemunha do universal' para se entregar ao culto da 'escrita literária', de evasão, destinada aos consumidores requintados inteiramente divorciados do povo" ${ }^{121}$. Porém, Barthes escreve o seguinte: “dès l'instant où l'écrivain a cessé d'être un témoin de l'universel pour devenir une conscience malheureuse (vers 1850), son premier geste a été de choisir l'engagement de sa forme, soit en l'assumant, soit en refusant l'écriture de son passé" ${ }^{122}$. Milliet vê na mudança de condição do escritor - de "témoin de l'universel" a "conscience malheureuse", nas palavras de Barthes - o progressivo isolamento em relação a seu público, restringindo-se esses escritores a produzir obras somente para uma pequena elite. Ora, Barthes não aborda a questão pelo viés da recepção às obras, mas pela ótica da história das formas: para ele, a nova condição do escritor engendrou a adoção de uma nova postura frente à obra literária, seja assumindo-a enquanto linguagem, fazendo dela objeto de labor, como o fez Flaubert, seja rejeitando-a, bucando silenciá-la enquanto linguagem e, consequentemente, aniquilá-la, como buscou Mallarmé, ou torná-la ausente, neutra, como o fizeram alguns escritores do século XX.

Interpretando o texto de Barthes como uma análise da problemática da distância entre o escritor e os leitores, para a qual a "escrita branca" seria a solução - "Para sair desse beco, teriam certos autores recorrido à 'escrita branca', a escrita não literária, característica de uma época pré-

\footnotetext{
${ }^{120}$ Primeiro Caderno, 17 de novembro de 1953, p. 8.

121 Ibidem.

${ }^{122}$ In $O C$ v 1, p. 172.
} 
revolucionária" 123 -, Milliet projeta em Le Degré zéro a teoria que desenvolve no ensaio "Marginalidade da pintura moderna" ${ }^{124}$, publicado pela primeira vez em 1942.

Em linhas gerais, segundo o crítico, nas civilizações Ocidentais há uma alternância entre períodos de clímax e de transição que se refletem na cultura e em suas expressões artísticas. Milliet diagnostica, da segunda metade do século XIX até seu momento presente, um período de transição e de crise, em que os artistas e escritores, com raras exceções, buscam produzir obras voltadas apenas para uma pequena elite intelectual. Esse "divórcio do povo" constitui um golpe contra a própria arte, na medida em que Milliet concebe toda obra de arte, no sentido amplo da expressão, sinônimo de comunicação, ou de "comunhão" - termo muitas vezes empregado pelo crítico - entre o autor e o público. Sob essa perspectiva, toda obra conceitual e/ou auto-referencial, por exemplo, só conseguiria se comunicar com poucos iniciados, o que reduziria o público da arte e, consequentemente, contribuiria para a diminuição de sua importância.

Quando na Introdução de Le Degré zéro o escritor explica o surgimento da écriture blanche, ele não a indica como uma solução para a tendência de elitização da literatura - pois isso não se constitui como um problema para ele. Para Barthes, a écriture blanche tem seu lugar no século XX, sendo praticada por alguns escritores, e é mais uma etapa da história da écriture descrita em Le Degré zéro: a écriture artisanale nascida com Flaubert conduziu a linguagem literária a uma busca impossível da pureza e da perfeição ao longo da segunda metade do século XIX. Ao final deste, essa busca tendeu para a desintegração da linguagem até culminar no silêncio. Posteriormente, no século XX, uma nova alternativa à linguagem literária foi posta em prática: a écriture blanche, "libérée de toute servitude à un ordre marqué du langage" ${ }^{125}$. Entretanto, Barthes, em momento algum, coloca a écriture blanche como uma solução ao problema da distância entre os escritores e seus leitores, como dá a entender Milliet na passagem que se segue: "O escritor deixaria então de ser 'testemunha do universal' para se entregar ao culto da 'escrita literária', de evasão, destinada aos consumidores requintados inteiramente divorciados do povo. Para sair desse beco, teriam certos autores recorrido à 'escrita branca' (...)" ${ }^{126}$. Nesse trecho, o crítico emprega a expressão "Para sair desse beco", de valor causal, como introdutora da solução do problema do "divórcio" entre escritores e leitores: a "escrita branca", estabelecendo, portanto, uma relação inexistente no livro de Barthes.

\footnotetext{
${ }^{123}$ Primeiro Caderno, 17 de novembro de 1953, p. 8.

${ }^{124}$ Recentemente publicado em Sérgio Milliet - 100 anos: trajetória, crítica de arte e ação cultural (org. Lisbeth Rebollo Gonçalves). São Paulo, ABCA/ Imprensa Oficial do Estado, 2004, pp. 193-245.

${ }^{125}$ In $O C$ v 1, p. 217.

${ }^{126}$ Primeiro Caderno, 17 de novembro de 1953, p. 8.
} 
Milliet conclui seu comentário de forma bastante sarcástica, começando por sentenciar: "Muito sutil, muito engenhosa a tese. Na realidade puro brinquedo intelectual, bem mais revelador de um estado de espírito infecundo do que a escrita de nosso tempo" ${ }^{127}$. O crítico volta à tese explicitada na introdução de seu comentário, associando o livro de Barthes a uma tendência da crítica de seu tempo, que se compraz com elucubrações teóricas sem qualquer relação com seu objeto de análise. E reforça: "Enquanto assim se divertem alguns, outros pesquisam seriamente a realidade contemporânea e preparam vasto material de estudo para os futuros sociólogos" ${ }^{128}$. Milliet não vê Le Degré zéro como um trabalho sério, mas como pura "diversão". Ele não enxerga na história da écriture de Barthes relações com a "realidade contemporânea", apesar de o escritor, na Introdução, resumir:

L'écriture blanche (...) c'est le dernier épisode d'une Passion de l'écriture, qui suit pas à pas le déchirement de la conscience bourgeoise.

Ce qu'on veut ici, c'est esquisser cette liaison; c'est affirmer l'existence d'une réalité formelle indépendante de la langue et du style; c'est essayer de montrer que cette troisième dimension de la Forme attache elle aussi, non sans un tragique supplémentaire, l'écrivain à sa société. ${ }^{129}$

A oposição que Milliet estabelece demonstra que ele não levou em conta o trecho acima citado, nem o sentido geral de Le Degré zéro, que recompõe a história da écriture sem se distanciar das relações entre a literatura e a sociedade. A crítica parece, portanto, improcedente.

Caráter diferente tem o estranhamento causado pela definição de écriture, fundada sobre elementos inusitados para Milliet: poeta simbolista tardio e modernista de primeira hora, sempre fundamentou seu exercício da crítica nas oposições entre nacional e estrangeiro, forma e conteúdo, hermetismo e engajamento social. Dualidades, aliás, correntes no Brasil de 1953. É, portanto, natural que Milliet discorde das proposições de Barthes e que repudie o vocabulário pouco usual com o qual o escritor expõe sua tese.

Tal julgamento de valor se apóia nos óculos a partir dos quais o crítico perscruta Le Degré zéro: uma das lentes permite ver as ideias barthesianas segundo a bagagem de Milliet e a outra mostra o pensamento do escritor francês pelo ângulo dos questionamentos existentes no contexto brasileiro. O resultado é uma imagem distorcida, refratada, e não uma imagem límpida de Barthes, pois, como demonstrei detalhadamente, Milliet usa sua leitura de Le Degré zéro tanto para expressar sua apreensão em relação ao momento em que vive, quanto para expor suas convicções literárias.

\footnotetext{
127 Ibidem.

128 Ibidem.

${ }^{129}$ In $O C$ v 1, p. 173.
} 
Por isso o comentário crítico fala mais de seu autor do que de Barthes e sua obra, conclusão a que se pode chegar frequentemente quando se estuda a recepção de um determinado escritor estrangeiro em uma cultura, como já apontavam Álvaro Manuel Machado e Daniel-Henri Pageaux em Da Literatura comparada à teoria da literatura ${ }^{130}$. O fenômeno de refração sofrido pela imagem de Barthes, seja em função das ideias pessoais daqueles que a veem, seja em função do contexto em que ela se dá a ver, repete-se em maior ou menor grau ao longo de toda a sua recepção no Brasil. Por isso, a análise minuciosa que fiz de "O Grau zero da escrita" poderia ser aplicada à imensa maioria de textos que compõem o corpus deste trabalho, e eu chegaria às mesmas conclusões. Para evitar repetições, uso o texto inaugural de Milliet como exemplo de análise do fenômeno de refração pelo qual a imagem de Barthes passou no Brasil. Nos demais textos que compõem o corpus, minha leitura buscará menos os detalhes de manipulação das frases ou ideias do escritor francês e mais o reflexo de sua imagem que transparece no espelho de palavras que é cada artigo de jornal.

Quem, então, abriu o primeiro caderno de $O$ Estado de S. Paulo à página 8 na terça-feira 17 de novembro de 1953, para conhecer os aniversariantes do dia ou para ficar a par da programação cultural da cidade, deparou-se com o comentário de Milliet sobre o livro de estreia de Roland Barthes. Como o autor da coluna, o leitor do jornal também deve ter taxado o livro como "puro brinquedo intelectual", mais um modismo parisiense sem maiores consequências.

Segundo Milliet, Le Degré zéro aparece em um momento particularmente difícil para a crítica literária. Tanto na França como no Brasil, questões sobre a crítica - seus objetivos e métodos - parecem obnubilar a própria atividade dos críticos. Milliet fala em "confusão e contradição reinantes" para caracterizar seu tempo, e seus comentários à obra de Barthes seguem a mesma direção: para Milliet, "Roland Barthes é desses ensaístas mais atentos à originalidade do que à veracidade de suas teses" ${ }^{131}$. Em suma, o que mais choca Milliet em Le Degré zéro são as definições inusitadas - notadamente o conceito barthesiano de estilo - e o vocabulário hermético empregado para expô-las.

A alusão inicial ao contexto da época, que abre o comentário de Milliet, oferece uma pista para a compreensão da leitura do crítico brasileiro, para além de suas convicções literárias pessoais. Serão, portanto, levadas em conta as discussões envolvendo cultura e literatura nos anos 50, o que permitirá não somente situar as opiniões de Milliet em seu tempo, como também acrescentar mais elementos ao estudo de seu comentário crítico, bem como aos primeiros anos da recepção de Barthes. Tais discussões serão recuperadas, principalmente, a partir de textos publicados em $O$

\footnotetext{
${ }^{130}$ Lisboa, Edições 70, 1988, p. 61.

${ }^{131}$ Primeiro Caderno, 17 de novembro de 1953, p. 8.
} 
Estado, por participarem do contexto imediato do texto de Milliet, e também por oferecerem um termômetro dos debates do momento.

A leitura de textos sobre cultura e literatura publicados em $O$ Estado de 1953 a 1959 permite destacar três linhas de pensamento distintas que convergem para uma mesma percepção, envolvendo a leitura que Milliet fez de Le Degré zéro e que será um dos paradigmas da recepção de Barthes nos anos 60. Durante a década de 50, os debates sobre a universidade brasileira, sobre as tendências da crítica literária brasileira e sobre o new criticism apontam para a mesma direção: a crítica ao hermetismo e ao isolamento frente à sociedade e ao público leitor, por parte dos intelectuais universitários e da crítica que estes praticavam, associada ao estabelecimento de um novo paradigma e de uma nova concepção da literatura.

\section{$O$ isolamento da universidade}

A universidade brasileira, em especial a Universidade de São Paulo, passou por uma crise durante as décadas de 50 e 60. Criada por um grupo pertencente à elite liberal paulista, nos anos 30 a USP tinha por objetivo oferecer uma formação de ponta às elites brasileiras que deveriam dirigir o país. Nos anos 50 esse ideal começou a ser questionado pela classe média crescente, e iniciou-se uma campanha pela reforma universitária, em nome de uma "universidade crítica e democrática", segundo o jargão da época. À universidade não mais cabia a função de formação de elites, mas trabalhar pela classe média e desempenhar um papel democratizante, estendendo seus frutos a uma parcela mais ampla da sociedade.

O sociólogo Florestan Fernandes, no livro A Questão da USP (1984), analisa detalhadamente os questionamentos pelos quais essa universidade passou durante seus primeiros cinquenta anos de existência. Suas reflexões são válidas para se pensar a universidade brasileira como um todo, pois, segundo ele, “O que ocorre com a USP não é um 'caso particular'. A USP é o paradigma. Universidades que floresceram a partir de um campo virgem desembocaram no mesmo impasse". 132

Fernandes afirma que "Na década de cinquenta desencadeia-se uma vigorosa denúncia do status quo universitário (...)" ${ }^{133}$, cujos termos serão colocados em destaque com a leitura de textos publicados em $O$ Estado à época. Em linhas gerais, ainda segundo Fernandes, nos anos 50,

\footnotetext{
${ }^{132}$ São Paulo, Editora Brasiliense, 1984, p. 39.

${ }^{133}$ Ibid., p. 37.
} 
Consolidou-se a ilusão de que a ciência, a pesquisa básica, o avanço tecnológico, a produção de qualquer forma de saber seria por si mesma autônoma e autonomizadora. A utopia dos fundadores [da USP], de renovação elitista equilibrada e controlada de cima, se estilhaçava e aparecia em seu lugar uma utopia de classe média emergente que vinha para conquistar o mundo. ${ }^{134}$

A classe média via com bons olhos o rigor científico característico da pesquisa universitária nascente, regado a teorias que circulavam exclusivamente dentro das universidades, pois, de uma maneira geral, eram os filhos dessa classe social que começavam a tirar proveito dele. Aos poucos, criou-se um jargão acadêmico que, ultrapassando os limites da universidade, passou a partilhar espaço, no jornal, com textos críticos e reflexivos assinados por intelectuais diletantes. Esse jargão, praticado pelos intelectuais universitários, compreendia conceitos, noções, sintaxe e léxico, em grande parte, estranhos aos leitores de jornal, e era visto não só como um tipo de discurso diferente, mas, sobretudo, como uma língua inacessível, logo, elitista. A universidade, por meio de seus produtos, uma vez mais se fechava à sociedade - mesmo que, inicialmente, em nome de uma democratização! - e esse fenômeno era percebido principalmente em termos de uma linguagem, de um poder exercido por uma nova elite intelectual, oriunda da classe média.

O crítico Wilson Martins, em sua coluna "Últimos Livros", publica em 1955 o texto entitulado "Trabalhos universitários", dedicado a três estudos recentemente produzidos por universitários da Faculdade de Filosofia, Ciências e Letras da USP ${ }^{135}$. Na introdução às resenhas desses estudos o crítico faz severos ataques às universidades brasileiras.

Para Martins, "Pode-se afirmar, sem muito exagero, que a Universidade ainda não se integrou em nossa existência coletiva" ${ }^{136}$. O crítico cita a baixa produtividade científica da maioria das universidades que, a seu ver, contentam-se em ser "meras escolas normais de médicos, engenheiros ou advogados, da mesma forma por que as faculdades de filosofia (...) adquiriam desde o início o deplorável través de se reduzirem a meras escolas normais de professores secundários" ${ }^{137}$.

Martins ataca também o autismo da produção universitária, que, com poucas exceções, circula somente intramuros, e conclama:

Não se sabe como sair desse círculo vicioso - mas, uma vez que alguma coisa precisa ser feita, eu sugeriria que se rompesse corajosamente o isolamento da Universidade mediante um

\footnotetext{
${ }^{134}$ Ibid., pp. 43-44.

135 Trata-se de Crescimento da população no Estado de São Paulo e seus aspectos econômicos (Ensaio sobre as relações entre a demografia e a economia) (1952), de José Francisco de Camargo, Aspectos fundamentais da cultura guarani (1954), de Egon Schaden e Do método em economia política (1954), de Paul Hugon, todos publicados pela Faculdade de Filosofia, Ciências e Letras da USP.

${ }^{136}$ Primeiro Caderno, 2 de novembro de 1955, p. 6.

137 Ibidem.
} 
esforço para se colocar ao alcance do grande público as suas produções e os resultados das suas pesquisas. ${ }^{138}$

Da leitura do texto de Wilson Martins depreende-se que, na década de 50, havia um hiato entre a universidade e a sociedade, que causava incômodo.

O isolamento das universidades brasileiras também é criticado por Adolfo Casais Monteiro, crítico português, desde 1954 radicado no Brasil. Em "A universidade e a cultura", texto publicado em sua coluna "Figuras e problemas do nosso tempo", em 1956, Casais Monteiro reflete sobre o isolamento das universidades face à sociedade. Na opinião do crítico,

Ela [a Universidade] não está dentro da Cidade, mas à margem. É um corpo estranho, reduzido à fabricação de doutores, isto é, de títulos, e não à formação de espíritos. Afinal, é feita de livros, em vez de ser feita de ideias. Julga-se obrigada a guardar, e não a dar; fecha-se, quando era necessário que se abrisse. Assim a designação de "professoral" se tornou quase sinônima de “dogmático" (...). ${ }^{139}$

Casais Monteiro constata a situação da universidade de seu tempo de acordo com sua função: a "fabricação de doutores", como se se tratasse de uma função utilitária, porém inútil, desprovida de conexão com a sociedade. Ora, se todo o percurso intelectual percorrido para se obter um título de doutor não serve nem à "formação de espíritos", para quê, então, serviria um doutor? Estranha, à primeira vista, a oposição estabelecida pelo crítico, mas que revela uma percepção muitas vezes corrente até os dias de hoje: a de que a formação universitária, sobretudo em níveis de pós-graduação, não teria um papel social.

O crítico fala da universidade como de um ambiente exclusivo, uma célula autônoma e, por isso, marginal. Todavia, desse "corpo estranho" emana um poder, o do professor universitário, cujas palavras são percebidas como dogmas. A universidade, portanto, é, ao mesmo tempo, uma instituição mal vista e respeitada, talvez até mesmo temida, pelos discursos nela produzidos e que chegam ao conhecimento da sociedade de tempos em tempos. Tal diagnóstico aplica-se, principalmente, às universidades europeias:

É por estes motivos que se deve depositar todas as esperanças nas Universidades ainda jovens, nas universidades dos países "novos", cuja vitalidade os parece indicar para a tarefa de dar nova vida à própria ideia de Universidade, por demais vinculada, no Velho Mundo, a esse espírito "corporativo" que a isola da realidade. ${ }^{140}$

\footnotetext{
138 Ibidem.

${ }^{139}$ Literatura e Arte, 10 de junho de 1956, [p. 1].

140 Ibidem.
} 
Ao se referir às "universidades dos países 'novos" " o crítico faz alusão às universidades estadunidenses e brasileiras. Seu texto também expressa suas desconfianças em relação ao sistema universitário europeu. Não era para menos: a leitura de Casais Monteiro denuncia a experiência de um intelectual que foi crítico feroz do provincianismo português ${ }^{141}$, esterilizador de novas ideias relativas à literatura e que revistas como Presença, de cuja direção participou, tentaram combater. Soma-se a esse contexto a ditadura de Salazar (1933-1974), que instituiu forte censura aos intelectuais, inclusive proibindo Casais Monteiro de lecionar e de assinar artigos e edições, em 1937. Quando, em 1954, com a desculpa de participar de um congresso no Brasil, Casais Monteiro sai de Portugal para nunca mais voltar, sobre uma sociedade já bastante tradicional e acanhada como a portuguesa do início do século XX, pesava também o cerceamento da liberdade de expressão que engessava os intelectuais e, obviamente, as atividades universitárias. Por essas razões, sua visão da universidade europeia não poderia ser mais negativa e, em 1956, há apenas dois anos no Brasil, contratado pela Universidade da Bahia, Casais Monteiro ainda se mostrava um tanto quanto esperançoso quando se referia às "Universidades ainda jovens".

Mas... esquecia-se o escritor que tais universidades foram criadas a partir de modelos universitários europeus? A Universidade de São Paulo, como foi visto, procurou reproduzir o mais fielmente possível as velhas universidades europeias, importando principalmente da França, para as humanidades, até mesmo seu quadro docente. Como poderiam, então, as tão recentes universidades brasileiras não repetirem o erro cometido pelas já calejadas universidades europeias?

O fato é que as universidades brasileiras estavam repetindo esse erro. Casais Monteiro resume o abismo existente entre universidade e sociedade com duas perguntas: "Por que é que a Universidade não tem influência sobre a cultura real? Por que é que existe uma 'cultura universitária', um 'espírito universitário', como se pudesse haver duas formas de cultura?" 142

As expressões que integram o adjetivo "universitário" denunciam a existência linguística de uma categoria: tudo o que se liga à universidade contém o adjetivo correspondente em sua denominação e, consequentemente, é taxado como estrangeiro, fora da realidade, marginal.

Nos anos 50, criou-se, então, um discurso sobre a universidade que enfatizava seu isolamento face à sociedade, sem perder de vista um certo poder exercido pelos universitários. Esse discurso, veiculado na imprensa - e talvez criado por ela -, nasceu como uma reação ao

\footnotetext{
${ }^{141}$ Cf. Carlos Leone, O Essencial sobre Adolfo Casais Monteiro, Lisboa, Imprensa Nacional/ Casa da Moeda, 2005, p. 26.

${ }^{142}$ Literatura e Arte, 10 de junho de 1956, [p. 1].
} 
desenvolvimento de um jargão acadêmico, percebido como um exercício de poder restrito a uma corporação. É nesse conflito de linguagens que se situa a querela da crítica brasileira.

\section{A querela da crítica}

Ao que parece, os adeptos da chamada "nova crítica" andam assanhados com as suas conquistas no Brasil. Soou a hora da crítica, segundo eles. Nunca se discutiu tanto o problema como agora. ${ }^{143}$

Temístocles Linhares

A história literária está repleta de querelas, disputas, controvérsias, embates e polêmicas, pois todas essas formas de discussão movimentam os ambientes literários e promovem revisões de valores. Nas palavras do historiador Antoine Lilti, que dedicou um estudo às controvérsias intelectuais, "Quelle que soit la dimension polémique de la controverse, celle-ci réorganise, à un degré plus ou moins important, l'économie des savoirs" ${ }^{144}$. O historiador vê na análise das controvérsias um ponto de partida para a compreensão da dinâmica da história das ideias. Lilti distingue duas perspectivas analíticas: a perspectiva dialógica associa a resolução das controvérsias ao progresso do conhecimento; a perspectiva conflitual enfatiza os mecanismos de funcionamento das controvérsias ${ }^{145}$. É observando esses mecanismos que identifico tanto a configuração de uma querela na crítica brasileira dos anos 50, como o lado da querela ao qual a obra de Barthes foi destinada, e que determinou sua primeira leitura no Brasil.

Enquanto na França a grande querela da crítica opôs, nos anos 60, os adeptos da nouvelle critique - Barthes em primeiro lugar - aos críticos tradicionais, agrupados em torno do professor da Sorbonne, Raymond Picard ${ }^{146}$; no Brasil a querela da crítica, que se iniciou na década anterior, opôs os mesmos grupos adversários - a crítica nova ${ }^{147}$ e a tradicional -, mas travestidos em outros termos.

\footnotetext{
143 Temístocles Linhares, "Sabedoria e serenidade da 'nova crítica' ”, Suplemento Literário, 9 de agosto de 1958, p. 1.

144 “Querelles et controverses. Les formes du désaccord intellectuel à 1'époque moderne”. In Mil neuf cent 2007/1, n” 25, p. 22.

145 Ibid., p. 13.

146 Tratarei da querela francesa no capítulo dedicado à recepção de Barthes nos anos 60, quando os jornais brasileiros repercutiram o assunto.

${ }^{147}$ Emprego a expressão "crítica nova" para me referir a toda crítica que se opôs à crítica tradicional. Não, há, portanto, uma alusão precisa e única ao que foi tratado no Brasil como nova crítica, new criticism ou nouvelle critique: "crítica nova" designa unicamente um dos lados da querela brasileira, preservando a heterogeneidade dos grupos que nele
} 
Em função do discurso sobre a universidade brasileira predominante na década de 50, a crítica universitária já nasceu estigmatizada: da mesma maneira que tudo o que dizia respeito à universidade era visto como pertencente a um mundo à parte, regido por leis próprias e, sobretudo, inacessível aos não-iniciados, a crítica universitária também foi percebida como hermética e sem relação com a sociedade da época. Esse tipo de crítica - que então era uma novidade - passou a dividir espaço nos jornais com a tradicional, assinada por escritores e por intelectuais autodidatas, que concebiam tal atividade em termos bastante diversos, mas em sua maioria opostos aos preceitos da crítica nova, que compreendia a universitária. Do embate entre esses dois tipos de crítica, e das concepções sobre as quais eles se estabeleceram, é que nasceu a querela brasileira.

Nos anos 50, Adolfo Casais Monteiro foi presença constante nos debates sobre literatura e seus pontos de vista endossaram as posições defendidas pelos críticos tradicionais. Em "Mistérios da crítica", publicado na coluna "Figuras e problemas do nosso tempo", em 1956, o escritor português define essa atividade, diferenciando-a da história literária. Curiosa distinção, que na França da mesma época não se fazia necessária, pois a história literária era a ferramenta mais prestigiada da crítica, desde o início do século $\mathrm{XX}^{148}$.

Para Casais Monteiro, a leitura crítica é acima de tudo o exercício de um dom. Segue-se sua explicação:

Não há dúvida de que o crítico não nasce feito. Mas também não há dúvida de que, sem a matéria-prima especial de que ele pode fazer-se, resultam inúteis todas as receitas para fazer boa crítica, já que não servem para fazer bons críticos. O aspirante a crítico pode frequientar as mais respeitáveis escolas, que não aprenderá nunca a acuidade graças à qual poderá detectar o bom poeta, o bom romancista, o bom dramaturgo. É que o dom do crítico vem a ser, sobretudo, receptividade ao que é vivo, e não a ciência das formas, dos gêneros, nem sequer a erudição que permite os mais sábios paralelos e ajuda a farejar a pista das mais ocultas influências. ${ }^{149}$

Embora em seu texto não mencione explicitamente a crítica universitária, Casais Monteiro refere-se a ela empregando palavras e expressões que evocam o ensino regular ("respeitáveis

\footnotetext{
atuaram, ora assumindo a identidade da crítica universitária, ora referindo-se ao new criticism, ora tratando-se da nouvelle critique ora representando os princípios da Chicago School, por exemplo.

${ }^{148} \mathrm{Na}$ França, a reforma do ensino secundário de 1902 tornou o estudo das letras greco-latinas opcional e primou pela diversidade e especificidade de suas disciplinas, tendo por baluarte os métodos científicos. Foi amplamente defendida por Gustave Lanson, o criador da história literária como disciplina e ferramenta científica para o estudo da literatura. Por conseguinte, até a metade do século XX, na França, a crítica literária se nutria de uma abordagem científica, difundida desde o ensino secundádio, que tinha no estudo histórico - contextual e biográfico -, fundamentado em métodos científicos, seu principal ponto de apoio. A propósito da reforma educacional, ver Martine Jey, "Gustave Lanson et la réforme de 1902: défense d'une réforme, compromis et décalage", Fabula, la recherche en littérature, 7 de outubro de 2005. Disponível em: http://www.fabula.org/atelier.php?Gustave_Lanson_et_la_r\%26eacute\%3Bforme_de_1902 (consultado em 4 de maio de 2013).

${ }^{149}$ Primeiro Caderno, 17 de maio de 1956, p. 7.
} 
escolas") onde ela nasceu, e o conhecimento aprofundado ("erudição"), qualidade que lhe é intrínseca. Casais Monteiro também alude a uma certa tendência formalista nos estudos literários, para ele mais um produto universitário, opondo ao "dom do crítico" a "ciência das formas". Para o autor, o aparato teórico oferecido pela universidade é insuficiente para que se faça uma boa crítica, pois a aptidão para exercê-la seria uma qualidade inata, restrita a algumas pessoas. Concepção romântica e ao mesmo tempo elitista, realmente oposta ao trabalho desenvolvido pela universidade, para a qual qualquer pessoa, em princípio, teria condições de aprender teorias e técnicas de análise literária, o instrumental da crítica.

Coroando sua explanação, Casais Monteiro escreve: "Em suma - velai o rosto, oh cientistas da crítica! - o bom crítico é... o artista da crítica!" ${ }^{150}$ Seriam, pois, os "cientistas da crítica" aqueles que aprenderam o ofício em "respeitáveis escolas", que praticam a "ciência das formas" e empregam sua "erudição que permite os mais sábios paralelos e ajuda a farejar a pista das mais ocultas influências". Em outras palavras, os críticos universitários, a quem o autor se dirige, em tom de provocação, como quem ataca um adversário.

Ao opor os "cientistas da crítica" aos "artistas da crítica", Casais Monteiro atualiza a velha disputa entre as ciências e as humanidades, particularmente importante na França do século XIX. Para Antoine Compagnon, as reformas educacionais de 1852 e de 1902 foram decisivas para a separação entre as duas culturas, a científica e a humanística ${ }^{151}$. Ora, diante dessa fissura, tornada definitiva porque institucionalizada pelas reformas educacionais, na França do final do século XIX e do século XX, a história literária, tal como defendida por Lanson, constituiu-se como uma tentativa de conciliação entre os métodos científicos e os estudos literários, buscando fazer da análise literária uma técnica objetiva, pautada na História, renegando o subjetivismo até então reinante. Porém, para Casais Monteiro, a história literária é de uso exclusivo dos "cientistas da crítica", que "fareja[m] as pistas das mais ocultas influências”. Faz-se, portanto, interessante, notar que, aos olhos do crítico português, diferentemente do que se passava na França, até então modelo inconteste, a história literária no Brasil se opõe à crítica e é associada, exclusivamente, à ciência.

No desenvolvimento do texto, ao comparar o crítico ao artista, o autor expõe sua compreensão da atividade crítica em termos providencialistas, com uma acepção bastante limitada e estereotipada da arte, banhada num misticismo que faz do artista um ser de exceção, dotado de uma centelha divina e do dom de criar. Casais Monteiro reclama ainda uma formação filosófica como

\footnotetext{
150 Ibidem.

${ }^{151}$ Cf. La littérature, pour quoi faire ?, Paris, Collège de France/ Fayard, 2007, p. 37.
} 
fundamental para o desenvolvimento do dom da crítica - o que parece contraditório depois dos ataques feitos à formação científica oferecida pela universidade.

À concepção da crítica como o exercício de um dom, o intelectual português acrescenta a noção de "preferência", entendida não somente como uma opinião subjetiva, mas como a identificação daquele que analisa uma obra literária com as escolhas e os valores de seu autor. Crítico e escritor devem, portanto, partilhar da mesma moral, ou não haverá espaço fértil para a análise criadora.

Defendendo a expressão da preferência pessoal como uma das bases sobre as quais se calca a boa análise da obra literária, Casais Monteiro ataca mais um elemento associado à crítica nova e não apenas restrito à universitária: o objetivismo científico. Em suas palavras, "A função combativa da crítica não é uma diminuição dela, senão aos olhos daqueles que ainda a pretendem julgar à luz duma ideia de objetividade que deixou de ter sentido" ${ }^{152}$. Ao referir-se à "função combativa da crítica", o autor tem em mente a leitura exegética que se debruça sobre as obras da atualidade. Tal crítica, já nessa época, muitas vezes era substituída pelas resenhas de divulgação, que não primavam por uma análise aprofundada das obras. Os possíveis ataques da crítica nova à combativa, aos quais Casais Monteiro alude, podem, talvez, ter como alvo mais os resenhistas do que os verdadeiros críticos. Em meio a confusões entre ambos, o fato é que os universitários, munidos de vasto aparato teórico e tendo o rigor científico como princípio norteador de sua atividade, opunham-se à crítica subjetivista, movida e fundamentada pelos sentimentos evocados pela obra literária, apanágio da crítica tradicional brasileira.

Casais Monteiro conclui seu texto distinguindo o crítico do historiador da literatura. Tal diferença, para o autor, estabelece-se sobre duas concepções: de um lado, o dom, a preferência, o subjetivismo como elemento criador, em suma, os "artistas da crítica"; de outro, a formação acadêmica, a erudição, a ciência das formas, o objetivismo, "os cientistas da crítica". O autor resume essa oposição como segue:

E aqui surge a diferença entre o historiador e o crítico, coisa que está longe de ter sido suficientemente esclarecida, tanto mais que, hoje, se dá uma invasão de professores no domínio da crítica - e os professores constituem uma classe em cujo seio tem dificuldade em brilhar a centelha da adivinhação do novo. ${ }^{153}$

\footnotetext{
152 Primeiro Caderno, 17 de maio de 1956, p. 7.

153 Ibidem.
} 
O autor associa o historiador da literatura ao crítico universitário, também chamado de "professor". E alerta para a intromissão desse tipo de intelectual na seara da crítica, empregando a palavra "invasão": os territórios estando claramente delimitados - o lugar do crítico é nos jornais, analisando obras literárias, e o lugar do professor é na universidade, escrevendo histórias da literatura -, nos anos 40 e 50 os "professores" invadiram o espaço dos críticos, e a querela entre os dois grupos foi instaurada.

Além de uma disputa por espaço, a querela brasileira, na década de 50, também se caracterizou como uma discussão conceitual e terminológica, tendo por cerne a definição de crítica. Para os intelectuais tradicionais, crítica era o que se fazia até então - mesmo que cada um tivesse sua própria definição. E as análises feitas à luz das novas teorias científicas não eram críticas, e mereciam outro nome - por exemplo, "história literária”, para Casais Monteiro.

Exemplar da problemática que envolve a querela brasileira é o texto "Crítica e Ciência", também de Casais Monteiro. Publicado em sua coluna "Figuras e problemas do nosso tempo", dentro do suplemento cultural Literatura e Arte, de 27 de maio de 1956, portanto dez dias após "Mistérios da Crítica", o autor traz ao público paulista uma polêmica sobre o assunto, ventilada no jornal porto-alegrense Diário de Notícias, tendo como protagonistas Heráclio Salles e Afrânio Coutinho.

A polêmica entre eles é mais uma faceta da querela brasileira: Salles defende uma posição tradicional e Coutinho, a crítica nova. Casais Monteiro viu na discussão um pretexto para defender suas ideias, e resume-a brevemente em seu texto, tomando o partido da crítica tradicional. O autor português entra na discussão sem nem mesmo conhecer Salles, mas identificando, em suas opiniões, o terreno que é também o seu:

(...) estou de alma e coração ao lado do crítico Heráclio Salles, do qual não sei se é bom ou mau crítico (...), mas que defende a posição que me parece sã, e para isto não importará nada que eu e ele tenhamos ideias muito semelhantes ou muito diferentes sobre a crítica; porque ele está certo, entendo eu, em não ter ilusões quanto às pretensões científicas da crítica, cavalo de batalha de Afrânio Coutinho. ${ }^{154}$

Para Casais Monteiro, o mais importante é detectar o inimigo, mesmo que entre os aliados não haja grande entendimento, o que caracteriza a querela intelectual: toda forma de ataque à crítica nova é por princípio louvável, pouco importando se, em outras questões, aqueles que estão do

\footnotetext{
${ }^{154}$ Literatura e Arte, 27 de maio de 1956, [p.1].
} 
mesmo lado estejam em acordo ou desacordo. Determinados os campos da batalha e situados seus participantes, o autor passa a investir contra Coutinho:

O objetivo deste artigo não é, aliás, entrar na polêmica, mas verificar, pelos escritos de Afrânio Coutinho, a inviabilidade da sua posição. E a chave desta inviabilidade está porventura num simples adjetivo, que encontrei no seu livrinho Por uma crítica estética, à p. 19 do qual ele qualifica a Poética e a Retórica de Aristóteles como... "livros de crítica literária". Vem, em reforço disto, a sua embirração, justamente posta em destaque por Heráclio Salles, pelo termo "ensaio", que em todas as conjunturas ele quer substituído pelo de "crítica". Em que medida a designação "ensaio" possa diminuir uma obra, e em que medida a de "crítica" a possa dignificar, não o soube explicar Heráclio Salles, e eu muito menos o sei. ${ }^{155}$

Casais Monteiro não pretende entrar na polêmica de Salles e Coutinho, mas unicamente desqualificar os argumentos deste último. Pois o autor português está engajado num problema maior, que engloba a discussão localizada do Diário de Notícias: a querela entre a crítica tradicional e a crítica nova. Identificando em Coutinho mais um inimigo, Casais Monteiro questiona os termos por ele empregados, introduzindo uma nova dimensão na querela: a luta por território físico entendido como o espaço nos jornais - torna-se também uma disputa terminológica, ou seja, a luta por território no interior da linguagem.

Por uma crítica estética (Rio de Janeiro, Ministério da Educação e Cultura, 1954), citada por Casais Monteiro, compreende duas conferências proferidas por Coutinho, entituladas "O conceito aristotélico da literatura e da crítica" e "A Poética: conceito e evolução". Ambas defendem a Poética de Aristóteles como fundamentação teórica a ser revitalizada e aplicada, tanto na criação de obras literárias, quanto em suas análises, o que está longe de ser razão de polêmica. Não há, portanto, nesse livro, a problematização dos conceitos de crítica e de ensaio, mas somente o emprego da alcunha "crítica literária" para a Poética, presente duas vezes em todo o livro. Casais Monteiro, ao estabelecer como ponto de partida de seu ataque a Coutinho os usos das palavras “crítica" e "ensaio", não discute o conteúdo de Por uma crítica estética, mas encontra nesse livro uma afronta ao sentido corrente desses importantes termos literários, que ele parece julgar indiscutíveis. E adivinha neles um novo sentido para o termo "crítica", o que o faz reagir em defesa de seu território, a crítica tradicional.

Mesmo sem teorizar, empregando a expressão "crítica literária” para tratar da obra de Aristóteles, Afrânio Coutinho propõe a ampliação do conceito de crítica, compreendendo o que, à época, chamava-se "ensaio", ou seja: um trabalho de pesquisa e reflexão sobre um determinado assunto. Salles e Casais Monteiro consideram tal proposta descabida, e atêm-se à distinção entre 
“ensaio" e "crítica": apesar de não conhecer a definição de Salles, Casais Monteiro dá a entender que eles dois estão de acordo com o objetivo corrente da atividade exegética: analisar e julgar uma obra literária. "Ensaio" e "crítica", portanto, seriam distintos por se tratar, respectivamente, de um trabalho predominantemente de pesquisa e por um trabalho predominantemente analítico e sentencioso.

Em termos absolutos, Casais Monteiro e Salles estão corretos, o ensaio e a crítica podem se constituir como gêneros textuais distintos, com características próprias. Mas esses autores não levam em conta dois fatores importantes que subjazem à proposta sutil de Coutinho: por um lado, as contribuições de novas teorias científicas, desenvolvidas no século XX, não só ofereceram aos intelectuais novas possibilidades de leitura das obras literárias, como também as tornaram mais eruditas, objetivas e científicas. Tais aportes introduziram na crítica elementos que até então não eram característicos desse tipo de texto, interferindo em sua estrutura e engendrando uma organização textual mais rigorosa, o emprego de vocabulário técnico, o uso de notas de rodapé, a presença de bibliografia ao final do texto, por exemplo, até então inusitados nos jornais. O questionamento sobre o conceito de crítica e a proposição de uma nova compreensão do termo, portanto, são naturais nesse momento em que o paradigma dessa atividade passa por transformações.

Por outro lado, Afrânio Coutinho, assim como Casais Monteiro, parece estar ciente de que está participando de uma querela e, ao empregar uma nova conceituação da palavra "crítica", luta pela hegemonia de sua acepção do conceito, desprestigiando o conceito tradicional. A querela terminológica envolve, portanto, os conceitos de "crítica", "ensaio" e, como já foi visto, o emprego enviesado da expressão "história literária" ou "história da literatura".

Mais adiante, Casais Monteiro volta à carga lançando mão do vocabulário em questão:

Realmente, aquilo que repugna a Afrânio Coutinho no tipo de crítica literária que condena é... a sua própria essência de crítica literária. Aquilo que lhe interessa, e que se obstina em designar como crítica, é a história da literatura. Com efeito, todas as "virtudes" que ele exige da crítica estão a matar como definição da boa história da literatura: não se inspirar no gosto pessoal, obedecer a cânones uniformes e coerentes, oferecer-nos "ensinamentos ou dados científicos sobre autores antigos ou contemporâneos" (V. o D. de N. de 13 do corrente). ${ }^{156}$

Casais Monteiro percebe que "crítica literária" não tem o mesmo significado para ele e para Coutinho. Para o autor português, o problema, portanto, pode ser resolvido com uma adequação de termos: é "crítica literária" o que Casais Monteiro entende por ela e é "história da literatura" o que Coutinho reivindica como crítica. Ou seja, os intelectuais tradicionais mantêm o termo "crítica" sob

156 Ibidem. 
sua tutela e os novos devem procurar outra palavra para designar seus textos. E Casais Monteiro sentencia: "Tem razão Heráclio Salles em dizer que Afrânio Coutinho não define a crítica. Não define, e não pode definir, porque a 'nossa' crítica nada tem a ver com a 'dele'." 157

Mais adiante, na conclusão de seu texto, o autor português volta a empregar a palavra "professores" para tratar dos adeptos da crítica nova, incluindo Afrânio Coutinho. Novamente defende a tese de que "crítica", como ele entende o termo, não se ensina e muito menos se faz com métodos científicos. Casais Monteiro conclui com um apelo, que não deixa de ser também um novo ataque: "Por que não deixam os senhores professores a crítica àqueles que insisto em chamar os ‘artistas da crítica'?" 158 Em outras palavras, pede aos novos, universitários, "professores”, que cessem de lutar pelo uso do termo "crítica" e que deixem o monopólio do emprego da palavra aos “artistas da crítica”, os intelectuais tradicionais.

Quem não conhece um pouco do pensamento crítico e da poética de Casais Monteiro pode se espantar com tais colocações, aparentemente fora de lugar em plena metade do século XX. Sobretudo quando formuladas por um escritor tão comprometido com novas estéticas, correspondente de Fernando Pessoa e grande defensor da liberdade de pensamento, um espírito aberto a novas ideias. O que, então, o conduzia a tais ataques à crítica universitária, à crítica nova?

Algumas das concepções literárias de Casais Monteiro são herança do romantismo tardio português, via José Régio e Gaspar Simões, que impregnou as reflexões sobre a literatura naquele país até pelo menos meados dos anos 30, do qual seu primeiro livro de crítica, Considerações pessoais (1933), ainda se ressente. Exemplos são a noção de "dom” e a concepção da crítica como uma obra de arte - certamente inspirada em Victor Hugo - a partir da qual ele defende os "artistas da crítica" em detrimento dos professores universitários, ou "cientistas da crítica", nos seus termos. Contudo, em Considerações, já aparece uma visão bastante moderna da literatura, a saber, a análise da linguagem como meio de se construir uma crítica às concepções estéticas vigentes em seu tempo $^{159}$. Coexistem, portanto, nesse livro, um certo Romantismo e uma atenção à linguagem típica de um estruturalismo embrionário, o que fará com que Casais Monteiro seja posteriormente reconhecido como um de seus precursores em Portugal:

Não só no século XIX, mas também entre os "jovens" que em 1915 se opunham ao republicanismo de cátedra de um Teófilo Braga e de um Júlio de Matos, o discurso crítico português subestimou quase sempre o papel próprio da linguagem e a sua função estruturante na argumentação crítica. Não por acaso, tão tarde quanto na década de 1960, o nome de Adolfo Casais

\footnotetext{
157 Ibidem.

${ }^{158}$ Ibidem.

${ }^{159}$ In Carlos Leone, O Essencial sobre Adolfo Casais Monteiro, op. cit., p. 19.
} 
Monteiro será referenciado, entre outros bastante mais novos (Eduardo Lourenço, Óscar Lopes, Jorge de Sena), como antecessores da "nova crítica" que introduz na Universidade portuguesa o estruturalismo das ciências humanas francesas "pós-humanistas". Muito do que é essencial em Adolfo Casais Monteiro enquanto crítico passa por esta relação intencional com a função crítica da linguagem, e isso é já legível nestes ensaios de 1933. ${ }^{160}$

Soa ainda mais estranho o mesmo Casais Monteiro, "antecessor da 'nova crítica' ", digladiando-se contra os críticos novos da década de 50. Mas tal contradição só é possível aos olhos de hoje, quando se tem bastante recuo para enxergar as contendas da época. Pois, naquele momento, as questões que alimentavam as discussões acaloradas, tais como o surgimento de um novo jargão científico e a formação mais técnica e menos intuitiva do crítico moderno, surgiam de maneira fragmentária e batiam de frente com as concepções estéticas do escritor português, oriundas de um romantismo, em alguns momentos, até mesmo pré-presencista; eram choques que incitavam as reações do escritor, aliás, célebre polemista.

Além do mais, eram ainda os idos de 1956, e no Brasil só se ouviam os primeiros acordes, e de maneira bastante distorcida, do concerto estético revolucionário regido pelo new criticism estadunidense e pelo estruturalismo francês. Casais Monteiro ainda tomaria parte em muitas discussões e leria muitos livros até, em 1968, publicar Estrutura e autenticidade como problemas da teoria e da crítica literárias (São Paulo, s.e., 1968), unindo um conceito tão moderno quanto o de estrutura a um romântico, o de autenticidade, num mesmo título. E como se pode operar tão curiosa união? Carlos Leone, estudioso da obra do escritor português, bem sintetiza:

Contrariamente à tese de José Régio sobre a necessidade de sinceridade para a obra do artista ser viva e original, Casais argumenta em favor da autenticidade, na medida em que é esta (contrariamente ao fundo romântico do pensamento regiano) que garante a sua própria realidade, numa variante tardia do seu grito de guerra antineo-realista "a arte é, não serve". Ora, o acesso crítico a esta autenticidade (categoria a nosso ver ainda romântica, mas isso não é essencial) realizase mediante a atenção à estrutura da obra, só existe obra pela estrutura; atento aos principais movimentos universitários da época, Casais cita Jakobson (por intermédio de Genette) para, no melhor modelo estruturalista, remeter a literatura para a literaridade (...). Neste processo, a despersonalização do ato crítico (...) não se oporia ao problema central da imaginação e da personalidade na criação (...), pelo contrário, ser-lhe-ia uma resposta, a resposta adequada. Ou seja: a estrutura imanente a toda a obra encontra a sua réplica na despersonalização da abordagem crítica $^{161}$.

$\mathrm{Na}$ contramão da maioria dos críticos tradicionais que, na década de 70, atacou veementemente o anti-humanismo estruturalista, Casais Monteiro procurou nele uma coerência e

\footnotetext{
${ }^{160} \mathrm{Ibid}$, p. 20.

${ }^{161}$ Ibid., pp. 66-67.
} 
enxergou uma explicação conciliadora: toda obra literária seria fruto de uma criação pessoal e, por isso, autêntica, única em sua origem. Porém, ao mesmo tempo, toda obra comportaria uma estrutura própria e autônoma, fruto de sua autenticidade, à qual corresponderia uma leitura objetiva e descritiva, uma vez que, para o escritor, "se a obra existe em si e por si, o que se torna necessário não é justificá-la, mas descrevê-la" ${ }^{162}$. Essa leitura seria, portanto, despida de subjetividade e de individualidade. Casais Monteiro, ao que parece, restringe a autenticidade ao nascimento da obra e a sua coesão interna, aplicando o conceito de estrutura a sua descrição e a sua leitura. Ou seja, a subjetividade se encontra do lado do autor, e não do crítico. Casais Monteiro elabora uma explicação que lembra a figura mitológica do centauro, metade romântica, metade estruturalista, para acomodar suas convicções pessoais às novas teorias, sendo um homem de seu tempo sem deixar de lado suas concepções mais profundas sobre a criação literária.

Desenvolvendo seu oxímoro teórico, em Estrutura e autenticidade, depois de uma primeira parte consagrada a reflexões da ordem da história das ideias sobre a literatura e as noções de sinceridade, verdade e autenticidade, o escritor português dedica a segunda parte do livro às reflexões contemporâneas sobre a literatura. Considera a autonomia da crítica um produto do século $\mathrm{XX}$, originária da "impregnação filosófica" que as reflexões literárias sofreram desde Albert Thibaudet, "um dos introdutores do espírito filosófico na literatura" ${ }^{163}$. Para Casais Monteiro, essa mistura de filosofia e literatura atende pelo nome de teoria literária e quando trata das particularidades da crítica no século XX, refere-se aos princípios teóricos que penetram as análises. Como se a crítica tradicional não lesse uma obra a partir de suas convicções, como se a ideia de inspiração enquanto essência da criação ou a visão histórica da obra não fossem princípios teóricos. Em suma, seu capítulo sobre a autonomia da crítica não faz dela uma defesa, mas constata a existência de um novo tipo de crítica.

Barthes, autor de Critique et vérité, obra em que defende sua concepção crítica, é citado algumas vezes em Estrutura e autenticidade, sempre como o ponto de chegada desse novo modelo de crítica: "Mas a tendência mais caracterizadamente filosófica parece ser a francesa, de Poulet a Barthes, em grande parte sob a égide de Bachelard" ${ }^{164}$. Casais Monteiro dialoga com Barthes, mais precisamente, no capítulo dedicado à estrutura: ao identificar nas tentativas de análise estruturalistas a dificuldade em se passar da parte para o todo, atingindo a obra no que ela tem de próprio, de

\footnotetext{
${ }^{162}$ In Estrutura e autenticidade como problemas da teoria e da crítica literárias, São Paulo, s.e., 1968, p. 103.

163 Ibid., p. 89.

${ }^{164}$ Ibid., p. 91.
} 
autêntico, o escritor português expõe suas precauções em relação ao estruturalismo, nomeando Barthes:

Assim, Roland Barthes põe como condição para se criar uma ciência da literatura que "o seu modelo será evidentemente linguístico" (20). É uma "evidência" para mim tão estranha como a de que a análise estrutural das obras literárias só poderia fazer-se "em função de modelos lógicos" (21).

(20) Roland Barthes, Critique et vérité, Aux Éditions du Seuil, Paris, 1966, p. 57.

(21) Idem, p. 37. ${ }^{165}$

Pois para o escritor português, a obra literária suplanta qualquer modelo, seja ele lógico ou linguístico, ou os dois ao mesmo tempo. Casais Monteiro, como outros intelectuais nos anos 50 e 60, acredita que a obra literária se consuma no leitor - "A estrutura das estruturas dá-se, acontece no leitor, tal como se tinha dado e acontecido no autor" (grifo do autor) ${ }^{166}$. Por isso a metade romântica do centauro teórico: embora dotada de uma estrutura, a obra literária é sempre um produto humano, e, portanto, constitutivamente ambíguo, multivalente e oriundo de um mistério, o mistério da criação. Em suas palavras, “O leitor que se encontra com a obra refaz para si próprio esse ser da obra de arte que nunca é redutível a um sistema, limitação que precisamente exigem as tentativas que, conforme vimos com Barthes, apelam em última análise para um 'modelo único' " (grifos do autor) ${ }^{167}$.

Casais Monteiro, por um lado, reconhece a estrutura como parte constitutiva da obra literária, o que lhe permite criar seu oxímoro teórico: "E aí temos o problema da estrutura: ela é consubstancial ao gênio e ao 'métier' "168, este entendido como o trabalho sobre o estilo. Por outro lado, não deixa de criticar as análises estruturalistas, que considera redutoras.

Lembro que as reflexões de Estrutura e autenticidade datam de 1968, mais de dez anos depois das colocações de Casais Monteiro na querela brasileira. Embora não sirvam para justificar seus ataques à crítica nova, elas permitem notar uma mutação no pensamento do escritor português que, posteriormente, e, talvez, graças aos debates da década de 50, incorporarão a noção de estrutura, mesmo que, surpreendentemente, ao lado de suas concepções românticas.

\footnotetext{
${ }^{165}$ Ibid., p. 124.

${ }^{166}$ Ibid., p. 126.

${ }^{167}$ Ibidem.

${ }^{168}$ Ibid., p. 115.
} 
Ainda longe de aceitar a noção de estrutura, Casais Monteiro, ferrenho defensor da crítica tradicional, fornece ricos exemplos de como a crítica nova era vista no Brasil dos anos 50. E como eram vistas as leituras tradicionais das obras literárias?

Bernardo Gersen, por exemplo, em “A literatura comparada”, publicado em 1957, descreve com precisão as caracterísitcas dos integrantes da crítica tradicional. Seu texto tem por objetivo divulgar os estudos comparados no Brasil e se apoia em uma das poucas publicações então disponíveis sobre o tema, A Literatura comparada, de Marius-François Guyard (Tradução de Mary Amazonas Leite de Barros, São Paulo, Difusão Europeia do Livro, 1956). Gersen enumera as razões pelas quais a literatura comparada desperta pouco interesse no país, o que inclui o perfil do crítico tradicional:

Depois há a natureza mesma do intelectual brasileiro - o que decorre em parte do ambiente cultural - em geral um franco-atirador, um intuitivo que veio para a literatura através de atividades laterais, um individualista refratário às exigências de um trabalho modesto de equipe e às pesquisas pacientes e apagadas de biblioteca. ${ }^{169}$

Ou seja, o oposto dos adeptos da crítica nova.

Menos radical que Casais Monteiro - que ataca os novos intelectuais - e Gersen - que não vê os tradicionais com bons olhos -, Brito Broca, intelectual tradicional, reflete com serenidade sobre as duas tendências, em “A propósito de crítica militante”, texto de 1959.

Seu ponto de partida é o falecimento do crítico francês Robert Kemp, que escrevia sobre as obras recém-lançadas para Les Nouvelles Littéraires, e sua substituição por Henri Petit, ensaísta. Para Brito Broca, esse fato reflete a perda de espaço e de prestígio da crítica para o ensaísmo, fenômeno que ele tem observado, sobretudo, nas letras francesas.

No entanto, tratando especificamente do rodapé da revista francesa, campo de atuação de Kemp, o autor dá a entender que o ensaísmo não é o único responsável pelo ocaso da crítica. Brito Broca vê em Kemp um "crítico militante", ou seja, um intelectual que se ocupa das obras recémlançadas, mas que era, antes de tudo, um reviewer, um resenhista. Kemp não fazia, portanto, da análise literária seu instrumento de trabalho, pois se limitava a comentar superficialmente as obras de que tratava. O mesmo perfil tinha seu antecessor na revista, Édmond Jaloux.

Brito Broca dá um exemplo do modus operandi de Kemp contando uma anedota:

\footnotetext{
169 Suplemento Literário, 14 de setembro de 1957, p. 4. Não foram encontrados mais exemplos de como os críticos tradicionais eram vistos por seus oponentes pelo fato de, na década de 50, o jornal ser o espaço por excelência da crítica tradicional, sendo, portanto, quase o veículo de transmissão de um único discurso.
} 
Leria sempre [Kemp], do começo ao fim, todos os livros sobre os quais opinava? Eis uma pergunta que nunca se devia fazer a um crítico. Mas a realidade mostra o quanto ela é justificável. Lembramo-nos de que Robert Kemp deixou escapar num rodapé a confissão bem estranha de que havia tomado de um volume com o propósito de folheá-lo apenas (quer dizer, de inteirar-se por alto do assunto), vindo, porém, a lê-lo, dado o interesse que lhe despertaram os primeiros capítulos. Conclui-se, logicamente, de que se não lhe agradasse tanto o começo, nem iria até ao meio, não deixando por isso de emitir um juízo sobre o livro. E daí a nossa hipótese, nada lisonjeira, de que talvez assim procedesse com relação a outras obras. Bem sabemos que há quem faça ler pela esposa os livros sobre os quais escreve. ${ }^{170}$

A observação de que nunca se deveria perguntar a um intelectual se este lera a obra sobre a qual escreveu coloca em evidência uma prática comum na crítica literária, francesa e brasileira: a arte de escrever sobre o que não se leu ${ }^{171}$. Tal prática era facilitada, no Brasil, até os anos 50, pela existência de um número reduzido de intelectuais. Por essa razão, era mais difícil confrontar pontos de vista, uma vez que o universo de leitores especializados era relativamente pequeno. No caso das obras estrangeiras, a tarefa era ainda mais simples devido à dificuldade em obtê-las. Diante desses fatos, corriqueiros, de alusões exclusivas ao primeiro capítulo de Le Degré zéro, e de problemas de compreensão já explicitados neste trabalho, fica a dúvida, por exemplo, se Milliet leu todo o livro de Barthes quando escreveu sobre ele, em 1953.

A crítica militante que se restringe a resenhar livros ao invés de analisá-los com profundidade e que, muitas vezes, nem se dá ao trabalho de ler "do começo ao fim" as obras que comenta, justificadamente não empolga Brito Broca. Mas em lugar de fazer uma apologia dos velhos tempos, ou de prever o apocalipse da crítica, como fazem muitos intelectuais da época, o autor mostra abertura de espírito e se volta para o outro lado do terreno, para a outra tendência existente:

O panorama mostra-se, porém, muito mais animador no momento em que deslocamos a perspectiva para a crítica universitária, a história literária e o ensaio. Duvido, mesmo, de que outra literatura, no momento, apresente, em tais setores, valores tão genuínos tanto nas velhas, como nas novas gerações. ${ }^{172}$

Brito Broca refere-se à crítica universitária francesa e não à brasileira, mas sua boa vontade para com a crítica nova fica evidente. Situa, nesse campo, a história literária, tal como o faz Casais Monteiro, e acrescenta o ensaio, pomo da discórdia entre o autor português e Afrânio Coutinho. Na querela dos anos 50, certos termos estão definitivamente associados à crítica nova, como o adjetivo

\footnotetext{
${ }^{170}$ Suplemento Literário, 19 de setembro de 1959, p. 1.

${ }^{171}$ Pierre Bayard dedicou ao assunto seu livro Comment parler des livres que l'on n'a pas lus (Paris, Minuit, 2007), mostrando que essa prática continua muito em voga.

${ }^{172}$ Suplemento Literário, 19 de setembro de 1959, p. 1.
} 
"universitário" e a "história literária" ou "história da literatura", ao passo que "ensaio" parece ainda não pertencer exclusivamente a um grupo.

Em outro momento de seu texto, ainda tratando de Robert Kemp, o autor novamente destoa da maioria dos intelectuais tradicionais:

A suspeição ante a originalidade podia levá-lo [Kemp] a rejeitar, com acerto, algumas experiências duvidosas, mas colocava-o em posição de lamentável intolerância ante o que exprimia uma busca legítima do novo, do inédito. Condenou assim, com certa intolerância, todas as "aventuras" do chamado roman nouveau. ${ }^{173}$

Assim como a crítica universitária, o Nouveau Roman também foi alvo de desconfianças e, muitas vezes, de virulentos ataques por parte de autores tradicionais no Brasil. Apontando a intolerância de Kemp em relação ao Nouveau Roman e, com isso, indo contra a corrente de sua geração, Brito Broca demonstra, acima de tudo, lucidez para julgar o desconhecido, sem preconceitos nem corporativismos.

Contudo, homens como Brito Broca são raros, e os ataques à crítica nova, naquela época, eram quase uma constante nos textos que se propunham a refletir sobre a literatura. Frederico Branco, em "Nacionalismo \& literatura", publicado em 1958, fornece mais um exemplo de como as novas tendências - tanto na crítica quanto nas obras literárias - eram habitualmente recebidas.

Branco resenha o segundo número da revista mineira Tendência, de 1958, conhecida por defender a importância do papel do nacionalismo na literatura brasileira. Dentre os artigos publicados na revista, o autor destaca "Literatura nacional: problemas", de Fábio Lucas, como uma espécie de manifesto do grupo que criou Tendência.

Lucas defende o nacionalismo literário brasileiro como um processo de "descolonização" cultural do país. Para ele, é preciso que se encontre uma forma de escrita adequada ao conteúdo nacional, o que somente a literatura realista é capaz de oferecer. Lucas defende seu ponto de vista atacando a tendência oposta à sua, conforme o trecho que Branco reproduz:

(...) a obra que foge deliberadamente aos motivos circundantes e procura abstratas idealidades pode chegar a ser uma graciosa composição, um jogo exótico de vocábulos, mas não passará, segundo um juízo literário, de uma peça irrelevante porque o que se julgou requintamento da forma não foi mais do que uso anárquico, irreverente e desrespeitoso de palavras, tanto mais grave quanto mais desligado da finalidade a que se destina a linguagem, instrumento de comunicação... ${ }^{174}$

${ }^{173}$ Ibidem.

${ }^{174}$ Suplemento Literário, 13 de setembro de 1958, p. 6. 
Fábio Lucas refere-se às obras literárias e não à crítica literária. Mas seu discurso é muito parecido com o discurso empregado por Sérgio Milliet em 1953, ao escrever sobre Le Degré zéro: Milliet conclui seu comentário afirmando que a tese de Barthes, fundamentada pelo conceito de écriture, é "puro brinquedo intelectual". Também se refere a ela como "devaneio" e conclui que se trata de mera diversão, referindo-se a Barthes como "alguns": "Enquanto assim se divertem alguns (...)" ${ }^{175}$. Milliet lê a obra do escritor francês tendo no horizonte a concepção de que a linguagem é apenas um meio de comunicação. Por sua vez, Lucas trata a obra literária não realista como "jogo exótico de vocábulos", "irrelevante", fruto de "uso anárquico, irreverente e desrespeitoso de palavras", "desligado da finalidade a que se destina a linguagem, instrumento de comunicação". Ora, os qualificativos utilizados por Milliet e por Lucas são diferentes, mas se equivalem. Tratando de Le Degré zéro ou de obras literárias não realistas, tanto Milliet quanto Lucas se veem diante do mesmo inimigo, e imbuídos de concepções literárias semelhantes, empregam contra ele as mesmas armas, os mesmos argumentos, fazendo os mesmos julgamentos. Eis, portanto, como as primeiras leituras da crítica nova e do nouveau roman se deram em termos muito semelhantes à primeira recepção à obra de Barthes.

Mal sua obra chegou ao Brasil, a crítica tradicional já associou Barthes à crítica nova ou universitária, tratando-o do mesmo modo como os críticos dessa tendência eram tratados. Portanto, antes mesmo de ser considerado o líder da nouvelle critique francesa, Barthes foi personagem na querela da crítica brasileira, engajado, mesmo sem o saber, ao lado da crítica nova. Posição ao mesmo tempo semelhante e díspare da que ocupou na querela francesa: semelhante pois nos contextos francês e brasileiro o escritor esteve com as novas tendências literárias, em oposição às práticas tradicionais; díspare porque na França a crítica tradicional alojava-se sobretudo nas velhas universidades, como a Sorbonne, por exemplo, e a nouvelle critique desenvolvia-se nas instituições menos tradicionais, como a École Pratique des Hautes Études en Sciences Sociales. Ou seja, no contexto francês, guardadas as nuanças, toda a crítica era universitária, ao passo que, no contexto brasileiro, somente a nova nascia e crescia na universidade, disputando espaço nos jornais com a tradicional. Por essa razão, um forte componente territorial sustentou a querela brasileira, o que fez com que, não por acaso, esta tenha perdurado até quando começaram a florescer as revistas universitárias (em meados dos anos 70 e início dos anos 80). A partir do momento em que a crítica nova criou seu próprio espaço de discussões, os embates com a crítica tradicional terminaram.

175 “Grau zero da escrita”, Primeiro Caderno, 17 de novembro de 1953, p. 8. 


\section{New Criticism e Nova Crítica}

Entre os anos 50 e 70, a expressão "nova crítica" frequentou os debates sobre literatura nos jornais. É preciso, portanto, compreender o que a expressão significa, em cada contexto em que foi utilizada: trata-se de uma tradução de new criticism, de nouvelle critique ou de uma expressão de sentido confuso, designando em geral os contestadores da crítica tradicional?

$\mathrm{Na}$ década de 50, é muito difícil separar a expressão "nova crítica" do new criticism, tendência estadunidense divulgada no Brasil no final dos anos 40, bastante debatida nos anos que se seguiram, até a década de 60. Por ser novidade no país em uma época de intensos debates literários, principalmente teóricos, o new criticism contribuiu para acirrar os ânimos dos críticos, não havendo literato indiferente aos seus princípios. Consequentemente, não havia intelectual que fosse neutro em relação à querela e a tendência estadunidense foi recrutada para as fileiras da crítica nova.

O new criticism foi menos uma "escola" crítica do que um grupo de autores que trabalhou mais ou menos sob as mesmas diretrizes, defendendo uma determinada prática de análise literária. Em razão da ausência de um princípio único direcionador dos trabalhos do grupo, o que foi taxado de new criticism pelos intelectuais brasileiros não poderia deixar de ser impreciso e, por isso, dele grassaram diferentes interpretações a serviço de um ou de outro grupo dentro da querela da crítica.

Ewa M. Thompson, em seu livro Russian Formalism and anglo-american New Criticism, confirma a pluralidade de sentidos que a expressão "new criticism" adquiriu: "(...) due to the abundance of language theories and the ensuing popularity of the 'close reading' idea, New Criticism has come to mean, in recent years, at least half a dozen different things." ${ }^{176}$ A autora ainda credita a variedade de sentidos agregados ao new criticism aos seus comentadores, que "could exercise pleasant freedom in singling out its characteristics and defining its boundaries." 177

Não obstante, Thompson resume as características mais recorrentes do new criticism e oferece uma visão panorâmica dessa tendência:

Among the generally recognized facts concerning New Criticism are the following: it arose to prominence in the United States in the 1930's and 40's, partly as a reaction to the literary criticism of the time, more interested in the causes of literature and in the place it occupies among other activities of man than in pointing out the architectonics of literary ambiguities. A reaction against a similar situation had earlier set in also in England, and the Americans owed a great deal to the examples of I. A. Richards, T. E. Hulme and the expatriate Eliot. Critics associated with J. C. Ransom and the Kenyon Review form the nucleus of New Criticism in the United States. They are all concerned with the close reading of the literary text. ${ }^{178}$

\footnotetext{
176 The Hague, Mouton, 1971 p. 8.

177 Ibid., p. 34.

178 Ibidem.
} 
Para a autora, as descrições dos princípios e das práticas do new criticism apontam para dois pontos de vista. O primeiro the permite qualificá-lo como uma atmosfera, e não como um movimento de crítica literária. Thompson enxerga na apologia ao estudo intrínseco das obras uma atmosfera que se desenvolveu em muitos países europeus entre o final do século XIX e a primeira metade do século XX. Nesse sentido, ela afirma que os formalistas russos são tão "novos críticos" quanto Gaston Bachelard e Roland Barthes, e John Crowe Ransom e Allen Tate. ${ }^{179}$

Embora empregue um termo assaz simbolista - "atmosfera" - para substituir "movimento", Thompson procura com ele traduzir a fluidez e a grande capacidade de penetração que teve a forma de análise proposta e defendida pelos news critics, a close reading. Como toda crítica pressupõe uma certa concepção da obra literária, a "atmosfera" do new criticism, "favorable to the intrinsic study and ill-disposed toward the extrinsic study of literature" ${ }^{180}$, portanto, privilegiava a compreensão do texto enquanto fenômeno artístico autônomo.

Ora, tal concepção remonta ao século XIX, a Flaubert, por exemplo, e foi levada às últimas consequências por Mallarmé, quando a obra literária passou a ser vista como um problema de linguagem ${ }^{181}$. Como a própria autora pontua, várias tendências críticas ao longo do século XX privilegiaram a visão do texto como um objeto autônomo, muitas vezes em detrimento de seu entorno. Considerá-las todas, portanto, como pertencentes a uma mesma "atmosfera" originária do new criticism parece-me um exagero que ignora os primeiros passos dados em direção à autonomia da obra literária e abriga sob o mesmo rótulo críticos de tendências bastante diferentes. Ao compreendê-lo como uma "atmosfera", Thompson repete o erro que ela mesma identifica na maioria dos textos sobre o assunto: a dificuldade em definir o new criticism acaba por diluí-lo em meio às demais tendências críticas do século XX, sem dar conta de suas particularidades.

O segundo ponto de vista corrige o primeiro e descreve o new criticism de uma maneira mais precisa, como uma tendência da crítica literária estadunidense, deste modo caracterizada:

The New Critics are preoccupied with showing the unavoidable ambiguity of language, the interrelation of the logical and the non-logical. In doing so, they first point at the categories of language that can be paraphrased in logical terms, and then demonstrate that the interplay of these categories creates unities that cannot be "retold" in logical discourse. They attempt to start with a scholarly, sometimes nearly linguistic, description of the literary work and then pass to a description of it wich surpasses the rationality of scholarship. ${ }^{182}$

\footnotetext{
${ }^{179}$ Ibid., pp. 34-35.

180 Ibid., p. 35.

${ }^{181}$ Ver Roland Barthes, "Préface”, Le Degré zéro de l'écriture, OC v. I, pp. 172-173.

${ }^{182}$ Russian Formalism and anglo-american New Criticism, op. cit., p. 36.
} 
Assim procedendo para analisar um texto, fica claro que o conceito de literatura para o new criticism estabelece-se sobre a relação entre os elementos "lógicos" e "ilógicos" da obra, seu método de exegese contemplando os dois pólos dessa oposição. A despeito, portanto, de como muitas vezes o new criticism foi visto - simplesmente como uma análise intrínseca e detalhada dos mecanismos do texto literário -, os elementos "ilógicos", irracionais, também ocupavam lugar importante na concepção da obra e eram levados em conta no momento da análise.

No entanto, tais elementos não devem ser confundidos com a expressão das emoções e dos sentimentos do autor, que fundamentavam a crítica romântica do século XIX, à qual o new criticism se opõe. Aquele tipo de crítica concebia a obra literária como uma extensão do autor, como concretização de um estado de espírito ou de uma interioridade e lançava mão de estudos históricos e biográficos para compreender as origens dos textos analisados. Em outras palavras, a crítica romântica justificava as obras literárias, associando fenômenos contingentes e exteriores ao texto à sua criação, privilegiando uma relação determinista de causa e efeito.

Os elementos "ilógicos" a que Thompson associa os New Critics dizem respeito ao conhecimento que somente a literatura é capaz de transmitir graças à sua linguagem particular. Trata-se, portanto, de um sistema de circulação de ideias diferente do sistema usual e "lógico", e, por essa razão, capaz de veicular valores essenciais ao homem. Tal concepção idealista da literatura não se opõe totalmente à corrente humanista de crítica existente no século XIX, que também via na literatura uma forma de transmissão de valores humanísticos ${ }^{183}$. Só que, em sua prática analítica, essa corrente apegava-se unicamente a elementos exteriores ao texto a fim de analisá-lo.

T. S. Eliot foi o crítico que melhor conseguiu articular a concepção bipartite da obra literária - constituída por pensamento e por sentimento, ou thought and feelings - com a recusa da análise literária fundada em elementos exteriores à obra. Ele defendeu a visão idealista da literatura como guardiã e transmissora de um tipo de conhecimento único e fundamental ao homem sem, por isso, ter deixado de se opor veementemente à associação direta entre contexto e biografia, e obra literária. Eliot criou uma expressão que se transformou num conceito operatório que sintetiza sua visão de literatura: the objective correlative. A expressão aparece no ensaio "Hamlet and his

\footnotetext{
${ }^{183}$ Nas palavras de Thompson, "Thus to see the New Criticism himself as a tendency counteracting on the whole front the tenets of the New Humanists is not accurate. The New Critics, from Eliot to Ransom, Tate and Brooks, do not merely investigate the ambiguities of language but also try to relate them to what is permanent and essential about man." (Russian Formalism and anglo-american New Criticism, op. cit, p. 38).
} 
problems" (1919) ${ }^{184}$, em que Eliot expõe suas críticas à visão romântica da obra literária. Segundo Thompson,

Life, emotions and feelings, he [Eliot] maintains, enter art only in the form of the objective correlative, i.e., of artistic correspondences which are "formulas" of emotions but which are not identical with them. Such formulas are, in literature, "a set of objects, a situation, a chain of events". As soon as the objective correlative appears we can speak of the author's detachment from its personal life, of an escape from emotions. ${ }^{185}$

Por sua capacidade de síntese e de sistematização dos princípios que se tornaram a base do new criticism, Eliot foi o primeiro new critic, a cujos escritos os demais recorreram e se reportaram com grande frequência. Dentre os muitos críticos que partilharam de seus pontos de vista, John Crowe Ransom, Allen Tate e Cleanth Brooks merecem ser citados como os nomes centrais do new criticism nos Estados Unidos. Ligados a universidades, além de prolíficos ensaístas, foram também editores de revistas acadêmicas e autores de manuais didáticos de ensino de literatura, os quais não só popularizaram, nas universidades, as concepções literárias do grupo, como também acabaram por identificá-lo e reduzi-lo a um método analítico, a close reading.

Defendendo a leitura intrínseca da obra literária, o new criticism acabou se fechando numa posição radical e não conseguiu oferecer respostas aos novos problemas literários propostos nos anos 50 e ulteriores, tendo, por conseguinte, perdido sua força gradativamente. Nessa época, no Brasil, o crítico Afrânio Coutinho, recém-chegado de uma temporada estadunidense, tornava-se o principal divulgador e defensor do new criticism e da Chicago School ${ }^{186}$, e os nomes de Eliot, Ransom, Tate, Brooks e outros passaram a frequentar as reflexões sobre literatura, presentes na imprensa brasileira.

De 1948 a 1961 Afrânio Coutinho manteve no jornal Diário de Notícias, do Rio de Janeiro, sua principal tribuna de divulgação e defesa da crítica nova, apoiada nos princípios do new criticism e da Chicago School, na coluna entitulada “Correntes cruzadas". Entre 1951 e 1960, também dirigiu a revista Coletânea, outro instrumento de sua campanha em favor das novas tendências críticas. Seus argumentos, incansavelmente expostos e repetidos, eram frequentemente referidos como uma

\footnotetext{
${ }^{184}$ Publicado em The sacred wood: essays on poetry and criticism (1920).

${ }^{185}$ Russian Formalism and anglo-american New Criticism, op.cit., pp. 41-42.

186 Aos princípios do new criticism o crítico brasileiro acrescentou o fundamento dos críticos da Chicago School, também conhecidos como Neo-Aristotelian Critics: a compreensão da Poética de Aristóteles como obra-mestra da crítica literária e a visão do texto como um objeto composto por saberes de natureza diversa - sociológicos, psicológicos, históricos, etc. - e que, portanto, precisavam ser levados em conta pela crítica. Em uma palavra, Coutinho defendia uma crítica ao mesmo tempo científica - porque fundada em métodos objetivos e em modernas teorias - e humanista - porque integradora da pluralidade dos conhecimentos humanos, aliando preceitos das duas tendências críticas que ele introduziu no Brasil.
} 
verdadeira pregação. Coutinho opunha-se de maneira veemente à crítica tradicional e impressionista e no texto introdutório a Correntes Cruzadas, livro que reuniu alguns dos textos publicados na coluna de mesmo nome, entre 1948 e 1953, o crítico detalha seus pontos de vista ${ }^{187}$.

Nesse texto, Coutinho demonstra ter consciência da existência de um embate entre dois modelos de crítica, que ele identifica como: "de um lado, o velho impressionismo, em suas formas artísticas e seus espécimes bastardos (...); do outro lado, as tendências ao estabelecimento de critérios críticos de cunho objetivo, critérios 'científicos'," 188

Tal como o fazem os críticos tradicionais, Coutinho também distingue dois lados nos debates sobre a crítica no Brasil. Ele não poupa o grupo a que se opõe, nomeando-o "velho impressionismo", o que, além de reduzir o subjetivismo característico da crítica tradicional a reles impressões, ainda o situa no passado, pelo emprego do adjetivo "velho". Por fim, qualifica como "bastardos" os produtos desse tipo de crítica. Do outro lado, que é o seu, Coutinho coloca em relevo a existência de critérios objetivos que norteiam a crítica nova, e provoca seus adversários, assumindo como seu um adjetivo frequentemente utilizado de forma pejorativa pela crítica tradicional: "científico". Em seguida, justifica: "Evidentemente, o ideal da crítica é ser tanto quanto possível científica" ${ }^{189}$, transformando, pois, a mais atacada característica da crítica nova em condição para uma crítica perfeita. Coutinho, desse modo, estrategicamente inverte um dos argumentos de seus opositores, demonstrando não só conhecê-los, como saber utilizá-los em seu favor. O que deixa claro que, também este adepto da crítica nova, encarava as discussões sobre a crítica como uma disputa terminológica, uma luta por territórios no interior da linguagem.

Segundo Coutinho, o grande problema da crítica brasileira é o método empregado, ou melhor, a falta dele. A crítica da época era essencialmente impressionista e subjetiva, nos moldes, por exemplo, dos pressupostos de Casais Monteiro. Para Coutinho, é preciso primeiramente criar uma "consciência crítica", ou seja, enxergar a crítica como um exercício sério e importante para as letras, e não como um simples pretexto para a exposição de opiniões pessoais e sentimentos. Para ele,

Essa consciência crítica só se cria pelo estudo superior e sistemático de letras, estudo universitário, em que pese à nossa descrença, de origem romântica, na viabilidade e eficiência do aprendizado de letras. Os fatos que nos mostram a história literária e a experiência estrangeira

\footnotetext{
187 Afrânio Coutinho publicou mais textos da seção "Correntes Cruzadas" no volume Da Crítica e da nova crítica (Rio de Janeiro, Editora Civilização Brasileira, 1957), referentes aos anos de 1953 a 1957. No entanto, nenhum deles tem a veemência e o poder de síntese do prefácio a Correntes Cruzadas e analisá-los seria repetitivo.

188 "Introdução". In Correntes cruzadas. Questões de literatura. Rio de Janeiro, A Noite, 1953, pp. I-XXIII.

${ }^{189}$ Ibidem.
} 
convencem que Literatura se ensina e aprende. Esse estudo sistemático desenvolverá a crítica sobre bases científicas e filosóficas, acentuando o papel da teoria e dos princípios, pois sem uma concepção geral da Literatura é vã qualquer procura de método crítico. ${ }^{190}$

Embora Coutinho tenha chegado às letras por caminhos enviesados, como toda sua geração, a dos críticos diletantes - formado em Medicina, abandonou a carreira médica para dedicar-se ao ensino da literatura -, ele defende uma das características mais atacadas da crítica nova, sua origem universitária. Propõe, portanto, a substituição das qualidades inatas e artísticas do crítico e sua empatia com a obra literária, requisitadas pela crítica tradicional, pelo aprendizado de um método de trabalho objetivo. Em um outro nível, o crítico sugere a troca do "antigo enciclopedismo crítico" 191 , do conhecimento acumulado de forma autodidata e muitas vezes superficial, pelo estudo consciencioso que conduz ao sólido aprendizado de teorias úteis à prática da crítica.

Ao aventar que a crítica seja aprendida na universidade, Coutinho acena para uma mudança de paradigma: que a obra literária passe a ser vista como um objeto estético autônomo, cuja análise exige o conhecimento de teorias específicas e adequadas a ele; e que a obra literária não mais seja compreendida como o fruto de elementos histórico-biográficos, de que uma cultura enciclopédica possa dar conta. Dito de outra forma: sugere que o texto seja analisado por um método que subordine às suas características intrínsecas os fatores extrínsecos que por ventura tenham interferido em sua composição. Seguindo, portanto, os pressupostos do new criticism, Coutinho coloca em questão o método histórico de análise literária, predominante em parte da Europa da primeira metade do século XX e que tinha adeptos no Brasil.

Atacando o método histórico, o crítico acaba por acertar um alvo muito mais resistente, porque profundamente enraizado na cultura brasileira: a influência cultural europeia, notadamente francesa, na formação dos intelectuais brasileiros. Presente no Brasil desde o século XVI, a França sempre fascinou os intelectuais brasileiros que, de longe, viam em sua cultura e em suas formas de governo - das monarquias às repúblicas - um modelo a seguir, alternativo ao proposto pelo país colonizador, Portugal ${ }^{192}$. A França, portanto, representava para os brasileiros uma colonização almejada e idealizada - porque nunca efetivada em termos territoriais -, e era considerada a

\footnotetext{
190 Ibidem.

${ }^{191}$ Ibidem.

192 Pierre Rivas desenvolve essa ideia em "Paris capital internacional", capítulo de sua obra Diálogos interculturais, São Paulo, Hucitec, 2005, pp. 118-149. Sobre as relações culturais entre a França e o Brasil, ver o belo livro de Mário Carelli, Culturas cruzadas. Intercâmbios culturais entre a França e o Brasil. Tradução de Nícia Adan Bonatti do original francês Cultures croisées - histoire des échanges culturels entre la France et le Brésil, de la découverte aux temps modernes (Paris : Éditions Nathan, 1993), Campinas (SP), Papirus, 1994.
} 
verdadeira pátria espiritual dos intelectuais e das elites, até o advento da Segunda Guerra Mundial. Com a vitória dos Aliados e o forte incremento da indústria dos Estados Unidos, a divulgação de sua cultura ganhou força e, aos poucos, foi ocupando o espaço que antes pertencia à França ${ }^{193}$.

É nesse contexto que Coutinho, descobridor precoce da cultura estadunidense, reprova o engajamento literário sartreano que vigora na França do pós-guerra: "Importando sobretudo à "nova crítica' a literatura, o exercício literário constitui atividade autônoma em relação às outras, máxime a política, sendo espúrias as formas de literatura de participação ('engagée'), pois o escritor só deve fidelidade à sua obra, sua vocação, sua arte.” 194

Em suma, em sua introdução a Correntes Cruzadas, o crítico defende a abertura dos espíritos brasileiros aos aportes dos Estados Unidos e decreta o fim do monopólio da França em uma passagem emblemática:

O alargamento das influências estrangeiras em nosso país, pondo-se termo ao monopólio e ao imperialismo cultural, e abrindo-se janelas para os vários quadrantes do horizonte. A cultura é supra-nacional, não pertence a este ou aquele país. (...)

Quem conhece o autor deste sabe que ele não é um admirador cego e passivo dos Estados Unidos, sua opinião pessimista já tendo sido mais de uma vez exposta de público. Não se peja ele de sua formação sobretudo francesa e sua fidelidade à cultura católica, sorvida por intermédio do grande rio gaulês. Mas, doutro lado, julga-se com suficiente independência de espírito para saber distinguir aquilo que na influência francesa é nefasto ou está errado, mormente para diferençar o que é a verdadeira e melhor tradição francesa do pechisbeque que seus importadores, por cálculo, vesguice ou comodismo mental, fazem passar por boa mercadoria, com nenhum outro intuito senão o de tirar disso o máximo partido. E, "ça va sans dire", essa independência conserva-lhe o juízo claro para enxergar o que há de progressista em outras plagas, especialmente o que há de fecundo para nós em abrirmos as janelas a todas as influências. Não tem culpa que muitos, por acanhamento provinciano, sejam impermeáveis a outros ares, numa adoração imutável, sentimental e acientífica do que chamam a "tradição francesa". O preconceito anti-americano, em particular, é muito comum em certos intelectuais que, por maiores que sejam as provas, simplesmente não tomam conhecimento da América, a despeito de, no mínimo, ela ser hoje o mais sério e mais importante centro de estudos do mundo. ${ }^{195}$

O discurso de Coutinho, no que tange à concepção da obra literária, à crítica e ao modelo cultural francês, destoa dos discursos de seus companheiros de geração, como, por exemplo, Casais Monteiro e Sérgio Milliet. Era de se esperar que Coutinho, por sua formação francesa, como as de Casais Monteiro e Milliet, fosse guiado por concepções literárias semelhantes às deles, e dos demais críticos tradicionais em atividade no Brasil dos anos 50. Essa expectativa poderia ser corroborada

193 Em 1936, o escritor modernista Mário de Andrade já refletia sobre a substituição da cultura francesa pela estadunidense como referência cultural dos intelectuais brasileiros, no ensaio "Decadência da influência francesa no Brasil". In Mário de Andrade, Vida literária, São Paulo: Editora da Universidade de São Paulo, 1993, pp. 3-5.

194 "Introdução". In Correntes cruzadas. Questões de literatura. Rio de Janeiro, A Noite, 1953, pp. I-XXIII.

195 Ibidem. 
pelo fato dos três terem passado por importantes experiências comuns: formaram-se em universidades e tiveram vivências no exterior: Casais Monteiro era formado em Letras e viveu em Portugal até 1954, quando mudou-se para o Brasil; Milliet tinha diploma de Economia e viveu na Suíça de 1912 a 1920. O que marca a diferença de Coutinho em relação a seus colegas de geração é seguramente sua experiência nos Estados Unidos, de 1942 a 1947, onde frequentou cursos universitários, notadamente em Nova Iorque, e conheceu uma concepção de literatura outra que não a aceita e implantada no Brasil por reflexo dos modelos europeus. Em outras palavras, o que parece distanciar Coutinho de Casais Monteiro e Milliet é sua opção de exílio em um país que, mesmo sobre bases europeias, desenvolveu uma visão particular da obra literária e da prática crítica. Já Casais Monteiro e Milliet, mesmo na Europa durante uma parte significativa de suas vidas, assim como os demais críticos brasileiros, habituados a espelhar-se nos países europeus, estavam ainda muito próximos do Brasil, que na primeira metade do século XX importou sem grandes adaptações o sistema universitário europeu - incluindo os professores, como já foi visto -, bem como sua concepção de literatura e de crítica. Até o final da década de 50, portanto, o Brasil seguia os padrões europeus em literatura e era nos Estados Unidos que se podia encontrar uma proposta diferente.

Coutinho continua seu texto - quase um manifesto em favor da crítica nova - descrevendo os escritores brasileiros, que, na maioria dos casos, eram também críticos, pois, até aquele momento, a crítica era um ramo da carreira de "literato" que não exigia conhecimentos específicos. E faz deles um retrato maldoso:

Ao invés de se propor uma obra de criação, o escritor brasileiro prefere viver literariamente. Dispersa a sua atividade, a sua capacidade, o seu gênio, nas rodas, nos corrilhos, nas disputas, nas intrigas. As lutas entre as várias capelinhas é uma delícia. Uma antologia de epigramas trocados entre os vários escritores e grupinhos, e de suas intrigas, faria o encanto dos amantes da sátira. Seria talvez mais genial do que a sua própria poesia. ${ }^{196}$

Diante desse quadro, o autor apregoa a necessidade de se revisar não somente os conceitos, mas também as práticas dos escritores e críticos brasileiros que, pela descrição acima, lembram, mais uma vez, a época romântica, quando se concebia a obra literária como produto de uma inspiração e não como fruto do estudo e do labor. Coutinho ainda lamenta que no Brasil não tenha surgido uma geração de críticos e escritores semelhante à geração literária estadunidense do pósguerra de 1914-1918 ${ }^{197}$, que, graças às contribuições teórico-práticas do new criticism e de

\footnotetext{
196 Ibidem.

${ }^{197}$ O crítico brasileiro faz referência a Exile's return. A literary odyssey of the 1920's (1934), de Malcolm Cowley, adaptando ao contexto brasileiro o conteúdo do livro, o que engendra duas interpretações possíveis: a primeira aproveita
} 
tendências afins, como a Chicago School, passou a encarar o texto a partir de um paradigma outro que não mais a história literária e o biografismo. O que o crítico ainda não podia enxergar era que a versão brasileira dessa geração estadunidense não demoraria a se firmar: os críticos universitários já existiam - mesmo que em função da oposição entre crítica tradicional e crítica nova - e se estabeleceriam no panorama literário brasileiro nas décadas seguintes, mudando a partir daí a maneira de se conceber o tex to literário ${ }^{198}$.

No jornal, a acolhida ao new criticism seguiu a mesma rotina de ataques que caracterizou as reflexões sobre a universidade e sobre a crítica nova, e teve como um dos principais opositores Adolfo Casais Monteiro. Seu texto "Ilusões da crítica: dividir para aprofundar", publicado em Literatura e Arte, em $1957^{199}$, exemplifica como o crítico associa os três principais elementos que compõem o panorama literário brasileiro da década de 50, sob o olhar da crítica tradicional.

Casais Monteiro inicia seu texto acusando o new criticism de pulverizar a obra literária por meio de seus métodos analíticos, em nome da busca da essência da literatura. Ele compara a close reading, com humor, à demanda do Santo Graal. No entanto, faz uma ressalva:

Quer isso dizer, simplesmente, que o atomismo crítico não é a única feição da crítica, nesse país [Estados Unidos]. Mas pode dizer-se, sem favor nenhum, que é a pior. Nem sequer a expressão "nova crítica" corresponde, como certos confusionistas podem ter feito crer a leitores mais ingênuos, unicamente aos furiosos das minudências, que tiram do pormenor o que não sabem encontrar no conjunto. Com efeito, "nova crítica" é uma denominação tão vaga que, com um pouco de atenção, se verifica corresponder a tudo o que se quiser, com Aristóteles ou sem Aristóteles, com Longino ou sem Longino. Pobre do Aristóteles, que tem as costas largas... ${ }^{200}$

Casais Monteiro aponta dois fatos, considerados por ele problemáticos, e intrinsecamente ligados ao new criticism: o primeiro diz respeito à pluralidade de tendências críticas existentes nos Estados Unidos dos anos 50, incluindo algumas contrárias aos preceitos dos new critics, e sua invisibilidade no Brasil. Não havendo ainda, naquela época, uma tradição cultural estadunidense consolidada no país, poucos eram os intelectuais brasileiros que conheciam, de maneira profunda, o panorama crítico nos Estados Unidos. Casais Monteiro, ao mesmo tempo em que se mostra bem

unicamente a ideia de uma geração revolucionária de escritores e intelectuais em ação a partir do final da Primeira Guerra Mundial, e que seria necessária no Brasil. A segunda interpretação dessa referência sugere uma comparação pretensiosa entre Afrânio Coutinho e os escritores pertencentes a The Lost Generation que, depois de um período de exílio no exterior, voltaram ao seu país e conferiram novos ares às práticas literárias.

${ }^{198}$ Fábio Lucas, jovem crítico já citado neste trabalho como defensor da prática literária a serviço do conhecimento da realidade brasileira, em outro texto abraça o credo da crítica nova, saudando Afrânio Coutinho e já enxergando na crítica brasileira daquele momento mudanças substanciais com relação à crítica praticada nos anos 40. Ver Fábio Lucas, “A nova crítica no Brasil", Suplemento Literário, 7 de junho de 1958, p. 1.

${ }^{199}$ Literatura e Arte, 10 de março de 1957, [p. 1].

${ }^{200}$ Ibidem. 
informado, não deixa de usar esse dado em favor de seu grupo, dentro da querela da crítica, relativizando a força do new criticism em seu país de origem, restringindo essa tendência a um grupo, e não mais considerando-a una e dominante, como Afrânio Coutinho a divulgava.

O segundo fato problemático decorre do primeiro e concerne a definição de "nova crítica", expressão que, para Casais Monteiro, não corresponde unicamente a uma tradução de new criticism. Caracterizando-a como "vaga", o autor esvazia o conteúdo da expressão e, por conseguinte, desvaloriza seus adversários, que se agrupam em torno dela. O autor ainda atribui tal compreensão da expressão, largamente ventilada na crítica brasileira, a "certos confusionistas": leia-se, Afrânio Coutinho. A pista que conduz a ele é a citação de Aristóteles, cuja Poética, à moda da Chicago School, fundamenta sua concepção de crítica, conforme já mencionado no início deste capítulo.

O que Casais Monteiro não percebe - ou finge não perceber, apegando-se somente ao sentido próprio da expressão - é que "nova crítica", no Brasil daquela época, não era somente a tradução de new criticism - embora fosse um new criticism mesclado por ideias da Chicago School. "Nova crítica" também significava toda e qualquer conceituação de crítica oposta à crítica tradicional. Tratava-se, portanto, de uma expressão de sentido voluntariamente amplo - e, por que não admitir com Casais Monteiro, "vaga"? -, já que estava a serviço de um grupo, no contexto de uma disputa de poder. Dêitica, "nova crítica" assumia uma nova significação a cada texto em que era utilizada sem, por isso, excluir seus demais sentidos: era a crítica universitária, a crítica científica, a crítica estética, o new criticism, a Chicago School, e tudo o mais que colocasse em questão os métodos e os preceitos da crítica tradicional, fosse ela subjetiva ou histórico-biográfica.

O crítico ainda cita um trecho de The Armed vision, de Stanley Edgar Hyman (Nova Iorque, A.A. Knopf, 1948), como exemplo de defesa da análise detalhada de todos os elementos constituintes da obra literária. Casais Monteiro, opondo-se a esse método analítico, defende uma leitura menos preocupada com os detalhes do que com a criação de um sentido global para a obra literária, como se sua interpretação total não estivesse no horizonte do new criticism. Mas o que chama a atenção é a caracterização do livro de Hyman como “ 'bíblia' dos furiosos da investigação do nada" 201: além de desqualificar a close reading, o crítico erige The Armed vision ao posto de obra mais importante do new criticism. Consequentemente, ao atacá-lo, ele acaba por desferir um golpe contra essa tendência crítica, acertando, por tabela, a crítica nova.

As investidas de Casais Monteiro contra a crítica nova nesse texto são bastante astutas e denotam uma visão estratégica acurada. Os ataques ao new criticism por meio da desqualificação de

${ }^{201}$ Literatura e Arte, 10 de março de 1957, [p. 1]. 
seu método analítico ultrapassam um simples debate de ideias e reforçam a querela pelo monopólio sobre a concepção da literatura no Brasil, como a passagem abaixo deixa evidente:

Não sei se algum leitor se lembrou, ao ler o título deste artigo, daquele famoso princípio político: "dividir para reinar". Eu só agora me lembrei, e realmente o paralelo não deixa de ter, pelo menos, uma certa graça. Mas até pode ter alguma coisa mais. Porque, realmente, o pedantismo dos críticos fragmentaristas, pulverizações, etc., é uma rancorosa desforra contra a resistência que lhes opõe a obra de arte. ${ }^{202}$

Casais Monteiro deixa implícita sua leitura da sobreposição das expressões "dividir para aprofundar"/ "dividir para reinar": ele acusa os adeptos da close reading de desmontarem, peça por peça, a obra literária, por não serem capazes de compreendê-la em sua totalidade. Ou seja, eles a dividem para se apoderar dela, dividindo-a para reinar. No entanto, uma outra compreensão da relação entre fragmentação e poder pode ser aplicada à própria estratégia do autor contra a crítica nova: Casais Monteiro busca colocar em evidência a pluralidade de tendências críticas existentes nos Estados Unidos a fim de pulverizar a propagada coesão do new criticism, desarticulando, assim, uma parte de seus inimigos. Dividindo a tendência crítica estadunidense, ele poderá reinar sobre ela.

Sua tática é comprovada na sequência do texto, em que Casais Monteiro cita mais um crítico, Malcolm Cowley, para corroborar sua afirmação de que nos Estados Unidos não se faz somente new criticism. Segundo o autor português, em The Literary situation (Nova Iorque, Viking Press, 1954), Cowley estabelece um paralelo entre os new critics e a crítica francesa do século XIX, associando a close reading à explicação de textos. A esta, Casais Monteiro associa o estudo da literatura em ambiente escolar. O crítico despreza a “análise 'professoral' de textos" 203, acrescentando ao método analítico o adjetivo "professoral", frequentemente empregado pelos críticos tradicionais ao se referirem à crítica nova, numa alusão a sua origem, a universidade. Para ele, o new criticism é um logro duplo: não representa a crítica literária estadunidense e nem é novo, pois reabilita um método analítico antiquado e comprovadamente ineficaz, conforme atestam as experiências escolares: “Acontece que nós não queremos voltar para a escola, por estarmos muito bem lembrados de lá raramente termos aprendido alguma coisa sobre literatura, e muito menos sobre crítica, no pleno sentido da palavra." ${ }^{204}$ Conclui, mais uma vez, atacando a expressão "nova crítica" e reforçando o caráter terminológico da querela brasileira:

\footnotetext{
${ }^{202}$ Ibidem.

203 Ibidem.

204 Ibidem.
} 
"Nova crítica"? Não. Afinal, simplesmente, velha escola. E a velha escola, infelizmente, já bem sabemos, da Europa, o que ela seja. Não é isso o que esperamos da América, a qual, felizmente, ao contrário do que se poderia supor lendo certos novos críticos traduzidos para português, tem mais alguma coisa para nos oferecer do que velhas casacas viradas do avesso. ${ }^{205}$

Casais Monteiro não está sozinho quando imputa ao new criticism um retrocesso em matéria de crítica literária, reduzindo seu ideário à close reading desprovida de interpretação. Temístocles Linhares exprime a mesma opinião em "Sabedoria e serenidade da 'nova crítica'", artigo publicado em 1958. O crítico parte da análise de Dimensões - I (Rio de Janeiro, José Olympio Editora, 1958), do jovem Eduardo Portella, para elogiar esse "novo crítico" e atacar o new criticism e Afrânio Coutinho. A "sabedoria" e a "serenidade" mencionadas no título não se referem, portanto, à nova crítica, entendida como crítica nova ou como new criticism, mas a Eduardo Portella, que cronologicamente pertence a uma nova geração de críticos brasileiros.

Ao ler a obra de Portella, Linhares reconhece as qualidades de um jovem crítico parcialmente alinhado à crítica tradicional, e suas ilusões no que tange ao emprego do impressionismo aliado ao estudo dos mecanismos de funcionamento da obra literária. O autor do artigo incita sutilmente o jovem a tomar o partido contrário à crítica nova, na seguinte passagem:

(...) mas convém assinalar que, no andar em que vai, não lhe [a Eduardo Portella] será muito difícil perceber quanto a idolatria estilística em que se abriga a "nova crítica" está presa à crença de ser a realidade mais vã que a sua figuração verbal, de o acento de uma ideia importar mais do que essa ideia, de um pretexto bem conduzido valer mais do que uma convicção, etc. ${ }^{206}$

Por "idolatria estilística" o crítico entende o estudo aprofundado das figuras de linguagem e de todos os elementos linguísticos que compõem a obra literária, elevados a uma categoria excessivamente importante, para os críticos tradicionais. A divisão da obra literária em duas partes, forma e conteúdo, subjaz ao discurso de Linhares, que interpreta o método analítico da crítica nova como uma valorização extrema da forma em detrimento do conteúdo: o conteúdo seria a "realidade", "mais vã", menos importante do que a forma, que seria "sua figuração verbal". Crítica semelhante foi feita por Milliet a Le Degré zéro, em 1953, quando este qualificou a obra de Barthes com a palavra "devaneios" e a tratou como objeto de diversão, em oposição àqueles que "pesquisam seriamente a realidade contemporânea" 207.

\footnotetext{
205 Ibidem.

${ }^{206}$ Suplemento Literário, 9 de agosto de 1958, p. 1.

207 "O grau zero da escrita", Primeiro Caderno, 17 de novembro de 1953, p. 8.
} 
Linhares ainda exalta a defesa feita por Portella da combinação da análise literária detalhada ao impressionismo crítico. Acusa Afrânio Coutinho e o new criticism de pretenderem impor um método analítico único, desrespeitando as particularidades de cada obra. E conclui pela incapacidade dos "novos críticos" - new critics e seus defensores brasileiros - de analisarem literatura lançando mão do “instinto". Nesse ponto, Temístocles Linhares se junta a Casais Monteiro, afirmando que:

No fundo, a sua sabedoria [da nova crítica] não é hostil à novidade, a tudo que seja realmente "novo"? Orgulhosos que se isolam na norma, os seus adeptos só se afirmam recuando. Que caminhos eles buscam senão os que lhes permitam ultrapassar ou neutralizar as suas contradições? Se o conseguem, estão provando, contudo, que estas careciam de vigor. Fazendo-lhes falta o instinto, torna-se-lhes fácil ser donos de si mesmos e pontificar, como já se disse, na anemia de suas serenidades. ${ }^{208}$

As censuras mais recorrentes à crítica nova encontram-se no trecho acima: a adjetivação empregada para definir os críticos novos - "Orgulhosos que se isolam na norma" - refere-se a seu isolacionismo, herança de sua estreita relação com a universidade, que, como foi mostrado, era percebida como um espaço exterior à sociedade, estendendo seu caráter marginal àqueles que a ela estavam ligados. A expressão "Fazendo-lhes falta o instinto" alude ao método analítico da crítica nova, oriundo, segundo a crítica tradicional, da ausência de "dom" ou de "intuição". E a associação da nova crítica à novidade, falsa aos olhos de Linhares, deve muito ao método analítico do new criticism, que contribuiu para fundamentar e consolidar as convicções da crítica nova brasileira, acrescentando-lhe ainda a chancela de uma inovação vinda dos Estados Unidos, país de influência mundial crescente desde o final da Segunda Guerra.

Os ataques à crítica nova dominam os textos sobre crítica literária no Brasil dos anos 50 e analisá-los todos seria extremamente repetitivo. Detive-me somente nos mais relevantes, procurando dar ênfase aos elementos que eles acrescentam à querela da crítica. Dois nomes sobressaem-se no período, Adolfo Casais Monteiro, figura de proa da crítica tradicional, e Afrânio Coutinho, arauto da crítica nova, fortemente influenciado pelos preceitos do new criticism e da Chicago School. Tais críticos não terão a mesma importância na década seguinte, quando a querela da crítica brasileira contará com novos personagens e será enriquecida pelas discussões sobre o estruturalismo e pelos ecos da querela da crítica francesa entre Raymond Picard e Roland Barthes. No entanto, o conhecimento do panorama da crítica de 1950 será fundamental para a compreensão da recepção à obra de Barthes na década seguinte: o escritor francês, que até então só havia sido notado por

${ }^{208}$ Suplemento Literário, 9 de agosto de 1958, p. 1. 
poucos, será efetivamente apresentado aos leitores brasileiros e seus livros e ensaios começarão a ser lidos e comentados, não só à luz dos ecos da recepção francesa à sua obra, mas, sobretudo, em função de seus princípios teóricos, e dos aliados e inimigos que eles conquistarão. 


\section{Anos 60: apresentação}

A nossa época é maravilhosa. Tudo está em questão, nada é certo, tudo é problemático. ${ }^{209}$

Joaquim de Montezuma de Carvalho

A epígrafe que escolhi como mote para esta parte pode soar ao leitor como um déjà vu. Em sua substância, exprime um momento de confusão de ideias, tal como as palavras de Sérgio Milliet, empregadas como epígrafe ao estudo da recepção de Barthes nos anos 50. Contudo, os dizeres do ensaísta português Joaquim de Montezuma de Carvalho, colaborador e debatedor frequente na imprensa brasileira da época, revelam um outro estado de espírito, que faz toda a diferença: em um artigo sobre o estruturalismo, publicado em 1969, o autor exalta as grandes discussões intelectuais que marcaram a década de 60 e se estenderão até o final dos anos 70, quando o jornal, gradativamente, deixa de ser uma arena de debates culturais.

A mudança de ponto de vista - de uma percepção negativa das novas questões literárias surgidas nos anos 50, para uma visão positiva - é sintomática de uma postura mais aberta às novas correntes teóricas que estavam tão em voga naquele momento. Claro que a opinião de Carvalho não se constitui como unanimidade, e nem que foi preciso mudar de decênio para que os humores da crítica brasileira se alterassem. Mas, dentro do continuum de discussões acerca da natureza da literatura e das funções da crítica que dominaram as décadas de 50-70, os anos de 1960 apresentam algumas particularidades, que incidem sobre a recepção a Barthes e, por conseguinte, sobre suas imagens.

Em vários artigos dessa década encontrei referências às questões relacionadas às críticas universitária e tradicional e ao new criticism, feitas de tal maneira que indicavam uma visão que já as entendia como parte do passado. Esse sentimento é partilhado por críticos que combateram dos dois lados da querela e pode ser situado aproximadamente na metade dos anos 60. Temístocles Linhares, antigo soldado da crítica tradicional, admite, em artigo sob a forma de diálogo, como era hábito seu, em 1965:

- V. quer chegar à especialização da crítica, não é?

209 “O estruturalismo é um anti-humanismo?”, O Estado de S. Paulo, Suplemento Literário, 21 de junho de 1969, p. 6. 
- Especializada ou não em determinado gênero, o crítico de hoje não se confunde com o de ontem. A crítica mesmo mudou muito entre nós e há quem atribua papel preponderante às faculdades de letras que, a despeito de suas deficiências, alargaram os horizontes, além de corrigirem em parte a desorientação intelectual inautêntica e divisionista em que antes nos debatíamos. Pelo menos, as faculdades constituem o primeiro esforço corretivo que tivemos nesse sentido, embora possam ser responsabilizadas pela criação de um tipo convencional e que já começa a existir em nossa literatura: a do scholar, meio pedante, autossuficiente, mas necessário à disciplinação da inteligência e até para dirigi-la rumo à terra e ao povo, com o fim de restabelecer a grande união inicial. As faculdades são centros onde arde a chama lúcida da inteligência arraigada e fiel e a crítica direta ou indiretamente já se tem beneficiado dessa mentalidade renovada. ${ }^{210}$

Chega a ser surpreendente a mudança do discurso sobre a universidade e a crítica em um espaço tão curto de tempo. Também começam a se fazer mais presentes nos jornais os críticos universitários que, naturalmente, defendem seu ponto de vista, como João Alexandre Barbosa, para o qual

(...) a crítica literária possui um "status" reconhecidamente importante dentre as atividades culturais e não se resume apenas à catalogação do reviewer ou ao puro jogo de espelhos do anotador de emoções à margem de versos suspirosos (!) É à crítica literária entendida como força de investigação que não pode prescindir de amarras especulativas que o crítico empresta o melhor de si mesmo. $^{211}$

A pesquisa situada no âmago da crítica, que não prescinde de sua "força de investigação", como apregoa Barbosa, abre as portas para a introdução de novas teorias na prática da exegese literária, o que, nesse momento, já caracteriza a nouvelle critique e é alvo de ataques na França.

Wilson Martins, em um artigo de título inspirador, "A Nova Guarda", sintetiza passado e presente como ninguém, apontando a nova tendência da crítica que aportará no Brasil no ano seguinte (1966) e que colocará Barthes no centro das atenções. Nesse texto, Martins faz um balanço geral dos debates literários dos anos 50, mostrando o esgotamento das polêmicas entre novos e tradicionais. Para tanto, compara dois críticos, a seu ver mais identificados com propósitos e ideais da década anterior, Fábio Lucas (que havia flertado com a crítica tradicional, mas mudara de lado, como assinalamos no capítulo anterior, para posicionar-se definitivamente na crítica sociológica de viés nacionalista, sempre contra o estruturalismo ${ }^{212}$ ) e Fausto Cunha, com outros dois críticos

\footnotetext{
210 “Ainda a crítica dos críticos”, Suplemento Literário, 15 de maio de 1965, p. 4.

211 “Tríplice desafio", Suplemento Literário, 25 de junho de 1966, p. 1.

${ }^{212}$ Fábio Lucas é figura complexa na história da crítica brasileira. Sua defesa, primeira, da crítica tradicional, condizia menos com o apoio à crítica impressionista do que com a refutação da análise puramente imanente da obra literária. Ele não defendia o subjetivismo crítico, porém atacava o ahistoricismo formalista e, posteriormente, estruturalista. Encontrou seu lugar na moderna crítica sociológica de fundo nacionalista, que não era determinista, e que via nas formas literárias elementos importantes para se compreender a cultura e a sociedade brasileiras.
} 
adeptos das novas concepções literárias, Léo Gilson Ribeiro e Assis Brasil. Martins inicia suas reflexões com um olhar panorâmico sobre o passado recente:

A década de 50 foi, na crítica brasileira, a época dos grandes debates teóricos, de que se encontram ainda os últimos ecos nos livros dos Srs. Fábio Lucas e Fausto Cunha; a década de 60 (reservando-se, em cada um desses períodos convencionais, a margem necessária para o desaparecimento das sobrevivências, nos primeiros anos e, logo em seguida, para a caracterização dos novos rumos) anuncia-se por uma tentativa simultânea de universalização estética, mas, também, de crítica aplicada. ${ }^{213}$

Martins não explica o que entende por "universalização estética". Talvez seja uma consequência do apaziguamento dos ânimos e da aceitação generalizada do rigor metodológico e do objetivismo da crítica universitária. Também não define a "crítica aplicada", mas a expressão faz pensar na aplicação de teorias - linguísticas, sociológicas, marxistas, psicanalíticas, etc. - à exegese das obras literárias, evidenciando seu conhecimento de práticas correntes na França, ainda importante pólo irradiador de modas literárias. Comparando os quatro críticos mencionados, o autor conclui:

Vê-se bem que, em todos os casos, os fundamentos teorizantes, se já não ocupam o primeiro e único ponto de incidência luminosa, dominam, não obstante, os subentendidos das tomadas de posição; essa é a parte de herança útil que nos transmitiram as febris e um pouco desordenadas discussões dos anos anteriores. ${ }^{214^{3}}$

Em outras palavras, a querela brasileira, com a vitória dos professores universitários, preparou o terreno para a aceitação do emprego, como ferramenta analítica, de um aparato teórico até então incompatível com a atividade crítica. Nessa época, muito contribuíram para a consolidação dessa vitória os congressos de literatura realizados pelo país.

Aliás, ouso afirmar que a década de 60, na crítica literária, teve início somente no mês de agosto, com o I Congresso de Crítica e História Literária, realizado no Recife, na Universidade Federal de Pernambuco ${ }^{215}$. A crítica universitária foi consolidada pelos congressos que se seguiram, em 1961, na Universidade Estadual Paulista, campus de Assis (de 24 a 30 de julho), e em 1962, na Universidade Federal de João Pessoa, na Paraíba (de 4 a 8 de dezembro).

\footnotetext{
${ }^{213}$ Suplemento Literário, 13 de novembro de 1965, p. 6.

214 Ibidem.

${ }^{215}$ Nem um pouco fortuita a escolha do Recife como sede desse primeiro evento: sofrendo forte resistência da crítica tradicional, como mostrei no capítulo anterior, nesse congresso os universitários abrigaram-se sob a égide dos primeiros críticos brasileiros, Tobias Barreto, Sílvio Romero e Araripe Júnior, dentre os mais eminentes, da Escola do Recife (final dos anos 1860 até 1914), que romperam com os padrões filosóficos espiritualistas e positivistas que até então subsidiavam as reflexões sobre o Direito e a Literatura, defendendo o cientificismo metodológico.
} 
Organizados por professores universitários em seu próprio território, esses eventos, já em seu nome, não permitiam ambiguidades: crítica e história não se misturavam, mas poderiam caminhar juntas. A crítica universitária, criando seus próprios espaços de ação, propunha uma solução aglutinadora dos saberes científicos em prol da leitura das obras literárias, buscando enterrar de uma vez por todas o impressionismo crítico ${ }^{216}$. Com uma só tacada, ela colocava um ponto final nas discussões que opunham subjetivismo e objetivismo e atualizava os debates literários inserindo na ordem do dia a contribuição de novos ramos do saber para o estudo do texto: na França da década de 60, as críticas de fundamentação psicanalítica, marxista, sociológica e outras, chamadas de nouvelle critique, eram objeto dos ataques da crítica tradicional, constituindo uma encarniçada querela. Ou seja, muito rapidamente, e graças à organização dos intelectuais dentro das novas universidades, no Brasil passou-se de uma discussão própria ao contexto local, nos anos 50, para uma discussão em âmbito local de uma problemática estrangeira. O que sinaliza, na década de 60, a integração gradual desta aos arcabouços teóricos dos intelectuais brasileiros.

Como consequência da rotação no eixo das discussões literárias, o olhar dos críticos brasileiros foi se desviando gradativamente do new criticism estadunidense para se fixar na nouvelle critique francesa. Tanto que as citações de críticos de língua inglesa foram cedendo espaço a outros nomes cada vez mais familiares aos intelectuais brasileiros: Butor, Blanchot, Bachelard, Sollers, Althusser, Lévi-Strauss, Mauron, Lacan, Duras, Robbe-Grillet e, mais discretamente, Barthes. Esse novo interesse pela França permitiu que, nos anos 60, "nova crítica" fosse entendida como sinônimo de nouvelle critique.

No mesmo navio, portanto, chegaram ao Brasil a nouvelle critique, o estruturalismo e sua pluralidade de concepções e de práticas, o nouveau roman e Barthes. Depois da incompreensão suscitada em 1953 por Le Degré zéro, o escritor continua a ser citado em O Estado de S. Paulo, nesse momento, sob o signo da desconfiança.

\section{Retrato de grupo}

As primeiras citações de Barthes nos anos 60 dão a entender que os autores dos textos em que elas figuram já tinham alguma informação sobre o escritor, só que dentro de um contexto que o

\footnotetext{
${ }^{216}$ Em artigo dedicado à crítica sociológica, redigido com base nos Anais do Segundo Congresso Brasileiro de Crítica e História Literária, Wilson Martins faz um balanço do evento que pode ser estendido aos outros dois congressos: "Longe de propor a supremacia de qualquer método crítico particular, o Congresso de Assis parece haver admitido tacitamente a ideia de que todos eles são legítimos e fecundos, conforme circunstâncias e objetivos determinados (...)”. In “A crítica sociológica I", Suplemento Literário, 4 de janeiro de 1964, p. 2.
} 
situava junto a outros jovens autores e críticos. Barthes, portanto, aparece primeiramente como se estivesse num retrato de grupo, em meio a outras pessoas, quase sem destaque individual.

Seu nome aparece sob a pena de Lívio Xavier, resenhista de periódicos do Suplemento Literário, responsável pela coluna "Revista das revistas". À primeira vista, essa descoberta surpreendeu, pois Xavier não demonstrava simpatia pela crítica nova. Mas a leitura de seu texto desfez a aparente contradição.

O artigo de Xavier, "Michel Butor, crítico" ${ }^{217}$, é uma resenha de "Michel Butor, critique", de Jean Roudat, publicado na revista Critique de julho de 1960, que se limita a reportar ao leitor brasileiro a tese e os argumentos do crítico francês. Em linhas gerais, Xavier transmite as reflexões de Roudat sobre Répertoire I (Paris: Minuit, 1960), coletânea crítica recém-lançada por Butor, cujos textos têm por fundamento a ideia de que uma obra deve ser interrogada a partir de seu interior. Esse a priori crítico, colocado em relevo por Xavier certamente porque Roudat também o faz, contrapõese à prática universitária tradicional francesa de análise literária, que até então se estabelecia sobre as bases do lansonismo: o biografismo, os fatores históricos, enfim, os elementos exteriores à obra determinavam sua leitura.

A nouvelle critique, em 1960, embora já reconhecesse alguns de seus autores mais eminentes, como Butor, ainda buscava seu espaço e firmava seus princípios. Dentre a pluralidade de pontos de vista reunidos sob a expressão nouvelle critique, destaco o caráter imanente da obra literária, que liberta sua compreensão de fatores que lhe são extrínsecos e demanda um olhar atento a seu funcionamento ou, para utilizar um vocabulário caro à época, ao mecanismo que gera suas significações. Tal concepção já era defendida pelo new criticism, que, como já exposto, no Brasil foi instrumentalizado contra a crítica tradicional e impressionista.

No contexto francês, portanto, Butor era conhecido por suas obras experimentais e desconcertantes, associadas ao nouveau roman, e com sua primeira coletânea de textos críticos, irmanava-se em concepções aos defensores da nouvelle critique. No Brasil, seu nome já havia frequentado bastante os jornais desde a década de 50 e a defesa da análise intrínseca da obra literária apenas corroborava a opinião vencedora na querela da crítica.

Implicitamente, portanto, a resenha de Xavier demonstra a consonância existente entre as novas concepções literárias na França e no Brasil, mas sem fazer alarde. Discretíssimo, nesse texto o resenhista brasileiro nem mesmo explicita seu ponto de vista sobre o assunto tratado, como ele habitualmente fazia: sua implicação se encontra, sobretudo, na escolha do texto a ser resenhado, que

\footnotetext{
${ }^{217}$ Publicado em 27 de agosto de 1960, p. 6.
} 
pode ser entendida como uma tentativa de atualizar o leitor brasileiro quanto às questões literárias em voga no contexto francês, acrescidas do olhar sobre um escritor de vanguarda.

Barthes, na resenha, é apenas um figurante. Seguindo de perto o texto de Roudat, depois de distinguir o método analítico da crítica universitária francesa, adotado pela maioria dos críticos tradicionais, do método de Butor, Xavier redige um parágrafo visando demonstrar que havia outros críticos trabalhando na mesma perspectiva do autor de Répertoire I: "O trabalho do crítico, dentro da obra literária, pode dirigir-se à procura do elemento que lhe servirá de ponto de referência. Assim como para Roland Barthes, a temática, para Maurice Blanchot, a metafísica implícita no romance, a forma para Butor assume o valor de elemento essencial." 218

A enumeração de autores que trabalham a obra literária sob a perspectiva imanente Barthes, Blanchot, Butor - evidencia um Barthes mencionado de maneira ao mesmo tempo clara como um membro do grupo - e obscura. A que Xavier se refere ao citar Barthes como um autor que tem na temática o eixo fundamental de suas análises, num momento em que suas únicas obras eram Le Degré zéro de l'écriture, Michelet e Mythologies? Tendo em vista que, dentre elas, a primeira e a última tiveram maior repercussão, seria de se esperar um Barthes identificado ao estilo, que o conceito de écriture, tal como exposto no primeiro livro, deixa entrever; ou um Barthes mitólogo, crítico da sociedade de seu tempo por meio da análise da linguagem empregada pelos mitos por ela criados; ou até mesmo um Barthes crítico teatral, devido a suas atividades como redator da Théâtre Populaire.

Mas é outro Barthes que aparece. Sua identificação à crítica temática provavelmente reflete um artigo de Gaëtan Picon publicado na Mercure de France relacionando Michelet a Littérature et sensation (1954), de Jean-Pierre Richard ${ }^{219}$. Sobre essa obra, o próprio Barthes se posicionou, festejando-a, em 1955, em resenha entitulada "Du nouveau en critique"? ${ }^{220}$ Nesse texto, o escritor analisa os ensaios de Richard sobre Stendhal, Flaubert, o pintor Fromentin e os irmãos Goncourt, destacando seus temas, como segue:

Les analyses de Richard mettent au jour d'une façon décisive, me semble-t-il, la propriété de chacun de ces auteurs: pour Stendhal, le mouvement de division et de circonscription de la matière; pour Flaubert, la voracité passive; pour Fromentin, le glacement du paysage; pour les Goncourt, la volupté de l'incomplétude des surfaces. De ces principes, Jean-Pierre Richard étend tout un réseau d'explications et d'analyses qui couvrent et épuisent la surface littéraire (et non conceptuelle) de

\footnotetext{
218 “Michel Butor, crítico", Suplemento Literário, 27 de agosto de 1960, p. 6.

219 A informação é imprecisa e não pôde ser verificada. Cf. José Guilherme Merquior, De Praga a Paris, tradução de Ana Maria de Castro Gibson, Rio de Janeiro, Nova Fronteira, 1991, p. 138.

${ }^{220}$ Publicada na revista Esprit de novembro de 1955 . In $O C$ v. 1, pp. 622-625.
} 
l'oeuvre, l'étendue des actes créateurs, infiniment compliqués, par lesquels l'écrivain institue la littérature. ${ }^{221}$

Entretanto, aos olhos de Barthes, não é a análise temática a tônica da obra crítica de Richard, e sim sua maneira, diferente da tradicional, de se relacionar com a História. Pois, já nessa época, na resenha de Littérature et sensation, Barthes ataca a subserviência da obra literária aos fatos históricos que dominava o panorama literário francês. À guisa de conclusão, o escritor resume:

Pour induire la littérature de l'histoire, qu'on le veuille ou non, il faut passer par un objet, qui est l'oeuvre. L'importance de Littérature et sensation, c'est d'avoir exploré quelques consciences corporelles, d'avoir, dans quelques cas précis, défini la structure de ces oeuvres-objets et d'avoir ainsi mis l'imaginaire de quelques écrivains à portée même de l'Histoire. ${ }^{222}$

Defendendo o papel central da obra na crítica literária - o que não exclui a História -, Barthes adianta sua reivindicação da década de 1960, a saber, a preponderância da linguagem enquanto Texto sobre todo e qualquer elemento exterior ao texto, que culminará com "La Mort de l'Auteur" (1968) e “De l'oeuvre au texte” (1971). Também já emprega, em um texto crítico, um termo bastante presente em Michelet, que se transformará em palavra-chave de sua obra a partir de Le Plaisir du texte: a palavra "corpo". Barthes salienta nas análises de Richard a corporeidade das obras - e sua autonomia -, salvaguardando suas identidades próprias, o que faz com que o autor as desvincule de uma leitura exteriorizante, subordinada à História, sem, contudo, fechar a obra a ela.

Outra possível hipótese explicativa da associação entre Barthes e a crítica temática advém de sua análise de L'Étranger (1942), de Albert Camus, "L'Étranger, roman solaire”, de abril de 1954, em que analisa a função do olhar e do sol nesse livro. Por vias tortas, quiçá essa leitura tenha ficado conhecida graças à breve polêmica Barthes-Camus, nos anos 50, na qual o escritor iniciante tentava se firmar e se posicionar politicamente frente ao escritor consagrado, herói da Resistência e futuro vencedor do Prêmio Nobel de Literatura de 1957. Minha hipótese é a de que o sol tenha sido visto como um tema da obra de Camus explorado por Barthes, justificando, para alguns, sua identificação à "crítica temática" nesse momento.

O conhecimento superficial da obra de Barthes permitiu que Xavier reproduzisse em seu texto a interpretação de Roudat, que, por sua vez, talvez espelhasse a leitura de outros intelectuais. O mesmo não acontece em 1964, no artigo “O Centro da esfera”, de Leyla Perrone-Moisés, dedicado a La Veille (1963), de Roger Laporte, publicado na coluna "Letras Francesas", do Suplemento

\footnotetext{
${ }^{221}$ Ibid., p. 623.

${ }^{222}$ Ibid., p. 624.
} 
Literário, cujo titular, até 1961, fora Brito Broca. Nesse texto, a autora expõe a complexidade da obra do escritor estreante Laporte, que trata da criação literária em seus mais ínfimos movimentos. Barthes novamente é citado dentro de um grupo, com a função de mostrar ao leitor brasileiro que a preocupação com a gênese literária não é exclusividade de Laporte, mas integra uma tendência crítico-literária francesa. Escreve a autora:

Laporte coloca-se, portanto, naquela linhagem de escritores atraídos pelo centro da esfera (1), pelo grau zero da escrita (2), dos que sacrificam a própria obra, às vezes, à procura de suas raízes mais fundas. (...)

(...). Em nossos dias, a procura da essência da Literatura constitui o principal objetivo de numerosos escritores. O próprio Blanchot, Roland Barthes, Samuel Beckett, o Butor de Degrés, são alguns dos exemplos desta atitude.

(1) A expressão é de Maurice Blanchot e foi utilizada em Le Livre à venir.

(2) Le Degré zéro de l'écriture é o título de uma obra de Roland Barthes. ${ }^{223}$

Embora não receba destaque individual, a não ser pela citação de Le Degré zéro, Barthes ao menos é mencionado de maneira mais coerente em relação a seus escritos, muito embora sua concepção de grau zero da escritura não se assemelhe à pesquisa de Laporte. Este, como a autora demonstra, promove uma excursão pelas entranhas da obra em devir, rumo ao seu surgimento. Barthes, diferentemente, estabelece o grau zero no seio da história francesa, sob o ponto de vista das formas literárias, e não o procura dentro de uma obra. Para ele, antes de 1850 havia uma única escritura, fosse de ordem de uma busca pelo conhecimento e de ordem de uma consolidação, bem como de um alargamento das fronteiras da língua francesa - no Renascimento; ou de ordem instrumental e ornamental - do Classicismo ao Romantismo -, que alimentava o mito da "escrita literária" e da Literatura Francesa enquanto instituição à qual só pertencia uma certa casta, a dos escritores. Havia sempre, portanto, em cada período, uma única Literatura, uma única escritura, e diversos escritores.

No entanto, segundo Barthes, uma conjuntura de fatores históricos, na metade do século XIX, criou uma situação em que a escritura burguesa, até então solitária no exercício da Literatura, passou a dividir espaço com outros tipos de escritura: "Chacune [cada escritura] désormais, la travaillée, la populiste, la neutre, la parlée, se veut l'acte initial pour lequel l'écrivain assume ou abhorre sa condition bourgeoise. Chacune est une tentative de réponse à cette problématique orphéenne de la Forme moderne: des écrivains sans littérature." ${ }^{224}$

\footnotetext{
${ }^{223}$ Suplemento Literário, 14 de março de 1964, p. 1.

${ }^{224}$ Le degré zéro de l'écriture. In OC v. 1, p. 208.
} 
A partir de Flaubert surge, portanto, uma concepção intransitiva da escritura: o trabalho do escritor passa a incidir sobre a própria linguagem e não mais sobre um referencial externo a ela. $\mathrm{O}$ que deságua em diferentes escrituras, conforme o trecho acima citado. Dentro dessa história das formas literárias, Barthes enxerga, em certos escritores do século XX, uma escritura neutra, que ele adjetiva como branca ou transparente e considera o "grau zero da escritura". Em suas palavras,

Toutes proportions gardées, l'écriture au degré zéro est au fond une écriture indicative, ou si l'on veut amodale (...). La nouvelle écriture neutre se place au milieu de ces cris et de ces jugements, sans participer à aucun d'eux; elle est faite précisément de leur absence; mais cette absence est totale, elle n'implique aucun refuge, aucun secret; on ne peut donc dire que c'est une écriture impassible; c'est plutôt une écriture innocente. Il s'agit de dépasser ici la Littérature en se confiant à une sorte de langue basique, également éloignée des langages vivants et du langage littéraire proprement dit. Cette parole transparente, inaugurée par L'Étranger de Camus, accomplit un style de l'absence qui est presque une absence idéale du style (...). ${ }^{225}$

A citação é um pouco longa porque a definição do grau zero da escritura é bastante complexa e precisa ser decodificada por partes. Primeiramente, nesse trecho ${ }^{226}$, chama a atenção a grande concentração de estruturas negativas: o grau zero da escritura é definido, sobretudo, por aquilo que ele não é, o que evidencia uma dificuldade em estabelecer suas características. Barthes parece não encontrar palavras capazes de explicá-lo a contento, tratando-o sem auxílio de negações somente como uma "escritura inocente" ou uma "língua básica". Dessa dificuldade decorre o interesse do recurso ao exemplo: mostrando o que é, fica mais fácil entender a écriture blanche. $\mathrm{E}$ com o exemplo de L'Étranger Barthes a associa ao estilo, dizendo o contrário em seguida: "Cette parole transparente (...) accomplit un style de l'absence qui est presque une absence idéale du style".

Ora, em capítulo anterior de Le Degré zéro Barthes situa a écriture entre a língua e o estilo $^{227}$. Como desfazer essa aparente contradição? A própria Leyla Perrone-Moisés, anos mais tarde, em 1978, em sua tese de livre-docência defendida na USP, entitulada Texto, crítica, escritura (São Paulo, Martins Fontes, 2005), reconhece que a separação entre escritura e estilo é bastante problemática na obra do escritor francês ${ }^{228}$. Como a autora claramente demonstra, o conceito de escritura sofreu deslocamentos dentro do pensamento barthesiano ao longo dos anos, adquirindo os ares de seus interesses na medida em que estes mudavam. Nos últimos anos - desde Le Plaisir du

\footnotetext{
${ }^{225}$ Ibidem, pp. 217-218.

${ }^{226}$ Em Le degré zéro de l'écriture Barthes define e explica em vários momentos seu conceito de écriture, écriture neutre, écriture blanche, écriture transparente, degré zero de l'écriture. Selecionei a passagem que me pareceu mais adequada a minha argumentação.

227 "Or toute Forme est aussi Valeur; c'est pourquoi entre la langue et le style, il y a place pour une autre réalité formelle: l'écriture". In Le degré zéro de l'écriture, $O C$ v. 1, p. 179.

${ }^{228}$ Texto, crítica, escritura, São Paulo, Martins Fontes, 2005, p. 33.
} 
texte - a escritura entrou em estreita relação com o corpo do escritor, comportando biografemas; nos anos de estruturalismo, seu caráter auto-referencial tomou a frente - na distinção entre écrivains e écrivants, por exemplo, no artigo de mesmo nome ${ }^{229}$; antes disso, em Le Degré zéro, a preocupação maior era situá-la histórica e socialmente, numa resposta ao Qu'est-ce que la littérature? (1948) de Sartre.

Em cada um desses momentos, o estilo foi descrito diferentemente: como passível de se tornar escritura, dependendo da força da enunciação nele presente - explicação apresentada em seminário na École Pratique des Hautes Études entre 1973-1974 e anotada por Leyla PerroneMoisés ${ }^{230}$-; como oposto à escritura (produto do escritor), enquanto atributo da escrevência (produto do escrevente), no período estruturalista ${ }^{231}$; como baliza da qual a escritura se distancia, segundo minha apreciação de Le Degré zéro, tendo em vista a escrita que contém uma "absence idéale du style" conseguida por Camus.

Em suma, a relação entre escritura e estilo é complexa e mutante ${ }^{232}$, como já anuncia o trecho sobre L'Étranger citado por Barthes. Na definição do grau zero, todavia, o que predomina é a relação desta com seu tempo, explícita na passagem que segue:

(...) l'écriture se réduit alors à une sorte de mode négatif dans lequel les caractères sociaux ou mythiques d'un langage s'abolissent au profit d'un état neutre et inerte de la forme; la pensée garde ainsi toute sa responsabilité, sans se recouvrir d'un engagement accessoire de la forme dans une Histoire qui ne lui appartient pas. ${ }^{233}$

Barthes desvincula o conceito de escritura das marcas da História sem, contudo, promover a alienação da linguagem. Pois, para ele, a escritura é histórica - situada em um dado momento da

\footnotetext{
229 “Écrivains et écrivants”, Essais critiques, $O C$ v. 2, pp. 403-410.

${ }^{230}$ In Texto, crítica, escritura, op. cit., pp. 35-36.

231 Ibid., pp. 29-38.
}

${ }^{232} \mathrm{Na}$ década de 70, Joaquim de Montezuma de Carvalho publica em $O$ Estado o artigo "Roland Barthes ou nada de novo sobre o estilo", em que coloca em questão a seguinte definição de estilo presente em Le Degré zéro: “Quel que soit son raffinement, le style a toujours quelque chose de brut; il est une forme sans destination, il est le produit d'une poussée, non d'une intention, il est comme une dimension verticale et solitaire de la pensée. Ses références sont au niveau d'une biologie ou d'un passé, non d'une Histoire: il est la 'chose' de l'écrivain, sa splendeur et sa prison, il est sa solitude. Indifférent et transparent à la société, démarche close de la personne, il n'est nullement le produit d'un choix, d'une réflexion sur la Littérature. Il est la part privée du rituel, il s'élève à partir des profondeurs mythiques de l'écrivain, et s'éploie hors de sa responsabilité" (Le Degré zéro de l'écriture, OC v. 1, p. 178). O autor compara essa definição a outras, de autores de língua portuguesa e espanhola, estabelecendo uma relação de equivalência apressada e sem levar em conta o contexto em que ela é formulada em Le Degré zéro. Seu objetivo, claro no artigo, é menos discutir o conceito barthesiano de estilo do que alardear que o então renomado Roland Barthes não apresenta nenhuma novidade quanto a esse conceito. A proposta de Carvalho é, portanto, questionar a importância do escritor francês. Cf. Suplemento Literário, 22 de julho de 1973, p. 1.

${ }^{233}$ In Le degré zéro de l'écriture, $O C$ v. 1, p. 218. 
história das formas literárias - e é comprometida com a busca de cada escritor por uma linguagem fundadora de sua verdade literária. Em outras palavras,

Aussi l'écriture est-elle une réalité ambigüe: d'une part, elle naît incontestablement d'une confrontation de l'écrivain et de sa société; d'autre part, de cette finalité sociale, elle renvoie l'écrivain, par une sorte de transfert tragique, aux sources instrumentales de sa création. Faute de pouvoir lui fournir un langage librement consommé, l'Histoire lui propose l'exigence d'un langage librement produit. ${ }^{234}$

A dupla filiação da escritura, que é o grau zero da escrita literária, em Le Degré zéro, compreendendo a menção ao fato do escritor ser conduzido pela escritura às "sources instrumentales de sa création", oferece o lastro necessário para filiar Barthes a Laporte e a Blanchot e demonstra o conhecimento de Leyla Perrone-Moisés, já em 1964, da obra do escritor.

No ano seguinte, Barthes mais uma vez é mencionado em um artigo como em um "retrato de grupo", mas com direito a mais informações, e até mesmo a citação de um texto seu, o que demonstra que, aos poucos, ele começava a ser lido no Brasil. O artigo se entitula "Problemas da crítica", é assinado por Willy Lewin, responsável pela coluna "Letras anglo-americanas" do Suplemento Literário, e tematiza a crítica literária moderna.

Tendo por ponto de partida o artigo de Robert Langbaum, "The function of criticism once more", publicado na Yale Review, no inverno norte-americano de 1965, Lewin reafirma, com o crítico estadunidense, a morte do new criticism enquanto movimento literário e o nascimento da “crítica moderna”. Esta, para os autores, constitui-se essencialmente de uma versão mais ampla do new criticism, também calcada na imanência da obra literária, e, sobretudo, composta por uma pluralidade de concepções da literatura e da atividade crítica.

É nesse ponto da argumentação que Lewin lança mão de Barthes. Para exemplificar a heterogeneidade de pontos de vista sobre questões essenciais da literatura, cita o Times Literary Supplement, em número especial entitulado Critics Abroad, de setembro de 1963, que reúne ensaios de vários autores sobre a crítica literária no mundo. Para Lewin,

Alguns desses críticos, colaboradores do mencionado número especial do TLS, como o francês Roland Barthes (preocupado, entretanto, com os sistemas semânticos particulares e com as estruturas do "Nouveau Roman"), adotam, inclusive, posições aparentemente antagônicas à objetividade "textual", isto é, posições, por assim dizer, relativistas. Barthes preconiza, por exemplo, "o diálogo entre dois subjetivismos, o do autor e o do crítico" a título de definição substancial para uma crítica moderna digna deste nome. ${ }^{235}$

${ }^{234}$ Ibid., pp. 180-181.

${ }^{235}$ Suplemento Literário, 14 de agosto de 1965, p. 1. 
Dentro do retrato feito nesse artigo, Barthes faz parte de um grupo de críticos que, mesmo se identificados à "crítica moderna", herdeira do new criticism, divergem de alguns de seus princípios de base, como por exemplo o objetivismo, sempre contraposto ao subjetivismo que pautava o impressionismo crítico. Para justificar sua afirmação, Lewin cita um trecho do ensaio “Qu'est-ce que la critique ?”, de Barthes, que integra os Essais critiques, mas fora publicado na Times Literary Supplement um ano antes. O autor retira de contexto a passagem que lhe interessa, onde Barthes emprega o termo-tabu "subjetivismo", tão atacado pelos jovens críticos. Ela integra o último parágrafo do ensaio, em que o escritor define seu conceito de crítica:

C'est en effet en reconnaissant qu'elle n'est elle-même qu'un langage (ou plus exactement un méta-langage) que la critique peut être contradictoirement mais authentiquement, à la fois objective et subjective, historique et existentielle, totalitaire et libérale. (...) Ainsi peut s'amorcer au sein de l'oeuvre critique le dialogue de deux histoires et de deux subjectivités, celles de l'auteur et celles du critique. Mais ce dialogue est égoïstement tout entier déporté vers le présent: la critique n'est pas un "hommage" à la vérité du passé, ou à la vérité de "l'autre", elle est construction de l'intelligible de notre temps. ${ }^{236}$

Barthes explica que a crítica, para ele, é uma construção, feita de elementos objetivos, determinados historicamente, como por exemplo a linguagem, e de elementos subjetivos, pessoais, como as razões que levam um crítico a escolher uma certa linguagem dentre as várias disponíveis em seu tempo. Ou seja, a crítica é uma obra literária tout court - ideia que será plenamente desenvolvida em Critique et vérité mas que já está presente em "Qu'est-ce que la critique ?" Portanto, Barthes está longe de defender o subjetivismo à la crítica impressionista: seu alvo é a crítica lansonista que predominava nos meios acadêmicos tradicionais franceses e sua proposta, fundamentada na linguística, vai muito além de qualquer oposição à “objetividade 'textual' ", equiparando o texto crítico ao texto literário.

Lewin situa Barthes dentro da "crítica moderna", vista como um balaio de gatos, onde tudo cabe - até mesmo a suposta defesa do até então refutado "subjetivismo". Ele conduz seu leitor a enxergar Barthes em relação à querela da crítica brasileira da década anterior, como se ele fosse um crítico moderno apregoando, paradoxalmente, um valor da crítica tradicional. Implicitamente, Lewin ataca a "crítica moderna", mostrando que ela não é assim tão moderna no final das contas, pois comporta algo da crítica impressionista.

Para além dessa leitura deveras particular de "Qu'est-ce que la critique ?", o autor associa a Barthes o estudo de "sistemas semânticos" e das estruturas do nouveau roman, o que demonstra

\footnotetext{
${ }^{236}$ In Essais critiques, $O C$ v. 2, p. 507.
} 
algum conhecimento sobre as atividades do escritor: entre 1963 e 1964 o seminário de Barthes na École Pratique des Hautes Études se intitulava "Inventaire des systèmes de signification contemporains" e tratava do discurso publicitário; por outro lado, vários ensaios publicados na época e reunidos nos Essais critiques o colocam como um dos defensores de primeira hora do nouveau roman.

De 1960 a 1965 Barthes foi mero figurante aos olhos dos intelectuais brasileiros que escreviam para $O$ Estado de $S$. Paulo. Incompreendido ou deturpado em função dos antagonismos estabelecidos pela já antiga querela da crítica brasileira, o escritor parecia ainda não ter luz própria no Brasil, embora eu veja uma progressão na maneira como ele aparece: de meras menções a seu nome, o escritor chega a ter uma frase citada. O que ainda é pouco, pois, na França dessa época, Barthes já se envolvia na mais famosa querela literária do século XX.

\section{A querela francesa e seus ecos no Brasil}

Selecionei, em $O$ Estado, três textos que repercutiram a querela da crítica francesa, todos publicados entre julho e agosto de 1966. Annus mirabilis ${ }^{237}$ do pensamento crítico, como Antoine Compagnon a ele se referiu em seu seminário de 2011, no Collège de France ${ }^{238}$, 1966 marca também o lançamento de Critique et vérité, palavra final de Barthes na querela da crítica francesa. Protagonizada pelo então célebre professor da Sorbonne e especialista da obra de Racine, Raymond Picard, e por Barthes, a querela opôs a velha tradição crítica, filológica e historiográfica, à chamada nouvelle critique, a "nova crítica" no Brasil dos anos 60, adepta da imanência e da pluralidade de sentidos do texto literário, bem como das novas correntes de saber que então se desenvolviam e que eram aplicadas à leitura, tais como a psicanálise, a sociologia e a linguística, dentre outras.

O pretexto oficial para a querela, apontado por Picard, foi Sur Racine (1963), de Barthes, uma visão pouco usual da obra do poeta clássico, que emprega conceitos da psicanálise em uma leitura estruturalista. Esse livro reúne três ensaios anteriormente publicados, escritos à luz de uma concepção que compreende a liberdade do crítico para praticar a linguagem que bem entender na análise de um texto. Ou, nas palavras de Barthes,

Et c'est parce que Racine a honoré parfaitement le principe allusif de l'oeuvre littéraire, qu'il nous engage à jouer pleinement notre rôle assertif. Affirmons donc sans retenue, chacun pour le

\footnotetext{
${ }^{237}$ A expressão dá título a um poema de John Dryden sobre 1699, ano do grande incêndio de Londres, e celebra o fato daquele ano não ter sido ainda pior do que foi.

${ }^{238}$ As conferências de Antoine Compagnon e de seus convidados podem ser vistas na íntegra no site do Collège de France: http://www.college-de-france.fr/site/antoine-compagnon/ (consultado em 7/5/2013).
} 
compte de sa propre histoire et de sa propre liberté, la vérité historique, ou psychologique, ou psychanalytique, ou poétique de Racine; essayons sur Racine, en vertu de son silence même, tous les langages que notre siècle nous suggère; notre réponse ne sera jamais qu'éphemère, et c'est pour cela qu'elle peut être entière (...). ${ }^{239}$

Esse conceito libertário de crítica, ao mesmo tempo histórico e pessoal, vai de par com a ideia de écriture, já explicitada, e que também é composta de história e subjetividade. Não por acaso, três anos mais tarde, em Critique et vérité, Barthes defenderá a equivalência entre o texto crítico e o texto literário, ambos sendo o produto de uma écriture.

Mas os ataques de Raymond Picard e seus epígonos se iniciaram antes de 1966, precisamente depois da publicação dos Essais critiques de Barthes, que continham dois textos de altíssimo potencial explosivo: "Les deux critiques" e "Qu'est-ce que la critique ?", anteriormente publicados em periódicos nos Estados Unidos ${ }^{240}$. Nesses textos, o escritor francês já reconhece o abismo que separa a prática da crítica exercida pelos velhos professores e as novas propostas trazidas, sobretudo, pela voga estrutural, presente nas humanidades à época. E defende a atividade crítica não mais como uma decifração que oferece ao leitor a verdade da obra, mas como uma obra ela mesma, verdadeira dentro de sua coerência interna, ou de sua validade, no termo de Barthes.

O que talvez não lhe fosse evidente - dado seu constrangimento e espanto diante dos ataques ferozes que recebeu - eram as proporções das reações engendradas por seus textos. Pois, mais do que o ineditismo de suas concepções - que, na realidade, tinham como precursores Victor Hugo e sua "crítica artista", no século XIX, dentre outros, e Albert Thibaudet e a "crítica dos mestres", em $1930^{241}$-, o que causou celeuma foi a contestação implícita do poder da crítica tradicional, que até aquele momento pontificava, a partir da Sorbonne, sobre as obras literárias de forma soberana. $\mathrm{O}$ fato de Barthes, em seus ensaios, distinguir duas críticas, duas maneiras de se exercer a crítica - a tradicional, ou velha crítica, ou crítica universitária, e a nouvelle critique -, já esfarelava o poder dos professores tradicionais deslocando-o para o domínio da pluralidade de opiniões: a crítica, então, passava a ser uma questão de leitura, e não mais de descoberta absoluta da verdade. Consequentemente, ela deixava de ser propriedade exclusiva de uma elite - formada pelos críticos tradicionais, que exerciam o métier segundo as mesmas concepções desde o final do século XIX - para pertencer também a grupos de intelectuais lotados em outros centros universitários que não a Sorbonne, os quais traziam o frescor das novas correntes teóricas aos estudos literários.

\footnotetext{
${ }^{239}$ In Sur Racine, $O C$ v. 2, p. 55.

${ }^{240}$ Primeiramente publicados, respectivamente, em Modern Languages Notes e no Times Literary Supplement, ambos em 1963.

${ }^{241}$ Cf. Physiologie de la critique, Paris, Librairie Nizet, 1930.
} 
Tanto nas entrelinhas da querela dos anos 60 havia uma disputa de poder, que em torno de seus personagens principais criaram-se dois grupos antagônicos: alinhados com Picard os professores da Sorbonne e de outras grandes universidades parisienses, e alguns periódicos como os tradicionais Le Monde e Le Figaro; e nas trincheiras de Barthes e da nouvelle critique, escritores de vanguarda - todo o nouveau roman, por exemplo -, intelectuais ligados a instituições de ensino superior menos tradicionais, como a École Pratique des Hautes Études, e a editora Seuil, com seu corpo de colaboradores e jovens autores ${ }^{242}$.

A contestação e quebra do paradigma até então vigente tirou o poder do crítico literário e o realocou no texto: antes, o crítico era o responsável por encontrar o sentido do texto. A partir dos anos 60, o Texto, grafado com letra maiúscula, passou a ser produtor de sentidos, declarando a morte do crítico enquanto porta-voz privilegiado do texto literário e, de quebra, o Autor também se foi, com "La Mort de 1'Auteur" ${ }^{243}$. O poder exercido por uns poucos foi distribuído a todos os Leitores.

Por conta desses fortes solavancos na teoria e crítica literárias, foram precisamente os ecos da polêmica Barthes-Picard que chegaram aos ouvidos dos intelectuais brasileiros. Em julho de 1966, Lívio Xavier consagra uma resenha a Nouvelle critique ou nouvelle imposture (1965), de Picard, um violento panfleto contra a nouvelle critique, dirigido principalmente a Barthes.

De início, já fica evidente que a leitura de Xavier é feita ainda com as lentes da década anterior, pois não distingue o new criticism da nouvelle critique, esta herdeira do movimento estadunidense e do formalismo, mas eminentemente francesa, aglutinadora dos diferentes campos de estudos das Humanidades e, em certa medida, adepta do estruturalismo. Após situar brevemente seu leitor na querela, reduzindo-a à introdução da nova escola crítica na França e aos ataques de Picard, o resenhista se posiciona claramente ao lado deste. Seguindo a mesma organização de Nouvelle critique ou nouvelle imposture, Xavier primeiramente aponta o interesse das obras de Barthes, "engordando a vítima por medidos elogios", como Picard o faz, afirmando sobre o escritor: "é

\footnotetext{
${ }^{242}$ Em "Les espaces de la controverse, Roland Barthes contre Raymond Picard: un prelude à Mai 68" (in Mil neuf cent. Revue d'histoire intellectuelle, 2007/1, $\mathrm{n}^{\circ}$ 25, pp. 141-155), Christophe Prochasson, que teve acesso ao espólio de Picard, revê a famosa polêmica em detalhes e aponta as insuficiências da célebre abordagem de Pierre Bourdieu. Esta resume o acontecimento a uma retomada da Querelle des Anciens et des Modernes do século XVII fundada na oposição entre a Sorbonne e a École Pratique, os estudos literários contra as ciências sociais (in Homo Academicus, Paris, Éditions de Minuit, 1984, p. 151, apud Prochasson, p. 141). A abordagem de Bourdieu é reiterada por François Dosse em sua Histoire du structuralisme (I, Le champ du signe, 1945-1966, Paris, La Découverte, 1991, p. 276, apud Prochasson, p. 142). Minha posição é a de que houve mais uma reação por parte de Picard e da crítica tradicional à contestação do poder do crítico praticada por Barthes em Sur Racine e teorizada nos artigos dos Essais critiques, do que uma disputa entre saberes, como coloca Bourdieu.

${ }^{243}$ In $O C$ v. 3, pp. 40-45.
} 
mesmo, nestes dez últimos anos, um dos exemplos mais significativos do esforço para elaborar uma nova crítica." 244

Em seguida, o autor menciona o principal ponto de ataque de Picard à nouvelle critique, na pessoa de Barthes, a linguagem por este empregada para tratar dos textos racinianos: "A crítica à nova crítica parece particularmente bem fundada quando o Sr. Raymond Picard investe contra o jogo de palavras ao qual, em suma, reduz a análise de Barthes dos personagens racinianos" ${ }^{245}$. Exemplifica essa afirmação com as caracterizações de "solar" e "sombrio" que o escritor francês confere a personagens de Racine, demonstrando o quão vagos e subjetivos tais adjetivos podem ser, como se Barthes, de maneira vã, almejasse a objetividade em sua leitura crítica. A exigência de uma conclusão irrefutável como condição para a sustentação dos textos barthesianos sobre Racine norteia os ataques de Picard e é aceita por Xavier: "Mas, observa o Sr. Picard, o jargão de Barthes tem outros efeitos: emprestar prestígio científico a verdadeiros absurdos, disfarçar lugares comuns e dissimular a indecisão de pensamento. $\mathrm{Na}$ verdade, os exemplos recolhidos pelo crítico na análise raciniana de Barthes são, por assim dizer, irremediáveis" ${ }^{246}$.

Irremediável é também o julgamento feito por Xavier a toda a nouvelle critique, na esteira de Picard, com o qual a resenha é concluída:

Esses críticos manifestam uma total indiferença pela obra literária, pelo que é ela. Vão explicá-la, ou pretendem-no, por uma estrutura diversa: psíquica, biográfica, metafísica, ou outra que tal, mas em todo o caso não-literária. Concebem a obra literária como uma coleção de sinais cujo sentido se deve procurar além da literatura, ou na psicanálise, ou num pseudomarxismo, ou ainda em um outro universo metafísico. Não se pode deixar de concordar com as restrições do Sr. Picard ao que se está tornando a "nova crítica" nas mãos dos seus adeptos franceses. ${ }^{247}$

Da condenação de Picard e Xavier ao emprego de uma linguagem não-literária na crítica depreende-se a defesa de uma suposta pureza da obra literária que deve ser preservada também na leitura que dela se faz. Aos olhos do resenhista brasileiro, parece que a nouvelle critique francesa desvirtua o verdadeiro sentido do objeto literário, fazendo dele apenas mais um em meio aos demais objetos eleitos pelas novas ciências que ora floresciam.

Sem conhecer o ponto de vista de Barthes, Xavier emite uma opinião com base em Nouvelle critique ou nouvelle imposture e alguma informação de segunda mão sobre o escritor francês, o que acaba por associá-lo à nova crítica brasileira dos anos 50 e não parece predispor o

\footnotetext{
244 "Resenha de Nouvelle critique ou nouvelle imposture, de Raymond Picard", Suplemento Literário, "Resenha bibliográfica", 23 de julho de 1966, p. 2.

${ }^{245}$ Ibidem.

${ }^{246}$ Ibidem.

${ }^{247}$ Ibidem.
} 
humor do resenhista a seu favor. O julgamento de Xavier se mantém em resenha de agosto do mesmo ano, dedicada a dois artigos publicados na revista Cahiers $d u$ Sud: "Nouvelle critique, ancienne querelle", de Françoise van Rossum Guyon, e "Picard, Barthes et la critique en question", de Joseph Guglielmi.

O primeiro artigo agrada mais a Xavier por seu tom ponderado e pelos elogios a Picard, sem deixar de conceder pontos a Barthes e aos nouveaux critiques. Guyon, em resumo, acredita que a finalidade da crítica "é redescobrir o espírito criador através do estilo e mediante análise precisa e pormenorizada da relação entre as palavras e as imagens, em suma, a originalidade de uma experiência" ${ }^{248}$. Como o resenhista brasileiro reconhece, a autora não está tão distante de Picard e da concepção tradicional de crítica.

A parte dedicada ao segundo artigo - este, francamente em defesa de Barthes e hostil a Picard - denuncia as precauções de Xavier em relação ao escritor e à nouvelle critique. $\mathrm{O}$ autor emprega termos hiperbólicos com o objetivo de esvaziar os conteúdos das frases que eles introduzem, como por exemplo o verbo "escandalizar-se": "Escandaliza-se o Sr. Guglielmi pela recomendação que faz Picard de que nós, leitores do século atual, devemos apreender unicamente a significação literal da obra de Racine (...)". Ou o adjetivo "estrênuo": "O Sr. Guglielmi é um defensor estrênuo da 'nova crítica', pelo menos de Barthes (...)". Conclui com uma ironia sobre o conceito de crítica, evidenciando sua discordância, talvez devida à relativização do papel julgador desta para a nouvelle critique: "Termina o Sr. Guglielmi dizendo que toda crítica é criação e reciprocamente toda criação encerra uma parte de crítica. O que não deixa de ser consolador para os críticos." 249

Nesse texto, Lívio Xavier expõe sua preferência na querela da crítica francesa de maneira mais sutil do que na resenha escrita um mês antes. Sinal de hesitação ou simplesmente mudança de humor? O fato é que os embates entre a nouvelle critique e a crítica universitária tradicional atravessavam o Atlântico e aportavam na imprensa brasileira sob a forma de resenhas de obras dos mais eminentes personagens da querela. No mesmo dia em que o Suplemento Literário publicou o artigo de Xavier sobre os textos da revista Cahiers $d u$ Sud, também publicou a resenha de Álvaro Lorencini sobre Pourquoi la nouvelle critique: critique et objectivité (1966), de Serge Doubrovsky.

Nesse texto, Lorencini - futuro tradutor de Le Degré zéro de l'écriture - relata brevemente as principais ideias de Doubrovsky, ressaltando seu caráter combativo contrário à "velha crítica",

\footnotetext{
${ }^{248}$ In "A crítica à crítica da nova crítica (Cahiers du Sud)". O Estado de S. Paulo, Suplemento Literário, "Revista das Revistas", 20 de agosto de 1966, p. 6.

${ }^{249}$ Ibidem.
} 
como alude ao grupo de Picard. Não deixa de apontar questões sem respostas na obra, concernentes, sobretudo, aos procedimentos concretos para a realização da atividade crítica, como no exemplo abaixo:

Apesar do esforço do A. em ser didático, as coisas não se apresentam simples assim e, à pergunta: "psicanálise como?", ele confessa que não há resposta que caiba numa fórmula. Recomenda, em todo caso, um método imanente, mas de uma imanência que seja ao mesmo tempo fechamento e abertura, num vai-e-vem que ele próprio prevê que alguns acharão complicado. ${ }^{250}$

O resenhista conclui com uma ideia-chave da obra de Doubrovsky, defendida por Barthes pelo menos desde Sur Racine e que foi central na querela francesa, sua concepção de crítica:

À obra do escritor, o crítico deve responder por outra obra, que é também uma forma de escritura, razão pela qual todo grande crítico cria uma linguagem particular. Segundo S. D. é esse o caso de Sartre, Poulet, Richard, Starobinski e do próprio Barthes, críticos da subjetividade que, ao que parece, serão examinados no $2^{\circ}$ volume. ${ }^{251}$

O segundo volume nunca foi publicado, mas a conclusão da resenha permite antever seu tema. Apesar de muito menos explícito do que Xavier, Lorencini marca sua posição favorável à nouvelle critique selecionando trechos da obra de Doubrovsky que evidenciam os principais pontos defendidos por seus adeptos. Menciona até mesmo Critique et vérité, obra que mereceria uma resenha como contraponto ao texto sobre Nouvelle critique ou nouvelle imposture, resenha essa que não foi escrita em $O$ Estado de S. Paulo.

Nesse livro, Critique et vérité, Barthes responde aos ataques de Picard e seus correligionários em duas partes: a primeira passa em revista os pontos colocados em questão pelos críticos tradicionais, problematizando de início as reações violentas à reivindicação de que a crítica literária possa ser composta por pura linguagem:

Ce qui est notable, dans cette opération [o questionamento periódico da literatura e de conceitos a ela associados], ce n'est pas tellement qu'elle oppose l'ancien et le nouveau, c'est qu'elle frappe d'interdit, par une réaction nue, une certaine parole autour du livre: ce qui n'est pas toléré, c'est que le langage puisse parler du langage. ${ }^{252}$

\footnotetext{
${ }^{250}$ In "Resenha de Pourquoi la nouvelle critique: critique et objectivité". O Estado de S. Paulo, Suplemento Literário, "Resenha bibliográfica", 20 de agosto de 1966, p. 2.

${ }^{251}$ Ibidem.

${ }^{252}$ In Critique et vérité, $O C$ v. 2, p. 761.
} 
Colocando os ataques à nouvelle critique sob o signo da intolerância, Barthes já explicita a direção de sua argumentação, que reivindicará, acima de tudo, o direito à liberdade plena ao escrever sobre literatura. Classifica os questionamentos do grupo de Picard sob as rubricas "Le Vraisemblable critique", "L’Objectivité", "Le goût", "La Clarté” e "L’Asymbolie", demonstrando que a atividade crítica, enquanto prática que lida com conceitos de literatura e formas de expressão, é regida por um conjunto de regras implícitas, estabelecidas por um grupo de intelectuais - os críticos tradicionais. Essas regras constituem o "vraisemblable critique" e abarcam as noções de objetividade, gosto e clareza, em nome das quais é vetado o emprego de símbolos quando se escreve sobre literatura.

Barthes argumenta que, assim como o "vraisemblable critique" é constituído por escolhas feitas por um grupo, as noções que o sustentam, bem como suas definições, também são frutos de decisões passíveis de questionamento. O que diferencia, portanto, esse conjunto de pontos de vista sobre a literatura das posições da nouvelle critique é simplesmente seu lugar de enunciação: Picard e seus epígonos lançavam suas farpas contra Barthes e os novos críticos do alto de uma posição há muito consolidada e endossada pela autoridade das grandes universidades parisienses, a Sorbonne em primeiro lugar.

Identificando a origem das hostilidades na doxa crítica, ou seja, em um lugar de onde emana o poder e não propriamente em seus conceitos ou argumentos, Barthes reivindica o direito a uma visão diferente do texto crítico e, consequentemente, da literatura. Ataca a censura às vozes destoantes do padrão e defende a liberdade plena de uso da linguagem - ferramenta partilhada pelo escritor e pelo crítico: “(...) Si la critique nouvelle a quelque réalité, elle est là: non dans l’unité de ses méthodes, encore moins dans le snobisme qui, dit-on commodément, la soutient, mais dans la solitude de l'acte critique, comme un acte de pleine écriture." 253

A compreensão da crítica, enquanto uma leitura do texto literário que resulta em um novo Texto, desrespeita a hierarquia existente entre obra literária e texto crítico, colocando-os no mesmo nível. Ao mesmo tempo, destrona o crítico, cujos pontos de vista, antes reveladores da "verdade" da obra, passa a ser apenas uma leitura dentre tantas outras, um novo Texto dentre tantos possíveis.

Os ecos da querela da crítica francesa em $O$ Estado param por aí. Embora falte o ponto de vista do escritor francês numa possível resenha de Critique et vérité, fica claro que os acalorados debates na França tornam o nome de Barthes, quando não conhecido, ao menos familiar aos intelectuais brasileiros. Definitivamente associado à nouvelle critique e ao nouveau roman - para o

${ }^{253}$ Ibid., p. 782. 
bem e para o mal, dependendo da tendência de quem o cita -, após 1966, Barthes também passa a frequentar os textos dedicados ao estruturalismo, outra moda francesa que chega ao Brasil.

\section{O estruturalismo é um humanismo e um anti-humanismo}

Uma das primeiras portas de entrada do estruturalismo no Brasil é a coletânea de ensaios $O$ Método estruturalista, que contém textos de Lévi-Strauss, Lucien Sebag, Roland Barthes, Luc de Heusch, Henri Lefebvre e Claude Lefort, organizada e traduzida por Carlos Henrique Escobar (Rio de Janeiro, Zahar Editores, 1967). A seleção de autores pode inicialmente causar estranhamento, pois reúne adversários em matéria de estruturalismo: se Sebag, Barthes e de Heusch abraçam a nova abordagem sistematizada por Lévi-Strauss e abrem-lhe novos caminhos, Lefebvre e Lefort colocamse como seus críticos. O primeiro, problematizando o caráter a-histórico e alienante do estruturalismo; o segundo, insurgindo-se contra a desumanização que o estruturalismo traz às Humanidades. A pergunta sobre o que, então, fazem juntos esses intelectuais, é respondida por Escobar na "Introdução" do livro:

(...) procurando [o organizador] sobretudo focar o clima de discussão em torno da penetração do estruturalismo, ao lado de artigos (Luc de Heusch, Lucien Sebag, Roland Barthès (sic)) que o deixariam, enquanto método, visível, estávamos todos tentando juntar essas duas tarefas. Levando em conta, sobretudo, a discussão desse método não só para a fundamentação das Ciências Sociais, mas também para a direção que, parece, vai tomando a filosofia, achamos que prestigiar LéviStrauss e interpô-lo entre críticas a ele dirigidas (Claude Lefort, Henri Lefebvre) seria sempre uma maneira, menos fria, de levar o leitor ao interior das questões. ${ }^{254}$

Ou seja, O Método estruturalista não só tem por objetivo fornecer ao leitor subsídios sobre o estruturalismo, como também situá-lo em relação aos ataques que vinha recebendo na França desde Les Structures élémentaires de la parenté (1949), de Lévi-Strauss, e sua vasta fortuna crítica. Como aconteceu com a nouvelle critique, o estruturalismo e as discussões por ele suscitadas desembarcaram simultaneamente no Brasil, incitando, em muitos casos, uma tomada de posição imediata por parte dos intelectuais brasileiros.

Em $O$ Estado, a novidade do lançamento do livro recebeu apenas uma nota na seção "Lançamentos", do Suplemento Literário de 21 de outubro de 1967, destacando os títulos dos ensaios nele publicados. De Barthes, "A Atividade estruturalista", anteriormente publicado nos Essais critiques, embora date originalmente de 1963, vincula sua imagem, que aos poucos se tornava conhecida, ao estruturalismo francês, fazendo do escritor um misto de nouveau critique e

\footnotetext{
${ }^{254}$ O Método estruturalista, op. cit., p. 8.
} 
estruturalista - apesar de seu nome aparecer grafado erroneamente, "Barthès", na capa e em todo o livro, o que evidencia sua circulação incipiente nos meios letrados brasileiros.

Bem a propósito, nesse ensaio, Barthes apresenta o estruturalismo, não como uma escola, um movimento ou mesmo um método, mas como uma "atividade" através da qual o homem constrói seu conhecimento. A atividade estruturalista tem por objetivo desmontar seu objeto e reconstitui-lo, criando um simulacro, de maneira que este seja igual ao objeto primeiro, acrescido do conhecimento que os procedimentos para atingi-lo geraram. Tal operação compreende as etapas de desmontagem (découpage) e arranjo (agencement): a primeira consiste na descoberta das unidades mínimas do objeto; a segunda, diz respeito às regras de associação dessas unidades com vistas a produzir sentidos.

Esse seria só mais um ensaio explicativo sobre o estruturalismo se não fosse a aguda percepção de Barthes das questões que o método analítico suscitava naquela época e a clarividência para antecipar questões que ainda viriam à baila ao longo da década, prevendo até mesmo a sua extinção. Já no parágrafo introdutório, testemunha as primeiras reações contrárias ao estruturalismo: explicando os conceitos saussurianos expressos nos pares operatórios signifiant-signifié e synchronie-diachronie, que fundamentam a prática estruturalista, afirma sobre este último par que “ce dernier couple est d'autant plus distinctif qu'il semble bien que la principale résistance au structuralisme soit aujourd'hui d'origine marxiste et que ce soit autour de la notion d'histoire (et non pas de structure) qu'elle se joue (...)." ${ }^{255}$ Pois no sistema de Saussure, o estudo sincrônico implica na parada do tempo e o estudo diacrônico vê a história como uma sequência de quadros. A história, portanto, seria fragmentada e fixada em momentos precisos. De suas raízes plantadas na linguística saussuriana, portanto, nasceram algumas das maiores críticas que o estruturalismo recebeu na França e também no Brasil, centradas em seu caráter a-histórico.

Barthes também responde àqueles que acusam o estruturalismo de ser uma técnica analítica mecanicista que descarta o papel do homem - tônica da crítica brasileira entre os anos 60 e 70 :

(...) ce qui est nouveau, c'est une pensée (ou une "poétique") qui cherche moins à assigner des sens pleins aux objets qu'elle découvre, qu'à savoir comment le sens est possible, à quel prix et selon quelles voies. À la limite, on pourrait dire que l'objet du structuralisme, ce n'est pas l'homme riche de certains sens, mais l'homme fabricateur de sens, comme si ce n'était nullement le contenu des sens qui épuisât les fins sémantiques de l'humanité, mais l'acte seul par lequel ces sens, variables historiques, contingentes, sont produits. Homo significans: tel serait le nouvel homme de la recherche structurale. ${ }^{256}$

\footnotetext{
${ }^{255}$ In Essais critiques, $O C$ v. 2, p. 466.

${ }^{256}$ Ibid., p. 471.
} 
O ensaio é concluído pela profecia de que um dia o estruturalismo será substituído por outro modo de ver o mundo, o que de fato aconteceu:

Et précisément, parce que toute pensée sur l'intelligible historique est aussi participation à cet intelligible, il importe peu, sans doute, à l'homme structural de durer: il sait que le structuralisme est lui aussi une certaine forme du monde, qui changera avec le monde; et de même qu'il éprouve sa validité (mais non sa vérité) dans son pouvoir à parler les anciens langages du monde d'une manière nouvelle, de même il sait qu'il suffira que surgisse de l'histoire un nouveau langage qui le parle à son tour, pour que sa tâche soit terminée. ${ }^{257}$

Em suma, "A Atividade estruturalista" detecta questionamentos feitos repetidamente ao estruturalismo na França nos anos 50 e, no Brasil, durante as décadas de 60 e 70, avançando respostas a eles, que, parece, não foram ouvidas ou não satisfizeram seus adversários franceses e brasileiros. Um dos primeiros a se manifestar sobre o assunto, mencionando Barthes entre os estruturalistas, foi Eduardo Sucupira Filho, por meio da resenha que publicou, em 1968, a propósito de Debate sobre o estruturalismo (Uma questão de ideologia) (tradutor não mencionado, São Paulo, Editora Documentos, 1968), de Lucien Goldmann, Henri Lefebvre e R. e L. Makarius. O título da resenha, "O estruturalismo: ideologia do status quo" já explicita a tese, com a qual Sucupira Filho parece concordar fazendo-se o porta-voz dos ataques dos autores do livro ao estruturalismo.

Recebe destaque na resenha o ponto de vista de Lefebvre no que tange a relação do estruturalismo com a história. Para ele, o novo método analítico nada mais é do que um eleatismo, e como tal, "não repele o movimento sensível - como em Parmênides - mas em contrapartida rejeita o movimento na história; nega-a não apenas como ciência; nega, sobretudo, sua conotação diacrônica, sob pretexto de que lhe falta orientação e sentido". Negando a história, o estruturalismo - de LéviStrauss, citado no texto - procura sufocar qualquer alteração no status quo, aos olhos do sociólogo francês, para quem 'Em última instância, pretenderia Strauss 'estruturar' a sociedade moderna para conservar-lhe a ordem." 258

Lucien Goldmann reforça a posição de Lefebvre associando o apogeu do capitalismo tecnocrata à emergência do estruturalismo, vendo nele um pensamento corroborador da ordem social dominante. Nessa parte da argumentação o nome de Barthes é evocado, entre parênteses, fora da discussão em torno do caráter supostamente conservador do estruturalismo, como se repentinamente o resenhista se lembrasse dele, escrevendo: “([o estruturalismo] representado, em França, também

${ }^{257}$ Ibid., p. 472.

${ }^{258}$ O Estado de S. Paulo, Suplemento Literário, 16 de novembro de 1968, p. 2. 
por Roland Barthes)" 259. A menção a Barthes parece obrigatória, mesmo que suas ideias não fizessem parte do debate e que em matéria de estruturalismo ele não se situasse ao lado de Goldmann e Lefebvre; como se fosse preciso acrescentar seu nome à "lista negra" dos estruturalistas franceses.

A aparente urgência de se colocar o nome de Barthes entre os estruturalistas revela a necessidade de se separar o joio do trigo diante da nova corrente de pensamento francesa que chegava ao Brasil. Era importante para os intelectuais brasileiros compreender o que o tal estruturalismo pretendia e quem eram seus defensores e detratores, a fim de que pudessem tomar suas posições rapidamente, uma vez que o debate já se desenrolava na França havia anos. As traduções de obras favoráveis e contrárias ao método analítico e as consequentes resenhas publicadas nos jornais constituíam-se como as grandes ferramentas de divulgação que norteavam opiniões e acirravam as discussões. Contudo, essa produção sobre o estruturalismo se intensificou no Brasil somente na segunda metade dos anos 60, momento de seu apogeu e do início de seu declínio na França, fazendo com que os principais textos teóricos dessa "atividade" e suas críticas aqui chegassem ao mesmo tempo. Isso quando estas não eram em maior número do que os textos de base do estruturalismo - As Estruturas elementares do parentesco, sua pedra fundadora, só foi traduzido em $1976^{260} \ldots$

\section{Na França}

Seguindo a linha de Barthes, que vê o estruturalismo como uma "atividade", ou seja, enquanto algo mais amplo do que uma metodologia, prefiro caracterizá-lo como "movimento de ideias", pois propôs uma nova maneira de conceber os objetos de análise de diversos ramos do conhecimento, da literatura à economia, da etnografia à psicanálise. Tendo sucedido o existencialismo sartreano do pós-guerra, o estruturalismo tem como registro de nascimento a tese de doutorado de Claude Lévi-Strauss, Les structures élémentaires de la parenté, defendida em 1948 e publicada no ano seguinte. Nessa obra, o autor emprega o modelo analítico linguístico no estudo antropológico das relações de união em diferentes sociedades indígenas. Essa, aliás, é a novidade da época: graças ao encontro com Roman Jakobson na New School for Social Research, em Nova Iorque, com quem conviveu de 1939 a 1948 trabalhando nessa instituição, Lévi-Strauss conheceu a

\footnotetext{
${ }^{259}$ Ibidem.

${ }^{260}$ Tradução de Mariano Ferreira, Petrópolis (RJ), Editora Vozes, São Paulo, Editora da Universidade de São Paulo, 1976.
} 
fonologia estrutural de Trubetskoi e viu na linguística de Saussure o rigor metodológico que lhe parecia faltar às Humanidades, em especial à antropologia.

Tendo como ponto de partida o emprego de seu instrumental teórico na análise antropológica, a linguística estrutural se infiltrou em muitas outras áreas do conhecimento, até então carentes de uma renovação que lhes concedesse um caráter mais científico, em acordo com as novas tendências e exigências do momento. Pois com o eclipse do marxismo no qual o existencialismo sartreano se apoiava - resultado das revelações sobre o regime totalitário stalinista e, sobretudo, de seus campos de concentração -, no final dos anos 50, "O objetivo da revolta mudou, já não [era] mais a ideia de uma subversão global da ordem social. Doravante, a revolta '[era] verdadeiramente o conjunto, o tecido de todas as nossas evidências, isto é, aquilo a que se poderia chamar de civilização ocidental" ". O trecho final da citação, marcado por aspas simples, é de Roland Barthes, em entrevista de $1967^{261}$, e oferece um depoimento no calor da hora de um dos mais ativos intelectuais daquela época.

Como Barthes diz, a revolta, naquele momento, não mais era uma reação a alguma coisa definida - ao sistema capitalista, por exemplo -, que pudesse ser pulverizada, mas transformava-se em uma visão de mundo generalizada e extremamente crítica. Na síntese de François Dosse, autor da História do estruturalismo,

É na desestabilização dos valores ocidentais dominantes, na crítica radical da ideologia pequeno-burguesa, da opinião, da doxa, que se exercerá tanto a crítica barthesiana quanto a do conjunto dos estruturalistas. Essa consciência paradigmática ou do paradoxo, que tem por objetivo abalar a doxa, passa pela consideração e desmontagem interna das lógicas e dos modelos, dos modos de ser e de parecer das construções ideológicas. ${ }^{262}$

Na sequência de tais questionamentos inserem-se três características do estruturalismo que foram bastante atacadas na França e dominaram o discurso antiestruturalista no Brasil, sobretudo no que tange à literatura: 1) a concepção imanente da obra literária que engendra 2) sua leitura ahistórica e seu método analítico, calcado na precisão científica, 3) reduzindo, portanto, o papel da subjetividade humana na leitura e interpretação do texto. Em outras palavras, trata-se do foco na leitura imanente, a-histórica e com limitada participação do crítico, seu lugar tendo sido cedido aos procedimentos analíticos científicos.

\footnotetext{
${ }^{261}$ Roland Barthes, entrevista com Georges Charbonnier, France-Culture, dezembro de 1967, reapresentação em 21 e 22 de novembro de 1988, apud François Dosse, História do estruturalismo, O campo do signo, tradução de Álvaro Cabral, revisão técnica de Marcia Mansor D’Alessio, Bauru (SP), Edusc, 2007, vol. 1, p. 278.

${ }^{262}$ In História do estruturalismo, op. cit., pp. 278-279.
} 
Nas décadas de 50 e 60, a inversão do modo de ver uma obra literária - de um composto de elementos históricos e psicológicos para uma estrutura autônoma - na realidade não alterou o objetivo final da crítica: descobrir a tal "verdade da obra". O que mudou foi a maneira de fazê-lo, acarretando, consequentemente, uma transformação na concepção do objeto literário. Nas palavras de Dosse, "Essa perspectiva pertence plenamente a uma época que busca o sentido nas profundezas das estruturas subjacentes, pois se a crítica é considerada um estágio necessário, ela só é atribuída a uma tarefa preparatória da descoberta da estrutura que detém a verdade essencial da obra.” 263

O foco, portanto, é na estrutura, o que afasta os elementos exteriores a ela, a começar pela História. Essa característica é uma herança da linguística de Saussure, que se fundamenta sobre pares de conceitos operatórios, tais como significante/significado e sincronia/diacronia, e é dentro deste último que acontece a guinada a-histórica, como Dosse explica:

As categorias saussurianas vão, portanto, servir de instrumento epistêmico ao estruturalismo generalizado, mesmo que os diversos trabalhos tomem certas liberdades com a palavra saussuriana a fim de adaptá-la à especificidade de seus respectivos campos. A principal inflexão será à preponderância atribuída à sincronia. Saussure ilustra esse privilégio e seu corolário, a insignificância da historicidade, com a metáfora do jogo de xadrez. A inteligência da partida resulta da visão do lugar e das combinações possíveis das peças colocadas no tabuleiro de jogo: "É totalmente indiferente que se tenha chegado a ela por um caminho ou outro." 264

O olhar que mira a obra sem dela se desviar também a retira de seu passado, fazendo com que o fim justifique os meios, conforme prega o Cours de linguistique générale (1916), de Saussure, citado entre aspas. Eis justamente o cerne de uma das maiores críticas ao estruturalismo: ao invés de se celebrar a atenção exclusiva à obra, sua retirada do tempo será vista como uma alienação ou, pior, como uma maneira de se calar face aos totalitarismos impostos pelos grupos sociais no poder.

Além dos pares conceituais mencionados, também integra a teoria saussuriana a distinção entre língua e fala, e é no seio dela que se dará a exclusão do homem do processo analítico estruturalista: a língua é concebida como o sistema de signos linguísticos passíveis de um estudo científico estrito, codificável, ao passo que à fala corresponde a função e a performance do falante, dependentes de características individuais. A fala, portanto, não se constitui como um objeto de estudo ideal, pois envolve fatores exteriores a ela e indissociáveis da psicologia do indivíduo, enquanto a língua é passível de ser analisada de maneira intrínseca, pois permite um recorte definido. Nas palavras de Dosse,

\footnotetext{
${ }^{263}$ Ibid., p. 128.

${ }^{264}$ Ibid., p. 86.
} 
A linguística só tem acesso ao estágio de ciência, para Saussure, na condição de delimitar muito bem o seu objeto específico, a língua, e deve, portanto, desembaraçar-se dos resíduos da fala, do sujeito, da psicologia. O indivíduo é expulso da perspectiva científica saussuriana, vítima de uma redução formalista na qual não tem mais seu lugar. ${ }^{265}$

Saussure, portanto, é o autor do pecado original que expulsou a História e o homem do paraíso das análises literárias, em nome de um novo deus, a cientificidade. Mas ele não é o único culpado por esse crime: ao longo das décadas de ascensão e queda do estruturalismo, muitos foram os intelectuais que se tornaram seus cúmplices, o primeiro deles, Roland Barthes, com "La Mort de l'Auteur", em 1968.

Os seguidores de Saussure, alguns mais, outros menos adeptos de seu Cours de linguistique générale, intelectuais identificados com a nouvelle critique, foram duramente atacados durante a querela da crítica francesa, pelos mesmos motivos que fundamentaram as críticas ao estruturalismo. Em uma certa medida, os nouveaux critiques também eram estruturalistas por adotarem muitos de seus princípios como elementos constitutivos de um novo olhar sobre a obra literária. Este era constituído por uma linguagem estranha às práticas literárias da época, em especial o jargão científico recheado de termos linguísticos, pelo privilégio da abordagem imanente, negligenciando os elementos exteriores à obra - sobretudo a História - e pela redução ou supressão do papel da subjetividade humana na análise.

Ao mesmo tempo em que esses eram os princípios essenciais do estruturalismo e da nouvelle critique, não faltaram adeptos de primeira hora para quebrar tais regras e subvertê-las. Barthes, novamente, foi o primeiro deles, ao adotar a visão analítico-científica da linguagem para criticar a sociedade francesa da época em Mythologies, já em 1957, oferecendo à análise linguística a possibilidade de abertura para a crítica social ${ }^{266}$. Ou em Critique et vérité, em 1966, quando reivindica ao crítico literário o direito de também ser um escritor, o analista, aos olhos de Barthes, podendo se tornar autor - o que exigia a total implicação do crítico no ato da escritura, resgatando a subjetividade humana na concepção da crítica-escritura. Ou ainda em 1971, quando escreve um prefácio à tradução brasileira dos Éléments de sémiologie:

Por outras palavras, cumpre passar por estes Elementos, mas não deter-se neles. Cada leitor deve reproduzir em si o movimento histórico que, a partir destas bases necessárias, levou a Semiologia não somente a aprofundar-se (o que é normal), mas também a diversificar-se,

\footnotetext{
265 Ibid., p. 90.

${ }^{266}$ Abertura, essa, que já estava presente nos princípios de base do Formalismo russo do início do século XX, é preciso ressaltar.
} 
fragmentar-se, até mesmo contradizer-se (entrar no campo fecundo das contradições), em suma, expor-se. ${ }^{267}$

Em seguida, em sua carreira de escritor, Barthes discute Le Plaisir du texte, a corporeidade da escritura em Roland Barthes par Roland Barthes, depois passa pelo discurso dos apaixonados em Fragments d'un discours amoureux, até fundar a cátedra de Semiologia literária no Collège de France. Nesse momento, já reconhece que a semiologia que pratica não mais é aquela das décadas de 50 e 60, conforme explica em Leçon, de 1978:

Et s'il est vrai encore que j'ai lié très tôt ma recherche à la naissance et au développement de la sémiotique, il est vrai aussi que j'ai peu de droits à la représenter, tant j'ai été enclin à en déplacer la définition, à peine me paraissait-elle constituée, et à m'appuyer sur les forces excentriques de la modernité, plus proche de la revue Tel Quel que des nombreuses revues qui, dans le monde, attestent la vigueur de la recherche sémiologique. ${ }^{268}$

Adiante, na mesma Aula Inaugural, surpreende os espectadores com sua definição de semiologia: "Bref, soit excès d'ascèse, soit excès de faim, fluète ou replète, la linguistique se déconstruit. C'est cette déconstruction de la linguistique que j'appelle, pour ma part, sémiologie." 269 Em 1978, a criatura dominou o criador - pois, para Barthes e ao contrário do que Saussure define, é a linguística que engloba a semiologia. Esta tomou o lugar privilegiado que o escritor oferecia à linguística nos Éléments de sémiologie ${ }^{270}$ para se emancipar e se transformar em uma disciplina autônoma, próxima de uma écriture: “Le sémiologue serait en somme un artiste (ce mot n'est ici ni glorieux ni dédaigneux: il se réfère seulement à une typologie): il joue des signes comme d'un leurre conscient, dont il savoure, veut faire savourer et comprendre la fascination." 271

Mais do que seu potencial questionador de padrões, o grande trunfo do estruturalismo foi seu caráter propositivo. Por mais que esse movimento de ideias se fundasse sobre a estrita cartilha saussuriana, seus melhores discípulos foram os mais indisciplinados, acrescentando novos conceitos e novos pontos de vista às sólidas bases científicas oferecidas pela linguística. Esta foi, sobretudo, um terreno fértil que possibilitou a germinação dos frutos os mais diversos. E assim o estruturalismo

\footnotetext{
${ }^{267}$ In Elementos de semiologia, tradução de Izidoro Blikstein, São Paulo, Editora Cultrix/ Editora da Universidade de São Paulo, 1971, p. 8.

270 “É preciso, em suma, admitir desde agora a possibilidade de revirar um dia a proposição de Saussure: a Linguística não é uma parte, mesmo privilegiada, da ciência geral dos signos: a Semiologia é que é uma parte da Linguística; mais precisamente, a parte que se encarregaria das grandes unidades significantes do discurso. Daí surgiria a unidade das pesquisas levadas a efeito atualmente em Antropologia, Sociologia, Psicanálise e Estilística acerca do conceito de significação". In Elementos de semiologia, op. cit., p. 13.

${ }^{271}$ In Leçon, $O C$ v. 5, p. 443.
} 
se transfigurou, abraçou novas concepções, adquiriu novos sentidos, foi desvirtuado. Sua maior qualidade, que permitiu que se perpetuasse durante tantos anos, foi sua promiscuidade.

\section{No Brasil}

O estruturalismo, uma vez em terras brasileiras, também deitou raízes profundas, que abalaram alguns pilares da crítica literária. Como não poderia deixar de ser, suscitou debates acalorados desde o início, pois, como já evidenciei, os ataques que o movimento vinha sofrendo na França aportaram no Brasil, juntamente com suas teorias de base. Por essa razão, em muitos casos as críticas que recebeu neste país reproduziram as sofridas além-mar.

Dentre as farpas lançadas pelos intelectuais brasileiros contra as ideias estruturalistas, destaco os ataques à diminuição da importância do papel do homem, ou em outros termos, a exclusão da subjetividade do crítico como ferramenta de análise do objeto literário. O que foi percebido simplesmente como um anti-humanismo.

As razões pelas quais essa característica estruturalista se sobrepôs às demais e, por isso, foi a mais atacada no Brasil, repousam na história cultural do século XX, mais precisamente a partir do Modernismo brasileiro de 1930, cujos ecos chegaram até os anos 60 e 70. É preciso, portanto, abrir espaço para uma breve digressão histórica, feita às avessas, tendo como ponto de partida o período de 1945-1964, passando pelos primeiros anos do golpe militar de 1964, para então voltar à década de 1930.

O período democrático situado entre a ditadura do Estado Novo e a ditadura militar, de 1945 a 1964, foi marcado por governos altamente populistas que buscavam perpetuar no poder os grupos políticos que os sustentavam, por meio da sedução do eleitorado com promessas e projetos de grande impacto aparente e pouca ou nenhuma relevância. Exemplos claros estão contidos nos slogans dos presidentes Getúlio Vargas (1951-1954), que se auto-intitulava “o pai dos pobres”; Juscelino Kubitschek (1956-1961), que pregava em seu governo a realização de "Cinquenta anos [de progresso] em cinco [de governo]"; e do presidente Jânio Quadros (1961), "Varre, varre, vassourinha, varre, varre a bandalheira", escolhendo a vassoura como símbolo da probidade administrativa, que varreria a corrupção do país. As ações populistas ancoravam-se num forte nacionalismo, repetido como um refrão pelos governos que se sucediam, em nome do qual obtinham aprovação da maioria da população. Evocando o "progresso" e o "desenvolvimento nacional", por exemplo, construiu-se a cidade de Brasília no centro do país, com a suposta função de integrar todas as regiões brasileiras, levando o progresso às menos desenvolvidas. Ideal que, como se sabe, não se concretizou, pois as regiões Norte e Nordeste foram esquecidas pelos governos, mandatos após 
mandatos, até poucos anos atrás. A ditadura militar de 64 deu continuidade a esse discurso nacionalpopulista, acrescentando a ele a suposta "ameaça comunista", em nome da qual se fez a "revolução

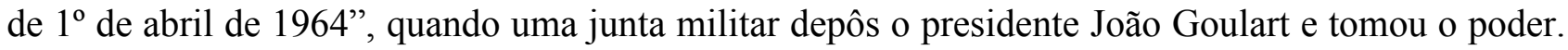
Ainda dentro desse discurso, todos aqueles que se opuseram aos governos militares que se sucederam, de 1964 a 1985, foram tachados de "comunistas" ou de "terroristas" que agiam "contra o Brasil". É daí que nasceram os slogans ufanistas, sendo o mais famoso, "Brasil, ame-o ou deixe-o", que justificava a condenação ao exílio de numerosos intelectuais, trabalhadores e estudantes pródemocracia, durante os anos de chumbo.

No centro do nacionalismo desenvolvimentista dessa época estava o homem brasileiro, representado desde os anos 30, na literatura regionalista, pelo sertanejo castigado pelo meio agreste e pelas injustiças sociais, forte e com a pele curtida pelo sol. Essa imagem era a resposta da época, que perdurou até as portas da década de 60, à pergunta formulada pelos escritores românticos e retomada pelos modernistas: qual seria o cerne da identidade brasileira e, no seu bojo, quem seria o homem brasileiro? O século XX descobriu, nos rincões do país, o trabalhador que luta diariamente contra o meio por sua sobrevivência. A esse homem, os escritores da Geração de 45 acrescentaram o citadino e suas relações conflituosas com o cotidiano. Na poesia, embora bastante compósita, essa geração primava pelo trabalho formal sem, contudo, abandonar a expressividade: a voz do poeta estava sempre presente nas obras, ora para fazer eco a seus anseios e angústias, ora para dar voz às dores de seu mundo. Independentemente do trabalho estético executado nos poemas e do lirismo neles contido, tanto nos maiores expoentes dessa geração, quanto em seus representantes mais medíocres, o homem e seus dilemas ocupavam sempre o centro das obras literárias, num misto de aprofundamento da psicologia do eu-lírico ou dos personagens e do retrato da vida no campo ou nas cidades. Penso nas obras de alguns dos maiores nomes do período: na prosa, Guimarães Rosa e Clarice Lispector; na poesia, Carlos Drummond de Andrade e João Cabral de Melo Neto.

Em suma, pelas questões específicas da história cultural brasileira, as obras dessa época revelam uma concepção da literatura que gravita em torno do homem. E não só no âmbito da criação, mas também no da recepção: havia uma preocupação, partilhada por muitos intelectuais, em assegurar a comunicação entre o escritor e o leitor através da obra literária, manifestada em vários textos críticos dos anos 50 em meio à querela da crítica brasileira. Lembro que os ataques à crítica universitária eram frequentemente propulsionados pelo "cientificismo" que governava suas leituras e que, por conseguinte, relegava o sujeito - fosse ele enunciador ou receptor, para empregar termos caros à linguística - a um papel secundário, a técnica e a teoria ocupando o lugar central das 
análises. Nesse contexto, uma teoria que colocasse o papel do homem em segundo plano não poderia ser bem recebida.

\section{O Jean-Paul Sartre do Brasil e o estruturalismo}

Tendo em vista esse breve histórico, caiu como uma luva a visita de Sartre e Simone de Beauvoir ao Brasil, de 12 de agosto a 21 de outubro de 1960, quando o casal conheceu os quatro cantos do país fazendo conferências em universidades, tendo conversas com estudantes e concedendo entrevistas.

Sartre, que então já era um intelectual de projeção mundial, teve um acolhimento digno de estrela hollywoodiana: sua agenda era cuidadosamente divulgada nos jornais, que enviavam fotógrafos para segui-lo aonde quer que fosse. Foi recebido por Jorge Amado, que o ciceroneou em quase todas as cidades que conheceu, de Manaus a Porto Alegre, de Recife a Araraquara, passando por São Paulo, Rio, Brasília, Salvador e as cidades históricas de Minas Gerais, dentre outras. Entre conferências e debates com intelectuais e estudantes, aconteceram inúmeros almoços e jantares em petit comité com a nata da intelligentsia brasileira, sendo até mesmo recebido pelo presidente Juscelino Kubitschek.

Todo o burburinho em torno da presença de Sartre no Brasil foi precedido pela recepção a sua obra, bastante debatida na imprensa, desde os anos 40. Segundo Luís Antônio Contatori Romano, autor de A Passagem de Sartre e Simone de Beauvoir pelo Brasil em 1960, os primeiros ecos da filosofia existencialista em terras brasileiras ainda não a associam à figura de Sartre e saem da pena de Euríalo Canabrava. Este, em sua obra Seis temas do espírito moderno (1941), previa grande repercussão do existencialismo devido às predisposições de "temperamento" dos brasileiros $^{272}$. Já Alceu Amoroso Lima, eminente crítico católico, que assinava seus textos com o pseudônimo de Tristão de Athayde, confere ao fenômeno de sua difusão uma dimensão histórica, que se coaduna com minha visão: para ele, o pós-modernismo brasileiro foi terreno fértil para a germinação de uma filosofia que tinha por centro o homem, pois

A ideia de personificação dos problemas especulativos e de um contato íntimo deles com o fluxo vital, que aproximam a literatura da filosofia, seria o ponto de contato entre o Existencialismo e escritores brasileiros como o poeta Carlos Drummond de Andrade e ficcionistas como Clarice Lispector e Guimarães Rosa, cujas personagens, em geral, têm aguçada capacidade de reflexão, remetendo o leitor de fatos de um cotidiano simples para questões que envolvem a condição humana. Tal como entende Sartre [em L'Existentialisme est un humanisme], nossa condição teria

\footnotetext{
${ }^{272}$ In A Passagem de Sartre e Simone de Beauvoir pelo Brasil em 1960, Campinas (SP), Mercado de Letras, São Paulo, Fapesp, 2002, p. 34.
} 
limites existenciais elementares, como a necessidade de conviver com os outros, trabalhar, compreender a própria mortalidade, estar no mundo e atribuir sentido às experiências. ${ }^{273}$

Embora, num primeiro momento, o existencialismo seja um humanismo que assenta bem no contexto cultural brasileiro, nem tudo são flores em sua recepção. Romano também trata dos ataques da crítica católica ao ateísmo dessa filosofia, já então estritamente associada a Sartre, conduzidos, sobretudo, pelo mesmo Alceu Amoroso Lima, nos anos 50. Em seu livro $O$ Existencialismo e outros mitos de nosso tempo (Rio de Janeiro, Agir, 1956), ele se dedica a examinar essa filosofia. Critica seu ateísmo, que suprimiria o "mistério" da criação artística, diretamente relacionado com o dom divino da criação; e sua consequente amoralidade, uma vez que, para Sartre, cada um seria responsável por seus atos, o que acarretaria uma relativização dos valores humanos, aos olhos da crítica católica ${ }^{274}$.

A leitura de Amoroso Lima - e de tantos críticos católicos, no Brasil, na França e em outros países - é rebatida pelo próprio Sartre em L'Existentialisme est un humanisme (1946), que explica o ateísmo de seu existencialismo pela compreensão segundo a qual "a existência precede a essência", isto é, o homem é definido por seus atos, que são livres, mas que devem ser responsáveis. Em outras palavras, para Sartre, não há um Deus criador, justificativa primeira de tudo, pois o homem ocupa esse lugar e, por essa razão, tem de arcar com as consequências de suas ações. $\mathrm{O}$ existencialismo não é uma filosofia da amoralidade, mas de morais múltiplas, que exige muito mais responsabilidade do homem do que a mística católica, uma vez que, segundo ela, o homem sempre pode recorrer à vontade divina como justificativa. Sartre conclui:

L'existentialisme n'est pas autre chose qu'un effort pour tirer toutes les conséquences d'une position athée cohérente. Elle ne cherche pas du tout à plonger l'homme dans le désespoir. (...) L'existentialisme n'est pas tellement un athéisme au sens où il s'épuiserait à démontrer que Dieu n'existe pas. Il déclare plutôt: même si Dieu existait, ça ne changerait rien; voilà notre point de vue. Non pas que nous croyons que Dieu existe, mais nous pensons que le problème n'est pas celui de son existence; il faut que l'homme se retrouve lui-même et se persuade que rien ne peut le sauver de lui-même, fût-ce une preuve valable de l'existence de Dieu. En ce sens, l'existentialisme est un optimisme, une doctrine d'action, et c'est seulement par mauvaise foi que, confondant leur propre désespoir avec le nôtre, les chrétiens peuvent nous appeler désespérés. ${ }^{275}$

\footnotetext{
${ }^{273}$ Ibid., p. 38. Essa maneira de ver o existencialismo em estreita relação com o que de melhor produziu a literatura brasileira da época é reforçada pelo estudo da temática existencial, na obra de Clarice Lispector, feito por Benedito Nunes, entitulado Leitura de Clarice Lispector (São Paulo, Quíron, 1973).

${ }^{274}$ Ibid., pp. 41-60.

${ }^{275}$ In L'Existentialisme est un humanisme, Paris, Nagel, pp. 94-95.
} 
Por causa de seus argumentos que recusam a existência de Deus ou, ao menos, seu lugar no centro da vida humana, toda a obra de Sartre foi colocada no Índex do Vaticano em 1948 e, no Brasil, atacada com todos os tipos de acusações, até mesmo as contraditórias: pois se o homem está no centro do existencialismo de Sartre, o que exclui Deus desse lugar, como bem compreendeu a crítica católica, como ler o trecho abaixo de Alceu Amoroso Lima?

Socratismo, no substrato humanista da filosofia existencial. Já vimos o seu [da filosofia existencialista] antropocentrismo. Vimos que ela coloca o homem no centro do universo, embora um homem desumanizado. O subjetivismo absoluto é a sua posição de partida. Sartre tem razão em dizer que o existencialismo é uma forma de humanismo. Trata-se de saber que forma de humanismo. É um humanismo inumano, sem dúvida, pois a hipertrofia ilegítima que atribui ao ser humano termina por negar a existência de uma natureza humana e por subordinar toda a liberdade a "situações" de tipo puramente inumano ou, pelo menos, extra-humano. ${ }^{276}$

Tachando o humanismo existencialista de "inumano", o crítico adota uma contradição como chave de leitura da filosofia sartreana: o protagonismo do homem existencialista seria, portanto, um logro, pois esse homem no comando de sua vida não seria humano. Mesmo não explicando como a "hipertrofia" atribuída por Sartre ao "ser humano termina por negar a existência de uma natureza humana", Amoroso Lima deixa clara sua intenção de esvaziar o mais forte argumento em prol do existencialismo, ao menos no Brasil: seu humanismo. Nesse sentido, o existencialismo seria um falso humanismo.

Mesmo contrariando a crítica católica, a viagem de Sartre ao Brasil foi um estrondoso sucesso de público - num país de grande maioria católica! -, contribuindo enormemente para a difusão do existencialismo. Este foi visto por vários intelectuais como uma filosofia que se amalgamava ao contexto desenvolvimentista brasileiro, num momento de grande estímulo ao consumismo desenfreado que, pela primeira vez, oferecia à população a possibilidade de adquirir bens materiais em moda, como eletrodomésticos e carros. Em suma, o espírito progressista que impregnava os discursos oficiais dos anos JK (Juscelino Kubitschek) favorecia a substituição de valores fixos pelas morais individuais que guiavam as ações dos homens, bem ao gosto do existencialismo sartreano.

Mesmo se imerso, ao mesmo tempo, em uma atmosfera de otimismo econômico e em um grande alvoroço causado por sua presença, Sartre não deixou de notar os profundos problemas sociais brasileiros. Romano relata frases do escritor que se transformaram em manchetes de jornal: "O Brasil é a maior democracia do Ocidente" e "No Brasil, parece que todo o mundo é de

${ }^{276}$ In $O$ Existencialismo e outros mitos de nosso tempo, op. cit., p. 42, apud A Passagem de Sartre e Simone de Beauvoir pelo Brasil em 1960, op. cit., pp. 52-53. 
esquerda”. Só que esses mesmos jornais, movidos por interesses ligados à manutenção das classes hegemônicas, não davam continuidade ao pensamento do escritor francês, passível de ser reconstituído pela leitura de suas entrevistas da época, registradas na íntegra, nas quais dizia: "mas é uma ditadura de 10 milhões que vivem nas cidades sobre 60 milhões de despossuídos que vivem nos campos" e "quando se desce ao fundo das coisas, vê-se que há uma grande diferença entre os homens, dependendo de como eles pensam que alguma coisa deve ser rompida." 277

Esse Sartre, homem político, e menos a estrela cujas filosofia e obras, a bem da verdade, poucos conheciam no Brasil, é quem foi instrumentalizado por setores de esquerda. Eles aproveitaram a exposição de sua figura para tentar colocar na ordem do dia questões até então silenciadas, relativas a demandas culturais e políticas organizadas pelos Movimentos de Cultura Popular do Recife e por associações sindicais, estudantis e artísticas ${ }^{278}$. Vendo em Sartre um inspirador das massas, o jornalista português exilado no Brasil, Miguel Urbano Rodrigues, em seu artigo "Apelo à juventude, a Sartre e à USP" ${ }^{279}$, deu forma e projeção ao pedido de permanência de Sartre no Brasil, como professor convidado pela Universidade de São Paulo - ideia que não encontrou eco no escritor francês. Os intelectuais que defendiam sua estada no país "percebiam nele a personalidade capaz de trazer para a juventude brasileira uma consciência de comprometimento com a resolução dos problemas sociais cuja existência no país foi notada pelo filósofo." ${ }^{280}$ Ponto de vista partilhado também por parte da imprensa, como informa Romano, citando o jornal carioca Última Hora que, em 3 de setembro de 1960, expressava sua opinião:

Para esse jornal, o filósofo não teria vindo ao país, como muitos outros visitantes, apenas para conhecer os seus aspectos pitorescos ou cosmopolitas, mas veio exaltar o nacionalismo brasileiro e atribuiu aos nossos intelectuais, particularmente aos escritores, a responsabilidade por uma participação mais ativa na elaboração de uma consciência nacional. ${ }^{281}$

Sartre, portanto, e a despeito das contestações que seu existencialismo gerava, era visto como uma figura internacional de grande importância que ratificava o nacionalismo brasileiro e sugeria uma mudança no comportamento dos intelectuais, instigando-os ao engajamento em favor de uma sociedade mais justa. O retrato feito pelo jornalista Dorian Jorge Freire, para o jornal araraquarense $O$ Imparcial, publicado em 9 de setembro de 1960 e transcrito por Romano, é emblemático:

\footnotetext{
${ }^{277}$ In A Passagem de Sartre e Simone de Beauvoir pelo Brasil em 1960, op. cit., p. 24.

278 Ibid., pp. 20-24.

${ }^{279}$ O Estado de S. Paulo, 8 de setembro de 1960.

${ }^{280}$ In A Passagem de Sartre e Simone de Beauvoir pelo Brasil em 1960, op. cit., p. 58

281 Ibid., p. 59.
} 
O Jean-Paul Sartre que empolga o Brasil não é, sem dúvida nenhuma, o papa existencialista. O homem de uma doutrina mais ou menos ignorada pela quase unanimidade do povo brasileiro. É o homem livre, o homem de esquerda, o grande patriota, o inimigo dos que na sua pátria assassinam os patriotas argelinos, o impávido defensor da revolução libertadora de Cuba. Uma cabeça inteligente e posta no seu devido lugar. Uma sensibilidade sempre pronta a captar as aspirações humanas. Uma cultura posta a serviço, exclusivamente, da causa do povo e dos melhores interesses da humanidade. Este é o Jean-Paul Sartre do Brasil. Discutido, disputado, admirado, debatido, nesta hora, por homens de todas as tendências, por jovens de todas as idades, por uma geração que nele vê a sua figura principal, o seu guia mais inteligente, a sua parte mais atuante e corajosa. ${ }^{282}$

Em outras palavras, o escritor francês representava um modelo de intelectual humanista, comprometido com questões sociais e de interesse nacional. E é esse Sartre - enfatizo, o intelectual humanista - que será empregado por parte dos intelectuais brasileiros como principal contraponto aos estruturalistas, grupo ao qual Barthes foi associado. Portanto, se, na França, o estruturalismo se opôs ao existencialismo sartreano e tomou seu lugar, no Brasil seu destino foi semelhante; pois ele também se opôs, não à filosofia existencialista, mas a uma gama de concepções e princípios centrados no homem, que a figura de Sartre só fez reforçar.

Essa situação de antagonismo - existencialismo/ humanismo versus estruturalismo/ antihumanismo - envolvendo Barthes aparece pela primeira vez no ensaio "O Estruturalismo é um antihumanismo?", do escritor português Joaquim de Montezuma de Carvalho, publicado em $O$ Estado de S. Paulo, em 1969. Seu título não é fortuito, uma vez que expõe uma das grandes questões da época: seria o estruturalismo contrário às convicções que por tanto tempo nortearam as reflexões filosófico-literárias no Brasil e também na Europa Ocidental?

O autor elege Sartre e seu existencialismo humanista como ponto de partida do texto, decretando que "Pode-se dizer que a filosofia do nosso tempo tornou-se existencialista porque o que tinha mais à mão era o tema homem" ${ }^{283}$, fazendo dessa tendência filosófica uma leitura fortemente ancorada no contexto do pós-guerra europeu. Depois de elencar as contribuições do existencialismo para as criações artísticas sob a forma de seus temas mais recorrentes - "[a] vida vivida, a experiência cotidiana, a conduta negativa, a consciência do fracasso, o drama da decisão, a ambiguidade das paixões, a dificuldade de ser e o absurdo da existência" -, Carvalho escreve: "O sol do existencialismo ainda não se ocultou. Algo aquece, mas a curva é agora a do seu declínio. $\mathrm{O}$ existencialismo está em agonia, agonia sem mais, sem esse sentido etimológico grego de luta...

\footnotetext{
${ }^{282}$ Ibid., p. 60.

${ }^{283}$ Suplemento Literário, 21 de junho de 1969, p. 6.
} 
Lutar para quê? É que nos últimos cinco anos apoderou-se do mercado das ideias o movimento estruturalista." 284

Em seguida, o autor se dedica a brevemente explicar o estruturalismo, citando seus principais adeptos, dentre os quais Barthes, como representante da crítica literária. E ressalta justamente a característica mais atacada no Brasil: o rigor científico. Para ele, das análises empreendidas pelos estruturalistas - e cita novamente o escritor -, "se vai desprendendo uma nova imagem do homem, ainda não absolutamente definida, mas desde já sem o calor de uma referência ao homem como centro clássico da atenção de si para si mesmo." ${ }^{285}$ Carvalho passa em revista as críticas ao estruturalismo no que tange seu anti-humanismo e seu a-historicismo, reproduzindo ideias de Sartre, Henri Lefebvre e Roger Garaudy, para contrapô-las à concepção de Foucault, em Les Mots et les choses (1966), segundo a qual o homem não é o centro do conhecimento e nem é condição sine qua non para atingi-lo.

Com a resposta de Foucault em conclusão à parte dedicada às críticas ao estruturalismo, Carvalho se mostra pelo menos simpático a esse movimento de ideias, pois não a questiona, voltando às reflexões sobre o crepúsculo do existencialismo e o amanhecer do estruturalismo. Para então retomar a pergunta-chave que muitos intelectuais brasileiros se faziam naquele momento: "Como decidir? Optar pelo estruturalista Michel Foucault com sua morte do homem? Optar pela reivindicação humanista de Garaudy?" 286

A resposta ao impasse é dada na conclusão do ensaio - como se fosse o desfecho de uma narrativa policial. Talvez muitos leitores tenham chegado a esse momento do texto ávidos por uma posição favorável ou contrária ao estruturalismo, procurando sofregamente por um alento, uma decisão argumentada sobre que posição tomar. Pois Carvalho adota um ponto de vista ecumênico, lançando mão da clarividência de Octávio Paz: "Não opto nem por um, nem pelo outro. Decido-me pelo poeta e ensaísta Octávio Paz, um dos primeiros ibero-americanos a interessar-se pelo estruturalismo. Paz reconhece que o nosso tempo comporta o fim do 'yo' e do homem como história e que outra história amanhece." 287

Solução conciliadora, que dá razão às duas partes sem, no entanto, concordar inteiramente com nenhuma delas, no que tange o pessimismo ou a falta de perspectiva que envolve a ideia de morte do homem. A resposta do autor, encontrada em Paz, não considera o estruturalismo e seus pilares somente em si mesmos, mas os insere na história das ideias, apontando para o surgimento de

\footnotetext{
${ }^{284}$ Ibidem.

${ }^{285}$ Ibidem.

${ }^{286}$ Ibidem.

${ }^{287}$ Ibidem.
} 
um novo conceito de homem. Nesse ponto, eles estão de acordo com Barthes, que também vê o estruturalismo sem maiores dramas, como uma vaga que se sobrepõe a outra e que, um dia será encoberta, como já explicitei. À guisa de conclusão, Carvalho define o estruturalismo como um humanismo e imagina como será o novo homem que dele surgirá, mais humilde a aberto a inovações.

Texto exemplar das dúvidas que a chegada do estruturalismo ao Brasil suscitou nos meios intelectuais, esse ensaio explicita o antagonismo da vez, em que Barthes será envolvido no Brasil: em contraposição a Sartre e aos valores humanistas, do lado frio e calculista dos cientistas da literatura. No entanto, nessa mesma época, paralelamente a etiquetas que eram coladas ao escritor francês, Leyla Perrone-Moisés escreve seus primeiros textos em que explica e emprega conceitos barthesianos como pontos de partida para reflexões ou contrapontos a leituras de outros autores. Com essa prática, presente em quatro artigos na década de 60, ela indiretamente apresenta Barthes aos intelectuais brasileiros, fazendo com que sua presença, como referencial teórico, passe a fazer parte das discussões sobre literatura.

\section{Barthes começa a receber destaque}

Na década de 60, como nas décadas que se seguiram, Leyla Perrone-Moisés merece destaque como divulgadora do pensamento de Barthes. Diferentemente de outros intelectuais que também citaram o escritor francês sem, no entanto, terem lido seus escritos ou tendo-os lido sem grande acuidade, relegando-lhe papéis secundários dentro de grupos, tantas vezes erroneamente, a autora desde muito cedo enxergou em Barthes o grande pensador da literatura que, mais tarde, a pós-modernidade consagraria.

Leyla Perrone-Moisés, nesses anos, emprega conceitos barthesianos como ferramentas de discussão dentro dos intensos debates literários da época, como no artigo "O poder da literatura", publicado no Suplemento Literário em 1966. Nesse texto, ela relata aos leitores brasileiros os resultados da enquete sobre as relações entre as manifestações artísticas e a sociedade - com ênfase na literatura -, feita na França e publicada com o título Que peut la littérature? (Collection l'Inédit 10/18, Union Générale d’Éditions, Paris, 1965). Constituem o corpo de entrevistados Jorge Semprun, Jean Ricardou, Jean-Pierre Faye, Simone de Beauvoir, Yves Berger e Sartre, cujas respostas, as mais díspares à questão, a autora resume em duas posições: a literatura vista como um veículo de transmissão de ideias e, portanto, de ação direta sobre a sociedade, e a literatura concebida como uma finalidade estética em si. Ao final do texto, ela adota uma resposta agregadora, 
porém partidária: “O mais importante é que a arte se faça espontaneamente, sem preocupações com o que deve ser dito mas também sem preconceito contra dizer algo." ${ }^{288}$ Ou seja, que a arte - e a literatura - possa existir por si só, que seja um fim em si, independentemente de bandeiras políticas, o que a arregimenta para o lado dos autores do nouveau roman. Sem, para tanto, excluir uma possível finalidade social.

Nesse artigo, Barthes é chamado à baila por Leyla Perrone-Moisés no parágrafo dedicado a resumir a opinião de Ricardou, que ela identifica com a distinção barthesiana entre écrivains e écrivants, desenvolvida no ensaio "Écrivains et écrivants", dos Essais critiques. Em suas palavras,

Os écrivants são os que usam a literatura como veículo de idéias (Ricardou os chama de informateurs); os écrivains são os que travam uma luta com a linguagem, à procura de novas formas e, por isso, não precisam "ter o que dizer" mas apenas saber "como dizer". Para Ricardou, como para a maioria dos novos-romancistas, a literatura é uma experiência da linguagem. ${ }^{289}$

Em seguida, a autora relata que, para Ricardou, a literatura não tem o poder de mudar a realidade, mas "serve para interrogar essa realidade" ${ }^{290}$. Mesmo sem aludir a Barthes dessa vez, o recorte do discurso de Ricardou conduz ao escritor francês que, nas respostas a um questionário elaborado pela Tel Quel, e publicadas sob o título "Littérature et signification", no mesmo Essais critiques, já afirmava:

Chaque fois que l'on valorise ou sacralise le "réel" (ce qui a été jusqu'à présent le propre des idéologies progressistes), on s'aperçoit que la littérature n'est que langage, et encore: langage second, sens parasite, en sorte qu'elle ne peut que connoter le réel, non le dénoter: le logos apparaît alors irrémédiablement coupé de la praxis; impuissante à accomplir le langage, c'est-à-dire à le dépasser vers une transformation du réel, privée de toute transitivité, condamnée à se signifier sans cesse elle-même au moment où elle ne voudrait que signifier le monde, la littérature est bien alors un objet immobile, séparé du monde qui se fait. Mais aussi, chaque fois que l'on ne ferme pas la description, chaque fois que l'on écrit d'une façon suffisamment ambiguë pour laisser fuir le sens, chaque fois que l'on fait comme si le monde signifiait, sans cependant dire quoi, alors l'écriture libère une question, elle secoue ce qui existe, sans pourtant jamais préformer ce qui n'existe pas encore, elle donne du souffle au monde: en somme la littérature ne permet pas de marcher, mais elle permet de respirer. ${ }^{291}$

A concepção barthesiana de literatura e sua relação com o mundo, tão poeticamente teorizada no trecho acima, é retomada no artigo "A escrita e o grito", publicado em abril de 1968, sobre o livro Compact, de Maurice Roche. Leyla Perrone-Moisés introduz longamente sua leitura da

\footnotetext{
${ }^{288}$ Suplemento Literário, 3 de dezembro de 1966, p. 1.

${ }^{289}$ Ibidem.

${ }^{290}$ Ibidem.

${ }^{291}$ In Essais critiques, $O C$ v. 2, p. 514.
} 
obra com reflexões sobre os porquês da escrita literária em seu tempo, problemática semelhante à que foi tratada no artigo de 1966. A resposta, que explicita o parti pris da autora pelos críticosescritores, é dada já no início do texto, quando afirma: "Frequentemente encontramos, hoje, obras cuja matéria é a reflexão sobre as origens, os meios e os fins da própria arte. Se antes refletia-se para criar, hoje se cria a partir da própria reflexão crítica." 292

Tal constatação é a deixa para, novamente, citar "Écrivains et écrivants", explicando o que Barthes entende para cada um desses conceitos. E conclui: "Evidentemente, o que nos interessa aqui é a escrita do escritor. Que é escrever, para o escritor? Escrever é interrogar a própria linguagem. Ocorre, porém, que indagando o porquê da escrita, o escritor acaba esbarrando no porquê do mundo." 293 Dessa maneira, Leyla Perrone-Moisés expõe a conexão entre a escrita do escritor, a écriture, e o mundo, estabelecida sobre uma questão jamais respondida por completo, mas cuja resposta repousa indefinidamente sobre uma ambiguidade.

A autora identifica nessa "meditação sobre linguagem" - termos dela - uma forte tendência na literatura francesa de seu tempo, como já havia feito em 1964 em seu artigo sobre La Veille, de Roger Laporte, quando pela primeira vez citou Barthes. Desta vez, associa à compreensão da obra literária enquanto questionamento da linguagem o livro Compact, de Roche, em edição prefaciada por Philippe Sollers, deixando entrever seu interesse pelas reflexões desenvolvidas pelo grupo constituído em torno da revista Tel Quel. Para Leyla Perrone-Moisés, "O livro todo é um grito da carne que se transforma, dolorosamente, em palavras." ${ }^{294}$ Essa relação entre a dor, manifestada pelo grito, e a prática da escrita literária, em lugar de destaque no título do artigo, foi buscada pela autora também em "Écrivains et écrivants", no trecho em que Barthes explica o que é a fala para o escritor - "La parole n'est ni un instrument, ni un véhicule: c'est une structure (...)" -, para mais adiante escrever: "on ne peut travailler un cri, sans que le message porte finalement beaucoup plus sur le travail que sur le cri" ${ }^{295}$ (trecho citado em português no artigo). Para a autora, Compact é uma obra que se concentra sobre a linguagem empregada para expressar o grito de dor, exemplo claro da concepção barthesiana de literatura, fundada na écriture.

\footnotetext{
${ }^{292}$ Suplemento Literário, 20 de abril de 1968, p. 3.

${ }^{293}$ Ibidem.

294 Ibidem.

${ }^{295}$ In Essais critiques, $O C$ v. 2, p. 405.
} 
O Estado de S. Paulo, Suplemento Literário, sábado, 20 de abril de 1968, p. 3. 
Essas questões e outras, bem ao gosto da época, reaparecem em "Uma necessidade livre", artigo da mesma autora, publicado em julho de 1968. Motivada pela viagem de Pierre Macherey ao Brasil no mês seguinte, para fazer conferências na USP, Leyla Perrone-Moisés comenta a sua última obra, Pour une théorie de la production littéraire (Paris, François Maspero, 1966), contrapondo-a às ideias principalmente de Barthes e Butor.

Precede sua leitura de Macherey um panorama dos debates sobre a crítica literária na França, traçado a partir de "Les Deux critiques", de Barthes, ensaio também publicado nos Essais critiques $^{296}$, no qual ele distingue dois tipos de crítica: a crítica universitária, inspirada no positivismo de Lanson, e a crítica de interpretação, que compreende as críticas existencialista, marxista, psicanalítica e fenomenológica. Nesse mesmo ensaio, o autor desenvolve sua reflexão e chega a uma nova distinção, separando a crítica que encontra em elementos exteriores à obra sua razão de ser, sua verdade, da crítica que não tem por fim descobrir ou instituir uma verdade, mas que busca levantar um ou vários sentidos, respeitando a ambiguidade da obra literária. Em suas palavras,

(...) bref, ce qui est récusé [pela crítica universitária], c'est l'analyse immanente: tout est acceptable, pourvu que l'oeuvre puisse être mise en rapport avec autre chose qu'elle-même, c'est-àdire autre chose que la littérature: l'histoire (même si elle devient marxiste), la psychologie (même si elle se fait psychanalytique), ces ailleurs de l'oeuvre seront peu à peu admis; ce qui ne le sera pas, c'est un travail qui s'installe dans l'oeuvre et ne pose son rapport au monde qu'après l'avoir entièrement décrite de l'intérieur, dans ses fonctions, ou, comme on dit aujourd'hui, dans sa structure; ce qui est rejeté, c'est donc en gros la critique phénoménologique (qui explicite l'oeuvre au lieu de l'expliquer), la critique thématique (qui reconstitue les métaphores intérieures de l'oeuvre) et la critique structurale (qui tient l'oeuvre pour un système de fonctions). ${ }^{297}$

Em seguida, muito didaticamente, Leyla Perrone-Moisés passa em revista as críticas psicológica ou psicanalítica, marxista, existencialista, temática, fenomenológica e estruturalista, explicando brevemente os pontos de vista a partir dos quais cada uma delas aborda a obra literária, bem como seus principais representantes. E informa, a respeito da crítica imamente, dita estruturalista: "Seguindo a trilha de Lévi-Strauss e Jakobson, vários críticos jovens se situam nessa tendência. Roland Barthes e Michel Butor são os grandes representantes desse tipo de crítica." 298

As considerações da autora sobre o momento crítico de seu tempo, mesmo que partidárias do olhar barthesiano, situam os leitores do jornal - incluindo os intelectuais que discutiam literatura - face aos debates que aconteciam na França e que chegavam aos ouvidos brasileiros em meio a

\footnotetext{
${ }^{296}$ In $O C$ v. 2 , pp. 496-501.

297 Ibid., p. 500.

298 Suplemento Literário, 6 de julho de 1968, p. 1. Esse texto foi reproduzido no recente volume de Leyla PerroneMoisés, Com Roland Barthes, São Paulo, WMF Martins Fontes, 2012, pp. 17-22, e por isso não consta do volume anexo que integra esta tese.
} 
muito ruído. Leyla Perrone-Moisés, portanto, mostra-se consciente da necessidade de explicar claramente aos leitores as diferenças entre as correntes críticas em questão, prestando importante serviço de informação - ao mesmo tempo em que divulga o pensamento de Barthes sem distorcê-lo.

No segundo momento do artigo, a autora se debruça sobre Pour une théorie de la production littéraire, detendo-se nos pontos mais sensíveis da argumentação de Macherey: os conceitos de criação, de imanência e de estrutura; a concepção da literatura enquanto linguagem; a ideia de unicidade da obra literária; a relação entre leitor e escritor. Um a um, ela os examina e contrapõe a compreensão de Macherey às de Butor e Barthes, promovendo um verdadeiro diálogo entre os autores.

Nessa época, Barthes ainda é adepto do estruturalismo - o que justifica sua identificação ao grupo e sua defesa pela autora fazendo uso das concepções barthesianas. Um exemplo é como ela rebate as críticas à compreensão da literatura como uma linguagem, feitas por Macherey:

Outra querela de Macherey com os estruturalistas (e no fundo a questão é sempre a mesma), diz respeito à palavra "linguagem". Na pág. 36 de seu livro, Macherey insiste em que "il ne faut pas dire que la littérature est un nouveau langage". Insiste ainda em que a literatura não cria uma realidade segunda, independente da primeira. ${ }^{299}$

A autora reconhece aí um ataque a Barthes, que concebe a literatura como uma parole seconde: “[O escritor deve] détacher une parole seconde de l'engluement des paroles premières que lui fournissent le monde, l'historie, son existence, bref um intelligible que lui préexiste, car il vient dans un monde plein de langage, il n'est aucun réel qui ne soit déjà classé par les hommes (...).” 300

Outro ponto discordante entre Macherey e Barthes concerne a relação entre leitor e escritor. Segundo Leyla Perrone-Moisés, o autor de Pour une théorie de la production littéraire vê um antagonismo entre esses dois termos, e o explica pelo fato de Macherey compreender a leitura como uma atividade passiva, que se dá após a escrita. O que se mostra o oposto do que Barthes escreve no final de Critique et vérité:

Passer de la lecture à critique, c'est changer de désir, c'est désirer non plus l'oeuvre, mais son propre langage. Mais par là même aussi, c'est renvoyer l'oeuvre au désir de l'écriture, dont ele était sortie. Ainsi tourne la parole autour du livre: lire, écrire: d'un désir à l'autre va toute la littérature. Combien d'écrivains n'ont écrit que pour avoir lu? Combien de critiques n'ont lu pour écrire? Ils ont rapproché les deux bords du livre, les deux faces du signe, pour que n'en sorte qu'une parole. ${ }^{301}$

\footnotetext{
299 Ibidem.

${ }^{300}$ Ibidem.

${ }^{301}$ In $O C$ v. 2, p. 801.
} 
Como último exemplo das diferenças teóricas entre os dois franceses, cito o conceito de imanência. Como diz Leyla Perrone-Moisés, "Para Barthes, crítica imanente é a que situa seu objeto na própria obra. Macherey chama de crítica imanente a que acredita num sentido único da obra." 302 Ora, as duas compreensões não são nem mesmo opostas, tanto elas são diferentes, tratando de características distintas da crítica. Para os estruturalistas, as obras artísticas não têm um único sentido, mas criam uma pluralidade de sentidos que são liberados a cada leitura. E com essa ideia Macherey está de acordo. A autora, porém, não deixa de esclarecer: "Essa crítica [estruturalista] pretende estudar a configuração da obra, seu modo de ser, pois é nos significantes que residem os significados." 303

Concluindo o artigo, Leyla Perrone-Moisés faz um diagnóstico das divergências entre Macherey e os estruturalistas, especialmente Barthes, que serve para a maior parte da crítica brasileira na década de 60: "Suas oposições aos estruturalistas nascem ora de uma interpretação inexata de suas posições, ora de uma confusão terminológica." 304

Seu artigo seguinte, “As Máscaras verbais”, publicado em maio de 1969, deixa de lado tais questões para fazer uso de Barthes como referencial teórico de sua leitura des Chants de Maldoror, de Lautréamont. Leyla Perrone-Moisés dedica seu texto à análise dos nomes dos personagens dessa obra, mostrando as relações entre suas escolhas e suas funções na construção da narrativa. $\mathrm{Na}$ introdução, ela cita Jakobson e o Barthes de "Introduction à l'analyse structurale des récits", texto publicado na revista Communications de novembro de 1966, sem, no entanto, dar a fonte: "Roland Barthes dá outra formulação da mesma idéia: "Numa obra, tudo é função. Tudo tem um sentido ou nada tem. Poder-se-ia dizer, de outra forma, que a arte não conhece o ruído (no sentido informacional da palavra)" ${ }^{305}$. O trecho de onde a autora tira a citação de Barthes, no entanto, é um pouco diferente: Leyla Perrone-Moisés resume as reflexões do escritor francês nas duas primeiras frases para reproduzir com exatidão o resto do parágrafo ${ }^{306}$. Fazendo isso, ela não só atende à necessidade de brevidade e de clareza de um artigo de jornal - de fato, Barthes explica longamente o que a autora consegue sintetizar com brilhantismo em duas frases -, como não deixa de trabalhar em favor da divulgação das ideias do escritor francês, resumindo-as com fidelidade.

O último texto de Leyla Perrone-Moisés da década de 60 dá o tom da maioria dos artigos que serão publicados sobre Barthes na década seguinte: com algumas exceções, que discutirão a

\footnotetext{
${ }^{302}$ Suplemento Literário, 6 de julho de 1968, p. 1.

303 Ibidem.

304 Ibidem.

${ }^{305}$ Suplemento Literário, 24 de maio de 1969, p. 1.

${ }^{306} \mathrm{Cf}$. "Introduction à l'analyse structurale des récits", $O C$ v. 2, p.836.
} 
obra do escritor, a maioria dos artigos evidenciará o quanto os intelectuais brasileiros já absorveram das teorias barthesianas, e de maneira muito rápida, graças às primeiras traduções de suas obras. Ao alcance dos brasileiros, Barthes será citado com frequência pelos críticos universitários, adeptos do estruturalismo e de outras novidades como a semiologia, por exemplo. No entanto, a querela dos críticos tradicionais contra o estruturalismo, na qual Barthes é embarcado, manifestada em termos meramente ideológicos nos anos 60 , sob a forma do anti-humanismo, terá apenas começado, tendo desdobramentos célebres nos anos 70 . 


\section{Anos 70: apropriação e debates}

La société intellectuelle peut faire de vous ce qu'elle veut, ce dont elle a besoin, ceci n'est jamais qu'une forme du jeu social, mais moi, je ne puis me vivre comme une image, l'imago de la sémiologie. ${ }^{307}$

Roland Barthes

Diferentemente dos períodos anteriores, a década de 70 foi pródiga em textos que citam Roland Barthes. Fazendo eco aos intensos debates da década de 60 no Brasil e na França acerca da nouvelle critique e do estruturalismo, intensificou-se o interesse pela linguística e pelos autores que a partir dela teorizaram sobre os mais diferentes assuntos. Consequentemente, o fluxo de publicações sobre linguística, que já existia, aumentou consideravelmente, alimentando, por sua vez, a febre intelectual do momento.

Esse diagnóstico é dado por Vilson Brunel Meller na resenha de Linguística e poética, de Daniel Delas e Jacques Filliolet (Tradução de Carlos Felipe Moisés, São Paulo, Cultrix, 1976), entitulada "Uma definição provisória de poesia" e publicada no Suplemento Cultural, em 1977. Seu texto se inicia com a seguinte constatação: "O interesse que a linguística tem despertado nestes últimos anos é o principal responsável por acontecimentos editoriais como este: menos de dois anos após seu lançamento na França, o público brasileiro é confrontado com este Linguística e Poética, numa bem cuidada tradução." ${ }^{308}$ E sentencia, explicitando o que parece ser uma consequência da enxurrada de estudos linguísticos: "Uma visão geral da obra poderá oferecer a impressão de que é um livro como tantos que têm surgido ultimamente - que pretende 'improvisar' qualquer coisa, escudado num título que traz a palavra mágica: Linguística." ${ }^{309}$ Porém, para o autor, ao contrário do que dá a entender uma primeira impressão, Linguística e poética se mostra útil na medida em que apresenta as grandes correntes linguísticas modernas, oferecendo ao leitor um panorama geral capaz de situá-lo em meio à floresta de teorias e concepções. Dentro desse quadro, aparece o nome de Barthes, junto a outros intelectuais como Benveniste, Derrida, Chomsky, Greimas, Eco, Hjelmslev, Martinet, Sapir, Kristeva, Jakobson, Lévi-Strauss, Saussure, etc.

A linguística, portanto, estava na moda no Brasil, sendo atraente tanto para aqueles que já a conheciam das décadas anteriores, munindo-os com material de debate e reflexão, quanto para aqueles que nela então se iniciavam. Fomentando tal interesse e se beneficiando dele, algumas

\footnotetext{
${ }^{307}$ In "L'Aventure sémiologique", $O C$ v. 4, p. 522.

${ }^{308}$ In Suplemento Cultural, 27 de março, p.13.

${ }^{309}$ Ibidem.
} 
editoras se destacavam nessa época, como conta Leônidas Hegenberg em seu artigo "Na área da linguística", publicado no Suplemento Cultural, também em 1977. Nesse texto, o autor afirma que "Duas editoras devotaram-se, com grande empenho, nos últimos anos, a divulgar trabalhos na área linguística; a Vozes, de Petrópolis, e a Cultrix, de São Paulo." ${ }^{310}$ Esta última, sintomaticamente, publicou o Curso de linguística geral, de Saussure, traduzido por Antonio Chelini, José Paulo Paes e Izidoro Blikstein, em 1970. Hegenberg explica que os bons resultados de vendagem abriram caminho para que outras editoras passassem a investir na tradução e publicação de obras relacionadas à linguística, pois "O número de editoras e de obras é um claro indício de interesse que a matéria vem despertando." ${ }^{311}$ Hegenberg cita a publicação de Elementos de semiologia, de Barthes, em 1971, como uma das grandes obras disponibilizadas ao público brasileiro graças à editora Cultrix.

A onda de estudos linguísticos que tomou conta das discussões acerca da literatura nos anos 70 favoreceu a difusão das obras de Barthes: seus livros começaram a ser traduzidos e publicados ao longo da década, constituindo um dos picos de tradução de suas obras no Brasil, conforme os dados sobre esse fenômeno editorial e a leitura que deles faço no capítulo "Traduções" demonstrarão.

Disponível em português, acessível a todos os bolsos pelas edições brasileiras (os livros portugueses da Edições 70, até então única versão em português das obras de Barthes, eram importados e bastante caros), facilmente encontrado nas livrarias, o escritor francês se popularizou no Brasil nessa época e, de autor desconhecido, etiquetado erroneamente e que necessitava ser apresentado, passou a figurar com frequência nos textos sobre literatura e outras artes então emergentes, como o cinema, a fotografia e os estudos sobre a comunicação de uma maneira geral. Nesse quadro, a maioria dos artigos que constituem o corpus deste trabalho têm por tema questões barthesianas tratadas nas obras traduzidas no período: Crítica e verdade, com seleção dos Ensaios críticos (1970), O Grau zero da escritura (1971), Elementos de semiologia (1971), "Análise estrutural da narrativa" (1971), Mitologias (1972), Novos Ensaios críticos seguidos de O Grau zero da escritura (1974), Sistema da moda (1979), O Prazer do texto (1977), Roland Barthes por Roland Barthes (1977) e O que é a literatura (1979), esta última, tradução de uma entrevista do autor.

Essas traduções permitem distinguir dois momentos do pensamento do escritor: um mais ligado às questões dos anos 60 , objeto das publicações brasileiras de Barthes até mais ou menos a metade da década, e outro pós-moderno, inaugurado pela tradução de $O$ Prazer do texto. Não por acaso, as recepções a esses dois momentos foram diferentes em $O$ Estado de $S$. Paulo: no que

\footnotetext{
${ }^{310}$ In Suplemento Cultural, 28 de agosto de 1977, p. 7.

${ }^{311}$ Ibidem.
} 
concerne a aplicação de teorias linguísticas à literatura, mote da década de 60, Barthes é apenas citado, prova de que os anos anteriores prepararam o terreno, mesmo que imperfeitamente, à chegada de suas posições. O mesmo não ocorre em relação a suas obras a partir de 1973, que não demoraram muito tempo para serem traduzidas, sua recepção se dando não com muito atraso tendo em vista suas publicações na França. Nesses casos, as obras de Barthes foram discutidas na imprensa brasileira, sendo objeto de artigos inteiramente dedicados a elas.

Neste capítulo, portanto, eu me debruçarei sobre esses dois momentos, essas duas recepções às obras de Barthes, que marcam os anos 70.

\section{Pau para toda obra, teoria para toda pesquisa}

A grande maioria dos textos da década de 70 em que o nome de Barthes aparece se resume a citá-lo e/ou a empregá-lo, e a seus conceitos, ideias e obras, enquanto ferramenta de análise, fundamentação teórica e argumento de autoridade. O que sinaliza que as traduções de suas obras começavam a fazer com que os intelectuais brasileiros passassem a conhecê-lo não só por ouvir dizer ou de segunda mão, mas a ter acesso a suas ideias na íntegra, incorporando-as a suas reflexões. Num corpus heterogêneo como é o jornal, naturalmente encontrei variada gama de temas em que o nome de Barthes é chamado à baila, o que incluem, por exemplo, artigos envolvendo seu conceito e sua decodificação dos mitos cotidianos ${ }^{312}$ e um longo texto que discute as relações entre a história e as vanguardas francesas das décadas de 60 e 70, em que ele é bastante citado, como grande mestre da modernidade, ao lado de Lévi-Strauss, Chomsky, Foucault, entre outros ${ }^{313}$. Todavia, para além de casos isolados, duas facetas de Barthes se sobressaem às demais, nesse período: o semiólogo e o estruturalista.

\section{A semiologia na ordem do dia}

Como na França, no Brasil Barthes era "l'imago de la sémiologie", seu representante supremo, pelo manual que concebera, Éléments de sémiologie, e por suas numerosas pesquisas nesse campo, publicadas sob forma de artigos e livros desde os anos 60. Em "L'Aventure sémiologique", texto-balanço de 1974 de suas atividades relacionadas à semiologia, o escritor a define de maneira surpreendente para aqueles que o viam como seu sumo pontífice: "Qu'est-ce donc pour moi, la

\footnotetext{
${ }^{312}$ Cf. Suzi Frankl Sperber, "Linguagem mitificante e desmitificação", Suplemento Literário, 10 de outubro de 1971, p. 4.

${ }^{313}$ Cf. Gilles Lapouge, "Intervir na história, a intenção da vanguarda francesa", Primeiro Caderno, 23 de novembro de 1975, pp. 40-41.
} 
Sémiologie? C'est une aventure, c'est-à-dire ce qu'il m'advient (ce qui me vient du Signifiant).",314 Situando-a nos domínios de sua percepção individual, Barthes se distancia das expressões generalizadoras e definitivas tão comuns àqueles que se arvoram direitos sobre algum ramo do conhecimento, dizendo com todas as letras, no mesmo texto: “(...) il me faut dire que je ne représente pas la sémiologie (ni le structuralisme): aucun homme ne peut représenter une idée, une croyance, une méthode, à plus forte raison quelqu'un qui écrit, dont la pratique élective n'est ni la parole ni l'écrivance, mais l'écriture." 315

Barthes, portanto, considerava-se um escritor e não o representante da semiologia, contrariamente à maneira como era visto por grande parte da imprensa e dos intelectuais que a ele se referiam. No Brasil não era diferente, muito em função da versatilidade da semiologia enquanto teoria e ferramenta de análise, popularizada por Elementos de semiologia. Nesse livro, fruto de seu seminário de 1962-1963 na École Pratique des Hautes Études, o escritor faz um apanhado de modernas teorias linguísticas e seu funcionamento quando aplicadas a sistemas de signos tão variados quanto o sistema vestimentário, o sistema mobiliário e o da alimentação, por exemplo. Combinando principalmente os conceitos cunhados por Saussure e Hjelmslev, Barthes procura construir uma nova ciência bastante abrangente: ao par saussuriano língual fala, ele associa o par hjelmsleviano esquema/ uso para alargar o campo de ação da semiologia. Partindo dos conceitos de base de Saussure, ele enxerga novos horizontes analíticos, pois, como diz a certa altura de seu livro, “La portée sociologique du concept de Langue/ Parole est evidente." ${ }^{316}$ E propõe sua aplicação a outros sistemas, não-verbais:

On a vu que la séparation de la Langue et de la Parole constituait l'essentiel de l'analyse linguistique; il serait donc vain de proposer d'emblée cette séparation pour des systèmes d'objets, d'images ou de comportements qui n'ont pas encore été étudiés d'un point de vue sémantique. On peut seulement, pour quelques-uns de ces systèmes supposés, prévoir que certaines classes de faits appartiendront à la catégorie Langue et d'autres à la catégorie Parole, en disant tout de suite que, dans ce passage sémiologique, la distinction saussurienne risque de subir des modifications, qu'il s'agira précisément de noter. ${ }^{317}$

Reconhecendo a necessidade de adaptar os conceitos de Saussure aos novos objetos de estudo, Barthes joga com a língua e a fala, reconhecendo-as, no exemplo de uma análise semiológica do vestuário, em lugares diferentes, a cada tipo de corpus: o vestuário descrito em um

\footnotetext{
${ }^{314}$ In $O C$ v. 4, p. 522.

${ }^{315}$ Ibid., pp. 521-522.

${ }^{316}$ In $O C$ v. 2, p. 646.

${ }^{317}$ Ibid., p. 648.
} 
jornal, fotografado e veiculado por uma revista e usado por uma pessoa constituem situações distintas em que o tema vestuário se apresenta. Por conseguinte, o lugar da língua - compreendida como sistema de regras - e o da fala - uso social da língua - variam de acordo com a situação mencionada. Os conceitos forjados por Saussure, portanto, são flexibilizados por Barthes, para que possam ser aplicados a outros objetos:

Les systèmes les plus intéressants, ceux du moins qui relèvent de la sociologie des communications de masse, sont des systèmes complexes, dans lesquels sont engagées des substances différentes: dans le cinéma, la télévision et la publicité, les sens sont tributaires d'un concours d'images, de sons et de graphismes; il est donc prématuré de fixer, pour ces systèmes, la classe des faits de langue et celle des faits de parole, d'une part tant qu'on n'a pas décidé si la "langue" de chacun de ces systèmes complexes est originale ou seulement composée des "langues" subsidiaires qui y participent, et d'autre part tant que ces langues subsidiaires n'ont pas été analysées (nous connaissons la "langue" linguistique, mais nous ignorons la "langue" des images ou celle de la musique). ${ }^{318}$

Não se pode, portanto, simplesmente sobrepor os conceitos de Saussure a outros sistemas como uma forma de estrela sobre a areia molhada, para se fazer uma estrela de areia. Há que se respeitar as particularidades de cada sistema e, sobretudo, que se adaptar os conceitos à matéria tratada: a areia molhada pode adquirir diversas formas, inclusive a de uma estrela, dependendo das mãos que a moldam. Pois estas levam em conta as potencialidades e limitações da matéria, colocando em relevo as singularidades reveladas pelo corpus, e não o esplendor de seus instrumentos de análise. Nas palavras de Barthes, "L'extension sémiologique de la notion Langue/ Parole ne va pas sans poser certains problèmes, qui coïncident évidemment avec les points où le modèle linguistique ne peut plus être suivi et doit être aménagé." 319

Essa possibilidade de adequar os conceitos saussurianos, combinando-os a noções oriundas das mais diversas fontes, em prol de análises dos mais variados sistemas, oferecia infinitos novos caminhos aos intelectuais. A semiologia flexível barthesiana também permitia que as ciências humanas se popularizassem, atualizando seus objetos de estudo e aproximando os intelectuais do grande público: revistas em quadrinhos, mobiliário, moda, sinais de trânsito, cinema, o kitsch, temas familiares a todo o mundo, tomavam o lugar dos herméticos escritores contemporâneos e dos grandes clássicos da literatura, cada vez menos lidos, nas análises publicadas em jornais, revistas, tratadas nos cursos universitários e nas teses doutorais. A semiologia era pop, e seu papa era Barthes.

\footnotetext{
${ }^{318}$ Ibid., p. 651.

${ }^{319}$ Ibidem.
} 
Em $O$ Estado, muitos são os textos que acusam a novidade: uma teoria ao mesmo tempo rigorosa, de matriz linguística, e maleável, capaz de se adaptar a qualquer objeto. Em "Proposições semiológicas", publicado em 1970, Eduardo Portella decreta, logo de início: "A investigação literária é, hoje, mais do que nunca, uma tarefa interdisciplinar" ${ }^{320}$, para anunciar a seus leitores o advento dos estudos semiológicos. O resumo anônimo de Semiologia e linguística, coletânea de artigos de vários autores, inclusive Barthes, publicado pela Editora Vozes em $1971{ }^{321}$, também recomenda o livro a estudiosos de diferentes ramos do saber, tais como as letras, comunicações e ciências sociais. Entretanto, mais do que simplesmente apregoar a pluralidade de objetos sobre os quais os intelectuais começavam a se debruçar munidos da semiologia como ferramenta de análise, os textos publicados em $O$ Estado davam provas dessa maleabilidade reflexiva.

Um exemplo é a série de seis artigos do professor da Escola de Comunicações e Artes da USP, Eduardo Peñuela Cañizal, entitulada “Abordagens semiológicas do discurso cinematográfico", publicada em 1970, cujo objetivo é propor análises do discurso fílmico fundamentadas em conceitos operacionais da semiologia. No primeiro artigo, o autor desqualifica os estudos da narrativa fílmica carentes de rigor científico. E cita Barthes para caracterizar a narrativa: “(...) a história - o plot, como já o entendia Foster - necessita de um código de casualidade que somente se manifesta ao nível do discurso ou, mais propriamente, como afirma, entre outros, Roland Barthes, na integração das funções, ações e narrações, planos constituintes da hierarquia do discurso narrativo" (grifos do autor) ${ }^{322}$. A escolha de Barthes, feita "entre outros", distingue o escritor francês como um modelo de cientificidade analítica, procurada por Cañizal, e encontrada no grande sucesso que foi "Introduction à l'analyse structurale des récits", onde Barthes estabelece a distinção recuperada pelo autor $^{323}$.

Mais adiante, tratando das diferenças entre a fotografia e o cinema, no que concerne à construção da narrativa, da história no sentido de enredo, o autor novamente lança mão das reflexões do escritor francês, o que deixa clara sua importância como referencial teórico: “(...) de um lado, como já mostraram as análises de Roland Barthes e Umberto Eco, a fotografia, pelo fato de ser uma codificação da realidade, transforma essa realidade - parcela da realidade - em referente -; a história, isto é, a mensagem narrativa, resulta da concatenação dos signos (no caso fotograma) e não dos referentes." 324

\footnotetext{
${ }^{320}$ Suplemento Literário, 5 de setembro de 1970, p. 1.

${ }^{321}$ Suplemento Literário, "Novos Livros", 15 de agosto de 1971, p. 2.

${ }^{322}$ Suplemento Literário, 10 de outubro de 1970, p. 6.

${ }^{323}$ Cf. $O C$ v. 2, p. 835.

${ }^{324}$ Suplemento Literário, 10 de outubro de 1970, p. 6.
} 
Barthes, que declarou em entrevistas, não gostava muito de cinema, tem uma produção bibliográfica assaz fecunda sobre o tema, de base semiológica, explorada por Cañizal também em outro artigo, "A mensagem artística e a situação simbólica" ${ }^{325}$, de 1978, dedicado às relações entre a representação e a significação das imagens, seguindo a mesma linha de pensamento da série de textos acima citada. Nesse artigo, a fim de explicitar seu ponto de partida, o autor resume detalhadamente "Le Troisième sens. Notes de recherche sur quelques photogrammes de S. M. Eisenstein", publicado nos números 217, 218 e 219 dos Cahiers du cinéma (novembro de 1969, março e abril de 1970) ${ }^{326}$.

Por fim, ainda a título de exemplo do largo emprego da semiologia barthesiana na época, cito a série de três artigos entitulados "Comunicação e ideologia": " I - A análise operacional dos veículos de massa", "II - Ciência crítica e crítica da ciência" e "III - A operação em círculos", de Louzada Filho, publicada em $1973^{327}$. Nesses textos, o autor se propõe a discutir as bases sobre as quais se fundamenta a recém-nascida teoria da comunicação, que tem por objeto as produções dos veículos da cultura de massa. Barthes se faz presente por meio dos Elementos de semiologia, manual teórico que formou gerações de estudiosos no vasto campo dos estudos da comunicação e que rendeu numerosos artigos na imprensa brasileira. $\mathrm{O}$ escritor francês, também no Brasil, era a própria encarnação da semiologia.

\section{Barthes e a comichão estruturalista}

\section{A comichão estruturalista no Brasil}

Na França, o estruturalismo entra em refluxo já no final da década de 60, precisamente a partir de 68, segundo François Dosse em sua História do estruturalismo. Consequentemente, a década seguinte será regida por um paradoxo: ao mesmo tempo em que será sucesso absoluto de mídia, ele se desintegrará lentamente, até se pulverizar por completo no início dos anos 80 .

O estruturalismo sofreu duras críticas desde as publicações dos primeiros livros e artigos divulgando algumas de suas principais vertentes teóricas. Neste trabalho, já destaquei a visão de Henri Lefebvre, que acusava o rigor e o cientificismo estruturalistas de compactuar, no plano teórico, com a tecnocracia acrítica que se instalava nas esferas culturais da sociedade francesa da época. Endossa essa opinião Jean-François Revel e acrescenta nova crítica: afirma que o

\footnotetext{
${ }^{325}$ Suplemento Cultural, 15 de janeiro de 1978, pp. 8-10.

${ }^{326}$ In $O C$ v. 3 , pp. $485-506$.

${ }^{327}$ Suplemento Literário, 16 de setembro, p. 5, 23 de setembro, p. 6 e 30 de setembro, p. 3.
} 
estruturalismo causa "a morte da cultura geral" 328 e "lamenta que a emancipação das ciências humanas dissolva gradativamente a noção de cultura geral e que, para tornarem-se ciências, precisem deixar de ser humanas." ${ }^{329} \mathrm{O}$ anti-humanismo apontado por Revel também foi bastante atacado por intelectuais brasileiros, como já pontuei quando tratei dos anos 60. Porém, o sucesso midiático do estruturalismo impediu que tais críticas fossem ouvidas e, embora existissem, elas não contribuíram definitivamente para o seu refluxo.

Foram os próprios desenvolvimentos das teorias e do pensamento dos grandes teóricos da "atividade estruturalista" que a envenenaram, corroendo suas entranhas em seus princípios de base, fazendo com que ela se esfarelace. Pois o estruturalismo não morreu, mas se desintegrou, fragmentou-se e transformou-se em mil pedaços, até se descaracterizar sem, no entanto, perder por completo alguns traços que um dia garantiram sua unidade. Por um lado, novas teorias começaram a ganhar espaço e a questionar a ambição estruturalista de encontrar modelos universais: as teses desconstrutivas de Derrida, a gramática gerativa de Chomsky e a teoria da enunciação de Benveniste ${ }^{330}$. Por outro, novas orientações começaram a surgir nos trabalhos dos velhos mestres, de que a trajetória de Barthes é um exemplo: depois das querelas críticas e das incontáveis defesas do estruturalismo feitas em artigos e em entrevistas, o escritor mudou de rumo. Com o impulso da teoria da polifonia do texto literário de Bakhtin, via Julia Kristeva, Barthes repensou suas concepções literárias e decidiu realocar a subjetividade, colocando-a no centro da construção literária. Então, o escritor partiu para o Japão - L'Empire des signes - , para as considerações sobre o prazer na literatura - Le Plaisir du texte -, para os biografemas - Roland Barthes par Roland Barthes -, dentre outros tantos textos que compõem essa parte de seu percurso intelectual. As preocupações teóricas da "Introduction à l'analyse structurale des récits" já estavam longe...

Tal revisão e consequente mudança de caminhos foi natural aos intelectuais franceses, tanto àqueles que ajudaram a estabelecer os fundamentos do estruturalismo, como Barthes, quanto a seus críticos. Dos ataques também nasceram as novas proposições que ajudaram a minar as bases estruturalistas, como explica François Dosse:

Se as primeiras reações ao estruturalismo foram antes de rejeição no grupo dos adeptos de Henri Lefebvre, a realidade ulterior foi, entretanto, mais complexa. Com efeito, cada um é atraído

\footnotetext{
${ }^{328}$ In L’Express, p. 123, 25 a 31 de março de 1968, apud François Dosse, História do estruturalismo, O canto do cisne, tradução de Álvaro Cabral, revisão técnica de Marcia Mansor D'Alessio, Bauru (SP), Edusc, 2007, vol. 2, p. 136.

${ }^{329}$ François Dosse, História do estruturalismo, O canto do cisne, op. cit., p. 136.

${ }^{330}$ Ibid., p. 77.
} 
por este ou aquele aspecto das produções estruturalistas, mesmo que desenvolva, por outro lado, uma crítica global do que é percebido como uma ideologia. ${ }^{331}$

Na década de 70, independentemente de posições fixadas nos anos anteriores a favor ou contra as teorias estruturalistas, numerosos intelectuais, dentre os quais alguns grandes mestres, como Barthes, por exemplo, adotam direções diferentes, abandonando certas aspirações antes acalentadas em tantos livros e artigos. Curiosamente, essa é a época em que a imprensa e as universidades finalmente celebram o estruturalismo, o que, para Dosse, contribuiu para sua decadência:

Mas ao mesmo tempo que o estruturalismo conquista o poder, institucionaliza-se graças à contestação de 1968, também se banaliza e perde grande parte de sua força crítica corrosiva. Portanto, pode-se também entrever por trás desse triunfo o sinal da desintegração vindoura, no decorrer da qual cada um, em sua disciplina, vai delinear uma lógica específica, uma vez que já não existe mais um combate comum a travar, nenhum adversário designado, nenhum alvo visível. A fase militante se encerra com o triunfo institucional. Inaugura-se o período da desintegração e da dissolução (...). ${ }^{332}$

A entrada do estruturalismo na universidade tem como maior exemplo a Universidade de Paris VIII - Vincennes. Esta foi construída às pressas, para o ano letivo de 1968-1969, tendo em seu corpo docente, em sua maioria, intelectuais alinhados com o estruturalismo, e em seu projeto pedagógico, a interdisciplinaridade, inspirada no modelo universitário estadunidense ${ }^{333}$. Vincennes foi concebida como uma universidade moderna, e a modernidade era estruturalista. Justamente por isso, o estruturalismo estava tão em voga nos meios de comunicação na França, o que garantiu sua sobrevida em outros países, como o Brasil, por mais alguns anos.

Em terras brasileiras, o estruturalismo vivia seu momento de maior vigor. A ponto de Temístocles Linhares empregar a expressão "comichão estruturalista" como título de um de seus artigos. Mesmo vindo de um ferrenho crítico ao estruturalismo, esse texto ${ }^{334}$ não é especialmente pródigo em diatribes contra a moda que tomava conta da intelectualidade brasileira: ele analisa Estruturas - Ensaio sobre o romance de Graciliano (Belo Horizonte, Editora Tendência, 1969), de Rui Mourão, uma leitura imanente e estruturalista dos romances de Graciliano Ramos, apontando até muito serenamente seus erros e acertos para, na conclusão, afirmar que os pontos altos do livro não se devem ao estruturalismo, mas à argúcia do crítico. Fica, portanto, implícito, o significado do

\footnotetext{
331 Ibid., p. 144.

332 Ibid., p. 181.

${ }^{333}$ Para mais informações sobre a criação da Universidade de Paris VIII - Vincennes, ver François Dosse, História do estruturalismo, O canto do cisne, op. cit., pp. 183-196.

334 “A Comichão estruturalista”, Suplemento Literário, 31 de janeiro de 1970, p. 4.
} 
título do artigo: Mourão poderia ter feito uma análise acertada da obra de Graciliano Ramos sem recorrer ao estruturalismo. Mas foi contaminado pela "comichão estruturalista", pelo "desejo veemente", pela "tentação", pelo "formigamento" e pela "gastura" - sinônimos elencados pelo dicionário Houaiss - que impelem ao emprego não só da metodologia estruturalista, mas de seu vocabulário e da palavra "estrutura", presente desde o título do livro.

A etimologia de "comichão", também segundo o dicionário, remete ainda à "ação de comer", o que permite comparar a vontade irresistível de ser estruturalista a uma grande fome, como se os literatos brasileiros estivessem à míngua há muito tempo. Seria essa uma fome de novidades teóricas? Talvez sim, pois foi o advento do estruturalismo que fortaleceu os críticos universitários e lhes forneceu munição para derrotar a crítica tradicional, nos idos dos anos 60. Como é natural depois de uma batalha, as fileiras dos vencedores viram seu contingente aumentar numericamente nos anos que se seguiram.

Em O Estado, as seções "Lançamentos", "Livros Novos" e "Resenha Bibliográfica" do Suplemento Literário, bem como "Lançamentos" do Suplemento Cultural, são um bom termômetro da efervescência da voga linguístico-estrutural no Brasil da década de 70. Além do já mencionado Curso de linguística geral, de Saussure, nesse período também foram publicados em português e/ou resenhados: Teoria da forma literária, de Kenneth Burke (Cultrix/ Editora da Universidade de São Paulo, $1969^{335}$ ), Perspectives in contemporary criticism, organizado por Sheldon Norman Grebstein (Nova Iorque e Londres, Harper and Row, $1968^{336}$ ), Linguística, poética, cinema, de Roman Jakobson (Perspectiva, 1970), Estruturalismo e Antropologia, de Dan Sperber (Cultrix, 1970), Estruturalismo e Linguística, de Oswald Ducrot, Estruturalismo e Poética, de Tzvetan Todorov, Estruturalismo e Filosofia, de François Wahl e Estruturalismo e Psicanálise, de Moustafa Safouxan (todos da coleção "Que é o estruturalismo" da Cultrix e Fundo Estadual de Cultura, 1970), Linguistique et enseignement du français, de Émile Genouvrier e Jean Peytard (Paris, Larousse, 1970), Semiologia e Linguística, de vários autores, inclusive Barthes (Vozes, 1971), Sobre o trabalho teórico, de Louis Althusser (Lisboa, Editorial Presença, 1971), Estruturalismo de LéviStrauss e marxismo de Louis Althusser, de Caio Prado Júnior (Brasiliense, 1971), Introdução aos estudos linguísticos, de Francisco da Silva Borba (Companhia Nacional, 1972), Chaves do estruturalismo, de Jean-Marie Auzias (Civilização Brasileira, 1972), Semiótica e filosofia, de Charles Sanders Peirce (Cultrix, 1972), O Estruturalismo e a miséria da razão, de Carlos Nélson Coutinho (Paz e Terra, 1973), O Sistema dos objetos, de Jean Baudrillard (Perspectiva, 1973),

\footnotetext{
335 A nota informando o lançamento do livro só saiu no Suplemento Literário em 23 de maio de 1970.

${ }^{336}$ A resenha do livro só saiu no Suplemento Literário em 4 de julho de 1970.
} 
Estilística estrutural, de Michel Riffaterre (Cultrix, 1973), Teoria da literatura: formalistas russos, de vários autores russos (Globo, 1973), Semântica estrutural, de Algirdas Julien Greimas (Cultrix, 1974), Os Signos e a crítica, de Cesare Segre (Perspectiva, 1974), Introdução à semanálise, de Julia Kristeva (Perspectiva, 1974), Linguística e poética, de Daniel Delas e Jacques Filliolet (Cultrix e Editora da Universidade de São Paulo, 1975), Fundamentos da teoria dos signos, de Charles W. Morris (Editora da Universidade de São Paulo, 1976), Semiótica narrativa e textual, de Claude Chabrol e outros (Cultrix, 1977), Introdução ao estruturalismo em linguística, de José Ribeiro Damasceno (Vozes, 1977), Texto, crítica, escritura, de Leyla Perrone-Moisés (Ática, 1978), O Círculo linguístico de Praga, de Jacqueline Fontaine (Cultrix e Editora da Universidade de São Paulo, 1978), dentre muitos outros.

Tal lista de títulos de obras, parcial e sucinta, faz estranhar o seguinte trecho encontrado na nota sobre o lançamento de Chaves do estruturalismo, sem assinatura: "A moda do estruturalismo já passou e é pena que só agora tenha sido traduzido este manual de Jean-Marie Auzias, que põe as coisas no lugar e desmistifica essa corrente do pensamento, tratando-a de forma objetiva e clara." 337 Por mais que se apregoasse que o estruturalismo estava ultrapassado, que seu tempo havia acabado, não é isso o que o intenso fluxo de publicações demonstra, ao menos no Brasil. A despeito do que acontecia na França, a voga teórica ainda estava muito em pauta, tanto na imprensa quanto nas universidades. Estas ofereciam ao mercado editorial um público constituído por alunos que se iniciavam nos estudos linguísticos e literários, acentuando a demanda por livros de caráter mais didático, como os da coleção "Que é o estruturalismo", ou Chaves do estruturalismo, ou ainda Introdução ao estruturalismo linguístico, por exemplo, há pouco citados.

Mesmo que o estruturalismo tenha se enraizado nas práticas literárias brasileiras, tendo executado um movimento irreversível, a década de 70 ainda foi pródiga em discussões. Estas, aliás, foram as responsáveis por alimentar a comichão que tomava conta das páginas de jornal quando o assunto era literatura.

\section{A querela do estruturalismo e a "tradição do impasse"}

Como mostrei na parte dedicada aos anos 60, o estruturalismo, naquela década, aportava em terras brasileiras, embora já trouxesse consigo parte dos debates franceses. Os anos 70 foram, de fato, os anos do estruturalismo no Brasil. Parece-me que sua maior porta de entrada foi a polêmica da nouvelle critique protagonizada por Barthes e Picard que, mesmo depois de superada, deixou

\footnotetext{
${ }^{337}$ In "Estruturalismo - Chaves do estruturalismo", Suplemento Literário, "Livros Novos", 13 de agosto de 1972, p. 2.
} 
como frutos as discussões sobre a crítica estruturalista e sua concepção da obra literária. Pontualmente, sobejaram críticas encarniçadas aos caráteres a-histórico e anti-humanista do estruturalismo, já que estes feriam de morte o que durante séculos norteara a literatura brasileira: sua história e sua gente. Pois a existência de uma literatura brasileira - diferente da portuguesa - e de um homem brasileiro - com características próprias - requeria o reconhecimento de seu percurso histórico e dos elementos particulares a seus autores e a seus referentes. Ou seja, o estruturalismo reduzia a literatura brasileira recém-emancipada das literaturas europeias e, portanto, que acabara de se firmar em sua identidade, ao lugar comum da linguagem. Consequentemente, os debates acerca do estruturalismo não poderiam evitar a velha discussão entre nacional e estrangeiro.

Essa percepção foi-me sugerida por Flora Süssekind que, em Literatura e vida literária, dedica alguns capítulos às polêmicas envolvendo o estruturalismo na década de 70. Em "Um tiro no Estruturalismo", a autora traça um breve panorama da época:

Já no Governo Geisel, outra polêmica. Desta vez, inesperado pomo de discórdia: a influência crescente do pensamento estruturalista nas ciências sociais e no ensaísmo literário brasileiro dos anos 70. De certa maneira, estará em pauta mais uma vez o velho mote nacionalista. Importado, como o "iê-iê-iê", o Estruturalismo, por si, já seria de molde a provocar desconfianças. ${ }^{338}$

A leitura que vê nos ataques ao estruturalismo ecos de um nacionalismo não pode deixar de enxergar as outras formas sob as quais tal oposição se manifestou na história da crítica brasileira, desde, pelo menos, o século XIX:

- no plano histórico: nacional x estrangeiro;

- no plano estético: particular x universal;

- no plano crítico: história x estética, ou leitura contextual x leitura imanente.

Dentro dessa visão esquemática de muitas das célebres querelas críticas ${ }^{339}$, nacional, particular, história e leitura contextual sempre apontaram para o mesmo lado, o da realidade brasileira, vista por intelectuais que visavam recriá-la enquanto discurso identitário. Tendo em vista tais planos, é possível observar que a história literária brasileira é pontuada por polêmicas, muitas

\footnotetext{
${ }^{338}$ Literatura e vida literária: polêmicas, diários \& retratos, Belo Horizonte, Editora UFMG, 2004, p. 50.

${ }^{339}$ Tenho em mente as querelas entre José de Alencar e Gonçalves de Magalhães, José de Alencar e Joaquim Nabuco, Sílvio Romero e José Veríssimo, Afrânio Coutinho e Álvaro Lins, Antonio Candido, seus discípulos uspianos e Haroldo de Campos, descritas por João Cezar de Castro Rocha em Crítica literária: em busca do tempo perdido? (Chapecó (SC), Argos, 2011, pp. 73-109). Acrescento a elas a querela entre críticos tradicionais e universitários, nos anos 50, que nos anos 70 se travestiu em querela entre o estruturalismo e a crítica sociológica ou engajada.
} 
vezes sem desfecho. É partindo dessa tese geral e estudando detidamente a obra - e as polêmicas de José Veríssimo que João Alexandre Barbosa escreveu A Tradição do impasse (1974). Nesse livro, que foi uma tese de doutorado, o autor identifica uma série de "impasses" teóricos e metodológicos nos escritos do célebre crítico do século XIX, sendo que o mais importante se refletia em suas tentativas de associação entre a análise crítica da obra literária e a crítica naturalista. Ou seja, Veríssimo buscava reunir a leitura atenta ao caráter estético da obra e sua inserção na história literária, sem, aparentemente, grande sucesso. Nas palavras de Barbosa, numa avaliação sobre a História da Literatura Brasileira (1916), de Veríssimo, que se valeu de princípios da Histoire de la Littérature Française (1894) de Gustave Lanson,

O que nos importa, entretanto, é acentuar como a sua História [de Veríssimo], embora fugindo a priori ao historicismo amplificador de seus predecessores, representa, mais uma vez, a impossibilidade de inserir a historicidade do fenômeno literário num quadro de avaliações críticas sem que a linguagem utilizada pelo crítico sofra a reconsideração de seus postulados, a partir daquilo que a sua época oferecia como resíduos de experimentação cultural. ${ }^{340}$

O grande impasse se manifesta na crítica que é concebida, segundo Barthes, referência constante no livro, como "construção do inteligível de nosso tempo" ${ }^{341}$. O que Barbosa repete, em outros termos, para explicar a intuição de Veríssimo que, no entanto, não a desenvolveu a contento, conduzindo sua obra a um beco sem saída:

Tinha razão José Veríssimo: literatura é arte literária - mas o maior rigor em sua análise não pode advir da simples adoção do postulado.

A crítica desta arte não se concretiza senão na medida em que ela própria, a linguagem da crítica, sofre a crítica da realidade captada por intermédio do modelo linguístico. ${ }^{342}$

Apesar de apontar as incongruências do crítico, Barbosa reconhece: "a obra de Veríssimo inaugurou uma tradição de impasses que parece não ter terminado. É, sem dúvida, o seu grande elogio." 343

João Cezar de Castro Rocha, que tem na polêmica a espinha dorsal da leitura que faz da história da crítica literária brasileira, em Crítica literária: em busca do tempo perdido? (2011), vê o livro de Barbosa como importante marco no contexto da querela do estruturalismo, desmembrada em diversos debates ao longo dos anos 70:

\footnotetext{
${ }^{340}$ A Tradição do impasse, São Paulo, Ática, 1974, p. 201.

${ }^{341}$ Ibid., p. 25. A citação, feita por Barbosa, é a frase final de “Qu'est-ce que la critique?", de Barthes, texto publicado nos Essais critiques.

342 Ibid., p. 201.

${ }^{343}$ Ibidem.
} 
João Alexandre Barbosa parece reler a obra crítica de Veríssimo a fim de tomar uma distância irônica em relação aos conflitos teóricos e metodológicos da época, propondo que o impasse não deve ser necessariamente superado, pois, se compreendido como sintoma de uma tensão que não se deve solucionar com maniqueísmos críticos, a "tradição do impasse" pode revelar-se indispensável para a vitalidade do sistema literário. ${ }^{344}$

A se levar em conta as páginas que dediquei e dedico a reconstituir debates, polêmicas e querelas neste trabalho, movidos todos por "impasses" de ordem teórico-crítica, depreende-se minha convicção de sua importância para a compreensão do contexto em que as obras de Barthes eram discutidas. $\mathrm{O}$ que permite extrair desse contexto as imagens que o escritor francês adquiriu no Brasil. A conturbada história da crítica literária de que o escritor francês involuntariamente participou só fez enriquecer a apropriação de sua obra, uma vez que, a cada nova polêmica, suas ideias e noções eram convocadas a integrar as tropas de um dos termos do impasse. Que nem sempre era superado ou, pelo menos, exposto nos jornais de forma equânime: um bom exemplo repousa no tratamento dado a Barthes nos anos 60, na repercussão brasileira da querela da crítica francesa: houve muito mais espaço - e, consequentemente, defensores - para Picard que para Barthes, cuja palavra final, Critique et vérité, mal foi mencionada...

\section{Terrorismo terminológico}

Dentre os incontáveis artigos sobre o estruturalismo publicados na imprensa brasileira, indubitavelmente um dos mais representativos do ponto de vista crítico a ele é "O Estruturalismo dos pobres", de José Guilherme Merquior. Publicado em 1974 no carioca Jornal do Brasil, o texto é um verdadeiro libelo contra o estruturalismo, condensando as principais críticas que essa "atividade" recebeu por parte dos intelectuais brasileiros. Seu parágrafo introdutório dá o tom:

Se você quer estudar letras, prepare-se: que ideia faz você, já não digo da metalinguagem, mas, pelo menos, da gramática generativa do código poético? Qual a sua opinião sobre o rendimento, na tarefa de equacionar a literariedade do poemático, de microscopias montadas na fórmula poesia da gramática/ gramática da poesia? Quantos actantes você é capaz de discernir na textualidade dos romances que provavelmente (tres-)leu? E que me diz do "plural do texto" de Barthes - é possível assimilá-lo ao genotexto da famigerada Kristeva? Sente-se você em condições de detectar o trabalho significante no nouveau roman, por exemplo, por meio de uma "decodificação" "semanalítica" de bases glossemáticas? Ou prefere perseguir a "significância", mercê de alguns cortes epistemológicos, no terreno da forclusão, tão limpidamente exposta no arquipedante seminário de Lacan? ${ }^{345}$

\footnotetext{
${ }^{344}$ In op. cit., p. 111.

${ }^{345}$ In José Guilherme Merquior, O Estruturalismo dos pobres e outras questões, Rio de Janeiro, Tempo Brasileiro, 1975, p. 7.
} 
O autor, de início, estabelece um diálogo com um hipotético futuro estudante, submetendoo a uma enxurrada de termos, expressões e conceitos criados e/ou divulgados pelas várias correntes estruturalistas da época, a sua maioria, de origem linguística. Nem Barthes escapa, em alusão a $S / Z$, obra na qual o escritor defende o texto literário como uma "galáxia de significantes" 346 . Diante da complexidade das perguntas formuladas, o estudante, atordoado, só pode desistir de suas aspirações ao estudo das Letras...

O efeito cômico, obtido graças à superposição de vocabulário técnico, tem por objetivo atacar o estruturalismo naquilo que ele mais preza em seus objetos: a linguagem. E Merquior dá continuidade a sua leitura sarcástica das teorias estruturalistas nos parágrafos seguintes, quando trata da pluralidade que a "atividade estruturalista" adquiriu:

E se você acha o estruturalismo uma parada, é pura ingenuidade sua: talvez você não saiba que o velho estruturalismo está superado, tão superado quanto a estilística; o estruturalismo vieille école faleceu em 1968, assassinado por Chomsky e pelo movimento de maio. Você não viu $A$ Estrutura Ausente, do Umberto Eco?... Já está circulando, traduzida para uma língua vagamente aparentada com o português. ${ }^{347}$

Lançando mão do mesmo procedimento, o autor despeja em cima do futuro estudante mais informações sobre o estruturalismo, dando conta de que este já é passado - quando no Brasil começa-se a apreendê-lo! - e de que, portanto, o momento é de passar a outras discussões. No trecho acima, Merquior também não deixa de atacar a linguagem estruturalista, quando diz que o livro de Eco está disponível no Brasil "traduzido para uma língua vagamente aparentada com o português".

Eis, em suma, as duas grandes características estruturalistas que entraram na mira de parte dos intelectuais, no Brasil: sua linguagem própria, recheada de termos advindos da linguística, bem como de outras áreas, e a multiplicidade de interpretações que o termo "estruturalismo" abrigou. Diferentemente da moda parisiense que o antecedeu, o existencialismo, em sua versão sartreana, que tinha seus princípios bem definidos em livros e textos de seu autor, o estruturalismo teve muitos autores, muitas leituras, muitas aplicações. Se, por um lado, como já escrevi neste trabalho, sua riqueza advinha de sua pluralidade, esta também gerava confusão, uma vez que desembarcava no Brasil com vários anos de atraso e, por isso, suas diversas interpretações e aplicações, bem como suas críticas, chegavam ao mesmo tempo às mãos dos brasileiros.

\footnotetext{
${ }^{346}$ In $O C$ v.3, p. 123.

${ }^{347}$ In $O$ Estruturalismo dos pobres e outras questões, op. cit., p. 8.
} 
Partindo do ataque ao jargão estruturalista, Merquior atinge seu alvo maior: os críticos universitários brasileiros que, a seu ver, medíocres, beneficiavam-se da importância que o estruturalismo concede ao método analítico. $\mathrm{O}$ que, para o autor, gera procedimentos mecânicos de leitura e, por não exigir grande talento ou formação sólida, mascara as deficiências dos críticos que a ele se agarram, como uma bóia para aqueles que não sabem nadar no mar de complexidade das obras literárias.

Junto da crítica ao método estruturalista, aparecem novamente severos ataques a sua linguagem:

Graças ao "estruturalismo", no seio das humanidades estrepitosamente tornadas "científicas", vinga e prospera o mais franco terrorismo terminológico. A seu lado, todavia, pontifica um não menor "terrorismo metodológico" (Starobinski).

(...) No entanto, os sacerdotes do Método não sabem sequer português. Nossa ensaística atual é o paraíso do solecismo, o éden do barbarismo. Se você encontrar um título sobre "escritura", não creia que se trata de uma obra para tabeliães: trata-se mesmo é de "écriture", que os nossos preclaros estruturalistas não sabem traduzir por "escrita"... ${ }^{348}$

O "terrorismo terminológico" suplanta o metodológico, pois sua presença é constante no texto, mesmo quando o foco do autor é a arrogância e a ignorância dos intelectuais universitários. O exemplo que Merquior escolhe não poderia ser mais curioso: a tradução do conceito de écriture, de Barthes. O autor trata do assunto como se o mesmo fosse banal: para ele, a tradução deve ser escrita, e o termo só é traduzido por escritura por inaptidão dos tradutores. Ora, Merquior não leva em conta que a escolha de escritura buscou, no termo em desuso em português, marcar a especificidade do conceito barthesiano. E tanto a escolha da tradução não é simples e evidente, que opõe Leyla Perrone-Moisés, tradutora primeira da obra de Barthes, tendo optado por escritura, e Mário Laranjeira, maior tradutor brasileiro de literatura francesa, que escolheu escrita em sua recente tradução de Le Degré zéro. A discussão, portanto, é entre gigantes e ainda está em aberto.

$\mathrm{O}$ autor resume sua argumentação afirmando que o estruturalismo, em suas características acidamente expostas e duramente criticadas, só tem espaço em um contexto universitário deficitário, tendo por pressupostos, em suas palavras, "a rarefação do espírito crítico cansada e estimulada pelo abaixamento intelectual da universidade (...)" ${ }^{349}$. O “estruturalismo dos pobres" seria, então, a apropriação brasileira de tudo de ruim que o estruturalismo francês teria a oferecer - o pedantismo com o qual os professores universitários empregavam um jargão obscuro e se lançavam com sofreguidão à aplicação de um método mecânico de análise literária -, deixando de lado suas

\footnotetext{
${ }^{348}$ Ibid., pp. 8-11.

${ }^{349}$ Ibid., p. 12.
} 
qualidades. E conclui: "Entretanto, se, ao exacerbar as taras do seu paradigma parisiense, o estruturalismo dos pobres é caricatura, ao denunciar fidedignamente as distorções do nosso ambiente universitário, ele se faz retrato." 350

Apesar de discordar de sua visão do estruturalismo, partilho de sua conclusão, abdicando da malevolência que ela comporta. Por um lado, não vejo o estruturalismo lido e assimilado pelos intelectuais brasileiros como uma caricatura da matriz francesa, uma vez que, parece-me, o sistema literário brasileiro já era complexo o suficiente para desenvolver uma visão crítica das teorias importadas, para selecionar o que delas aproveitar, rejeitar e discutir. A simples cópia, portanto, seria impossível, nos anos 60. Consequentemente, uma caricatura, isto é, uma cópia mal feita ou grotesca, também. A apropriação do estruturalismo francês, para mim, é mais um fenômeno de refração, a sua versão brasileira comportando as marcas de seu contexto histórico-cultural.

Por outro lado, e seguindo a linha de pensamento fornecida pela imagologia, explicitada na "Introdução" a este trabalho, concebo, com Merquior, as marcas características do contexto de chegada que a versão brasileira do estruturalismo comporta, como um retrato das convicções, das questões e dos anseios próprios ao momento de reflexões teórico-críticas sobre a literatura vivenciado pelos intelectuais brasileiros. O estruturalismo brasileiro - e não "dos pobres", na medida em que uma "atividade" ou um movimento de ideias não pode ser comum a uma condição sócio-econômica, mas particular a cada contexto - é, ao mesmo tempo, refração dos modelos franceses e retrato do pensamento literário brasileiro. Os dois lados do espelho.

Em sua crítica às universidades e aos universitários brasileiros, por meio do estruturalismo, Merquior abre uma exceção: "Não é à toa que a universidade brasileira menos afetada pelo delírio estruturalóide - a USP - é a mais sedimentada, a mais amadurecida das nossas instituições do gênero". ${ }^{351}$ Sem, todavia, concordar com a relação entre a qualidade da universidade e sua pouca adesão aos preceitos estruturalistas, acho importante registrar, neste panorama de debates no qual Barthes se inscreveu, a postura excepcional de grande parte dos intelectuais uspianos. Num momento em que a comichão estruturalista contagiava o pensamento literário e que a semiologia era instrumental para todo e qualquer estudo, a prudência e o discernimento com os quais Antonio Candido, o mestre da geração de jovens professores universitários, refletia sobre as novas teorias em voga, chama a atenção. A título de testemunho, cito trechos de entrevista de Davi Arrugucci Jr., eminente crítico literário e, à época, também professor na USP:

\footnotetext{
350 Ibid., pp. 13-14.

${ }^{351}$ Ibid., p. 13.
} 
Com o avanço da teoria literária, ganhou-se em precisão, mas se perdeu grande parte da visão filológica da literatura. Isso ocorreu porque houve uma especialização muito grande e com os anos do formalismo, a situação piorou. Nós nunca cedemos ao estruturalismo, pela perspectiva histórica que nunca abandonamos. Isso foi e continua sendo básico para nós e acho que é a grande herança de Antonio Candido, o ponto decisivo. Nós sempre estivemos atentos à relação entre a obra literária e a experiência histórica. Cada vez ficou mais importante, para mim, analisar essa relação, que não permite uma abordagem esquemática sempre igual, mas ao contrário envolve a colocação de problemas particulares a cada passo e o enfrentamento dialético da complexidade. Sempre achei que era fundamental saber o máximo possível, por dentro e por fora dos textos.

(...) Ele [Antonio Candido] foi acentuando cada vez mais, desde os anos de 1960, a ideia de que o que é realmente social na obra de arte é a forma. ${ }^{352}$

De fato, na década de 60, Antonio Candido afiou e demonstrou incessantemente sua concepção de obra literária, que alia elementos externos e internos a ela. Tal concepção estava implícita e amplificada em sua teoria da literatura enquanto sistema, tese central da Formação da literatura brasileira (1959). Em 1965, publicou Literatura e sociedade, uma coletânea de ensaios, a maioria escrita entre 1955 e 1961, textos nos quais teoriza e pratica a lição aprendida por Arrigucci $\mathrm{Jr}$.

O ensaio de abertura da coletânea, "Crítica e sociologia", estabelece a base sobre a qual repousam as análises literárias presentes nos demais textos. Nele, Antonio Candido faz um balanço das relações entre crítica literária e sociologia, passando em revista as abordagens sociológicas da literatura, tal como eram feitas nos séculos XVIII e XIX, e recenseando as modernas compreensões do tema. $\mathrm{O}$ autor não se furta a explicitar seu próprio entendimento das relações entre os elementos externos e internos à obra literária, de que toda análise não pode prescindir, nestes termos: “(...) Sabemos, ainda, que o externo (no caso, o social) importa, não como causa, nem como significado, mas como elemento que desempenha um certo papel na constituição da estrutura, tornando-se, portanto, interno." 353

A dialética entre externo e interno é demonstrada pelo autor com um exemplo claro: sua leitura do romance Senhora (1875), de José de Alencar, evidencia o duelo velado entre Aurélia Camargo e Fernando Seixas como elemento estruturante do texto, transposto para a estrutura da obra por meio do mecanismo social de compra e venda, no âmbito do matrimônio. Nesse caso, o elemento externo, a prática social, transforma-se em interno, integrando a estrutura do texto. Em outro ensaio, "Estrutura literária e função histórica", a mesma dialética é mostrada na cuidadosa análise do Caramuru (1781), poema épico de Santa Rita Durão. O objetivo do autor é demonstrar

\footnotetext{
352 Entrevista a Luiz Jackson, Fernando Pinheiro Filho e Gustavo Sorá, Tempo Social - Dossiê Crítica Literária, São Paulo, vol. 23, $\mathrm{n}^{\mathrm{o}}$ 2, novembro de 2011. Disponível em: http://www.scielo.br/scielo.php?pid=S010320702011000200007\&script=sci_arttext (consultado em 10/5/2013).

${ }^{353}$ In Literatura e sociedade: estudos de teoria e história literária, Rio de Janeiro, Ouro sobre Azul, 2008 , p. 14.
} 
que “(...) a função histórica ou social de uma obra depende da sua estrutura literária. E que esta repousa sobre a organização formal de certas representações mentais, condicionadas pela sociedade em que a obra foi escrita." 354 Após coligir elementos que permitem compreender o contexto histórico e ideológico no qual a obra foi concebida e analisar detidamente as funções do elemento colonizador, da natureza e do índio no poema, o autor conclui que eles se constituem nos princípios estruturais a partir dos quais Caramuru é construído. Assim, elementos marcados por um determinado momento histórico, que numa leitura sociológica poderiam ser vistos como meros dados de uma certa realidade, são considerados essenciais à construção do texto literário. Pois, para o autor,

A literatura é essencialmente uma reorganização do mundo em termos de arte; a tarefa do escritor de ficção é construir um sistema arbitrário de objetos, atos, ocorrências, sentimentos, representados ficcionalmente conforme um princípio de organização adequado à situação literária dada, que mantém a estrutura da obra. ${ }^{355}$

Voltando a "Crítica e Sociologia”, Antonio Candido sintetiza:

Neste caso [da análise proposta pelo autor], saímos dos aspectos periféricos da sociologia, ou da história sociologicamente orientada, para chegar a uma interpretação estética que assimilou a dimensão social como fator de arte. Quando isto se dá, ocorre o paradoxo assinalado inicialmente: o externo se torna interno e a crítica deixa de ser sociológica, para ser apenas crítica. O elemento social se torna um dos muitos que interferem na economia do livro, ao lado dos psicológicos, religiosos, linguísticos e outros. Neste nível de análise, em que a estrutura constitui o ponto de referência, as divisões pouco importam, pois tudo se transforma, para o crítico, em fermento orgânico de que resultou a diversidade coesa do todo. ${ }^{356}$

O autor tem no termo "estrutura" a noção-chave de sua teoria analítica, como os trechos citados permitem observar. No entanto, a palavra não tem relação alguma com o estruturalismo, uma vez que foi empregada por Antonio Candido antes que ele se tornasse uma comichão intelectual. Aliás, como o próprio autor explica no prefácio à $3^{\text {a }}$ edição de Literatura e sociedade, de 1972, quando "estrutura", no Brasil, não poderia ser empregada sem trazer consigo uma alusão à moda teórica parisiense:

Os referidos escritos esboçam uma posição segundo a qual a estrutura constitui aspecto privilegiado e ponto de referência para o trabalho analítico. Neste sentido, numa nota que está na página 25 desta edição, onde uso as palavras "estrutural" e "funcional", eu falava nas edições

\footnotetext{
${ }^{354}$ Ibid., p. 177.

${ }^{355}$ Ibid., p. 187.

${ }^{356}$ Ibid., p. 17.
} 
precedentes em ponto de vista "estruturalista" ou "funcionalista", termos que atualmente se repelem, tendo o primeiro adquirido conotação bastante diversa. De fato, a nota foi escrita em 1964, e logo depois ele passou a designar de modo avassalador, que não admite outras acepções, a aplicação do estruturalismo linguístico ao estudo da literatura, com amputação, ainda que de modo estratégico, das conexões histórico-sociais que isto importa. ${ }^{357}$

Os significados dos termos "estruturalista", "estrutural" e "estrutura", na década de 70, eram, então, totalmente diferentes de quando Antonio Candido os colocou no centro de seu método analítico. Contrariamente à acepção estruturalista ortodoxa, que exclui a história da análise literária, a "estrutura" do autor é feita de elementos extrínsecos ao texto, a história e os fenômenos sociais tendo lugar privilegiado.

A USP, na década de 70, tinha, portanto, em Antonio Candido e em seus discípulos, um grupo de intelectuais com uma já consolidada abordagem teórico-crítica da literatura. A penetração da moda estruturalista nos espaços por eles ocupados aconteceu pontualmente e de forma mais prudente... Quando não houve desconfiança e até mesmo certa resistência ao estruturalismo e aos autores a ele identificados.

Ao lado dos intelectuais mais virulentos, como José Guilherme Merquior, nos jornais havia também aqueles que enxergavam o estruturalismo com os mesmos olhos e apontavam para os mesmos elementos, porém de maneira mais ponderada. Nesse rol coloco Affonso Romano de Sant'Anna, que em "Estrutura ou forma da narrativa?", publicado em $O$ Estado, em 1974, resenha $A$ Estrutura do romance (1974), do teórico português Vitor Manuel de Aguiar e Silva, autor de uma Teoria da literatura bastante difundida no Brasil, segundo informação de Sant'Anna. A Estrutura do romance é mero pretexto para o autor, na verdade, escrever sobre o estruturalismo, uma vez que ele mesmo afirma: "Se alguma discussão ou ressalva cabe a esta obra seria a de analisar a pertinência do título do ensaio." ${ }^{358}$ Ou seja, o conteúdo do livro não constitui matéria de discussão, e sim o termo “estrutura”, que Sant'Anna opina seja substituído por “formas”. Essa sugestão, que ocupa o centro do artigo, é enquadrada pelas considerações do autor sobre o estruturalismo. Antecedendo-a, um parágrafo de apresentação da teoria tão em voga:

(...) As dezenas de revistas e as centenas de livros publicados em torno do formalismo e do estruturalismo nessa última década trouxeram um surplus de colocações teóricas ainda não digeridas pelos alunos e pelos professores. É comum, portanto, que os estudantes se apresentem perdidos em meio à terminologia nova. Os professores, por sua vez, não têm possibilidade de

\footnotetext{
${ }^{357}$ Ibid., p. 10.

${ }^{358}$ Suplemento Literário, 15 de setembro de 1974, p. 5.
} 
consumir a bibliografia que os consome. Escolhem uma linha determinada e nela trabalham por opção, às vezes, justificada brilhantemente. ${ }^{359}$

A observação é praticamente a mesma feita por Merquior no texto que citei há pouco: ela se refere à dificuldade de estudantes em se adaptar ao léxico estruturalista. Porém, expõe o "terrorismo terminológico" com a naturalidade de uma consequência comum aos primeiros contatos com novas teorias. Sant'Anna também menciona os professores universitários, apresentando uma opinião contrária à exposta em "Estruturalismo dos pobres", na medida em que lança sobre eles um olhar benevolente, como se justificasse pelo excesso de informação disponível as frequentes aplicações desastrosas das teorias estruturalistas. A respeito destas, depois de seu breve comentário sobre $A$ Estrutura do romance, o autor igualmente aponta a pluralidade de estruturalismos como fator complicador de sua compreensão e apropriação por parte dos intelectuais:

Já se disse muitas vezes que existem tantos estruturalismos quantos estruturalistas. Mas extraindo da frase seu caráter de blague sabe-se que o estruturalismo que trabalha com "modelos" é o mais bem acabado, o mais rigoroso e realmente o mais estruturalista. Isto, evidentemente, não faz de tal estruturalismo o "verdadeiro método de estudar", como quereriam alguns de seus seguidores mais fanáticos. ${ }^{360}$

Sant'Anna simplesmente constata a existência de diversas teorias estruturalistas sem, contudo, ver nisso um problema. Pelo contrário, faz uso desse dado para contestar a suposta existência de um estruturalismo superior, em alguma medida, aos demais, e para afirmar a importância de haver várias abordagens do texto literário, mesmo que todas se abriguem sob um mesmo guarda-chuva, e respondam por um mesmo termo, "estruturalismo". Argumentando no sentido contrário ao de Merquior, que via o estruturalismo como uma metodologia única, pronta a ser aplicada a qualquer objeto, Sant'Anna celebra os estruturalismos e suas abordagens do objeto literário, pois, para ele, cada texto exige um método analítico diferente, capaz de extrair alguns de seus significados.

Leituras tão diferentes da comichão estruturalista denotam posturas totalmente opostas face às novidades teóricas importadas da França naquele momento. Todavia, elas apontam essencialmente para as mesmas características, que dificultavam a apreensão das teorias estruturalistas e sua aplicação com resultados interessantes: a linguagem e a diversidade teórica. Entre elas, a terminologia ainda aparece com maior frequência nos artigos sobre o estruturalismo, nos anos 70. Cito um exemplo advindo de um texto cujo título é emblemático: "Linguística: ciência

\footnotetext{
359 Ibidem.

${ }^{360}$ Ibidem.
} 
e deslumbramento", de autoria de Maria Thereza Fraga Rocco. Publicado em 1977 em O Estado, o artigo oferece uma reflexão sobre o panorama dos estudos linguísticos no Brasil, destacando, por um lado, projetos importantes em andamento, que visavam incidir nos processos de ensino de português nas escolas; por outro, e de maneira mais enfática, colocando em relevo os problemas criados pela importância que a linguística conquistava frente às demais ciências humanas. Nas palavras da autora,

Creio que um dos problemas básicos [da linguística brasileira], ou seja, aquele referente ao excesso de sofisticação, tem sua origem no deslumbramento provocado por uma ciência nova, que pretende ditar moda às demais e chega a tornar-se matéria de fé, mesmo para aqueles que absolutamente nada conhecem do credo. ${ }^{361}$

Por "excesso de sofisticação" a autora entende o jargão específico de que as várias teorias linguísticas lançavam mão para desenvolver seus argumentos e formular seus conceitos. O "deslumbramento" a que Rocco se refere é o efeito causado pela ascensão da ciência linguística ao nível de religião, numa união no mínimo inusitada, à época. A linguística, ciência basilar do estruturalismo, era também acusada de "terrorismo terminológico", mas em termos mais sutis:

Excessivamente preocupados em utilizar uma nomenclatura inacessível e pretendendo com isso que os fatos se transformem em ciência, esses grupos acabam por se divorciar totalmente do real, do viável, transformando-se em blocos frios, herméticos, identificáveis apenas através de terminologia complexa, indecifrável e por vezes inadequada (ainda que os fenômenos a que se refiram digam respeito ao mesmo homem que pensa e fala de forma organizada!). ${ }^{362}$

A autora sugere que a linguística, alçada à condição de ciência da moda, provoca um "deslumbramento" capaz de cegar muitos intelectuais. Estes, na ânsia de colocar em prática novas teorias, para demonstrar o quão atualizados e bem informados estão em seu domínio de estudos, muitas vezes acabam por aplicar o jargão linguístico e seus modelos analíticos de forma totalmente alienada às particularidades de seus objetos. Nesse processo apressado em que os resultados importam menos do que a demonstração da técnica, Rocco destaca seu lado mais aparente: a linguagem cifrada que a poucos permite $\mathrm{o}$ acesso às novas teorias linguísticas.

Tal percepção também encontrava eco na França, de que Barthes foi alvo, por exemplo, em 1978, no Roland Barthes sans peine, de Michel-Antoine Burnier e Patrick Rambaud (Paris,

\footnotetext{
${ }^{361}$ Suplemento Cultural, 30 de janeiro de 1977, p. 4.

${ }^{362}$ Ibidem.
} 
Balland). Nesse livro os autores fazem um pastiche da linguagem do escritor, distinguindo-a como "Roland-Barthes":

Le R.B. (en Roland-Barthes, Roland Barthes se dit R.B.) apparut sous sa forme archaïque voilà vingt-cinq ans, dans l'ouvrage intitulé Le degré zéro de l'écriture. Depuis, il s'est peu à peu détaché du français dont il est partiellement issu, se constituant comme langage autonome avec sa grammaire et son vocabulaire propres. ${ }^{363}$

Face a uma língua estrangeira, os autores oferecem exemplos de frases empregadas em situações de diálogo, tal como um manual prático de conversação:

1 - "Salut! Salut!" Tel est, irrépressible, rabâché, le salve qui suture notre distance logosphérique.

Français: Bonjour, cher ami, comment ça va? positif.

2 - “J'intériorise votre apostrophage (le mangeur d'apostrophes?) en (l'in)versant dans le Français: Ça va bien, merci.

3 - Le sereno coelo, c'est la réification actuelle d'un il-fait-drôlement-bon, "comme si de rien n'était".

Français: Quel beau temps!

4 - La libido phoebale se théorise/ rentabilize irréductiblement sous forme jubilatoire. Français: Oui, le soleil est vraiment splendide. (grifos dos autores) ${ }^{364}$

O contraste entre a obscuridade do "Roland-Barthes" e a frugalidade da língua francesa não deixa de provocar riso. Contudo, praticar um idioma próprio não é privilégio de Barthes, segundo os autores que, na introdução ao livro, isentam-se de ensinar as demais línguas estruturalistas:

P.S. Nous ne traiterons pas des idiomes proches du R.B., le Jacques-Derrida, le PhilippeSollers, le Lacan, plus sévères et moins riches. Nous négligerons également les patois comme le Guattaro-Deleuzisme, le Ricardou et le Cixous. Enfin nous n'entrerons pas dans la polémique sur les influences reciproques de ces divers idiomes. (grifos dos autores) ${ }^{365}$

Embora esse livro não tenha sido notado no jornal, algumas críticas à linguagem dos estruturalistas feitas na França, mesmo que difusas, chegavam à imprensa brasileira. Um exemplo é o artigo "Autores no espelho" (1974), de Matthieu Galey, colaborador internacional de O Estado, em que resenha a série Tableau de la littérature française, especialmente o terceiro tomo. Trata-se

\footnotetext{
${ }^{363}$ Roland Barthes sans peine, Paris, Ballard, 1978, p. 7.

${ }^{364}$ Ibid., p. 19.

365 Ibid., p. 13.
} 
de uma série de livros idealizada por André Malraux, em 1928, com retratos analíticos de escritores franceses do passado elaborados por escritores do presente. Galey narra o conturbado caminho até a edição do terceiro tomo, em 1974, destacando, sempre com muito humor e certa dose de ironia, os retratos e seus autores, até chegar em Barthes, que escreveu sobre Léon Bloy: “(...) Roland Barthes, límpido (isso pode lhe acontecer quando ele quer) determina, muito brilhantemente, o papel do dinheiro na obra e na vida do célebre brigador Léon Bloy (...).” 366

É tudo o que o autor escreve sobre Barthes. Mas sua afirmação é reforçada pela fotografia de Barthes ilustrando o artigo e sua legenda: "Barthes consegue ser claro". O texto de Galey evidencia, por meio da ironia, sua opinião segundo a qual o escritor não escreve com clareza. A fotografia, seguida da legenda, ratifica essa opinião e muito provavelmente é obra do editor do caderno ou de outro profissional brasileiro, que trabalhava para o jornal. O que é testemunho da associação de Barthes ao "terrorismo terminológico" estruturalista, tanto na França, quanto no Brasil. Terrorismo esse, também para Galey, inerente ao linguajar acadêmico, conforme denuncia seu apontamento sobre a contribuição de Derrida, reproduzindo um trecho do texto supostamente incompreensível ou obscuro: "Há também os pedantes, os obscuros que têm graus universitários, tipo Derrida, sinceramente desolado pois 'a indizibilidade da observação mallarmeana proíbe a polissemia de ter seu horizonte...,, 367 .

Lembro que, na querela dos anos 50, os críticos tradicionais acusavam os críticos novos, aliás críticos universitários, de se esconder atrás de um jargão elitista. É, portanto, digno de nota que, cerca de vinte anos mais tarde, a mesma observação, em tom violento ou de mera constatação, seja feita aos críticos estruturalistas, por parte... dos demais críticos, oriundos do jornal ou mesmo das universidades, franceses ou brasileiros. Barthes, ao lado dos estruturalistas no período de difusão de suas obras no Brasil, nunca conseguiu se livrar da pecha de "terrorista terminológico", a que ele deve, em grande parte, sua reputação de "autor difícil".

\section{O estruturalismo coloca a literatura em perigo}

O terror nas letras brasileiras proporcionado pelo estruturalismo não se restringiu à terminologia, ao "estruturalês", como alguns autores a ele se referiram. Como Flora Süssekind bem explica, “Transformou-se simplesmente o Estruturalismo numa espécie de arquiinimigo, de adversário do pensamento engajado, de um lado; da leitura prazerosa, de outro; da prática e da

\footnotetext{
${ }^{366}$ Suplemento Literário, 3 de março de 1974, p. 1.

367 Ibidem.
} 
própria literatura, enfim." ${ }^{368}$ Em outras palavras, o estruturalismo foi visto como um inimigo da literatura por seu jargão próprio e por sua determinação científica que fazia da obra literária, ainda na metade do século XX dotada de uma aura romântica, um mero objeto de análise, como poderiam ser uma propaganda de refrigerante ou um novo modelo de carro. Seus tentáculos teóricos desnaturalizavam o texto literário e o transformavam num cadáver frio a ser decorticado.

Diante desse cenário fúnebre, muitos defensores da literatura se apresentaram e alimentaram a gama de polêmicas envolvendo o estruturalismo. Süssekind faz um breve resumo fundamentado na imprensa carioca ${ }^{369}$ :

No segundo semestre de 1975, a polêmica atingiu um ponto crítico. Bombardeios de todos os lados. No Jornal do Brasil, artigo de Emanuel de Moraes: "A Crítica sob o império do Estruturalismo"; na revista Visão, Antônio Houaiss; no Jornal do Brasil, ainda, o poema "Exorcismo" de Carlos Drummond de Andrade, contra todas as correntes teóricas que o poeta consegue nomear; no Jornal de Letras, Assis Brasil; artigos de Carlos Nélson Coutinho, Antônio Carlos de Brito (Cacaso) e Ana Cristina Cesar no Opinião; em O Globo, Ledo Ivo e o fúnebre "A Morte da literatura brasileira". Na sua maioria os textos se apresentam como da autoria de anjos da guarda, vigias da literatura, defensores de uma crítica sem imperialismos metodológicos, do ensino voltado mais para a criação literária do que para o estudo teórico, e do prazer da leitura antes de tudo. ${ }^{370}$

Não deixa de ser irônico, em 1975, ver Barthes associado ao inimigo número um da literatura, do lado oposto ao do "prazer da leitura". Ele que, dois anos antes, publicara Le Plaisir du texte, seu livro dedicado ao prazer e ao gozo suscitados pela leitura, rompendo com a frieza dos paradigmas estruturalistas mais estritos. Mas o Barthes dos anos 70, no Brasil, para a grande maioria dos intelectuais, ainda era o autor de Le Degré zéro, dos Essais critiques e dos Éléments de sémiologie...

A natureza da literatura estava sendo questionada pelo estruturalismo e também em São Paulo não faltaram artigos e ensaios discutindo o assunto. "O Fim da literatura" foi até mesmo anunciado em 1970, em $O$ Estado, por Naief Sáfady, crítico e professor de literatura.

Examinando a relação entre a produção literária e a sociedade de massas, Sáfady defende a função comunicativa da obra literária e coloca em cheque a atitude de autores e críticos que se

\footnotetext{
${ }^{368}$ In Literatura e vida literária: polêmicas, diários \& retratos, op. cit., p. 56.

369 As discussões sobre o estruturalismo no Rio de Janeiro são recuperadas por Regina Lúcia de Faria em “A Polêmica do estruturalismo ou 'Quem tem medo de teoria?' ", comunicação apresentada no XI Congresso Internacional da ABRALIC - Tessituras, Interações, Convergências, realizado na Universidade de São Paulo de 13 a 17 de julho de 2008. Disponível nos Anais do evento e no seguinte endereço: http://www.abralic.org.br/anais/cong2008/AnaisOnline/simposios/pdf/041/REGINA_FARIA.pdf (consultado em 11/5/2013).

${ }^{370}$ In Literatura e vida literária: polêmicas, diários \& retratos, op. cit., p. 56.
} 
recusam a dialogar com um público mais amplo. Isso se daria porque, para certos autores, buscar estabelecer uma conversa com um grande número de leitores significaria submeter suas obras aos caprichos da "massa", um público que eles, a bem da verdade, menosprezavam. Para o crítico, a produção literária sem relação com o público fatalmente conduziria a um número cada vez mais restrito de leitores e à morte da literatura. Nas palavras de Sáfady, "O fim da literatura - isto é - sua extinção paulatina nesse mundo contemporâneo residirá, não tenham dúvida, nessa evidência cada vez mais generalizada de os autores tenderem para um sistema de individuação e elitização." 371

Os questionamentos trazidos pela crítica estruturalista - sobre o conceito de literatura e os tipos de textos que ele abarca - naturalmente penetravam as salas de aula e levaram à organização do I Encontro Nacional de Professores de Literatura, realizado em agosto de 1974, na Pontifícia Universidade Católica do Rio de Janeiro. A memória desse evento ficou registrada no Suplemento Literário de $O$ Estado de 17 de novembro do mesmo ano, que publicou as comunicações nele apresentadas.

Como era de se esperar, o ponto de encontro desses textos e, consequentemente, da maior parte das inquietações, é o estruturalismo, presente de duas formas: por um lado, o largo uso do jargão linguístico e o conhecimento de suas principais teorias e conceitos demonstram o quão familiar o estruturalismo era aos intelectuais brasileiros. Por outro lado, os ácidos ataques que essa moda francesa recebeu, por parte de alguns autores, revelam não só uma visão crítica sobre ela, mas também uma resistência contra a nova concepção da literatura por ela proposta.

Pontualmente, a substituição da noção de expressão pela de linguagem abriu caminho para a compreensão do texto literário como um tecido de signos relativamente autônomo em relação a seu autor. Às vésperas da década de 70, "La Mort de l'auteur", de Barthes, como já escrevi, concretizou a suspeita de que o Autor não mais era a entidade guardiã do sentido do texto literário, e sim o próprio Texto, cujas significações se realizavam no Leitor. A deposição - ou o assassinato do autor deu sinal verde para outras subversões, desta vez, da ordem dos gêneros textuais: passavam a ser também literatura e, por isso, dignos de análise, autores considerados menores, anúncios publicitários e todo tipo de texto que até então era excluído dessa categoria. A literatura definitivamente não era mais a mesma.

Dentre os textos apresentados nesse I Encontro, destaco dois, que refletem opiniões opostas. "Teses para uma crítica antiformalista", de José Guilherme Merquior, organizado em 12 fragmentos, nos quais o autor tece comentários sobre características ou aspectos do estruturalismo

\footnotetext{
${ }^{371}$ Suplemento Literário, 25 de abril de 1970, p. 4.
} 
aplicados aos estudos literários. Em sua tônica, esse artigo é extremamente crítico, especialmente à importação e transformação das teorias estruturalistas em coqueluche brasileira, o que, diga-se de passagem, não surpreende vindo de Merquior. Em suas palavras, na décima “tese”,

X. Não esquecer que a crítica literária francesa era, até o princípio dos anos 60 , a mais retrógrada da Europa. Não seria ingênuo supor que a simples assimilação do formalismo russo, ou de seus frutos tardios (como a "poesia da gramática" do segundo Jakobson), viesse erradicar de súbito todos os estigmas de tão longo atraso? O fascínio hipnótico com que a nossa crítica novíssima se pauta por Todorov, Genette ou Greimas é uma regressão deplorável em relação ao universalismo de modelos possibilitados pela emancipação intelectual modernista. Em 1974, estamos intelectualmente menos livres, menos criticamente disponíveis, do que em $1922 !^{372}$

Ao comparar a situação dos estudos literários em seu tempo e na época da Semana de Arte Moderna de 1922, o autor demonstra preocupação com a independência do pensamento crítico brasileiro, inserindo-se na tradição que se consolida no romantismo do século XIX e chega até a década de 1960, buscando maneiras de se libertar do jugo do pensamento estrangeiro. No entanto, a crítica de Merquior, sobretudo quando pronunciada mais de cinquenta anos depois da Semana, soa ingênua, pois dá a entender que é possível conceber a existência de uma cultura isoladamente. Ora, basta lembrar que, durante o modernismo, a tão celebrada revolução artística só aconteceu graças à combinação entre linguagens tipicamente brasileiras - como o folclore, os falares populares, as cores consideradas caipiras, etc. - e estrangeiras, notadamente as desenvolvidas em Paris. O que o autor chama de "fascínio hipnótico" de um setor da crítica brasileira pelos autores estruturalistas, nada mais é do que um primeiro momento de contato com o pensamento estrangeiro, quando a cultura local busca apreender a novidade estrangeira para, então, adaptá-la às suas próprias necessidades. Em 1974, Merquior ainda não tem o recuo temporal necessário para enxergar que a voracidade com que os intelectuais brasileiros se alimentavam das teorias e do léxico estruturalistas e os empregavam a torto e a direito em suas leituras e escritos, longe de esterilizar seu pensamento crítico, iria enriquecê-lo com novas perspectivas de análise dos problemas literários locais.

Um olhar diferente sobre o estruturalismo, elemento desestruturante do sistema críticoliterário brasileiro, é apresentado por Affonso Romano de Sant'Anna, no mesmo Encontro, e publicado em $O$ Estado. Em "Por um novo conceito de literatura: indicações para uma reformulação", o autor enumera proposições que, a seu ver, são necessárias à redefinição da literatura. Pois para ele, a compreensão desta e de suas implicações eram obsoletas e demandavam

\footnotetext{
${ }^{372}$ Suplemento Literário, 17 de novembro de 1974, p. 5.
} 
uma atualização, levando-se em conta, dentre outras questões, aquelas suscitadas pelo estruturalismo:

2. Nos últimos anos, no entanto, com a redescoberta do Formalismo Russo e com a Expansão do Estruturalismo (ou dos Estruturalismos), com a redefinição das Ciências Humanas e com a aceitação da Linguística no rol das chamadas ciências exatas, parece que adveio uma crise tanto no objeto quanto no método do estudo da literatura. Talvez seja hora de se repensar um e outro. ${ }^{373}$

O artigo de Sant'Anna amealha indagações e pistas de possíveis caminhos a seguir. Ele mostra como o conceito de literatura, naquele momento, estava se alargando com as discussões acerca do tipo de obra que deveria integrá-lo. Havia diversas hipóteses em jogo sendo discutidas por numerosos intelectuais, que compreendiam a literatura definida pela literariedade, e/ou as histórias em quadrinhos, os romances policiais, a ficção científica, a literatura oral e folclórica, o romance policial, a ficção científica, os best sellers. Os domínios da literatura incluiriam tantos territórios? Mais de vinte anos depois de Qu'est-ce que la littérature? de Sartre, perguntava-se, no Brasil: afinal, o que é literatura?

Tendo em vista tais questões, Sant'Anna problematiza o cânone literário, o produto de escolhas feitas por uma elite que deseja perpetuar seus valores. O autor denuncia todo o tipo de autoritarismo aplicado à literatura, do preconceito embutido no adjetivo "kitsch" para designar certas obras, à arrogância das vanguardas que se impõem como acima do bem e do mal. E pondera:

8. É preciso deixar de lado o tipo de leitura por exclusão e iniciar um outro tipo de leitura mais objetivo, mais científico e produtivo - o da leitura da inclusão. Proponho um trabalho mais amplo, que vá de encontro ao mais autêntico sentido da palavra Semiologia, que deve abranger, conter, explicitar o sentido do "literário" e do "não literário", do "belo" e do "feio", da "vanguarda" e da "retaguarda", do "historicismo" e do "ahistoricismo".

Sant'Anna rechaça toda compreensão limitada e excludente da literatura, seja ela qual for, e, evocando a semiologia, defende a "leitura da inclusão". Em outras palavras, ele lança mão de uma corrente de pensamento estrangeira, na época, polêmica, para se opor a um tipo de submissão. Em seguida, conclui:

9. Todas essas considerações estariam invalidadas se se oferecesse aqui uma visão do fazer literário enfatizando apenas a atividade crítica e analítica. O Estruturalismo na linhagem de Roland

\footnotetext{
${ }^{373}$ Suplemento Literário, 17 de novembro de 1974, p. 1.

${ }^{374}$ Ibidem.
} 
Barthes procurou encaminhar uma solução através da expansão do conceito de leitura/ interpretação/ criação. Mas se trata de ir ainda mais longe. ${ }^{375}$

Citando um dos grandes nomes do estruturalismo, o autor demonstra como é possível incorporar proficuamente ideias estrangeiras a uma reflexão propositiva sobre questões locais, provando o quanto as prevenções de Merquior estavam equivocadas. Sant'Anna enxerga na obra estruturalista de Barthes, provavelmente em "La Mort de 1'auteur”, em S/Z e em alguns dos Essais critiques, a alternativa libertária à autoridade exercida pelo autor na construção dos sentidos e, no contexto brasileiro, por elites intelectuais - tradicionais e vanguardistas. Seu artigo ainda contempla, como sugestão de resistência ao sistema autoritário em que os estudos literários estavam mergulhados à época, o ensino da literatura, tanto na universidade, quanto nas escolas. A seu ver, as instituições de ensino deveriam consagrar menos tempo ao estudo das correntes teóricas e abrir espaço para cursos de criação literária, pois "Incentivar o indivíduo a explorar a sua criatividade é colocá-lo junto às fontes do ser, é prepará-lo melhor para o mundo onde todo indivíduo pode se converter num autor /autoridade capaz de gerir a escrita de sua própria vida." 376

O tom altamente libertário das considerações de Sant'Anna não deixa de chamar a atenção, sobretudo quando se tem em mente que elas foram feitas em plena ditadura militar, sob vigência do Ato Institucional $\mathrm{N}^{\mathrm{o}} 5$, no governo do general Ernesto Geisel. Num momento em que os direitos políticos dos cidadãos estavam suspensos, bem como os direitos ao habeas corpus e às manifestações populares, e vigorava a censura prévia à imprensa e às artes, o campo literário, compreendido como o interior do texto, a crítica e as teorias literárias, parecia ser um dos poucos terrenos em que era possível lutar contra o jugo autoritário sem arriscar a própria vida.

A favor ou contra o estruturalismo, o fato é que em 1974, no Brasil, ele já estava incorporado aos discursos sobre a literatura. Restava aos intelectuais redefini-la tendo em vista as novidades que a voga intelectual parisiense trazia, e que, como Sant'Anna evidencia, poderiam responder a demandas específicas ao contexto brasileiro, como a luta contra o autoritarismo e a busca pela liberdade, naquele momento, extremamente perigosa nas dimensões política e social.

Paralelamente às incertezas sobre a definição de literatura e sobre a abrangência de seu campo, os estudos estruturalistas também provocaram reflexões sobre a função da literatura, de que é um exemplo a conferência “A literatura e a formação do homem”, de Antonio Candido, proferida em 1972. Nela, o autor defende a tese de que a literatura tem uma função social: contribuir para a formação do homem que, por sua vez, deve atuar na sociedade.

\footnotetext{
${ }^{375}$ Ibidem.

376 Ibidem.
} 
O autor inicia sua argumentação dialogando explicitamente com o estruturalismo que, afirma, não contempla as relações entre a literatura e a sociedade. $O$ autor defende o conceito de função, entendido como "o papel que a obra literária desempenha na sociedade" ${ }^{377}$ :

Este conceito social de função não está muito em voga, pois as correntes mais modernas se preocupam sobretudo com o de estrutura, cujo conhecimento seria, teoricamente, optativo em relação a ele, se aplicarmos o raciocínio feito com referência à história. Em face desta os estruturalistas optam, porque acham que é possível conhecer a história ou a estrutura, mas não a história $e$ a estrutura. Os dois enfoques seriam mutuamente exclusivos. ${ }^{378}$

Para Antonio Candido, história e estrutura podem e devem integrar juntas os estudos literários, constituindo, para tanto, dois momentos: a atenção exclusiva à estrutura da obra comporia o momento analítico; e o estudo das relações da obra com seu contexto, compreendendo seu valor e sua função, integraria o momento crítico. Com sua proposta lúcida e conciliadora, o autor responde ao suposto cientificismo mecanicista do estruturalismo com uma tese que visa a restabelecer o contato entre a literatura e o homem. Em outras palavras, o crítico entende que as funções humana e social da literatura estejam ameaçadas e parte em sua defesa: “(...) os estudos modernos de literatura se voltam mais para a estrutura do que para a função. Privada de seus apoios tradicionais mais sólidos (o estudo da gênese, a aferição do valor, a relação com o público), a noção de função passa de fato por uma crise." 379

A constatação da "crise de função" por que passava a literatura levou Antonio Candido a detectar com perspicácia o momento de hesitação que se seguiu à pergunta sobre a finalidade da criação literária. Mais uma vez, queria-se saber, no Brasil, para que servia a literatura, embora não houvesse dúvidas de que ela servia para alguma coisa. Diante de uma possível resposta exclusivamente técnica, Antonio Candido corajosamente se posicionou em público em defesa da missão formadora da literatura.

Tal missão, no seu entender, não excluía o estruturalismo, mas o integrava às análises literárias. Essa postura equilibrada, contudo, não impediu Antonio Candido de ser um dos protagonistas de mais uma polêmica envolvendo as novas teorias ${ }^{380}$, com Affonso Romano de

\footnotetext{
${ }^{377}$ In Textos de intervenção, São Paulo, Duas Cidades/ Editora 34, 2002, p. 77.

378 Ibidem.

379 Ibid., p. 79.

380 A polêmica é descrita em sua íntegra por Ângela Maria Rubel Fanini em "Textos de Antonio Candido, Affonso Romano de Sant'Anna e Roberto Schwarz em torno de O Cortiço", Revista de Letras, v. 9, 2007, pp. 13-18. Disponível em:

http://www.dacex.ct.utfpr.edu.br/site_angela/Arquivos/Producao/Antonio_Candido_Affonso_Romano_e_Roberto_Schw arz_em_torno_de_O_Cortico.pdf (consultado em 12/5/2013).
} 
Sant'Anna, outro crítico avesso aos dogmatismos e simpático às novidades teóricas vindas da França. Pelo perfil dessses intelectuais, esboçado por meio dos seus artigos e ensaios comentados nesta parte do trabalho, depreende-se que a polêmica assemelhou-se mais a um desacordo entre cavalheiros do que a uma acirrada disputa verbal, o que aconteceu em outras situações, com outros intelectuais.

Primeiramente, Sant'Anna publicou Análise estrutural de romances brasileiros (1973), obra que reúne análises estruturalistas de alguns dos grandes romances brasileiros dos séculos XIX e XX, desenvolvidas por ele e seus alunos na Pontifícia Universidade Católica do Rio de Janeiro. No prefácio do livro, como numa premonição do que iria se passar, Sant'Anna afirma que não decidiu publicar tais análises para acrescentar mais lenha à fogueira das polêmicas envolvendo o estruturalismo. Ao contrário, orgulha-se de se manter ao largo de tais discussões. Não imaginava as discussões que um de seus textos iria gerar.

Sua posição ponderada no espaço intelectual da época transparece no texto do prefácio, também por expor a razão pela qual desenvolve tais análises: a fim de preencher uma lacuna, aliás, bastante lembrada pela crítica anti-estruturalista, a saber, a carência de aplicação das teorias em voga. Isso, no entanto, não faz de Sant'Anna um estruturalista, mas um intelectual aberto a novidades teóricas, curioso por testá-las. Como ele bem escreve ao final desse prefácio, e que Antonio Candido também assinaria,

É bem possível que dentro da cena brasileira o Estruturalismo tenha se convertido numa tábua de salvação para aqueles que tiveram que substituir valores apressadamente num certo momento de desorientação política ou existencial. Sem escamotear nada, devo dizer que, assim como acho impertinentes aqueles achaques que "de fora" movem ao Estruturalismo alguns de seus detratores, por outro lado, acho prova de imaturidade intelectual e emocional a atitude daqueles que "de dentro" do Estruturalismo advogam que somente certas (as suas) posições são as verdadeiras. ${ }^{381}$

Longe, portanto, de se colocar como "dono da verdade", Sant'Anna propõe uma leitura de O Cortiço (1890), de Aluísio Azevedo, fundamentada na termodinâmica e na biologia. Bem à moda estruturalista, o autor procede à sua análise estabelecendo pares opositivos sobre os quais a estrutura da obra se sustenta, sem economizar nos esquemas e na distribuição dos termos de modo a formar cadeias de léxico para melhor demonstrar a organização interna da narrativa.

À essa leitura puramente imanente, Antonio Candido responde com "A Passagem do dois ao três (contribuição para o estudo das mediações na análise literária)", publicado na Revista de História, no ano seguinte. Em seu ensaio, o autor aponta a insuficiência do método aplicado por

${ }^{381}$ Petrópolis (RJ), Editora Vozes, 1973, p. 13. 
Sant'Anna. Para Antonio Candido, o estruturalismo é obsecado pelos binarismos e é preciso ultrapassá-los para se construir uma interpretação mais ampla, que mostre o sentido do texto literário para o seu tempo. Daí a necessidade da "passagem do dois ao três", do par operatório ao terceiro elemento, que seria de ordem contextual e, especialmente nesse ensaio, marxista. A ênfase na leitura que vê nem $O$ Cortiço uma representação crítica da realidade sócio-econômica da sociedade brasileira do século XIX amplifica, portanto, a leitura primeira de Sant'Anna, ensejando uma réplica.

Esta vem com "Curtição: o cortiço do mestre Candido e o meu", publicado em Por um novo conceito de literatura brasileira (1977), ensaio no qual Sant'Anna expõe as simplificações contextuais nas quais a visão marxista naturalmente implica, empregando conceitos derridianos de descontinuidade e ausência de centro. Endereça a Antonio Candido, pois, a mesma crítica que recebeu, de estreiteza de visão da obra literária. E amplia seus horizontes apontando os elementos que precisariam ser abordados numa nova análise.

Antonio Candido respondeu ainda uma vez a Sant'Anna, com "De cortiço a cortiço", ensaio de 1991, publicado em 1993 no volume $O$ Discurso e a cidade. O autor mantém sua posição, mas ameniza as cores do marxismo, desfazendo a associação mecânica entre o capital e as funções dos personagens da trama narrativa. Também amplia sua leitura, relacionando o naturalismo de Aluísio Azevedo com o de Zola, sem incorrer numa análise especular: para Candido, O Cortiço se vale de pressupostos zolianos para inovar criando uma linguagem própria, particular ao contexto brasileiro e que com ele dialoga de forma crítica.

Por fim, Roberto Schwarz, discípulo de Antonio Candido, em 1991 arremata a discussão com "Adequação nacional e originalidade crítica", comunicação apresentada no colóquio La Crítica literaria en Latinoamérica, na Universidade Livre de Berlim, e publicada na revista Novos Estudos Cebrap no ano seguinte. Exalta a leitura de Candido e ataca a perspectiva analítica baseada na ausência de centro, defendida por Sant'Anna apoiado em Derrida, argumento que Schwarz refuta a partir de sua análise que situa a realidade brasileira retratada em $O$ Cortiço na periferia do sistema capitalista. Em sua perspectiva, a noção de centro, portanto, é essencial.

A polêmica se encerrou vinte anos depois de ter começado ${ }^{382}$. Apesar de sua longa duração, em momento algum os participantes partiram para ataques pessoais, comentários violentos,

\footnotetext{
${ }^{382}$ E foi muito recentemente retomada, por ocasião da reedição de Análise estrutural do romance brasileiro, em 2012. Alcides Villaça, professor da USP, publicou uma leitura bastante negativa da obra, no Caderno 2 de 7 de outubro de 2012, criticando o caráter démodé do estruturalismo, seus binarismos, sua cientificidade veiculada por uma terminologia esterilizante. Sant'Anna respondeu em artigo de 21 de outubro, também no Caderno 2, defendendo os ganhos teóricos e
} 
satíricos ou pelo menos irônicos. Pelo contrário, o altíssimo nível da argumentação possibilitou que a cada resposta ao opositor, o intelectual desenvolvesse mais seu ponto de vista, modificando-o e enriquecendo-o. Aos olhos de hoje, a polêmica entre Antonio Candido e Affonso Romano de Sant'Anna mostra que as discordâncias constantes acerca do estruturalismo poderiam render bons frutos.

Aparentemente fora dessa discussão, Barthes, contudo, não deixou de ser citado. Em "A Passagem do dois ao três", a certa altura de sua análise de $O$ Cortiço, Antonio Candido escreve:

Mais ainda: ricos e pobres, separados economicamente, são por outro lado equiparados pelo substrato animal comum. Mas este, por sua vez, não é uma categoria unívoca, pois no livro podemos verificar três níveis de conceito de animal: 1) os animais substantivos, propriamente ditos, irrelevantes no caso, a não ser como indiciantes e, às vezes, "catálises", no sentido de Barthes; $(\ldots) .^{383}$

O "sentido de Barthes" não é explicitado, o que faz pensar que era corrente àquela época. Pois esse sentido é definido na “Introduction à l'analyse structurale des récits" ${ }^{384}$, um dos primeiros textos traduzidos no Brasil, já em 1971, e que, junto dos Éléments de sémiologie, converteu-se em manual de análise estruturalista. Antonio Candido, portanto, novamente dá provas de sua abertura para o que de mais moderno havia em termos de teoria à época, integrando um autor e um texto absolutamente estruturalistas a sua defesa de uma leitura não estruturalista - pelo menos não no sentido ortodoxo da mesma.

\section{Barthes no front estruturalista}

Nos primeiros anos da década de 70, artigos e ensaios explicativos sobre o estruturalismo inundaram as páginas da imprensa brasileira especializada em literatura. Evocá-los todos seria extremamente repetitivo e por isso apenas tratarei brevemente de alguns exemplos, sendo o primeiro, "Estruturalismo e crítica literária”, de Fábio Lucas, publicado em O Estado, em 1970.

Nesse artigo, o autor explica didaticamente o estruturalismo, fundamentando-se, sobretudo, em "L’Activité structuraliste" de Barthes, publicado nos Essais critiques e que já comentei na parte dedicada aos anos 60. Lucas destaca a compreensão barthesiana do estruturalismo enquanto uma atividade eminentemente relacional entre os elementos que integram o texto literário. Em resumo,

técnicos estruturalistas e rememorando a polêmica com Antonio Candido, que também reconheceu o interesse construtivo do debate.

${ }^{383}$ In Revista de História, ano 25, tomo 3, volume 50, n 100, outubro/dezembro de 1974, p. 792.

${ }^{384}$ Barthes define a catálise da seguinte maneira: “(...) la fonction constante de la catalyse est donc, en tout état de cause, une fonction phatique (pour reprendre le mot de Jakobson): elle maintient le contact entre le narrateur et le narrataire". In $O C$ v. 2, p. 841. 
seu método de análise consiste na desmontagem e remontagem do texto, criando um simulacro - e não uma simples cópia. Nas palavras do autor do artigo,

Pouco importa, segundo Barthes, que o objeto submetido à atividade de simulacro seja extraído ao real social ou do real imaginário: "não é a natureza do objeto copiado que define uma arte (tenaz preconceito de todos os realismos), é o que o homem lhe acrescenta reconstituindo-o: a técnica é o próprio ser de toda a criação". 385

Entre o original e seu simulacro residiria, segundo Lucas, apoiado em Barthes, o caráter humano da análise literária, pois

Assim o simulacro é o intelecto acrescentado ao objeto e essa adição tem um valor antropológico, dado que ela é o próprio homem, a sua história, a sua situação, a sua liberdade e a própria resistência que a natureza opõe ao seu espírito. Teríamos, então, revivido com Roland Barthes o velho preceito: homo additus naturae? ${ }^{386}$

$\mathrm{O}$ autor reconhece na concepção barthesiana de simulacro o mesmo preceito de Francis Bacon (1561-1626), que afirmou que "Ars homo additus Naturae", a arte é o homem acrescentado à natureza, mas Lucas suprimiu a arte. A diferença entre a definição do filósofo inglês e a de Barthes reside em um deslocamento, que se mostra essencial: o escritor francês define um método de análise e Bacon define a arte. O primeiro trata de um procedimento, de uma dinâmica, de um olhar sobre a obra de arte (literária) e o segundo se refere à própria obra. A comparação de Lucas, portanto, não é nada além de uma anedota erudita.

Definida a "atividade estruturalista" segundo Barthes, o autor lança mão de explicações complementares oriundas de Tristes tropiques (1955), de Lévi-Strauss, e de citações de Eduardo Prado Coelho, autor português de Estruturalismo - antologia de textos teóricos (1968). Ou seja, desde o início da década, Barthes já era considerado, pela crítica brasileira, um dos mestres do estruturalismo, colocado lado a lado com duas das maiores referências sobre o assunto.

Apenas uma semana mais tarde, o mesmo Fábio Lucas publicou em $O$ Estado outro artigo sobre o estruturalismo, muito mais ambicioso e abrangente. "Do Estruturalismo à 'nova crítica' " pretende explicitar de que maneira as teorias estruturalistas incidem sobre a atividade crítica, propondo também uma reflexão sobre essa atividade no contexto brasileiro. Para tanto, o autor parte da compreensão de crítica de Barthes, definida em “Qu'est-ce que la critique?”, publicado nos Essais critiques. Lucas, primeiramente, relembra, em linhas gerais, a definição de estruturalismo de

\footnotetext{
${ }^{385}$ Suplemento Literário, 11 de julho de 1970, p. 1.

${ }^{386}$ Ibidem.
} 
"L'Activité structuraliste", minuciosamente exposta em seu artigo precedente, citando um trecho do ensaio em que o escritor francês explica que o objetivo da atividade estruturalista é criar um simulacro da obra literária, que difere desta por conter sua compreensão. E complementa: "Roland Barthes, já mostramos isso, revela que a fabricação de um mundo parecido com o primeiro, não pela cópia, mas pela capacidade de torná-lo inteligível, constitui a atividade estruturalista, fundamentalmente 'uma atividade de imitação'." 387

Em seguida, passa a discorrer sobre o papel do crítico dentro dessa atividade, e baseia-se na definição de Barthes, explicitada em "Qu'est-ce que la critique?", destacando o novo papel do crítico: não mais um descobridor das verdades do texto literário, mas um construidor de validades, de sistemas de signos coerentes, na medida em que o discurso crítico é linguagem sobre a linguagem, isto é, uma metalinguagem, ou "linguagem segunda", na expressão barthesiana. Em suma, nos termos de Lucas,

Sendo a literatura uma linguagem, ou melhor, um sistema de signos, sua essência não está na mensagem, mas nesse sistema. Segundo Barthes, toda crítica deve incluir em seu discurso um discurso implícito, sobre ela própria, pois toda crítica é crítica da obra e crítica de si mesma. Não é uma tábua de resultados ou um corpo de julgamentos, mas essencialmente, uma atividade; vale dizer, uma sequência de atos intelectuais profundamente engajados na existência histórica e subjetiva de quem a exerce. Não pretendendo explicar o texto, prefere explicitá-lo. ${ }^{388}$

O trecho acima, embora não esteja entre aspas, reproduz assaz fielmente um parágrafo do texto barthesiano ${ }^{389}$ e interessa ao autor para, no final do artigo, fundamentar suas reflexões sobre a crítica literária e o contexto brasileiro. Tendo passado por Mencken (Antologia da crítica literária, 1968) e Doubrovski (Pourquoi la Nouvelle Critique - Critique et objectivité, 1968), Lucas volta a Barthes e à noção de validade da crítica, para então ponderar:

Numa sociedade como a brasileira, tudo o que é válido tem de estar radicalmente ligado a seu próprio destino, numa fase de transformação profunda em que todos os valores são postos em questão. A atividade crítica se torna sublime na medida em que é capaz de conceber uma reformulação da estrutura social a nível superior, de contorno mais humano e mais duradouro. A crítica tem de desprezar friamente as obras que colaboram em nada para aprofundar o conhecimento

\footnotetext{
${ }^{387}$ Suplemento Literário, 18 de julho de 1970, p. 4.

${ }^{388}$ Ibidem.

389 “(...) Toute critique doit inclure dans son discours (fût-ce de la façon la mieux détournée et la plus pudique qui soit) un discours implicite sur elle-même; toute critique est critique de l'oeuvre et critique de soi-même; (...). En d'autres termes encore, la critique n'est nullement une table de résultats ou un corps de jugements, elle est essentiellement une activité, c'est-à dire une suite d'actes intellectuels profondément engagés dans l'existence historique et subjective (c'est la même chose) de celui qui les accomplit, c'est-à-dire les assume.” In $O C$ v. 2, p. 504.
} 
do homem brasileiro, dos mecanismos que impedem o exercício de sua plena capacidade humana; $(\ldots) .{ }^{390}$

O autor que, um dia, já havia se pronunciado de forma veemente contra a crítica nova e a leitura imanente dos textos literários, passados alguns anos, mostra não somente ter absorvido algumas das teorias estruturalistas, do veio barthesiano, como também procura aplicá-las à realidade brasileira. Lucas associa a validade da obra crítica, no Brasil, a seu contexto de produção. E sonha com uma crítica capaz de transformar a realidade social do país, em prol de um humanismo igualitário que auxilie as camadas menos favorecidas da população. De que maneira, mais precisamente, essa utopia se tornaria possível, no entanto, o artigo não explicita.

Mesmo que um tanto vaga, a tentativa de Fábio Lucas de aplicar a noção de crítica barthesiana ao contexto social brasileiro já prenuncia o segundo momento de apreensão das ideias do escritor francês: depois de lido e compreendido, Barthes começa a ensejar novas leituras, particulares ao contexto local. Isto é, suas concepções começam a render frutos nacionais, como a comunicação de Affonso Romano de Sant'Anna para o I Encontro Nacional de Professores de Literatura, em que, à luz de textos de Barthes, propõe rumos libertários para o ensino da literatura; ou o próprio artigo de Lucas. Embora não passem de ideias sem realização concreta, essa disponibilidade em pensar o próprio a partir do alheio ${ }^{391}$ demonstra que os ataques vazios de argumentos e cheios de insultos aos estruturalistas estavam com os dias contados e que se aproximava o tempo das discussões mais sérias e do aproveitamento das novas teorias.

Prova disso é a publicação, cada vez mais frequente, de textos como "Revivendo o estruturalismo linguístico”, de Carlos Burlamáqui Köpke, escrito em 1973. Nesse artigo, o autor traça um panorama das principais correntes de estudos linguísticos e, quando trata da semiologia, ao invés de explicar seus preceitos, como fez com as teorias segundo Hjelmslev, Bernot, Benveniste, Saussure, Jakobson, Karcevski, Troubetzkoi, Sapir, Bloomfield e Chomski, Köpke escreve:

A Hjelmslev (...) está, finalmente, ligada uma corrente importantíssima - a dos semiólogos, da qual fazem parte alguns dos linguistas mais atuantes de nossos dias, como B. Pottier (que já esteve entre nós), A. J. Greimas e Roland Barthes, o último dos quais com excepcional penetração na crítica literária dos nossos dias. É interessante fazer-se um trabalho aproximando-se Barthes e Hjelmslev, principalmente em se tomando como ponto de partida Mythologies, de 1957, onde Barthes, em certo sentido, se mostra um comunicólogo. ${ }^{392}$

\footnotetext{
390 Ibidem.

391 Aludo ao título do livro de Tania Franco Carvalhal, O Próprio e o alheio. Ensaios de literatura comparada (São Leopoldo (RS), Editora do Vale do Rio dos Sinos, 2003), pois o tenho como uma das bases deste trabalho, pelas reflexões gerais sobre a literatura comparada que ele apresenta.

${ }^{392}$ Suplemento Literário, 15 de abril de 1973, p. 3.
} 
O trecho acima permite observar um fenômeno que se tornará comum somente a partir dos anos 80: a descrição da semiologia cede espaço para os intelectuais que a praticam, numa substituição do conteúdo pelos nomes que, àquela altura, já eram conhecidos. Tal procedimento demonstra que Pottier, Greimas e, principalmente, Barthes, eram autores cujos nomes já valiam por si, ou seja, eram representativos de uma série de noções, conceitos e obras, que se sustentavam sem a necessidade de maiores explicações. A sugestão de estudo feita pelo autor reforça essa ideia, pois demonstra seu conhecimento da obra barthesiana, uma vez que Mythologies fora traduzido no Brasil apenas um ano antes do artigo. A reboque do sucesso dos Essais critiques, dos Éléments de sémiologie e da "Introduction à l'analyse structurale des récits", outras obras de Barthes começaram a despertar o interesse dos brasileiros.

\section{A polêmica das ignorâncias altamente especializadas}

Apesar de navegar em águas menos hostis ao estruturalismo do que na década de 60, e de já gozar de um certo estatuto dentro da classe intelectual brasileira, a batalha ainda não estava ganha para Barthes. Junto do maior conhecimento de suas ideias vieram os questionamentos, e as discussões se seguiram. Destaco uma polêmica em torno da obra barthesiana protagonizada por Oswaldino Marques e Leyla Perrone-Moisés, realizada entre junho e agosto de 1970.

Marques escreve dois artigos de mesmo título: "Estrutura das ignorâncias altamente especializadas", publicados em $O$ Estado, em 6 e 13 de junho. O primeiro coloca em questão o estruturalismo sob um ponto de vista teórico e geral. O segundo critica violentamente Barthes. Nesses textos, notadamente no primeiro, Marques tenta provar que não há comunicação entre as teorias modernas, em voga na literatura, na sociologia e na psicologia, dentre outras, e as ciências, tais como a matemática e a física. Por exemplo, segundo o autor, nos últimos anos, o termo "estrutura" foi obscurecido por todos os significados que as novas teorias lhe acrescentaram; e os novos sentidos desse termo fundamental do estruturalismo são fruto da ignorância e da preguiça dos teóricos modernos, que não encontraram palavras pertinentes nas obras de filósofos e cientistas, para reutilizá-las. Consequentemente, Marques não vê interesse nas teorias de Jakobson ou Eco, citadas no artigo, uma vez que elas não têm nada de original, em sua opinião, pois tudo já foi dito por outros autores ou cientistas. Ele considera, portanto, os teóricos em voga, sobretudo aqueles que se associam ao que ele chama de nouvelle critique, como impostores que iludem os menos atentos.

As concepções explicitadas no primeiro artigo ainda fazem eco às críticas dos intelectuais tradicionais endereçadas aos universitários, no que tange o emprego de uma linguagem técnica e, 
por isso, elitista. O "terrorismo terminológico" estruturalista dos anos 70 reanimou esse aspecto da velha querela dos anos 50, e os textos de Marques fazem parte dessa nova onda de ataques fundamentados na crítica da linguagem estruturalista. O próprio título de seus artigos se refere aos críticos universitários - e desde meados dos anos 60, predominantemente estruturalistas -, qualificando-os como "ignorantes", apesar de seu elevado nível de especialização. Sua "ignorância" seria provada pela invenção de novos sentidos às palavras e conceitos que existem desde sempre, pois os universitários ignorariam seus significados originais. A conclusão do artigo de 6 de junho também menciona os poetas concretos - arautos das novas teorias linguísticas aplicadas à literatura - por meio do substantivo "doutores", alusão às teses de doutorado, então em curso, de Haroldo de Campos e Décio Pignatari, dois dos fundadores da poesia concreta. O emprego da palavra “doutores" coloca os poetas concretos do lado da crítica moderna e universitária que, apesar de suas pretensões à originalidade, para Marques parece vazia.

Dando continuidade a seu objetivo de “desmascarar" os autores em moda, os críticos estruturalistas e universitários, no segundo artigo Marques aponta sua arma para Barthes:

Desde seu primeiro livro, o Degré zéro de l'écriture, que muito justamente o empurrou de sopetão para a fama, passando por Critique et vérité até, segundo tudo indica, sua última produção de título cabalístico $S / Z$, o lúcido dialeta da nouvelle critique manipula uma parafernália doutrinária que pode parecer nimbada de originalidade tão só às pessoas a quem o quadro da literologia contemporânea se apresenta fora de foco. ${ }^{393}$

O autor continua seu ataque pela citação de características de Barthes até então bastante comentadas, tais como a ironia e o emprego da semiologia como ferramenta de análise. Marques afirma solenemente que antes de Barthes houve outros autores que tinham um estilo sofisticado e bem-humorado, como por exemplo Kenneth Burke, e que o escritor francês não foi o primeiro a se servir da semiologia nos estudos literários, pois o new criticism já o teria feito na década de 20.

Em suma, a crítica se fundamenta tanto na exigência de originalidade absoluta quanto no desconhecimento das obras de Barthes e de seu percurso intelectual. Na passagem citada, Marques precede seus comentários sobre $S / Z$ pela expressão "segundo tudo indica", o que coloca em relevo seu conhecimento de segunda mão da obra que cita. Refere-se a Barthes como se este fosse "professor da Sorbonne", o que o escritor nunca foi. Mas, enfim, o conhecimento da obra e de seu autor não são essenciais para um crítico que procura menos compreendê-los do que simplesmente colocá-los do lado inimigo: Marques reconheceu na obra de Barthes, sobretudo na linguagem nela

${ }^{393}$ Suplemento Literário, 13 de junho de 1970, p. 1. 
empregada - "sua última produção de título cabalístico $S / Z$ ", onde "cabalístico" evoca com ironia o mistério indecifrável do título -, mais uma representante da crítica universitária estruturalista, que é preciso combater em nome de inovações verdadeiras.

Um outro exemplo de sua crítica à "falta de originalidade" pode ser observado quando o autor cita "O Voo dos significantes" ${ }^{394}$, artigo de Leyla Perrone-Moisés sobre Barthes, publicado dois meses antes, no mesmo jornal:

Quem diria que, a esta altura do pensar e do fazer crítico literário contemporâneo, ainda fosse necessário recorrer ao testemunho de alguém para tornar patente que a Crítica que, "no conceito atual perde sua conotação de censura ou julgamento, passa a ser uma atividade lúdica e criativa"? É, não obstante, o que faz a articulista Leyla Perrone-Moisés, com a preciosa indicação de que se trata de uma "opção" de Roland Barthes (...). ${ }^{395}$

Munido, como sempre, de uma ironia grosseira, Marques considera as afirmações de Leyla Perrone-Moisés evidentes e surpreende-se com o interesse que elas suscitam no público brasileiro. Todavia, ele não enxerga nem o contexto da crítica francesa dos anos 60 , que torna as posições de Barthes bastante significativas e até mesmo corajosas, nem o contexto, em seu ensaio, em que Leyla Perrone-Moisés coloca as ideias do escritor.

Lembro que no momento em que Barthes se insurge contra a crítica tradicional, nos anos 60, provocando a querela da crítica francesa e polemizando com Raymond Picard, a crítica era governada pelo ideal da busca da verdade na obra literária. A crítica procedia como se só houvesse um sentido na obra e que somente o crítico fosse capaz de compreendê-lo. Nesse contexto, mesmo que a polissemia da obra literária não seja uma reivindicação nova, Barthes articula esse conceito à de écriture. Ele coloca em prática sua concepção de crítica através de sua écriture e propõe uma crítica literária entendida como uma atividade de criação. Portanto, para o escritor francês, não se trata simplesmente de uma crítica livre do jargão tradicional, mas de todo um universo teórico novo, o que Leyla Perrone-Moisés explicita.

No que concerne o contexto interno ao artigo, Marques também não tem razão em sua crítica. Em "O Voo dos significantes", Leyla Perrone-Moisés analisa $S / Z$ à luz de vários conceitos de Barthes, em um ensaio cujo objetivo é apresentar o escritor francês ao público brasileiro. Quando ela menciona a compreensão barthesiana da crítica, citada por Marques, a autora só explicita a

\footnotetext{
${ }^{394}$ Suplemento Literário, 4 de abril de 1970, p. 1. Esse texto foi reproduzido no recente volume de Leyla PerroneMoisés, Com Roland Barthes, São Paulo, WMF Martins Fontes, 2012, pp. 28-33, e por isso não consta do volume anexo que integra esta tese.

395 “Estrutura das ignorâncias altamente especializadas”, Suplemento Literário, 13 de junho de 1970, p. 1.
} 
opinião escolhida por Barthes para analisar "Sarrasine", de Balzac, em $S / Z$ : Barthes cria um texto que tem por pretexto a obra de Balzac e que se constitui como uma leitura dentre outras possíveis.

Em um ensaio publicado aproximadamente dois meses mais tarde e entitulado "Roland Barthes, o infiel", Leyla Perrone-Moisés continua seu trabalho de divulgação da obra do escritor francês. Apresentando os Essais critiques e Critique et vérité, que acabavam de ser publicados no Brasil, em sua tradução, ela mostra a importância da ideia de deslocamento na obra de Barthes e indica certas invariáveis em seu percurso intelectual, tais como a autonomia da linguagem literária, a distinção entre sentido e significação (a literatura sendo um processo de criação de sentidos, portanto, de significação), bem como a concepção da crítica como uma metalinguagem. Perto do final do ensaio, Leyla Perrone-Moisés responde a Marques, sem, entretanto, citá-lo diretamente:

Tendo falado de sua "infidelidade", falemos agora de sua "falta de originalidade". Está claro que nem tudo é novo no sistema crítico de Barthes. Primeiramente porque, para ser captada, nenhuma informação pode ser totalmente nova: a recorrência e o reconhecimento impõem-se para a transmissão de qualquer mensagem. Em segundo lugar, porque são cada vez mais frequentes as coincidências no ideário crítico contemporâneo, a ponto de se tornar difícil (e pouco proveitoso) buscar as fontes primeiras. Mesmo porque, geralmente, remontaríamos a Aristóteles. ${ }^{396}$

Contra a agressividade que emana do ensaio de Marques desde seu título, Leyla PerroneMoisés emprega a ironia fundamentada no conhecimento do contexto cultural de seu tempo. Ela informa os leitores sobre as origens dos conceitos utilizados por Barthes, para então afirmar que a importância das teorias barthesianas reside na combinação que ele faz desses conceitos. A autora, assim, serve-se dos mesmos elementos que sustentam a tese de Marques para invertê-la, pois onde ele só vê ausência de inovação, ela enxerga criatividade.

Leyla Perrone-Moisés conclui seu ensaio com uma consideração sobre a incompreensão que a obra de Barthes suscita: trata-se de um sinal de sua força, da obra que incomoda justamente porque vai de encontro às balizas tradicionais, porque tira o conforto do saber estabelecido para provocar e para propor algo até então impensável. Tais características são potencializadas pelo contexto literário brasileiro, então bastante dividido em grupos a favor do estruturalismo e contra ele.

De sua parte, Barthes respondeu aos ataques que recebeu na França, com Critique et vérité, bem como em outros ensaios. Nessas críticas, também havia a acusação de elitismo terminológico,

\footnotetext{
396 Suplemento Literário, 29 de agosto de 1970, p. 1. Esse texto foi reproduzido no recente volume de Leyla PerroneMoisés, Com Roland Barthes, São Paulo, WMF Martins Fontes, 2012, pp. 28-33, e por isso não consta do volume anexo que integra esta tese.
} 
tão frequente no Brasil. Em entrevista a Pierre Daix, publicada na revista Lettres Françaises, em 1968, o escritor francês mostra seu ponto de vista:

Il y a un poujadisme intellectuel qui est toujours possible: méfiance brutale à l'égard du langage, congé donné aux formes, réputées toujours sophistiquées, accusation de "jargon", refus de l'écriture, etc.: on connaît ce vieux mythe anti-intellectualiste, si tenace en France.

(...)

Cette tentation anti-intellectualiste, je la crois profondément nuisible, parce qu'elle empêche toute réflexion théorique; et pour ma part, je ne veux aller que là où il y a un effort d'analyse d'une situation, qu'elle soit politique, universitaire ou "littéraire"; seule la théorie peut faire avancer les choses, seule la théorie peut détruire. ${ }^{397}$

Barthes reconhece a existência de um pensamento anti-intelectualista na França, de onde são lançados os dardos contra as novas teorias, especialmente quando estas são veiculadas numa linguagem inovadora. Para construir sua reflexão, o escritor faz referência a Pierre Poujade, político reacionário que defendia os valores tradicionais das classes médias do interior da França, na década de 50. Foi objeto de duas mitologias barthesianas, nas quais o escritor descreve e analisa a ideologia poujadista que impregna seu discurso e é repetida por setores da sociedade francesa.

Em "Quelques paroles de M. Poujade”, Barthes demonstra a lógica tautológica do raciocínio poujadista, que recusa qualquer saída que extrapole seu sistema - o qual, de maneira populista, o político considera o mesmo dos pequenos comerciantes do interior, que ele pretende representar. Dentro desse raciocínio circular, somente o que é contável é aceito, como dentro de um comércio, o que exclui toda atividade intelectual do que categoriza como "trabalho". O escritor então resume:

(...) M. Poujade verse au néant toutes les techniques de l'intelligence, il oppose à la "raison" petite-bourgeoise les sophismes et les rêves des universitaires et des intellectuels discrédités par leur seule position hors du réel computable. ("La France est atteinte d'une surproduction de gens à diplômes, polytechniciens, économistes, philosophes et autres rêveurs qui ont perdu tout contact avec le monde réel.”). ${ }^{398}$

Barthes detecta nesse discurso anti-intelectualista a recusa de toda reflexão que se desenvolva fora do sistema fechado do pequeno comerciante, tão exaltado por Poujade. Trata-se, consequentemente, da recusa do diferente, o que o escritor vê como uma atitude típica dos

\footnotetext{
${ }^{397}$ In "Structuralisme et sémiologie", entevista a Pierre Daix, Lettres Françaises, 31 de julho de 1968, OC v. 3, pp. 8182.

${ }^{398}$ In Mythologies, $O C$ v. 1, p. 737.
} 
fascismos. Em "Poujade et les intellectuels", Barthes é ainda mais incisivo em sua leitura do discurso poujadista contra os intelectuais:

Suspendus dans le vide supérieur, les intellectuels en sont tout emplis, ils sont "le tambour qui résonne avec du vent": on voit ici apparaître le fondement inévitable de tout antiintellectualisme: la suspicion du langage, la réduction de toute parole adverse à un bruit, conformément ao procédé constant des polémiques petites-bourgeoises, qui consiste à démasquer chez autrui une infirmité complémentaire à celle que l'on ne voit pas en soi, à charger l'adversaire des effets de ses propres fautes, à appeler obscurité son propre aveuglement et dérèglement verbal sa propre surdité. ${ }^{399}$

Tal como na entrevista há pouco citada, onde Barthes menciona Poujade ao responder aos ataques ao estruturalismo, ao descrever os ataques do político à linguagem empregada pelos intelectuais, ele também responde aos próprios intelectuais brasileiros que criticavam as linguagens estruturalistas, como Marques. Para Barthes, portanto, o "terrorismo terminológico", fruto das "ignorâncias altamente especializadas" impulsionadas pela "comichão estrututalista", nada mais era do que a manifestação da intolerância ao outro, ao diferente, uma forma com a qual seus adversários explicitavam suas próprias limitações.

Mesmo que alguns intelectuais partilhassem essa opinião, a impressão geral causada pelas linguagens estruturalistas, notadamente as de cepa linguística, na década de 70, ainda era a pior possível, representando elitismo e opressão dos que não integravam o seleto grupo que dominava ou parecia dominar - as novas teorias. $\mathrm{O}$ barulho causado pelo estruturalismo foi captado pelo poeta Carlos Drummond de Andrade, que o devolveu em forma de um poema que mostra o lugar de Barthes no Brasil da época:

\section{Exorcismo}

Das relações entre topos e macrotopos

Do elemento suprassegmental

Libera nos, Domine

Da semia

Do sema, do semema, do semantema

Do lexema

Do classema, do mema, do sentema

Libera nos, Domine

Da estruturação semêmica

Do idioleto e da pancronia científica

${ }^{399}$ Ibid., p. 814. 
Da reliabilidade dos testes psicolingüísticos

Da análise computacional da estruturação silábica dos falares regionais

Libera nos, Domine

Do vocóide

Do vocóide nasal puro ou sem fechamento consonantal

Do vocóide baixo e do semivocóide homorgânico

Libera nos, Domine

Da leitura sintagmática

Da leitura paradigmática do enunciado

Da linguagem fática

Da fatividade e da não fatividade na oração principal

Libera nos, Domine

Da organização categorial da língua

Da principalidade da língua no conjunto dos sistemas semiológicos

Da concretez das unidades no estatuto que dialetaliza a língua

Da ortolinguagem

Libera nos, Domine

Do programa epistemológico da obra

Do corte epistemológico e do corte dialógico

Do substrato acústico do culminador

Dos sistemas genitivamente afins

Libera nos, Domine

Da camada imagética

Do espaço heterotópico

Do glide vocálico

Libera nos, Domine

Da lingüística frástica e transfrástica

Do signo cinésico, do signo icônico e do signo gestual

Da clitização pronominal obrigatória

Da glossemática

Libera nos, Domine

Da estrutura exo-semântica da linguagem musical

Da totalidade sincrética do emissor

Da lingüística gerativo-transformacional

Do movimento transformacionalista

Libera nos, Domine

Das aparições de Chomsky, de Mehler, de Perchomock

De Saussure, Cassirer, Troubetzkoy, Althusser

De Zolkiewsky, Jakobson, Barthes, Derrida, Todorov

De Greimas, Fodor, Chao, Lacan et caterva

Libera nos, Domine ${ }^{400}$

${ }^{400}$ In Carlos Drummon de Andrade, Poesia e prosa, Rio de Janeiro, Nova Aguilar, 1979, p. 793. 
O poema, em forma de ladainha, ironicamente suplica a Deus que liberte o poeta da linguagem estruturalista, estendendo o pedido a alguns dos líderes da nova onda teórica, o que inclui Barthes. Publicado em 1977 em Discurso de primavera e algumas sombras, "Exorcismo" é sintomático do sentimento que envolvia o estruturalismo e seus mentores no Brasil, para os leitores em geral e para grande parte da crítica especializada: cansaço pela repetição constante de termos demasiadamente técnicos para serem compreendidos e vontade de repeli-los em nome da volta à leitura dos textos literários, livre de teorias e simplesmente prazerosa.

\section{À margem das querelas: Barthes em discussão}

Para além da presença de Barthes em textos de todo o tipo sobre o estruturalismo, é nesses anos 70 que sua obra começa a ser comentada e discutida por um espectro mais amplo de intelectuais. Novamente, Leyla Perrone-Moisés tem papel importante nessa leva de textos cujo tema é Barthes, ou algum conceito, noção ou obra de sua autoria.

Já em 1970 ela publica em O Estado "A Floração das revistas" 401 , belo título de um artigo que divulga no Brasil as principais revistas literárias de vanguarda na França naquele momento, $\mathrm{Tel}$ Quel, Change e Poétique. A autora descreve o perfil de cada uma delas e observa que o ponto comum a todas é a presença de Barthes, seja no corpo editorial, seja como autor. Embora o artigo, portanto, tenha por foco um recorte do panorama literário francês, é a figura do escritor que é colocada em primeiro plano.

Outro texto que segue pelo mesmo caminho, mas de forma mais sutil, é "Sartre e a situação da literatura", de 1976. Nele, Leyla Perrone-Moisés faz uma detalhada resenha de Situations X, de Sartre, precedida por uma breve reflexão sobre o existencialismo sartreano e o estruturalismo, em que escreve:

Nos anos 60, a estrela de Sartre entrou em eclipse parcial, enquanto os estruturalistas ocupavam o primeiro plano: Lévi-Strauss, Foucault, Althusser, Lacan e Barthes vieram nortear (ou desnortear - leia-se como se quiser: pejorativa ou elogiosamente) todas as reflexões acerca do homem, de sua lógica, seu inconsciente, sua linguagem e suas práticas. ${ }^{402}$

O filósofo, então, cedeu espaço às novas teorias e seus autores. Contudo,

Com o refluxo da vaga estruturalista, a partir de 1970, e também graças ao relativo distanciamento que o tempo conferiu à sua obra, deixando-a assentar nas prateleiras, seu nome [de

\footnotetext{
${ }^{401}$ Suplemento Literário, 23 de maio de 1970, p. 1.

${ }^{402}$ Suplemento Literário, 17 de outubro de 1976, p. 4.
} 
Sartre] voltou progressivamente à pauta e, uma estrela ascendente, Barthes, declarou que Sartre seria em breve relido e reestudado por aqueles que o haviam esquecido, ou por aqueles, mais novos, que não tinham tido oportunidade de o conhecer. ${ }^{403}$

Nesse trecho, de caráter contextual e que justifica a leitura atual de Sartre, razão pela qual a autora resenha seu novo livro, fica subentendida, no entanto, a importância de Barthes: depois de ter sido alçado ao "primeiro plano" nos anos 60 junto da voga estruturalista e de outros autores, com a decadência da mesma, na década de 70, o escritor continuou a ser "uma estrela ascendente", podendo até mesmo prognosticar sobre o destino da obra de um dos intelectuais franceses mais importantes do século XX. Num artigo dedicado a Sartre, portanto, dentro da curta introdução à resenha de Situations $X$, recebe destaque mais uma vez Barthes: Leyla Perrone-Moisés confere ao escritor o lugar que ele ocupava na cena intelectual parisiense a que, no Brasil, ele ainda não tinha direito.

Além desses dois artigos em que Barthes não é o tema central, mas cuja figura transparece no texto, a autora publicou em $O$ Estado, na mesma década, "O Voo dos significantes" e "Roland Barthes, o infiel", ambos em 1970, que fizeram parte da polêmica entre Leyla Perrone-Moisés e Oswaldino Marques, já tratada neste trabalho. Esses artigos não discutem propriamente o conceito de crítica barthesiano em $S / Z$ ("O Voo dos significantes) e a noção de deslocamento ("Roland Barthes, o infiel"), mas os descrevem e explicam dentro do pensamento de Barthes, de maneira aprofundada, como se, ao mesmo tempo em que o público dos anos 70 já estivesse mais preparado para compreender as minúcias dos textos do escritor francês, também fosse preciso "explicar" Barthes. Esses artigos, portanto, embora mais profundos, não renegam seu caráter didático.

Antecipando a década de 80, a autora escreve "Discurso amoroso e discurso de poder", em 1977, sobre um tema muito caro a Barthes e à pós-modernidade: a crítica ao poder que se esconde na doxa. Leyla Perrone-Moisés articula as reflexões sobre o discurso de poder contidas na Leçon, aula inaugural proferida no Collège de France em 7 de janeiro de 1977, e Fragments d'un discours amoureux, publicado no mesmo ano.

Primeiramente, a autora demonstra como Barthes, em seu percurso intelectual, identificava em toda posição fixa, em todo estereótipo, um poder discursivo: uma concepção inconteste, um lugar-comum, uma idéia feita, uma praxe social, a doxa, o natural, o bom senso. Pois todas elas implicam numa relação hierárquica, de autoridade e submissão, que Barthes procurava combater. Portanto, sempre que diante de uma posição cristalizada, o escritor se deslocava, procurando outro lugar, como uma forma de resistência ao poder.

403 Ibidem. 
Foi assim em todo o seu percurso intelectual: quando o próprio Barthes chegava a uma certa posição, quando começava a ter seguidores, abandonava-a, deslocando-se para outro lugar. Nos anos 50 ocupou-se de questões conceituais sobre a escrita literária e a linguagem e elaborou a mais refinada crítica da sociedade de consumo francesa, identificando no que era tido como "natural” ou "fruto do bom senso" seu caráter puramente histórico e contextual. Quando despertou a atenção da intelectualidade, trocou a crítica social, feita por intermédio do texto, pela crítica literária tout court e descobriu a psicanálise, o nouveau roman, viveu a querela da crítica dos anos 60 e dela saiu vencedor - suas concepções hoje estão presentes já no ensino médio e soam como óbvias aos estudantes de graduação em Letras. Erigido ao posto de mestre da nouvelle critique, Barthes abdicou de seu título e passou às leituras de Balzac, a seus estudos sobre o léxico da moda e a seu livro sobre o Japão. Ainda no início dos anos 70, quando parecia que o intervalo havia acabado e que voltaria à crítica, Barthes novamente driblou todas as expectativas e voltou-se para seu prazer enquanto leitor, escrevendo Le Plaisir du texte, e enquanto autor, com Roland Barthes par Roland Barthes, uma biografia que subverte o gênero. Depois, tratou de amor nos Fragments, num momento em que o tema era cafona e que a liberdade sexual já havia sido descoberta. Coroando a linha personalista que se delineava em sua obra, concentrou seu interesse na fotografia, teorizando a partir de fotos de sua infância e de sua mãe; publicou, em 1980, sua última obra, La Chambre claire.

Em meio a esse percurso de nômade do saber, Barthes acabou por ocupar a mais alta posição na intelectualidade francesa e uma das mais altas em escala mundial: obteve uma cátedra no Collège de France, a mais prestigiosa instituição de pesquisa e ensino na França, onde já haviam lecionado nomes como Paul Valéry, Fernand Braudel, Henri Bergson, Émile Benveniste, Roman Jakobson e Maurice Merleau-Ponty, e que naquela época mantinha no quadro docente Claude LéviStrauss e Michel Foucault, dentre os mais eminentes.

Ao subir ao palco do grande anfiteatro do Collège e posicionar-se diante de mais de 300 espectadores para proferir sua Aula Inaugural, embora Barthes dissesse que falava de um lugar horspouvoir $^{404}$ porque lá não há exigências curriculares, nem controle de frequência, exames ou notas, e o lema é "Enseigner la recherche en train de se faire", claro que ele tinha consciência de que estava ocupando o lugar máximo de poder possível a um intelectual. Suas palavras soariam como lei e seu discurso ecoaria muito além da França - a essa altura, Barthes já era um nome internacionalmente conhecido.

${ }^{404}$ In Leçon, $O C$ v. 5, p. 430. 
E sobre o que falou, nessa ocasião paradoxalmente por ele sempre evitada? O tema de sua Leçon foi justamente o poder, uma aula sobre como escapar ao poder intrínseco à língua e à linguagem - sua frase mais repetida: “Mais la langue, comme performance de tout langage, n'est ni réactionnaire, ni progressiste; elle est tout simplement: fasciste; car le fascisme, ce n'est pas d'empêcher de dire, c'est d'obliger à dire." 405 Pois a língua, com sua lógica de funcionamento, obriga a dizer de uma certa maneira : em português somos obrigados a escolher o sujeito da frase, a conjugar o verbo de acordo com esse sujeito, todos os substantivos devem ser necessariamente masculinos ou feminimos, por exemplo. A queixa de Barthes é que não existe o neutro ou o complexo, não existem - nem na língua francesa e nem na portuguesa - nuanças ou hibridez de gênero, os modalizadores são tentativas desesperadas de suavizar o poder ditatorial da língua. Há, portanto, uma relação de poder fundamentada na sujeição em toda língua, que é o veículo da linguagem.

Que profilaxia então adotar para se evitar o mal do poder que se inocula na linguagem? O combate contra esse poder deve ser feito dentro da própria linguagem, para Barthes: deve-se utilizar a linguagem de maneira a escapar às normas, sem, contudo, cair no erro da incompreensão absoluta, que também tem suas regras. Deve-se então desorientar, sobretudo, empregando o verbo profético do M. Teste de Mallarmé, “decepcionar”: não corresponder às expectativas, não estar onde se espera que se esteja. Nos termos de Barthes, "Cette tricherie salutaire, cette esquive, ce leurre magnifique, qui permet d'entendre la langue hors-pouvoir, dans la splendeur d'une révolution permanente du langage, je l'appelle pour ma part: littérature." 406

Desviar dos caminhos já batidos, romper com os padrões estabelecidos, criar dentro da linguagem, eis o verbo que se casa com o substantivo liberdade. Dito de outro modo, deslocar-se seguindo seu desejo, sem se sujeitar a normas, como Barthes sempre fez e como ele concebe o ensino, situação que necessariamente implica o emprego da linguagem:

Et je me persuade de plus en plus, soit en écrivant, soit en enseignant, que l'opération fondamentale de cette méthode de déprise, c'est, si l'on écrit, la fragmentation, et, si l'on expose, la digression, ou, pour le dire d'un mot précieusement ambigu: l'excursion. J'aimerais donc que la parole et l'écoute qui se tresseront ici soient semblables aux allées et venues d'un enfant qui joue autor de sa mère, qui s'en éloigne, puis retourne vers elle pour lui rapporter un caillou, un brin de laine, dessinant de la sorte autour d'un centre paisible toute une aire de jeu, à l'intérieur de laquelle le caillou, la laine importent finalement moins que le don plein de zèle qui en est fait. ${ }^{407}$

\footnotetext{
${ }^{405}$ Ibid., p. 432.

${ }^{406}$ Ibid., p. 433.

${ }^{407}$ Ibid., pp. 444-445.
} 
Mesmo numa posição de que emana poder - professor no Collège de France -, Barthes não deixou de questioná-lo de forma direta - a acusação da língua de fascismo chocou na época. E a promoção da excursão, da deambulação, do vagar sem rumo a método de trabalho também não era esperada pelo auditório, para dizer o mínimo. Na passagem acima, o escritor ainda menciona o fragmento como forma literária mais adequada ao exercício de esquiva do poder da doxa: Barthes já o praticava desde Michelet (1954), tendo-o substituído pelo ensaio durante um período, para voltar a ele nos anos 70 .

Esses preceitos, aplicados à criação literária - o fragmento e a digressão, o discurso errante - são todos praticados nos Fragments, como Leyla Perrone-Moisés observa:

(...) O discurso amoroso, assim como o discurso poético, parece-lhe [a Barthes] antídoto contra o discurso de poder. Enquanto neste fala uma "voz autorizada", no discurso amoroso fala um enunciador tão desautorizado que é visto pela opinião corrente e bem pensante como louco ou simplesmente ridículo; enquanto a voz do poderoso é segura e auto-suficiente, a voz do apaixonado é desfalecente e balbuciante; enquanto a voz do poder é dirigida e dirigente, a voz do amor é desgarrada e errante. ${ }^{408}$

Tal constatação da autora pode ser comprovada em qualquer parte do livro. Todavia, o fragmento sobre a errance é justamente entitulado "Le vaisseau fantôme", numa alusão ao deslocamento infinito do apaixonado, que projeta seu amor a cada momento sobre uma pessoa diferente, incessantemente, condenado a vagar para sempre como um navio fantasma:

(...) je ne peux m'arrêter d'errer (d'aimer) en vertu d'une ancienne marque qui me voua, dans les temps reculés de mon enfance profonde, au dieu Imaginaire, m'affligeant d'une compulsion de parole qui m'entraîne à dire "Je t'aime", d'escale en escale, jusqu'à ce que quelque autre recueille cette parole et me la retourne; mais nul ne peut assumer la réponse impossible (d'une complétude insoutenable), et l'errance continue. ${ }^{409}$

Esse eterno vagar sem destino daquele que se apaixona porque o porto de chegada, a completude no outro, não existe, pode ser interpretado como uma metáfora da própria écriture barthesiana, a errar de assunto em assunto, de fragmento em fragmento, de frase em frase, desviando-se dos portos seguros construídos pela doxa. Ainda no mesmo fragmento, Barthes escreve como se tratasse menos do apaixonado do que de sua própria obra: "La 'mutabilité perpétuelle' (in inconstantia constans) dont je suis animé, loin d'écraser tous ceux que je rencontre

\footnotetext{
${ }^{408}$ Suplemento Cultural, 30 de outubro de 1977, p. 7. Esse texto foi reproduzido no recente volume de Leyla PerroneMoisés, Com Roland Barthes, São Paulo, WMF Martins Fontes, 2012, pp. 89-94, e por isso não consta do volume anexo que integra esta tese.

${ }^{409}$ In Fragments d'un discours amoureux, OC v. 5, p. 134.
} 
sous un même type fonctionnel (ne pas répondre à ma demande), disloque avec violence leur fausse communauté: l'errance n'aligne pas, elle fait chatoyer: ce qui revient, c'est la nuance." 410

O brilho em movimento provocado pelo vagar sem rumo aparenta-se com os reflexos do sol na água do mar por onde navega o vaisseau fantôme de Barthes, cuja obra se constitui de cada reflexo, mesmo que fugaz. O conceito de écriture é um deles, e foi tema de "Escrita ou escritura?"411, publicado em O Estado, em 1979.

Nesse artigo, Leyla Perrone-Moisés, que acabara de traduzir a Leçon de Barthes, expõe parte do trabalho de pesquisa que realizou para a empreitada de transpor para a língua portuguesa o texto barthesiano. A autora, que já havia estudado minuciosamente a noção de écriture em sua tese de livre-docência, em $1975^{412}$, elabora um pequeno glossário explicativo de termos recorrentes na obra de Barthes, representativos de noções e conceitos particulares ao pensamento do escritor francês, que justifica suas escolhas como tradutora. $\mathrm{O}$ artigo corresponde a uma primeira versão de redação, para os termos écriture e jouissance, de "Lição de casa", publicado à guisa de posfácio à tradução da Leçon. Mais abrangente, o texto final contém reflexões sobre como a autora teve acesso a uma gravação em áudio da aula inaugural no Collège, sobre as particularidades em se traduzir o texto de Barthes e sobre os termos fantasme e jeu/ jouer, além dos já mencionados.

Leyla Perrone-Moisés, no texto publicado no jornal, justifica a escolha do termo escritura, como tradução de écriture, pela existência da palavra em português com acepção equivalente à francesa e, principalmente, por conter uma pequena limitação em seu uso em português que, em determinadas situações, distinguem-na de escrita, termo mais corrente. Essa diferença é suficiente para marcar seu emprego específico em contexto barthesiano - e não só, pois também Derrida, Lacan e outros autores modernos a utilizaram -, significando o texto literário. A explicação para a tradução de jouissance por gozo e não por fruição, tal como figura nas traduções portuguesa e brasileira, também encontra lastro, para a autora, na compreensão do termo na teoria lacaniana, de conotação sexual - numa relação de perda - e não puramente prazerosa.

$\mathrm{O}$ artigo, portanto, visa a desfazer um impasse em que as obras de vários autores franceses modernos colocaram os tradutores e intelectuais brasileiros e que, lembro, foram, por exemplo, motivo de ataques de José Guilherme Merquior em “O Estruturalismo dos pobres”. Leyla Perrone-

\footnotetext{
${ }^{410}$ Ibid., p. 135.

${ }^{411}$ Suplemento Cultural, 29 de julho de 1979, pp. 5-6. Esse texto foi reproduzido no recente volume de Leyla PerroneMoisés, Com Roland Barthes, São Paulo, WMF Martins Fontes, 2012, pp. 69-74, e por isso não consta do volume anexo que integra esta tese.

${ }^{412}$ Texto, crítica, escritura, São Paulo, Martins Fontes, 2005 (1978).
} 
Moisés, mais uma vez, agiu em prol da difusão do pensamento de Barthes, divulgando-o e esclarecendo-o com argumentos fundamentados em sólida base teórica.

Os anos 70 também vêm em $O$ Estado o aparecimento de uma outra voz em defesa de Barthes, ao lado da de Leyla Perrone-Moisés: o jornalista e escritor francês Gilles Lapouge, correspondente do jornal até hoje, mostra-se um entusiasta da obra barthesiana e também escreve artigos divulgando e comentando seus livros. Assim como a estudiosa brasileira, em 1977, Lapouge dedica um artigo à aula inaugural no Collège de France, fazendo com que Barthes ocupe, pela primeira vez, uma página inteira do jornal, e fora dos espaços consagrados à literatura.

Pelas mãos do correspondente francês, dentro do jornal brasileiro, Barthes atinge, portanto, um outro status, o de celebridade reconhecida internacionalmente. $\mathrm{O}$ tratamento que o escritor recebe também é diferente do dispensado por Leyla Perrone-Moisés: esta, consciente da ignorância de grande parte da crítica a respeito de Barthes e da resistência contra ele surgida no bojo dos ataques ao estruturalismo, preocupava-se, em seus textos, em explicar didaticamente as principais ideias e noções, os mais importantes conceitos de Barthes, apresentando-os e situando sua obra em meio às novas teorias que surgiam na Europa. Já Lapouge, talvez menos consciente da hostilidade do contexto brasileiro e escrevendo de dentro do contexto francês, no qual, na década de 70, Barthes já era reconhecido como um dos mestres da modernidade literária, preocupa-se menos em explicar os textos do escritor, do que em celebrá-los. O jornalista que, sendo também escritor, é um ótimo contador de histórias, comenta o percurso intelectual barthesiano e festeja suas divagações, suas descobertas e as perguntas que ele coloca.

O título de seu longo artigo de 77 já diz muito: "Barthes, a contestação da linguagem numa linguagem brilhante". Publicado em 6 de fevereiro, portanto menos de um mês depois da conferência no Collège, o texto preserva o relato feito no calor da hora, menos minucioso e detalhista na explanação das ideias do escritor, do que entusiasmado com o evento: "E foi exatamente o que aconteceu: o novo eleito [do Collège de France] pronunciou um discurso impossível de classificar - uma espécie de 'aporia', de paradoxo incompreensível, no qual cada uma das palavras era como bomba - e reduzido a cinzas pelo ambiente no qual foi feito, pelo aparato que o envolvia." 413

${ }^{413}$ Geral, 6 de fevereiro de 1977, p. 22. 
O Estado de S. Paulo, Primeiro Caderno, domingo, 6 de fevereiro de 1977, p. 22. 
O arrebatamento do autor, contudo, não exime seu texto da análise do significado de se proferir uma conferência sobre o poder que se esconde em todo o tipo de discurso... num local de poder:

Mas retomemos essa grande cena de execução, por Barthes, do poder. Primeiramente, ela se desenrola no maior teatro do poder intelectual da França. Em segundo lugar, ela se passa em presença de todos os representantes do poder intelectual. E, finalmente, essa execução da linguagem como poder exprime-se na mais bela das linguagens, uma língua elegante, clássica, toda matizada e cintilante, sustentada por esses instrumentos implacáveis do poder que são uma gramática irrepreensível, uma sintaxe refinada, uma retórica perfeita. De tal forma que o círculo se fecha - é como se, por meio de sua aula inaugural, Barthes tivesse querido mostrar, por uma espécie de pantomima, que o poder é uma Hidra de cem cabeças, que ele é mais forte justo no momento em que o destruímos, que se fortalece na proporção dos golpes que recebe. ${ }^{414}$

O discurso de Barthes contra o poder do discurso, num espaço de poder, não poderia deixar de ser altamente irônico. Ironia que se percebe somente ao final do texto, quando o escritor a desfaz, com sua proposta de ensino:

Il est un âge où l'on enseigne ce que l'on sait; mais il en vient ensuite un autre où l'on enseigne ce que l'on ne sait pas: cela s'appelle chercher. Vient peut-être maintenant l'âge d'une autre expérience: celle de désapprendre, de laisser travailler le remaniement imprévisible que l'oubli impose à la sédimentation des savoirs, des cultures, des croyances que l'on a traversés. Cette expérience a, je crois, un nom illustre et démodé, que j'oserai prendre ici sans complexe, au carrefour même de son étymologie: Sapientia: nul pouvoir, un peu de savoir, un peu de sagesse, et le plus de saveur possible. ${ }^{415}$

Lapouge reconhece nesse aparente paradoxo entre linguagem e discurso de poder uma atitude perversa de Barthes, porém consciente. E o entusiasmo novamente toma a frente, ao se referir ao escritor, refletindo-se nos encadeamentos de adjetivos que pontuam o texto: "Nesse sentido, esse revoltado, doce e terno, esse irredutível maleável, esse revolucionário amável estava sendo fiel a tudo o que sabemos dele e de sua obra há vinte anos." ${ }^{416} \mathrm{O}$ autor passa, então, a seguir o rastro sinuoso da obra barthesiana, enfatizando suas idas e vindas, seus dribles geniais em seus seguidores. E conclui demonstrando que o constante desbravar de novos territórios, o que não permitia a Barthes fixar-se numa posição confortável, é que determina sua condição de escritor de vanguarda.

Lapouge ainda coloca em relevo o fato de o escritor, em sua aula inaugural, afirmar que não havia mais grandes escritores na França, como Malraux e Sartre, maîtres à penser que

${ }^{414}$ Ibidem.

${ }^{415}$ In Leçon, $O C$ v. 5, p. 446.

${ }^{416}$ O Estado de S. Paulo, Geral, op. cit., p. 22. 
influenciavam gerações de jovens e de intelectuais com suas opiniões sobre a literatura, mas também sobre a sociedade e a política. E novamente acusa a ironia:

Mas ao mesmo tempo não é divertido e perverso ouvir esse veredito de condenação à morte do maître à penser, ou do grande escritor, da boca de um homem que precisamente hoje preenche com perfeição esse papel? E que essa condenação do maître à penser seja pronunciada no Collège de France, no próprio templo da maîtrise de penser, e na presença de uma multidão de estudantes que bebiam as palavras do maître, não é uma perfídia suplementar, um prazer paradoxal, uma outra volta da lógica infernal desse temível fabricante de "aporias" que é Barthes? ${ }^{417}$

Barthes, nesse artigo de Lapouge, recebe o mesmo destaque que tinha na França. No entanto, o ardor com o qual o autor descreve a aula inaugural no Collège e coloca o escritor no posto mais alto da intelectualidade literária francesa, elevando-o à categoria de maître à penser, era uma novidade no Brasil, endossada por extratos da aula inaugural, traduzidos e publicados à parte, na mesma página, para dar mais relevo às palavras do escritor.

Poder-se-ia depreender que Barthes fosse o maître à penser de Leyla Perrone-Moisés, pela frequência com que ela publicava artigos sobre ele e o defendia dos ataques contra o estruturalismo, assim como pela justeza de suas colocações, fundamentadas em leituras cuidadosas de sua obra. Porém, quando a qualificação de maître à penser é explicitada, e sob a pena de um correspondente internacional, a afirmação adquire um peso diferente, e sai dos cadernos culturais para ser publicada no noticiário internacional. Com Lapouge, Barthes rompeu de vez as barreiras que o prendiam ao campo específico e limitado das reflexões intelectuais e passou a ser assunto de um público mais vasto. Sua canonização estava próxima.

Antes desse artigo apoteótico, Lapouge havia publicado outros textos em que citava Barthes. Em 75, dedicou-lhe um artigo entitulado "Roland Barthes, antes de tudo, um escritor", em que descobre, com a leitura de Roland Barthes par Roland Barthes, o grande escritor que foi Barthes. O autor observa que, em obras anteriores, já se adivinhava o escritor por trás do crítico:

Em várias oportunidades, já víramos luzir, sob a máscara do doutrinário, olhos zombeteiros, sorrisos silenciosos e vivos. Em certos momentos o teórico chegou até a cabular aula, partindo para o campo, dando cambalhotas nas florestas das palavras e nos trazendo na volta uma braçada de cores resplandecentes, de arco-íris de palavras. ${ }^{418}$

Enfim, com Roland Barthes par Roland Barthes, Lapouge se pergunta:

${ }^{417}$ Ibidem.

${ }^{418}$ Geral, $1^{\text {o }}$ de junho de 1975, p. 14. 
Depois de errar durante 20 anos entre o Caríbdis da linguística e o Cila da semiótica, Ulisses teria finalmente reencontrado Ítaca e sua pequena Penélope, a literatura? E este percurso expiatório por terrenos que não haviam sido trilhados pelas ciências humanas, viagem que durou 20 anos, não foi uma maneira de conjurar uma paixão exclusiva, a paixão pela literatura? ${ }^{419}$

A imagem do viajante em busca de sua paixão, calcada na literatura grega, é cara ao escritor Gilles Lapouge, à época futuro autor de romances de mesma temática. Ao mesmo tempo, ela é interessante para representar as errâncias teórico-metodológicas de Barthes, que o autor descreve em seu artigo. Na reconstituição desse trajeto, dá voz às críticas que o escritor recebeu pelo “abandono" das teorias estruturalistas e elogia sua escolha pela criação literária... que sempre esteve presente até mesmo em seus textos críticos:

Com Barthes, a crítica tornou-se criação. Neste sentido, ele é um grande contrabandista. Passa a vida a cruzar fronteiras, acampando em todas as divisas. (...)

Por outro lado, é possível que em seu último livro, fingindo oferecer-nos um texto sobre ele mesmo, exista um "tratado sobre o estilo". 420

$\mathrm{O}$ artigo trata menos de Roland Barthes par Roland Barthes, seu pretexto, do que celebra a escolha do escritor em publicar um tex to literário - embora o próprio Lapouge reconheça que não se trata da primeira obra do gênero no percurso barthesiano. A única consideração de ordem mais analítica sobre o livro encontra-se no trecho acima, e não é desenvolvida. Entendo a leitura de Lapouge à luz do fragmento "L'écriture commence par le style", do mesmo livro, que define o estilo, tendo em mente o de Chateaubriand, como algo que “(...) sert à louer une valeur nouvelle, l'écriture, qui est, elle, débordement, emportement du style vers d'autres régions du langage et du sujet, loin d'un code littéraire classé (code périmé d'une classe condamnée)." Ou seja, a écriture é feita do estilo que se esparrama pela linguagem e pelo autor, como se fosse o estilo que desse a liga entre os dois, permitindo a elaboração da écriture que, por sua vez, sempre é própria e móvel, nunca previamente classificada. O “je” que escreve Roland Barthes par Roland Barthes continua:

(...) sa [do sujeito que escreve o livro] manière d'écrire s'est formée à un moment où l'écriture de l'essai tentait de se renouveler par la combinaison d'intentions politiques, de notions philosophiques et de véritables figures rhétoriques (Sartre en est plein). Mais surtout, le style est en quelque sorte le commencement de l'écriture: même timidement, en s'offrant à de grands risques de récupération, il amorce le règne du signifiant. ${ }^{421}$

${ }^{419}$ Ibidem.

${ }^{420}$ Ibidem.

${ }^{421}$ Roland Barthes par Roland Barthes, $O C$ v. 4, p. 653. 
O estilo, portanto, unindo o homem e a linguagem, é o primeiro passo para se elaborar uma écriture, uma escrita literária própria que, segundo Lapouge, desfila aos olhos do leitor de Roland Barthes par Roland Barthes.

Esse livro também foi comentado por Walter Faber, no Suplemento Cultural, em 1979, fazendo um eco tardio à publicação de sua tradução, em 1977, por Leyla Perrone-Moisés. Texto sem grande interesse, "Roland Barthes, personagem de romance" mais parece uma resenha do livro escrita por alguém que não soube muito bem o que dizer a respeito. Nem entusiasta, nem crítico, Faber mescla citações de fragmentos do livro com considerações sobre Barthes, apresentando-o, sobretudo, como um autor cujos escritos costumam gerar polêmicas - refere-se à querela com Picard e à afirmação de que a língua é fascista, por exemplo. Sobre Roland Barthes par Roland Barthes, limita-se a apontar novo paradoxo barthesiano: embora se pressuponha que o livro é uma autobiografia, a primeira frase que se lê é "Tout ceci doit être considéré comme dit par un personnage de roman" ${ }^{422}$, mergulhando o leitor Faber na dúvida entre a verdade biográfica e a construção romanesca. E ele opta pelo caminho da verdade estilística para ler o livro, repetindo a interpretação de Lapouge: "É o seu universo estilístico que produz a visão peculiar do mundo que apresenta." ${ }^{423}$ Em outras palavras, o protagonista do texto barthesiano é a linguagem de Barthes, que não produz assertivas, mas indagações, sendo fiel a sua compreensão do papel da literatura.

Tanto Leyla Perrone-Moisés quanto Gilles Lapouge, nos textos há pouco examinados, citam entrevistas de Barthes publicadas em periódicos franceses. Leyla Perrone-Moisés, em "Discurso amoroso e discurso de poder" (1977), menciona uma ponderação sobre as palavras revolução e subversão, com a definição desta, extraída de uma entrevista de Barthes a Le Nouvel Observateur. Lapouge, em "Roland Barthes, antes de tudo, um escritor" (1975), reproduz parte de uma entrevista publicada em Les Nouvelles Littéraires sobre a possível futura escrita de um romance. Antes deles, em 1972, Lívio Xavier já comentava duas entrevistas do escritor, evidenciando o sucesso de Barthes na França: somente um autor de relevo seria procurado para conceder entrevistas em tal número que algumas delas atravessassem o Atlântico e ecoassem na imprensa brasileira.

Pois as primeiras apareceram no artigo de Xavier, "Viagem em torno de Roland Barthes", mesmo título da entrevista concedida a Gilles Lapouge para La Quinzaine Littéraire, publicada em dezembro de 1971, reportada no artigo, juntamente de "Plaisir/ Écriture/ Lecture", entrevista a Jean Ristat para Les Lettres Françaises, em fevereiro de 1972. Em seu texto, o responsável pela "Revista

\footnotetext{
${ }^{422}$ Ibid., p. 577.

${ }^{423}$ Suplemento Cultural, 8 de julho de 1979, p. 11.
} 
das revistas" do Suplemento Literário, Xavier, coloca Barthes no posto de novo guru intelectual da França. Todavia, ao contrário de Lapouge, que o faz justificando os méritos do escritor, o autor relativiza a importância de Barthes. Depois de mencionar Sartre e Lévi-Strauss, escreve:

Mas a roda da fortuna literária não pode parar muito tempo no mesmo lugar. Pelo visto, um valor mais alto se alevanta na publicidade que se faz em torno de Roland Barthes, o qual está em vias de canonização. Não se trata, no caso, de um filósofo eminente que, apesar de frequentar perigosamente a esquerda, o seria mesmo sem o Nobel, nem o de um professor, cuja ciência, talvez um tanto árida, a compensa com uma imaginação poderosa. Não: Roland Barthes é um crítico literário vestido de linguista, ou melhor, um professor de comunicações, matéria que é a última encarnação do saber sociológico. ${ }^{424}$

Mencionando indiretamente Sartre, o filósofo, e Lévi-Strauss, o professor, o autor, mesmo que expondo sua ressalva em relação ao estruturalismo - "ciência, talvez um tanto árida" -, estabelece a comparação entre ambos e Barthes, excluindo-o do rol de "merecedores" de tamanha honraria. O "não" que inicia a parte final do parágrafo distingue o escritor de seus antecessores e o desqualifica, classificando-o como "crítico literário vestido de linguista" e "professor de comunicações", pois ambas as expressões apontam para essências que se disfarçam sob aparências: a linguística traveste o crítico e as "comunicações" são a nova roupagem da sociologia. Muito sutilmente, portanto, Xavier coloca em dúvida as qualidades que levaram Barthes à "canonização". Lembro que as prevenções do autor em relação ao escritor datam dos anos 60, época da querela contra Picard, e que sempre foram manifestadas sorrateiramente em seus artigos, nunca atacando Barthes diretamente.

Ao traçar um brevíssimo - e sempre desconfiado - histórico intelectual de Barthes, nomeando suas obras, o autor chega a Sade, Fourier, Loyola, seu então último livro, tema da entrevista de Lapouge com o escritor para La Quinzaine Littéraire. Desta, Xavier pinça inicialmente a pergunta do entrevistador sobre o que reuniria sob uma mesma tese três autores tão díspares. $\mathrm{O}$ autor do artigo, pretendendo se apoiar em Lapouge, discorre bastante sobre o aparente "embaraço" que a pergunta pode ter causado, sem reportar a resposta de Barthes. O leitor fica com a impressão de que Fourier e Loyola são próximos pela biografia e Sade interessa ao escritor como criador de uma linguagem própria no século XVIII. Contudo, tal impressão é falsa. Na entrevista, não só o escritor não demonstra embaraço algum, como o próprio entrevistador, em um pequeno texto introdutório, adianta a resposta de Barthes:

${ }^{424}$ Suplemento Literário, "Revista das revistas", 2 de julho de 1972, p. 6. 
Une curieuse équipe, celle que Roland Barthes a recrutée pour ce livre - un pornographe, un saint et un utopiste - mais s'ils sont éberlués, peut-être, Sade, Loyola et Fourier, de figurer dans le même ouvrage, on peut leur faire confiance, ils seront rapides à se forger un langage commun puisque c'est précisément cela, le langage, qui forme leur petit délire singulier et l'unique sol (...) où entrecroiser les lignes de leurs trois systèmes. ${ }^{425}$

Pelo trecho citado, primeiro parágrafo da introdução à entrevista, fica claro que esta acontece sob o signo da confiança do entrevistador no trabalho do escritor, que ele conhece e compreende, sem nenhuma animosidade ou mesmo simples afronta.

Apesar dessa constatação, em seguida, Xavier coloca Lapouge como um provocador de Barthes - "Mas Lapouge não é desses que abandonam a presa (...)" ${ }^{426}$ - e ataca o estruturalismo em sua relação problemática com a história. Barthes se safa dizendo que há diversas compreensões do estruturalismo e diferentes visões da história. No mesmo tom, o autor escreve: "Lapouge começa agora um pouco perversamente a sua viagem à roda de Roland Barthes, perguntando-lhe se ele não acha demais essa coisa de ser considerado mestre e ter um número especial (de Tel Quel) todinho consagrado à sua pessoa." ${ }^{427}$ Enfatizando a naturalidade da resposta do escritor, o autor parece insinuar a falta de modéstia por parte de Barthes. E logo passa à última pergunta, sobre a possibilidade de se criar uma ciência da literatura. Diante da negativa do escritor, Xavier desabafa:

Felizmente não. Barthes já não crê em uma ciência da literatura e se acha muito velho para tal, o que pode entender-se que isso é uma tolice ou uma novidade. E declara que, com o passar dos anos, é mais sensível ao prazer do texto do que à sua lei. Pois, ao contrário do que se pensa geralmente, os mais velhos são mais livres. Boa resposta aos menos capacitados de certas verdades mais banais. ${ }^{428}$

Sempre destilando sua crítica sutilmente, o autor escolheu colocá-la nas ambiguidades, sempre entre dois, nesse texto. Anteriormente, desqualificou Barthes pelo que ele parecia ser e na verdade era, pela disciplina que nada mais era do que um disfarce da antiga sociologia. Agora, sua afirmação pode ser tanto uma "tolice" quanto uma "novidade", e sua resposta final é boa, mas para os "menos capacitados..." Sem criticar abertamente Barthes, Xavier o julga severamente, porém sempre nas entrelinhas, como se tivesse receio em atacá-lo frontalmente. Sua escolha de trechos a citar evidencia tanto seu parti pris contrário a Barthes que ele omite, por exemplo, a modéstia do escritor. Este, na entrevista, afirma, sobre si mesmo: "Je ne suis pas un grand lecteur. Je ne suis pas non plus un grand débatteur. Bref, je ne suis pas un véritable intellectuel..." Ao que Lapouge

${ }^{425}$ In "Voyage autor de Roland Barthes", $O C$ v. 3, p. 1045.

426 "Viagem em torno de Roland Barthes", op. cit, p. 6.

${ }^{427}$ Ibidem.

${ }^{428}$ Ibidem. 
escreve, entre parênteses: “(Mon Dieu, me dis-je, à ce moment-là, et dans les dessous de mon propre discours, s'il n'est pas, Roland Barthes, un intellectuel, alors, comment faut-il s'y prendre et n'est-ce pas un peu décourageant? )" 429 .

Sobre a entrevista concedida por Barthes a Jean Ristat, publicada em Les Lettres Françaises, Xavier redige apenas um curto parágrafo, espaço suficiente para observar um escritor diferente do entrevistado por Lapouge, "pomposo e quase pedante" ${ }^{430}$, bem professor da École Pratique, segundo o autor. Depois da crítica, o elogio - "O que não lhe tira valor informativo sobre o geral e o particular das questões tratadas" ${ }^{431}$-, para novamente situar Barthes na ambiguidade e evitar o confronto. Desnecessário dizer que, para mim, a entrevista a Ristat não apresenta nada que se possa classificar como "pomposo e quase pedante", tal qualificativo fica por conta da má vontade de Xavier com o escritor.

A leitura da entrevista de Barthes para Les Lettres Françaises, centrada em Sade, Fourier, Loyola, aborda o interesse crescente do escritor pelo prazer provocado pela leitura de certos textos e é assaz explorada pelo entrevistador. A conversa sobre esse tema tem início com a evocação de L'Empire des signes, no qual Ristat entrevê a ruptura com os estudos semiológicos mais ortodoxos e o início da busca pelo prazer na écriture. A esse respeito, Barthes diz:

(...) Le Japon m'a donné une sorte de courage d'écriture. J'ai été heureux d'écrire ce texte. Il m'a permis de m'installer un peu plus dans cet espace hédoniste ou, pour mieux dire, érotique, du texte, de la lecture, du signifiant. Maintenant, je suis très tenté de poursuivre cette voie, d'écrire des textes de plaisir et d'inclure dans la théorie du texte une réflexion sur le plaisir du texte, sur la séduction. Il faudrait presque parler du donjuanisme du texte. Pourquoi un texte séduit-il, qu'est-ce que la séduction d'un texte? Le plaisir du texte est-il purement culturel? Dépend-il de niveaux de culture ou est-il plus corporel et par conséquent entretient-il avec la culture un rapport dialectique comportant beaucoup de médiations? Voilà le type de questions que j'aimerais poser peu à peu. ${ }^{432}$

Anunciando, mesmo sem o saber ao certo, Le Plaisir du texte, o escritor explicita as inquietações que o perseguem e sua vontade de explorá-las. Fato que engendra uma pergunta premonitória por parte do entrevistador:

Il ne faut pas mésestimer cependant qu'une telle prise de position - dire que l'on va entreprendre une réflexion théorique sur le plaisir - va ou peut paraître comme étant à contrecourant du travail même de la modernité. J'imagine même aisément les malentendus que certains

429 "Voyage autour de Roland Barthes", op. cit, p. 1049.

430 "Viagem em torno de Roland Barthes", op. cit., p. 6.

${ }^{431}$ Ibidem.

432 "Plaisir/ Écriture/ Lecture", $O C$ v. 4, p. 201. 
sont prêts à exploiter. Voulez-vous nous dire en quoi ce que vous faites aujourd'hui est un travail d'avant-garde nécessaire? ${ }^{433}$

Há duas respostas para essa pergunta. A primeira é possível somente a quem conhece todo o trajeto intelectual de Barthes, ou pelo menos a maior parte dele, e vê em seu deslocamento de temas e de métodos a manifestação de desejos pessoais como arma de combate empregada em sua luta contra a fixidez da doxa. A segunda resposta é a de Barthes ao entrevistador, que tem relação íntima com a primeira: ele vê no estudo do prazer uma tática para se libertar da linguagem politizada dos intelectuais de seu tempo e se concentrar unicamente na linguagem. Dedicar-se ao prazer do texto seria uma forma de resistência à nova doxa surgida nos anos 60.

Nesse início da década de 70, quando Barthes publica $S / Z$ e L’Empire des signes, obras tão diferentes na fatura e no propósito, depois Sade, Fourier, Loyola, para acrescentar mais um elemento despistador dos caminhos do escritor, sua imagem estabelecida até então, a de líder da crítica estruturalista e semiólogo-referência, começa a balançar. Ainda nessa entrevista, ele demonstra ter consciência desse período de transição por que sua imagem passava:

L'image qu'on me renvoie de moi-même inclut en effet cette ambiguïté. Car tantôt j'apparais comme un sémiologue, l'un des premiers en date: je suis alors affublé d'un indice de scientificité. Tantôt, au contraire, on trouve que je ne suis pas rigoureux, scientifique, et on me taxe de subjectivité et d'impressionnisme. ${ }^{434}$

Tal ambiguidade confundiu não só seus seguidores, mas também os intelectuais e, em $O$ Estado, Le Plaisir du texte foi objeto de um artigo igualmente ambíguo, e anônimo: "Barthes, a reabilitação do prazer de ler", publicado em março de 1973, pouco tempo depois do lançamento do livro na França. O texto apresenta brevemente o escritor de maneira hiperbólica, a deixar no ar uma certa ironia ou uma admiração desmedida. Inicia-se assim: "Com a edição de Le Plaisir du texte (Le Seuil, 112 págs.) revela-se o último paradoxo do grande mestre da crítica literária: ser legível não é mais um crime." A saudação a Barthes é seguida de uma alusão irônica ao "terrorismo terminológico" dos anos estruturalistas, o que faz pensar nos artigos de Lívio Xavier, nos quais os elogios ao escritor eram sempre seguidos por críticas. A continuidade da apresentação segue a mesma linha, beirando o sarcasmo: "Ele [Barthes] é uma espécie de Comendador, à entrada da República das letras, admitindo apenas os mandarins trajados completamente a rigor." 435

\footnotetext{
433 Ibid., p. 202.

${ }^{434}$ Ibid., p. 205.

${ }^{435}$ Suplemento Literário, 18 de março de 1973, p. 1.
} 
Contudo, a segunda parte do artigo é favorável ao escritor, quando o autor passa a tratar de Le Plaisir du texte: "O Prazer do texto e seus parágrafos curtos, que possuem, cada um deles, o valor de um livro, vêm desferir, no momento preciso, o golpe na lenda que começa a se formar. É preciso lembrar que Barthes não é tecnocrata frio, como se afirma, mas um crítico que tratou a inteligência com a maior voluptuosidade." ${ }^{436}$ E tece considerações sobre o quão desnorteados deveriam estar os discípulos do escritor, sobretudo aqueles que haviam se habituado a não mais ler obras literárias por deleite, mas unicamente para escrever "tese universitária", numa crítica às práticas do estruturalismo ortodoxo. Talvez esse autor anônimo, que mesmo assim publica um texto na primeira página do Suplemento Literário, fosse algum crítico feroz das práticas estruturalistas, tendo até mesmo atacado Barthes em anos anteriores. Depois de mudar de ideia com a guinada do escritor, talvez ele preferisse o sossego do anonimato a assumir uma opinião nova.

Fato é que o artigo que começou ambíguo, suscitando desconfiança, mostra-se francamente positivo, celebrando o livro de Barthes, que consegue demonstrar que o prazer não é reacionário, mas revolucionário:

Naturalmente, um texto de elogio do prazer, que não proporcionasse prazer, ele próprio, seria iconcebível. Cada frase é, para o espírito, uma dose de anfetamina. Barthes tem, de Valéry, não apenas o perfil intelectual e a capacidade de agir com rasgos de genialidade, na noite das palavras: tem ainda essa arte misteriosa, cujo segredo só ele é capaz de mostrar e que dá ao leitor a impressão de que ele é tão inteligente quanto crítico.

Isto acontece porque Barthes, mais do que um crítico, é um criador. Ele escreve sobre os livros como os romancistas escrevem sobre a vida, e confere às teorias uma força, um calor, que em muitos casos, os personagens de ficção não possuem. ${ }^{437}$

Que definição de Barthes poderia ser mais precisa naquele momento, reconhecendo na écriture barthesiana, mesmo quando esta teoriza, uma criação literária em si, o desfile da linguagem diante dos olhos do leitor, e não seu emprego para transmitir uma ideia? E por que uma leitura elogiosa da obra de Barthes não poderia ter uma assinatura?

Esse artigo parece-me emblemático sobre a presença de Barthes em $O$ Estado, na década de 70: uma mistura de reconhecimento presente e lembrança ruim do estruturalista dos anos 60, regada à insegurança sobre seus próximos passos. Estaria o crítico cedendo espaço ao escritor? Ou o crítico teria sido sempre um escritor? Tais questões, à época, ainda não tinham resposta para a maioria dos intelectuais brasileiros. Seria preciso esperar mais alguns anos para sabê-lo.

\footnotetext{
${ }^{436}$ Ibidem.

437 Ibidem.
} 


\section{A partir dos anos 80: consagração}

Como é que vocês vão se arranjar com tudo isso? ${ }^{438}$

Roland Barthes

A pergunta que constitui a epígrafe é atribuída a Barthes pelo redator do caderno Cultura, como introdução à entrevista concedida pelo escritor a Philip Brooks e a Patrick Sarfati, publicada no jornal com o título "Barthes: a crise do desejo", como homenagem póstuma. Trata-se da última entrevista concedida pelo escritor, publicada em Le Nouvel Observateur de 20 de abril de 1980. Ou seja, suas palavras, nesse texto, dada a circunstância da morte inesperada, adquiriram o peso de um verdadeiro testamento.

Nessa entrevista, Barthes é instigado a falar sobre o papel dos intelectuais na França daquele momento, sua forma pessoal de engajamento, pela linguagem, sua vontade de escrever um romance, e diagnostica uma "crise do desejo" em certos comportamentos sociais. Curiosamente, o que, segundo o caderno Cultura, é a frase final dessa entrevista, reproduzida na epígrafe, não consta de sua edição em Le Grain de la voix, nem nas Oeuvres complètes. Teria sido ela apenas relatada indiretamente pelos autores da entrevista, como conclusão, em Le Nouvel Observateur, ficando fora do corpo da mesma e por isso, tendo sido excluída das edições posteriores? Também o nome de Sarfati não consta como entrevistador nas edições em livro. Seria ele o editor da entrevista, na revista francesa, e por isso coautor do texto? Informações imprecisas à parte, o fato é que a pergunta, supostamente feita por Barthes, ao cabo de algumas horas de conversa, em alusão aos diferentes assuntos abordados, resume a perplexidade com que intelectuais do mundo todo receberam a notícia de seu desaparecimento: como lidar com uma obra tão desconcertante? E, num segundo momento, na década de 80, à medida que as vozes de outros grandes mestres dos anos $60 \mathrm{e}$ 70 se calavam, como lidar com as perdas, além da de Barthes, as de Sartre, Foucault, Lacan e Althusser?

A morte de Barthes, em 26 de março de 1980, em decorrência de complicações seguidas a um atropelamento, surpreendeu a todos, pois seu estado de saúde, após o acidente, não era grave, apenas inspirava cuidados. No dia seguinte a seu desaparecimento, O Estado de S. Paulo dedica-lhe grande espaço em seu primeiro caderno, com direito a chamada na primeira página, evidenciando a

\footnotetext{
438 "Barthes: a crise do desejo" (entrevista concedida a Le Nouvel Observateur). Cultura, domingo, 27 de julho de 1980, p. 16.
} 
importância do escritor para a cultura de um modo geral: a notícia de sua morte não era uma simples nota que interessaria somente a intelectuais e frequentadores do caderno de cultura, mas assinalava uma perda grande o suficiente para ser de interesse de um público muito mais amplo e menos especializado. Ao mesmo tempo, o artigo, fartamente ilustrado com fotos do escritor e trechos de Roland Barthes par Roland Barthes, traz em seu título, "Os símbolos perdem Roland Barthes”, a estreita relação do escritor com a semiologia, na tradução de signe por símbolo.

Seu necrológio, embora restrito a uma página, comporta a reportagem sobre o acidente e o período em que Barthes ficou hospitalizado, uma breve revisão de sua trajetória intelectual, repertoriando seus livros, e alguns depoimentos de professores universitários brasileiros que o haviam conhecido e conheciam sua obra. Nas falas dos docentes entrevistados, tem destaque Éléments de sémiologie, não por acaso, a obra de maior penetração nos meios intelectuais durante os anos 60 e 70.

Um terço da página é ocupado por belo artigo de Gilles Lapouge, "Na 'feira das vaidades', um intelectual discreto", misto de testemunho sobre o escritor, que o jornalista conheceu, e tentativa de balanço do legado barthesiano. Lapouge também retoma o acidente de Barthes, sua biografia e seu percurso intelectual, bem como as impressões subjetivas que recolheu nos encontros com o escritor, para concluir: "Para nós, entretanto, não é o possante teórico ( $O$ Sistema da moda, Elementos de semiologia, Crítica e verdade) que retemos em primeiro lugar. Certamente, não se trata de negligenciar a ambição e o êxito dessa construção teórica, mas além dessa teoria, como um rio, havia o charme de um magistral escritor." 439

Ao contrário do que mostram os depoimentos dos professores universitários brasileiros, naquele momento ainda hipnotizados pela obra estruturalista de Barthes, para Lapouge, também um intelectual, porém não domesticado pela academia, são os Fragments d'un discours amoureux e La Chambre claire que melhor definem o escritor: "Assim, os dois últimos livros desse teórico arrogante, científico e árduo, são livros nos quais a teoria, sem se apagar, é substituída pela poesia. E a mais bela, sem dúvida - aquela que em todo caso convinha a esse homem -, é a do amor." 440

Depois do desaparecimento de Barthes, a década de 80 assistiu ainda aos funerais de Sartre (1905-1980), Romain Gary (1914-1980), Jacques Lacan (1901-1981), Michel Foucault (1926-1984) e Louis Althusser (1918-1980-1990) ${ }^{441}$, mortes que marcam o final de uma era em que, na França, a

\footnotetext{
${ }^{439}$ Geral, 27 de março de 1980, p. 32.

440 Ibidem.

${ }^{441}$ Para Althusser a data de 1980 se refere ao assassinato de sua esposa, o que o conduziu à internação em um hospital psiquiátrico e consequente silêncio, mesmo após o fim de seu período de tratamento, que durou 3 anos. 1990 é o ano de sua morte.
} 
teoria literária despertava mais paixões do que o romance e a poesia. Apoiado em constatação semelhante e premonitória, porque desenvolvida em julho de 1980, Lapouge se interroga, no artigo "O fim da era dos gigantes?", sobre a extinção dos grandes romancistas e poetas (entre o século XIX, o início do século XX, até 1945) e o surgimento da era da "teoria", no pós-guerra. Ao final de sua argumentação sobre a inexistência de nomes de escritores de peso, como Gide, Malraux e Proust, por exemplo, desde o final da Segunda Guerra, o que anunciaria uma conclusão lamuriosa, Lapouge escreve:

Será o deserto? Certamente não. A vida intelectual francesa transferiu-se para outro campo, sem que com isso tenha perdido em intensidade e ardor.

(...) se é verdade que a prateleira encantada do romance ficou desprovida e quase vazia depois que Mauriac, Malraux ou Sartre se calaram, nem por isso está em crise a literatura francesa. Num certo sentido o oposto é que é verdade: Paris de 1980 é tão brilhante quanto a Paris de 1930. Só que a literatura moveu-se, para iluminar outras áreas que não a do romance. A genialidade francesa, faz 30 anos, mudou-se, armou sua tenda em novos territórios. E, entretanto, numerosos sinais permitem crer que o romance, depois da cura de emagrecimento necessária, sem dúvida, mas letal, que lhe aplicou o "novo romance" e o que se chamou de "vanguarda", prepara para nós fascinantes ressurreições. ${ }^{442}$

Os gigantes do porte dos escritores citados, no pós-guerra foram substituídos pelos gigantes da teoria, que reinaram por quase quarenta anos, aproximadamente, até se extinguirem, por sua vez, na década de 80. A essa conclusão chega Lapouge em artigo de 1983, uma continuação do texto acima: em "Quando as ideologias saem de moda", o autor lê a história literária francesa sob o prisma de uma sucessão de ideologias, desde o cristianismo, a primeira delas, até as ideologias surgidas após 1945, o existencialismo, o marxismo, o estruturalismo e a psicanálise. Para ele, desde o pós-guerra, "a França muda de ideologias como quem muda de camisa" ${ }^{443}$, referindo-se à sucessão de modas teóricas que tomou conta das Humanidades na época. Contudo, as manifestações de maio de 68 interromperam essa dinâmica que, aos olhos de Lapouge, durava séculos:

Pode-se então aceitar a hipótese de que maio de 68 representou efetivamente um papel na derrota e na derrocada das ideologias: é neste braseiro meio delirante que são queimadas todas aquelas doutrinas (estruturalismo, freudismo e, sobretudo, marxismo) que atavam, desde 1945, todas as inclinações do pensamento individual. ${ }^{444}$

O fim das ideologias, progressivo desde o final dos anos 60, completou-se na década de 80, com o desaparecimento dos grandes mestres, sem substituição até aquele momento. Também no

${ }^{442}$ Cultura, 13 de julho de 1980, p. 11.

${ }^{443}$ Cultura, 14 de agosto de 1983, p. 2.

${ }^{444}$ Ibid., p. 4 
campo do romance e da poesia, nenhum autor à altura se apresenta, como constatou em artigo anteriormente citado. Face a tal situação, o inevitável tom melancólico do texto é, no entanto, revertido em esperança em seu parágrafo final, como acontece em “O Fim da era dos gigantes?”:

Pelo menos podemos observar isto: uma espécie de aurora colore com os seus pálidos raios a literatura francesa em 1983. Esta aurora será prolongada por dias ensolarados ou por belas tempestades, ninguém o sabe, mas é preciso agir rapidamente. Apostamos, efetivamente, que, na sombra, especialistas, sem dúvida universitários, já estão manejando suas limas e serras para fabricar uma nova ideologia que virá tomar o lugar das falhas do existencialismo, do estruturalismo, do marxismo ou da linguística. ${ }^{445}$

Que aurora seria essa? Que sinais Lapouge estaria vendo no âmbito da literatura francesa naquele momento? Por outro lado, sua crença no movimento inexorável da história das ideias parece-me mais plausível, e o autor não perderá por esperar as novas vagas de ideologias, ou teorias, que dominarão o espaço literário na década seguinte, reunidas no vasto leque da pós-modernidade. O que ele provavelmente não poderia imaginar é que tais ideologias não seriam criadas na França, mas, num movimento contrário ao que na época era habitual, elas seriam levadas à Europa por ventos transatlânticos, oriundos de universidades estadunidenses.

Essa esperança, em 1990, ainda não havia tido eco. A morte de Althusser provoca novo artigo de Lapouge sobre a constatação de que uma era terminava e que ainda não se podia enxergar o que viria pela frente ${ }^{446}$. Como se o mundo da literatura tivesse entrado em compasso de espera, gerando uma angústia indisfarçável, presente nos artigos citados, apesar do constante esforço do autor de concluí-los com palavras de esperança. Com sua série sobre o tema, Lapouge exerce o papel de arauto do final de uma época.

Nessa função, é secundado por Sérgio Augusto que, em 1997, em plena pós-modernidade, em "Tiros pela culatra no QG da literatura", enxerga, na voga das teorias culturalistas e da desconstrução, o desaparecimento da França enquanto celeiro teórico do mundo. Jornalista cultural e, portanto, muito distante da sólida formação humanística de tantos autores mencionados nestre trabalho, Sérgio Augusto aborda o tema de maneira muito menos analítica e cuidadosa. Desfiando críticas sob a forma de lugares-comuns numa linguagem ao mesmo tempo descontraída e ácida, o autor defende a mesma tese de Lapouge - a cultura francesa perdeu os grandes mestres dos anos 50, 60 e 70 e não conseguiu substituí-los:

\footnotetext{
445 Ibidem.

446 “Louis Althusser, a morte com as ideologias", Cultura, $1^{\circ}$ de dezembro de 1990, p. 4.
} 
Exageros à parte, não há como negar que a cultura francesa perdeu um bocado do seu elã, do seu poder de fogo. Sua literatura é um lixo (o primeiro prego no caixão foi martelado pelo nouveau roman). Seus artistas plásticos há muito frequentam as divisões inferiores. Sua música popular não existe. Nem em Cannes seu cinema impõe mais respeito. Teóricos e pensadores tipo exportação, como os dois Jacques (Lacan e Derrida), Jean Baudrillard, Paul Virilio, Pierre Bourdieu, Michel Serres e Jean-François Lyotard eles ainda têm, mas isso parece ser pouco para um país que se acostumou a dominar o cérebro do mundo. E ainda não metabolizou o fato de ser um italiano o intelectual europeu de maior prestígio ou mais ampla audiência da atualidade. Umberto Eco, bien sûr. ${ }^{447}$

Como o trecho acima permite ver, o texto de Sérgio Augusto tem apenas em seu tema o ponto em comum com o lamento de Lapouge, publicado no jornal ao longo da década de 80. As afirmações taxativas e apressadas - a literatura francesa "é um lixo", as artes plásticas francesas pertencem a "divisões inferiores", "Sua música popular não existe”, etc. - não deixam espaço para um olhar pormenorizado que o panorama francês dos anos 90 merece. O autor, declaradamente, apóia sua leitura na visibilidade mercadológica da cultura, quando trata dos "Teóricos e pensadores tipo exportação", como se só tivesse qualidade a produção cultural aceita ou requisitada por outros mercados. E o pensamento imperialista aplicado à cultura ainda é reforçado pela constatação de que a França não mais "domina o cérebro do mundo", tendo perdido a causa para um intelectual italiano, ninguém menos do que Umberto Eco. Tal compreensão é colocada em relevo na legenda que acompanha as fotografias de Lacan, Barthes e Sartre: "sem substituição à altura para dominar o cérebro do mundo".

Essa leitura da produção cultural, além de ser cega e surda às obras que não visam o mercado, também não admite a diversidade, criticando a cultura francesa como um todo por não mais exercer o fascínio alcançado em outros séculos e na década de 60 do século XX. Tal ponto de vista esclarece mais sobre o autor do que sobre o objeto criticado: evidencia o perfil de "especialista em cultura" de Sérgio Augusto, ou seja, um profissional do jornalismo chamado a divulgar e a opinar sobre todos os componentes da "cultura" sem, todavia, ter conhecimento para tanto. O que conduz fatalmente à torrente de estereótipos de que seu artigo se compõe.

Já no século XXI, a mesma questão foi colocada, com fatura muito semelhante, pela revista estadunidense Time Magazine, quando, em 2007, dedicou a capa de sua edição europeia a "The Death of French culture" ${ }^{448}$. O artigo sobre a "decadência da cultura francesa", assinado pelo jornalista radicado em Paris, Donald Morrisson, segue a mesma linha de pensamento do artigo de Sérgio Augusto, ou seja: a cultura francesa está morta porque não tem a circulação de outrora, ou

\footnotetext{
${ }^{447}$ Caderno 2/ Cultura, 7 de junho de 1997, p. D3.

${ }^{448}$ Nova Iorque, 21 de novembro de 2007. Disponível em: http://www.time.com/time/magazine/article/0,9171,1686532,00.html (acesso em 19/05/2013).
} 
porque não é absorvida pelos mercados como acontecia em outras épocas. Ao artigo seguiram-se várias réplicas por parte de intelectuais franceses como Maurice Druon, da Académie Française, e Antoine Compagnon, do Collège de France, dentre outros. No calor da hora, a editora Denoël publicou um volume contendo um ensaio de Morrisson e outro de Compagnon, registrando a discussão ${ }^{449}$.

Para além de debates sobre o mercado da cultura francesa e constatações sobre a diminuição de sua influência no mundo, os anos pós-estruturalistas $(80,90,2000)$ paradoxalmente parecem nunca ter se recuperado da febre estruturalista, lamentando seu fim e procurando novos ídolos para ocupar as cadeiras dos maîtres à penser desaparecidos. Para aqueles que viveram as quatro décadas pós-1945, como Lapouge, as mortes de Barthes, Sartre, Lacan, Althusser e Foucault encerram o período de ouro da teoria literária francesa e iniciam um momento de perda de rumos. Para jornalistas pertencentes a uma geração mais nova, como Sérgio Augusto e Donald Morrison, a ausência dos grandes mestres é uma ferida aberta que deflagra a fragilidade de uma cultura doente. Para todos que se manifestam sobre o assunto, o mesmo gosto amargo de final de enterro.

\section{Barthes e o jornalismo cultural}

As reflexões engendradas pelo desaparecimento de toda uma geração de teóricos brilhantes, conduzidas principalmente por Lapouge, têm o grau de profundidade possível para um veículo como o jornal até meados dos anos 70. No entanto, a partir dos anos 80, as análises do jornalista francês começam a destoar dos demais textos encontrados no jornal: predominam, então, na imprensa de massa, os artigos de divulgação cultural, via de regra textos informativos porém rasos, quando não em tom forçadamente polêmico, apesar de vazios de argumentos. Eis aí as características da crítica cultural, que substituiu as críticas diletante e universitária. A primeira tendo sido extinta, a segunda tendo migrado para as universidades e para os periódicos acadêmicos, o espaço da crítica, nos jornais, foi ocupado pelos jornalistas culturais. E são majoritariamente eles que passam a citar Barthes depois de sua morte.

Embora a escassez de textos que analisam e discutem a obra de Barthes se deva à crítica cultural, o espaço que o jornal disponibiliza à cultura, de um modo geral, também determina, em parte, o tipo de texto a ser publicado. A partir dos anos 80, a tônica é dada às reportagens sobre acontecimentos culturais, às notícias sobre eventos. Escreve-se muito sobre prêmios, como o Prêmio Jabuti de Literatura ou o Prêmio Eldorado de Música, sobre novos autores e lançamentos de obras,

${ }^{449}$ Que reste-t-il de la culture française? suivi de Le Souci de la grandeur, Paris, Denoël, 2008. 
mas toda essa informação é agrupada no espaço comum da "cultura", no Caderno 2, no caderno Cultura e no Sabático, no caso de $O$ Estado. Teatro, música, cinema, literatura, pintura, fotografia, escultura, dança, gravura, história, filosofia, televisão, sociologia, estética, teoria da comunicação... tudo tem o mesmo destino, o caderno cultural do jornal, e o acontecimento se sobrepõe à reflexão. Dentro dessa lógica, têm relevo os livros, sobretudo os novos, mas não a literatura propriamente. Em suma, o desaparecimento dos grandes teóricos franceses, no Brasil, coincidiu com a mudança dos parâmetros críticos nos jornais.

Tal mudança foi sentida e acusada no próprio jornal, por jornalistas e professores universitários, em reportagens e artigos de opinião que enfatizam aspectos diferentes da "crise da crítica", como foi chamada. Eduardo Maretti, em "Acadêmicos, entre a tese e o jornalismo" 450 , noticia o lançamento da revista Resgate, da Unicamp, em 1990, como uma feliz tentativa de aproximação entre a universidade e a sociedade. Assim como aconteceu nos anos 50, uma vez mais é diagnosticado o isolamento da universidade, e a publicação de revistas acadêmicas que buscam divulgar a produção científica a um público mais vasto, extramuros, é saudada como iniciativa importante. A relevância desse artigo reside em apontar a condição universitária como destacada do contexto social brasileiro, o que, dentre outras consequências, reflete-se no divórcio entre a crítica universitária e a crítica jornalística, esta mais atrativa à grande massa que ora se constitui como público leitor do jornal.

A mesma constatação transparece em "Universidade deve preparar público para fruição cultural" ${ }^{451}$, resumo das conferências promovidas por $O$ Estado de S. Paulo acerca das relações entre as produções artísticas e a universidade, com os professores da USP Teixeira Coelho, Leyla Perrone-Moisés e Eduardo Peñuela Cañizal, em 1993. O ponto comum das considerações dos três conferencistas se encontra na compreensão da distância entre a universidade e o gosto popular, que não aprecia as grandes obras plásticas, literárias e cinematográficas, para ficar nos domínios de especialidade dos professores citados. A conclusão dos debates engendrados pelo evento dá título à reportagem: a função da universidade seria a de formar um público mais amplo para as obras de arte clássicas e de vanguarda.

Sem se referir à universidade, Adílson Citelli, professor da USP, também reflete sobre a cisão entre a cultura de massa e os clássicos. Em "Cultura de massa marginaliza obras-primas" ${ }^{452}$, artigo de 1994, o autor defende a leitura de obras como Édipo Rei, os romances de Balzac, A la

\footnotetext{
${ }^{450}$ Caderno 2, "Leitura", quinta-feira, 2 de agosto de 1990, p. 4.

${ }^{451}$ Cultura, sábado, 24 de abril de 1993, p. 1.

${ }^{452}$ Caderno 2 Especial Domingo, 2 de fevereiro de 1994, p. D3.
} 
Recherche du temps perdu, os poemas de Baudelaire e de Mallarmé e Grande sertão: Veredas, colocando em relevo a dimensão humana que compõe todos os grandes clássicos da literatura e da arte. Fator de enriquecimento pessoal, as situações atemporais e universais recriadas nos textos literários, teoricamente não deixariam de interessar aos leitores da pós-modernidade. Todavia, esta parece ter relegado os clássicos ao limbo das "leituras difíceis" ou "de elite", em prol de uma suposta democratização da cultura, privilegiando textos muitas vezes superficiais e de autoria de escritores mais respeitados pelas causas que defendem do que pela qualidade estética de suas obras.

Também refletindo sobre o tema, Leyla Perrone-Moisés se interroga, em 1996: “Que fim levou a crítica literária?", texto publicado no jornal Folha de S. Paulo e posteriormente recolhido na coletânea de ensaios Inútil poesia e outros ensaios breves. A autora se detém sobre a situação atual da crítica traçando, resumidamente, seu diagnóstico: "Hoje, em tempos ditos pós-modernos, ela [a crítica] anda um pouco anêmica, reduzida ao rápido resenhismo jornalístico, necessário mas não suficiente." ${ }^{453}$ Arremedo do que fora nos séculos XVIII e XIX, a crítica jornalística, aos olhos da autora, é mais um produto da pós-modernidade. Pois para Leyla Perrone-Moisés, a onda dos Cultural Studies teve o efeito de um verdadeiro tsunami, reduzindo a literatura a um simples repositório de memória e cultura, substituindo as obras, até então consideradas clássicas e canônicas, por obras reconhecidas por sua combatividade social. Nessa nova ideologia dominante, a crítica literária tem pouca ou nenhuma razão de ser, pois com a substituição do cânone que tinha em seus pilares mais ou menos os mesmos princípios estéticos desde o século XVIII, desaparecem os padrões segundo os quais as obras eram julgadas. Para a autora, em resumo, "A desconfiança na estética como disciplina idealista e elitista, a proliferação de critérios particulares e o questionamento do 'grande relato' que constitui a história ocidental solapam as bases de qualquer crítica." Mais adiante, ela completa:

Ora, não pode existir crítica literária se não houver um conjunto de valores estéticos reconhecidos e, por conseguinte, un cânone de referência. Não pode mais existir crítica se não houver um conceito forte de literatura, tal como houve durante os dois últimos séculos e como ainda havia na alta modernidade literária. (...) E a crítica literária, sua correlata [da literatura], era diálogo, ampliação da leitura, extensão do saber e da ação da obra. ${ }^{454}$

A autora explica como a crítica literária, compreendida como uma prática diferente da crítica jornalística, não tem lugar na pós-modernidade e propõe, ao final de seu texto, diante da nova

\footnotetext{
${ }^{453}$ São Paulo, Companhia das Letras, 2000, p.335.

${ }^{454}$ Ibid., pp.341-342.
} 
concepção de literatura que ora se impõe, que escritores, professores e críticos se desloquem, como fazia Barthes quando sentia que iria se tornar prisioneiro da doxa.

Leyla Perrone-Moisés apresenta uma visão extremamente negativa da pós-modernidade, desconsiderando que o mesmo ecletismo que, a princípio, faz tábula rasa de tudo em nome de “critérios particulares", também acolhe os "velhos" critérios estéticos e aceita os grandes clássicos da literatura de sempre. Na pós-modernidade da fatuidade do tempo, da entronização quase instantânea de autores e de obras, das paixões literárias sazonais, há sempre espaço para novas leituras de Racine, Rousseau, Baudelaire, Proust, Sartre, e de outros grandes nomes da literatura. E pouco importa se, hoje, A la Recherche du temps perdu desperta menos interesse por sua construção poética do que é admirado como romance de temática homossexual: a obra máxima de Proust continua a defender seu lugar no cânone universal, resistindo às leituras as mais enviesadas e improváveis. O conceito forte de literatura, a meu ver, existe na pós-modernidade, comportando um número até então impensável de facetas, constituindo-se de possibilidades quase infinitas de objetos e leituras. O consenso, portanto, é necessariamente impossível. E a crítica literária, nesse contexto, não pode mais ser concebida como o foi até as décadas de 60 e 70: que ela seja mais criativa e menos judicativa em tempos em que praticamente os valores universais foram substituídos por uma infinitude de valores particulares. Desloquemo-nos em direção ao conceito de crítica de Barthes em Critique et vérité, recuperando e revigorando a ideia de se buscar as validades da obra analisada, como pretexto para se escrever uma nova obra, suspendendo os juízos de valores.

Em minha perspectiva, portanto, a crise da crítica literária se deve à pós-modernidade, mas não é prisioneira dela. A crítica, hoje, não tem o vigor e a inventividade de outrora porque seus autores, nos jornais, não têm a formação literária necessária para exercê-la com competência. Em outras palavras, foi a substituição dos intelectuais - diletantes ou universitários - por jornalistas, a causa da decadência da crítica - nos jornais, pois nos periódicos universitários, sobretudo nas revistas sustentadas por programas de pós-graduação de relevo, ela se porta bem.

Escritor célebre, Barthes, naturalmente, foi constantemente objeto, ou melhor, vítima do jornalismo cultural. A exposição comemorativa dos cinquenta anos de publicação de Le Degré zéro de l'écriture, no Centre Georges Pompidou, em Paris, em 2003, foi um prato cheio para a imprensa. Sheila Leirner, em artigo muito elogioso sobre a exposição ${ }^{455}$, exaltando seu caráter multimidiático, refere-se a Barthes como um "ícone do século XX”, por seu vasto leque de interesses. Eis aí uma imagem do escritor que ganha destaque, desde seu desaparecimento: "ícone do século XX”, ou seja,

455 “Barthes, presente numa rede de imagens", Caderno 2/ Cultura, “Literatura”, 2 de fevereiro de 2003, p. D7. 
uma imagem (“ícone” vem do grego eikon, imagem) representativa de um período histórico. Barthes encarnaria o finado século XX pela pluralidade de temas que abordou, aos olhos de Leirner. Visão, contudo, mais adequada à pós-modernidade do final do século. Esta, por meio dos textos dos jornalistas culturais, preocupou-se menos em discutir Barthes do que em celebrá-lo, citando-o com e sem propriedade, por gosto pelo anedótico cult, somente como uma referência com a qual se acostuma ou por falta de conhecimento de sua obra.

Na década de 80, por exemplo, Stefânia Bril, crítica de fotografia do jornal, não poupou citações aos conceitos barthesianos presentes em La Chambre claire, em seus artigos sobre exposições realizadas em São Paulo. O punctum, o operator, o spectrum, e outras alusões ao último livro de Barthes são uma constante em seus textos e evidenciam não só a compreensão, mas, sobretudo, a apropriação da teoria do escritor sobre a fotografia. A propósito da exposição de Carlos Freire, no Museu de Arte de São Paulo, em 1981, escreve: “Carlos Freire consegue o que Roland Barthes, como spectator, pede ao fotógrafo: 'Gostaria, em suma, que a minha imagem móvel, vagando por entre mil fotos mutantes, ao sabor das situações, das idades, coincida sempre com o meu eu'." 456 O desejo de Barthes de fazer coincidir seu eu com sua imagem era um ideal inalcansável, como ele mesmo sabia e foi explicitado na Introdução deste trabalho. No entanto, da citação feita por Bril, fica a ideia da mobilidade da imagem, de seu vagar pelo tempo e pelo espaço, como de fato aconteceu e acontece nas páginas de jornal com a imagem do escritor francês, que se transforma a cada apropriação de que é objeto, a cada texto a que é integrada.

A imagem de Barthes, frequentemente, tem sido usada na crítica cultural como referência, sem menção alguma a obras, conceitos ou ideias, com o objetivo de agregar um valor de contemporaneidade e de cultura ao texto. Por exemplo, em "Máquina de escrever: o prodígio de aço que o computador matou", de 2007, Sérgio Augusto discorre sobre a máquina de escrever, sua história e algumas anedotas a respeito de seu papel para escritores famosos. Para tanto, baseia-se em The Iron whim: a fragmentary history of typewriting, livro de Darren Wershler-Henry, então recémlançado nos Estados Unidos e disponível na Amazon, segundo informa o autor. Sua apreciação da obra reflete bem as análises caras ao jornalismo cultural: "Embora fragmentária e um tanto pósmodernista para o meu gosto, seu estoque de curiosidades [do livro citado] é grande o bastante para deleitar os leitores pouco ou nada interessados em Roland Barthes, Michel Foucault e Jean Baudrillard" ${ }^{457}$. Na qualidade de eclética e libertária, a pós-modernidade comporta também a crítica de si mesma, como o faz o jornalista, principalmente quando sustentada pelo critério de aferição de

\footnotetext{
456 “Apaixonante diálogo com a multidão”, Geral, 6 de agosto de 1981, p. 31.

${ }^{457}$ Caderno 2, "Literatura Resgate", 14 de abril de 2007, p. D7.
} 
valor em vigor: o gosto pessoal. Por isso, as curiosidades que o livro apresenta, de leitura fácil e informativa, nada têm a ver com a experiência de leitura das obras de alguns mestres da pósmodernidade, dentre os quais, Barthes. Pela oposição estabelecida entre os tipos de texto apresentados pelo livro e pelos escritos dos intelectuais franceses citados, o autor distingue dois públicos: o primeiro, habituado aos fragmentos e à ligeireza da anedota, à moda pós-moderna, e o segundo, capaz de ler Barthes, Foucault e Baudrillard.

Embora critique a pós-modernidade em sua superficialidade, Sérgio Augusto não cita autores do quilate de Proust, Joyce ou Sartre, como exemplos de escritores densos e, portanto, de pouco interesse para o público do livro resenhado. Ele menciona os grandes ícones do momento, sabendo que seus nomes serão reconhecidos pelos leitores por serem representativos de uma cultura mais intelectualizada e de não tão fácil acesso. O problema é que apenas lançando os nomes desses ícones, sem nenhum tipo de explicação ou reflexão, o autor simplesmente entra no círculo vicioso do jornalismo cultural que encerrou Barthes e outros escritores na pós-modernidade: suas obras não mais são lidas ou relidas, reavaliadas e discutidas. Nem sequer existem mais, tendo restado somente os nomes de seus autores, emblemas opacos a refletir indefinidamente o brilho de sua celebridade, que impede que se enxerguem o que os tornou famosos. Crítico da pós-modernidade obtusa, Sérgio Augusto, contudo, contribui para a cegueira generalizada em torno de Barthes e outros escritores modernos, calando sobre eles.

Outro exemplo sintomático da apropriação pós-moderna de Barthes encontra-se em artigo de João Marcos Coelho, que assina a crítica de música erudita de $O$ Estado. Em "A Paixão encantatória de Mahler", sobre a leitura do regente Justin Brown da Quarta Sinfonia de Mahler, executada pela Orquestra Sinfônica do Estado de São Paulo, o autor cita Barthes no parágrafo introdutório:

Nenhuma música na Terra pode ser comparada à nossa, canta a soprano no movimento final da Quarta Sinfonia de Mahler. De fato, como as cantatas de Bach e as sinfonias de Beethoven, a partir da Eroica, os vastos afrescos sinfônicos de Mahler convidam não só à participação num ritual virtualmente comunitário, mas quase sempre nos alertam, como disse Roland Barthes: "Ouçam, vou tocar algo que vocês nunca ouviram". ${ }^{458}$

O parágrafo segue sem qualquer outra menção ao escritor francês ou ao contexto em que ele proferiu a frase citada. Banal, desprovida de conceitos ou de uma reflexão elaborada, "Ouçam, vou tocar algo que vocês nunca ouviram." poderia ter sido dita por qualquer um apto a tocar um

${ }^{458}$ Caderno 2, "Música. Erudito", 22 de março de 2010, p. D5. 
instrumento musical. Mas o autor pretende que seja uma frase de Barthes. Como acontece na imensa maioria das críticas jornalísticas do período, inserir o nome do escritor francês no texto tem mais importância do que mencionar sua obra. Ou, pior ainda, tem mais valor até mesmo do que o que está sendo citado, que passa a ter sua função invertida e é relegado à categoria de mero pretexto ${ }^{459}$.

Como se estivesse prevendo seu futuro como celebridade pós-moderna, Barthes escrevia, em 1975, em Roland Barthes par Roland Barthes, o que poderia ser lido como um protesto contra sua condição atual: "Voici une suite de propositions démodées (si elles n’étaient contradictoires): je ne serais rien si je n'écrivais pas. Cependant je suis ailleurs que là où j'écris. Je vaux mieux que ce que j'écris." 460 Naquele momento, reivindicar uma existência para além de uma imagem (a de escritor) já era um lugar comum e, portanto, apontado como fora de moda. A crítica cultural, pela exploração frenética da imagem de suas referências, parece ter adotado essa premissa: a imagem de Barthes vale mais do que seus escritos.

\section{Fragmentos de um discurso amoroso, a peça teatral}

Em meio às reflexões e lamentos ensejados pelo desaparecimento de Barthes, o sucesso dos Fragmentos de um discurso amoroso, publicado no Brasil somente em 1981, conferiu à memória do escritor um tom festivo para parte da crítica jornalística. Na França, como em outros países, a recepção a essa obra foi avassaladora, a ponto de se tornar um best seller, fenômeno raro quando o livro é assinado por um intelectual respeitado por elaborados conceitos literários. Barthes tinha consciência do caráter extraordinário de tal sucesso de vendas, e o explica na já referida entrevista a Philip Brooks, para Le Nouvel Observateur, publicada na edição da revista de 20 de abril de 1980:

J'ai dit que Fragments serait mon livre "le plus lu et le plus vite oublié", parce que c'est un bouquin qui a atteint un public qui n'est tout de même pas le mien. Et il est probable qu'avec mes autres livres, et surtout celui sur la photo, je vais retrouver mon public, qui est moins important.

\footnotetext{
${ }^{459}$ No seminário dedicado ao Neutro, ministrado no Collège de France de 1977-1978, Barthes investiga a resposta como forma discursiva e reflete sobre o jogo de perguntas e respostas das entrevistas jornalísticas, observando a diferença de recepção, na imprensa, de dois de seus livros, o que implica em uma mudança em relação ao exercício do poder no discurso jornalístico. Essa mudança acaba por engendrar um deslocamento no foco do interesse do jornalista: da obra, passa-se à pessoa, tal como observo. Nas palavras de Barthes, “(...) b) multiplicação das entrevistas, arrogância, a cominação da pergunta: índice da ascensão atual do jornalismo como poder. Entrevista (perguntas sobre tudo): direito régio do jornalista sobre o entrevistado. Entrevista: tende a substituir a crítica. Há vinte anos, O Grau zero da escrita: dossiê crítico $\neq$ hoje, Fragmentos de um discurso amoroso: dossiê de entrevistas. Não vale a pena comentar um livro: vamos interrogar o autor; mas o direito, a ascendência do jornalista (sua voz distante) volta na forma do pressuposto das perguntas, do terrorismo da pergunta: jornalista: uma espécie de policial que gosta de você, que lhe quer bem, pois lhe dá a palavra e lhe oferece a publicidade." In O Neutro, anotações de aulas e seminários ministrados no Collège de France, 1977-1978. Texto estabelecido, anotado e apresentado por Thomas Clerc, tradução de Ivone Castilho Benedetti, São Paulo, Martins Fontes, 2003, pp. 222-223.

460 "Moi, je", $O C$ v. 4, p. 741.
} 
Parce que Le Discours amoureux n'était pas très intellectualiste mais assez projectif; on peut s'y projeter non pas à partir d'une situation culturelle mais à partir d'une situation qui est la situation amoureuse. Tandis que, dans les autres livres, je continuerai probablement à partir d'une situation plus intellectuelle. Mais ça, je ne sais pas, je ne peux pas parler de l'avenir. ${ }^{461}$

Como fino analista da cultura de massa, de que Mythologies é o melhor exemplo, Barthes conhecia a fórmula do sucesso de vendas: um texto sobre o qual o leitor pudesse se projetar, capaz de despertar o sentimento de que fora escrito para ele, como dois amigos, escritor e leitor, que partilham uma experiência comum. No entanto, sua intenção nunca foi a de escrever um "livro de sucesso", no sentido mercadológico da expressão, mas de levar a termo uma pesquisa de dois anos desenvolvida na École des Hautes Études, onde trabalhava e animava um seminário de estudos avançados. Integrante de uma equipe de pesquisadores que tinham nas noções de discurso e de discursividade seu objeto, Barthes escolheu estudar o discurso amoroso, e durante dois anos expôs e debateu suas reflexões com seus interlocutores, no espaço de seu seminário. Constatando que tanto ele, quanto os ouvintes, projetavam-se no que era dito, o escritor conclui:

Dans ces conditions, je me suis dit que l'honnêteté, à partir du moment où je passais du séminaire au livre, était non pas d'écrire un traité sur le discours amoureux, car cela aurait été une sorte de mensonge (je ne prétendais plus à une généralité de type scientifique), mais au contraire d'écrire moi-même le discours d'un sujet amoureux. Il y a eu un renversement. ${ }^{462}$

A reviravolta na maneira de abordar o tema do discurso amoroso significou mais uma reviravolta em sua trajetória intelectual, tanto pelo assunto de seu livro, quanto por seu alcance. No Brasil, a recepção aos Fragmentos foi ambivalente: por um lado, também foi um grande sucesso de público, pois a primeira tradução, de 1981, teve 12 edições até 1994; por outro, o livro teve um acolhimento frio em $O$ Estado, contando com apenas duas críticas: de Leyla Perrone-Moisés, datada de outubro de 1977 e já apresentada no capítulo anterior, e de José Maria Cançado, publicada em setembro de 1981.

"Tratado sobre o desejo e seu rastro linguístico", de Cançado, tem por introdução as primeiras reações suscitadas pelos Fragmentos: "Resta lugar no mundo administrado para o absoluto do amor e do desejo? Para a sua disposição de deixar-se gastar sem reservas? E isso num mundo em que tudo é regulado quase contabilmente?" ${ }^{463} \mathrm{O}$ inusitado do tema provoca tais questões

\footnotetext{
461 “La crise du désir", $O C$ v. 5, p. 944.

${ }^{462}$ Entrevista a Jacques Henric para Art-Press, publicada em maio de 1977. In $O C$ v. 5, p. 401.

${ }^{463}$ Geral, 27 de setembro de 1981, p. 36.
} 
e coloca o então novo livro de Barthes no Brasil onde ninguém esperaria que estivesse. Estratégia do escritor que, em entrevista, afirma:

Ma pensée profonde sur le sujet amoureux est qu'il est un marginal. D'où la décision, d'une certaine façon, pour moi de publier ce livre en tant que donnant une voix à une marginalité d'autant plus forte aujourd'hui qu'elle n'est même pas dans la mode des marginaux. Un livre sur le discours amoureux est beaucoup plus kitsch qu'un livre sur les drogués, par exemple. ${ }^{464}$

Marginal dentre os marginais, o discurso amoroso, para Cançado, faz com que Barthes entre "pela porta dos fundos da nossa cultura verbal", dando voz a uma fala sem prestígio universitário, "sem nenhuma função social" ${ }^{465}$. Mas para o autor do artigo, essa porta, embora sem glamur, permite ao escritor desvelar esse tipo de discurso aparentemente tão banal, jogando luzes sobre as doçuras e as angústias, principalmente sobre as intermitências dos efeitos do amor. Diante da trivialidade das situações que o livro desfila ao leitor, Cançado novamente evoca o julgamento inexorável do utilitarismo de seu tempo: “É certo que ocorram perguntas de todos os lados: 'Mas a que vem tamanha bobagem? A que vem esse enciclopedismo de segunda, essa quinquilharia toda, essa sabedoria de cortesão? A que vem esse livro quase desfrutável?" " 466 A resposta está na identificação do leitor com o texto, na projeção que este exige, a ponto de Cançado sugerir um novo título,"Leitores e enamorados reunidos", resumindo a convivência, mesmo que nos domínios do Imaginário, que o texto barthesiano proporciona.

Apesar de seu sucesso de vendas também no Brasil, ou, quem sabe, por causa desse sucesso, Fragmentos não recebeu um número de críticas proporcional a sua repercussão. Somente sete anos depois da publicação de sua primeira tradução e onze após seu lançamento na França, a obra passou a frequentar as páginas de $O$ Estado, por ocasião da montagem da peça teatral de mesmo título ${ }^{467}$.

A adaptação do romance de Barthes para o teatro surgiu no âmbito de uma disciplina de pós-graduação sobre o escritor francês, ministrada por Leyla Perrone-Moisés, na Universidade de São Paulo, em 1983: a então aluna Teresa de Almeida escolheu fazer seu trabalho de aproveitamento de curso dentro do tema "Roland Barthes e o amor", um dos propostos pela

${ }^{464}$ Entrevista a Jacques Henric para Art-Press, publicada em maio de 1977. In $O C$ v. 5, p. 403.

${ }^{465}$ Geral, 27 de setembro de 1981, p. 36.

${ }^{466}$ Ibidem.

467 Além da montagem de 1988, encontrei outra adaptação de Fragmentos de um discurso amoroso para o teatro, entitulada Enamorados e dirigida por Marcelo Lazzaratto. A peça esteve em cartaz em São Paulo em agosto de 2001. Houve também várias outras peças mais livremente inspiradas no livro de Barthes - e que não propunham exatamente sua encenação, mas reivindicavam a obra barthesiana como fonte -, bem como inúmeros espetáculos de dança que tiveram nos Fragments barthesianos seu ponto de partida. Mais recentemente, em 2011, o grupo teatral Os Crespos levou aos palcos de São Paulo uma nova montagem do livro de Barthes. 
ministrante. Tendo em vista a formação da aluna como atriz, Leyla Perrone-Moisés sugeriu que, ao invés de redigir um ensaio acadêmico, Teresa de Almeida adaptasse Fragments d'un discours amoureux para o teatro, o que resultou no trabalho sobre 12 fragmentos, desenvolvido em uma linguagem coloquial e que contém a ideia geral do livro. Ao longo dos anos, o texto foi apreciado por vários críticos teatrais e passou pelas mãos de atores, até chegar a Antônio Fagundes em 1987. O ator, então já um nome conhecido nacionalmente, decidiu montar a peça, tendo nela o papel principal. A Companhia Estável de Repertório, grupo teatral com o qual trabalhava, comprou a ideia e, com a direção de Ulysses Cruz, cenários de Ninette Van Vuchelen, trilha sonora original de André Abujamra e as atuações de Marcos Winter, Mara Carvalho, Luís Furlanetto, Jarbas Toledo e do próprio Fagundes, estreou no Teatro Cultura Artística, em São Paulo, em 10 de março de $1988^{468}$.

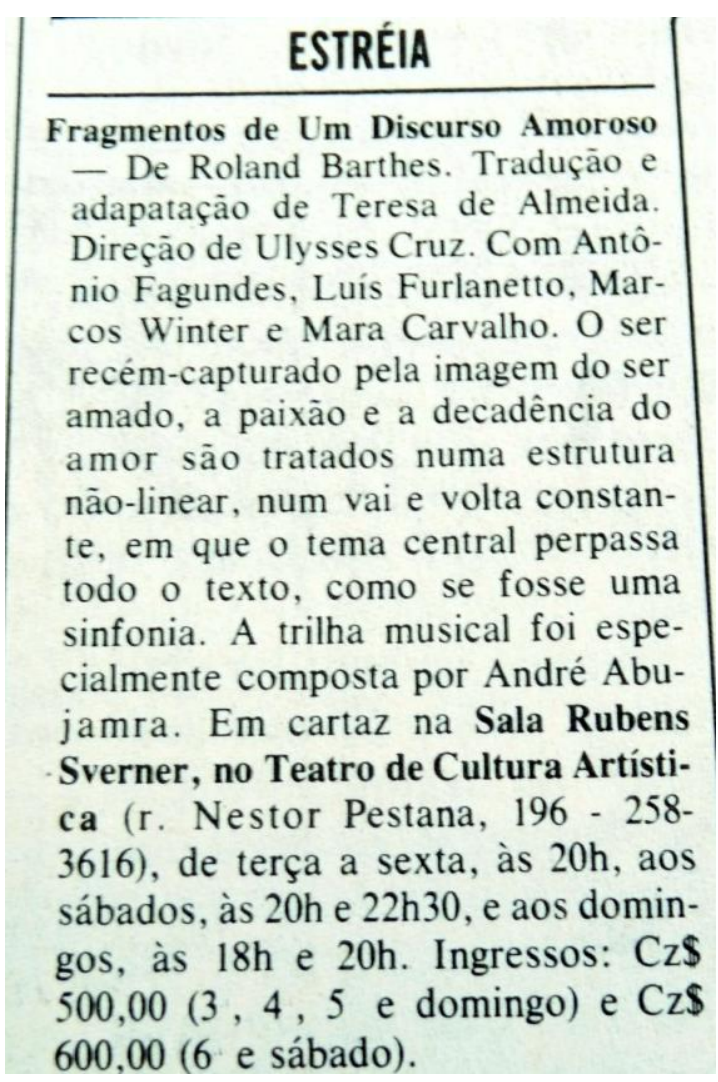

Anúncio de estreia da peça Fragmentos de um discurso amoroso O Estado de S. Paulo, Caderno 2, p. 6.

\footnotetext{
${ }^{468}$ Informações obtidas em artigo de Sílvia Penteado, “A Paixão segundo Roland Barthes”, Caderno 2, “Aplausos”, 5 de março de 1988, p. 3, e nos anúncios da peça veiculados em $O$ Estado de S. Paulo.
} 
O acolhimento da crítica à peça foi o melhor possível, dando maior visibilidade a Barthes frente a um público ainda mais amplo do que o alcançado pelos Fragmentos, o livro. Tudo foi elogiado: o texto, a atuação de Fagundes, a trilha sonora, a direção de Cruz. As temporadas em cartaz em São Paulo se sucederam, até que a quarta e última se encerrou com a apresentação de 16 de março de 1989. A peça também foi apresentada em palcos de outras cidades brasileiras, tendo atraído grande público. Seu sucesso foi coroado pelo prestigioso prêmio Molière de melhor ator do teatro brasileiro, conferido em 1988 a Antônio Fagundes por sua performance na peça ${ }^{469}$.

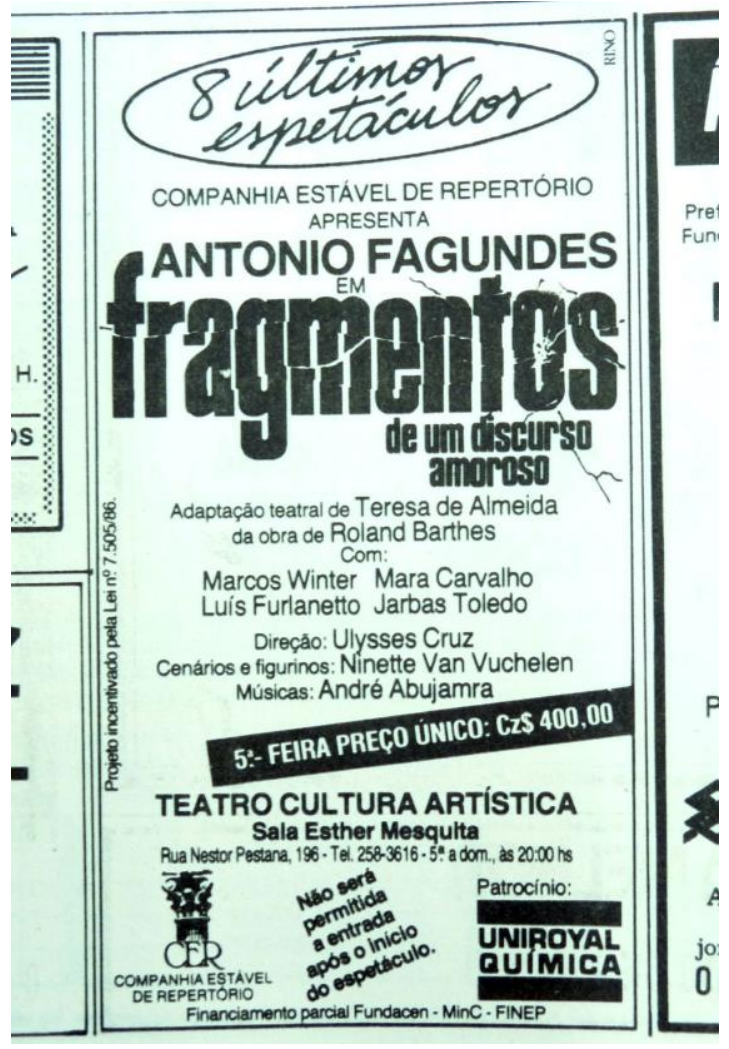

Propaganda da $2^{\mathrm{a}}$ temporada da peça Fragmentos de um discurso amoroso O Estado de S. Paulo, Caderno 2, 26 de maio de 1988.

No jornal, portanto, a recepção a Fragments d'un discours amoureux não pode ser dissociada da recepção à peça teatral, mesmo que esta tenha sido levada aos palcos somente sete anos mais tarde, a contar a partir da publicação de sua tradução. A peça proporcionou ao livro uma

\footnotetext{
${ }^{469}$ Fragments d'un discours amoureux também teve várias adaptações para o teatro na França, sendo que a última delas foi assinada por Arnaud Churin e levada ao palco do Théâtre de la Bastille em 2010 e 2011.
} 
nova voga de interesse, novas edições e uma ainda maior popularização: apesar de seu sucesso não ter se revertido em textos críticos, nem em citações diretas, mensuráveis na pesquisa de corpus, ele pode ser atestado por toda uma gama de citações indiretas que pululavam no jornal nas décadas de 80,90 e nos primeiros anos de $2000^{470}$.

Ao som do sucesso de 1977 de John Paul Young, "Love is in the air", que ainda ecoava no Brasil dos anos 80, e da repercussão dos lançamentos de Histoires d'amour (1983) e $A u$ commencement était l'amour. Psychanalyse et foi (1995), de Julia Kristeva, o amor parece ser um dos grandes temas da época do post mortem barthesiano. Em 1986 a Fundação Nacional de Arte (Funarte) promoveu um ciclo de palestras sobre os sentidos da paixão em autores como Platão, Freud, Pasolini, Stendhal, Montaigne e Clarice Lispector, dentre outros autores, proferidas por renomados intelectuais brasileiros e estrangeiros radicados no Brasil. Em São Paulo, Brasília, Curitiba e no Rio de Janeiro, onde as palestras foram realizadas, o público superou as expectativas dos organizadores. O Estado de S. Paulo noticiou o evento com a manchete "Quando o amor vira a cabeça", relatando as reações do público e suas impressões sobre os eventos. A respeito da inesperada procura pelas palestras, um espectador entrevistado arrisca uma explicação: “Cláudio acha também que tanta gente apareceu porque o tema está na moda 'e de repente é chique dizer para os amigos que participou do curso, " 471 .

Definitivamente, love was in the air naquele momento e os Fragmentos de Barthes, em português, sob a forma de livro e de peça teatral, alimentavam a onda e nela surfavam. Em 1988, o cenário da peça de teatro Praga, de Gerald Thomas, é um restaurante fictício localizado na capital Tcheca cujo nome é... Barthes! O que demonstra, por um lado, a consolidação do nome do escritor na qualidade de signo emblemático e familiar, capaz de ser lido pelo menos em parte de sua complexidade pelo público de teatro à época. Por outro lado, o "restaurante Barthes" também se constitui como fenômeno de apropriação dentro de um circuito extra-literário e extra-acadêmico, ainda pertencente à esfera intelectual, mas com um toque popular.

A apropriação de Barthes e, mais especificamente, dos Fragments d'un discours amoureux, marcou uma forma de recepção inusitada para a obra do escritor francês. Até então suas ideias e seus textos eram citados em artigos, com direito a notas de rodapé, reprodução de suas palavras

\footnotetext{
${ }^{470}$ Fragments d'un discours amoureux também inspirou o curta metragem A Espera, escrito e dirigido por Luiz Fernando Carvalho, tendo sido agraciado com os prêmios de melhor filme, melhor atriz e melhor fotografia no Festival de Cinema de Gramado, em 1986, além de outras distinções internacionais. O mesmo livro foi igualmente o ponto de partida para o média metragem de 45 minutos Carlota Amorosidade, de Adílson Ruiz, que participou da mostra de curtas do Festival de Cinema de Gramado de 1988. Sobre este último filme, cf. Carlos Motta, "Os Curtas que fazem inveja a muito longa", Caderno 2, 23 de junho de 1988, p. 10.

${ }^{471}$ Moisés Kakowicz, "Quando o amor vira a cabeça", Caderno 2, 4 de outubro de 1986, p. 1.
} 
entre aspas ou sob forma de paráfrases. Pois com os Fragments foi diferente: pouquíssimo comentado e discutido, como já afirmei, o livro, embalado pela "moda do amor" e pelos sucessos de vendagem e de público no teatro, foi diretamente incorporado à linguagem de jornalistas culturais e tornou-se objeto de jogos de palavras, da década de 80 em diante. Assim, em 1987, em reportagem sobre a posse de Gilberto Gil como Secretário da Cultura de Salvador, trechos de seu discurso foram reproduzidos sob o título "Fragmentos de um discurso vigoroso" ${ }^{472}$. Em 2001, o artigo sobre a nova coreografia do Balé da Cidade de São Paulo, "Como se não coubesse no peito", teve por título "Fragmentos coreografados do discurso amoroso" ${ }^{473}$. Um ano depois, "No palco, fragmentos de um triângulo amoroso", anunciava a estreia da peça Souvenirs, de Fernando Bonassi e Victor Navas, sobre uma mulher que trai o marido ${ }^{474}$. Em 2003, "Fragmentos de um discurso rigoroso", sobre a posse de Gilberto Gil como Ministro da Cultura, dialoga com o texto de 87 e sua então condição de Secretário da Cultura, com o discurso "vigoroso" daquela ocasião, bem como com o título de Barthes ${ }^{475}$. Nesses textos - exceto no artigo sobre o espetáculo do Balé da Cidade de São Paulo ${ }^{476}$ - nem o escritor e nem sua obra sequer são mencionados. Ou seja, na maioria dos textos que encontrei, a referência aos Fragments fala por si, sem que haja a necessidade de qualquer tipo de explicação complementar. Tais títulos, encabeçando textos jornalísticos, são verdadeiras piscadelas para os leitores que, certamente, entendiam o jogo de palavras estabelecido com a obra barthesiana. Essa cumplicidade entre os autores das reportagens culturais e seus leitores em torno dos Fragments não pode ser contabilizada em número de ocorrências, mas permite ver o quão familiar ao público leitor de jornal era o livro de Barthes. Os Fragments d'un discours amoureux estavam no ar, voláteis, difíceis de se apreender, mas impregnando toda a atmosfera da época.

\section{Barthes, o estruturalista (ainda)}

Mais de vinte anos passados desde 1966, ano-chave do estruturalismo francês, nas críticas à peça Fragmentos de um discurso amoroso, Barthes ainda é visto como um autor estruturalista, adepto da linguagem complexa e hermética, batizada nos anos 70 com a expressão "terrorismo terminológico", como já demonstrei neste trabalho. Em “A paixão segundo Barthes”, de Charles Magno Medeiros, tal ponto de vista é anunciado logo no primeiro parágrafo, reproduzindo as

\footnotetext{
${ }^{472}$ Maurício Stycer, “Andar com fé eu vou, que a fé não costuma faiá”, Caderno 2, 8 de janeiro de 1987, p. 1.

${ }^{473}$ Karla Dunder, "Fragmentos coreografados do discurso amoroso", Caderno 2, 12 de junho de 2001, p. D16.

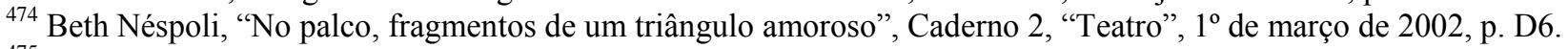

475 Jotabê Medeiros, "Fragmentos de um discurso rigoroso", Caderno 2, "Política Cultural", 4 de janeiro de 2003 , p. D3.

${ }^{476}$ Em "Fragmentos coreografados de um discurso amoroso", o livro de Barthes é referido como uma das leituras feitas pelos coreógrafos quando da pesquisa sobre o tema.
} 
expectativas do autor e, muito possivelmente, de grande parte dos leitores de Barthes e possíveis espectadores da peça que ora entrava em cartaz:

Quem leu Fragmentos de um discurso amoroso, o refinado, elegante e pouco ortodoxo ensaio do escritor francês Roland Barthes, morto em 80, sobre a paixão, por certo se surpreenderá com a montagem de Ulysses Cruz em cartaz no Teatro da Cultura Artística (rua Nestor Pestana, 196). Não foram poucos os que deduziram que a adaptação do texto para o teatro iria resultar numa peça inapelavelmente chata, discursiva, num monólogo monótono.

Não foi o que aconteceu. (...) ${ }^{477}$

Apesar de "refinado", "elegante" e "pouco ortodoxo", os Fragmentos parecem, à primeira vista, não se prestarem a uma adaptação teatral, segundo Medeiros. Talvez porque o autor pense que o livro seja "difícil" ou "intelectual” demais, embora não o diga. Fato é que a montagem de Cruz superou suas expectativas, mostrando-se dinâmica e acessível. Impressão semelhante teve o próprio Antônio Fagundes, que levou a adaptação de Teresa de Almeida aos palcos. Em trecho de entrevista reproduzida em "A paixão segundo Roland Barthes", de Sílvia Penteado, o ator afirma que "A estrutura dos Fragmentos atende a esses requisitos [ser um tema não convencional, que suscita discussão e polêmica] sem ser um texto incompreensível ao público" ${ }^{478}$.

Como as precauções descritas dão a entender, a sombra do "terrorismo terminológico" dos anos estruturalistas ainda pairava sobre Barthes na década de 80, associando seu texto ao hermetismo conceitual e linguístico pelo qual ficou conhecido no Brasil na década anterior. Por exemplo, Maria José de Queiroz, em resenha de 1988 sobre O Rumor da língua, tradução de Le Bruissement de la langue que então fora publicado em português, apresenta a obra do escritor como a responsável por consagrá-lo como "criador de um idioleto de grandíssimo prestígio entre nós". Ou seja, a marca de Barthes, para a resenhista, foi a linguagem por ele praticada, que fez sucesso entre os professores universitários brasileiros, cujos textos, nos anos 70, ainda frequentavam as páginas de jornais: o jargão estruturalista. Naturalmente, esse tipo de sucesso não era um atrativo para a leitura do novo livro que chegava ao mercado brasileiro, pois a autora escreve que não é "a curiosa e nem sempre feliz aclimatação do ideário e da terminologia veiculados pelo mestre da crítica francesa o que agora avulta aos nossos olhos" ${ }^{479}$. Ao contrário, há uma diferença entre a obra consagrada, escrita no "idioleto" e na "terminologia" barthesianos, e os ensaios de Le Bruissement, o que recomenda a leitura do livro resenhado. Segundo Queiroz, esse livro apresenta o percurso do escritor sob a forma de textos diversos, não se limitando a sua produção dos anos 60 .

\footnotetext{
477 Caderno 2, “Crítica", 29 de março de 1988, p. 7.

${ }^{478}$ Caderno 2, “Aplausos”, 5 de março de 1988, p. 3.

479 “O Itinerário de Roland Barthes”, Cultura, 18 de junho de 1988, p. 10.
} 
Nas entrelinhas dessa forma de apresentação do livro, que o diferencia de suas obras consagradas pela linguagem estruturalista, está presente a dicotomia sobre a qual repousa a imagem de Barthes na época: por um lado, o escritor é bastante conhecido e citado, tanto no jornal quanto em revistas acadêmicas, pois seus escritos começam a frequentar as bibliografias de disciplinas de cursos universitários; por outro, a complexidade intrínseca aos conceitos e às teorias expostos em seus ensaios conferem-lhe a pecha de "autor difícil" e criam resistência à leitura de seus escritos. Essas duas faces da imagem de Barthes coexistem em todo o período de seu post mortem, de cujos exemplos as citações ao escritor são pródigas.

Barthes, "autor estruturalista", é a referência mais comumente encontrada. Autran Dourado, por exemplo, em breve artigo sobre a crítica genética, “A nova teoria literária francesa", evocando os primórdios dos estudos imanentes dos textos literários, menciona os trabalhos "dos autores do estruturalismo francês, de um Roland Barthes e Gilles Deleuze (...)" ${ }^{480}$. Esse tipo de referência, breve informação situando o escritor no seio da corrente crítica estrutural, extremamente frequente, demonstra que Barthes dispensava maiores apresentações, pois já era uma celebridade intelectual.

Ao mesmo tempo, tal associação entre Barthes e o estruturalismo, feita de maneira neutra, coexiste com julgamentos de valor mais gerais sobre a voga teórica dos anos 60, tais como os proferidos por Marisa Lajolo e Benício Medeiros, em seus textos sobre obras fíccionais que têm por personagens intelectuais como Barthes, Propp e Sollers, dentre outros. Em "Meserani faz paródia dos contos de fadas", Lajolo resenha o novo livro infanto-juvenil do escritor brasileiro Samir Meserani, Confusão maior no reino de Tânger Menor (1996), que faz uma releitura de tradicionais histórias infantis, com direito a personagens diretamente saídos das teorias linguísticas e literárias, como Barthes. Na introdução, a autora apresenta Meserani, no contexto dos anos 60:

(...) Nos idos de 60, a teoria e a prática de Samir [Meserani] eram uma espécie de reserva verde na paisagem árida de concepções de linguagem que a empobreciam no binarismo estruturalista.

Mas os anos 60 se foram, foi-se o Estruturalismo. Foram-se mesmo? Foram-se. Ficou um Samir ou, o que é melhor, ficou um Samir que, embora mantendo a identidade de mestre (guarnecida agora com um doutorado comme il faut), afiou a pena e virou escriba. ${ }^{481}$

A visão retrospectiva que a autora projeta sobre o estruturalismo não é nada lisonjeira e se limita a uma única característica das análises estruturais, o frequente binarismo que dispõe concepções teóricas apoiadas sobre dois conceitos, tão cara a Saussure. Não é o intuito de Lajolo

\footnotetext{
${ }^{480}$ Cultura, 8 de outubro de 1988 , p. 4.

${ }^{481}$ Caderno 2 Especial Domingo, 5 de maio de 1996, D10.
} 
fazer uma aprofundada crítica do estruturalismo, mas apenas estabelecer a relação entre Meserani e a época de onde ele importou alguns personagens de sua história. O que me interessa no trecho acima reproduzido é a imagem negativa da corrente crítica, vista como uma "paisagem árida" que faz parte do passado.

Compartilha desse ponto de vista Benício Medeiros que, no mesmo ano, escreve sobre Os Samurais, de Kristeva, que acabara de ser publicado em português. Em sua resenha, o autor cita Barthes junto de Lucien Goldmann, caracterizando-os como "teóricos renomados” de quem Kristeva foi aluna. Para além da citação de Barthes, como uma referência que agrega valor à autora do romance, Medeiros também trata da época em que a trama romanesca é situada:

Revisionismo. Estruturalismo. Maoísmo. Quem ainda se lembra dessas coisas? São, no entanto, conceitos-chave no livro de Julia. Era o que se discutia nas universidades e nos cafés de Paris em 1968. No Rio e em São Paulo também. Postos em livro, esses debates, antes de mais nada, dão o que pensar sobre a espantosa fugacidade de certas ideias. Verdades absolutas num dia, viram logo depois castelos de cartas que desmoronam de repente, não mais que de repente, ao sabor e à força do tempo e dos fatos.

De tudo o que Julia põe no livro, parece ter sobrado, para estas vésperas do terceiro milênio, apenas a psicanálise e, por que não dizer, o tai chi chuan. ${ }^{482}$

O descaso com o qual o autor se refere ao estruturalismo faz com que ele o relegue a um passado aparentemente distante e acabado, não vendo seus frutos em seu tempo, na década de 90. Essa desvalorização aos olhos de Lajolo, Medeiros e muitos outros autores que seria repetitivo evocar, contamina a imagem de Barthes, indissociado do estruturalismo a partir da década de 80, na grande maioria dos textos que compõem o corpus desta pesquisa. Também ensaios como "Introduction à l'analyse structurale des récits" e o livro Éléments de sémiologie, para me restringir a duas das obras mais populares de Barthes no Brasil, contribuíram para a construção da imagem negativa do estruturalismo, como uma técnica "árida", presa a binarismos, veiculada por meio de uma terminologia própria, acessível somente aos iniciados, como os artigos citados evidenciam.

Se a má reputação do estruturalismo, a partir dos anos 80, foi prejudicial à imagem de Barthes, ou se foi parte da obra do escritor que justificou os ataques ao estruturalismo, é impossível definir. Provavelmente as duas hipóteses se combinam. Fato é que os dois, o estruturalismo e a parte estruturalista da obra barthesiana, confundem-se, um sendo sinônimo do outro, e por isso dividem a mesma imagem. "Autor de leitura considerada difícil" é o que Silviano Santiago diz de Barthes, segundo Edmílson Silva em seu artigo sobre a exposição de pinturas do escritor, no Centro Cultural

${ }^{482}$ Caderno 2/ Cultura, 24 de agosto de 1996, p. D9. 
Banco do Brasil, no Rio de Janeiro, em $1995^{483}$. Essa opinião, note-se bem, não reflete necessariamente o que Santiago pensa de Barthes, mas traz em si um ponto de vista mais vasto, composto por uma amostra de opiniões, na medida em que o sujeito do verbo "considerar" está oculto pela forma passiva e, por isso, enseja uma massa de vozes que "consideram difícil" a leitura dos textos do escritor.

Essa opinião negativa "geral" ou, pelo menos, partilhada por muitos, também é expressa em "Três cenógrafos do drama da significação", resenha de Teixeira Coelho dedicada a Sade, Fourier, Loyola, publicado no Brasil em 1990. Em seu texto, o autor escreve:

Roland Barthes (1915-1980) foi menos o semiólogo divulgador de Saussure (como ficou conhecido e em cuja condição anda esquecido) que um leitor sagaz que utilizou a semiologia como andaime apenas perceptível para descobrir aspectos inéditos de textos e autores já bem estudados. Longe do rótulo de erudito tedioso e de leitura difícil, que alguns ainda lhe colam, Barthes abre seu Sade, Fourier, Loyola dizendo não existir nada de mais deprimente que tomar um texto como objeto de reflexão. ${ }^{484}$

Para Teixeira Coelho, a sua condição de estruturalista, ligado a Saussure, Barthes deve sua fama e seu esquecimento, bem como sua má reputação, apontada em termos semelhantes por Edmílson Silva. Contrapondo-se a tal constatação, o autor da resenha a Sade, Fourier, Loyola coloca em relevo o repúdio do escritor às leituras de suas obras como meros tratados teóricos, expressa em 1971, quando da publicação do livro na França, num movimento em direção à concepção do texto como objeto de prazer e gozo.

As opiniões seguem divididas entre as duas faces da relação de Barthes com o estruturalismo, havendo também leituras positivas, reconhecedoras de seu papel importante na década de 60 e de sua herança para o pensamento teórico desenvolvido nos anos subsequentes. Dib Carneiro Neto, por exemplo, em artigo de 1999 sobre os trinta anos de carreira literária de Ana Maria Machado, apresenta a escritora por intermédio de Barthes:

Quando desenvolvia sua tese de doutorado na França, tendo como orientador o semiólogo Roland Barthes, a brasileira Ana Maria Machado ouviu do autor dos Fragmentos de um discurso amoroso o maior elogio que o papa dos sintagmas e dos paradigmas poderia fazer a alguém: "Você domina os conceitos e rejeita os jargões." A autora de Bisa Bia, Bisa Bel e Raul da Ferrugem Azul acabava de ganhar o título de Ph.D. em simplicidade. ${ }^{485}$

483 “Exposição revela outra face de Roland Barthes", Caderno 2, 3 de agosto de 1995, p. D5.

${ }^{484}$ Caderno 2, "Semiologia/ França", 13 de setembro de 1990, p. 5.

485 “Ana Maria Machado: mas que festa!", Caderno 2, "Bolo e refrigerante”, 23 de outubro de 1999, p. D11. 
Apesar de ecoar o sucesso dos Fragmentos nos anos 80, Barthes não deixa de ser associado ao estruturalismo, quando chamado de "papa dos sintagmas e dos paradigmas", numa evocação de duas das categorias linguísticas de maior sucesso na década de 60. O comentário do escritor e então orientador de Machado também não poderia ser mais técnico, refletindo o momento em que fora feito, na transição entre os estudos estruturalistas e a exploração do prazer do texto - Ana Maria Machado esteve em Paris entre 1970 e $1972{ }^{486}$. Ao mesmo tempo, revela o repúdio barthesiano pelos lugares-comuns, pelo emprego de um linguajar só pelo fato de estar na moda.

Se para Dib Carneiro Neto ser o "papa” do estruturalismo não é necessariamente ruim, para Leda Tenório da Motta, Barthes é o grande nome dos anos 60 pelo vigor de sua obra. Seu artigo de 2010 sobre a edição ilustrada das Mythologies é um verdadeiro elogio ao escritor:

Trinta anos depois de seu desaparecimento, Roland Barthes parece afirmar-se como o mais influente dos intelectuais ligados ao linguistic turn francês que chamamos "estruturalismo". É o que nos convida a pensar, primeiro, o jorro incessante de suas obras póstumas, que não acabam nunca de ser editadas, o que não é dado, por exemplo, aos legados de Michel Foucault e Jacques Lacan, por mais que possam ser expressivos. Segundo, o fato de que, entre seus contemporâneos de maior prestígio, ele é hoje o que mais se resenha, traduz, revê, interpreta, como atesta uma fortuna crítica que, de tão gigantesca, já começa a ser inadministrável, até mesmo para o pesquisador interessado num estado da arte barthesiana. Terceiro e mais importante, a coesão interna de seus escritos, tal como nos é retrospectivamente revelada. Ligada ao círculo virtuoso do desarme dos mitos, é principalmente esta última hipótese que vem derrubando a ideia do pensador errático, cujo único trunfo seria o estilo suntuoso. ${ }^{487}$

Para Motta, o estruturalismo intrínseco a Barthes não é uma mácula em sua trajetória, mas uma característica de parte de sua obra, tratada com naturalidade e situada em um momento da história da cultura dentro da qual ele se destaca. Em outras palavras, o estruturalismo é visto pela autora como o ponto de partida de um percurso que ainda não chegou a seu termo, dada a exuberância das edições de obras póstumas e de textos críticos sobre Barthes. Produção que permite ao leitor atual ter uma visão mais ampla e completa do pensamento barthesiano, desvelando sua coerência interna, até então detectada por poucos, dentre os quais Leyla Perrone-Moisés ${ }^{488}$.

Em meio a acusações ressentidas ao estruturalismo que respingavam em Barthes e a seu reconhecimento como um dos grandes nomes dessa corrente crítica, já nos anos 90 o escritor foi associado ao pós-estruturalismo, ou à pós-modernidade. Entendidos como sinônimos, como nos

\footnotetext{
${ }^{486}$ Informação obtida no site pessoal da escritora. Disponível em: http://www.anamariamachado.com/biografia (acesso em 20/05/2013).

487 “A Ideologia por trás dos discursos", Sabático, "Ensaio", 13 de novembro de 2010, p. S8.

488 A autora já tratara da coerência do pensamento do escritor e da coesão interna da obra de Barthes em "Roland Barthes, o infiel”, publicado no Suplemento Literário de 29 de agosto de 1970, p. 1.
} 
textos encontrados no jornal, neste trabalho esses termos se referem ao movimento de ideias que sucedeu o estruturalismo dos anos 60 e 70, e que está em curso, englobando a desconstrução, os Cultural studies e a multiplicidade de correntes críticas que povoam os estudos literários na atualidade.

José Guilherme Merquior teve o mérito de ser um dos primeiros a identificar na efervescência de ideias que lhe era contemporânea, já em 1986, a ligação direta entre Barthes e a pós-modernidade, registrada em seu livro From Prague to Paris: a critique of structuralist and poststructuralist thought (Londres, Editora Verso). Em 1991, por ocasião da morte do autor e da publicação brasileira de De Praga a Paris (Rio de Janeiro, Nova Fronteira), o Caderno 2 dedicou uma página a trechos de seu novo livro, sob o título apelativo de "Estruturalismo é obra de acadêmicos petulantes" ${ }^{489}$. A frase foi extraída do livro de Merquior, que comporta julgamentos de valor ainda mais ácidos sobre o estruturalismo e os intelectuais a ele relacionados. Com a proposta de ser uma história da corrente crítica, a obra é composta por capítulos dedicados às origens do estruturalismo, a Lévi-Strauss, a Barthes e ao pós-estruturalismo. A relação entre os temas dos dois últimos capítulos - Barthes e o pós-estruturalismo - é particularmente interessante, pela precocidade com que foi apontada, como já sublinhei.

No capítulo dedicado ao escritor francês, Merquior faz uma leitura bastante detalhada de sua obra, detendo-se quase em todos os seus livros, examinando-os com uma lupa, sem, no entanto, deixar de atacá-los - a única exceção é Sur Racine. O autor só faz descrever as obras de Barthes e alguns de seus ensaios mais célebres, apontando suas incongruências em relação aos pressupostos linguísticos de Saussure, Benveniste e outros linguistas, sem admitir a possibilidade de Barthes defender sua própria leitura dos conceitos em voga nos anos 60. Também critica as idas e vindas do escritor dentro de sua própria obra, acusando-o de contradição, e não se cansa de apontar autores que antes de Barthes formularam ideias por ele defendidas, como se este tivesse alguma vez reivindicado a primazia pelo emprego de uma noção ou conceito. Em meio a ataques que engendram neologismos divertidos e frases engraçadas ${ }^{490}$, o autor por vezes elabora críticas certeiras sobre a obra do escritor - mas que se perdem em meio à enxurrada de comentários depreciativos em nome

\footnotetext{
${ }^{489}$ Caderno 2, "Tradução/ Inédito", 10 de janeiro de 1991, p. 4.

490 Por exemplo, Merquior trata a teoria de Barthes sobre "a morte do autor" como "teoria autoricida" (p. 171); referindo-se a "De l'oeuvre au texte", o autor confere ao escritor o título de "primeiro 'tarado textual' " (p. 170); a semiologia barthesiana é chamada de "semiotécnica" (p. 156); Le Système de la mode transformou "um ensaísta inteligente como Barthes num perfeito chato" (p. 154), etc. Sua metralhadora verbal não se limita a Barthes, variando o alvo de vez em quando: sobre Lacan, escreve: "Até 1982, quando morreu, havia apenas duas pessoas no mundo realmente capazes de entender as teorias do Dr. Lacan: o próprio e Deus.” Cf. De Praga a Paris, op. cit., pp. $133-222$.
} 
de uma visão mais tradicional da literatura, que repudia a leitura imanente e todas as contribuições do estruturalismo para os estudos literários.

Todas as suas análises e seus argumentos são devidamente fundamentados por uma infinidade de citações de obras que revelam a erudição do autor e sua escolha bibliográfica dirigida exclusivamente para os livros e ensaios dedicados a contestar o pensamento barthesiano. Entrar no detalhe de toda a crítica de Merquior à obra de Barthes implicaria numa digressão longa demais e distante do foco deste trabalho, uma vez que suas opiniões não encontraram eco no corpus examinado. Nos trechos de De Praga a Paris reproduzidos em O Estado, só diz respeito a Barthes uma pequena menção a sua relação com a pós-modernidade, localizada no início do capítulo final do livro, e que tem relevância na medida em que anuncia uma relação essencial para a construção da imagem do escritor no Brasil, na contemporaneidade.

Em parte do capítulo sobre Barthes consagrada a sua teoria crítica, Merquior, em tom acusatório, identifica no escritor francês um "furor antiexpressivista", isto é, a refutação da concepção da literatura como expressão de uma ideia ou de um sentimento ${ }^{491}$. O autor diagnostica na visão crítica barthesiana a "negação do significado interior, subjetivo bem como objetivo" (grifos do autor), deduzindo: "Mas Barthes também se recusa a apoiar qualquer pressuposição de que os significados internos objetivos estejam presentes nos textos em si, esperando para que os descubramos, decifremos ou revelemos" ${ }^{492}$. Sua constatação permite compreender as precauções contra o Barthes de "Qu'est-ce que la critique?", motivação de tais comentários: para Merquior, há significados nos textos à espera do crítico, capaz de "descobri-los", "decifrá-los" ou "revelá-los", verbos que exprimem ações destinadas a uma elite intelectual.

Ora, é justamente contra esse pensamento fundamentado numa autoridade - institucional ou intelectual - que Barthes se insurge em sua concepção crítica, manifesta nesse ensaio e já explicitada quando tratei da querela da nouvelle critique contra Raymond Picard. Para ilustrar a concepção barthesiana de texto literário, Merquior cita a conclusão de "Le style et son image", ensaio de 1969, publicado nos Estados Unidos em 1971 - o autor leu Barthes predominantemente em inglês - e em francês somente na edição de Le Bruissement de la langue:

(...) si jusqu'à présent on a vu le texte sous les espèces d'un fruit à noyau (un abricot, par exemple), la pulpe étant la forme et l'amande étant le fond, il convient de le voir plutôt maintenant sous les espèces d'un oignon, agencement superposé de pelures (de niveaux, de systèmes), dont le volume ne comporte finalement aucun coeur, aucun noyau, aucun secret, aucun principe

${ }^{491}$ De Praga a Paris, op. cit., p. 200.

492 Ibidem. 
irréductible, sinon l'infini même de ses enveloppes - qui n'enveloppent rien d'autre que l'ensemble même de ses surfaces. ${ }^{493}$

Merquior vê no trecho acima a comprovação de sua leitura da teoria crítica de Barthes, ou seja, a seus olhos, o escritor concebe a obra literária como algo vazio - “(...) os próprios textos estão vazios, em branco, brilhantes como os recipientes resistentes e estruturados de um conteúdo que sempre varia.", como ele escreve mais adiante, sobre a mesma ideia ${ }^{494}$. No entanto, ele parece não enxergar que, para além da recusa da ideia de que a obra contém um segredo - un secret -, Barthes subordina ao verbo comporter "l'infini même de ses enveloppes". Portanto, a obra literária, para o escritor, nunca é vazia, mas plena de significados, dispostos em camadas, como as que consituem a cebola $^{495}$.

No suposto vazio em que Barthes transforma o texto literário, Merquior vê o espaço da multiplicação das escritas, "uma vasta proliferação do significado através de uma profusão de significantes" ${ }^{496}$, no que ele tem razão, mesmo que tenha chegado a essa conclusão por vias tortas. Sua irritação para com Barthes repousa na fundamentação teórica que seus textos forneceram à derrubada da concepção elitista da literatura, manipulada por uns poucos eruditos, grupo de que Merquior fazia parte, abrindo caminho para uma maior democratização do texto literário, enquanto objeto de análise aberto a uma infinitude de leituras. A indignação contra o escritor francês se manifesta:

Para o Barthes estruturalista, a glória da crítica repousava em colonizar as Américas da poética: o crítico, portanto, não devia andar atrás do significado, porque primeiro devia expor a pura gramática da significação. Mas para o Barthes pós-estruturalista, a crítica tampouco lidava com o significado, já que o significante abundante, liberto, estava sempre bem à frente do seu significado destronado. Portanto, o crítico mais intimamente associado à visão de que a matéria da literatura são os signos - na verdade, signos em profusão - coloca em última análise uma distância intransponível entre signo e sentido. O signo literário enquanto forma e não sentido - tal é a posição essencial da visão barthesiana da crítica, durante e depois do estruturalismo. ${ }^{497}$

Mais uma vez, a leitura de Merquior não concebe a pluralidade de significados, defendida por Barthes e seus epígonos, como o extremo oposto da ausência deles. Para o autor, parece que a destituição do significado do texto literário de seu sentido único, muito bem expressa pelo adjetivo “destronado", implica em sua negação. Seu raciocínio continua: "Somente este fato lança uma forte

${ }^{493}$ In $O C$ v. 3, pp. 980-981.

${ }^{494}$ De Praga a Paris, op. cit., p. 201.

${ }^{495}$ Eis um exemplo da leitura que Merquior aplica à quase totalidade da obra barthesiana e que me abstive de expor neste trabalho em atenção a sua dimensão e centro de interesse.

${ }^{496}$ De Praga a Paris, op. cit., p. 202.

${ }^{497}$ Ibid., pp. 203-204. 
luz sobre a influência de Barthes na crítica francesa moderna. Na verdade, se a história da nouvelle critique pode ser contada em grande parte em termos do eclipse do significado e da perda da referência, isso é, em grande parte, culpa de Barthes.” 498

Essa constatação conduz Merquior a sua grande crítica às teorias literárias pósestruturalistas, a saber, a perda de caminhos da literatura: na medida em que a relação entre significado e significante é falseada - pela ausência de significado, segundo ele, proposta por Barthes -, toda a literatura perde seu sentido e sua razão de ser, uma vez que esta só existe enquanto manifestação da "riqueza humana" ${ }^{499}$. Enfim, para o autor, o escritor francês é culpado pela situação dos estudos literários, fazendo deles um retrato bastante atual:

Na nossa época de modernismos senis, as tendências neoformalistas na crítica ligaram-se a versões da doxa modernista e assumiram grande parte do estudo acadêmico da literatura (atualmente o habitat de noventa por cento da crítica literária) ao institucionalizar o ensino e a pesquisa baseados no emprego maciço de métodos ready-made. Daí a notável inchação doentia da "teoria literária" e a metodologia crítica nos currículos. A exposição prolongada à literatura definha, ao passo que são devoradas toneladas de teoria literária e metodologia crítica. Esta grotesca situação é agravada pelo fato de que a maioria dos alunos nas universidades de massa hoje em dia não parecem trazer para o nível superior do ensino uma cultura literária decente, adquirida antes dos anos de graduação, como ainda era o caso dos diminutos grupos de estudantes de literatura quando o tema era confiado a scholars de formação filológica, que sabiam pouco ou nada de teoria literária, mas muito sobre poemas, romances, peças e ensaios.

A maior ironia é que o domínio da teoria e método, longe de reforçar a objetividade na atual discussão sobre a literatura, leva diretamente a uma destruição da relevância e precisão no discurso crítico. Mais do que nunca, os críticos e intérpretes tendem teórica e metodologicamente a projetar sobre o texto suas próprias visões à la page, sem se importar com o que o texto realmente diz ou implica. Cada vez mais, os textos são mal lidos porque neles se lê o que se quer. ${ }^{500}$

Esse panorama escrito em 1986 condiz à perfeição com o momento presente. Merquior não viveu para contemplar o que para ele provavelmente seria uma visão apocalíptica, e para não mais apenas culpar, mas para amaldiçoar Barthes. O autor tem razão em seu diagnóstico quando enumera os problemas do estudo da literatura em ambiente acadêmico - a supervalorização da teoria em detrimento das obras e a parca cultura literária dos alunos. Merquior parece ter nostalgia da época em que a literatura era privilégio de uns poucos e não oferece propostas para solucionar o problema de formação dos novos ingressantes nos cursos de letras. Conclui lamentando a liberdade crítica instituída pela abertura do texto literário a uma pluralidade de sentidos, para a qual as teorias barthesianas contribuíram. Pois, para ele, mais uma vez, o texto parece ter sempre um único sentido,

\footnotetext{
498 Ibid., p. 204.

${ }^{499}$ Ibid., p. 205.

${ }^{500}$ Ibid., pp. 207-208.
} 
universal e atemporal, e toda leitura que desafie a palavra final do crítico e não veja "o que o texto realmente diz”, para empregar uma expressão sua, será uma má leitura.

Semelhante análise da situação da literatura no momento presente é feita por Tzvetan Todorov em La littérature en péril (2007). Tendo em vista o modo como a literatura é ensinada nas escolas e universidades da França e as tendências atuais da produção literária de escritores franceses, o autor chega a conclusões semelhantes às apontadas por Merquior sem, contudo, ver em Barthes a causa de tais males. Para Todorov, assim como para o autor brasileiro, a literatura tem uma função humanística: "La littérature peut beaucoup. Elle peut nous tendre la main quand nous sommes profondément déprimés, nous conduire vers les autres êtres humains autour de nous, nous faire mieux comprendre le monde et nous aider à vivre" ${ }^{501}$. Em outras palavras, "La réalité que la littérature aspire à comprendre est, tout simplement (mais en même temps, rien n'est plus complexe), l'expérience humaine." 502 Novamente como Merquior, Todorov imputa à supervalorização da teoria a pouca atenção voltada à compreensão das obras literárias e o desinteresse a que elas são relegadas cada vez mais. Contudo, ao contrário do crítico brasileiro, o autor não prega uma volta ao sentido único do texto literário, proporcionado por uma abordagem outra que a imanente (de ordem formalista e/ ou estruturalista), mas justamente o contrário:

Ce dont on se rend compte, peu à peu, est que toutes ces perspectives ou approches d'un texte, loin d'être rivales, sont complémentaires - pourvu que l'on admette d'emblée que l'écrivain est celui qui observe et comprend le monde dans lequel il vit, avant d'incarner cette connaissance en histoires, personnages, mises en scène, images, sons. Autrement dit, les oeuvres produisent du sens, l'écrivain pense; le rôle du critique est de convertir ce sens et cette pensée dans le langage commun de son temps - et peu nous importe de savoir par quels moyens il parvient à son but. ${ }^{503}$

A visão de Todorov não nega seu passado estruturalista e incorpora os princípios dessa corrente crítica a todos os outros, passados e presentes, desde que em prol da produção de sentido. E este, para o autor, não pode ser uno, uma vez que depende da linguagem do crítico e se concretiza de maneira diferente para cada leitor, a cada nova leitura.

Barthes, em momento algum de sua obra, pregou o vazio de sentido de um texto literário, mas sempre defendeu sua pluralidade, dentro de uma perspectiva impregnada de liberdade e tolerância, partilhada por Todorov e oposta à leitura que Merquior fez de seus textos. A imagem de Barthes como "papa dos sintagmas e dos paradigmas", grande referência do estruturalismo, aos poucos, transformou-se em imagem do papa da pós-modernidade. Imagem negativa, para Merquior,

\footnotetext{
${ }^{501}$ Paris, Flammarion, p. 72.

502 Ibid., p. 73.

${ }^{503}$ Ibid., p. 87.
} 
imagem equivocada, para Leyla Perrone-Moisés, como demonstrarei em seguida, mas, sobretudo, imagem positiva e consagrada para a imensa maioria dos intelectuais cujos textos constituem o corpus deste trabalho, com maior ênfase a partir dos anos 2000.

\section{Barthes, o mestre pós-moderno}

Antes de colocar em evidência a construção da imagem pós-moderna de Barthes, é preciso tecer algumas considerações sobre a noção de pós-modernidade. Complexa é a tarefa de defini-la, sobretudo porque, ao que tudo indica, ainda nos encontramos em seus territórios espaço-temporais. Antoine Compagnon se dedicou, ou melhor, arriscou-se, a escrever sobre o tema, no último capítulo de Les Cinq paradoxes de la modernité (1990), a respeito do derradeiro paradoxo moderno, a pósmodernidade. Suas ponderações parecem-me pertinentes para fornecer um fundo contextual capaz de unir os diversos textos jornalísticos que se referem a Barthes como autor pós-moderno.

Inicialmente, Compagnon investiga a etimologia da palavra, que contém em si a ruptura com a noção de modernidade: a pós-modernidade seria um estágio além da modernidade, uma reação a ela, e sua recusa. Paradoxalmente, com esse movimento, ela se insere na "tradição moderna" - expressão oximórica pelo termo "tradição", associado a práticas estabelecidas, opor-se à "modernidade", habitualmente compreendida como sinônimo de inovação. Tal "tradição moderna" se fundamenta na negação da estética que a precedeu para criar algo "novo", mesmo que esse "novo" seja uma volta ao passado. A novidade dentro dessa relação com o moderno, proposta pela pós-modernidade, residiria na abolição da ideia de que o moderno deve sempre ultrapassar o que já existia: desde a segunda metade do século XIX, com ênfase nas vanguardas artísticas, era considerado moderno o que fosse "novo", o que rompesse com a tradição até então em voga. Ora, a pós-modernidade, por um lado, rompendo com a modernidade e, por isso, integrando essa tradição de ruptura, instituiu uma nova lógica: o "novo" pós-moderno não é necessariamente original. O enterro definitivo do conceito romântico de originalidade ofereceu a artistas e a intelectuais uma gama inédita de opções, permitindo que tudo fosse dito, mesmo que repetidas vezes, sob a justificativa da pessoalidade. Ou seja, desde que pessoal, pontuado pela subjetividade de cada autor, todo tex to é válido e reconhecido enquanto tal.

Esse novo parâmetro de aferição de valor, quase infinitamente vasto, é definido por Compagnon como "syncrétisme" ou, mais ironicamente, "maison de tolérance" 504, imagem que representa bem a prostituição de ideias, teorias e conceitos aliciados, frequentemente, sem

\footnotetext{
${ }^{504}$ Paris, Seuil, p. 158.
} 
discernimento por escritores e intelectuais. Toda referência passa a ser válida, unicamente por ser uma referência, pois "Idéologie de la fin des idéologies, le postmodernisme se caractériserait partout par la permissivité et le renoncement à la critique." ${ }^{505}$ Dito de outra forma,

La subjectivité de l'artiste et le plaisir du spectateur sont exaltés. Le culte de l'inauthentique a triomphé de celui de l'originalité, et l'éclectisme se donne pour un dépassement, de façon à prévenir l'accusation de néo-académisme.

Le postmodernisme peut alors prendre n'importe quelle forme. "L'éclectisme, écrit Lyotard, est le degré zéro de la culture générale contemporaine [...]. Il est facile de trouver un public pour les oeuvres éclectiques. En se faisant kitsch, l'art flatte le désordre qui règne dans le 'goût' de l'amateur. L'artiste, le galeriste, le critique et le public se complaisant ensemble dans le n'importe quoi et l'heure est au relâchement." 506

A citação de La Condition postmoderne (1979), de Jean-François Lyotard, mostra a que ponto a pós-modernidade se volta para seu público, buscando, acima de qualquer valor estético préestabelecido, relacionar-se com espectadores e, no caso da literatura, leitores. Essa relação passa então a determinar o caráter estético das obras: seu potencial de interação com o público. "Les oeuvres postmodernes se soucient en revanche du bien-être de leurs lecteurs, comme les bâtiments postmodernes ont soin de leurs habitants", escreve Compagnon ${ }^{507}$.

Com a pós-modernidade, desaparecem as categorias que regiam o pensamento: moderno versus retrógrado, modernismo versus realismo, abstrato versus figurativo e, mais recentemente, nos anos 50 e 60, estruturalismo versus história, estruturalismo versus humanismo, estruturalismo versus existencialismo, língua $e$ fala, significado $e$ significante, sintagma $e$ paradigma, Texto versus obra, Texto versus autor, cultura de massa versus elite cultural, etc. Opositivas ou não, as dicotomias aprisionavam a reflexão estética havia mais de um século. Seu abandono em prol de uma nova relação com o público favoreceu não só o ecletismo absoluto, mas a legitimação de culturas populares que, nos Estados Unidos, redundou na ascenção de questões propostas por minorias socialmente desprestigiadas a objetos de reflexão estética. Tal tendência se consolidou sob a forma dos Cultural studies.

Face a tamanha ausência de parâmetros, o balanço de Compagnon é complacente e positivo:

\footnotetext{
${ }^{505}$ Ibidem. Lembro que a ideia de crise das ideologias também assombrava os artigos de Gilles Lapouge desde o início dos anos 80, revelando as incertezas sobre os rumos das reflexões teórico-críticas com o desaparecimento dos mestres estruturalistas.

${ }^{506}$ Ibid., p. 166.

${ }^{507}$ Ibid., p. 158.
} 
Nous nous sommes remis de la vision téléologique du modernisme, ce qui ne veut pas dire que "Tout soit bon", mais, plus modestement, qu'on ne peut plus refuser une oeuvre sous prétexte qu'elle serait dépassée ou rétrograde. Si l'art ne poursuit pas, de dépassement critique en dépassement critique, quelque fin d'abstraction sublime, comme les récits orthodoxes de la tradition moderne le voulaient, alors nous jouissons d'une liberté inconnue depuis un bon siècle. A l'évidence, il n'est pas facile d'en user! ${ }^{508}$

"Que fazer senão aceitar as novas regras do jogo?", parece se indagar o autor. A regra sendo quase não haver regras, louvemos a liberdade conquistada. Contudo, tendo em mente o Barthes pós-moderno descrito no jornal, saliento um elemento da nova ordem teórico-reflexiva que, no caso das associações do escritor francês à pós-modernidade, parece ser norma: o emprego da subjetividade como meio de acesso ao leitor, que Barthes tanto sublinhou desde Le Plaisir du texte.

A construção dessa nova imagem, que já se insinuava desde a década de 80, ganha impulso significativo em 2000, vinte anos após sua morte, quando a editora Martins Fontes iniciou a republicação da obra de Barthes, com o relançamento de $O$ Grau zero da escrita. O projeto editorial concretizou-se em 2003 na Coleção Roland Barthes, dirigida por Leyla Perrone-Moisés e que desde então vem recolocando no mercado editorial, em edições muito bem cuidadas, com traduções revistas ou inteiramente novas, obras que se tornaram de difícil acesso porque esgotadas. Dedico mais espaço a esse acontecimento editorial e a suas implicações na recepção à obra de Barthes no capítulo "Traduções". Por ora, registro a nova voga de interesse pelo escritor, ao mesmo tempo propulsionada e alimentada pela gradativa e constante disponibilidade de seus livros no mercado.

Dois mil e três também marca o cinquentenário de publicação de Le Degré zéro de l'écriture e essa data foi celebrada na França com o lançamento das obras completas de Barthes pela Editora Seuil e pela já mencionada exposição multimídia dedicada ao escritor em Paris, com imenso sucesso de público. Repercutindo tais eventos, Luiz Zanin Oricchio escreve em O Estado "Saudades de Barthes e reabertura do 'caso' Céline”, artigo também dedicado ao autor de Voyage au bout de la nuit (1932). Sobre Barthes, Oricchio reconhece que as novas publicações dos já conhecidos livros, acrescidas de grande quantidade de escritos inéditos em volume, até então espalhados em uma panóplia de periódicos, engendram uma revisão da obra do escritor. Reproduzindo opinião de JeanPaul Enthoven, para Le Point, fonte de informações do autor brasileiro, este ainda pondera:

(...) alguns desses trabalhos mais estruturados, como Sistema da moda, Mitologias e $S / Z$ talvez não tenham resistido bem ao passar do tempo. Já Fragmentos de um discurso amoroso, $O$ Império dos signos e $O$ Prazer do texto são livros incomparáveis, conservam todo o frescor e sentido de inovação. Além disso, mostram Barthes como ele gostava de ser: não um mestre, mas

${ }^{508}$ Ibid., p. 175. 
uma espécie de guia, aquele tipo amigável de "professor-artista", ideal para despertar vocações. Enfim, alguém que tinha grande prazer em pensar e transmitia esse prazer a quem o ouvia e lia. Saber com sabor, como ele mesmo definia a matéria com a qual lidava. ${ }^{509}$

A concordância de Oricchio com o ponto de vista de Enthoven se manifesta pela reprodução sem ressalvas da leitura que este faz da obra de Barthes: alguns de seus livros, notadamente mais marcados pelo estruturalismo, não envelheceram tão bem quanto os dos anos 70, de caráter mais pessoal.

A distinção entre esses dois momentos na obra barthesiana, aproximadamente antes e depois de L'Empire des signes ou de Le Plaisir du texte, determina o valor do escritor, também, para Regina Schöpke. Em artigos dedicados ao relançamento de O Grau zero, em 2000, a autora não esconde seu entusiasmo, expresso no título "O Livro em que Barthes redefiniu a literatura". Tratando menos do livro do que do percurso intelectual do escritor, a autora rebate as críticas segundo as quais Barthes era um intelectual volúvel, tanto temática, quanto metodologicamente. Para ela, o escritor era versátil, e vê nessa qualidade o que assegura o lugar de Barthes entre os grandes intelectuais do século XX, cuja obra se irradia pelo século XXI:

Porém, a verdade é que o seu aparente ecletismo esconde uma proposta que ultrapassa todo e qualquer objeto ou objetivo transitório. Tal proposta diz respeito a uma crítica profunda da "significação" (...). Trata-se de trazer à luz a "moral" que se esconde por trás das palavras, ou seja, aquela que revela não o seu significado explícito, normativo, mas algo mais profundo, furtivo e fugidio.

Hoje, mesmo depois de 20 anos de sua morte, Barthes continua sendo o referencial de uma nova prática literária. E isso porque, embora acusada por muitos de inconsistente, a sua obra tem experimentado a única garantia de sua força e de sua veracidade: o tempo. ${ }^{510}$

A "crítica da significação" barthesiana, aos olhos da autora, seria um instrumento de desmascaramento de ideologias que, sorrateiras, exercem seu poder de maneira enviesada, por trás de palavras, imagens e conceitos. Seria, portanto, uma ferramenta de libertação, no sentido iluminista do termo, isto é, de esclarecimento visando a liberdade proporcionada pela consciência. A força dessa vontade de libertação dos anos 90 e 2000, em confluência com a obra barthesiana, seria a responsável por sua perenidade, evidenciando sua estreita relação com os novos ideais da pósmodernidade, em rota de colisão com o normatismo estruturalista, tantas vezes dicotômico, e com os discursos opressores que até então anulavam as vozes das minorias socialmente desprestigiadas.

\footnotetext{
${ }^{509}$ Caderno 2/ Cultura, "Revista das revistas", 5 de janeiro de 2003, p. D4.

${ }^{510}$ Caderno $2 /$ Cultura, $1^{\circ}$ de outubro de 2000, p. D3.
} 
Nessa mesma linha de pensamento, a autora, em mais um artigo publicado ainda por ocasião do relançamento de $O$ Grau zero, ressalta o percurso pessoal atípico que levou Barthes ao Collège de France, escrevendo: "Ele se descreve [na Leçon] como alguém impuro e incerto, mas toda essa modéstia não esconde o óbvio: é justamente a 'incerteza' e a abertura para o novo que constituem o diferencial e o valor de Barthes." 511 Ou seja, é o escritor imprevisível, que paradoxalmente foge às regras que ele mesmo ajudou a criar - por exemplo, os elementos constitutivos das análises narrativas, na "Introduction à l'analyse structurale des récits" -, que chama a atenção no momento da revisão de sua obra.

Não é outra a leitura de Sônia Régis, ao resenhar Roland Barthes, o saber com sabor, de Leyla Perrone-Moisés, em 1983. Bastante precoce, a análise da autora já aponta para uma das bases da obra barthesiana que conduziu seu autor para o centro da cena pós-moderna: sua luta contra os padrões estabelecidos: "A profunda consciência ética do intelectual Barthes, que leu todos os signos de forma crítica, analisando a retórica dos mais diversos discursos (da publicidade, da moda, da crítica, do amor), fez com que toda a sua produção tivesse qualidade política, desencadeando na escrita um sujeito em processo e uma linguagem revolucionária." 512 Essa linguagem tem no conceito de écriture seu fundamento, enquanto prática crítica indissociável da criação literária "que questiona o mundo sem oferecer respostas e libera a significação sem fixar sentidos." 513

A herança pós-moderna de Barthes também é destacada por Haroldo Cevarolo Sereza quando, em 2003, escreve um artigo sobre o lançamento da nova tradução de Fragmentos de um discurso amoroso, em que trata da coleção da editora Martins Fontes e da nova "onda Barthes" na França e no Brasil. Reproduzindo palavras de Leyla Perrone-Moisés, escreve:

Para Leyla Perrone, os vários Barthes encontram diferentes leitores no Brasil. O primeiro público a ser influenciado pelo autor é o universitário que, nos anos 1970, no Brasil, foi profundamente marcado pelo estruturalismo. A partir de O Prazer do texto (Perspectiva), um outro Barthes, que hoje pode ser chamado de 'pós-estruturalista', passa a exercer um novo tipo de influência.

Em termos de popularidade, é o Barthes de Fragmentos de um discurso amoroso - que no Brasil se transformou numa montagem teatral com Antônio Fagundes no elenco - o que alcança o maior público. ${ }^{514}$

Esse breve resumo dos diferentes momentos da recepção à obra de Barthes coloca em relevo o escritor não mais visto como "estruturalista", imagem dos anos 60 até hoje ainda viva,

511 "Originalidade marcou seu trajeto intelectual". Caderno 2/ Cultura, $1^{\circ}$ de outubro de 2000, p. D3.

512 "Barthes: o saber com sabor", Cultura, "Nas Livrarias", 24 de julho de 1983, p. 15.

${ }^{513}$ Ibidem.

514 “Fragmentos inicia em maio 'minicoleção' do autor”, Caderno 2/ Cultura, 2 de fevereiro de 2003, p. D7. 
como já foi mostrado, mas enquanto intelectual "pós-estruturalista" e que, por isso, "passa a exercer um novo tipo de influência”. Que influência seria essa? O artigo não responde à pergunta, mas a leitura de outros textos da época, encontrados em $O$ Estado, encaminha a resposta pela mesma via apontada por Regina Shöpke.

Por exemplo, novamente Sônia Régis, ao resenhar a edição brasileira de Sob o signo de Saturno, de Susan Sontag, em 1986, reflete sobre a natureza da atividade crítica nos seguintes termos:

O exercício crítico, na atualidade, está espremido entre os resíduos de um impressionismo subjetivo e a impostura de um falso rigor científico. (...)

A postura crítica cristalizou-se à sombra de um pensamento fragilizado pelos fantasmas da exatidão e da certeza e fustigado pelas miragens de um saber "isento". E por isso mesmo apenas toca de leve e temerosamente naquilo que Fernando Pessoa, pela voz de Bernardo Soares, chamava de "erudição da sensibilidade". A emoção da razão ainda é mais forte do que a razão da emoção; o sentimento, a vivência que resulta dos sentidos, parece não caber na linguagem crítica. Há o temor infundado de que a conjugação de razão e sentimento se transforme num estatuto de avaliação ambígua, insensata e geradora de confusões, no esquecimento de que são ambos, na realização criativa, elementos igualados pela mediação simbólica da linguagem, pela representatividade de uma mesma razão: a do sujeito do discurso. ${ }^{515}$

O diagnóstico presente no trecho acima evidencia a hesitação entre o cientificismo dos anos estruturalistas e sua negação, por meio do discurso crítico personalista que coloca em primeiro plano as emoções daquele que escreve, tateando uma nova concepção crítica capaz de comportar posições subjetivas. $\mathrm{O}$ veredicto da autora reflete os novos ares libertários, ainda cheios de incertezas, que sopravam para os lados da teoria e da crítica literárias: "Despojar-se para ver: a bênção e a graça de uma percepção sem os limites constrangedores e convencionais que a chamada linguagem crítica (imperativa e totalitária) nos impõe. Essa é, na verdade, a tarefa da escrita como pensamento, a forma que a ensaísta [Sontag] encontrou para registrar uma voz genuína." 516

Para a resenhista brasileira, Susan Sontag, em 1972, ano da publicação de Under the sign of Saturn, já praticava essa forma de escrita crítica que Sônia Régis elogiava em Barthes, por ocasião do lançamento de Roland Barthes, o saber com sabor, de Leyla Perrone-Moisés, em 1983. A citação acima permite enxergar a associação entre as normas da linguagem estruturalista e uma postura crítica autoritária e repressora. Pois o primado da "percepção livre" na crítica literária estava em pauta desde a década de 80, corroendo as estruturas dos anos 60 e 70, e dela Barthes começava a ser visto como grande prenunciador. Anos mais tarde, em 1982, no ensaio L'écriture même: à propos

\footnotetext{
515 “A Verdadeira contemplação crítica”, Cultura, 15 de novembro de 1986, p. 3.

${ }^{516}$ Ibidem.
} 
de Barthes, Sontag analisou a escrita barthesiana colocando em relevo a pessoalidade de sua écriture, para afirmar seu caráter de ruptura:

C'est le même mandat qui est donné par les notions de "texte" et de "textualité". Elles sont la traduction dans le domaine de la critique de l'idéal d'une littérature ouverte, polysémique, caractéristique de la modernité; du même coup, elles font du critique, au même titre que les créateurs littéraires, l'inventeur du sens. (Le but de la littérature, affirme Barthes, est de mettre du "sens" dans le monde, mais pas "un sens".) Décider que l'objet de la critique est de modifier et de restituer le sens (par addition, soustraction, multiplication) revient à fonder les efforts du critique sur une entreprise de refus, et par là même à remettre la critique, si elle lui avait jamais échappé, sous l'empire du goût." 517

Com o emprego da subjetividade do gosto individual, Barthes, por meio das noções de Texto e de textualidade, abandona seu estruturalismo para se tornar a grande referência da pósmodernidade libertária, pois 'L'allure caracolante de ses derniers livres met en scène à la fois sa fécondité (insatiabilité et légèreté) et son désir de subvertir toutes les tendances à la systématisation." 518 (grifo da autora) Nenhuma obra passa a ter interesse se não se configurar como contestação de um poder estabelecido, seja ele de que natureza for. Nesse sentido, a aula inaugural de Barthes, no Collège de France, adquire quase a força de um manifesto, e se completa retrospectiva e prospectivamente com a execução de Le Plaisir du texte, Roland Barthes par Roland Barthes, Fragments d'un discours amoureux e La Chambre claire. Nas palavras de Sontag, "Dans les derniers écrits, le thème de la contestation du pouvoir en tant que tel prend la forme d'une définition de l'expérience de plus en plus centrée sur les passions privées, et d'une définition de la pensée comme jeu." 519 Esse “jogo”, para Barthes, é sinônimo da tricherie salutaire, da esquive, do leurre magnifique que, na Leçon, frustram, iludem e desmontam os sistemas pré-estabelecidos, os sentidos cristalizados, os lugares-comuns ideológicos que permeiam as linguagens. Esse “jogo", como o escritor enfatiza, atende pelo nome de literatura $^{520}$ (grifo do autor).

Inserindo-se pessoalmente em seus ensaios e livros, Barthes se esquiva do normatismo crítico, traçando rumos inesperados que muitos de seus leitores de então tinham dificuldades em seguir. A constatação de Sontag sintetiza: "Une méditation courageuse sur ce qui est privé, sur le moi, est au centre de ses derniers écrits et séminaires." ${ }^{521}$ Esse caminho de contestação e ruptura escolhido por Barthes, porque coloca em relação estreita seu corpo e sua écriture, foi percebido e

\footnotetext{
${ }^{517}$ Paris, Christian Bourgois, 2009, pp. 16-17.

518 Ibid., p. 22.

519 Ibid., p. 53.

${ }^{520}$ OC v. 5, p. 433.

${ }^{521}$ Paris, Christian Bourgois, 2009, p. 56.
} 
aceito como pós-moderno por muitos, e imitado. Um dos desdobramentos dessa postura diante do texto, que não foi exclusiva a Barthes, possivelmente, é a tendência literária atual "solipsista", segundo Tzvetan Todorov. No já citado Littérature en péril, o autor identifica três correntes majoritárias na atual literatura francesa: a formalista, a nihilista e a solipsista, sendo que esta última pode ser explicada como segue:

Une autre pratique littéraire provient en effet d'une attitude complaisante et narcissique, qui amène l'auteur à décrire par le menu ses moindres émois, ses plus insignificantes expériences sexuelles, ses réminiscences les plus futiles: autant le monde est répugnant, autant le soi est fascinant! Dire du mal de soi-même ne détruit d'ailleurs pas ce plaisir, l'essentiel étant de parler de soi - ce qu'on en dit est secondaire. La littérature (on dit plutôt dans ce cas "l'écriture") n'est plus alors qu'un laboratoire où l'auteur peut s'étudier à loisir et tenter de se comprendre. ${ }^{522}$

A menção ao termo "écriture" como designativo do tipo de texto solipsista que grassa nas livrarias francesas remete ao conceito de Barthes. Mesmo que grande parte dos autores da "littérature du moi" contemporânea não conheça a fundo a écriture barthesiana, sua fundamentação teórica e suas idas e vindas, eles certamente leram Le Plaisir du texte, Roland Barthes par Roland Barthes e o incontornável Fragments d'un discours amoureux. Todorov dá a entender que os escritores frequentemente se apropriam do termo, o que justifica minha hipótese sobre as consequências atuais da escolha personalista de Barthes, consagrada como pós-moderna porque subvertora.

Além de conceitos e, mais amplamente, de toda uma postura face à linguagem, tornaram-se objeto de adoração pós-moderna alguns ensaios de Barthes, como "De l'oeuvre au texte", de que tratarei no capítulo "Barthes em Língua e Literatura", e "La Mort de l'auteur". Este foi referido, por exemplo, por Elias Thomé Saliba, em resenha sobre o livro Os Cem primeiros anos de Mikhail Bakhtin, de Caryl Emerson, então publicado no Brasil, na qual o brasileiro sublinha o caráter "pósmodernista" da metáfora da morte do autor, tornada célebre por Barthes ${ }^{523}$. De uma forma geral, principalmente nos anos 2000, o escritor francês passou a encarnar os ideais pós-modernos, seja por sua écriture personalista, seja pelo desprendimento em romper com teorias que ajudou a consolidar, seja pela combatividade constante contra a doxa e todo o tipo de autoritarismo, o que foi metamorfoseado em atitude em defesa das minorias.

Essa mudança de caminhos de Barthes foi fielmente retratada, mais uma vez, por aquele que se firmou, ao lado de Leyla Perrone-Moisés, como divulgador da obra do escritor no Brasil:

\footnotetext{
522 Paris, Flammarion, 2007, p. 35.

${ }^{523}$ Caderno 2/ Cultura, "Teoria literária”, 27 de julho de 2003, p. D4.
} 
Gilles Lapouge. Em artigo de capa para o Caderno 2/ Cultura de 2 de fevereiro de 2003, o autor decreta, já no título: "O Melhor Barthes ficou fora da sala de aula”, manifestando sua preferência pelos escritos "pós-modernos" em detrimento dos estruturalistas, naquela época já incorporados ao ensino universitário. O texto curto que introduz o artigo resume essa apreciação: "Exposição em Paris homenageia o professor, o artista plástico amador e o teórico pernóstico, mas o que permanece, nestes 20 anos de sua morte, é a personalidade vibrante, seu toque de humanidade e o estilo supremo".

Novamente por ocasião do cinquentenário de publicação de Le Degré zéro de l'écriture, do lançamento das obras completas de Barthes, na França, e da exposição no Centre Georges Pompidou, Lapouge revisitou a trajetória intelectual do escritor e fez um balanço de sua herança. O resultado está expresso na citação acima: o elogio do escritor pós-moderno e a condenação do teórico estruturalista, visto como "teórico pernóstico", indubitavelmente pelo largo emprego do jargão cientificista dos anos 60. A passagem de um "estado" - o estruturalista - a outro - o liberto, pessoal e subjetivo - é contada no artigo de forma bem humorada:

Para mim, essa exposição dissipa um formidável mal-entendido que se criou em torno de Barthes durante sua existência: adulado e admirado muito cedo, professor fascinante, dotado de uma bela e doce voz, ele ficou "congelado" no papel de "teórico", de "semiótico". Fizeram dele ele mesmo fez de si próprio - um teórico rigoroso, austero, um homem da "estrutura" ou do "sintagma", o grande amante de neologismos ou de citações gregas e de gíria, em resumo, um pedante sedutor.

Gerações de estudantes desmaiaram diante de seus estudos estilísticos ou estruturais. Hoje, quando se relêem esses estudos, essas pesadas "lições dobradas de castigo" caem de nossas mãos: um estudo como Le Système de la mode é cruciante, desprovido de qualquer interesse e, além disso, mal conduzido no plano da teoria.

Mas o verdadeiro Barthes era bem diferente. (...)

Muito felizmente, é este outro Barthes - um Barthes livre, alegre, brincalhão e insolente, folgazão e intrépido, apaixonadamente livre de toda teoria, amante do mundo e das pessoas - que a exposição resolveu exaltar, não o Barthes embalsamado em Marx e, sobretudo, em Saussure, ou na teoria estruturalista. ${ }^{524}$

Por trás da couraça sisuda dos sintagmas e dos paradigmas, há outro Barthes, mais leve e, por que não, divertido? Tal é a ambivalência da imagem do escritor em seu post mortem: o grande teórico estruturalista e o libertário pós-moderno, como Lapouge sintetiza, apontando para um paradoxo ${ }^{525}$ : "Percebemos então que este autor, considerado difícil, teórico, abstrato, é, na

\footnotetext{
${ }^{524}$ Caderno 2/ Cultura, 2 de fevereiro de 2003, p. D1.

525 Outros "paradoxos de Barthes", porém intrínsecos a sua obra, foram objeto de estudo de Patrizia Lombardo em The three paradoxes of Roland Barthes (Atenas e Londres, The University of Georgia Press, 1989) e de Antoine Compagnon, no capítulo "Roland Barthes en saint Polycarpe", em Les Antimodernes: de Joseph de Maistre à Roland Barthes (Paris, Gallimard, 2005).
} 
realidade, um homem que se farta de concreto, que fala de coisas, e não de ideias." ${ }^{526}$ Ou seja, um homem de carne e osso e que, por isso, pode ser próximo de seus leitores. O Barthes pós-moderno não é mais o teórico difícil, e sim o autor sensível.

Entretanto, essa metamorfose não representou uma unanimidade em torno de Barthes. Em alguns textos críticos, o escritor foi combatido justamente por sua pós-modernidade, conforme mostra a resenha de Haroldo Cevarolo Sereza sobre o livro de Carlo Ginzburg, Relações de força, lançado no Brasil em 2002. Segundo o resenhista brasileiro, nessa obra o autor defende a ideia de que a pós-modernidade, com a consequente relativização dos discursos, esvaziou o texto histórico, questionando seu compromisso com a verdade. Barthes é atacado por ser um dos mestres da pósmodernidade na medida em que suas teorias, e pontualmente sua concepção de crítica, contribuíram para que todos os discursos, inclusive o histórico, fossem vistos como formas autônomas e independentes, e por isso não mais comprometidas com a verdade, mas com "validades", isto é, com elementos que compõem seu funcionamento. Aos olhos do historiador, tal concepção esvazia o discurso histórico de seu caráter ético, e por essa razão ele se insurge contra o escritor francês, dentre outros intelectuais.

A crítica à pós-modernidade de Barthes feita por Leyla Perrone-Moisés é de outra natureza. A autora, chamada a dar várias entrevistas sobre o escritor quando do lançamento de novos volumes da Coleção Roland Barthes da editora Martins Fontes, falou do assunto, reiterando a ideia geral transmitida em ensaio de 1993, entitulado "Barthes foi atropelado pela pós-modernidade", texto que discutirei no capítulo "A crítica atual: deslocamentos". Para a autora, que, ao contrário de Compagnon, não via a pós-modernidade com bons olhos, a obra de Barthes é muito mais complexa, profunda e provida de ética do que a maioria dos escritos aclamados como pós-modernos. Em entrevista a José Castello, por ocasião do lançamento de sua coletânea de ensaios Inútil poesia, em 2000, Leyla Perrone-Moisés reitera sua opinião, nas palavras do jornalista:

Cético, eclético, hedonista, errante, ele [Barthes] chegou a ser tomado como um teórico pósmoderno - mas lhe faltavam a superficialidade e a amoralidade que caracterizam o pensamento dos pós-modernistas. Citando Valéry, Leyla sugere que o lema de Barthes deveria ser, talvez, o "eu decepciono". Abandonando a onipotência intelectual, Barthes sugeria que pensar é, um pouco, fracassar.

(...)

Acontece que as ideias pós-modernistas são muito rasas para o grande abismo que Roland Barthes abriu na crítica literária contemporânea. Ele desejou uma crítica que desdenhasse o discurso da arrogância e a histeria dos debates; ao contrário, interessava-se pelo que chamava de "rumor da

${ }^{526}$ Caderno 2/ Cultura, 2 de fevereiro de 2003, p. D1. 
língua”, murmúrio incompleto, irrealizado, apenas pressentido, que se camufla por trás das palavras. ${ }^{527}$

Evocando o M. Teste de Valéry, a autora reivindica para Barthes o lugar em que provavelmente ele se colocaria, se tivesse vivido no mundo pós-moderno: não o lugar de referência, que lhe foi imposto, mas o lugar incerto da decepção, da frustração das expectativas que sobre ele recairiam. Por essa razão, Leyla Perrone-Moisés o considera "atropelado pela pós-modernidade": pois por esta Barthes foi alçado a uma condição da qual ele se esquivou durante toda sua trajetória intelectual. E, como se isso não bastasse, o escritor ainda foi entronizado como rei de territórios que nunca foram os seus - a superficialidade e a amoralidade.

Mas não seria exigir demais que o movimento de ideias que buscava se impor primeiramente rompendo com o frio cientificismo anti-humano estruturalista não visse no Barthes terno, sentimental e amoroso dos últimos anos o mártir de sua causa? A despeito de sua aversão ao papel de mestre, o escritor, paralisado pela morte, não pôde evitar sua consagração e a consequente transformação de seus conceitos e ideias em argumentos de autoridade para toda uma geração de intelectuais, das mais diversas áreas.

A defesa dos ideais barthesianos por Leyla Perrone-Moisés se justifica pela tentativa de preservar a integridade de sua obra. Todavia, a melhor maneira de fazê-lo não seria justamente permitindo e até mesmo incentivando que a obra de Barthes fosse lida e apreendida das mais variadas maneiras, respeitando a vontade do escritor de não se fixar em posição alguma? Não seria mais fiel à sua vontade favorecer o deslocamento de sua obra, a transmutação de suas noções, a metamorfose de seus conceitos? Pois é no movimento que os textos e a própria memória de Barthes se mantém vivos, praticando o ideal da "revolução permanente da linguagem", como a mesma Leyla Perrone-Moisés afirma quatro anos mais tarde, em entrevista a Antônio Gonçalves Filho. Respondendo a questão sobre o lançamento das obras completas de Barthes, no Brasil, em 2004, a autora reconhece: "A publicação de suas obras completas provoca o descobrimento de Barthes por uma nova geração de leitores, permitindo, ao mesmo tempo, uma reavaliação de suas ideias sobre a revolução permanente da linguagem." ${ }^{528}$ E a propósito do imenso sucesso de público atingido pela exposição do Centre Georges Pompidou em 2003, respondendo à questão "Como explicar a popularidade de um literato que, apesar de voltado para a cultura de massa, não é exatamente um exemplo de leitura fácil?", conclui:

\footnotetext{
527 "Sob o signo de Barthes ensaísta pratica a contundência do texto", Caderno 2/ Cultura, 19 de novembro de 2000, p. D5.

528 “A Revolução permanente da linguagem”, Caderno 2/ Cultura, 19 de setembro de 2004, p. D6.
} 
O resultado [da montagem da exposição] era um espaço de sedução, a mesma sedução que ele [Barthes] exercia em pessoa, fazendo com que o "difícil" de seu discurso, que não era impositivo mas convidativo, provocasse um desejo de compreensão. A inexistência, nos dias atuais, de intelectuais franceses com esse vasto leque de interesses e com esse aspecto pouco acadêmico suscita, nos mais jovens, um desejo de conhecer sua obra. ${ }^{529}$

O jargão estruturalista, outrora chamado de "terrorismo terminológico", transformou-se em arma de sedução. Só a pós-modernidade poderia operar tal milagre, invertendo a imagem que afugentava leitores - "Gerações de estudantes desmaiaram diante de seus estudos estilísticos ou estruturais", dizia Gilles Lapouge um ano antes - para criar a imagem do escritor que atrai novos admiradores. O próprio Barthes, segundo Leyla Perrone-Moisés nessa entrevista, confessava seu desinteresse por suas obras estruturalistas, o que naturalmente deslocava o foco das atenções para seus escritos da década de 70. À guisa de balanço geral, o entrevistador formula uma pergunta, à qual a autora responde: “Quanto à leitura de Barthes no século 21, ela é oportuna porque ele foi um fino analista da cultura de massa e porque sua obra apresenta alternativas a esta. Ou pelo menos um modo menos passivo e mais crítico de conviver com ela." ${ }^{530} \mathrm{O}$ grande legado do escritor, para a entrevistada, é, portanto, sua crítica à cultura de massa, isto é, a crítica à massificação da cultura, eleita objeto de reflexão estética e consolidada pela pós-modernidade: uma crítica à própria pósmodernidade e a seus instrumentos de construção e de legitimação de poder.

O Barthes da pós-modernidade, amoroso crítico do poder, não é resultado exclusivamente de sua imagem no jornal, construída por jornalistas culturais. Essa percepção atual do escritor, que ainda divide espaço com o teórico estruturalista, também aparece no meio acadêmico. No capítulo seguinte, apresento um estudo pontual sobre a recepção à obra barthesiana na revista Língua $e$ Literatura, o que me permitirá estabelecer como contraponto ao jornal um periódico universitário, aos jornalistas culturais, os professores.

\footnotetext{
529 Ibidem.

530 Ibidem.
} 
O Estado de S. Paulo, Caderno 2/ Cultura, domingo, 19 de setembro de 2004, p. D6. 


\section{Barthes em Lingua e Literatura}

Pode ser que, ao final do exposto, a atividade analítica proposta se revele senão utópica, pelo menos exigente. Mas é a exposição da inquietação experimentada antes e depois da escrituração de um texto. ${ }^{531}$

Carlos Alberto da Fonseca

A revista dos cinco departamentos de Letras da USP, Língua e Literatura, constitui-se como um corpus totalmente diferente de $O$ Estado de $S$. Paulo, pois é composto por 24 artigos e ensaios científicos, destinados a um público exclusivo à universidade. Consequentemente, trata-se de textos densos, que versam sobre assuntos bastante específicos e limitados a estudos linguísticos e literários. Estes, muitas vezes, não se furtam a seu caráter exploratório, quando são, em sua origem, trabalhos de aproveitamento para disciplinas de pós-graduação, comunicações apresentadas em eventos, partes de relatórios de pesquisa ou de dissertações de mestrado e teses de doutorado. Ou seja, devido a sua característica ensaística e a sua circulação, restrita entre pares, os textos encontrados em Língua e Literatura são frutos da "inquietação experimentada" por seus autores “antes e depois da escrituração de um texto", como escreve Carlos Alberto da Fonseca, autor de um dos textos selecionados: estes são experimentos, exercícios de reflexão.

Nesse ambiente, Barthes é figura bastante frequente, pois aparece em 16 dos 29 números da revista, publicada de 1972 até 2011, por vezes em vários textos de um mesmo número. O método de seleção do corpus oriundo da revista foi o mesmo aplicado ao jornal: consultei todos os exemplares de Língua e Literatura na Biblioteca da Faculdade de Filosofia, Letras e Ciências Humanas da USP e fotocopiei os textos em que Barthes era citado. Mais uma vez, procedi a uma busca de agulhas num palheiro, assumindo o risco de ter deixado escapar a presença do escritor em alguns artigos ou ensaios, e por isso não pretendendo ter desenvolvido uma pesquisa exaustiva. Contudo, considero o montante de textos selecionado representativo da frequentação das obras de Barthes nessa revista universitária uspiana. A lista completa dos textos que compõem o corpus de Língua e Literatura, bem como seus autores e suas referências, pode ser consultada na Bibliografia deste trabalho.

531 “O Signo entre o texto e o contexto (projeto de uma análise integral)”, Língua e Literatura, n ${ }^{\circ}$ 4, 1975, p. 34. 
A leitura do corpus me possibilitou observar a dinâmica da presença de Barthes nos textos acadêmicos da revista. Para melhor visualização dos dados, dispu-los cronologicamente na tabela que segue: 


\begin{tabular}{|c|c|c|}
\hline Título & Ano & Barthes de... \\
\hline $\begin{array}{c}\text { "Les modes de l'action dans Le } \\
\text { Rouge et le Noir" }\end{array}$ & 1972 & $\begin{array}{c}\text { "Introduction à l'analyse structurale } \\
\text { des récits" }\end{array}$ \\
\hline "Há cavalos noturnos: mel e fel" & 1973 & O Grau zero da escritura \\
\hline $\begin{array}{l}\text { "Narração e metalinguagem em } \\
\text { Grande Sertão: Veredas" }\end{array}$ & 1973 & $\begin{array}{c}\text { "Introduction à l'analyse structurale } \\
\text { des récits", O Grau zero da escritura, } \\
\text { Elementos de semiologia, "L'Effet de } \\
\text { réel" }\end{array}$ \\
\hline "Fábula e trama" & 1974 & $\begin{array}{l}\text { "Introduction à l'analyse structurale } \\
\text { des récits" }\end{array}$ \\
\hline $\begin{array}{l}\text { "O signo entre o texto e o contexto } \\
\text { (projeto de uma análise integral)" }\end{array}$ & 1975 & $\begin{array}{l}\text { O Grau zero da escritura, Mitologias, } \\
\text { Crítica e verdade, O Prazer do texto }\end{array}$ \\
\hline $\begin{array}{c}\text { "Os índices da peça de teatro: Deus } \\
\text { lhe pague" }\end{array}$ & 1975 & Elementos de semiologia \\
\hline "Um projeto de Pierre Menard" & 1975 & $\begin{array}{c}\text { "Introdução à análise estrutural da } \\
\text { narrativa", "O Efeito do real" (via } \\
\text { Literatura e semiologia) }\end{array}$ \\
\hline "Psychanalyse et traduction" & 1975 & Mythologies, Le Plaisir du texte \\
\hline $\begin{array}{l}\text { "Em Camões e nos poetas } \\
\text { inconfidentes: uma questão de tópica } \\
\text { e/ou de influência literária" }\end{array}$ & 1976 & O Grau zero da escritura \\
\hline $\begin{array}{l}\text { "Do prazer e do divertimento - } \\
\text { Estudo sobre Barthes e Palazzeschi" }\end{array}$ & 1977 & Le Plaisir du texte, O Prazer do texto \\
\hline $\begin{array}{c}\text { "Tres Novelitas burguesas y lo } \\
\text { aleatório de los eventos" }\end{array}$ & 1978 & $\begin{array}{c}\text { O Prazer do texto, } \\
\text { "Sociología y socio-lógica" }\end{array}$ \\
\hline "Mestre em tempo do contra" & 1979 & "Escritores, intelectuais, professores" \\
\hline $\begin{array}{l}\text { "Algumas reflexões sobre os modelos } \\
\text { em linguística" }\end{array}$ & 1980 & $\begin{array}{c}\text { Le Degré zéro de l'écriture, Éléments } \\
\text { de sémiologie }\end{array}$ \\
\hline $\begin{array}{c}\text { "A Escritura de Günter Eich enquanto } \\
\text { epifania" }\end{array}$ & 1980 & Crítica e verdade \\
\hline $\begin{array}{l}\text { "La jouissance singulière de Swann et } \\
\text { l apetite phrase de Vinteuil" }\end{array}$ & 1986 & Le Plaisir du texte \\
\hline $\begin{array}{l}\text { "Borges e Drummond em seita } \\
\text { blasfema: a Biblioteca e a Torre" }\end{array}$ & $1987-1988$ & Aula \\
\hline $\begin{array}{l}\text { "Roland Barthes e a escrita } \\
\text { fragmentária" }\end{array}$ & 1989 & $\begin{array}{l}\text { Roland Barthes por Roland Barthes, } \\
\text { Incidentes, A Câmara Clara, } \\
\text { Fragmentos de um discurso amoroso }\end{array}$ \\
\hline "Correspondências" & 1989 & $\begin{array}{c}\text { Mythologies, "Diderot, Brecht, } \\
\text { Eisenstein" }\end{array}$ \\
\hline $\begin{array}{c}\text { "Jorge Luis Borges: o sentido latente } \\
\text { no leitor" }\end{array}$ & $1992-1993$ & O Rumor da língua \\
\hline "A pessoa subvertida" & 1994-1995 & Roland Barthes par Roland Barthes \\
\hline $\begin{array}{l}\text { " 'Não diferem o historiador e o } \\
\text { poeta...' O texto histórico como } \\
\text { instrumento e objeto de trabalho" }\end{array}$ & 1996 & $\begin{array}{c}\text { "O Efeito do real" (via O Rumor da } \\
\text { língua) }\end{array}$ \\
\hline $\begin{array}{l}\text { "Texto como enunciação. A } \\
\text { abordagem de Mikhail Bakhtin" }\end{array}$ & 1996 & $\begin{array}{c}\text { "Da obra ao texto" (via } O \text { Rumor da } \\
\text { língua) }\end{array}$ \\
\hline $\begin{array}{l}\text { "Representação das linguagens } \\
\text { sociais no romance: desencontro } \\
\text { cultural e ideológico em São } \\
\text { Bernardo, de Graciliano Ramos }\end{array}$ & 1996 & $\begin{array}{c}\text { "A Divisão das linguagens" (via } O \\
\text { Rumor da língua) }\end{array}$ \\
\hline $\begin{array}{l}\text { "Digressão: palavra desviante ou } \\
\text { estratégia argumentativa?" }\end{array}$ & 1997 & "A Retórica antiga" \\
\hline
\end{tabular}


Visando a concisão e o interesse deste trabalho nas imagens de Barthes, não incluí na tabela os nomes dos autores dos textos. Na coluna sobre as obras do escritor, estas são referidas nos idiomas em que foram citadas, constando em português as advindas de edições portuguesas e brasileiras, informações que fornecem dados importantes sobre a vinculação da presença de Barthes à circulação de suas obras no Brasil. Entre parênteses, as obras de que constam os ensaios mencionados, quando referidas.

A leitura dos textos, sistematizada na tabela, mostra três momentos distintos da presença de Barthes em Língua e Literatura: um período inicial, até 1975 ou 1976; um período intermediário, situado entre 1975 e meados da década de 80; e do final dos anos 1980 em diante.

No período incial, imperam “Introduction à l'analyse structurale des récits”, Le Degré zéro de l'écriture e Éléments de sémiologie, em edições francesas ou mesmo brasileiras, pois esses livros e o ensaio foram traduzidos em 1971. Barthes aparece como referencial teórico das análises linguísticas e literárias e é apenas citado como autor de conceitos operatórios para as leituras propostas. Sua função nos textos, portanto, é a de oferecer um ponto de partida e/ou referendar reflexões dos autores, tal como foi frequente em toda a década de 70 em $O$ Estado. Pois, na universidade, nessa época, o escritor era o grande representante da semiologia e suas obras, em especial as três referidas, eram os manuais de análise mais em moda - graças, também, a sua disponibilidade no país, proporcionada pelas traduções.

Dando razão aos muitos críticos do estruturalismo que atacaram veementemente sua linguagem, alguns dos textos encontrados abusam do jargão linguístico, como "Há Cavalos noturnos: mel e fel” (1973), em que Lídia Neghme Echeverría analisa o poema de Jorge de Lima de mesmo título. No ensaio, a autora emprega uma terminologia de difícil acesso aos não-iniciados, mesmo quando esta não implica o uso de conceitos específicos. Numa análise sintagmática do poema, escreve sobre o primeiro verso, "HÁ CAVALOS noturnos: mel e fel":

Percebemos que é no primeiro verso que se configuram os núcelos sêmicos diferenciais, sob o ponto de vista tanto do conteúdo quanto da expressão. Isto é assim porque embora os semas "mel" e "fel" sejam, sintaticamente, equivalentes, apresentam uma marca diferencial que os opõe, tanto semiologicamente quanto fonematicamente. ${ }^{532}$

Echeverría lança mão do conceito de sema da semântica estrutural de Greimas (Sémantique structurale, 1966), aliado aos conceitos de Hjelmslev de conteúdo e de expressão (Prolégomènes à une théorie du langage, 1968), sem citar os autores explicitamente, modalizados por advérbios que

${ }^{532}$ In Língua e Literatura, $\mathrm{n}^{\mathrm{o}} 2,1973$, p. 35. 
evocam a semiologia e a fonemática, para destacar a oposição entre "mel" e "fel", tanto do ponto de vista fonético, quanto conteudístico. Será que para fazer tal observação era mesmo preciso evocar Greimas, Hjelmslev, a Semiologia e a Fonemática? Claro que não, mas como era comum entre os intelectuais, naquele tempo, a autora demonstra dominar o linguajar científico que um artigo acadêmico poderia exigir.

Restringir-me-ei à passagem citada para não incorrer em repetições, uma vez que mais exemplos de mesma natureza se multiplicam no texto de Echeverría e em muitos outros do corpus de Língua e Literatura. Barthes, nos artigos e ensaios, alimentava esse linguajar com seus manuais de análise semiológica e estruturalista. Contudo, em meio ao mar de conceitos, notei uma tendência no uso das citações das obras do escritor francês: ao contrário do que uma leitura apressada do material recolhido pode dar a entender, em várias vezes, Barthes é citado como o autor de conceitos que não corroboram o estruturalismo mais ortodoxo, do texto fechado em si mesmo. Os autores parecem pinçar em suas obras definições que apontam para uma abertura em direção ao contexto, à história, à realidade, aos referentes, anunciando o arrefecimento do estruturalismo enquanto produtor de modelos analíticos rígidos e a procura de outras chaves a partir das quais compreender seus objetos.

No próprio texto de Echeverría, já mencionado, campeão de "terrorismo terminológico", a autora cita a definição de Barthes de écriture, de Le Degré zéro, na introdução à análise:

Esta abordagem retoma ainda a ideia de "escritura" de Roland Barthes, já que, segundo esse teórico, a escritura como ato de solidariedade histórica "é uma função: é uma relação entre criação e sociedade, é a linguagem literária transformada por sua destinação social, é a forma apreendida na sua intenção humana e ligada assim às grandes crises da História". ${ }^{533}$

Ao invés de buscar na obra de Barthes uma descrição da écriture como linguagem autorreferente, liberta do peso histórico que o termo literatura tinha até meados dos anos 60, e que se coadunaria com sua leitura estruturalista do poema de Jorge de Lima, a autora escolheu um trecho que trata do caráter social e histórico do conceito. O que é coerente com sua análise que, na parte final, abre-se para captar elementos externos à obra e a sua linguagem a fim de compor a interpretação.

Essa paradoxal busca por brechas para o contexto nas teorias estruturalistas levou Ítalo Caroni, em "Fábula e trama" (1974), a também citar um Barthes eminentemente estruturalista com a finalidade de encontrar uma leitura mais arejada. Fundamentando-se em teorias formalistas, Caroni

${ }^{533}$ Ibid., p. 31. 
discute a distinção entre fábula e trama, mencionando a compreensão de Todorov, segundo a qual essa distinção seria equivalente à existente entre enunciado e enunciação. Apoiando-se em "Introduction à l'analyse structurale des récits", o autor recorre a Barthes, para ratificar a natureza linguística das duas noções: “(...) Como estes dois últimos - enunciado e enunciação -, a dupla fábula e trama dá vida a duas realidades puramente linguísticas. Barthes diz a mesma coisa quando pretende que 'na narrativa nunca ocorre nada, e o que acontece é a linguagem apenas, 'cuja' vinda nunca cessa de ser festejada'." 534

Apesar de a citação acima ser menos claramente voltada à abertura da leitura da obra literária a seus referentes externos, não deixa de admiti-los, mesmo que sob a forma de uma linguagem. Complementando, novamente através do escritor francês, Caroni afirma que "Quanto a Barthes, a procura de uma realidade superior enigmática, escondida atrás dos fatos evocados pela narrativa, não se concebe sem o pressuposto de que estes mesmos fatos sejam comunicados ao leitor pela linguagem" 535 .

O sentimento de insuficiência do modelo analítico estruturalista dos anos 60 parece incomodar ao menos parte dos intelectuais que publicaram seus textos na revista, na primeira metade da década de 70. Dentre os vários autores que combinaram às leituras imanentes a busca por uma interpretação que lançasse mão de elementos exteriores ao texto, Carlos Alberto da Fonseca, cuja manifestação de suas inquietações se tornou epígrafe deste capítulo, foi o mais ousado. Em " $\mathrm{O}$ Signo entre o texto e o contexto (projeto de uma análise integral)" (1975), propõe a superação do modelo estruturalista por uma "análise integral", que combinasse a leitura cerrada da obra literária com sua abertura para os elementos contextuais. Nas palavras do autor,

A abertura analítica oferecida por este tipo de trabalho ultrapassa os limites da descrição estruturalista e se vê ampliada por uma interpretação de intenção globalizante, que se afirma sobre a intelecção dos signos (sistema linguístico) - especificando sua manipulação como constituintes de um texto (sistema semiológico) - e se volta, pela mediação estabelecida no interior deste texto, para a captação dos valores ideológicos do contexto exterior à obra, procurando estabelecer, até, uma dimensão mítica possível na transposição deste contexto (um objeto neutro a ser manejado conforme escolhidos instrumentos de composição) para um espaço literário próprio - o texto (um objeto individualizado). ${ }^{536}$

Sua justificativa parece resumir os anseios por novos ares entrevistos, aqui e ali, por vezes escondidos em meio a enxurradas de termos linguísticos e conceitos, nos artigos e ensaios desses

\footnotetext{
${ }^{534}$ In Língua e Literatura, $\mathrm{n}^{\mathrm{O}} 3,1974$, p. 158.

535 Ibidem.

${ }^{536}$ In Lingua e Literatura $\mathrm{n}^{\circ} 4,1975$, p. 46.
} 
primeiros anos de Língua e Literatura. O estruturalismo ortodoxo aos poucos foi perdendo espaço e um outro Barthes passou a frequentar os textos da revista, num período intermediário, até meados da década de 80. Nesse interstício, a descoberta de Le Plaisir du texte, recentemente traduzido no Brasil, em 1977, passou a responder majoritariamente pelas citações do escritor francês, refletindo a busca por novas perspectivas analíticas. A estrutura dos objetos - textos literários e corpora linguísticos - cedia seu protagonismo aos efeitos provocados pela leitura, fazendo emergir, junto do olhar psicanalítico sobre a literatura, questões sobre prazer, gozo e fruição.

Nesse momento, o autor de Le Plaisir du texte novamente é citado de maneira operatória, invariavelmente para fornecer suas definições de texto de prazer e de gozo. Isso ocorre no âmbito de leituras fortemente apoiadas na psicanálise lacaniana, como "Psychanalyse et traduction" (1975) e "La Jouissance singulière de Swann et la petite phrase de Vinteuil" (1986), de Philippe Willemart. Por exemplo, neste último artigo, cujo foco é o gozo do personagem de À la Recherche du temps perdu, com a ajuda de Barthes, o autor fixa a base sobre a qual vai trabalhar: "Il y a donc une jouissance première à se dépouiller et jouissance n'est pas plaisir, Barthes les distingue soigneusement. Alors que le plaisir touche à la culture, au douillet et aux retrouvailles, la jouissance transborde, brise et suspend: 'le plaisir en pièces; la langue en pièces; la culture en pièces'. " 537

Para além da fundamentação teórica necessária a uma abordagem nova e psicanalítica do texto, a definição de texto de gozo - na época, traduzido por texto de fruição -, evocada pelos autores, com frequência foi empregada sob o ângulo da contestação e da subversão de concepções tradicionais. O que se justifica como sintoma da vontade de romper com os preceitos estruturalistas e caminhar rumo a noções mais amplas e menos limitadoras da leitura dos objetos, sobretudo os literários. Pois dessa época decresce a presença de Barthes nos artigos e ensaios de temas linguísticos, para quase desaparecer: uma consequência não só do esgotamento do interesse por obras como Éléments de sémiologie e "Introduction à l'analyse structurale des récits", mas também da guinada personalista da obra do escritor nos anos 70, menos passível de aproveitamento em reflexões sobre questões técnicas, de ordem unicamente linguística.

A procura pelo autor que situou no prazer hedonista o potencial subversivo do texto literário colocou Barthes na introdução de "Do Prazer e do divertimento - estudo sobre Barthes e Palazzeschi” (1977), de Aurora Fornoni Bernardini. Diferentemente do que seu título indica, o artigo não é em nenhuma medida um estudo sobre Barthes, mas emprega sua compreensão de prazer

${ }^{537}$ In Língua e Literatura, $\mathrm{n}^{\mathrm{o}} 15,1986$, p. 165. 
como a priori crítico para desenvolver reflexões sobre o "divertimento" na obra do poeta italiano Aldo Palazzeschi:

Um desses aspectos [das possíveis acepções do termo fruição, por Barthes], um tipo particular de fruição, portanto, intervém de maneira singular quando o texto é libertado (pelo leitor) dos imaginários da linguagem (a palavra como unidade singular, mônada mágica; a fala como instrumento ou expressão do pensamento; a escrita como transliteração da fala; a frase como medida lógica, fechada; a própria carência ou recusa de linguagem como força primária, espontânea, pragmática) ${ }^{538}$.

O foco sobre o poder libertador da "fruição", da jouissance, no termo de Barthes, coloca-o em oposição aos “imaginários da linguagem” elencados pela autora. Já Lidia Neghme Echeverría amplia esse uso, em "Tres Novelitas burguesas y lo aleatorio de los eventos" (1978), ao estudar contos de José Donoso. Em seu artigo, a autora escreve:

Una redundancia de las "novelitas" de Donoso revela que un objeto artístico (canción, cuadro y, aquí música de Ravel) injerta acontecimentos aleatórios. Se unen los linguajes musicales y plásticos a la referencia de alienaciones y subversiones del mundo. Esta ambivalência señala la modernidad, según Barthes: el ángulo subversivo señala "el lugar de una perdida, de una hendidura, el corte, el fading que se apodera del sujeto en la cima de la fruición" 539.

A autora relaciona o mecanismo narrativo dos contos de Donoso - um elemento extraliterário, como a música, engendra os acontecimentos que compõem o enredo - à modernidade, e recorre ao escritor francês, por meio de sua definição de texto de gozo. O lugar da perda, da fissura, a ruptura com o esperado, que provoca o gozo, é também o lugar da pós-modernidade, nos anos 80 , marcando a presença de Barthes em Língua e Literatura do final dessa década em diante.

Essa pós-modernidade aberta a novas linguagens, na revista, acaba por relegar o teórico estruturalista ao segundo plano, e as citações ao escritor francês começam a ser empregadas de modo mais diversificado, à medida que sua nova face se consolida no Brasil: num intervalo de poucos anos, Barthes passa de referência estruturalista, a "pai" do textualismo. Tal mudança de enfoque deve muito à circulação no Brasil da nova concepção de Texto e suas implicações para os estudos literários.

Debruça-se sobre o assunto Fabio Akcelrud Durão, discutindo o papel da Teoria nos estudos literários, em seu Teoria (literária) americana: uma introdução crítica (2011). Nesse livro, o autor trata da vertente "textualista" que reinou nos Estados Unidos nas décadas de 70 e 80 e que

\footnotetext{
${ }^{538}$ In Língua e Literatura, $\mathrm{n}^{\mathrm{o}} 6,1977$, p. 37.

${ }^{539}$ In Língua e Literatura, $\mathrm{n}^{\mathrm{o}}$ 7, 1978, p. 170.
} 
também teve saída no Brasil do mesmo período. Segundo Durão, o ponto de vista "textualista" concebe a cultura como texto, multiplicando os objetos da Teoria e fazendo dela "literária", por se ocupar de textos, ao mesmo tempo em que deixa de sê-lo, pois qualquer coisa pode ser vista como texto, como por exemplo, séries televisivas, hábitos culturais, eventos, etc ${ }^{540}$. Ressalto que tal renovação dos objetos de estudo se iniciara com o advento da semiologia, nos anos 70, como mostrei neste trabalho. Os primórdios do "textualismo", portanto, remontam a essa época, e devem aos ensaios de Barthes "La Mort de l'auteur" e, sobretudo, "De l'oeuvre au texte" (1971), sua teorização e defesa.

Nesse ensaio fundamental para os estudos literários que é "De l'oeuvre ao texte", o escritor francês opõe à concepção tradicional de obra literária - na França da época, ainda muito devedora de princípios oriundos do século XIX - sua compreensão de Texto, objeto plural e infinito, de onde emanam significações as mais diversas, construídas a cada ato de leitura. Um espírito libertário, portanto, governa o Texto segundo Barthes, que substitui as intrincadas relações estruturais pelo ecumenismo conciliador capaz de tudo abarcar.

Como consequência dessa mudança de ares nos domínios da Teoria literária, o mesmo Fabio Akcelrud Durão, em sua crítica ao ensaio de Barthes, entitulada "Do Texto à Obra" (2011), defende o restabelecimento do conceito de Obra, revigorado por ter em sua base as qualidades das grandes obras literárias. Enumerando os problemas contidos no conceito barthesiano de Texto, escreve:

Por fim, o conceito de Texto trouxe consigo a possibilidade de sua extrapolação. A forma como foi apropriado posteriormente, como espaço de plena liberdade e abundância a priori ignorando o aspecto destruidor do gozo ao qual se relaciona - presente em todo e qualquer artefato, não representou apenas um enfraquecimento e diluição, mas correspondeu à potencialização de forças no interior do próprio conceito. O impulso proliferante da textualidade foi rapidamente institucionalizado e incorporado à máquina universitária/jornalística de produção de textos. ${ }^{541}$

Dentro da nova concepção mencionada pelo autor, não estou certa de que a ampliação dos territórios abrangidos pelo Texto tenha causado o esvaziamento do conceito. Por que não pensar em seu fortalecimento, uma vez que seus poderes foram aumentados? Fico com a constatação de que seu alargamento de horizontes propiciou um uso mais amplo, ultrapassando as fronteiras do literário no sentido tradicional e, com isso, contribuindo para propulsionar Barthes para outros campos do conhecimento.

\footnotetext{
${ }^{540}$ Campinas (SP), Autores Associados, p. 54.

${ }^{541}$ In Alea, vol. 13, n 1 , janeiro-junho de 2011, p. 74.
} 
Em Língua e Literatura, revista evidentemente restrita às áreas de Letras e Linguística, essa outra faceta de Barthes não aparece sob a variedade de formas às quais seu pensamento foi aplicado desde os anos 70, devido ao campo específico em que se situa esse corpus. No entanto, no contexto da revista, o horizonte barthesiano se alarga consideravelmente nos anos 80 e as obras citadas se diversificam, tendo repercussão, sobretudo, $O$ Rumor da língua, tradução de 1988 de Le Bruissement de la langue (1984). Nessa coletânea de ensaios, têm lugar textos bem diversos, alguns de cunho ainda estruturalista, outros já de ruptura, outros sobre a imagem. François Wahl, responsável pela seleção e edição do livro, sintetiza: "Presque tout traite, dans le dernier recueil que voici, du langage et de l'écriture littéraire ou, pour mieux dire, du plaisir qu'on doit au texte." ${ }^{542}$ Em outras palavras, a linguagem, sob diferentes formas, imagem ou Texto, é a protagonista do livro, e nos artigos e ensaios de Língua e Literatura, ela também tem papel de destaque, revelando o interesse pelas reflexões de Barthes do pós-estruturalismo e da pós-semiologia nessa seara. Interesse, aliás, manifestado pela tradução da obra, que foi publicada no Brasil apenas quatro anos após seu lançamento na França, antes mesmo de outras coletâneas póstumas, como Le Grain de la voix (1981), traduzida em 1995, Essais critiques III. L'Obvie et l'obtus (1982), traduzida em 1990 e L'Aventure sémiologique (1985), traduzida em 2001.

Nos artigos e ensaios publicados na revista, as citações de $O$ Rumor da língua são, em geral, bem pontuais, servindo como referência para ratificar uma informação fornecida pelo autor do texto. Por exemplo, em "Representação das linguagens sociais no romance: desencontro cultural e ideológico em São Bernardo, de Graciliano Ramos” (1996) ${ }^{543}$, de Maria Celina Novaes Marinho, uma citação de "A divisão das linguagens", ensaio contido em $O$ Rumor, a propósito do manejo, por Balzac, dos diferentes registros de linguagens sociais, reforça a observação da autora sobre a presença codificada da "opinião corrente" na obra de Ramos. Ou em "Jorge Luis Borges: o sentido latente no leitor" (1992-1993) ${ }^{544}$, de Maria Helena da Nóbrega, sobre a desconstrução do conceito de autoria enquanto ideia unificadora dos sentidos de um texto na obra de Borges e o papel do leitor na construção dos sentidos do texto literário. Nesse artigo, a autora lança mão de trecho de "A Morte do autor" para definir a escritura como neutro e, portanto, destituída de origem, e de citação de "Da Leitura", para fundamentar suas reflexões sobre a relação íntima entre o leitor e o livro.

Vai um pouco além de meras citações ratificadoras de ideias o uso que Irene Machado faz de "A Morte do autor”, em “Texto como enunciação. A abordagem de Mikhail Bakhtin” (1996).

\footnotetext{
${ }^{542}$ In Essais critiques IV. Le Bruissement de la langue, Paris, Seuil, 1984, p.8.

${ }^{543}$ In Língua e Literatura, $\mathrm{n}^{\mathrm{O}} 22$, pp. 123-135.

${ }^{544}$ In Língua e Literatura, $\mathrm{n}^{\mathrm{O}} 20$, pp. 137-142.
} 
Nele, a autora expõe a concepção bakhtiniana de texto fundamentada nas formas discursivas e procura opô-la à de Barthes, discutindo-a, mesmo que brevemente. Segundo Machado, Bakhtin considera o enunciado "como unidade elementar de organização das formas linguísticas produtoras do discurso-língua (...)" ${ }^{545}$, o que lhe permite deduzir que a base da intertextualidade se encontra em gêneros textuais, no sentido amplo, abarcando os orais e os escritos. Dessa ideia parte sua discussão com Barthes:

O encaminhamento que Bakhtin dedica aos problemas da textualidade a partir da combinatória dos gêneros é algo que entra em confronto com os conceitos de texto mais divulgados. Roland Barthes, por exemplo, eliminou o gênero de seu conceito de texto porque, tomando o esquema hierárquico consagrado pela clássica teoria dos gêneros literários, pareceu-lhe impossível entender o texto como "um tecido de citações saídas dos mil focos da cultura", cabendo ao escritor "imitar um gesto sempre anterior, jamais original: seu único poder está em mesclar estruturas, ... a 'coisa' interior que tem a pretensão de traduzir não é senão um dicionário todo composto, cujas palavras só se podem explicar através de outras palavras". ${ }^{546}$

De início, a passagem acima contém uma contradição: citando Barthes, a autora afirma que ao escritor francês "pareceu-lhe impossível entender o texto como 'um tecido de citações saídas dos mil focos da cultura" ". Pois a própria citação de Barthes diz o contrário: que o escritor compreende o texto como "um tecido de citações...". Nas palavras de Barthes, "Nous savons maintenant qu'un texte n'est pas fait d'une ligne de mots (...), mais un espace à dimensions multiples, où se marient et se contestent des écritures variées, dont aucune n'est originelle: le texte est un tissu de citations, issues des mille foyers de la culture." ${ }^{547}$ Em seguida ao trecho citado, Machado aponta um problema no conceito barthesiano de texto: "o inter-relacionamento das palavras via dicionário nem de longe reproduz as complexas relações dialógicas que se encarregam de constituir o 'tecido de citações, saídas dos mil focos da cultura'. " 548 Ora, ao lançar mão da metáfora do dicionário para explicar seu conceito de texto, Barthes não se refere literalmente às palavras, mas ao processo combinatório que resulta no texto. Mais adiante, ainda em “La Mort de l'auteur”, vejo essa explicitação:

(...) succédant à l'Auteur, le scripteur n'a plus en lui passions, humeurs, sentiments, impressions, mais cet immense dictionnaire où il puise une écriture qui ne peut connaître aucun arrêt: la vie ne fait jamais qu'imiter le livre, et ce livre lui-même n'est qu'un tissu de signes, imitation perdue, infiniment reculée. ${ }^{549}$

\footnotetext{
${ }^{545}$ In Língua e Literatura, ${ }^{\mathrm{o}} 22$, p. 90.

${ }^{546}$ Ibid., p. 91.

${ }^{547}$ In $O C$ v. 3, p. 43.

${ }_{548}$ In Lingua e Literatura, $\mathrm{n}^{\mathrm{o}} 22$, p. 91.

${ }^{549}$ In $O C$ v. 3, p. 44.
} 
No dicionário barthesiano há écritures, pedaços de texto, e não palavras, no sentido literal, da mesma maneira como há signos, elementos constitutivos do texto. Ou seja, palavras, écritures e signos, nesse contexto, são equivalentes, pois o que interessa é o processo de combinação de elementos pré-existentes, rompendo com as ideias românticas de originalidade e de autoria. Machado, portanto, parece querer forçar uma interpretação do texto de Barthes a fim de colocar a leitura que defende, de Bakthin, em relevo. Ademais, a autora parece ignorar outro ensaio clássico publicado em $O$ Rumor da língua, "Da obra ao texto", em que o escritor novamente explicita o conceito de texto, dessa vez, sem ajuda da metáfora do dicionário:

C'est ce qui se passe pour le Texte: il ne peut être lui que dans sa différence (ce qui ne veut pas dire son individualité); sa lecture est semelfactive (ce qui rend illusoire toute science inductivedéductive des textes; pas de "grammaire" du texte), et cependant entièrement tissée de citations, de références, d'échos: langages culturels (quel langage ne le serait pas?), antécédents ou contemporains, que le traversent de part en part dans une vaste stéréophonie. ${ }^{550}$

O emprego do termo "stéréophonie" me parece determinante da herança bakhtiniana penso na noção de polifonia - no pensamento de Barthes, apreendido por meio de Julia Kristeva e declarado em "L'Étrangère", texto redigido para saudar a publicação de Sèméiotikè e republicado em Le Bruissement. Machado, portanto, não consegue justificar sua tentativa de oposição entre as concepções de Bakthin e de Barthes, sendo que a segunda se alimentou da primeira e não a contradiz em momento algum. Uma leitura mais atenta dos demais ensaios contidos no livro talvez pudesse ter evitado seu erro de avaliação.

Em Língua e Literatura ainda se reflete o interesse por outros temas tratados por Barthes em ensaios e artigos que circulavam, entre as décadas de 70 e de 90, por meio de outras edições que não O Rumor. Assim, Teresa Pires Vara, em "Correspondências" (1989) ${ }^{551}$, ao analisar o filme Le festin de Babette (1987), faz breve alusão a "Diderot, Brecht, Eisenstein", publicado originalmente em 1973 e, depois, em Essais critiques III. L'Obvie et l'obtus (1982). E Maria Lúcia Andrade, em estudo histórico sobre a digressão e sua presença na obra de Cícero, "Digressão: palavra desviante ou estratégia argumentativa?" (1997) ${ }^{552}$, alude a "L’Ancienne rhétorique. Aide-mémoire", longo ensaio de Barthes sobre o tema, publicado em 1970 e republicado em L'Aventure sémiologique

\footnotetext{
${ }^{550}$ In $O C$ v. 3, p. 912.

${ }^{551}$ In Língua e Literatura, ${ }^{\circ} 17$, pp. 181-196.

${ }^{552}$ In Língua e Literatura, $\mathrm{n}^{\mathrm{o}} 23$, pp. 121-149.
} 
(1985). A autora o cita apenas na bibliografia, traduzido como "A Retórica antiga", na coletânea Pesquisas de retórica, de Jean Cohen et alii (1975) ${ }^{553}$.

As informações encontradas nos textos da revista permitem comprovar a circulação de textos e ideias de Barthes os mais variados, muito ao sabor das publicações brasileiras de suas obras. Contudo, há um ponto comum a tantas citações empregadas em textos distintos, sobre linguística e sobre literatura: o abandono, nesse último período do corpus, do Barthes estruturalista. Tendo sido substituído pelo escritor textualista, ou pelo teórico da morte do autor e da ascenção do leitor ao posto de protagonista, ou pelo interessado em cinema, ou ainda pelo estudioso da retórica, o Barthes dos anos 60 parecia definitivamente morto para a academia. E despontava, entre os anos 80 e 90, o escritor que nos anos 2000 seria consagrado pela crítica universitária: o subvertor da doxa.

Em "Borges e Drummond em seita blasfema: a biblioteca e a torre" (1987-1988) ${ }^{554}$, Maria do Carmo Campos faz uma análise comparativa do conto de Borges, "A Biblioteca de Babel”, e do poema de Drummond, "A Torre sem degraus". Nesse poema, o eu-lírico descreve uma torre sem degraus, e "alude à construção possível de um real em ruptura, sem pontos de referência ou apoio. A solidez da pedra é iluminada por imensos vazios lógicos e estruturais, na desierarquização grave e poética de uma escada que paulatinamente se constrói e se desmonta." ${ }^{555}$ Em sua leitura, a autora enxerga nessa torre sem degraus um paradoxo, e muito brevemente recorre a Barthes, "que mostrou uma DOXA a permear a linguagem, a cultura e as mais diferentes relações" ${ }^{556}$. Campos se refere à Aula, tradução da Leçon, que foi publicada no Brasil em 1980, como apoio para sua análise do poema drummondiano como uma proposta de subversão dos parâmetros tradicionais do conhecimento da realidade.

A essa menção solitária de um dos textos mais famosos de Barthes, juntam-se dois artigos que também ressaltam o caráter subvertor do escritor francês. “A Pessoa subvertida” (1994-1995) 557 é um trabalho de José Luiz Fiorin sobre os usos de uma pessoa do discurso com o sentido de outra, ou seja, o emprego da terceira pessoa do singular pela primeira, como Barthes faz em Roland Barthes por Roland Barthes, traduzido no Brasil em 1977, citado por Fiorin, quando o escritor escreve sobre si mesmo utilizando-se de "ill" ao invés de "je". E "Roland Barthes e a escrita fragmentária” (1989), de Regina Pontieri, um estudo detalhado que alia ao fragmento como forma literária a ideia de modernidade, tendo como exemplo Roland Barthes por Roland Barthes. Para a

\footnotetext{
${ }^{553}$ Petrópolis (RJ), Vozes, pp. 147-221.

${ }^{554}$ In Língua e Literatura, $\mathrm{n}^{\mathrm{O}} 16$, pp. 43-52.

555 Ibid., p. 49.

556 Ibid., p. 50.

${ }^{557}$ In Língua e Literatura, $\mathrm{n}^{\mathrm{o}} 21$, pp. 77-107.
} 
autora, a escrita fragmentária do escritor francês, no livro mencionado, bem como em Fragments d'un discours amoureux e Incidents, revela um sistema coeso, apesar de sua forma. Ou melhor, é na forma fragmentária, em que cada fragmento emana sentidos, que a coesão sistêmica da obra se consolida. Nas palavras da autora, "Adiante veremos que a multiplicação dos fragmentos, num jogo infinito de superposições de falas, responderá pelo funcionamento de Roland Barthes por Roland Barthes como forma de impedir a interrupção do fluxo do discurso, o coágulo ideológico." 558

Pontieri, autora do único ensaio verdadeiramente consagrado a Barthes em Língua $e$ Literatura, propõe três "portas de entrada" - leia-se "leituras" - de Roland Barthes por Roland Barthes, tendo por base sua estrutura fragmentária: "estruturação (que Barthes chama de patchwork), encenação, metalinguagem" 559. Sob a rubrica "estruturação", a autora compreende fragmentos que aludam à própria construção do texto. Sob "encenação", ela elenca fragmentos em que o escritor reflete sobre a natureza teatral da écriture. E sob "metalinguagem", reconhecendo que a rubrica engloba as duas anteriores, Pontieri menciona fragmentos que tratam do funcionamento do livro, "não mais como processo de estruturação ou encenação, mas como movimento contínuo de encaixe de peças que falam umas das outras ou mesmo de outros livros do autor." 560

À guisa de balanço final, a autora desenvolve reflexões sobre a escrita fragmentária barthesiana e a tradição do fragmento como forma literária, apontando para duas conclusões: por um lado, os fragmentos na obra de Barthes convidam o leitor a construir os sentidos do texto, o que caracteriza as obras modernas; por outro, a autora "vê no estilhaçamento da escrita a resultante da recusa do pensamento totalizante e totalitário." 561 Considerando esta a mais importante das duas conclusões, Pontieri coloca em relevo o Barthes que resiste à prisão da doxa por meio do livre exercício da literatura.

Embora bem menos vasto e heterogêneo do que o material selecionado em $O$ Estado, o corpus extraído de Língua e Literatura oferece um panorama relevante da recepção à obra de Barthes no seio de uma grande instituição universitária, a Universidade de São Paulo. De 1972 até 2011, a leitura dos ensaios e artigos publicados na revista permite destacar duas imagens do escritor: o teórico estruturalista e o teórico textualista pós-moderno, nuançadas pelas imagens mais vagas do teórico do prazer do texto e do autor que escreve sobre os temas mais diversos. Aparece, ainda que timidamente, uma outra faceta do escritor celebrado pela pós-modernidade, o crítico da doxa,

\footnotetext{
${ }^{558}$ In Língua e Literatura, $\mathrm{n}^{\mathrm{o}} 17$, p. 90.

559 Ibid., p. 92.

${ }^{560}$ Ibid., pp. 92-93.

561 Ibid., p. 97.
} 
imagem predominante de Barthes na literatura acadêmica dos anos 2000 em diante, de que tratarei no próximo capítulo. 


\section{A crítica atual: deslocamentos}

Quand un ensemble de positions paraissent se réifier, constituer une situation sociale un peu précise, alors effectivement, de moi-même et sans y penser, j'ai envie d'aller ailleurs. Et c'est en cela que je pourrais me reconnaître comme un intellectuel (...). ${ }^{562}$

Roland Barthes

Roland Barthes reconhecia na rigidez discursiva ou no emprego de uma linguagem axiomática o exercício de um poder e, por conseguinte, uma relação de servidão, à qual era extremamente sensível e que repudiava com veemência. Para escapar a ela, deslocava-se permanentemente entre temas, discursos e linguagens, ao mesmo tempo desnorteando seguidores e criando uma legião de admiradores que só poderiam acompanhar com o olhar esse mestre nômade do saber, sem imaginar qual seria seu próximo passo.

Sua obra, feita de perambulações ao sabor de seus desejos, também errou pela crítica brasileira, que tentou apreendê-la em artigos e ensaios desde os anos 50. Neste capítulo, ocupo-me da bibliografia em livro dedicada a Barthes, no Brasil, no momento presente. Esta é bastante restrita: foram encontradas duas coletâneas de ensaios, De volta a Roland Barthes (2005) ${ }^{563}$ e Viver com Barthes (2005) ${ }^{564}$, um estudo sobre a écriture, A Escritura inquieta (1999) ${ }^{565}$, bem como alguns ensaios publicados em periódicos ou em volumes. Recentemente foram lançados Roland Barthes, uma biografia intelectual (2011) ${ }^{566}$, de Leda Tenório da Motta, e Com Roland Barthes (2012) ${ }^{567}$, de Leyla Perrone-Moisés. Embora não seja exaustivo, o levantamento que fiz oferece um panorama da produção acadêmica atual envolvendo Barthes, contemplando textos de tendências as mais diversas.

Além desses livros, encontrei ainda resenhas e estudos de obras de Barthes que procuram apresentá-las aos leitores ${ }^{568}$, ensaios que empregam conceitos barthesianos de maneira operatória para tratar de questões específicas ${ }^{569} \mathrm{e}$, naturalmente, estudos sobre vários aspectos de sua obra ${ }^{570}$.

\footnotetext{
562 Entrevista de Barthes a Jacques Henric, maio de 1977. "Entretien”, $O C$ v. 5, p. 399.

${ }^{563}$ Coletânea organizada por Maria Elizabeth Chaves de Mello e Leyla Perrone-Moisés, Niterói (RJ), EdUFF.

${ }^{564}$ Coletânea organizada por Vera Casa Nova e Paula Glenadel, Rio de Janeiro, 7Letras.

565 De Neiva Pitta Kadota, São Paulo, Estação Liberdade.

${ }^{566}$ São Paulo, Iluminuras.

567 São Paulo, WMF Martins Fontes.

${ }^{568}$ Refiro-me, por exemplo, a "Barthes", de Leda Tenório da Motta, resenhade Incidentes, publicada primeiramente no caderno "Ilustrada" da Folha de São Paulo em 2 de julho de 1988 e republicada em Lições de literatura francesa (Rio de Janeiro, Imago, 1997), pp. 167-172.
} 
Um misto dos dois últimos tipos de textos elencados é A escritura inquieta, de Neiva Pitta Kadota, um estudo sobre o conceito de écriture e sua aplicação nas leituras de obras de Julio Cortázar, Clarice Lispector e Octavio Paz. De estrutura bastante tradicional e didática, o livro é composto primeiramente por dois capítulos introdutórios que recuperam conceitos básicos de Saussure, nos quais Barthes se pautou para desenvolver suas reflexões sobre a linguagem literária e cunhar o conceito de écriture. Seguem-se a eles um capítulo de considerações gerais sobre a escritura, reunindo reflexões sobre a linguagem poética de lavra variada, e um capítulo dedicado à écriture de Barthes, no qual a autora a define em sua totalidade, como uma linguagem à deriva, incessantemente em movimento para escapar à doxa, regida pelos desejos de seu enunciador e prenhe de sentidos. A autora reconhece essas características, que são devidamente esmiuçadas no livro, em obras dos escritores latino-americanos citados, e, com o auxílio de textos críticos, procede a leituras que buscam colocar em relevo suas escrituras, aproximando-as do conceito de Barthes. Portanto, ao mesmo tempo em que se dedica a um elemento do pensamento barthesiano, o conceito de écriture, Neiva Pitta Kadota o instrumentaliza, empregando-o como guia para suas leituras fecundas - de partes das obras de Cortázar, Lispector e Paz.

De fatura e objetivos diferentes, Roland Barthes: uma biografia intelectual, de Leda Tenório da Motta, é um vasto estudo do neutro na obra barthesiana, que a autora considera central para se compreender não só a écriture, como os deslocamentos constantes do escritor. O livro mescla informações sobre a vida e os escritos de Barthes com uma perseguição implacável dos rastros da ideia de neutro em sua obra, elaborada enquanto conceito só posteriormente, por ocasião de seu curso de 1977-1978, no Collège de France. A fim de desenvolver sua leitura, a autora elege determinados momentos dentro do pensamento barthesiano, a partir dos quais fundamenta sua tese: primeiramente, ela destaca o ceticismo como orientação filosófica de Barthes, identificando-o em sua postura sempre voltada para a abertura de espírito que considera todas as possibilidades, implícita nas análises do escritor. O segundo capítulo é dedicado às fontes do neutro, radicadas no grau zero da escrita, na écriture blanche defendida no primeiro livro do escritor e em seus ensaios

569 "O que é o fait divers? Considerações a partir de Roland Barthes", de Ana Alencar, publicado em Viver com Barthes, pp. 115-128, é um exemplo desse tipo de texto, que, para analisar o fait divers enquanto gênero textual, vale-se das reflexões de Barthes presentes em "Structure du fait divers", artigo publicado nos Essais critiques (OC v. 2, pp. 442451).

${ }^{570}$ Cito a minuciosa leitura que Leyla Perrone-Moisés faz de Comment vivre ensemble (2002) e de Le Neutre (2002), em comparação com a aula inaugural de Barthes no Collège de France, presente no ensaio "A Prática da Aula nos cursos do Collège de France", publicado em De Volta a Roland Barthes, pp. 131-142. Ou a bela análise de Manuel da Costa Pinto da polêmica entre Barthes e Camus, "Um mundo enclausurado: a polêmica entre Barthes e Camus", igualmente publicado em De volta a Roland Barthes, pp. 69-80. Ou ainda "Écrire sans écrire: Barthes et la recherche du roman", de Claudia Amigo Pino, uma análise dos manuscritos de Vita Nova à luz de A la recherche du temps perdu, publicada na Revista Criação \& Crítica (São Paulo, n ${ }^{0} 2,2009$, pp. 25-25). 
dos anos 40 e 50. Em seguida, a autora estuda o neutro no seio da semiologia barthesiana, com ênfase nos textos de Mythologies, para, no quarto capítulo, deter-se na discussão entre Barthes e Raymond Picard sobre a natureza da crítica literária, nos anos 60, com base em Sur Racine e Critique et vérité. Nesse momento, Motta coloca em relevo a insurgência da nouvelle critique, em sua modalidade barthesiana, contra os padrões críticos lansonianos então em voga, tornando evidente o a priori crítico do escritor, estabelecido sobre o princípio da liberdade de escrita. O capítulo final conclui pela centralidade do neutro na poética de Barthes, constituída pela escolha do diário e dos fragmentos como forma de escrita. Extremamente bem fundamentado do ponto de vista da bibliografia de e sobre o escritor, Roland Barthes: uma biografia intelectual apresenta, em suma, uma visão bastante particular: substitui a noção de écriture pelo conceito de neutro na base do pensamento barthesiano, o que implica em leituras inusitadas e, em alguns casos, um pouco forçadas.

O mais recente livro brasileiro dedicado a Barthes, Com Roland Barthes, de Leyla PerroneMoisés, é uma coletânea de textos da autora dedicados ao escritor e até então de difícil acesso ou inéditos no Brasil. Reunindo artigos de imprensa, comunicações escritas para eventos acadêmicos, ensaios publicados em revistas francesas, notas de preparação de aulas, cartas e entrevistas, o volume é um testemunho da dedicação de Leyla Perrone-Moisés à obra de Barthes, dos anos 60 até o momento presente. Sua organização é cronológica, marcando três etapas da "convivência" da autora com o escritor e sua obra: a primeira, entitulada "Descoberta e encontro", compreende textos publicados em $O$ Estado de S. Paulo e em La Quinzaine Littéraire nas décadas de 60 e 70, bem como cartas e bilhetes datando de até 1974. Nesses textos, a autora apresenta Barthes: explica suas noções-chave, como a de écriture, a distinção entre écrivains e écrivants e sua concepção de crítica; evidencia a coerência de sua obra por meio da ideia do deslocamento que é intrínseco a sua écriture, forma de escrita caracterizada pelo movimento da deriva; analisa o recém-lançado $S / Z$; e discute alguns estudos sobre a obra de Barthes, inserindo-se em sua fortuna crítica.

A segunda parte do livro, "Passando o anel", concentra os escritos da autora posteriores ao primeiro momento e, portanto, mais voltados para a divulgação da obra barthesiana. Compõem essa parte questões levantadas pela tradução dos escritos de Barthes, apontamentos empregados em cursos sobre o escritor e textos relativos à repercussão de Fragments d'un discours amoureux, incluindo o do livreto da peça teatral brasileira, bem como um inédito sobre as relações entre linguagem e culinária no pensamento barthesiano.

"Depois de Barthes", terceira parte do livro, apresenta estudos consagrados à herança do escritor e a suas relações com as obras de outros intelectuais, tais como Derrida, Sartre e Blanchot. 
A discussão dos textos e das noções barthesianos à luz de teorias celebradas, sobretudo, nos anos 90, respondem por um balanço de sua obra na pós-modernidade. Também têm lugar análises dos cursos ministrados no Collège de France, publicados no início dos anos 2000, de cuja recepção a autora se ocupou, não abandonando sua prática desde o primeiro livro de Barthes. Ao final de cada parte, cartas e bilhetes do escritor, reproduzidos e traduzidos, e algumas entrevistas de Leyla PerroneMoisés. O que confere ao denso volume de textos críticos a leveza da palavra afetuosa do mestre à discípula aplicada e a lembrança desta da memória intelectual barthesiana. Além de testemunho de sessenta anos de dedicação à obra de Barthes, Com Roland Barthes é uma bela homenagem da autora ao escritor.

Em meio à pluralidade de abordagens e de temas relacionados aos conceitos e às ideias barthesianas, é possível enxergar características comuns a uma grande parte das leituras atuais da obra do escritor francês, que podem ser federadas em uma linha temática. Esta privilegia o Barthes crítico do poder, libertário, indócil às tentativas de submissão e entusiasta das experimentações. Não se trata, portanto, do Barthes de um livro ou de um ensaio, mas de um recorte feito tendo em vista toda uma trajetória intelectual. Esse recorte, contudo, não é estanque. Ele tem matizes que denunciam uma gradação na percepção dessa faceta de Barthes, que colocarei em relevo.

Há, inicialmente, muitos textos que elegem Barthes e sua relação com a doxa como tema. João Batista Natali, em “O horror à estereotipia e o discurso político" ${ }^{571}$, por exemplo, demonstra que não existe um "barthesianismo", uma doutrina cunhada por Barthes que pode ser cultuada e praticada, devido à natureza difusa - ou nômade, como a vejo - de seus objetos de reflexão. Natali resume bem essa ideia quando menciona o que acontecia quando Barthes começou a se tornar uma figura conhecia, depois de Mythologies:

Em suma, os que se interessavam pelo político (ou pela "superestrutura" dos mecanismos sociais de dominação de classe) se aproximavam de Roland Barthes e não o encontravam no local em que acreditavam que ele estivesse. Algo muito semelhante ao desejo do histérico. Dele havia apenas pistas, indícios. Eram, no entanto, indícios tão absurdamente enriquecedores e inovadores que algum tipo de encontro chegava fantasmaticamente a ocorrer, apesar de, insisto, Roland Barthes nele não estar presente como corpo, como voz, como texto (...). ${ }^{572}$

O próprio Barthes, como assinala Natali, também tinha aversão aos discursos estereotipados que constituíam a doxa. Por exemplo, nos anos 70, quando foi seu aluno em Paris, o ensaísta brasileiro observava que, num momento em que o Programa Comum de Governo,

\footnotetext{
${ }^{571}$ In De Volta a Roland Barthes, op. cit., pp. 63-67.

572 Ibid., p. 64.
} 
alternativa que socialistas e comunistas propunham à direita, dominava o noticiário francês, inflamado também pelas eleições de 1974, Barthes preferia se ocupar de Goethe e de Proust em seus seminários. E continua: "Tanto lhe [a Barthes] era repulsiva a ideia de inexistência de algo intermediário entre o sim e o não, entre o masculino e o feminino, oposições nas quais se fundamentam justamente as representações ideológicas e dependentes, portanto, do verossímil" 573.

O estereótipo, forma discursiva da doxa, é, portanto, limitado e limitador: permanece fixo num extremo ou no outro, não permitindo estabelecer-se no terreno movediço do entre. É aí que se encontram as nuanças, as formas combinadas e complexas, as idas e vindas do pensamento e da linguagem. Em suma, é no entre que se encontra o interesse de Barthes, e por isso não se pode apreendê-lo. Consequentemente, ele não se constitui nunca em doxa, pois não para de se mover, escapando entre os dedos como areia fina. Barthes preferia o movimento, para não se entediar. Para Natali, “(...) a meu ver, Roland Barthes, um dos homens mais refinados de seu tempo, de certo modo, sabia que esbarraria em formas enfadonhas de convivência com estereótipo caso aceitasse essa parceria [para a elaboração de uma teoria]. Ele quis ser um crítico, um escritor. Não um ideólogo." 574 Ele quis ser um desbravador da linguagem, sempre à procura de formas novas.

O ensaio de Natali pode ser endossado por "Em todo lugar, em lugar nenhum”, de Márcio Venício Barbosa ${ }^{575}$, que trata dos deslocamentos constantes das reflexões barthesianas em oposição ao lugar fixo necessário ao exercício de um poder. Ou pelo ensaio de Márcio Renato Pinheiro da Silva, "O entrelugar da escritura" ${ }^{576}$, onde o autor mostra como Barthes se opõe à doxa ao mesmo tempo em que a incorpora, sua écriture se fazendo no eterno processo de começar e recomeçar a escrever - de que, aliás, a forma do fragmento, tantas vezes por ele empregada, é testemunha.

Também associo ao ensaio de Natali e, de uma maneira mais geral, à temática da oposição à doxa em Barthes, o texto de Paula Glenadel, "Corpo a corpo: leitura e escrita em Barthes" 577. Nele, a autora se debruça sobre o pensamento barthesiano no que tange a oposições tradicionalmente aceitas - tais como mundo real e texto literário, por exemplo -, para mostrar como elas perdem seu sentido tradicional para o escritor francês: "Sua crítica [de Barthes] desfaz a separação entre a série corpo, concreto, denotação, natureza e a série espírito, abstrato, conotação, linguagem - tudo é código na linguagem, não há naturalidade nela, senão aquela que ideologicamente interessa fazer

\footnotetext{
${ }^{573}$ Ibid., pp. 65-66.

574 Ibid., p. 67.

${ }^{575}$ In Viver com Barthes, op. cit., pp. 43-52.

${ }^{576}$ Ibid., pp. 33-42.

${ }^{577}$ Ibid., pp. 83-90.
} 
passar por natural." 578 Barthes embaralha as cartas dos conceitos que antes tinham seus lugares delimitados para... satisfazer seu desejo. Eis então o elemento que permite desfazer a dicotomia vida/ obra, separadas por uma barra, transformando-a em vida-obra, unidas por um hífen, e apagar as fronteiras tradicionalmente estabelecidas: “(...) a 'vida' do sujeito Barthes, as sensações e experiências que ele atravessa com seu corpo passam, assim, a compor um agenciamento com os aspectos propriamente intelectuais da leitura e da escrita crítica ou teórica" ${ }^{579}$.

Inserindo biografemas em sua écriture, Barthes toca o leitor, insuflando nele o desejo de também ser autor, rompendo com mais uma dicotomia, autor/ leitor, desafiando as distinções estanques das ortodoxias. Essa forma de contestação da doxa que se vale da subjetividade, que elege o eu como sujeito de toda e qualquer ação e que a ele só - e a seu desejo - deve explicações, constitui um matiz dentro das leituras atuais de Barthes no Brasil. Ela aparece, por exemplo, no ensaio de Marcelo Jacques de Moraes, "O rumor do autor em Fragmentos de um discurso amoroso" ${ }^{, 580}$, sobre como a noção barthesiana de autor resiste a "La Mort de 1'Auteur" e impregna suas obras posteriores, sob a forma de um rumor, até se confundir com o leitor. Para Moraes, a tão celebrada "morte do Autor" não sepulta totalmente a figura do autor, que continua a existir sob a forma de uma intenção, guiando as escolhas estéticas dos escritores citados por Barthes no famoso ensaio, Mallarmé, Valéry, Proust e os surrealistas. A grande contribuição de Barthes residiria, portanto, menos na extinção de uma noção absoluta do que no "assassinato" de um conceito tradicional.

Aliada a essa compreensão do ensaio de Barthes está a primazia do Leitor, postulada na conclusão de “La Mort de l'Auteur”, e que Moraes vê em termos de uma ordem lógica: “(...) o leitor precede o autor: toda escrita é, antes de mais nada, trabalho de um leitor." 581 Como consequência, toda escrita é assombrada pelas leituras que a precederam, e o autor, aquele cuja intenção determina as escolhas do texto, nunca é somente ele mesmo, mas é também a voz daqueles que ele leu. Nas palavras de Moraes, "Escrever é, pois, para ele [para o autor], em solilóquio, tornar seu dizer consciente dessa alteridade constitutiva e dialogar com o outro, interrogar-se e interrogá-lo, e, assim, alterar-se, tornar-se, por sua vez, outro" 582 .

Nesse movimento constante de transformação do eu em outro cohabitam elementos pertencentes a ambas as partes, o que compreende a própria interioridade do autor. "Aderido a si

\footnotetext{
${ }^{578}$ Ibid., p. 84.

${ }^{579}$ Ibid., p. 86.

${ }^{580}$ Ibid., pp. 163-174. Também publicado em De Volta a Roland Barthes, op. cit., pp. 99-111.

${ }^{581}$ Ibid., p. 166.

582 Ibidem.
} 
próprio" ${ }^{583}$, o autor profere um enunciado composto por uma mistura de vozes sem deixar de ser pessoal, como no exemplo mais acabado desse movimento, Fragments d'un discours amoureux. Autor e leitor, numa metamorfose sem fim, encontram-se no eu cuja enunciação se encena no best seller de Barthes, repleto de referências de leituras.

Segue o mesmo caminho proposto por Moraes o ensaio de André Rangel Rios, “O prazer do autor" ${ }^{584}$. Nesse texto, Rios aborda as implicações da morte do autor e seu caráter revolucionário, libertando o Texto de um sentido único agenciado pela figura do Autor tradicional. Coloca em evidência o descompasso que há entre a aceitação atual da tese barthesiana e as exigências acadêmicas de publicação - que fazem com que os universitários exerçam cada vez mais o papel de autor, no sentido tradicional. E conclui incitando o leitor a também se tornar um autor no sentido barthesiano, ou seja, aquele que goza do prazer proporcionado pelo exercício intransitivo da escrita.

As reflexões sobre o encontro do autor e do leitor no eu enunciador - consequência da contestação de valores literários tradicionais - tomam novo rumo no ensaio de Evando Nascimento, “A paixão isenta (o 'pequeno Barthes')" 585.

Inicialmente, a partir de comentários sobre a recepção atual de Barthes, Nascimento constata a legitimidade do legado do escritor francês por meio da realização de eventos a ele dedicados - os colóquios da Universidade de São Paulo e da Universidade Federal Fluminense em 2003 -, bem como pela publicação de suas aulas no Collège de France e pelas reedições de suas obras no Brasil.

O legado barthesiano, todavia, é dinâmico, pois sua recepção varia segundo critérios subjetivos: cabe a cada leitor se apropriar do pensamento do escritor, tornando-se, assim, seu herdeiro. Novamente, a primazia do desejo pessoal invade o ensaio acadêmico e Nascimento se pergunta:

Desse modo, o ponto seria: diante do Barthes que está aí, publicado e reeditado, exposto, o que me toca particularmente nesse lote? Qual seria meu Barthes, o Barthes que escolheria trazer para este mundo que é o meu - lembrando uma famosa fórmula na abertura do $S / Z$ ? Em outras palavras, o que Barthes significa hoje para mim? ${ }^{586}$

\footnotetext{
583 Ibid., p. 172.

${ }^{584}$ Ibid., pp. 21-31.

${ }^{585}$ In De Volta a Roland Barthes, op. cit., pp. 81-98.

${ }^{586}$ Ibid., p. 82.
} 
O mundo de Nascimento - no âmbito de seu texto - é o ensaio acadêmico, escrito para ser lido em um colóquio e posteriormente publicado numa coletânea sobre Barthes. Ou seja, Nascimento escreve sobre um autor, num contexto universitário para um público especializado, e por essa razão é esperado que ele o faça dentro de certas normas, que incluem um olhar objetivo sobre o tema de sua eleição. No entanto, colocando-se como herdeiro de Barthes, ele escolhe receber como legado a independência do escritor face a certas práticas institucionalizadas e reconhecidas como pertencentes ao "mundo acadêmico", esperadas quando vindas de um "intelectual". E adota suas preferências, seu desejo, como fios condutores do ensaio.

A primeira pessoa, antes presente explicitando o plano do texto, contextualizando o leitor, enfim exercendo plenamente seu papel de consciência zelosa da clareza da tese e dos argumentos sobre os quais ela se estabelece, muda de função. De voz neutra e objetiva, ela passa a ter as cores da subjetividade do autor que uma vez mais se funde com o leitor, transformando-se no escritor. Só que agora isso se dá deliberadamente sob o ímpeto de seu desejo pessoal, e não mais por contingências teóricas, como acontece nos textos de Moraes e Rios. Nesses textos, os autores desembocam no emprego da primeira pessoa do singular seguindo o curso das ideias barthesianas. Já Nascimento, mesmo também tendo em vista a obra de Barthes, faz uma escolha pessoal:

Ler-escrevendo é a herança potente por excelência e, dentre os traços da escrita barthesiana, é o que elejo como o que mais me estruturou até aqui, enquanto escrevente ou crítico-escritor pretenso.

Para mim, ler - ao menos desde que leio Barthes - traz embutida a possibilidade da escrita, de modo tal que inúmeras vezes me vejo interrompendo a mais urgente das leituras para anotar, compor um esboço de texto ou mesmo desenvolver todo um ensaio a partir de alguns poucos parágrafos sofregamente decifrados. E ao final, nunca sei exatamente o que engendrou o que, se me ponho a ler para escrever algo, ou se escrevo porque li uma novela, vi um filme, analisei um ensaio, preparei uma aula. ${ }^{587}$

Tal como Barthes mostrara - e também outros teóricos, dentre os quais Bakhtin e Kristeva -, leitura e escritura, ou leitor e autor são inseparáveis para Nascimento. E este, leitor de Barthes, escreve sobre Barthes... à moda de Barthes, ou seja, deixando para trás - mais precisamente para o início do texto - os procedimentos de escrita típicos do ensaio acadêmico, para expor sua prática pessoal de escrita, com suas dificuldades, suas idas e vindas, e suas dúvidas. A pessoa por trás do intelectual se desvela despudoradamente, causando certo estranhamento ao leitor do ensaio acadêmico, habituado ao apagamento da primeira em favor do segundo.

${ }^{587}$ Ibid., p. 85 . 
Não por acaso, a segunda parte do ensaio explica e celebra o Barthes das Mythologies, crítico ácido da doxa pequeno-burguesa. Nascimento demonstra que não se deve monumentalizar ou mitificar o escritor que tanto combateu os mitos sociais de seu tempo. Para tanto, ele revela o seu Barthes, o "pequeno Barthes" do título do ensaio, o escritor que se ocupava com os fatos comezinhos do dia-a-dia, tanto nos anos 50, quanto nas últimas mitologias, crônicas escritas em 1978 e 1979, para, nesse momento, concluir que criticar o poder é também uma forma de exercê-lo. Mais vale então se deslocar, numa busca por uma nova forma literária, exercendo a liberdade que só a deriva ao som do desejo concede. Liberdade essa que será compreendida por outros intelectuais brasileiros sob a forma de uma recusa das normas acadêmicas, levando a cabo o movimento iniciado por Nascimento.

Outra nuança pode então ser observada em alguns textos sobre Barthes: o questionamento das normas do ensaio acadêmico e a consequente experimentação de novos caminhos de escrita. Dentro dessa tendência se encontra o ensaio de Lúcia Teixeira, "O que existe para mim: fichas, cores, fragmentos" ${ }^{588}$, uma reflexão sobre a obra de Barthes a partir da visita da autora à exposição a ele dedicada no Centre Georges Pompidou, em Paris, em 2003.

Logo na introdução do texto, citando Barthes, Lúcia Teixeira faz alusão a uma inquietação que implicitamente é também a sua: a necessidade de se escolher entre uma "linguagem "expressiva"" e uma "linguagem 'crítica' " ${ }^{589}$, ou seja, entre respeitar um modelo consagrado de linguagem crítica ou empregar uma linguagem própria, individual e subjetiva, no momento da escrita. A autora então passa a descrever detalhadamente sua visita à exposição, percurso que se inicia pelas fichas de Barthes, expostas em mesas de vidro que permitem apreciar a caligrafia do escritor e a deduzir - com a ajuda de informações biográficas - seu método de trabalho. Seu desejo de conhecer o cotidiano de Barthes fica evidente, pois é o escritor em seu ambiente de trabalho que “existia para ela" ${ }^{590}$. E o ensaio, até então desenvolvido dentro de uma lógica descritiva rigorosa e objetiva, abre espaço para a emoção da autora:

No entanto, as fichas estavam lá e me emocionavam - a lembrança delas ainda hoje, aqui, ecoando. Lá elas me pareciam apenas o contraponto de um espírito livre: a escritura desafiadora, obscura às vezes, sinuosa outras, em busca de um tom menos obediente às regras da academia (o

\footnotetext{
${ }^{588}$ In De Volta a Roland Barthes, op. cit., pp. 113-129.

589 Ibid., p. 113.

590 “Anotações em forma de verbetes, indicações bibliográficas, lembretes, roteiros de publicação - eram estes pequenos fragmentos, ao lado das aquarelas e guaches de Barthes, os objetos que 'existiam para mim' naquele lugar de penumbra". Ibid., p. 114.
} 
esgotamento do saber, a explicação rigorosa, a produção de uma verdade), ancorava-se, enfim, no saber disciplinado, na ordem classificatória, na preocupação com a minúcia e o rigor. ${ }^{591}$

A visão dos objetos de Barthes inspira a Lúcia Teixeira a menção à "busca de um tom menos obediente às regras da academia", mesmo que tal busca, no escritor, se apoie em um método acadêmico de trabalho. Numa relação de espelhamento, a leitura do texto sugere que a autora oscila entre continuar no caminho seguro do ensaio acadêmico e se empenhar na mesma busca de Barthes. Pois ela se deixa guiar por seu desejo de conhecer determinadas facetas do escritor, como se refizesse seu percurso na exposição, ao mesmo tempo em que não abandona a preocupação em associar os elementos citados a conceitos barthesianos, assegurando assim o rigor esperado de um ensaio.

O olhar da visitante-autora se detém sobre os desenhos e pinturas de Barthes, pouco conhecidos no Brasil. Estabelece uma tipologia das imagens: uma disposição mais concentrada e outra dispersiva dos traços e das cores, e tenta dar um sentido a mais a essa oposição barthesiana. Mas a dúvida entre o que dizer se instala:

Comecemos por dizer: as pinturas de Barthes são belas e sensíveis. Ora, nada existe nessa frase de louvável do ponto de vista da escritura acadêmica. Digamos em seguida: as pinturas de Barthes não são manifestações plásticas de qualidade artística, que envolvam, por exemplo, as noções de sublime ou de ruptura. Segunda frase a ser menosprezada num texto acadêmico. E no entanto, essas são as frases que me motivam a escrever, isso é o que "existe para mim", é de onde posso começar. ${ }^{592}$

Novamente a hesitação entre duas formas de escrita, ou duas condutas diante do objeto, aparece no meio do ensaio acadêmico, que passa, portanto, a abrigar enunciados inusitados, como o questionamento da autora e seu desejo de escrever banalidades sobre a obra pictórica de Barthes. Contudo, antes de se permitir escrever "o que existe para si”, Lúcia Teixeira já havia feito uma leitura analítica das pinturas, interpretando-as à luz de conceitos barthesianos, incluindo bibliografia sobre o tema, "L'écriture et le dessin de Roland Barthes", de Jean-Marie Floch. Ou seja, a autora já havia cumprido o "serviço militar" do ensaio acadêmico, apresentando minuciosamente seu objeto, citando outros autores que dele se ocuparam, procedendo à análise e à interpretação do mesmo. Como se ela, só então, pudesse se entregar ao exercício da liberdade, dizendo das pinturas de Barthes o que bem tivesse vontade.

\footnotetext{
${ }^{591}$ Ibid., p. 115.

${ }^{592}$ Ibid., pp. 123-124.
} 
Estabelecida essa dualidade de olhares - análise acadêmica versus expressão dos sentimentos -, a autora começa a questionar os dois termos que a compõem: a análise acadêmica não bloquearia o gozo literário? Por outro lado, a recusa da análise não implicaria na renúncia em exercer o papel de intelectual?

Como Evando Nascimento, Lúcia Teixeira faz sua escolha: depois de constatar que a ludicidade e as contingências são intrínsecas às pinturas de Barthes, por isso aparentemente anulando a validade de toda e qualquer análise interpretativa desse aspecto de sua obra, ela afirma: "Prefiro então dizer que os trabalhos são belos, sensíveis, interessantes. Dizer nada. (Saberá o leitor que disse tudo e agora desdigo. Saberá, talvez, avaliar minha incapacidade, minha insegurança." 593

A liberdade para desdizer o que foi dito, desfazendo a forma canônica do ensaio acadêmico, além de marcar a eleição do seu desejo como fio condutor do texto, também encontra respaldo nos deslocamentos contínuos de Barthes, sempre para longe dos modelos estabelecidos:

Prefere-se a dissertação contínua ao texto interrompido, elíptico, pouco conclusivo. Preferese o centro, o principal, ao acessório. Barthes preferia o que não se prefere e é por isso que obriga ao gesto da oscilação, porque é preciso encontrar, para além ou para fora da linearidade, os muitos modos de produzir um pensamento. ${ }^{594}$

Mencionando pontualmente o texto dissertativo, oposto ao texto fragmentado e inconclusivo, a autora justifica nas escolhas de Barthes sua própria hesitação entre a forma canônica do ensaio acadêmico e a expressão de seu desejo de simplesmente adjetivar, de modo intensamente subjetivo, as pinturas do escritor francês. Para, à guisa de conclusão, reafirmar sua escolha:

Não há origem nem finalidade nos textos, sempre o que há, para que se fale o novo, o nunca antes, é, só pode ser, experimentação - amadorismo, risco, audácia. R/B só existe como RB se a escolha é o salto. E o salto tanto pode ser... mas não é possível concluir com mais um binarismo! O salto é uma inconclusão.

Não concluindo, Lúcia Teixeira não aprisiona Barthes em uma afirmação, respeitando seu modus operandi fundado nos deslocamentos. Mas surpreende o leitor, que não encontra uma conclusão explícita do ensaio acadêmico, podendo somente deduzi-la.

A mesma inquietação de ordem formal e discursiva aparece no ensaio de Celina Maria Moreira de Mello, "Fragmentos de uma crítica afetuosa ou Roland Barthes, sem adjetivos" 595 , cuja

\footnotetext{
593 Ibid., p. 125.

${ }^{594}$ Ibid., p. 126.

${ }^{595}$ In Viver com Barthes, op. cit., pp. 53-66.
} 
primeira parte se intitula: “1. Do ensaio ou da experimentação?" ${ }^{596}$ A autora já responde à questão nas primeiras linhas do ensaio, anunciando sua proposta: “A quebra da armadura textual, em que se tornou a estrutura ensaística à francesa, sugere que se opte, aqui, por fragmentos de escritura, cujas remissões respondem a uma intenção didática: propor uma releitura da obra de Roland Barthes." 597 Tal como Evando Nascimento e Lúcia Teixeira, Celina Mello escolhe romper com o padrão ensaístico tradicional, apresentando um texto sustentado por recortes da obra de Barthes, ordenados cronologicamente, e não necessariamente interligados por marcadores de coesão, mas por um mesmo discurso libertário inspirado no escritor.

O texto se detém sobre alguns dos principais conceitos barthesianos, como a estética do fragmento e as dicotomias entre Texto e Obra e leitura e escritura. Mas o que chama a atenção é o parti pris formal da autora, que até mesmo inclui, ao final do texto, um "Modo de ler", evidenciando a consciência de que seu texto difere de um ensaio acadêmico tradicional. Nele, lê-se:

- $\quad$ Traduzimos as citações do texto de Barthes e as inserimos no texto do ensaio, para que se configure visualmente o sentido barthesiano de citar;

- As datas de publicação das obras de Barthes referidas ao longo do ensaio estão assinaladas em negrito, para possibilitar ao leitor reconstruir um percurso cronológico. ${ }^{598}$

A menção ao "sentido barthesiano de citar" justifica as constantes imbricações entre o discurso de Celina Mello e o de Barthes, a abolição das fronteiras entre um e outro. Que, além de não serem comuns no ensaio acadêmico, acabam por desnortear o leitor, tornando o texto, por vezes, não muito claro, apesar das abundantes notas de rodapé que fazem referência às fontes citadas. A autora também rompe com o pradrão ensaístico ao destacar no corpo do texto as datas de publicação das obras mencionadas: fazendo isso, ela incita o leitor a construir parte da compreensão de seus argumentos de maneira autônoma, recurso típico dos textos ficcionais e não dos ensaios acadêmicos. Mais uma vez se tem um texto que, seguindo pressupostos barthesianos, desloca-se de seu lugar tradicional para experimentar uma nova forma e uma nova voz, modalizadas de acordo com o desejo de seu autor, seja ele composto por hesitações e dúvidas, ou pela vontade de se aproximar, ao menos parcialmente, da narrativa ficcional.

Todos esses textos que problematizam a escrita e o objeto do ensaio acadêmico o fazem sem, no entanto, desfigurá-lo por completo: eles apresentam um ponto de partida, uma tese, os argumentos que a sustentam, fazem citações, mais ou menos visíveis, têm notas de rodapé contendo

\footnotetext{
${ }^{596}$ Ibid., p. 53.

${ }^{597}$ Ibidem.

${ }^{598}$ Ibid., p. 63.
} 
referências bibliográficas. Mas também propõem novos caminhos para esse gênero textual consagrado na universidade. Em suma, tais textos procuram subverter a estrutura do ensaio acadêmico, tanto em sua forma, como em seu olhar sobre o objeto, sem destruí-lo. A voz do enunciador é distorcida, mas nunca calada, pois apenas se transforma: torna-se a voz da pessoa que escreve, e não mais a do intelectual comprometido com as normas acadêmicas. Fazendo um trabalho de sapa, Evando Nascimento, Lúcia Teixeira e Celina Mello praticam a forma mais eficaz de contestação, aos olhos de Barthes, celebrada em Sade, Fourier, Loyola: "La meilleure des subversions ne consiste-t-elle pas à défigurer les codes, plutôt qu'à les détruire? " 599

Postura diferente adotam os autores de textos que compõem a derradeira nuança da linha temática agrupando parte das leituras atuais de Barthes no Brasil. A preocupação em expor as reflexões do escritor francês a respeito de seus deslocamentos, materializados em suas obras, ou, por parte do autor, em explicar ao leitor suas escolhas, sequer está presente em "A Amizade de Barthes" ${ }^{\circ 00}$, de Francisco Bosco. O texto se propõe a fazer um relato das leituras de seu autor, associando-as a citações e a ideias do escritor francês, constituindo um exercício de escrita pessoal:

Este texto: encenar a manifestação da amizade no cotidiano de um leitor - no dia-a-dia de suas leituras. A amizade enquanto "pensar com". Homenagear o amigo flagrando as múltiplas emergências do "pensar com", através das quais vem à tona a importância do amigo na ativação de uma vida semiológica. Procurar o lugar, a necessária distância, onde a amizade é mais fiel a si mesma - propiciando a invenção da escrita. ${ }^{601}$

À moda barthesiana, o texto é composto exclusivamente por fragmentos e é recheado de citações de Barthes sem, no entanto, mencionar suas fontes, não apresentando referências bibliográficas - "Como se trata, nesse texto, de escrever a partir de uma memória ativa das leituras de Barthes, não usarei notas remetendo às referências bibliográficas" ${ }^{602}$. Cada fragmento do texto constitui uma unidade, tratando tanto das leituras que o autor fazia no momento em que recebeu o convite para redigir o ensaio sobre Barthes - Bouvard et Pécuchet e Vidas e doutrinas dos filósofos ilustres, de Diógenes Laércio -, quanto de acontecimentos de sua vida cotidiana, como um e-mail, um livro escrito por um amigo, o filme que viu no cinema, outras leituras ocasionais, como Nietzsche, Bataille e Machado de Assis. Dentre esses recortes de ideias, um se mostra bastante fecundo: Bosco relata que recebeu um e-mail de uma pessoa a quem havia submetido um ensaio

\footnotetext{
${ }^{599}$ Sade, Fourier, Loyola. In $O C$ v. 3, p. 809.

${ }^{600}$ In Viver com Barthes, op. cit., pp. 175-183.

${ }^{601}$ Ibid., p. 175.

${ }^{602}$ Ibid., p. 183.
} 
para análise. A crítica apontou para o uso frequente de citações de segunda mão e pediu-lhe que se debruçasse sobre as fontes. Esse acontecimento provoca-lhe uma reflexão:

Dessa queixa se desprende uma certa suspeita, como se o apud fosse um modo citacional, se não apócrifo, ao menos inconsistente, frouxo - talvez mesmo preguiçoso. Barthes emprega largamente o apud. Por quê? Talvez porque a censura ao apud esteja ligada a um pensamento da fidelidade, do rigor teórico entendido como exatidão expositiva, ao passo que o uso das citações de segunda mão encaixa-se bem em um pensamento da apropriação, dos deslocamentos, do rigor teórico entendido como produção de diferença. ${ }^{603}$

Tais considerações me parecem bastante certeiras e apontam para a insubordinação barthesiana às normas e aos padrões. No universo da escrita acadêmica, Barthes primava por não se submeter às convenções, pois buscava incessantemente a écriture, a sua écriture, o que significava, naquele momento, "produzir diferença”. Ora, Bosco parece justificar suas próprias escolhas pelas atitudes do escritor: como Barthes, cita de segunda mão, como Barthes, não se submete às normas acadêmicas, como Barthes, procura "produzir diferença". E, tendo em vista a totalidade do texto, como Barthes, Bosco também adota o fragmento como unidade essencial, também escreve guiado por seus desejos - de falar do e-mail que recebera, de comentar o filme que vira, de mencionar as leituras que fazia.

A intenção de se aproximar de Barthes - até "se apropriar" dele - é manifesta num fragmento da seguinte maneira:

Sensação desconfortável de escrever sobre Barthes: sinto-me grosseiro - fadado à impossibilidade de sutilizá-lo (ou mesmo de corresponder à sua sutileza). Tento, aqui, abordá-lo de maneira enviesada, apropriar-me dele - mas ainda não é essa a distância necessária: sua presença muito próxima, ressaltando minha grosseria, faz-me sentir o tempo todo a iminência de perdê-lo. ${ }^{604}$

Bosco sente a proximidade excessiva que faz com que ele não veja a si mesmo, mas somente seu objeto de admiração, Barthes. Deste, o autor se apropria até mesmo da maneira de trabalhar, por meio de fichas, conforme escreve:

Há uma pré-escrita desse texto: como Barthes, escrevo fichas. É um modo, bem barthesiano, de multiplicar os prazeres, mas sinto um incômodo efeito colateral: decepciono-me um pouco na passagem da ficha ao fragmento, como se esse não conseguisse cumprir o que a ficha, feita de

${ }^{603}$ Ibid., p. 177.

${ }^{604}$ Ibid., p. 178. 
elipses e expectativa, prometia: situo assim meu gozo em um espaço irrealizado, entre a ficha e o fragmento - situo meu gozo numa promessa. ${ }^{605}$

Assim como no trecho anteriormente citado, novamente o incômodo aparece no fragmento em que o autor confessa sua tentativa de se aproximar ao máximo de Barthes. Bosco parece acreditar que a simples repetição do ritual de écriture do escritor francês seria suficiente para proporcionar-lhe o gozo de que trata Barthes em seus ensaios e obras, notadamente Le Plaisir $d u$ texte. Todavia, o método não lhe rende o efeito esperado, e em seu lugar surge a decepção. Esta, aos olhos do autor, é finalmente vencida no penúltimo fragmento, em que ele anuncia ter encontrado a distância necessária para poder adequadamente tratar de Barthes, privilegiando o escritor que incitava seus leitores a também escrever.

Visto por outro lado, pelo lado do leitor, o texto de Bosco gera um desconforto, do início ao fim. Nos fragmentos em que confessa sua dificuldade ou sua decepção, ele ensaia um olhar para além de Barthes, mas não consegue enxergar o que está ao lado ou... mais perto: não enxerga a si mesmo. A última frase do texto, "Tal como um conhecido narrador, agora posso escrever" ${ }^{606}$, causa ao leitor uma forte impressão de déjà vu: depois de terminado o exercício da cópia, o autor finalmente poderá executar sua própria obra, sua própria écriture. Porém, o que é oferecido ao leitor nada mais é que a preparação para a tal obra. O texto de Bosco, executando um tenaz e constante movimento de identificação à écriture barthesiana, não consegue ser mais do que um pastiche.

Com a mesma proposta - escrever um texto a partir de suas leituras de Barthes - e uma realização diferente, o texto de Vera Casa Nova, "Barthes: o demônio da teoria" 607, consegue se descolar do discurso do escritor francês e se mostra mais elaborado, mais próximo de uma possível écriture da autora. Ele também é constituído por fragmentos, como o texto de Bosco, mas apresenta notas de rodapé e citações claramente delimitadas, não rompendo totalmente com o gênero ensaístico tradicional, apenas subvertendo-o.

Outra particularidade do texto de Vera Casa Nova reside na matéria que constitui cada fragmento: não há lugar para os acontecimentos de sua vida pessoal e suas reflexões são fortemente ancoradas nos conceitos barthesianos. Estes, ora são pontos de partida para a exposição de uma ideia pessoal, ora estão presentes numa citação ou paráfrase, como se o fragmento fosse uma ficha de leitura. Diferentemente do texto de Bosco, as leituras das obras de Barthes, no texto de Vera Casa Nova, sofrem um tratamento particular: a maioria dos fragmentos se inicia com substantivos e

${ }^{605}$ Ibid., p. 181.

${ }^{606}$ Ibid., p. 183.

${ }^{607}$ Ibid., pp. 75-81. 
abundam as frases nominais e as enumerações. A estrutura objetiva do ensaio acadêmico cede lugar à escritura poética que causa estranhamento ao leitor sendo, por vezes, até mesmo opaca. Por exemplo, não fica clara a aproximação entre Barthes e o livro de Antoine Compagnon, Le Démon de la théorie: littérature et sens commun (1998), presente no título do texto. Sobre isso, a autora escreve:

Barthes: o demônio da literatura. Sem apropriação do sentido de Compagnon. Demônio enquanto utilizo uma metáfora-guia.Um demônio inteligente microscópico violador da lei $\left(2^{\mathrm{a}}\right.$ Lei da Termodinâmica, a entropia). Demônio de Maxwell. O que conseguira observar o estado de um sistema (o literário, o da comunicação, etc.) e aproveitaria as flutuações favoráveis para diminuir a entropia. ${ }^{608}$

A autora não se apropria do demônio de Compagnon - saído de um poema em prosa de Baudelaire, com o sentido de uma critatura ativa e de combate ${ }^{609}$ - e com isso, ao incorporar ao título de seu texto o nome do livro do crítico francês, fornece ao leitor uma falsa pista. O demônio a que ela associa Barthes integra a linhagem da física e, em linguagem não especializada, desrespeita uma lei da termodinâmica que define um certo grau de desordem em um dado sistema, sendo esse demônio o fator responsável pelo restabelecimento da ordem. O "demônio da literatura" ou "da teoria”, para Vera Casa Nova, seria uma metáfora da função de franco-atirador exercida por Barthes no sistema literário - mesmo que, paradoxalmente, em prol do restabelecimento da ordem estável, posição diametralmente oposta a todas as atitudes do escritor. Em outra parte do texto, uma nova menção ao demônio: "Pelo gozo o projeto de dissolução se inscreve no percurso de Barthes. Mais uma vez se insinua o demônio da teoria. No jogo de texto-autor, texto, texto-leitor. Cruzamento dos olhares. Fricções diversas entre leituras." ${ }^{610}$ E mais adiante, "Barthes, o demônio do múltiplo olhar, dos múltiplos fragmentos." 611

A metáfora do demônio, empregada sem muito zelo, parece designar, no final das contas, um ser único e maravilhoso, que atua no sistema literário para subverter sua ordem, para romper com seus padrões. Mais do que construir um sentido, a autora procura construir vários sentidos, deslocando a imagem continuamente: da associação imediata ao livro de Compagnon - evocando o conhecimento teórico, uma vez que o livro é um manual de teoria literária - ao demônio de Maxwell e deste à criatura "do múltiplo olhar". Com esse procedimento, num primeiro momento Vera Casa Nova desnorteia o leitor, frustrando suas expectativas relativas a um ensaio acadêmico, obnubilando

\footnotetext{
${ }^{608}$ Ibid., p. 75.

${ }^{609}$ Antoine Compagnon, Le Démon de la théorie: littérature et sens commun, Paris, Seuil, 1998, p. 9.

${ }^{610}$ In Viver com Barthes, op. cit., p. 78.

${ }^{611}$ Ibidem.
} 
sua compreensão. Porém, ela também lhe oferece um novo caminho de leitura, percorrendo um texto poético que preserva alguns elementos comuns ao ensaio tradicional, tais como a precisão das referências e citações e o diálogo com bibliografia afim - a autora menciona a tradução brasileira para jouissance, gozo, diferente da tradução portuguesa, fruição ${ }^{612}$, problematizada por Leyla Perrone-Moisés em "Lição de casa", posfácio à edição por ela traduzida de Leçon ${ }^{613}$. O texto, portanto, constitui-se como um híbrido, entre o ensaio acadêmico e o texto poético, construído com elementos dos dois gêneros textuais. Mas que tende para um deles, num movimento de deslocamento:

(...) Dissolução do eu, das ideias, dos sentidos. Gesto radical da língua, do corpo. "On” que se diz "Je". Saltos discursivos, fragmentação do texto. Ensaio ou teoria crítica?

Subjetividade pura? Vertigem da subjetividade? Como encarar a academia pretensamente objetiva, supondo-se científica? Talvez a impossibilidade existente na confrontação como termos contraditórios, opostos em termos de leitura de um texto. ${ }^{614}$

Do ensaio acadêmico objetivo ao seu oposto, o texto poético subjetivo: a autora propõe a demolição do sentido unívoco e o apagamento do enunciador "imparcial" para erigir em seu lugar os sentidos plurivalentes sob o comando do eu, assumindo as implicações intrínsecas a essa escolha: a escrita não linear provoca o questionamento sobre a natureza do texto: "Ensaio ou teoria crítica" ou, ainda, texto poético?

A subjetividade do eu enunciador se justifica pela obra de Barthes e consolida a posição de Vera Casa Nova:

Posturas, imposturas. O texto-leitura coloca o leitor em seu lugar de cultura, ele mesmo como um texto. $\mathrm{O}$ que o leitor estende. Grande deslocamento. Proposta dionisíaca - em seu sentido de renversement, bouleversement, ou seja, inquietação. Barthes nos aponta para as inquietações. Que conforto a literatura e as artes podem nos trazer? Amor do texto, esse texto enamorado do qual só podemos controlar impulsos e rupturas. ${ }^{615}$

O desconforto da proposta da autora - a écriture pessoal de um texto poético fundado em leituras de Barthes - é fruto do bouleversement da noção tradicional de ensaio. Seu "texto-leitura" atinge o alvo, realiza com sucesso seu projeto, por um lado construindo um olhar pessoal sobre Barthes, sem perdê-lo de vista e sem perder a si mesmo de vista. Por outro, causando inquietação ao

\footnotetext{
${ }^{612}$ Ibid., p. 76.

${ }^{613}$ In Roland Barthes, Aula, São Paulo, Cultrix, 2007 [1980], pp. 83-86.

${ }^{614}$ In Viver com Barthes, op. cit., p. 76.

${ }^{615}$ Ibid., p. 79.
} 
leitor, desviando-o do caminho conhecido para mostrar-lhe um caminho paralelo: nem totalmente diferente do texto esperado, nem totalmente igual, e por tudo isso, paradoxal. Pois Vera Casa Nova consegue ser leitora e autora ao mesmo tempo.

Em Sade, Fourier, Loyola, tratando dos modos de censura sofridos por Sade, Barthes escreve:

La subversion la plus profonde (la contre-censure) ne consiste donc pas forcément à dire ce qui choque l'opinion, la morale, la loi, la police, mais à inventer un discours paradoxal (pur de toute doxa): l'invention (et non la provocation) est un acte révolutionnaire: celui-ci ne peut s'accomplir que dans la fondation d'une nouvelle langue. ${ }^{616}$

E é na criação de sua própria língua, sua própria écriture, que o texto de Vera Casa Nova difere do de Francisco Bosco, pois o primeiro cria uma nova língua a partir das leituras de Barthes, e o segundo se contenta em tentar sobrepor às citações de conceitos e de trechos de obras do escritor francês fatos cotidianos e não uma linguagem propriamente, onde a subjetividade se encontra somente na obviedade da primeira pessoa do singular.

"Barthes: o demônio da teoria" é um exemplo dos mais fecundos de parte das leituras atuais da obra de Roland Barthes, voltadas para sua faceta contestadora da doxa, aclamada pela pósmodernidade. Seja respeitando os padrões do ensaio acadêmico e dissertando sobre esse Barthes libertário, seja questionando a própria academia e suas tradições, seja enfim rompendo com elas, todos os textos mencionados neste capítulo foram escritos por docentes universitários ou doutorandos, futuros docentes. Barthes, portanto, tem sido lido na atualidade como uma ferramenta para... minar o próprio poder da universidade, por parte daqueles que constituem seus pilares.

O intelectual que nunca conseguiu terminar sua tese de doutorado e que, apesar de seu percurso cheio de desvios, chegou ao Collège de France e se tornou um ídolo para gerações de professores e estudantes universitários, que adotavam algumas de suas obras como verdadeiras bíblias, no Brasil de hoje continua presente na universidade. Só que corroendo sem estardalhaço os modelos tradicionais de escrita acadêmica.

Eis aí "O lugar de Barthes", anunciado por Leyla Perrone-Moisés em artigo de mesmo título, publicado em $1990^{617}$ : um lugar paradoxalmente em movimento, a serviço da decomposição da doxa. Nesse artigo, que marca dez anos sem Barthes, a autora faz um balanço do legado do

\footnotetext{
${ }^{616}$ Sade, Fourier, Loyola. In $O C$ v. 3, p. 812.

${ }^{617}$ Leyla Perrone-Moisés, Inútil poesia e outros ensaios breves, São Paulo, Companhia das Letras, 2000, pp. $288-293$. As primeiras publicações do ensaio se deram, com o título de "Le souvenir de Barthes", na Quinzaine Littéraire, n' 551, Paris, 16 a 31 de março de 1990, e no caderno "Ideias" do Jornal do Brasil, Rio de Janeiro, 25 de março de 1990.
} 
escritor e antevê, em linhas gerais, algumas das conclusões a que cheguei analisando a produção crítica contemporânea sobre o escritor. Enfatizando o quanto Barthes é insubstituível, ela acrescenta: "ele o era ainda mais pelo fato de não ter lugar. Seu ensino não era um discurso de saber, mas uma postura e uma impostação, indissociáveis de sua pessoa, de sua voz, de modo que o prosseguimento de sua fala só poderia produzir imitações irrisórias." 618

Desenvolvendo essa ideia, Leyla Perrone-Moisés afirma que Barthes não é o tipo de escritor que se presta à pesquisa universitária, pois sua obra, por apresentar tantos caminhos diferentes, é difícil de ser apreendida, sintetizada e reempregada como instrumental teórico. Afinal, Barthes não elaborou teorias, no sentido estrito do termo. Para a autora, "Seus livros andam por aí em muitas mochilas e mesas-de-cabeceira. São os melhores. Os que figuram em bibliografias de teses são os que envelheceram, os que ele não reconhecia mais." ${ }^{619}$ Estes são, provavelmente, Le Degré zéro de l'écriture, alguns dos Essais critiques, os Éléments de sémiologie, o Système de la mode, talvez até mesmo Critique et vérité, obras mais fortemente marcadas pelo pensamento estrutural, pelas descobertas das potencialidades da linguística aplicadas aos estudos literários. Em 1990, tendo os anos 70 e 80 como bases, tal afirmação se justifica plenamente. E é até mesmo visionária, quando aponta indiretamente como os melhores livros de Barthes, os mais fecundos, aqueles que circulavam mais informalmente, possivelmente Le Plaisir du texte, Roland Barthes par Roland Barthes, Fragments d'un discours amoureux, Leçon, La Chambre claire. O que Leyla Perrone-Moisés não poderia prever é que tais livros sairiam das mochilas e das mesas-de-cabeceira e entrariam nas bibliografias dos cursos universitários nos anos seguintes, sendo as obras mais influentes do escritor dentro da universidade, como os ensaios e textos analisados neste capítulo comprovam ${ }^{620}$.

Ao renunciar a um lugar fixo na cena literária, Barthes também renunciava à posteridade segundo a autora, pois "Essa empresa de libertação e de renovação da linguagem, própria da linguagem poética, colocava o autor de ensaios entre dois abismos: o ilegível e a bobagem" ${ }^{621}$. De fato, Barthes foi qualificado com essas duas palavras quando de sua recepção nos anos 50 e 60, no Brasil, e talvez o fato de ele ainda hoje ser considerado por muitos um autor "difícil” seja um eco de sua suposta "ilegibilidade" herdada dos anos estruturalistas. Apesar dessas leituras e do ranço que delas persiste, o escritor foi assimilado aos estudos linguístico-literários na universidade, que

\footnotetext{
${ }^{618}$ Ibid., p. 289.

619 Ibidem.

${ }^{620}$ A propósito, o primeiro livro de Barthes que li foi Le Plaisir du texte, em tradução brasileira, no primeiro semestre de graduação em Letras na USP, para a disciplina de Língua Portuguesa I, em 1995.

${ }^{621}$ Ibid., p. 290.
} 
transformou suas propostas em "novos academismos", como escreve Leyla Perrone-Moisés ${ }^{622}$. Como balanço final de seu legado, a admiradora de Barthes, que teve o privilégio de conhecê-lo e de ser sua aluna, conclui, em testemunho: "O tom de sua voz, audível em sua escritura, e o lugar flutuante (receptivo, generoso) em que ele soube manter sua enunciação permanecem infinitamente sugestivos e aptos a ecoar, no devido tempo, em outras palavras" ${ }^{623}$. Para mim, elas ecoam nas palavras de professores brasileiros quando evocam Barthes para questionar as normas acadêmicas e o atual sistema universitário, ou quando Barthes lhes inspira a sair da estrada pavimentada do ensaio tradicional para desbravar novos caminhos de escrita.

Uma pergunta se impõe: por que Barthes tem sido lido dessa maneira? Acredito que não haja uma resposta definitiva. Contudo, arrisco uma hipótese ao mesmo tempo generalizante e compósita e, portanto, perigosa. Na maioria dos textos observo, por parte dos autores, uma saturação das ferramentas discursivas acadêmicas, cheias de regras e, portanto, repetitivas. O ensaio acadêmico se tornou uma "armadura", como diz Celina Mello ${ }^{624}$, ou uma mera exigência para se conseguir bolsas e recursos financeiros para projetos e programas de pesquisa, como evidencia André Rios ${ }^{625}$. Em outras palavras, com frequência o ensaio não mais é um espaço de gozo, de inquietação e de prazer proporcionado pela prática da escrita. Seu consequente questionamento deságua na procura por uma nova forma, uma terceira forma, diferente da procurada por Barthes na Préparation du roman I et II, entre a poesia e o romance, mas situada entre o ensaio e a obra literária, capaz de aliar a erudição universitária à expressão pessoal. No bojo da crítica às normas acadêmicas, encontra-se, de uma maneira mais ampla, a crítica ao autoritarismo do sistema universitário atual, que associa diretamente quantidade de produção a gratificações e reconhecimento, ensejando a produção quase maquinal de ensaios e sua ânsia por publicação. $\mathrm{O}$ intelectual universitário, em muitos casos, não mais escreve porque tem algo a dizer, mas porque é obrigado a publicar cada vez mais, para atingir sua quota anual e contribuir para que seu departamento receba uma maior quantidade de incentivos públicos e/ ou privados. Nesse contexto em que o intelectual se sente encurralado pelo sistema universitário, é o Barthes libertário e contrário a toda e qualquer doxa que se evidencia, mais uma vez como um modelo a ser seguido embora a maneira mais fiel de seguir seu ensinamento seja justamente não o seguir.

Tal leitura situada precisamente no universo acadêmico e que não é privilégio brasileiro integra um contexto mais amplo, o da chamada pós-modernidade. Leyla Perrone-Moisés, em seu

${ }^{622}$ Ibid., p. 292.

${ }^{623}$ Ibid., p. 293.

${ }^{624}$ In Viver com Barthes, op. cit., p. 53.

${ }^{625}$ Ibid., p. 27. 
artigo "Barthes e o pós-modernismo" ${ }^{626}$, publicado nas imprensas francesa e brasileira em 1993, mostra como o escritor foi transformado no grande mestre da pós-modernidade pelos intelectuais estadunidenses, e explica: "Barthes não viveu o suficiente para se pronunciar a respeito. Os americanos o etiquetam de pós-modernista porque ele colaborou para a derrocada das 'metanarrativas totalizantes e legitimadoras', pregou a dissolução do sujeito numa jouissance egotista, estetizou a vida etc." 627 Ora, no Brasil atual, como mostrei em minhas análises, os questionamentos e as tentativas de ruptura com as normas impostas pela tradição acadêmica vão nessa mesma direção, pois se fundamentam no caráter libertário e contrário às doxas de certos conceitos e ideias barthesianos.

No entanto, Leyla Perrone-Moisés refuta essa leitura de Barthes, que o fixa em um rótulo privilegiando apenas uma faceta de sua obra. Preocupada em ser fiel à totalidade do pensamento do escritor, a autora relembra seu lado clássico, que cultivava como valores a ética, a significação e a história, palavras-chave da obra de Barthes, no seu entender ${ }^{628}$. O escritor lia autores clássicos para o seu deleite e prezava acima de tudo a tolerância - não muito em alta na grande fatia da pósmodernidade que tem nos discursos das minorias uma nova forma de autoritarismo e impõe a ditadura do politicamente correto. A autora então conclui: "O lugar de Barthes, portanto, não era o pós-modernismo, mas bem antes, entre o classicismo e a modernidade, entre o prazer e o gozo: ‘sujeito incerto' (Aula, 1977), escritor a cavalo entre duas sensibilidades" ${ }^{629}$.

Como leitura totalizante da trajetória intelectual de Barthes, Leyla Perrone-Moisés novamente está certa em não desprezar a importância da formação clássica do escritor, perfeitamente integrada em seu pensamento e em suas práticas durante toda a sua vida. E em observar que não se levou em conta que a mesma pós-modernidade defensora das minorias erigia novos autoritarismos, contrários às posturas do escritor. Mas sua correção nos óculos que enxergam Barthes como um autor pós-moderno não invalida essa leitura que dele se faz, inclusive no Brasil. Leitura enviesada, como toda leitura, e influenciada por fatores históricos: num momento em que a desconstrução dos discursos autoritários se tornava a nova teoria em voga, Barthes foi lido como um precursor, pois se fazia necessário arregimentar nomes importantes que endossassem a nova tendência. O lugar de Barthes, portanto, não era na pós-modernidade, mas também nela, e em outros tantos lugares que de suas ideias venham a se apropriar.

\footnotetext{
${ }^{626}$ In Inútil poesia e outros ensaios breves, op. cit., pp. 294-300. Publicado com o título "Roland Barthes: comment s'en débarrasser" na Quinzaine Littéraire, $\mathrm{n}^{\circ}$ 618, Paris, 16 a 28 de fevereiro de 1993 e com o título "Barthes foi atropelado pela pós-modernidade" no caderno Cultura de O Estado de S. Paulo em 10 de abril de 1993.

${ }^{627}$ Ibid., p. 298.

${ }^{628}$ Ibidem.

${ }^{629}$ Ibid., p. 300.
} 


\section{Traduções}

(...) peu de goût pour les littératures étrangères, pessimisme constant à l'égard de la traduction, affolement devant les questions des traducteurs, tant ils paraissent souvent ignorer ce que je crois être le sens même d'un mot: la connotation. ${ }^{630}$

Roland Barthes

Barthes nunca traduziu uma única obra. Não era um grande conhecedor de idiomas ${ }^{631} \mathrm{e}$ pouco se interessou por questões relativas à tradução, o que ele explica na citação que selecionei como epígrafe. Mas em algumas de suas reflexões sobre a crítica literária manifestou posições que se aproximam de certos conceitos modernos de tradução.

Em “Qu'est-ce que la critique?”, célebre artigo de 1963 publicado primeiramente na Times Literary Supplement e, na França, nos Essais critiques, Barthes define a crítica literária como uma metalinguagem, nos seguintes termos: "la critique est discours sur un discours; c'est un langage second, ou méta-langage (comme diraient les logiciens), qui s'exerce sur un langage premier (ou langage-objet)." ${ }^{632}$ Mais adiante, colocando em questão a ideia de que a crítica tem a palavra final sobre a obra - à época, muito cara aos críticos tradicionais -, explica que

son rôle [da crítica] est uniquement d'élaborer elle-même un langage dont la cohérence, la logique, et pour tout dire la systématique, puisse recueillir, ou mieux encore "intégrer" (au sens mathématique du terme) la plus grande quantité possible de langage proustien, exactement comme une équation logique éprouve la validité d'un raisonnement sans prendre parti sur la "vérité" des arguments qu'il mobilise. ${ }^{633}$

Ou seja, a crítica deve se constituir como uma linguagem segunda que "integra" a linguagem da obra literária, tal como um marceneiro encaixa duas partes de um móvel, fazendo, para tanto, os ajustes necessários, segundo a comparação de Barthes. O crítico, então, "ajusta" "le langage que lui fournit son époque (existentialisme, marxisme, psychanalyse) au langage, c'est-à-

\footnotetext{
${ }^{630}$ Roland Barthes par Roland Barthes, $O C$ v. 4, p. 691.

${ }^{631}$ Embora admitisse um certo gosto por línguas bastante diferentes do francês, como, por exemplo, o japonês, cuja estrutura lhe representava o outro. In Roland Barthes par Roland Barthes, op. cit., p. 691.

${ }^{632}$ In $O C$ v. 2, pp. 504-505.

${ }^{633}$ Ibid., p. 505.
} 
dire au système formel de contraintes logiques élaboré par l'auteur selon sa propre époque." ${ }^{634}$ Em outras palavras, Barthes vê a atividade crítica como a elaboração de uma linguagem, no sentido pleno do termo, o de écriture, ancorada no presente do crítico, que, contudo, mantém uma relação estreita com a linguagem da obra literária, esta, ligada a seu tempo mas nunca a ele confinada, pois prenhe de sentidos em devir ${ }^{635}$.

Em A Operação do texto, o poeta concretista e tradutor Haroldo de Campos relembra seus primeiros passos traduzindo Maiakóvski. Apesar de seus parcos conhecimentos do idioma russo na época, mostra como obteve êxito porque "tinha também presente o problema específico da tradução de poesia, que, a meu [seu] ver, é modalidade que se inclui na categoria da criação. Traduzir poesia há de ser criar, sob pena de esterilização e petrificação, o que é pior do que a alternativa de trair." ${ }^{636}$ O conceito de transcriação é central na poética da tradução de Campos ${ }^{637}$ e reúne as ideias de criação e de transposição de linguagens, as molas-motoras da escrita literária e da tradução, respectivamente. Para ele, traduzir uma obra significa recriá-la, ou transcriá-la, criar uma nova obra a partir da transposição de sua linguagem para uma outra língua:

Tudo isto o tradutor tem que transcriar, excedendo os lindes de sua língua, estranhando-lhe o léxico, recompensando a perda aqui com uma intromissão inventiva acolá, a infratradução forçada com a hipertradução venturosa, até que o desatine e desapodere aquela última Húbris (culpa luciferina, transgressão semiológica?), que é transformar o original na tradução de sua tradução. ${ }^{638}$

Quando o original se torna a "tradução de sua tradução", rompe-se a barreira entre a obra literária e sua tradução, prevalecendo unicamente a relação de precedência, sem que, no entanto, ela implique em uma hierarquia de valores. Ora, também uma quebra de paradigma - a supremacia da obra literária sobre o texto crítico - é o que propõe Barthes. E Campos, grande leitor do escritor francês desde os anos 60, e com base nas teorias de Max Bense e Ezra Pound, estabelece a conexão entre tradução e crítica: nessa mesma década, os poetas concretistas, pretendendo estrategicamente

\footnotetext{
634 Ibidem.

635 A pluralidade de sentidos da obra literária é fortemente reivindicada por Barthes como argumento contrário à "verdade única" da obra defendida pela velha crítica francesa ao longo do século XX. Cf. "Les deux critiques”, "Qu’estce que la critique?" e Critique et vérité. In $O C$ v. 2, respectivamente pp. 496-501, 502-507, 757-801.

${ }^{636}$ São Paulo, Perspectiva, pp. 43-44, apud Boris Schaiderman, "Haroldo de Campos e a transcriação da poesia russa moderna", Fragmentos, n 25, Florianópolis, julho-dezembro de 2003, p. 61.

637 Haroldo de Campos fundamenta sua teoria na tradução de poesia. Porém, não há nada que impeça que ela seja compreendida num sentido mais largo, como uma teoria da tradução literária, da maneira que eu a interpreto.

${ }^{638}$ In Dante Alighieri, Seis cantos do Paraíso, tradução de Haroldo de Campos, São Paulo, Fontana/ Instituto Italiano de Cultura, 1976, p. 19, apud Boris Schaiderman, "Haroldo de Campos, poesia russa moderna, transcriação", conferência apresentada em Salto Oriental, Uruguai, em 28 de junho de 1991, no simpósio internacional sobre a obra de Haroldo de Campos. Versão revista pelo autor e acrescida de um Post-Scriptum. Revista da USP n ${ }^{\circ}$ 59, São Paulo, setembronovembro de 2003, p. 179.
} 
preparar o sistema literário brasileiro para seus poemas então revolucionários, dedicaram-se a uma intensa atividade tradutória, naturalmente escolhendo as obras estrangeiras que corroboravam suas convicções e contribuíam para o desenvolvimento de suas reflexões sobre a literatura: "Fazendo-o, tinham presente justamente a didática decorrente da teoria e da prática poundiana da tradução e suas ideias quanto à função da crítica - e da crítica via tradução - como 'nutrimento do impulso' criador." 639

Embora Barthes não seja citado no trecho acima - e sim Ezra Pound, outro grande pensador da linguagem -, a compreensão da crítica enquanto alimento da criação literária a aproxima da definição da crítica como écriture, da crítica enquanto Texto ${ }^{640}$. E sua relação com a tradução, esta entendida por Campos como uma atividade criadora e crítica ao mesmo tempo, permite que os três conceitos - texto literário, crítica e tradução - se imbriquem.

De uma maneira explícita, é Tania Carvalhal quem faz a ponte entre Barthes e a tradução, em seu ensaio "Tradução e recepção na prática comparatista" ${ }^{641}$, citando um trecho de $S / Z$ :

"Há, de um lado, o que é possível escrever e, de outro, o que não é mais possível escrever: o que é na prática do escritor e no que dela decorre: que textos aceitaria eu escrever (reescrever), desejar, lançar como uma força neste mundo que é o meu?"

Retomando e transformando as palavras finais do autor, diríamos: "que textos aceitaria eu traduzir para lançá-los como uma força neste mundo que é o meu?" ${ }^{642}$

Tanto no verbo escrever, para Barthes, quanto em traduzir, para Tania Carvalhal, estão compreendidos dois movimentos inseparáveis: a criação, ou recriação, ou transcriação, trabalho

\footnotetext{
${ }^{639}$ Haroldo de Campos, "Da Tradução como criação e como crítica", Metalinguagem e outras metas, São Paulo, Editora Perspectiva, 1992, p. 42.

${ }^{640}$ Em Critique et vérité, tratando da definição de crítica, Barthes afirma: "Lorsqu'un critique tire de l'oiseau et de l'éventail mallarméens un 'sens' commun, celui de l'aller-et-retour, du virtuel, il ne designe pas une dernière vérité de l'image mais seulement une nouvelle image, ele-même suspendue. La critique n'est pas une traduction, mais une périphrase." ( $O C$ v. 2, p. 797). Nesse trecho, Barthes repudia a comparação entre crítica e tradução porque se refere a esta como a transposição final e única de uma palavra ou expressão para outro sistema linguístico, o que revela uma concepção limitada da atividade tradutória. A tradução pode e, em muitos casos, deve ser perífrase, e portanto implica em uma interpretação, em uma leitura pessoal, como já explicava Jakobson em "Aspectos linguísticos da tradução": "A tradução intralingual de uma palavra utiliza outra palavra, mais ou menos sinônima, ou recorre a um circunlóquio. (...) Da mesma forma, na tradução interlingual, não há comumente equivalência completa entre as unidades de código, ao passo que as mensagens podem servir como interpretações adequadas das unidades de código ou mensagens estrangeiras. (...) Mais frequentemente, entretanto, ao traduzir de uma língua para outra, substituem-se mensagens em uma das línguas, não por unidades de código separadas, mas por mensagens inteiras de outra língua. Tal tradução é uma forma de discurso indireto: o tradutor recodifica e transmite uma mensagem recebida de outra fonte. Assim, a tradução envolve duas mensagens equivalentes em dois códigos diferentes." (In Linguística e comunicação, tradução de Izidoro Blikstein e José Paulo Paes, São Paulo, Cultrix, 1995 (1969)).

${ }^{641}$ In $O$ Próprio e o alheio. Ensaios de literatura comparada, São Leopoldo (RS), Editora da Universidade do Vale do Rio dos Sinos, 2003, pp. 217-259.

${ }^{642}$ Ibid., p. 247.
} 
desenvolvido no interior da linguagem movido pelo desejo do autor e/ou tradutor; e a sua disseminação.

As traduções, lançadas "como uma força" num sistema literário, interferem em seu funcionamento, introduzindo novos conceitos ou ratificando ideias vigentes. Acerca desse fenômeno Itamar Even-Zohar desenvolveu fecundas reflexões concebendo sua Teoria do Polissistema Literário. Para esse autor, as traduções não podem ser vistas fora de um sistema cultural, como ele explica:

My argument is that translated works do correlate in at least two ways: (a) in the way their source texts are selected by the target literature, the principles of selection never being uncorrelatable with the home co-systems of the target literature (to put it in the most cautious way); and (b) in the way they adopt specific norms, behaviors, and policies - in short, in their use of the literary repertoire - which results from their relations with the other home co-systems. ${ }^{643}$

Essa concepção dinâmica das relações entre traduções e sistemas literários mostra-se bastante útil para a leitura da recepção à obra de Barthes no Brasil pelo viés de suas traduções. Por um lado, a voga dos estudos linguísticos e sociológicos no Brasil dos anos 60 e 70, alimentada pela consolidação das instituições universitárias, fez com que se procurasse, no exterior, bibliografia então quase inexistente no país. Nesse contexto, destacam-se as editoras paulistas Cultrix e Perspectiva, graças à grande quantidade de títulos publicados nas áreas citadas, a maioria composta por traduções de obras estrangeiras, francesas e estadunidenses, sobretudo. Como se vê, as obras traduzidas - inclusive os livros de Barthes e diversas coletâneas que continham artigos do escritor eram selecionadas segundo as necessidades locais, em acordo com o item "a" da argumentação de Even-Zohar.

Por outro lado, as teorias e concepções que desembarcavam por meio dessas traduções traziam ao Brasil questões e maneiras de encarar problemas próprias às realidades dos países estrangeiros, muitas vezes resultando em um choque entre culturas: ideias longamente amadurecidas em um contexto universitário diversificado e antigo aportavam repentinamente no ainda acanhado ambiente intelectual brasileiro - tal como aconteceu com Le Degré zéro de l'écriture, cuja recepção primeira foi bastante negativa, como demonstrei no capítulo dedicado aos anos 50. Ou seja, as traduções fornecem ao sistema um arcabouço de questões e significados próprio a seu sistema de origem, passíveis de gerar controvérsia e incompreensão dentro do sistema de chegada, como EvenZohar descreve no item "b" do trecho citado.

643 "The Position of translated literature within the literary polysystem". In Lawrence Venuti (org.), The Translation Studies Reader, Londres, Routledge, 2000, pp. 192-193. 
A fim de examinar as relações entre as traduções das obras de Barthes e os diferentes momentos do sistema literário brasileiro, organizei cronologicamente as obras publicadas em primeira edição na França e suas traduções no Brasil (cf. volume anexo).

Da listagem destaco dois momentos na história das traduções de Barthes no Brasil: as décadas de 70 e de 2000. Nos anos 70, foram traduzidos predominantemente os livros de Barthes que melhor respondiam à necessidade de bibliografia sobre linguística aplicada à leitura do texto literário, de que o sistema literário brasileiro carecia, conforme já mencionei. Foram publicados, no período: Crítica e verdade seguido de coletânea dos Ensaios críticos (1970), O grau zero da escritura (1971), Elementos de semiologia (1971), Análise estrutural da narrativa (1971), Mitologias (1972), Novos ensaios críticos seguidos de O grau zero da escritura (1974), O Prazer do texto (1977), Roland Barthes (1977), Sistema da Moda (1979), O que é a literatura (entrevista com Barthes) (1979) e Aula (1978).

Além da clara predominância das editoras Cultrix (cinco traduções) e Perspectiva (duas traduções) na publicação dos livros de Barthes na década, saliento também o papel fundamental de Leyla Perrone-Moisés, tradutora da primeira obra de Barthes no Brasil, Crítica e verdade e da seleção dos Ensaios críticos, bem como de Roland Barthes e de Aula. Seu trabalho de divulgação das ideias do escritor, além de pioneiro, estendeu-se pelos anos que se seguiram nos jornais, na universidade e junto a editoras, até o momento presente.

Na primeira década do século XXI identifico novo momento em que as obras de Barthes foram traduzidas em grande número. O interesse de muitos de seus conceitos foi reconhecido pela pós-modernidade, que revitalizou seus escritos publicados a partir de Le Plaisir du texte, como a produção acadêmica atual evidencia e procurei mostrar no capítulo "A crítica atual: deslocamentos". No entanto, segundo a listagem das traduções de Barthes no Brasil, suas obras foram publicadas por várias editoras diferentes, muitas delas tendo demorado para serem traduzidas, como Michelet e $O$ Império dos signos, que esperaram por nada menos do que 37 anos, dentre outros casos menos gritantes. A inconstância das reedições de obras já traduzidas e a demora para se traduzir obras inéditas no Brasil fizeram com que durante aproximadamente 20 anos o acesso aos livros de Barthes ficasse bastante difícil, muitas vezes restrito às caras edições portuguesas das Edições 70, ao passo que a demanda por seus escritos recebia novo impulso por parte dos estudos chamados pósmodernos. 
Mais uma vez, uma necessidade do sistema literário alavancou a presença de Barthes no mercado editorial brasileiro: a Editora Martins Fontes, desde 2005 WMF Martins Fontes ${ }^{644}$, criou, em 2003, a Coleção Roland Barthes, cuja direção está a cargo de Leyla Perrone-Moisés. Portanto, novamente, a trajetória dessa grande intelectual se mistura à história de Barthes, divulgando seus escritos ao público brasileiro. Foram publicados na coleção, até o presente momento, entre novas traduções e inéditos, os seguintes livros: O Grau zero da escrita seguido de Novos ensaios críticos (2000), A Aventura semiológica (2001), Como viver junto. Simulações romanescas de alguns espaços cotidianos. Cursos e seminários no Collège de France 1976-1977 (2003), O Neutro. Anotações de aulas e seminários ministrados no Collège de France 1977-1978 (2003), Fragmentos de um discurso amoroso (2003), O Grão da voz. Entrevistas (1962-1980) (2004), O Rumor da língua (2004), Incidentes (2004), Inéditos, I: teoria (2004), Inéditos, II: crítica (2004), Inéditos, III: imagem e moda (2005), Inéditos, IV: política (2005), A Preparação do romance I - Da Vida à obra. Notas de cursos e seminários no Collège de France, 1978-1979 (2005) A Preparação do romance II - A obra como Vontade. Notas de curso no Collège de France 1979-1980 (2005), Sade, Fourier, Loyola (2005), O Império dos signos (2007), Escritos sobre teatro (2007), Sobre Racine (2008), Sistema da moda (2009), Diário de luto. 26 de outubro de 1977-15 de setembro de 1979 (2011), Cadernos da viagem à China (2012).

O interesse renovado pelas ideias de Barthes nos anos 2000 e o novo influxo de edições lançadas no mercado pela Martins Fontes contagiou outras editoras detentoras dos direitos de publicação das traduções de algumas de suas obras no Brasil a reeditarem suas antigas edições ou até mesmo a se iniciarem nesse "novo" filão. Exemplo disso foi a edição de Roland Barthes por Roland Barthes, traduzido por Leyla Perrone-Moisés para a editora Cultrix em 1977, pela editora Estação Liberdade, em 2003. Ou as reedições de A Câmara clara pela Nova Fronteira (2000), Mitologias pela Difel (2003 e 2009, esta última, pela primeira vez uma edição completa, as anteriores tendo se limitado a uma coletânea das mitologias de 1957), Análise estrutural da narrativa pela Editora Vozes (2008), O Prazer do texto e Crítica e verdade seguido de coletânea dos Ensaios críticos pela Perspectiva (2008 e 2009, respectivamente).

A dinâmica das traduções das obras de Barthes permite definir algumas das imagens dele criadas, segundo as quais o escritor foi lido no Brasil: primeiramente, foi, principalmente, o autor estruturalista que interessou aos intelectuais brasileiros, graças a suas reflexões sobre a linguagem,

\footnotetext{
${ }^{644}$ A editora nasceu da Livraria Martins Fontes, esta, empresa familiar fundada em Santos (SP), em 1960. Vinte anos mais tarde, em São Paulo, firmou-se enquanto livraria e também se tornou uma referência no mercado editorial brasileiro, por suas publicações de relevância, selecionadas independentemente de seu potencial de vendagem.
} 
calcadas nas teorias linguísticas em voga, tendo como alvo tanto a linguagem literária quanto a linguagem dos jornais e revistas. No período que se seguiu, longo de vinte anos, esses escritos pareceram datados em demasia e Barthes não mais era procurado com tanto interesse. Mas a pósmodernidade do final dos anos 90 e dos anos 2000, reconhecendo nele um precursor, acrescida do trabalho obstinado de uma intelectual, ressuscitou o escritor e sua obra como um todo, recolocando seus livros nos catálogos das editoras e dando novo fôlego para que suas obras e ideias frutifiquem muito além do território francês. 


\section{À guisa de conclusão}

Mais, malgré tout, quand on écrit, on dispense des germes, on peut estimer qu'on dispense une sorte de sémence et que, par conséquent, on est remis dans la circulation générale des sémences. ${ }^{645}$

Roland Barthes

O texto reproduzido na epígrafe faz parte de uma entrevista concedida por Barthes poucos dias antes de ser atropelado. Mesmo sem saber que aquelas seriam suas últimas palavras a seus leitores, o escritor, àquela altura já detentor de uma vasta obra, refletia sobre as razões da escrita. Referia-se justamente às sementes que os escritos disseminam, sobre as quais - no caso de Barthes, em forma de textos críticos - me debrucei durante alguns anos, até que elas germinassem neste trabalho. Prova de que seus textos foram recolocados em circulação, para talvez frutificar em novos textos.

Nesse processo, tem papel especial a leitura, que revivifica o que foi escrito. Em "Sur la lecture", conferência proferida por Barthes em 1975, aventa a possibilidade de se identificar as estruturas essencias da leitura, como Propp as encontrou nas narrativas. E passa a investigá-la, perguntando-se sobre o porquê da crise da leitura na França. Detecta em sua origem a falta de desejo de ler, o que o faz explorar a relação entre a leitura, o leitor e o desejo, propulsionado pelo prazer.

Nessa equação, Barthes insere uma nova variável, a écriture:

Enfin, il y a une troisième aventure de la lecture (j'appelle aventure la façon dont le plaisir vient au lecteur): c'est, si l'on peut dire, celle de l'Écriture; la lecture est conductrice du Désir d'écrire (...); ce n'est pas du tout que nous désirions forcément écrire comme l'auteur dont la lecture nous plaît; ce que nous désirons, c'est seulement le désir que le scripteur a eu d'écrire, ou encore: nous désirons le désir que l'auteur a eu du lecteur lorsqu'il écrivait, nous désirons le aimez-moi qui est dans toute écriture. (...) Dans cette perspective, la lecture est véritablement une production: non plus d'images intérieures, de projections, de fantasmes, mais, à la lettre, de travail: le produit (consommé) est retourné en production, en promesse, en désir de production, et la chaîne des désirs commence à se dérouler, chaque lecture valant pour l'écriture qu'elle engendre, à l'infini. ${ }^{646}$

A relação entre o autor, o Texto e o leitor é circular: movido pelo desejo do autor de despertar o desejo de seu leitor, este também é incitado a praticar a écriture e a produzir novos

645 "La Crise du désir", entrevista concedida a Philip Brooks para Le Nouvel Observateur em 20 de abril de 1980. In OC v. 5 , p. 945.

${ }^{646}$ In $O C$ v. 4, p. 934. 
Textos, tornando-se, por sua vez, autor. Barthes concebe, portanto, os papéis de autor e de leitor como intercambiáveis, separados unicamente pela prática da écriture. O Texto seria, então, uma zona prenhe de sentidos na qual o leitor, cedendo ao desejo, poderia se metamorfosear em autor, incorrendo no que o escritor francês chama de "Paradoxe du lecteur":

(...) il est communément admis que lire, c'est décoder: des lettres, des mots, des sens, des structures, et cela est incontestable; mais en accumulant des décodages, puisque la lecture est de droit infinie, en ôtant le cran d'arrêt du sens, en mettant la lecture en roue libre (ce qui est sa vocation structurelle), le lecteur est pris dans un renversement dialectique: finalement, il ne décode pas, il sur-code; il ne déchiffre pas, il produit, il entasse des langages, il se laisse infiniment et enlassablement traverser par eux: il est cette traversée. ${ }^{647}$

O leitor concretiza a travessia pelo Texto e torna-se autor. Assim como todos os críticos diletantes, os professores universitários e os jornalistas culturais que, com seus textos sobre Barthes, integraram a história que contei neste trabalho, sobre a recepção à obra do escritor e as imagens que ela gerou. Tais textos - alguns belíssimos, outros nem tanto, a maioria medíocre -, independentemente da qualidade de sua execução, de sua écriture ou apenas tentativa de sê-lo, tais textos, sendo produto de écrivains, como Leyla Perrone-Moisés, Gilles Lapouge e Vera Casa Nova, ou de écrivants, trazem em seu bojo imagens de Barthes, algumas bem construídas, outras rapidamente esboçadas.

Inseridas na infinita "cadeia dos desejos", na expressão barthesiana, cada uma das leituras feitas por esses autores vale pelas écritures ou tentativas de écritures que elas engendraram, bem como pelas imagens do escritor que elas veiculam. Pois Barthes é o grande centro para o qual todas as linguagens recolhidas neste trabalho convergem, e seu ponto de partida: autor por ter desejado o desejo de outros escritores, Barthes, por meio de sua écriture, despertou novos desejos e estimulou a criação de novos textos. Muitos deles, mesmo quando não tiveram por tema o escritor francês ou sua obra, conservaram de forma indelével as marcas de sua passagem por eles, que foram rastreadas e estudadas neste trabalho. A partir dessas marcas, montei o quebra-cabeças das imagens de Barthes no Brasil, reconstituindo alguns dos retratos nos quais o escritor foi fixado: como a batata frita se metamorfoseia quando é envolvida pelo óleo quente, Barthes também, por sua vez, foi metamorfoseado pelas linguagens que o envolveram, fazendo de seus retratos, não imagens fiéis, mas imagens refratadas pelos efeitos do tempo e do contexto em que foram projetadas.

Por ojeriza à cristalização e à imobilidade das imagens, Barthes escreveu em seu diário, em 29 de março de 1979: "Je vis sans aucun souci de la postérité, aucun désir d'être lu plus tard (sauf,

${ }^{647}$ Ibid., p. 935. 
financièrement, pour M.), la parfaite acceptation de disparaître complètement, aucune envie de 'monument' - mais je ne peux pas supporter qu'il en soit ainsi pour mam. (peut-être parce qu'elle n'a pas écrit et que son souvenir dépend entièrement de moi)." ${ }^{648}$ Exceto por razões materiais, para não deixar seu irmão desamparado, e para perpetuar a lembrança de sua mãe, o que faz em $L a$ Chambre claire, livro que começou a escrever alguns dias depois dessa anotação, Barthes afirma não se importar com sua posteridade. Parece até mesmo preferir não tê-la. Contudo, não foi isso o que o tempo lhe reservou.

Na década de 50, praticamente um desconhecido no Brasil, Barthes não foi compreendido. Le Degré zéro de l'écriture foi tratado como mais um "brinquedo intelectual", dentre outros tantos que grassavam na época, escritos por jovens ambiciosos e desejosos de inovação, sobretudo na França. Ao lado dessa imagem pouco lisonjeira e quase sem destaque, Barthes também era o crítico teatral marxista da Théâtre Populaire, mas quem o conhecia pela revista, desconhecia o autor de Le Degré zéro, e quem o conhecia pelo livro, não sabia de seu interesse pelo teatro. O foco de sua imagem, portanto, era duplo, porém bastante esfumaçado, sem nitidez.

A década seguinte foi mais pródiga para o escritor. Embora ainda frequentasse quase exclusivamente retratos de grupo, as imagens começavam a ganhar contornos mais definidos, evidenciando, principalmente, o teórico estruturalista e o defensor do Nouveau roman e da nouvelle critique francesa. Também começou a transparecer a imagem de um intelectual que compreendia a atividade de escrita como a realização de uma écriture, e junto desse conceito nascia toda uma gama de reflexões sobre a escrita literária, notada pela crítica brasileira. Enfim, nessa época Barthes era visto no Brasil como um escritor e moderno teórico da literatura, como o eram Michel Butor e Maurice Blanchot, dentre outros.

Os anos 70 mudaram tudo: de uma quase mancha irreconhecível nos retratos antigos e coadjuvante nas fotografias então mais recentes, Barthes passou a ocupar o centro das atenções e sua imagem, a ganhar destaque. Era então o grande mestre do estruturalismo, autor do manual de análise literária Éléments de sémiologie e do texto-referência no assunto, "Introduction à l'analyse structurale des récits". Escritor renomado, também desnorteava seus novos discípulos brasileiros com escritos pouco afeitos ao jargão estruturalista, como suas reflexões sobre o prazer do texto e sua autobiografia. Era uma referência para os jovens professores universitários e detestado pela velha guarda. Em suma, Barthes adquiriu o status de celebridade entre os intelectuais das mais diversas

${ }^{648}$ In Journal de deuil, 26 octobre 1977 - 15 septembre 1979, Paris, Seuil/ Imec, 2009, p. 245. 
áreas, sua imagem comportanto, ao mesmo tempo, o estruturalismo que ele já havia abandonado e o hedonismo libertário a partir do qual desenvolvia suas reflexões.

O que se seguiu a sua morte talvez tivesse espantado o tímido e pacato Barthes, tão avesso aos holofotes da mídia. Os anos 80 e 90 festejaram os Fragments d'un discours amoureux e incorporaram o tema do amor e a forma dos fragmentos a seu vocabulário, a ponto de o título de seu livro mais vendido ser adaptado e transformado em manchetes de reportagens sem relação alguma com o escritor. Tais referências implícitas são prova do quanto Barthes já fazia parte do imaginário dos jornalistas culturais e era acessível à imensa massa leitora do jornal, como autor de best seller e, ainda, nome de destaque do estruturalismo. Ao mesmo tempo, ele era coroado como grão-mestre da pós-modernidade por jornalistas e professores universitários, que descobriam em sua obra a luta constante contra a doxa, ou contra todo tipo de imposição, por meio do uso da linguagem literária, sua écriture. A imagem do escritor, em vigor até hoje, é dupla: por um lado, ela preserva sua marca dos anos 60 e 70 e é visto como uma referência dentro do estruturalismo; por outro, é o mestre insurgente da pós-modernidade, cujo exemplo tem inspirado muitos intelectuais. Passado e presente coabitam sua imagem, fazendo jus ao escritor paradoxal que Barthes sempre procurou ser.

Do autor incompreendido, que não foi levado a sério, ao escritor que todos conhecem e admiram: grande metamorfose sofreu a imagem de Barthes, que compreendeu várias fases. Estas também refletem os diferentes momentos da história literária brasileira, nos anos de transição da crítica tradicional, exclusivamente jornalística, para a crítica universitária e para o jornalismo cultural. Ainda que de modo enviesado, seguindo a pista de Barthes, visitei e revisitei muitos textos críticos de referência, documentos testemunhais da mudança de perfil da crítica e dos intelectuais brasileiros, bem como de seus espaços de atuação. Sem o saber, o escritor teve papel importante nessa história, o que faz pensar, num primeiro momento, em sua influência na história da crítica brasileira. A propósito, respondendo a uma pergunta sobre a influência que seu então novo livro, Essais critiques, poderia ter no meio intelectual francês, pondera:

D'ailleurs, d'une façon plus générale, je ne sais trop ce qu'est une "influence"; à mon sens, ce qui se transmet, ce ne sont pas des "idées", mais des "langages", c'est-à-dire des formes que l'on peut remplir différemment; c'est pourquoi la notion de circulation me paraît plus juste que celle d'influence; les livres sont plutôt des "monnaies" que des "forces". ${ }^{649}$

\footnotetext{
${ }^{649}$ In "Je ne crois pas aux influences", entrevista concedida a Renaud Matignon para France-Observateur. In OC v. 2, p. 616.
} 
Mais do que escritor influente no Brasil ou em outro país, Barthes fez com que sua obra circulasse, despertando o desejo de seus leitores. Involuntariamente, instigou polêmicas, foi instrumentalizado por elas, alimentou disputas, incitou discussões e, sobretudo, estimulou a escrita de mais textos, que têm se multiplicado, pois sua obra continua em debate. Talvez toda essa efervescência protagonizada por seus textos, por estar sempre tão longe de um consenso, fizesse o escritor rever sua recusa à posteridade, considerando que esta não precisa ser, necessariamente, a concretização de uma única imagem, uma prisão. Pois sua obra circula mais do que nunca, errando, vagueando, e faz circular. Esta tese é só mais uma na espiral flexível de vozes que envolve a écriture de Barthes sem, contudo, imobilizá-la. Que venham outras.

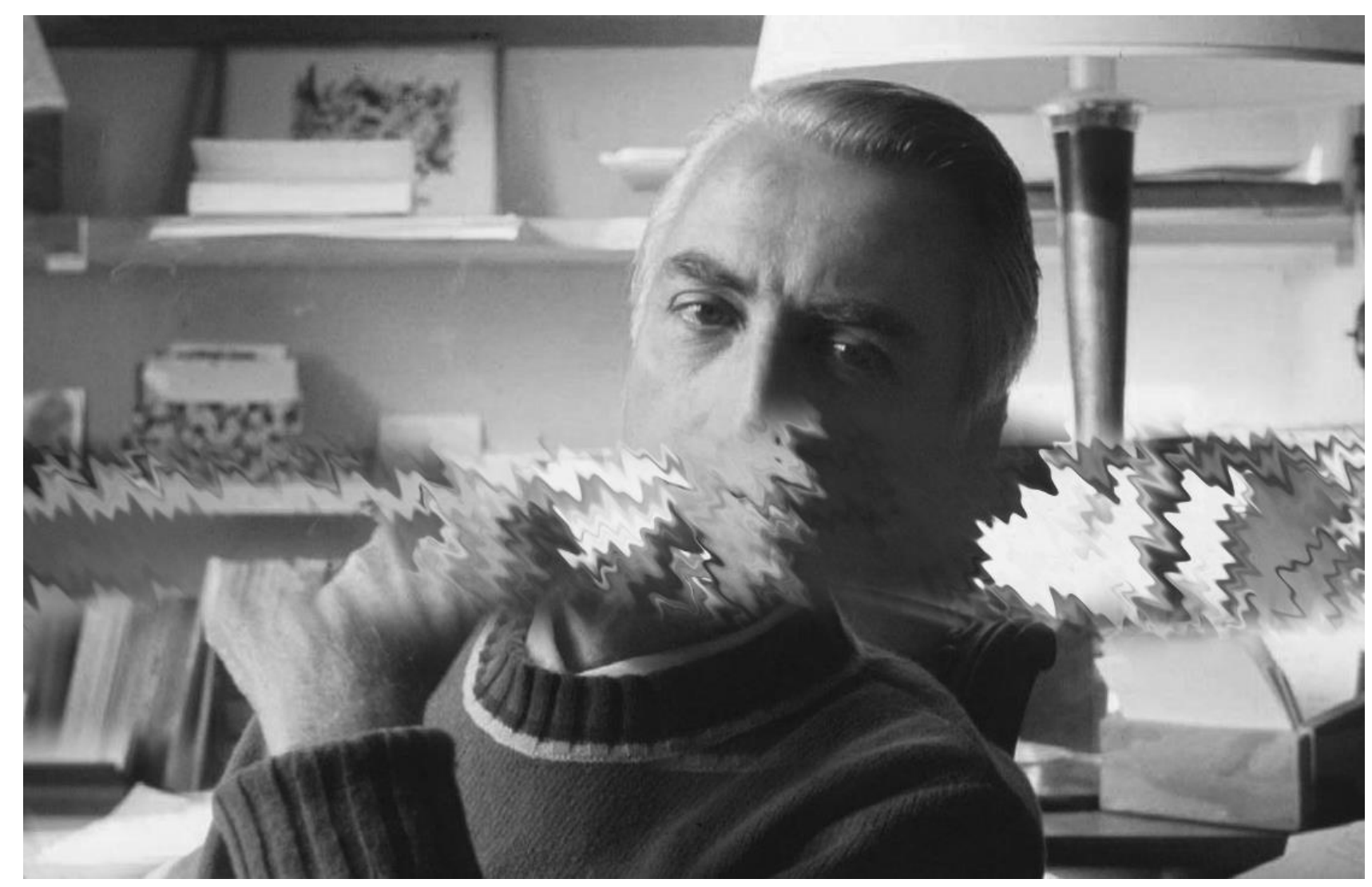

Imagem de Barthes com efeito de refração 


\section{Bibliografia}

\section{De Roland Barthes (em ordem cronológica, incluindo as publicações brasileiras)}

Le Degré zéro de l'écriture. Paris : Éditions du Seuil, 1953.

Michelet. Paris: Éditions du Seuil, 1954.

Le Degré zéro de l'écriture suivi de Éléments de sémiologie. Paris : Gonthier, 1965.

Mythologies. Paris : Éditions du Seuil, 1970 (1957).

Sur Racine. Paris : Éditions du Seuil, 1979 (1963).

Essais critiques. Paris : Éditions du Seuil, 1981 (1964).

Critique et vérité. Paris : Éditions du Seuil, 1999 (1966).

Système de la mode. Paris : Éditions du Seuil, 1983 (1967).

S/Z. Paris : Éditions du Seuil, 1976 (1970).

L'Empire des signes. Paris : Éditions du Seuil, 2005 (Genebra : A. Skira, 1970).

Crítica e verdade. Tradução de Leyla Perrone-Moisés. São Paulo : Editora Perspectiva, 1970.

Sade, Fourier, Loyola. Paris : Éditions du Seuil, 1980 (1971).

O grau zero da escritura. Tradução de Anne Arnichand e Álvaro Lorencini. São Paulo: Cultrix, 1971.

Elementos de semiologia. Tradução de Izidoro Blikstein. São Paulo: Cultrix/ Editora da Universidade de São Paulo, 1971.

Análise estrutural da narrativa (seleção de ensaios da revista Communications $\mathrm{n}^{0}$ 8, 1966). Tradução de Maria Zélia Barbosa Pinto. Rio de Janeiro: Editora Vozes, 1971.

Mitologias. Tradução de Rita Buongermino e Pedro de Souza. São Paulo: Difusão Europeia do Livro, 1972.

Le Degré zéro de l'écriture suivi de Nouveaux essais critiques. Paris: Éditions du Seuil, 1972.

Le Plaisir du texte. Paris : Éditions du Seuil, 1973.

Novos Ensaios críticos seguidos de O Grau zero da escritura. Tradução de Heloysa de Lima Dantas, Anne Arnichand e Álvaro Lorencini. São Paulo: Cultrix, 1974.

Roland Barthes par Roland Barthes. Paris : Éditions du Seuil, 1975.

Fragments d'un discours amoureux. Paris: Éditions du Seuil, 1977.

Poétique du récit (em colaboração). Paris: Éditions du Seuil, 1977.

O Prazer do texto. Tradução de J. Guinsburg. São Paulo: Editora Perspectiva, 2006 (1977).

Roland Barthes. Tradução de Leyla Perrone-Moisés. São Paulo : Cultrix, 1977.

Leçon. Paris : Éditions du Seuil, 1978.

Sollers écrivain. Paris : Éditions du Seuil, 1979.

Sistema da moda. Tradução de Lineide do Lago Salvador Mosca, revisão e supervisão Isaac Nicolau

Salum. São Paulo: Nacional/ Editora da Universidade de São Paulo, 1979.

O que é a literatura. Entrevista com Roland Barthes. Tradução de Nestor de Sousa e Irineu Garcia. Rio de Janeiro: Salvat Editora, 1979.

La Chambre claire. Note sur la photographie. Paris : Éditions de l'Étoile/ Gallimard/ Seuil, 1980.

Aula. Tradução e posfácio de Leyla Perrone-Moisés. São Paulo: Cultrix, 2007 (1980).

Le Grain de la voix. Entretiens (1962-1980). Paris : Éditions du Seuil, 1981.

Fragmentos de um discurso amoroso. Tradução de Hortênsia dos Santos. Rio de Janeiro: F. Alves, 1981.

Essais critiques III. L'Obvie et l'obtus. Paris : Éditions du Seuil, 1992 (1982).

Sollers escritor. Tradução de Lígia Maria Ponde Vassallo. Rio de Janeiro: Tempo Brasileiro, Fortaleza: Universidade Federal do Ceará, 1982. 
Essais critiques IV. Le Bruissement de la langue. Paris : Éditions du Seuil, 1993 (1984).

A Câmara clara. Nota sobre a fotografia. Tradução de Júlio Castanon Guimarães. Rio de Janeiro: Nova Fronteira, 1984.

L’Aventure sémiologique. Paris : Éditions du Seuil, 1985.

Incidents. Paris : Éditions du Seuil, 1987.

Sobre Racine. Tradução de Antonio Carlos Viana. Porto Alegre: L\&PM Editores, 1987.

O Rumor da língua. Tradução de Mário Laranjeira. São Paulo: Editora Brasiliense, 1988.

Incidentes. Tradução de Júlio Castanon Guimarães. Rio de Janeiro: Editora Guanabara, 1988.

La Tour Eiffel. Photographies d'André Martin. Paris: Seuil, 1989.

Sade, Fourier, Loyola. Tradução de Mário Laranjeira. São Paulo: Secretaria de Estado da Cultura/ Editora Brasiliense, 1990.

O Óbvio e o obtuso. Ensaios críticos III. Tradução de Léa Novaes. Rio de Janeiro: Nova Fronteira, 2004 (1990).

Michelet. Tradução de Paulo Neves. São Paulo: Companhia das Letras, 1991.

S/Z. Uma análise da novela Sarrasine de Honoré de Balzac. Tradução de Léa Novaes. Rio de Janeiro: Nova Fronteira, 1992.

Cuvres complètes. Édition préparée par Éric Marty. Paris : Éditions du Seuil, 1993 (v. 1, 19421965), 1994 (v. 2, 1966-1973), 1995 (v. 3, 1974-1980).

O Grão da voz. Tradução de Anamaria Skinner. Rio de Janeiro: Francisco Alves, 1995.

O Grau zero da escrita seguido de Novos ensaios críticos. Tradução de Mário Laranjeira. São Paulo: Martins Fontes, 2000.

A Aventura semiológica. Tradução de Mário Laranjeira. São Paulo: Martins Fontes, 2001.

Euvres complètes. Nouvelle édition revue, corrigée et présentée par Éric Marty. Paris : Éditions du Seuil, 2002, 5v.

Comment vivre ensemble. Simulations romanesques de quelques espaces quotidiens. Cours et séminaires au Collège de France 1976-1977. Paris : Éditions du Seuil, 2002.

Le Neutre. Cours et séminaires au Collège de France 1977-1978. Paris : Éditions du Seuil, 2002.

Écrits sur le théâtre. Textes présentés et réunis par Jean-Loup Rivière. Paris : Éditions du Seuil, 2002.

La Préparation du roman I et II. Cours et séminaires au Collège de France (1978-1979 et 19791980). Paris : Éditions du Seuil, 2003.

Roland Barthes. Tradução de Leyla Perrone-Moisés. São Paulo: Estação Liberdade, 2003.

Fragmentos de um discurso amoroso. Tradução de Márcia Valéria Martinez de Aguiar. São Paulo: WMF Martins Fontes, 2003.

Como viver junto. Simulações romanescas de alguns espaços cotidianos. Cursos e seminários no Collège de France 1976-1977. Tradução de Leyla Perrone-Moisés. São Paulo: WMF Martins Fontes, 2003.

O Neutro. Anotações de aulas e seminários ministrados no Collège de France 1977-1978. Tradução de Ivone Castilho Benedetti. São Paulo: WMF Martins Fontes, 2003.

O Grão da voz. Entrevistas (1962-1980). Tradução de Mário Laranjeira, revisão da tradução de Lígia Fonseca Ferreira. São Paulo: WMF Martins Fontes, 2004.

Incidentes. Tradução de Mário Laranjeira. São Paulo: WMF Martins Fontes, 2004.

O Rumor da língua. Tradução de Mário Laranjeira, revisão da tradução de Andréa Stahel M. da Silva. São Paulo: WMF Martins Fontes, 2004.

Le Sport et les hommes. Texte du film Le Sport et les hommes d'Hubert Aquin. Montréal : Les Presses de l'Université de Montréal, 2004.

Inéditos, I: teoria. Organização: Leyla Perrone-Moisés. Tradução: Ivone Castilho Benedetti. São Paulo: WMF Martins Fontes, 2004. 
Inéditos, II: crítica. Organização: Leyla Perrone-Moisés. Tradução: Ivone Castilho Benedetti. São Paulo: WMF Martins Fontes, 2004.

Inéditos, III: imagem e moda. Organização: Leyla Perrone-Moisés. Tradução: Ivone Castilho Benedetti. São Paulo: WMF Martins Fontes, 2005.

Inéditos, IV: política. Organização: Leyla Perrone-Moisés. Tradução: Ivone Castilho Benedetti. São Paulo: WMF Martins Fontes, 2005.

A Preparação do romance I - Da vida à obra. Notas de cursos e seminários no Collège de France, 1978-1979. Tradução de Leyla Perrone-Moisés. São Paulo: WMF Martins Fontes, 2005.

A Preparação do romance II - A obra como Vontade. Notas de curso no Collège de France 19791980. Tradução de Leyla Perrone-Moisés. São Paulo: WMF Martins Fontes, 2005.

Sade, Fourier, Loyola. Tradução de Mário Laranjeira. São Paulo: WMF Martins Fontes, 2005.

Le Discours amoureux. Séminaire à l'École Pratique des Hautes Études 1974-1976. Suivi de Fragments d'un discours amoureux: inédits. Avant-propos d'Éric Marty, présentation et édition de Claude Coste. Paris : Seuil, 2007.

Escritos sobre teatro. Tradução de Mário Laranjeira, revisão da tradução de Andréa Stahel M. da Silva. São Paulo: WMF Martins Fontes, 2007.

O Império dos signos. Tradução de Leyla Perrone-Moisés. São Paulo : WMF Martins Fontes, 2007.

Sobre Racine. Tradução de Ivone Castilho Benedetti, revisão da tradução de Márcia Valéria Martinez de Aguiar. São Paulo : WMF Martins Fontes, 2008.

Mitologias. Tradução de Rita Buongermino, Pedro de Souza e Rejane Janowitzer. Rio de Janeiro: Difusão Europeia do Livro, 2009.

Sistema da moda. Tradução de Ivone Castilho Benedetti. São Paulo: WMF Martins Fontes, 2009.

Journal de deuil. 26 octobre 1977-15 septembre 1979. Texte établi et annoté par Nathalie Léger. Paris : Éditions du Seuil/ IMEC, 2009.

Carnets $d u$ voyage en Chine. Édition établie, présentée et annotée par Anne Herschberg Pierrot. Paris : Christian Bourgois Éditeur/ IMEC, 2009.

Le Lexique de l'auteur. Séminaire à l'École Pratique des Hautes Études 1973-1974. Suivi de fragments inédits du Roland Barthes par Roland Barthes. Avan-propos d'Éric Marty, présentation et édition d'Anne Herschberg Pierrot. Paris : Seuil, 2010.

Sarrasine de Balzac. Séminaires à l'École Pratique des Hautes Études (1967-1968 et 1968-1969). Texte établi et anoté par Claude Coste et Andy Stafford. Paris : Seuil, 2011.

Diário de Luto. 26 de outubro de 1977 - 15 de setembro de 1979. Tradução de Leyla PerroneMoisés. São Paulo: WMF Martins Fontes, 2011.

Cadernos da viagem à China. Tradução de Ivone Castilho Benedetti. São Paulo: WMF Martins Fontes, 2012.

\section{Sobre Roland Barthes}

ALPHANT, Marianne, LÉGER, Nathalie (org.). $R / B$, Roland Barthes. Catálogo de exposição realizada no Centre Georges Pompidou (Paris). Paris : Seuil/ Éditions du Centre Pompidou/ IMEC, 2002.

BURNIER, Michel-Antoine, RAMBAUD, Patrick. Le Roland-Barthes sans peine. Paris: Balland, 1978.

CALVET, Louis-Jean. Roland Barthes, uma biografia. Tradução de Maria Ângela Villela da Costa. São Paulo: Editora Siciliano, 1993.

CAMPOS, Haroldo de. "Sobre Roland Barthes". In Metalinguagem \& outras metas. Ensaios de teoria e crítica literária. São Paulo: Editora Perspectiva, 1992, pp. 119-126. 
COMPAGNON, Antoine (dir.). Prétexte : Roland Barthes. Paris : Union Générale d'Éditions, 1978. . "Roland Barthes en saint Polycarpe". In Les Antimodernes : de Joseph de Maistre à Roland Barthes. Paris : Gallimard, 2005, pp. 404-440.

GRÜNEWALD, José Lino. "O grau zero de Barthes”. In O Grau zero do escreviver. São Paulo: Perspectiva; Rio de Janeiro: Fundação Biblioteca Nacional, 2002, pp. 217-219.

KADOTA, Neiva Pitta. A Escritura inquieta. São Paulo: Estação Liberdade, 1999.

LOMBARDO, Patrizia. The three paradoxes of Roland Barthes. Atenas e Londres: The University of Georgia Press, 1989.

MELLO, Maria Elizabeth Chaves de, PERRONE-MOISÉS, Leyla (org.). De volta a Roland Barthes. Niteroi (RJ): EdUFF, 2005.

MERQUIOR, José Guilherme. "De Sartre a Barthes". In As Ideias e as formas. Rio de Janeiro: Nova Fronteira, 1981, pp. 192-198.

MOTTA, Leda Tenório da. "Barthes". In Lições de literatura francesa. Rio de Janeiro: Imago Editora, 1997, pp. 167-172.

. Roland Barthes: uma biografia intelectual. São Paulo: Iluminuras/ FAPESP, 2011.

NOVA, Vera Casa; GLENADEL, Paula (org.). Viver com Barthes. Rio de Janeiro: 7Letras, 2005.

PERRONE-MOISÉS, Leyla. Roland Barthes, o saber com sabor. São Paulo: Editora Brasiliense, 1985 (1983).

. A crítica-escritura. Um discurso dúplice. Tese de livre-docência apresentada à Faculdade de Filosofia, Letras e Ciências Humanas da Universidade de São Paulo. São Paulo, 1975.

. Flores da escrivaninha. Ensaios. São Paulo : Companhia das Letras, 1990.

Inútil poesia e outros ensaios breves. São Paulo: Companhia das Letras, 2000.

Texto, crítica, escritura. São Paulo: Martins Fontes, 2005.

. Com Roland Barthes. São Paulo: WMF Martins Fontes, 2012.

PROCHASSON, Christophe. "Les espaces de la controverse. Roland Barthes contre Raymond Picard: un prélude à Mai 68". Mil neuf cent. Revue d'histoire intellectuelle, 2007/1 n ${ }^{\circ}$ 25, pp. 141-155.

PINO, Claudia Consuelo Amigo. "Écrire sans écrire: Barthes et la recherche du roman". In Revista Criação \& Crítica, São Paulo, n ${ }^{0}$ 2, 2009, pp. 25-35.

- "Nem sempre fracassamos ao falar do que amamos. O discurso e a narrativa amorosa de Roland Barthes". In Remate de Males, Campinas (SP), n 31.1-2, janeiro/ dezembro de 2011, pp. 211-226.

ROGER, Philippe. Roland Barthes, roman. Paris: Éditions Grasset \& Fasquelle, 1986.

SONTAG, Susan. L'écriture même : à propos de Roland Barthes. Tradução de Philippe Blanchard e da autora. Paris : Christian Bourgois, 1982.

. "Relembrando Barthes". Sob o signo de Saturno. Tradução de Ana Maria Capovilla e Albino Poli Jr. Porto Alegre e São Paulo: L\&PM Editores, 1986, pp. 127-133.

SILVA, Márcio Renato Pinheiro da. As Fissuras da forma: Roland Barthes, da língua à escrita. Tese de doutorado. São José do Rio Preto (SP): Instituto de Biociências, Letras e Ciências Exatas da Universidade Estadual Paulista “Júlio de Mesquita Filho”, 2008.

\section{Números especiais de revistas, exposições e colóquios dedicados a Roland Barthes}

Cult, $\mathrm{n}^{\mathrm{0}}$ 100, "Roland Barthes, subversivo e sedutor", março de 2006.

Magazine Littéraire, $\mathrm{n}^{\circ}$ 97, fevereiro de 1975, $\mathrm{n}^{\circ}$ 314, outubro de 1993 e n ${ }^{\circ} 482$, janeiro de 2009.

Le Point, edição especial Références: "Lévi-Strauss, Foucault, Lacan, Derrida, Bourdieu, Deleuze, Barthes... Nos derniers maîtres. Les textes fondamentaux", setembro-outubro de 2011. 


\section{Textos sobre Barthes publicados no Estado de S. Paulo}

1953

MILLIET, Sérgio. "Grau zero da escrita". Primeiro Caderno, "Vida Intelectual”, terça-feira, 17 de novembro de 1953 , p. 8.

1956

MAGALDI, Sábato. “Crise do teatro francês”. Suplemento Literário, “Teatro”, sábado, 6 de outubro de 1956 , p. 5.

1957

LEWIN, Willy. "Madame Solario: um sucesso anônimo". Suplemento Literário, "Letras AngloAmericanas", sábado, 15 de junho de 1957, p. 1.

LINHARES, Temístocles. "Uma obra diferente". Terceito Caderno, Literatura e Arte, domingo, 16 de junho de 1957, p. 80.

DACOSTA, Antonio. "Simbolismo". Primeiro Caderno, "Em Paris...", sexta-feira, 9 de agosto de 1957, p. 6.

MARTINS, Wilson. "Ingleses”. Suplemento Literário, "Últimos livros”, sábado, 21 de dezembro de 1957, p. 2.

1958

“Cadernos de teatro”. Primeiro Caderno, “Teatro”, sábado, 24 de maio de 1958, p. 7.

1959

MARTINS, Wilson. “A ambiguidade do conto". Suplemento Literário, "Últimos livros”, sábado, 4 de abril de 1959, p. 2.

CARPEAUX, Otto Maria. "Pretensão sem surpresa". Suplemento Literário, sábado, 30 de maio de 1959, p. 1.

BROCA, Brito. "Os editores e o Roman Nouveau”. Suplemento Literário, "Letras Francesas", sábado, 21 de novembro de 1959, p. 1.

1960

XAVIER, Lívio. "Michel Butor, crítico". Suplemento Literário, Revista das Revistas, sábado 27 de agosto de 1960, p. 6.

1962

"Robbe-Grillet falará hoje sobre literatura e cinema na UBE". Primeiro Caderno, quinta-feira, 13 de setembro de 1962, p. 11.

RAMOS, Vítor. "Encontro com Robbe-Grillet". Suplemento Literário, sábado, 22 de setembro de 1962, p.3.

PERRONE-MOISÉS, Leyla. “A estação dos romances”. Suplemento Literário, "Letras Francesas", sábado, 22 de dezembro de 1962, p. 1. 
1964

PERRONE-MOISÉS, Leyla. "O centro da esfera”. Suplemento Literário, sábado, 14 de março de 1964, p. 1.

\section{5}

LEWIN, Willy. "A Experiência imediata". Suplemento Literário, "Letras Anglo-Americanas", sábado, 3 de abril de 1965, p. 1.

THEODOR, Erwin. Resenha de Von Oxford bis Harvard, Hans Mayer (org.). Suplemento Literário, "Resenha Bibliográfica", sábado, 3 de abril de 1965, p. 2.

LEWIN, Willy. "Problemas da crítica". Suplemento Literário, sábado, 14 de agosto de 1965, p. 1.

CAMPOS, Haroldo de. "Miramar revém”. Suplemento Literário, sábado, 14 de agosto de 1965, p. 4.

CARPEAUX, Otto Maria. “As aulas e o vento". Suplemento Literário, sábado, 9 de outubro de 1965, p. 4.

ÁVILA, Affonso. "Sousândrade: o poeta e a consciência crítica II". Suplemento Literário, sábado, 16 de outubro de 1965 , p. 3.

1966

CAMPOS, Augusto de . "Poesia e/ ou pintura". Suplemento Literário, sábado, 2 de fevereiro de 1965, p. 2.

XAVIER, Lívio. Resenha de Nouvelle critique ou nouvelle imposture? de Raymond Picard. Suplemento Literário, "Resenha bibliográfica", sábado, 23 de julho de 1966, p. 2.

LORENCINI, Álvaro. Resenha de Pourquoi la Nouvelle critique : critique et objectivité, de Serge Doubrovsky. Suplemento Literário, "Resenha bibliográfica", sábado, 20 de agosto de 1966, p. 2.

XAVIER, Lívio. "A crítica à crítica da nova crítica". Resenha de texto de Françoise van Rossum Guyon publicado em Cahiers $d u$ Sud. Suplemento Literário, "Revista das revistas", sábado, 20 de agosto de 1966, p. 6.

CAMPOS, Augusto de. "Entrevista com Umberto Eco". Suplemento Literário, sábado, 17 de setembro de 1966, p. 1.

ALTMANN, Eliston. "Depoimento de Anatol Rosenfeld”. Suplemento Literário, sábado, 17 de setembro de 1966, p. 3.

BARBOSA, João Alexandre. "Nove novena novidade". Suplemento Literário, sábado, 12 de novembro de 1966, p. 3.

PERRONE-MOISÉS, Leyla. "O poder da literatura”. Suplemento Literário, sábado, 3 de dezembro de 1966 , p. 1.

\section{7}

SILVA, Mario da. "Brecht à moda da casa". Suplemento Literário, sábado, 14 de janeiro de 1967, p. 5.

AUGUSTO, Sérgio. “Quine, Hawks: polêmica”. Suplemento Literário, sábado, 29 de abril de 1967, p. 5.

MARTINS, Wilson. “Quem tem medo de Sainte-Beuve? II”. Suplemento Literário, sábado, 10 de junho de 1967, p. 4.

Resumo sem assinatura de $O$ método estruturalista, de vários autores inclusive Barthes. Traduzido para o português por Carlos Henrique Escobar (Rio de Janeiro : Zahar Editores, 1967). Suplemento Literário, "Lançamentos”, sábado, 21 de outubro de 1967, p. 2. 
1968

PERRONE-MOISÉS, Leyla. “A escrita e o grito”. Suplemento Literário, sábado, 20 de abril de 1968, p. 3.

. "Uma necessidade livre". Suplemento Literário, sábado, 6 de julho de 1968, p. 1. Recentemente publicado em Com Roland Barthes, da mesma autora.

CAMPOS, Haroldo de. "Comunicação na poesia de vanguarda - I". Suplemento Literário, sábado, 24 de agosto de 1968 , p. 1.

LUCAS, Fábio. "Osman Lins e a renovação do conto". Suplemento Literário, sábado, 14 de setembro de 1968, p. 1.

SUCUPIRA Filho, Eduardo. "O estruturalismo: ideologia do status quo". Suplemento Literário, sábado, 16 de novembro de 1968, p. 2.

1969

PERRONE-MOISÉS, Leyla. "Por uma poética estrutural”. Suplemento Literário, sábado, 25 de janeiro de 1969, p. 1.

ÁVILA, Affonso. "O Graciliano que nos interessa". Suplemento Literário, sábado, 22 de fevereiro de 1969 , p. 3.

MENDONÇA, Fernando. "Projeção internacional do romance português". Suplemento Literário, sábado, 8 de março de 1969, p. 1.

CAMPOS, Haroldo de. "Serafim: análise sintagmática". Suplemento Literário, sábado, 8 de março de 1969 , p. 6.

PERRONE-MOISÉS, Leyla. “As máscaras verbais”. Suplemento Literário, sábado 24 de maio de 1969 , p. 1.

CARVALHO, Joaquim de Montezuma de. “O estruturalismo é um anti-humanismo ?" Suplemento Literário, sábado, 21 de junho de 1969, p. 6.

XAVIER, Lívio. "O Amor em Rosalia de Castro e a destruição das suas cartas (Cuadernos Hispanoamericanos)". Suplemento Literário, sábado, 23 de agosto de 1969, p. 4.

LEAL, César. "Perspectiva da crítica literária no Brasil". Suplemento Literário, sábado, 23 de agosto de 1969 , p. 6.

XAVIER, Lívio. "A Teorização do barroco na Península Ibérica ( $O$ Barroco)”. Suplemento Literário, "Revista das revistas", sábado, 30 de agosto de 1969, p. 5.

MENDONÇA, Fernando. "A questão Coimbrã e o método em questão". Suplemento Literário, "Resenha Bibliográfica", sábado, 13 de setembro de 1969, p. 2.

MARQUES, Oswaldino. "Fenomenologia da obra literária II". Suplemento Literário, sábado, 13 de setembro de 1969 , p. 3.

PERRONE-MOISÉS, Leyla. "Do formalismo ao estruturalismo”. Suplemento Literário, sábado, 20 de setembro de 1969, p. 1.

MENDONÇA, Fernando. "Da letra à reflexão". Suplemento Literário, sábado, 11 de outubro de 1969, p. 1.

MARTINS, Wilson. “Caminhos da crítica”. Suplemento Literário, sábado, $1^{\text {o }}$ de novembro de 1969, p. 4.

CAMPOS, Haroldo de. "A pele da escritura - II". Suplemento Literário, sábado, $1^{\circ}$ de novembro de 1969, p. 6.

\section{0}

CAÑIZAL, Eduardo Peñuela, LOPES, Edward. "De Asturias a Cortázar”. Suplemento Literário, sábado, 7 de março de 1970, p. 1. 
PERRONE-MOISÉS, Leyla. “O voo dos significantes”. Suplemento Literário, sábado, 4 de abril de 1970, p. 1. Recentemente publicado em Com Roland Barthes, da mesma autora.

"A floração das revistas". Suplemento Literário, sábado, 23 de maio de 1970, p. 1.

DIMAS, Antonio. "O fenômeno literário". Resenha de A Arte no horizonte do provável, de Haroldo de Campos. Suplemento Literário, "Resenha bibliográfica", sábaddo, 30 de maio de 1970, p. 2.

“Ionesco, o revolucionário". Primeiro Caderno, terça-feira, 2 de junho de 1970, p. 11.

MARQUES, Oswaldino. "Estrutura das ignorâncias altamente especializadas". Suplemento Literário, sábado, 13 de junho de 1970, p. 1.

LUCAS, Fábio. "Estruturalismo e crítica literária”. Suplemento Literário, sábado, 11 de julho de 1970 , p. 1.

. "Do estruturalismo à 'nova crítica"”. Suplemento Literário, sábado, 18 de julho de 1970, p. 4.

XAVIER, Lívio. "A Cultura, comida quente (Spectator)". Suplemento Literário, "Revista das revistas", sábado, 8 de agosto de 1970, p. 6.

PERRONE-MOISÉS, Leyla. “Roland Barthes, o infiel”. Suplemento Literário, sábado, 29 de agosto de 1970, p. 1. Recentemente publicado em Com Roland Barthes, da mesma autora.

PORTELLA, Eduardo. "Proposições semiológicas". Suplemento Literário, sábado, 5 de setembro de 1970 , p. 1.

Resumo sem assinatura de Crítica e Verdade, de Roland Barthes. Traduzido para o português por Leyla Perrone-Moisés (São Paulo: Editora Perspectiva, 1970). Suplemento Literário, "Lançamentos", sábado, 12 de setembro de 1970, p. 2.

GIACOMELLI, Eloah F. "A Estética do filme" (resenha de Signs and meaning in the cinema). Suplemento Literário, "Resenha bibliográfica", sábado, 19 de setembro de 1970, p. 2.

CAÑIZAL, Eduardo Peñuela. "Abordagens semiológicas do discurso cinematográfico - I". Suplemento Literário, sábado, 10 de outubro de 1970, p. 6.

“Abordagens semiológicas do discurso cinematográfico - II". Suplemento Literário, sábado, 24 de outubro de 1970.

. “Abordagens semiológicas do discurso cinematográfico - III”. Suplemento Literário, sábado, 7 de novembro de 1970, p. 3.

PIZA, Clélia. "Romance com 3 prefácios”. Suplemento Literário, domingo, 6 de dezembro de 1970, p. 2.

MARTINS, Wilson. "O Estético e o social". Suplemento Literário, domingo, 6 de dezembro de 1970, p. 4.

1971

CAMPOS, Haroldo de. "Bense e o estruturalismo". Suplemento Literário, domingo, 3 de janeiro de 1971, p. 1.

LUCAS, Fábio. "Crítica e estruturalismo”. Suplemento Literário, domingo, 21 de fevereiro de 1971, p. 1.

Lançamento da revista BACAB Estudos semiológicos. Suplemento Literário, "Lançamentos", domingo, 28 de março de 1971, p. 2.

SANTIAGO, Silviano. "Eça, autor de Madame Bovary - 1". Suplemento Literário, "Lançamentos", domingo, 28 de março de 1971, p. 6.

ÁVILA, Affonso. "O dorso (iluminado) do tigre". Suplemento Literário, domingo, 4 de abril de 1971, p. 2.

LOPES, Edward, CAÑIZAL, Eduardo Peñuela. "Tradição e vanguarda”. Suplemento Literário, domingo, 25 de abril de 1971, p. 2. 
LAPOUGE, Gilles. "Sartre rompe com Flaubert o longo silêncio literário". Primeiro Caderno, domingo, 23 de maio de 1971, p. 7

LOPES, Edward, CAÑIZAL, Eduardo Peñuela. "Tradição e ruptura por ambiguidade". Suplemento Literário, domingo, 13 de junho de 1971, p. 1.

Lançamento do Dicionário crítico de comunicação. Suplemento Literário, "Lançamentos", domingo, 13 de junho de 1971, p. 2.

LINHARES, Temístocles. "Traduções importantes". Suplemento Literário, domingo, 8 de agosto de 1971, p. 4.

RICARDO, Cassiano. "Grafitos e Murilogramas”. Suplemento Literário, domingo, 15 de agosto de 1971, p. 1.

Resumo de Semiologia e linguística, de vários autores inclusive Roland Barthes, publicado pela editora Vozes, 1971. Suplemento Literário, "Novos Livros", domingo, 15 de agosto de 1971, p. 2.

LAUS, Lausimar. "O sentido do mito”. Suplemento Literário, domingo, 5 de setembro de 1971, p. 6.

SPERBER, Suzi Frankl. "Linguagem mitificante e desmitificação". Suplemento Literário, domingo, 10 de outubro de 1971, p. 4.

CAMPOS, Haroldo de. "De Livro de ensaios: Galáxias". Suplemento Literário, domingo, 7 de novembro de 1971, p. 3.

1972

LINHARES, Temístocles. "Estado atual da poesia brasileira - 9”. Suplemento Literário, domingo, 2 de janeiro de 1972, p. 4.

KÖPKE, Carlos. "Um poeta nostálgico da ordem" (resenha de Veio e via, de Geraldo Pinto Rodrigues). Suplemento Literário, "Livros Novos", domingo, 30 de abril de 1972, p. 2

XAVIER, Lívio. "Viagem em torno de Roland Barthes" (sobre entrevistas de Barthes na Quinzaine littéraire (1/15 dez., 1/15 jan.) e em Lettres Françaises ( $\mathrm{n}^{\circ}$. 1422)). Suplemento Literário, "Revista das revistas", domingo, 2 de julho de 1972, p. 6.

BARBOSA, Rolmes. "Repentinamente os muros, esses muros" (resenha de Sombras de reis barbudos, de José J. Veiga). Suplemento Literário, "Livros Novos”, domingo, 15 de julho de 1972, p. 2.

LAPOUGE, Gilles. "Uma França sem romance ou ficção". Primeiro Caderno, domingo, 24 de setembro de 1972, p. 12.

XAVIER, Lívio. "Em torno de Barthes" (carta de Gilles Lapouge). Suplemento Literário, "Revista das Revistas", domingo, 22 de outubro de 1972, p. 2.

Resumo de Mitologias, de Roland Barthes, traduzido do inglês, e publicado pela editora Difusão Europeia do Livro, 1972. Suplemento Literário, "Livros Novos", domingo, 29 de outubro de 1972, p. 2.

“Poesia e instauração práxis". Suplemento Literário, domingo, 5 de novembro de 1972, p. 3.

"Veríssimo volta e vai escrever para crianças". Primeiro Caderno, quarta-feira, 6 de dezembro de 1972, p. 9.

FIGUEIREDO, Luiz Antonio de . "Da plasticidade ao conteúdo da poesia". Suplemento Literário, domingo 24 de dezembro de 1972, p. 4.

Lançamento de Introdução aos estruturalismos, de Hubert Lepagneur. Suplemento Literário, "Livros Novos", domingo, 31 de dezembro de 1972, p. 2.

1973

SILVA, Maria Beatriz Nizza da. "Foucault e a ciência histórica". Suplemento Literário, domingo, 21 de janeiro de 1973, p. 1. 
TAVARES, Zulmira Ribeiro. “O sistema dos objetos”. Suplemento Literário, domingo, 11 de março de 1973, p. 5.

"Barthes. A reabilitação do prazer de ler". Suplemento Literário, domingo, 18 de março de 1973, p. 1.

Resumo de $O$ estruturalismo e a miséria da razão, de Carlos Nelson Coutinho, publicado pela editora Paz e Terra, 1973. Suplemento Literário, "Livros Novos", domingo, 25 de março de 1973, p. 2.

KÖPKE, Carlos Burlamaqui. "Revivendo o estruturalismo linguístico". Suplemento Literário, domingo, 15 de abril de 1973, p. 3.

CARVALHO, Joaquim de Montezuma de. "Roland Barthes ou nada de novo sobre estilo". Suplemento Literário, domingo, 22 de julho de 1973, p. 1.

“Amanhã a conferência de Greimas na USP”. Primeiro Caderno, domingo, 22 de julho de 1973, p. 16.

MOTA, Carlos Guilherme. “Os Fazendeiros do ar”. Suplemento Literário, domingo, 2 de setembro de 1973, p. 5.

SUCUPIRA Filho, Eduardo. "Na senda de Lukács". Resenha de O estruturalismo e a miséria da razão, de Carlos Nelson Coutinho. Suplemento Literário, "Livros Novos", domingo, 16 de setembro de 1973, p. 2.

LOUZADA Filho, O. C. "Comunicação e Ideologia I. A análise operacional dos veículos de massa". Suplemento Literário, domingo, 16 de setembro de 1973, p. 5.

- "Ideologia e comunicação II. Ciência crítica e crítica da ciência". Suplemento Literário, domingo, 23 de setembro de 1973, p. 6.

BARBOSA, Rolmes. "Dignidade em meio ao torvelinho de gladios" (sobre A Noite e os objetos, de Geraldo Pinto Rodrigues). Suplemento Literário, "Livros Novos", domingo, 21 de outubro de 1973, p. 2.

COELHO, Nelly Novaes. "Literatura de transgressão - IV”. Suplemento Literário, domingo, 4 de novembro de 1973 , p. 3.

1974

Lançamento de Erté, de Barthes. Suplemento Literário, “Lançamentos no exterior”, domingo, 13 de janeiro de 1974, p. 2.

Lançamento de A Ficção do tempo, de Muniz Sodré. Suplemento Literário, "Livros Novos", domingo, 20 de janeiro de 1974, p. 2.

GALEY, Matthieu. "Autores no espelho". Suplemento Literário, contribuição de L'Express, domingo, 3 de março de 1974, p. 1.

BRAYNER, Sônia. “José de Alencar e o romance histórico”. Suplemento Literário, domingo, 24 de março de 1974, p. 1.

CAMPOS, Roberto de Oliveira. "Crazy World (Mondo Cane)... - I". Primeiro Caderno, quarta-feira, 24 de abril de 1974, p. 5.

Resumo de Novos ensaios críticos - O grau zero da escritura, de Roland Barthes, publicado pela editora Cultrix, 1974. Suplemento Literário, "Livros Novos", domingo, 12 de maio de 1974, p. 2.

LINHARES, Temístoles. "Anti-Romance, o último livro de Cortázar". Suplemento Literário, domingo, 5 de maio de 1974, p. 1.

BARBOSA, Rolmes. "Mapa dos caminhos sem saída" (sobre Onde estivestes de noite?, de Clarice Lispector). Suplemento Literário, "Livros Novos", domingo, 30 de junho de 1974, p. 2.

MOTTA Filho, Candido. "Os contos de Rodrigo Melo Franco de Andrade". Suplemento Literário, domingo, 6 de outubro de 1974, p. 3. 
SCHNAIDERMAN, Boris. "Macunaíma, um diálogo entre surdos”. Suplemento Literário, domingo, 27 de outubro de 1974, p. 1.

SILVEIRA, Alcântara. "Anatole France 50 anos depois". Suplemento Literário, domingo, 3 de novembro de 1974, p. 6.

FISCHER, Almeida. "A desumanização da arte". Resenha de Introdução à Teoria da informação estética, de J. Teixeira Coelho Netto, publicado pela editora Vozes, 1974. Suplemento Literário, Livros Novos, domingo, 10 de novembro de 1974, p. 2.

SANTANNA, Affonso Romano de. "Por um novo conceito de literatura". Suplemento Literário especial "O ensino da literatura", domingo, 17 de novembro de 1974, p. 1.

NUNES, Benedito. "Comentário”. Suplemento Literário especial "O ensino da literatura”, domingo, 17 de novembro de 1974 , p. 3.

MERQUIOR, José Guilherme. "Teses para uma crítica antiformalista”. Suplemento Literário especial "O ensino da literatura", domingo, 17 de novembro de 1974, p. 5.

SANT'ANNA, Affonso Romano de. "Teorreias". Suplemento Literário, domingo, 24 de novembro de 1974, p. 3.

ZANOTTO, Ilka Marinho de Andrade. "Da função da crítica". Suplemento Literário, domingo, 24 de novembro de 1974, p. 5.

SANT'ANNA, Affonso Romano de. "Uma leitura de Clarice Lispector". Suplemento Literário, domingo, 8 de dezembro de 1974, p. 4.

1975

"Três escritores, três diálogos com a morte". Primeiro Caderno, terça-feira, 25 de fevereiro de 1975, p. 16.

SCALZO, Nilo. "A crítica totalizadora”. Primeiro Caderno, domingo, 13 de abril de 1975, p. 20.

LAPOUGE, Gilles. “O tempo do niilismo”. Primeiro Caderno, domingo, 11 de maio de 1975, p. 14.

LAPOUGE, Gilles. "Roland Barthes, antes de tudo, um escritor”. Primeiro Caderno, domingo, $1^{\circ}$ de junho de 1975, p. 16.

. "Intervir na história, a intenção da vanguarda francesa". Primeiro Caderno, domingo, 23 de novembro de 1975 , pp. 40-41.

1976

BLIKSTEIN, Isidoro. "Cem anos de linguística no Brasil”. Suplemento do Centenário, 7 de fevereiro de 1976, pp. 4-5.

SCALZO, Nilo. "Divergência entre o escritor e os teóricos de arte literária". Primeiro Caderno, domingo, 29 de fevereiro de 1976, p. 9.

LAPOUGE, Gilles. “Na França, um 'novo maoísmo' ”. Primeiro Caderno, domingo, 23 de maio de 1976, p. 2.

"Barthes demole o filme de Pasolini". Primeiro Caderno, quarta-feira, 16 de junho de 1976, p. 8.

LAPOUGE, Gilles. "A história do serralheiro, fenômeno literário”. Primeiro Caderno, domingo, 17 de outubro de 1976, p. 38.

PERRONE-MOISÉS, Leyla. "Sartre e a situação da literatura". Suplemento Cultural, domingo, 17 de outubro de 1976, pp. 4-5.

"Erté, desenhista e pintor dos anos 30". Primeiro Caderno, domingo, 31 de outubro de 1976, p. 14.

LAPOUGE, Gilles. "Foucault faz revisão política da sexualidade". Primeiro Caderno, domingo, 5 de dezembro de 1976, p. 216. 
1977

"Para Barthes, 'toda linguagem é fascista' ". Primeiro Caderno, quarta-feira, 26 de janeiro de 1977, p. 8.

"Dilermando nega as acusações de tortura a preso". Primeiro Caderno, sábado, 5 de fevereiro de 1977, p. 10.

"Roland Barthes e os paradoxos da linguagem fascista". Capa, domingo, 6 de fevereiro de 1977.

" 'O fascista Barthes' ”. Primeiro Caderno, "Notas e Informações", domingo, 6 de fevereiro de 1977, p. 3.

LAPOUGE, Gilles. "Barthes, a contestação da linguagem numa linguagem brilhante". Primeiro Caderno, domingo, 6 de fevereiro de 1977, p. 22.

LAPOUGE, Gilles. "Esquerdista faz a crítica do burguês Marx". Primeiro Caderno, domingo, 13 de fevereiro de 1977, p. 196.

LAPOUGE, Gilles. "O Ocidente entre a mistificação e a decadência". Primeiro Caderno, domingo, 27 de fevereiro de 1977, p. 208.

MELLER, Vilson Brunel. "Uma definição provisória de poesia”. Resenha de Linguística e poética, de Daniel Delas e Jacques Filliolet. Suplemento Cultural, domingo, 27 de março de 1977, p. 13.

LAPOUGE, Gilles. "Filósofo contesta o novo programa". Primeiro Caderno, quinta-feira, 2 de junho de 1977, p. 16.

DACOSTA, Antonio. "Paris vê 'Mitologias Cotidianas"'. Primeiro Caderno, sábado, 18 de junho de 1977, p. 8.

Lançamento de Semiótica narrativa e textual, de Claude Chabrol. Suplemento Cultural, "Lançamentos", domingo, 19 de junho de 1977, p. 12.

"Os 'novos filósofos' de esquerda". Primeiro Caderno, "Notas e Informações", domingo, 26 de junho de 1977, p. 3.

ELLMANN, Richard. "A política de James Joyce". Suplemento Cultural, domingo, 17 de julho de 1977, p. 3.

LAPOUGE, Gilles. "O folhetim volta e traz consigo o romanesco". Primeiro Caderno, domingo, 17 de julho de 1977, p. 18.

"Editora lança sete autores brasileiros". Primeiro Caderno, sexta-feira, 12 de agosto de 1977, p. 9.

HEGENBERG, Leônidas. "Na área da linguística". Suplemento Cultural, domingo, 28 de agosto de 1977, pp. 7-8.

OLIVEIRA, Gabriel Alves de. "Contra a literatura instrumental". Primeiro Caderno, domingo, 25 de setembro de 1977, p. 28.

VERSIANI, Marçal. “ 'Democrática, incoercitiva e moderna?' ”. Primeiro Caderno, domingo, 16 de outubro de 1977, p. 10.

PERRONE-MOISÉS, Leyla. "Discurso amoroso e discurso de poder". Suplemento Cultural, domingo, 30 de outubro de 1977, pp. 7-8. Recentemente publicado em Com Roland Barthes, da mesma autora.

"França extradita advogado alemão aliado do terror". Primeiro Caderno, quinta-feira, 17 de novembro de 1977, p. 12.

"Destino de escritor preocupa franceses". Primeiro Caderno, sexta-feira, 25 de novembro de 1977, p. 10.

“A prisão de intelectuais no Paraguai". Primeiro Caderno, quinta-feira, 15 de dezembro de 1977, p. 19.

SANTIAGO, Silviano. "Liderança e hierarquia em Alencar". Suplemento Cultural, domingo, 18 de dezembro de 1977, pp.7-11.

LAPOUGE, Gilles. "França, um país que esteriliza com prêmios sua vida literária". Primeiro Caderno, domingo, 25 de dezembro de 1977, p. 15. 
1978

CAÑIZAL, Eduardo Peñuela. “A mensagem artística e a situação simbólica”. Suplemento Cultural, domingo, 15 de janeiro de 1978, pp. 8-10.

PERRONE-MOISÉS, Leyla. "Teorias do símbolo". Suplemento Cultural, domingo, 22 de janeiro de 1978, pp.13-14.

WILLEMART, Philippe. "Freud e a escrita". Suplemento Cultural, domingo, 19 de fevereiro de 1978, p. 10.

STEINBERG, Martha. "Problemas de semiótica". Resenha de Semiótica narrativa e textual, de Claude Chabrol e outros. Suplemento Cultural, domingo, 26 de março de 1978, p. 14.

WILLEMART, Philippe. "Lacan e a crítica literária". Suplemento Cultural, domingo, 2 de abril de 1978, pp. 7-8.

CAÑIZAL, Eduardo Peñuela. "A mensagem fotográfica e as modalidades de representação". Suplemento Cultural, domingo, 23 de abril de 1978, pp. 6-10.

GURGUIËRE, André. "Toda sociedade constrói sua gramática do poder”. Décimo Caderno, domingo, 7 de maio de 1978, p. 182.

DUMAZEDIER, Joffre. "George Friedmann ou o humanismo sociológico". Suplemento Cultural, domingo, 16 de junho de 1968, pp. 10-11.

LEIRNER, Sheila. "Arte conceitual, incentivo para a nova crítica". Primeio Caderno, domingo, 2 de julho de 1978, p. 22.

PERRONE-MOISÉS, Leyla. "Traduzir Lacan”. Suplemento Cultural, domingo, 13 de agosto de 1978, p. 15.

HEGENBEG, Leônidas. “As várias noções do estruturalismo”. Suplemento Cultural, 10 de setembro de 1978, pp. 16-17.

"Um refrigerante derruba a 'cortina de bambu' ". Primeiro Caderno, "Notas e Informações", sextafeira, 22 de dezembro de 1978, p. 3.

1979

WALDMAN, Berta. "A evolução da crítica literária”. Resenha de Texto, crítica, escritura, de Leyla Perrone-Moisés. Suplemento Cultural, domingo, 28 de janeiro de 1979, pp. 15-16.

LAPOUGE, Gilles. "Ocidente, hoje uma civilização sem projeto" (entrevista de Françoise Giroud). Nono Caderno, domingo, 10 de junho de 1979, pp. 153 e 198.

FABER, Walter. "Roland Barthes: personagem de romance". Suplemento Cultural, domingo, 8 de julho de 1979, p. 11.

LAPOUGE, Gilles. "O historiador e o reencontro das civilizações” (entrevista de Jacques Le Goff). Nono Caderno, domingo, 8 de julho de 1979, p. 174.

SCALZO, Nilo. "Editorial”. Suplemento Cultural, domingo, 29 de julho de 1979, p. 2.

PERRONE-MOISÉS, Leyla. "Escrita ou escritura?" Suplemento Cultural, domingo, 29 de julho de 1979, pp. 5-6. Recentemente publicado em Com Roland Barthes, da mesma autora.

\section{0}

"Os símbolos nas vestes femininas". Primeiro Caderno, terça-feira, 19 de fevereiro de 1980, p. 11.

"Sartre reage à enfermidade". Primeiro Caderno, sábado, 22 de março de 1980, p. 15.

"Os símbolos perdem Roland Barthes". Primeiro Caderno, quinta-feira, 27 de março de 1980, p. 32.

LAPOUGE, Gilles. "Na 'feira das vaidades', um intelectual discreto". Primeiro Caderno, quintafeira, 27 de março de 1980, p. 32.

REALI JÚNIOR. “O gênio, no lamento dos intelectuais". Primeiro Caderno, quinta-feira, 17 de abril de 1980, p. 27. 
REALI JÚNIOR. “Após Sartre e Barthes, a perda do autor cubano”. Primeiro Caderno, sábado, 26 de abril de 1980, p. 16.

"Um depoimento sobre Roland Barthes, por Leyla Perrone-Moisés". Anúncio de texto publicado no Jornal da Tarde. Primeiro Caderno, quinta-feira, 29 de maio de 1980, p. 16, sexta-feira, 30 de maio de 1980, p. 14.

BRIL, Stefânia. "Barthes e o 'gênio' da fotografia”. Primeiro Caderno, domingo, 15 de junho de 1980, p. 38.

“Uma Trienal válida, mas que não é representativa". Primeiro Caderno, domingo, 22 de junho de 1980, p. 48.

. "Três aspectos significativos da I Trienal". Primeiro Caderno, domingo, 29 de junho de 1980, p. 44.

MENGOZZI, Federico. "A cor na fotografia, difícil e rara”. Primeiro Caderno, domingo, 29 de junho de 1980, p. 44.

LAPOUGE, Gilles. “O fim da era dos gigantes?” Cultura, domingo, 13 de julho de 1980, pp. 10-11.

"Barthes: a crise do desejo" (entrevista concedida ao Nouvel Observateur). Cultura, domingo, 27 de julho de 1980, p. 16.

ECO, Umberto. "A Cultura como fenômeno semiótico". Texto extraído do livro Tratado geral de semiótica. Cultura, domingo, 3 de agosto de 1980, pp. 6-7.

LEIRNER, Sheila. "Tuneu: meros exercícios sob acentuado cromatismo". Primeiro Caderno, terçafeira12 de agosto de 1980, p. 10.

LAPOUGE, Gilles. "O Livro da Semana: L'Après Socialisme, de Alain Touraine”. Cultura, domingo, 12 de outubro de 1980, pp. 14-15.

"Um ano de perdas para o pensamento Ocidental". Primeiro Caderno, terça-feira, 30 de dezembro de 1980, p. 18.

\section{1}

BRIL, Stefânia. "Paranapiacaba, na versão subjetiva de 2 câmaras". Primeiro Caderno, sexta-feira, 6 de março de 1981, p. 16.

. "Intimidades com a vida do espaço". Primeiro Caderno, quarta-feira, 20 de abril de 1981, p. 20.

SILVEIRA, Alcântara. "Proust". Cultura, domingo, 14 de junho de 1981, pp. 6-7.

BRIL, Stefânia. “ 'Nãn’á', imagens simples de uma existência solitária”. Primeiro Caderno, quintafeira, 9 de julho de 1981, p. 22.

MENGOZZI, Federico. "Um fotógrafo encontra o seu país". Primeiro Caderno, quarta-feira, 29 de julho de 1981, p. 19.

BRIL, Stefânia. "Apaixonante diálogo com a multidão". Primeiro Caderno, quinta-feira, 6 de agosto de 1981, p. 31.

LAPOUGE, Gilles. "O homem que enganou a França”. Cultura, domingo, 9 de agosto de 1981, pp. 8-9.

CAMPOS, Haroldo de. "A transcriação do Fausto" (entrevista). Cultura, domingo, 16 de agosto de 1981, p. 14-16.

CANÇADO, José Maria. "Tratado sobre o desejo e seu rastro linguístico". Primeiro Caderno, domingo, 27 de setembro de 1981, p. 36.

SARDUY, Severo. "Um autor, mais do que uma personagem, ou uma história, é um tom" (entrevista a Napoleão Sabóia). Cultura, domingo, 18 de novembro de 1981, p. 7-8.

CICCACIO, Ana Maria. "Recriar Valéry, com paciência e arte”. Primeiro Caderno, domingo, 22 de novembro de 1981, p. 37. 
1982

LUCAS, Fábio. “A obra e a crítica”. Cultura, domingo, 3 de janeiro de 1982, p. 8-9.

BRIL, Stefânia. "Um livro indispensável ao profissional da fotografia”. Primeiro Caderno, sábado, 6 de fevereiro de 1982, p. 17.

MORIN, Edgar. "O intelectual se define pelo valor de universalidade que atribui às ideias". Cultura, domingo, 4 de abril de 1982, pp. 8-10.

DOURADO, Autran. "Notas à margem de uma tradução". Cultura, domingo, 11 de abril de 1982, p. $10-11$.

MEDINA, Cremilda. "Cresce, no mundo, o grande apelo mágico". Primeiro Caderno, domingo, 6 de junho de 1982, p. 54.

SCHÜLER, Donald. "Um estudo sério e profundo dos mitos e da mitologia". Primeiro Caderno, sábado, 10 de julho de 1982, p. 14.

LAPOUGE, Gilles. "O romance policial”. Cultura, domingo, 25 de julho de 1982, pp. 3-4.

RÉGIS, Sônia. "Sollers escritor". Resenha de Sollers écrivain, de Roland Barthes. Cultura, "Nas Livrarias", domingo, 22 de agosto de 1982, p. 11.

BRIL, Stefânia. "A imagem da Espanha que chega através da fotografia”. Primeiro Caderno, domingo, 19 de setembro de 1982, p. 48.

SCHÜLER, Donald. “As profundidades em Ledo Ivo”. Primeiro Caderno, quarta-feira, 20 de outubro de 1982, p. 20.

1983

SILVEIRA, Alcântara. "A poesia barroca e engajada de Louis Aragon”. Cultura, domingo, 30 de janeiro de 1983, pp. 5-6.

LAPOUGE, Gilles. "França versus EUA: 'campeonato' absurdo”. Primeiro Caderno, domingo, 13 de março de 1983, p. 36.

LEIRNER, Sheila. "Nos círculos de Tunga, o prazer secreto de provocar". Primeiro Caderno, quinta-feira, 14 de julho de 1983, p. 16.

RÉGIS, Sônia. "Barthes: o saber com sabor". Resenha de Roland Barthes, o saber com sabor, de Leyla Perrone-Moisés. Cultura, "Nas Livrarias", domingo, 24 de julho de 1983, p. 15.

LEIRNER, Sheila. "A forma de manifestar o agora". Primeiro Caderno, domingo, 24 de julho de 1983 , p. 25.

LAPOUGE, Gilles. "Quando as ideologias saem de moda”. Cultura, domingo, 14 de agosto de 1983, pp. 2-4.

. "Raymond Aron, o último iluminista". Cultura, domingo, 9 de outubro de 1983, pp. 8-10.

"Sutilezas da paixão em vários níveis e 'zooms'". Primeiro Caderno, sábado, 15 de outubro de 1983 , p. 15.

1984

SILVEIRA, Alcântara. "O universo sutil e harmonioso de Giraudoux". Cultura, domingo, 15 de janeiro de 1984, p. 11.

CAÑIZAL, Eduardo Peñuela. "A fábula do cordeiro e do lobo e os conflitos da ficção”. Cultura, domingo, 8 de abril de 1984, pp. 10-11.

LAPOUGE, Gilles. "Foucault, o demolidor de mitos". Cultura, domingo, 8 de julho de 1984, pp.13.

RÉGIS, Sônia. “O Canibalismo amoroso. A História do desejo em nossa cultura”. Cultura, domingo, 5 de agosto de 1984, p. 10.

PERRONE-MOISÉS, Leyla. "O império literário de Michel Butor”. Cultura, domingo, 9 de setembro de 1984, pp. 6-7. 
AMARANTE, Leonor. "Butor, o escritor contra os dogmas". Primeiro Caderno, sexta-feira, 14 de setembro de 1984, p. 16.

PERROTTI, Edmir. "O canto de fé à literatura em $O$ Livro de Berenice". Primeiro Caderno, 15 de setembro de 1984, p. 16.

CICACCIO, Ana Maria. "Merton e Blake, dois homens dispostos a ouvir, a meditar". Primeiro Caderno, domingo, 30 de dezembro de 1984, p. 25.

1985

FREYRE, Gilberto. "Joaquim Nabuco reconsiderado". Primeiro Caderno, domingo, 10 de fevereiro de 1985, p. 20.

TOLEDO, Marleine P. M. e F. de. "Byron: a construção do herói romântico". Cultura, sábado, 6 de abril de 1985, pp. 5-6.

LAPOUGE, Gilles. "França esquece Chardin". Primeiro Caderno, quarta-feira, 10 de abril de 1985, p. 10.

PERROTTI, Edmir. “Tchau, ato de amor às letras e aos jovens”. Geral, sábado, 27 de abril de 1985, p. 20.

KUJAWSKI, Gilberto de Mello. “A vida das imagens”. Cultura, domingo, 5 de maio de 1985, pp. 12.

"Pessoa, precursor de caminhos". Primeiro Caderno, sexta-feira, 7 de junho de 1985, p. 15.

"O universo do ser apaixonado em duas peças". Primeiro Caderno, quarta-feira, 19 de junho de 1985, p. 18.

"Fotos de Emilie para textos de Barthes". Geral, quinta-feira, $1^{\circ}$ de agosto de 1985, p. 18.

PEYRE, Henry. "Jean Cocteau, 'un enfant terrible' ". Cultura, domingo, 4 de agosto de 1985, p. 8.

BRIL, Stefânia. "Uma grande exposição pequena”. Primeiro Caderno, quinta-feira, 15 de agosto de 1985 , p. 25.

LAPOUGE, Gilles. "Uma voz de coloração singular, quase única”. Primeiro Caderno, sexta-feira, 20 de setembro de 1985, p. 15.

BRIL, Stefânia. "A construção dos seres compostos". Cultura, domingo, 22 de setembro de 1985, p. 10.

CAPRARA, Loredana. “A obra narrativa de Italo Calvino". Cultura, domingo, 29 de setembro de 1985, pp. 4-5.

SEABRA, José Augusto. "Em mim, o político não matou o escritor" (entrevista a João Alves das Neves). Cultura, domingo, 6 de outubro de 1985, p. 7.

\section{6}

PAULINO, Ana Maria A. "Germano Graeser - um universo autônomo". Cultura, domingo, 9 de fevereiro de 1985, p. 5.

BRIL, Stefânia. "Carlos Freire e as luzes da Índia". Primeiro Caderno, quinta-feira, 27 de fevereiro de 1985, p. 24.

AUGELLI, Marielza. "Preferência francesa". Caderno 2, "Carta de Paris", sexta-feira, 9 de maio de 1986, p. 2.

Nota sobre o espetáculo Fragmentos do Amor. Caderno 2, "Dança", sábado, 10 de maio de 1986, p. 5.

RÉGIS, Sônia. “Um por todos. Repensando o papel do poeta no mundo”. Cultura, sábado, 7 de junho de 1986, p. 8.

MORAES, Reinaldo. "O amor, do outro lado do Equador". Caderno 2, "Antena”, sexta-feira, 13 de junho de 1986, p. 2. 
TEIXEIRA, Maria de Lourdes. "Bela do Senhor. Negação absoluta do otimismo kantiano”. Cultura, sábado, 12 de julho de 1986, p. 11.

TREVISAN, Armindo. "Leitura de poesia". Cultura, sábado, 19 de julho de 1986, p. 12.

Fragmentos de um discurso amoroso como recomendação de leitura. Caderno 2, "Guia de Leitura", domingo, 3 de agosto de 1986, p. 9.

"Editora Francisco Alves amplia atividades em SP". Primeiro Caderno, sexta-feira, 15 de agosto de 1986, p. 32.

MONTEIRO, Nilson. "Escritores e livros invadem a Barão". Caderno 2, "Ponto de Encontro", sexta-feira, 15 de agosto de 1986, p. 10.

SABÓIA, Napoleão. "Brasil e França: um caso de amor" (entrevista com Hervé Terry). Cultura, sábado, 13 de setembro de 1986, pp. 1-3.

DECOL, René. “Os artistas encontram a Solução 16”. Caderno 2, "Pau na máquina”, quarta-feira, 15 de outubro de 1986, p. 8.

TEIXEIRA, Maria de Lourdes. "Caminho Santiago. A articulação entre história e ficção". Cultura, sábado, 18 de outubro de 1986, p. 10.

CARVAlHO, Marco Antonio de. "Sapatilhas de Satã. Mas quem dança é o leitor". Caderno 2, "Mau Passo", domingo, 19 de outubro de 1986, p. 4.

ABREU, Caio Fernando. "Um livro plenamente habitável". Caderno 2, "Releitura", domingo, 2 de novembro de 1986, p. 4.

RÉGIS, Sônia. “A verdadeira contemplação crítica”. Resenha de Sob o signo de Saturno. Cultura, sábado, 15 de novembro de 1986, p. 8.

LEIRNER, Sheila. "Feministas e militantes". Cultura, sábado, 6 de dezembro de 1986, p. 6.

\section{7}

STYCER, Maurício. "Fragmentos de um discurso vigoroso" (sobre a posse de Gilberto Gil como secretário de cultura de Salvador). Caderno 2, quinta-feira, 8 de janeiro de 1987, p. 1.

. "Gerald Thomas, o teatro entre o punk e Beckett". Caderno 2, terça-feira, 13 de janeiro de 1987, p. 1.

ESCOBAR, Pepe. “O camaleão Arcimboldo".Caderno 2, sexta-feira, 3 de abril de 1987, p. 1.

BERRETTINI, Célia. “As diversas interpretações da Fedra”. Cultura, sábado, 23 de maio de 1987, p. 4.

Nota sobre o espetáculo de dança Fragmentos de amor, do Grupo Passo a Passo, dirigido por Marisa Magalhães. Coreografia inspirada em Fragmentos de um discurso amoroso. Caderno 2, "Teatro", quinta-feira, 28 de maio de 1987, p. 6.

ESCOBAR, Pepe. "Pensamentos do terceiro grau". Caderno 2, sábado, 30 de maio de 1987, p. 7.

SEABRA, José Augusto. "Fernando Pessoa e o texto jornalístico". Cultura, sábado, 27 de junho de 1987, pp. 1-2.

MEDEIROS, Jotabê. "Na literatura, os primeiros passos". Caderno 2, quarta-feira, $1^{\circ}$ de julho de 1987, p. 3.

SCALZO, Nilo. "O retrato da nossa formação". Primeiro Caderno, domingo, 27 de julho de 1987, p. 26.

SILVA, Deonísio. “A bela França foi parar no divã”. Caderno 2, "Miserere", domingo, 23 de agosto de 1987, p. 4.

ESCOBAR, Pepe. "Fricotes de uma velha dama indigna". Caderno 2, "Vulgar", sexta-feira, 2 de outubro de 1987, p. 3.

ABREU, Caio Fernando. "Sem via de acesso". Caderno 2, "Antena", quarta-feira, 25 de novembro de 1987, p. 2. 
GIRON, Luís Antônio. "Suspeito fora de suspeita". Caderno 2, "Estreia Shows", quinta-feira, 26 de novembro de 1987, p. 5.

AUGELLI, Marielza. "A moda não sai da moda". Caderno 2, terça-feira, 22 de dezembro de 1987, p. 1.

\section{8}

ESCOBAR, Pepe. "A sedução da barbárie”. Caderno 2, "Carta de Paris", sexta-feira, 29 de janeiro de 1988, p. 2.

"O que vai pintar nos palcos de SP". Caderno 2, "Guia", terça-feira, 9 de fevereiro de 1988, p. 5.

PENTEADO, Sílvia. “A paixão segundo Roland Barthes”. Caderno 2, sábado, 05 de março de 1988, p. 3.

Nota "Novos livros no mercado" (lançamentos e promoções de livros). Caderno 2, "Visuais", terçafeira, 15 de março de 1988, p. 8.

MEDEIROS, Jotabê. "Por que você caiu fora?" Caderno 2, quinta-feira, 24 de março de 1988, p. 1.

MEDEIROS, Charles Magno. "A paixão segundo Barthes”. Caderno 2, "Crítica”, terça-feira, 29 de março de 1988, p. 7.

JOSEF, Bella. "Anaconda, a espiritualização do mundo animal”. Cultura, sábado, 16 de abril de 1988, p.8.

AZEVEDO Filho, Leodegário A. "A lírica de Camões e a crítica genética". Cultura, sábado, 4 de junho de 1988, p. 5.

QUEIROZ, Maria José de. "O itinerário de Roland Barthes". Resenha de O rumor da língua. Cultura, sábado, 18 de junho de 1988, p. 10.

"Leia de junho está nas bancas". Caderno 2, terça-feira, 21 de junho de 1988, p. 4.

MOTTA, Carlos. "Os curtas que fazem inveja a muito longa". Caderno 2, quinta-feira, 23 de junho de 1988, p. 10.

MORETTO, Fúlvia L. "Jean-Paul Sartre, a história em processo". Cultura, sábado, 16 de julho de 1988, p. 10.

GIRON, Luís Antônio. “Autor das Mitologias cai na teia do mito”. Caderno 2, domingo, 17 de julho de 1988, p. 4.

BONAS, Ariovaldo. "Júnior Gomes é gente nossa”. Primeiro Caderno, "Espaço Aberto", terça-feira, 30 de agosto de 1988, p. 2.

BARROS, Jefferson. "Xuxa, a deusa da infertilidade". Caderno 2, "Televisão", domingo, 18 de setembro de 1988, p. 5.

ESCOBAR, Pepe. "Perfil: vida e obra de um erudito e sua vasta personalidade". Caderno 2, "Leitura", sábado, $1^{\circ}$ de outubro de 1988, p. 4.

DOURADO, Autran. “A nova teoria literária francesa”. Cultura, sábado, 8 de outubro de 1988, p. 4.

CARDOSO, Zélia de Almeida. "A Saga do cavalo indomado. Romance para se degustar vagarosamente". Cultura, sábado, 19 de novembro de 1988, p. 9.

MENEZES, Philadelpho. "A poética do som que vem da voz" (entrevista com Paul Zumthor). Caderno 2, "Leitura", sábado, 19 de novembro de 1988, p. 6.

“ 'Mitologia', no Madame Satã”. Caderno 2, "Clipe”, quarta-feira, 30 de novembro de 1988, p. 2.

FERREIRA, Jairo. "Uma semana paulista na tela do MIS". Caderno 2, "Festival", terça-feira, 6 de dezembro de 1988 , p. 3.

GALVÃO, João Candido. "Prazer e emoção da cor, na obra de Tuneu". Caderno 2, "Pintura/crítica", quarta-feira, 7 de dezembro de 1988, p. 3. 
1989

MILLIET, Maria Alice. “A migração dos signos nas artes”. Cultura, sábado, 7 de janeiro de 1989, pp. 4-5.

TRIGO, Luciano. "As palavras que coincidem com as imagens". Caderno 2, "Crítica”, sábado, 11 de fevereiro de 1989, p. 4.

MOTTA, Leda Tenório da. "Silviano, ou o crítico como leitor". Resenha de Nas malhas da Letra. Caderno 2, sábado, 18 de fevereiro de 1989, p. 5.

LAPOUGE, Gilles. "As entrevistas do Le Monde". Caderno 2, "Leitura", sábado, 4 de março de 1989, pp. 6-7.

DUARTE, Júlio Carlos. "Kristeva”. Caderno 2, sábado, $1^{\circ}$ de abril de 1989, p. 7.

FORTUNA, Felipe. "A paisagem corporal, o erotismo na poesia de João Cabral de Melo Neto". Cultura, sábado, 19 de agosto de 1989, p. 4.

SANTOS, Lidia. "A história de um desejo". Cultura, sábado, 4 de novembro de 1989, p. 5.

SCARANO, Julita. "As relações de amor no Brasil”. Cultura, sábado, 25 de novembro de 1989, p. 9.

MERTEN, Luiz Carlos. Filmes na TV. Caderno 2, "Guia”, sábado, 25 de novembro de 1989, p. 6.

1990

COELHO, Teixeira. "A palavra pecadora e suas flores do mal". Caderno 2, quarta-feira, 10 de janeiro de 1990, p. 1.

FISCHER, Almeida. "Quatro estudos literários”. Cultura, sábado, 3 de fevereiro de 1990, p. 9.

COELHO, Teixeira. "Almodóvar e Luna, sem adjetivos". Caderno 2, quarta-feira, 7 de fevereiro de 1990, p. 3.

ESCOBAR, Pepe. "Uma cidade onde tudo pode acontecer". Caderno 2, domingo, 4 de março de 1990, p. 4.

COSTA, Cristina. “Os mistérios da amizade”. Cultura, sábado, 17 de março de 1990, p. 11.

SALIBA, Elias Thomé. "Crônica da Revolução Francesa". Cultura, sábado, 24 de março de 1990, pp.6-7.

LAPOUGE, Gilles. "Imagens de uma vida". Cultura, sábado, 21 de abril de 1990, p. 3.

FREIRE, Norma. "Caem as mil máscarasa de Foucault.". Caderno 2, "Leitura", quinta-feira, 7 de junho de 1990, p. 4.

GARCIA, Marco Aurélio. "E esquerda e a marcha do Leste para o Ocidente". Caderno 2, domingo, 26 de agosto de 1990, p. 6.

FABRIS, Mariarosaria. “A quem pertencem as palavras?” Cultura, sábado, $1^{\circ}$ de setembro de 1990, pp. 1-2.

COELHO, Teixeira. "Três cenógrafos do drama da significação". Caderno 2, "Semiologia/ França", quinta-feira, 13 de setembro de 1990, p. 5.

MORAES, Eliane Robert. "A radicalidade do herói de Sade". Cultura, sábado, 29 de setembro de 1990, pp. 6-7.

"Mais Fragmentos de Fagundes”. Caderno 2, “O que há", quarta-feira, 24 de outubro de 1990, p. 3.

LAPOUGE, Gilles. "Louis Althusser, a morte com as ideologias". Cultura, sábado, $1^{\circ}$ de dezembro de 1990, p. 4.

\section{1}

“Municipal quer lotar em janeiro". Caderno 2, "Coluna 2", terça-feira, 1 de janeiro de 1991, p. 2.

MERQUIOR, José Guilherme. "Estruturalismo é obra de acadêmicos petulantes". Caderno 2, "Tradução/ Inédito", quinta-feira, 10 de janeiro de 1991, p. 4.

"Tem teatro no Municipal". SP-Grande Bandeirantes, "Do bom e do melhor", quinta-feira, 10 de janeiro de 1991, p. 5. 
RÉGIS, Sônia. "Direitos da linguagem criativa”. Cultura, sábado, 6 de abril de 1991, p. 3.

ESCOBAR, Pepe. "No final do milênio Deus fez Vanessa Paradis". Caderno 2, domingo, 21 de abril de 1991, p. 4.

. "Miss Sontag, uma leitora muito particular". Caderno 2, terça-feira, 23 de abril de 1991, p. 1.

PIMENTA, Ângela. "Um mestre da imagem quer cristalizar o tempo" (entrevista com Lucien Clergue). Caderno 2, "Fotografia/ Workshop", sexta-feira, 3 de maio de 1991, p. 20.

ALMEIDA, Orlando de. "Fronteira - a arte de um hotel muito exclusivo". Suplemento de Turismo, terça-feira, 4 de junho de 1991, p. 12.

GUERREIRO, Regina. “Georges Henri”. Caderno 2, sábado, 22 de junho de 1991, p. 2.

FRANCIS, Paulo. "As glórias de Edmund Wilson". Caderno 2, "Diário da corte", domingo, 7 de julho de 1991, p. 14.

SODRÉ, Muniz. "Choque heterodoxo no coloquial”. Cultura, "Língua”, sábado, 2 de novembro de 1991, p. 2.

RIBEIRO, Renato Janine. "Visão míope da filosofia francesa". Cultura, sábado, 2 de novembro de 1991, p. 3.

GÓES, Marta. "Grupo Tapa faz discurso machista da Megera". Caderno 2, sábado, 30 de novembro de 1991, p. 1.

1992

FRANCIS, Paulo. "Nova York por aí". Caderno 2, "Diário da Corte”, domingo, 8 de março de 1992, p. 10.

LAPOUGE, Gilles. "Convite a Gorbachev é polêmico". Internacional, sexta-feira, 27 de março de 1992, p. 11.

NOLASCO, Sônia. "Gênio malcriado volta a dançar nos EUA”. Caderno 2, sexta-feira, 14 de abril de 1992, p. 1.

PERRONE-MOISÉS, Leyla. "Marcel Proust. A continuidade do tempo existe no espaço ilimitado do livro". Cultura, sábado, 25 de julho de 1992, p. 1.

NOLASCO, Sônia. "Sontag troca erudição por história de amor". Caderno 2, sexta-feira, 21 de agosto de 1992, p. 14.

ORICCHIO, Luiz Zanin. "Veríssimo lança nova coletânea de crônicas". Caderno 2, "Livro/ Lançamento" sexta-feira, 11 de setembro de 1992, p. 14.

\section{3}

FRANCIS, Paulo. “Cândido"Caderno 2, "Diário da Corte”, quinta-feira, 11 de março de 1993, p. 8

PERRONE-MOISÉS, Leyla. "Barthes foi atropelado pela pós-modernidade”. Cultura, sábado, 10 de abril de 1993, p. 1.

"Morre o escritor cubano Severo Sarduy". Caderno 2, “Autor”, sábado, 12 de junho de 1993, p. 3.

GRAIEB, Carlos. "Convidado estrangeiro fecha a série". Cultura, sábado, 26 de junho de 1993, p. 4.

MEDEIROS, Sérgio. "Lévi-Strauss volta com mito e história". Caderno 2, "Livros", quarta-feira, 18 de agosto de 1993, p. 10.

Lista de livros mais vendidos: Roland Barthes, de Calvet. Cultura, sábado 25 de setembro de 1993, p. Q2.

FRANCIS, Paulo. "O desprezado Freud". Caderno 2, "Diário da Corte", quinta-feira, 11 de novembro de 1993, p. D14. 
1994

"Historiador revisa estruturalismo". Caderno 2, "Livros", domingo, 9 de janeiro de 1994, p. D8.

SANTOS, Hamílton dos. "Brasil é tema de mais um romance escrito por estrangeiro". Caderno 2, terça-feira, 15 de fevereiro de 1994, p. D2.

MUSSE, Ricardo. "Debate põe filosofia uspiana na berlinda”. Cultura, sábado, 12 de março de 1994, p. Q2.

MOCARZEL, Evaldo. “ "Pentesiléias' encena o drama dos bastidores”. Caderno 2, "Teatro”, quintafeira, 24 de março de 1994, p. D2.

ROUANET, Sérgio Paulo. "Memória de família resgata história do país”. Cultura, sábado, 9 de abril de 1994, p. Q1.

ORICCHIO, Luiz Zanin. “Artepensamento combate cultura da pressa”. Cultura, sábado, 16 de abril de 1994, p. Q2.

GIOBBI, Cesar. "Pão e circo". Caderno 2, "Persona", sábado, 4 de junho de 1994, p. D6.

FRANCIS, Paulo. "Memento". Caderno 2, "Diário da Corte", domingo, 7 de agosto de 1994, p. D12.

. “A razão por quê". Caderno 2, "Diário da Corte”, domingo, 21 de agosto de 1992, p. D12.

MEDEIROS, Jotabê. “' 'K.' combate o fascismo da linguagem”. Caderno 2, "Guia”, terça-feira, 25 de outubro de 1994, p. D5.

FRANCIS, Paulo. Caderno 2, "Diário da Corte”, quinta-feira, 22 de dezembro de 1994, p. D3.

\section{5}

Citação atribuída a Barthes como mote da seção: "Toda imagem é uma narrativa". Caderno 2, "Imagens", segunda-feira, 20 de fevereirode 1995, p. D8.

PASTA Jr., José Antônio. “Um teatro ao mesmo tempo presente e inacessível”. Cultura, sábado, 25 de fevereiro de 1995, p. Q2.

PEIXOTO, Fernanda. "Febvre discute Michelet e a Renascença". Cultura, sábado, $1^{\circ}$ de abril de 1995, p. Q2.

GRAIEB, Carlos. "Mostra vai revelar Barthes pintor”. Caderno 2, terça-feira, 23 de maio de 1995, p. D1.

. "Crítico queria ter escrito romance". Caderno 2, terça-feira, 23 de maio de 1995, p. D1.

ALVES, Rubem. "Sobre os professores e as cozinheiras". Caderno 2, domingo, 11 de junho de 1995, p. D2.

SILVA, Edmilson. "Exposição revela outra face de Roland Barthes". Caderno 2, quinta-feira, 3 de agosto de 1995, p. D5.

Sugestão de leitura de $O$ Grão da voz, de Barthes. Caderno 2, "Bienal do Livro" sexta-feira, 18 de agosto de 1995, p. D5.

OLIVEIRA, Felipe. "Fundação Gilberto Freyre está sem recursos e com as portas fechadas". Caderno 2, sexta-feira, $1^{\circ}$ de setembro de 1995, p. D7.

COELHO, Teixeira. "Pignataria aceita risco de pensar o presente". Caderno 2, "Livros", domingo, 8 de outubro de 1995, p. D13.

MORETZSOHN, Virgílio. "Filósofos norte-americanos explicam obra de Foucault". Caderno 2 Especial Domingo, 14 de novembro de 1995, p. D14.

BETING, Joelmir. Citação atribuída a Barthes como mote: "Profissional nota 10 é aquele que acrescenta 2 pontos de esforço, 3 pontos de talento e 5 pontos de caráter". Economia, quartafeira, 29 de novembro de 1995, B2.

"Noites quer desmistificar elitismo da dança". Seu Bairro, terça-feira, 5 de dezembro de 1995, p. Z1. MARQUES, Fernando. "Versões começaram quase como brincadeira". Caderno 2, sexta-feira, 29 de dezembro de 1995, p. D9. 
BRUNET, Claire, TIBERGHIEN, Gilles. "Autora critia a ortodoxia do modernismo" (entrevista com Rosalind Kraus). Caderno 2, sábado, 30 de dezembro de 1995, p. D8.

\section{6}

GONÇALVES Filho, Antonio. "Bienal abre sala pra Cy Twombly". Caderno 2, "Visuais", quintafeira, 8 de fevereiro de 1995, p. D3.

BOIS, Yve-Alain. "Carlos Zilio entre a ambição e a modéstia". Caderno 2, sábado, 6 de abril de 1996, p. D9.

MURICY, Kátia. "Biógrafo de Foucault revisita o filósofo". Caderno 2 Especial Domingo, 7 de abril de 1996, p. D14.

REALI Jr. "Proteção na área cultura evita monopólios" (entrevista com Jean Galard). Caderno 2, domingo, 21 de abril de 1996, p. D6.

LAJOLO, Marisa. "Meserani faz paródia dos contos de fadas". Caderno 2 Especial Domingo, 5 de maio de 1996, p. D10.

VALLE, Marina Della. "Mulheres apresentam 14 coreografias". Caderno 2, "Dança", 15 de maio de 1996, p. D8.

LEIRNER, Sheila. "Cartier-Bresson capta eternidade num instante”. Caderno 2, sábado, 15 de junho de 1996, p. D1.

SADER, Emir. "Obra é o melhor compêndio sobre ideologia". Caderno 2, "Livros", domingo, 14 de julho de 1996, p. D11.

MEDEIROS, Benício. “Os Samurais propõe confronto de ideias”. Caderno 2/ Cultura, sábado, 24 de agosto de 1996, p. D9.

"Vito Taufer pesquisa a linguagem". Caderno 2, "Artes cênicas", quarta-feira, 14 de agosto de 1996, p. D8.

RIBEIRO NETO, Amador. "Foucault pensa as leis do discurso". Caderno 2 Especial Domingo, 8 de setembro de 1996, p. D13.

MOCARZEL, Evaldo. " 'O vampiro é a sedução em todos os níveis' " (entrevista com Antunes Filho). Caderno 2, "Personalidade”, sábado, 14 de setembro, pp. D4-D5.

MARTÍNEZ, Tomás Eloi. "Ficção e história: apostas contra o futuro". Cultura, sábado, 5 de outubro de 1995, p. D10.

\section{7}

FRANCIS, Paulo. “As regras do jogo". Caderno 2, "Diário da Corte”, quinta-feira, 6 de feveiro de 1997, p. D7.

ORICCHIO, Luiz Zanin. "Cinema do escritor segue pressupostos da literatura". Caderno 2, "Personalidade", sábado, 22 de fevereiro de 1997, p. D5.

SCLIAR, Moacir. "Uma conversa sobre letras e influências" (entrevista com Alan Pauls). Caderno 2, "Literatura", sábado, $1^{\circ}$ de março de 1997, p. D7.

VELlOSO, Beatriz. "Peça As Tias vai ser programa de TV". Caderno 2, "Teatro", quarta-feira, 12 de março de 1997, p. D2.

CASTELLO, José. "Jacques-Alain Miller divulga Lacan no país" (entrevista com Jacques-Alain Miller). Caderno 2, "Psicanálise", sábado, 26 de abril de 1997, p. D9.

AUGUSTO, Sérgio. "Tiros pela culatra no QG da cultura”. Caderno 2/ Cultura, sábado, 7 de junho de 1997, p. D3.

. “Cenas pós-modernas numa visão argentina". Caderno 2, "Cultura", 24 de julho de 1997, p. D2.

CASTELLO, José. "Casares sonha acordado (ilegível) páginas por dia” (entrevista com Bioy Casares). Caderno 2, sábado, 26 de julho de 1997, pp. D8-D9. 
MIRANDA, Ana. "Uma aristocracia da sensibilidade”. Caderno 2, domingo, 27 de julho de 1997, p. D2.

KATZ, Helena. "Espetáculo de Gerald Thomas é auto-referente". Caderno 2, "Dança", segundafeira, 18 de agosto de 1997, p. D2.

MEDEIROS, Jotabê.'“Obras permitem diálogo sobre tema da forma”.Caderno 2, quarta-feira, 20 de agosto de 1997, p. D1.

LIMA, Mariangela Alves de. "Simplicidade dita ritmo e movimento de Marcos Breda". Caderno 2, "Fim de Semana", sexta-feira, 29 de agosto de 1997, p. D19.

AUGUSTO, Sérgio. "De como a fofoca salvou a espécie humana". Caderno 2, "Comportamento", sábado, 30 de agosto de 1997, p. D3.

LLOSA, Mario Vargas. “A hora dos charlatães”. Espaço Aberto, domingo, 31 de agosto de 1997, p. A2.

CASTELLO, José. "Luis Gusmán contrapõe-se à moda literária” (entrevista com Luis Gusmán). Caderno 2, "Literatura Argentina", sábado, 13 de setembro de 1997, p. D23.

. "Manoel de Barros faz do absurdo sensatez". Caderno 2, sábado, 18 de outubro de 1997, p. D1.

SHIRTS, Matthew. "Como explicar os carecas?". Cidades, "Crônica”, quarta-feira, 17 de dezembro de 1997, p. C2.

1998

Anônimo. "Prova de Língua Portuguesa da FUVEST - correção feita pelos professores do Objetivo no primeiro exame da segunda fase". Primeiro Caderno, "Vestibular", terça-feira, 6 de janeiro de 1998, p. A9.

ZERO, Katia. "A nova cara do comércio". Caderno 2, quinta-feira, 19 de fevereiro de 1998, p. D1.

KUJAWSKI, Guilherme. "Grammatron". Zap!, sexta-feira, 13 de março de 1998, p. G2.

SALEM, Helena. "Biografia revela toda a sensibilidade de Truffaut". Caderno 2, quinta-feira, 9 de abril de 1998, p. D9.

CASTELLO, José. "Lygia Fagundes guarda grãos de loucura e de mistério". Caderno 2, "Personalidade", sábado, 6 de junho de 1998, p. D3.

ITIBERÊ, Suzana Uchôa. "Ana Maria Machado remenda os anseios dos adultos". Caderno 2, "Personalidade", sábado, 27 de junho de 1998, D3.

PERSICHETTI, Simonetta. "Sara Facio expõe as faces da literatura latino-americana" (entrevista com Sara Facio). Caderno 2, quinta-feira, 6 de agosto de 1998, p. D3.

ORICCHIO, Luiz Zanin. "Dinheiro queimado retrata tragédia à argentina”. Caderno 2, sábado, 22 de agosto de 1998, p. D9.

ARAÚJO, Ricardo. "Estudo revela projeto inacabado de Graciliano Ramos". Caderno 2, domingo, 30 de agosto de 1998, p. D4.

ESCOBAR, Pepe. “O liquidificador do século 21”Caderno 2, sábado, 19 de setembro de 1998, p. D18.

GAMA, Júlio. “ 'Teatro parece um grão de areia perto da TV' ”. Caderno 2, terça-feira, 29 de setembro de 1998, p. D1.

BETING, Joelmir. Citação atribuída a Barthes como mote: "Não é que os políticos não vejam a solução. O que eles não enxergam é o problema." Economia, domingo, $1^{\circ}$ de novembro de 1998, p. B2.

SALEM, Helena. "Carvalho 'volta para casa' com Lavoura Arcaica" (entrevista com Luiz Fernando Carvalho). Caderno 2, segunda-feira, 23 de novembro de 1998, pp. D6-D7. 
1999

MAGANO, Octavio Bueno. "O Direito do trabalho e o terceiro milênio". Economia, quinta-feira, 7 de janeiro de 1999, p. B2.

MERTEN, Luís Carlos. “'Contos de Lygia' expõe universo da dama da literatura”. Caderno 2/ Fim de Semana, sexta-feira, 12 de fevereiro de 1999, p. D12.

COURI, Norma. "Jurandir Freire Costa aposta na cura do ser humano". Caderno 2/ Cultura, domingo, 28 de fevereiro de 1999, p. D7.

GIOBBI, Cesar. "Um cult entre estrelas". Caderno 2, "Persona", sábado, 27 de março de 1999, p. D9.

MARQUES, Luiz. "Historiador é o último herdeiro de Voltaire”. Caderno 2/ Cultura, domingo, 7 de março de 1999, p. D9.

DEBRAY, Régis. "Hipnotizada, Europa compartilha mito dos EUA". Internacional, "Europa", segunda-feira, 12 de abril de 1999, p. A10.

LLOSA, Mario Vargas. "Jorge Luis Borges, o grande personagem borgiano". Caderno 2, "Personalidade", sábado, 19 de junho de 1999, p. D20.

Anônimo. Citação de Barthes como cabeçalho ou frase inspiradora do dia: "Profissional de talento é aquele que soma 2 pontos de esforço, 3 pontos de talento e 5 pontos de caráter". Roland Barthes (1915-1980), sociólogo francês. Economia, domingo, 25 de julho de 1999, p. B2.

BUENO, Wilson. "Marquês de Sade é autor de uma poética do gozo". Caderno 2, "Literatura", sábado, 10 de julho de 1999, p. D6.

GUTERMAN, Débora. "Bonisson recria a imagem poética". Caderno 2, "Fotografia", quinta-feira, 30 de setembro de 1999, p. D6.

SCHNEIDER, Michel. "O Pintor de paixões". Caderno 2/ Cultura, domingo, 19 de setembro de 1999, p. D5.

CARNEIRO NETO, Dib. "Ana Maria Machado: mas que festa!" Caderno 2, "Bolo e refrigerante", sábado, 23 de outubro de 1999, p. D11.

Anônimo. "Lançamentos no Brasil/ O Sabor da vida, de Gilberto de Mello Kujawsky". Caderno 2/ Cultura, domingo, 28 de novembro de 1999, p. D3.

\section{0}

LAPOUGE, Gilles. "Romarias ao socialismo hoje soam ridículas". Internacional, "Guerra Fria", domingo, 23 de janeiro de 2000, p. A23.

Lançamento de Sentido e contra-senso, de Kristeva. Caderno 2/ Cultura, "Lançamentos No Brasil", domingo, 13 de fevereiro de 2000, p. D2.

Lançamento de Miúdos metafísicos, de Arthur Dapieve. Caderno 2/ Cultura, "Lançamentos No Brasil", domingo, 19 de março de 2000, p. D3.

BRASIL, Ubiratan. "Baudrillard nega existência do mundo real". Caderno 2, "Filosofia", segundafeira, 3 de abril de 2000, p. D6.

MATTOS, Carlos Alberto. "Retrato do artista múltiplo". Caderno 2, "Personalidade", sábado, 6 de maio de 2000, p. D2.

Lançamento de Fifty Key Contemporary Thinkers, de John Lechte. Caderno 2/ Cultura, "Lançamentos No Mundo", domingo, 11 de junho de 2000, p. D3.

LAPOUGE, Gilles. "A prosa inquietante de um general obstinado". Caderno 2/ Cultura, "A política como arte da palavra", domingo, 11 de junho de 2000, p. D7.

CASO, Fabiana. "A encantadora de crianças". Feminino, "Perfil”, sábado, 15 de julho de 2000, p. F4.

ORICCHIO, Luiz Zanin. "Nietzsche, o saber com sabor e a 'Mostra do Redescobrimento' ". Caderno 2, "Crônica", quinta-feira, 17 de agosto de 2000, p. D4. 
“A Escritura Inquieta”, de Neiva Pitta Kadota. Breve apresentação do livro. Caderno 2 /Cultura, "Lançamentos No Brasil", domingo, 10 de setembro de 2000, p. D7.

LOMBARDI, Andrea. "Furio Monicelli revela o escândalo da hipocrisia". Caderno 2, "Livros", sábado, 30 de setembro de 2000, p. D6.

SHÖPKE, Regina. "O livro em que Barthes redefiniu a literatura”. Caderno $2 /$ Cultura, domingo, $1^{\circ}$ de outubro de 2000, p. D3.

. "Originalidade marcou seu trajeto intelectual". Caderno $2 /$ Cultura, domingo, $1^{\circ}$ de outubro de 2000, p. D3.

RODRIGUES, Antonio Medina. "Ele buscava a impressão provocada pela palavra". Caderno 2/ Cultura, $1^{\circ}$ de outubro de 2000 , p. D3.

BUENO, Wilson. "Anotações críticas e poéticas de Felipe Fortuna". Caderno 2, "Livros”, sábado, 4 de novembro de 2000, p. D6.

CASTELLO, José. "Inútil poesia", "Onda do politicamente correto empobrece as letras", "Sob o signo de Barthes, ensaísta pratica a contundência do texto". Caderno 2/ Cultura, domingo, 19 de novembro de 2000, capa e pp. D4 e D5.

MEDEIROS, Jotabê. "Amélie, a menina levada da literatura francesa". Caderno 2/ Cultura, domingo, 31 de dezembro de 2000, p. D7.

\section{1}

PIZA, Daniel. "Das cordas do teu violão". Caderno 2/ Cultura, "Sinopse", domingo, 21 de janeiro de 2001, p. D3.

CAETANO, Maria do Rosário. "MPB embala festa do $2^{\circ}$ Grande Prêmio Brasil". Caderno 2, "Cinema Brasileiro", segunda-feira, 12 de fevereiro de 2001, p. D12.

LAPOUGE, Gilles. "Livro escrito em 75 agora constrange Cohn-Bendit”. Internacional, sexta-feira, 23 de fevereiro de 2001, p. A 12.

AMÂNCIO, Moacir. "A busca do sentido de todas as línguas". Caderno 2/ Cultura, domingo, 2 de março de 2001, p. D5.

SHIRTS, Matthew. "Como dublar um americano". Caderno 2, "Crônica", segunda-feira, 9 de abril de 2001, p. D4.

SILVA, Beatriz Coelho. "Ana Carolina não teme o estigma do segundo disco". Caderno 2, "Música", 24 de abril de 2001, p. D7.

DUNDER, Karla. "Fragmentos coreografados do discurso amoroso". Caderno 2, terça-feira, 12 de junho de 2001, p. D12.

SEREZA, Haroldo Cevarolo. "Conferências discutem influência das teorias francesas na América". Caderno 2/ Cultura, domingo, 5 de agosto de 2001, p. D11.

Nota sobre a peça Enamorados. Caderno 2/ Cultura, "Guia", domingo, 12 de agosto de 2001, p. D13.

LAPOUGE, Gilles. "Romance de Houellebecq irrita os muçulmanos". Caderno 2, "Literatura", sábado, 15 de setembro de 2001, p. D3.

SALIBA, Elias Thomé. "Grupo rejeitava literatura pitoresca". Caderno 2/ Cultura, "História da Cultura", domingo, 14 de outubro de 2001, p. D7.

LEIRNER, Sheila. "A discreta exposição de dois brasileiros em Paris". Caderno 2, "Visuais", sábado, 27 de outubro de 2001, p. D8.

TRIGO, Luiz Gonzaga Godoi. "Livro analisa aspecto sociológico do turismo". Viagem, terça-feira, 25 de dezembro de 2001, p. V2. 
2002

NOGUEIRA, Armando. "Futebol é coisa séria". Esportes, "Na Grande Área", domingo, 6 de janeiro de 2002, p. E2.

MERTEN, Luís Carlos. "Techiné inédito promete emoções”. Caderno 2, "Filmes”, sexta-feira, $1^{\circ}$ de fevereiro de 2002, p. D10.

NÉSPOLI, Beth. "No palco, fragmentos de um triângulo amoroso". Caderno 2, "Teatro", sextafeira, $1^{\circ}$ de março de 2002 , p. D6.

LAPOUGE, Gilles. "O estilo invisível de Roger Martin du Gard”. Caderno 2/ Cultura, "Literatura”, domingo, 3 de março de 2002, p. D1.

MEDEIROS, Jotabê. "Lulu Santos e sua cápsula do tempo musical". Caderno 2, "Música", sextafeira, 17 de maio de 2002, p. D9.

BRASIL, Ubiratan. "O humanismo de Brecht na era da globalização”. Caderno 2/ Cultura, domingo, 2 de junho de 2002, p. D1.

SEREZA, Haroldo Cevarolo." 'A prova não é uma ilusão positivista', diz Ginzburg”. Caderno 2/Cultura, "História", domingo, 22 de setembro de 2002, p. D6.

PIZA, Daniel. "A vingança dos fatos". Caderno 2/ Cultura, "Sinopse", domingo, 10 de novembro de 2002, p. D3.

LAPOUGE, Gilles. "França reabilita Alexandre Dumas". Caderno 2, "Literatura", quinta-feira, 28 de novembro de 2002, p. D10.

\section{3}

MEDEIROS, Jotabê. "Fragmentos de um discurso rigoroso". Caderno 2, "Política Cultural", sábado, 4 de janeiro de 2003, p. D3.

ORICCHIO, Luiz Zanin. "Saudades de Barthes e reabertura do 'caso' Céline". Caderno 2/Cultura, "Revista das revistas", domingo, 5 de janeiro de 2003, p. D4.

LAPOUGE, Gilles. "O melhor Barthes ficou fora da sala de aula”. Caderno 2/Cultura, domingo, 2 de fevereiro de 2003, p. D1.

LEIRNER, Sheila. "Barthes, presente numa rede de imagens". Caderno 2/ Cultura, domingo, 2 de fevereiro de 2003, p. D7.

SEREZA, Haroldo Ceravolo. "Fragmentos inicia em maio 'minicoleção' do autor". Caderno 2/ Cultura, domingo, 2 de fevereiro de 2003, p. D7.

SABÓIA, Napoleão. “Cidadania global”. Caderno 2/Cultura, domingo, 23 de fevereiro de 2003, pp. D1 e D7.

. "O ser humano sempre começa do zero". Caderno 2/Cultura, domingo, 23 de fevereiro de 2003, p. D7.

"Morre o crítico Maurice Blanchot". Caderno 2, "Breves", terça-feira, 25 de fevereiro de 2003, p. D2.

PIZA, Daniel. "Noturnos". Caderno 2/ Cultura, "Sinopse", domingo, 23 de março de 2003, p. D3.

SEREZA, Haroldo Ceravolo. "A estranha luta de Roland Barthes". Caderno 2/Cultura, "Ideias", domingo, 23 de março de 2003, p. D4.

KIMMELMAN, Michael. "O Mistério de Lucian Freud". Caderno 2/ Cultura, "Visuais", domingo, 6 de abril de 2003, p. D14.

"Roland Barthes por Roland Barthes". Caderno 2/ Cultura, "Lançamentos", domingo, 29 de junho de 2003, p. D3.

BRASIL, Ubiratan. "Vida Furtiva de Genet desafia seu biógrafo". Caderno 2/ Cultura, domingo, 20 de julho de 2003, p. D1.

DUNDER, Karla. "Agora em cores, os clássicos de Ana e Ruth". Caderno 2, "Livros", quinta-feira, 24 de julho de 2003, p. D3. 
SALIBA, Elias Thomé. "Bakhtin, o filósofo do riso e das inquietações". Caderno 2/ Cultura, "Teoria literária”, domingo, 27 de julho de 2003, p. D4.

ORICCHIO, Luiz Zanin. "Morre Guido Crepax, o criador de Valentina". Caderno 2, "Memória", sexta-feira, $1^{\circ}$ de agosto de 2003 , p. D12.

MERTEN, Luiz Carlos. "A Arte de duas grandes francesas". Caderno 2, "Filmes", sábado, 9 de agosto de 2003, p. D8.

LAPOUGE, Gilles. "Mitologias de Lévi-Strauss". Caderno 2/Cultura, domingo, 19 de outubro de 2003, p. D1.

SEREZA, Haroldo Cevarolo. "Leitura". Caderno 2/ Guia, "Para ficar em casa", de 24 a 30 de outubro de 2003, p. 24.

SALIBA, Elias Thomé. "Peripécias da família Agulha". Caderno 2/ Cultura, domingo, 2 de novembro de 2003, p. D14.

DIAS, Mauro. "Muniz Sodré: cultura, filosofia, antropologia". Caderno 2, sexta-feira, 28 de novembro de 2003, p. D9.

\section{4}

ORICCHIO, Luiz Zanin. "George Steiner, um administrador de impasses". Caderno 2/Cultura, domingo, 4 de janeiro de 2004, p. D4.

“La Préparation du Roman I et II". Caderno 2/Cultura, "Lançamentos", domingo, 11 de janeiro de 2004, p. D3.

LAPOUGE, Gilles. "Franceses acusam governo de descaso". Caderno 2, "Polêmica", terça-feira, 24 de fevereiro de 2004, p. D2.

"El Sistema de la Moda". Caderno 2/Cultura, "Lançamentos", domingo, 7 de março de 2004, p. D3.

GUEDES, Paulo Antônio. Carta enviada ao jornal sobre questões de patrimônio histórico de São Paulo. Cidades, "São Paulo Reclama", domingo, 14 de março de 2004, p. C2.

“La Torre Eiffel”. Caderno 2/Cultura, "Lançamentos", domingo, 4 de abril de 2004, p. D3.

GONÇALVES Filho, Antônio. "As memórias de um fantasma chamado Céline”. Caderno 2, "Literatura Francesa", domingo, $1^{\circ}$ de agosto de 2004, p. D5.

LEIRNER, Sheila. "Sempre no lugar certo e no momento exato". Caderno 2, quinta-feira, 5 de agosto de 2004, p. A18.

GONÇALVES Filho, Antônio. "A revolução permanente da linguagem”. Caderno 2/Cultura, domingo, 19 de setembro de 2004, p. D6.

BRASIL, Ubiratan. "O editor brasileiro" (nota sobre a morte de Derrida). Caderno 2, "Memória", segunda-feira, 11 de outubro de 2004, p. D5.

GONÇALVES Filho, Antônio. "Dois autores sob o signo de Saturno". Caderno 2/ Cultura, domingo, 24 de outubro de 2004, p. D1.

FONTES, Cida. "Luizianne vence e quer mudar eixo do PT para Nordeste". Nacional, segundafeira, $1^{\circ}$ de novembro de 2004 , p. A17.

\section{5}

MEDEIROS, Jotabê. "O adeus a Sontag, sem unanimidade". Caderno 2, "Personalidade

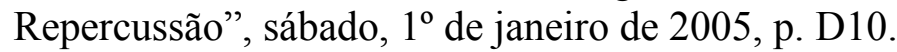

NESPOLI, Beth. "Décio de Almeida Prado, mito da crítica". Caderno 2/ Cultura, "Livros Teatro", domingo, 16 de janeiro de 2005, p. D4.

GONÇALVES Filho, Antônio. "O olhar estrangeiro de Susan Sontag”. Caderno 2, sábado, 19 de março de 2005, p. D1.

. "Susan em sintonia com o mundo". Caderno 2, sábado, 19 de março de 2005, p. D3. 
WILLIAMS, Hywel (The Guardian). "Paris, cidade dos mortos". Caderno 2/ Cultura, "Filosofia Ensaio", domingo, 20 de março de 2005, p. D6.

ORICCHIO, Luiz Zanin. "Depardieu, Santo Agostinho e o papa". Caderno 2/ Cultura, domingo, 10 de abril de 2005, p. D6.

\section{6}

"No Mundo. Lançamentos internacionais". Caderno 2/ Cultura, domingo, 15 de janeiro de 2006, p. D5.

ORICCHIO, Luiz Zanin. "Dossiê Roland Barthes no n'.100 da Cult". Caderno 2/ Cultura, "Revista das revistas", domingo, 5 de março de 2006, p. D6.

GIOBBI, Cesar. "Miúdas" (nota sobre debates organizados pela revista Cult acerca da obra de Roland Barthes na Bienal do Livro). Caderno 2, sábado, 11 de março de 2006, p. D4.

PIZA, Daniel. "O ler e o tempo". Caderno 2/ Cultura, domingo, 7 de maio de 2006, p. D3.

VERÍSSIMO, Luís Fernando."Uma França”. Esportes, "Crônica”, quinta-feira, 26 de junho de 2006, p. E3.

"Sai lista da 27a . Bienal de São Paulo". Caderno 2, "Visuais Exposição", sexta-feira, 30 de junho de 2006, p. D11.

“Antologia Pessoal/ Pedro Maciel (escritor)". Caderno 2/ Cultura, domingo, 2 de julho de 2006, p. D14.

MELLO, Chris. "Bienal Top 10”. Caderno 2, quinta-feira, 13 de julho de 2006, p. D9.

MOLINA, Camila. "Seminário discute conceitos da grande mostra". Caderno 2, "Visuais Bienal", terça-feira, 8 de agosto de 2006, p. D3.

MEDEIROS, Jotabê. "Patativa, Chico e os artistas do povo". Caderno 2/ Cultura, "Livros Cultura popular", domingo, 20 de agosto de 2006, p. D4.

"Antologia Pessoal/ Ivam Cabral (ator e dramaturgo). Caderno 2/ Cultura, domingo, 3 de setembro de 2006, p. D14.

HIRSZMAN, Maria. "Como Viver longe: ironia ao tema da grande mostra". Caderno 2, segundafeira, 2 de outubro de 2006, p. D1.

MOLINA, Camila. "Bienal começa hoje, mas no cinema". Caderno 2, "Visuais 27a . Bienal de São Paulo", quarta-feira, 4 de outubro de 2006, p. D7.

GONÇALVES Filho, Antonio. "A Utopia de Barthes". Caderno 2, "Especial 27a. Bienal", sextafeira, 5 de outubro de 2006, p. H5.

. "Hélio Oiticica, de renegado a superastro". Caderno 2, "Especial 27a . Bienal", sexta-feira, 5 de outubro de 2006, p. H5.

MERTEN, Luiz Carlos. "Tudo bem, de cara nova. Como Jabor sempre sonhou”. Caderno 2, "30". Mostra de cinema", sexta-feira, 27 de outubro de 2006, p. D3.

GONÇALVES Filho, Antonio. "Bienal cata restos da civilização e não faz arte". Caderno 2, "Visuais Últimos Dias", sábado, 16 de dezembro de 2006, p. D14.

\section{7}

AUGUSTO, Sérgio. "Máquina de escrever: o prodígio de aço que o computador matou”. Caderno 2, "Literatura Resgate", sábado, 14 de abril de 2007, p. D7.

LAPOUGE, Gilles. "Políticos franceses exibem declínio cultural". Primeiro Caderno, "Internacional", sábado, 21 de abril de 2007, p. A26.

SILVA, Beatriz Coelho da. "Música popular é o tema de estreia de Cultura Brasileira". Caderno 2/ Cultura, "Revista das revistas", domingo, 29 de abril de 2007, p. D6.

SCHWARCS, Lilia Moritz. “A Consciência inquieta do saber”. Caderno 2/ Cultura, domingo, 15 de julho de 2007, p. D7. 
“Antologia pessoal”. Entrevista com Kátia Canton. Caderno 2/ Cultura, domingo, 22 de julho de 2007, p. D14.

GONÇALVES Filho, Antônio. “O Editor que não quer publicar pelo bem da ecologia”. Caderno 2/ Cultura, domingo, 16 de setembro de 2007, pp. D10-D11.

MANTOVANI, Bráulio. "Bráulio Mantovani, roteirista, quer saber: quem são os fascistas?". Caderno 2, sexta-feira, 5 de outubro de 2007, p. D6.

KATZ, Helena. "O Corpo imune aos podres poderes". Caderno 2, "Dança/ Estreia”, sábado, 24 de novembro de 2007, p. D6.

SHIRTS, Mattew. "Uma Expedição tropical". Caderno 2, segunda-feira, 3 de dezembro de 2007, p. D12.

\section{8}

MOTTA, Leda Tenório da. “ 'Natureza feminina' desconstruída”. Caderno 2/ Cultura, domingo, 13 de janeiro de 2008, p. D6.

GONÇALVES Filho, Antonio. "Robbe-Grillet morre na França aos 85 anos". Caderno 2, "Literatura/ Memória", terça-feira, 19 de fevereiro de 2008, p. D3.

NÉSPOLI, Beth. “"Eliminar enigmas mata a sua obra'”. Caderno 2, "Diálogos com Samuel Beckett", terça-feira, 18 de março de 2008, p. D5.

BRASIL, Ubiratan. "A luta pela qualidade da informação". Caderno 2/ Cultura, "Globalização Entrevista", domingo, $1^{\circ}$ de junho de 2008, p. D3.

PIRES, Francisco Quinteiro. "O exigente e atual desafio do amor". Caderno 2, "Comportamento Debates", terça-feira, 17 de junho de 2008, p. D5.

PERSICHETTI, Simonetta. "Equívocos comuns sobre a imagem”. Caderno 2/ Cultura, "Fotografia Ensaios", domingo, 22 de junho de 2008, p. D2.

BOSCO, Francisco. "Um incômodo universo discursivo". Caderno 2/ Cultura, "Livros Ficção", domingo, 13 de julho de 2008, p. D4.

BRASIL, Ubiratan. " "Vivemos de mentiras essenciais"”. Caderno 2, "Literatura Entrevista”, quartafeira, 10 de setembro de 2008, p. D5.

SCHWARCZ, Lilia Moritz. "Obra continua a produzir modelos". Caderno 2/ Cultura, "Claude LéviStrauss 100 anos", domingo, 23 de novembro de 2008, p. D10.

GALVÃO, Walnice Nogueira. “O soldado sociólogo da Missão Francesa no Brasil”. Caderno 2/ Cultura, "Claude Lévi-Strauss 100 anos", domingo, 23 de novembro de 2008, p. D10.

MOTTA, Leda Tenório da. "Intersecções entre sujeito e hisória". Caderno 2/ Cultura, "Claude LéviStrauss 100 anos", domingo, 23 de novembro de 2008, p. D11.

\section{9}

"Racine é um convite para debater a linguagem". Caderno 2/ Cultura, "Lançamentos no Brasil", domingo, 18 de janeiro de 2009, p. D4.

PIZA, Daniel. "Perigos da literatura". Caderno 2/ Cultura, "Sinopse", domingo, $1^{\circ}$ de fevereiro de 2009, p. D3.

COELHO, João Marcos. "Poeta é poeta, letrista é letrista, cada um em seu espaço". Caderno 2/ Cultura, "Música Entrevista", domingo, 15 de fevereiro de 2009, p. D2.

"Antologia pessoal". Entrevista com Francisco Bosco. Caderno 2/ Cultura, domingo, $1^{\circ}$ de março de 2009, p. D12.

AUGUSTO, Sérgio. "As lições de vida e morte dos grandes filósofos". Caderno 2, "Filosofia Artigo", 7 de março de 2009, p. D3

NÉSPOLI, Beth. " 'Quero compartilhar com outros minha vivência' ". Caderno 2, quinta-feira, 2 de abril de 2009, p. D14. 
MOTTA, Leda Tenório da. "A palpitante teatralização da fala". Caderno 2/ Cultura, "Livros Romance", domingo, 3 de maio de 2009, p. D4.

MELLO, Chris. Notinha em que Barthes é citado. Caderno 2, "Em cena", quinta-feira, 21 de maio de 2009, p. D4.

"A moda vista como uma produtora de significados". Caderno 2/ Cultura, "Lançamentos no Brasil", domingo, 5 de julho de 2009, p. D4.

AUGUSTO, Sérgio. "Literatura em 140 caracteres". Aliás, domingo, 19 de julho de 2009, p. J3.

COELHO, João Marcos. "Piano forte". Caderno 2/ Cultura, "Música Personalidade”, domingo, 26 de julho de 2009, p. D8.

AUGUSTO, Sérgio. "No vale-tudo póstumo, caiu na rede, é peixe". Caderno 2, "Literatura Patrimônios", sábado, $1^{\circ}$ de agosto de 2009, p. D7.

RESENDE, Beatriz. "Letra para a melodia da selva". Caderno 2/ Cultura, "Livros Ficção", domingo, 19 de setembro de 2009, p. D5.

GONÇALVES Filho, Antonio. "O teórico contra o corsário da arte". Caderno 2/ Cultura, "Visuais Vanguardas", domingo, 4 de outubro de 2009, p. D2.

MOTTA, Leda Tenório da. "Romance de formação raro e obcecado pela palavra justa". Caderno 2/ Cultura, "Literatura Francesa", domingo, 4 de outubro de 2009, p. D7.

AUGUSTO, Sérgio. "Lévi-Strauss: o que ele gostava de ver na tela". Caderno 2, "Cinema Memória", sábado, 7 de novembro de 2009, p. D8.

LAPOUGE, Gilles. “ 'Sou um homem do neolítico'”. Aliás, domingo, 8 de novembro de 2009, p. J4.

PIZA, Daniel. "Futebol e amor". Esportes, "Boleiros", quarta-feira, 11 de novembro de 2009, p. E4.

PIRES, Francisco Quinteiro. "As marcas de uma vida forjada no calor da hora". Caderno 2/ Cultura, domingo, 13 de dezembro de 2009, p. D6.

GAMA, Rinaldo. "Natal de palavras". Cultura Especial, domingo, 20 de dezembro de 2009, p. H2.

\section{0}

GONÇALVES Filho, Antonio. "A vida dos outros por um olhar cúmplice”. Sabático, "Capa", sábado, 20 de março de 2010, p. S4.

SANTIAGO, Silviano. "Mudando a minha cabeça". Sabático, "Prosa de sábado", sábado, 20 de março de 2010, p. S2.

COELHO, João Marcos. "A paixão encantatória de Mahler". Caderno 2, "Música. Erudito", segunda-feira, 22 de março de 2010, p. D5.

LAPOUGE, Gilles. "Um homem e suas contradições". Sabático, "Capa” sábado, 10 de abril de 2010, p. S4.

FERNANDES Júnior, Rubens. "O que é fotográfico na fotografia?" Sabático, "Ensaio”, sábado, 17 de abril de 2010, p. S8.

GUIMARÃES, Lúcia. “ “Conspirações exóticas são um desserviço histórico' ”. Sabático, sábado, 22 de maio de 2010, p. S3.

NATALI, Marcos. "Amor e ceticismo perante a escrita". Sabático, "Literatura latino-americana", sábado, 22 de maio de 2010, p. S4.

LIMA, Marcelo. "Permanente transformação". Casa, "Antena", 20 a 26 de junho de 2010, pp. 2021.

COELHO, João Marcos. "A dor do mundo recriada em sons". Sabático, "Música”, sábado, 31 de julho de 2010, p. S3.

MUNIZ, Rosana, VIANA, Fausto. "O essencial (não) é invisível aos olhos". Caderno 2, "Moda", domingo, 8 de agosto de 2010, p. D7. 
GONÇALVES, Filho, Antonio. "Pequeno, mas levado a sério”. Sabático, sábado, 28 de agosto de 2010, p. S3.

MOTTA, Leda Tenório da. "Viagem aos limites da linguagem”. Sabático, sábado, 11 de setembro de 2010, p. S7. . "A ideologia por trás dos discursos". Sabático, "Ensaio", 13 de novembro de 2010, p. S8.

NÊUMANNE, José. "Sobre o desafio do dissenso". Sabático, sábado, 4 de dezembro de 2010, p. S7.

\section{1}

SANTIAGO, Silviano. "Doença, culpa e vingança divina". Sabático, sábado, $1^{\circ}$ de janeiro de 2011, S7.

. "Liberdade interior”. Sabático, "Prosa de sábado”, sábado, 22 de janeiro de 2011, p. S2.

MENEZES, Maria Eugênia de. "Andreatto mira novas formas do amor". Caderno 2, "Teatro Estreia", sexta-feira, 4 de fevereiro de 2011, p. D10.

. "Crespos trocam a política pelos afetos". Caderno 2, "Teatro Estreias", quinta-feira, 10 de fevereiro de 2011, p. D10.

GONÇALVES Filho, Antonio. "A filosofia na mira do mercado”. Sabático, “Capa”, sábado, 19 de março de 2011, p. S3.

SALLES, Cecília Almeida. "Mobilidade poética desconcertante". Sabático, sábado, 26 de março de 2011, p. S7.

GONÇALVES Filho, Antonio. “Apóstolos de um mundo sem Deus”. Sabático, "Capa”, sábado, 9 de abril de 2011, p. S4.

SANTIAGO, Silviano. "Mathieu e seus dois pais". Sabático, "Prosa de Sábado", sábado, 30 de abril de 2011, p. S2.

JABOR, Arnaldo. “Obama x Osama”. Caderno 2, terça-feira, 17 de maio de 2011, p. D10.

GUIMARÃES, Lúcia. "No palco, com todas as obras”. Sabático, sábado, 14 de maio de 2011, p. S8.

TELLES, Sérgio. "Um assunto espinhoso". Caderno 2 + música, sábado, 28 de maio de 2011, p. D14.

COZER, Raquel. "Duas vezes Barthes”. Sabático, "Babel”, sábado, 4 de junho de 2011, p. S2.

MOTTA, Leda Tenório da. "Uma descoberta iluminista do país". Sabático, "Babel”, sábado, 4 de junho de 2011, p. S3.

COZER, Raquel. “Ao mestre com carinho". Sabático, "Babel”, sábado, 6 de agosto de 2011, p. S2.

HARDMAN, Francisco Foot. "Um ofício escrito no plural". Sabático, "Literatura Brasileira", sábado, 27 de agosto de 2011, p. S6.

GONÇALVES Filho, Antonio. "A morte ao pé da letra”. Sabático, “Capa”, sábado, 10 de setembro de 2011, p. S4.

AZEVEDO, Carlito. "Em fragmentos, o elogio do inacabado". Sabático, "Capa", sábado, 10 de setembro de 2011, p. S4.

PIZA, Daniel. "Ensaios d'amor". Caderno 2, "Sinopse", domingo, 18 de setembro de 2011, p. D12.

MENEZES, Maria Eugênia de. "Quem inventou o amor?" Caderno 2, "Teatro. Estreia”, terça-feira, 11 de outubro de 2011, p. D10.

GONÇALVES Filho, Antônio. "Cientista lírico". Caderno 2, "Literatura. Entrevista”, sexta-feira, 28 de outubro de 2011, p. D10.

EDINGER, Claudio. “A janela de Lula”. Aliás, domingo, 20 de novembro de 2011, p. J8.

GONÇALVES Filho, Antonio. "Vida completa em fragmentos". Sabático, "Literatura Francesa", sábado, 26 de novembro de 2011, p. S3. 
2012

Nota sobre exposição de Valeska Soares. Divirta-se, sexta-feira, 2 de março de 2012, p. 86.

PERSICHETTI, Simoneta. "Arte moderna e fotografia". Caderno 2, "Visuais. Palestras", quintafeira, 29 de março de 2012, p. D12.

AUGUSTO, Sérgio. "Da Hungria ao Brejal do Millôr". Sabático, "Prosa de sábado", sábado, 7 de abril de 2012, p. S2.

BRASIL, Ubiratan. " 'Minha aposta é confiar no poder da palavra para tudo' ". Sabático, "Capa", sábado, 5 de maio de 2012, p. S4.

GONÇALVES Filho, Antonio. "Cidades visíveis de Teju Cole”. Caderno 2, domingo, 8 de julho de 2012 , p. D4.

COELHO, João Marcos. "Luzes eruditas em alto e bom som pop”. Sabático, "Música”, sábado, 27 de julho de 2012, p. S6.

Nota sobre o lançamento de Cadernos da viagem à China, de Barthes. Sabático, "Estante”, sábado, 4 de agosto de 2012, p. S7.

MEDEIROS, Jotabê. “Tom Zé amarra suas pontas”. Caderno 2, "Seleção da semana", domingo, 16 de setembro de 2012, p. D15.

Nota sobre o lançamento de Com Roland Barthes, de Leyla Perrone-Moisés. Sabático, "Estante", sábado, 20 de outubro de 2012, p. S7.

SANT'ANNA, Affonso Romano de. "Quem tem medo do estruturalismo?" Caderno 2, "Livros. Teoria", domingo, 21 de outubro de 2012, p. D2.

GONÇALVES Filho, Antonio. “Um Raskólnikov 'camusiano' em Cabul”. Sabático, sábado, 3 de novembro de 2012, p. S4.

FIERRO, Danúbio Torres. "Páginas de um senhor das letras". Sabático, "Ensaio", sábado, 24 de novembro de 2012, p. S6.

BRASIL, Ubiratan. "A eterna magia do estúdio Harcourt". Caderno 2, segunda-feira, 24 de dezembro de 2012, p. D1.

DINIZ, Débora. “O novo status da imagem”. Aliás, domingo, 30 de dezembro de 2012, p. J6.

\section{Textos que citam Barthes publicados em Língua e Literatura}

PERRONE-MOISÉS, Leyla. “Les modes de l'action dans Le Rouge et le noir”. N 1, 1972, pp. 185 203.

ECHEVERRÍA, Lídia Neghme. “ 'Há cavalos noturnos : mel e fel’ ”. Nº 2, 1973, pp. 31-47.

CORTEZ, Irlemar Chiampi. "Narração e metalinguagem em Grande sertão: veredas". N 2, 1973, pp. 63-91.

CARONI, İtalo. “Fábula e trama”. N³, 1974, pp. 157-170.

FONSECA, Carlos Alberto da. "O signo entre o texto e o contexto (projeto de uma análise integral)". $\mathrm{N}^{\mathrm{o}} 4,1975$, pp. 33-58.

DANTAS, Isabel. “Os índices da peça de teatro: Deus lhe pague”. N 4, 1975, pp. 205-223.

PASTA Júnior, José Antonio. “Um projeto de Pierre Menard”. $N^{0}$ 4, 1975, pp. 285-304.

WILLEMART, Philippe. "Psychanalyse et traduction". $\mathrm{N}^{0}$ 4, 1975, pp. 505-509.

SANTILLI, Maria Aparecida. "Em Camões e nos poetas inconfidentes : uma questão de tópica e/ou de influência literária". N 5, 1976, pp. 229-246.

BERNARDINI, Aurora Fornoni. "Do prazer e do divertimento - Estudo sobre Barthes e Palazzeschi”. Nº 6, 1977, pp. 37-42.

ECHEVERRÍA, Lídia Neghme. “Tres Novelitas burguesas y lo aleatorio de los eventos". $N^{0} 7$, 1978, pp. 157-174. 


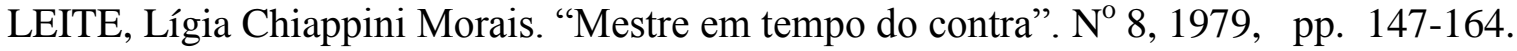

PAIS, Cidmar Teodoro. "Algumas reflexões sobre os modelos em linguística”. Nº 9, 1980, pp. 89116.

HEISE, Eloá Di Pierro. “A Escritura de Günter Eich enquanto epifania”. Nº 9, 1980, pp. 117-122.

WILLEMART, Philippe. "La jouissance singulière de Swann et la petite phrase de Vinteuil”. $\mathrm{N}^{\mathrm{O}} 15$, 1986, pp. 163-170.

CAMPOS, Maria do Carmo. "Borges e Drummond em seita blasfema: a Biblioteca e a Torre". $\mathrm{N}^{\mathrm{o}} 16,1987-1988$, pp. 43-52.

PONTIERI, Regina. "Roland Barthes e a escrita fragmentária". N $^{\mathrm{0}} 17,1989$, pp. 81-98.

VARA, Teresa Pires. "Correspondências”. N 17, 1989, pp. 181-196.

NÓBREGA, Maria Helena da. “Jorge Luis Borges : o sentido latente no leitor”. N² 20, 1992-1993, pp. 137-142.

FIORIN, José Luiz. “A pessoa subvertida”. N²1, 1994-1995, pp. 77-107.

CHIAPPETTA, Angélica. "Não diferem o historiador e o poeta...' O texto histórico como instrumento e objeto de trabalho". $\mathrm{N}^{\mathrm{0}} 22,1996$, pp. 115-34.

MACHADO, Irene A. “Texto como enunciação. A abordagem de Mikhail Bakhtin”. N²2, 1996, pp. 89-105.

MARINHO, Maria Celina Novaes. "Representação das linguagens sociais no romance : desencontro cultural e ideológico em São Bernardo, de Graciliano Ramos”. $\mathrm{N}^{0}$ 22, 1996, pp. 123-135.

ANDRADE, Maria Lúcia da Cunha Victório de Oliveira. "Digressão: palavra desviante ou estratégia argumentativa ?" $\mathrm{N}^{\mathrm{O}} 23,1997$, pp. 121-149.

\section{Demais textos publicados no Estado de S. Paulo (em ordem cronológica)}

\section{Anos 1950}

MARTINS, Wilson. "Trabalhos universitários". Primeiro Caderno, coluna "Últimos Livros", 2 de novembro de 1955 , p. 6.

MONTEIRO, Adolfo Casais. "Mistérios da crítica". Primeiro Caderno, coluna "Figuras e problemas do nosso tempo", 17 de maio de 1956, p. 7.

. "Crítica e ciência". Literatura e Arte, coluna "Figuras e problemas do nosso tempo", 27 de maio de 1956, [p. 1].

"A universidade e a cultura". Literatura e Arte, coluna "Figuras e problemas do nosso tempo", 10 de junho de 1956, [p. 1].

MARTINS, Luís. "Críticos, ou decifradores de charadas?" Suplemento Literário, 6 de outubro de 1956, p. 1.

LINHARES, Temístocles. “Literatura mais literária?” Suplemento Literário, 4 de janeiro de 1957, p. 4.

MONTEIRO, Adolfo Casais. "Ilusões da crítica: dividir para aprofundar". Literatura e Arte, 10 de março de 1957, [p. 1].

. "Da crítica como arte". Suplemento Literário, 6 de abril de 1957, p. 1.

LINHARES, Temístocles. "Como ser bom crítico". Literatura e Arte, 14 de abril de 1957, p. 1.

MONTEIRO, Adolfo Casais. "Razão e sensibilidade da crítica”. Suplemento Literário, 27 de abril de 1957, p. 4.

MARTINS, Wilson. “A jovem crítica”. Suplemento Literário, 13 de julho de 1957, p. 2.

MONTEIRO, Adolfo Casais. "Comentários de comentários". Suplemento Literário, 24 de agosto de 1957, p. 2.

GERSEN, Bernardo. “A literatura comparada”. Suplemento Literário, 14 de setembro de 1957, p. 4. 
PEREIRA, Lúcia Miguel. "Declínio de uma influência”. Suplemento Literário, 5 de outubro de 1957, p. 1.

MONTEIRO, Adolfo Casais. "Crítica e cultura geral”. Suplemento Literário, 19 de outubro de 1957, p. 1.

MILLIET, Sérgio. "Ler e reler". Primeiro Caderno, coluna "Vida Intelectual", 24 de novembro de 1957 , p. 17.

MONTEIRO, Adolfo Casais. "Vocação para crítica". Literatura e Arte, 18 de janeiro de 1958, [p. 1].

LUCAS, Fábio. “A nova crítica no Brasil”. Suplemento Literário, 7 de junho de 1958, p. 1.

LINHARES, Temístocles. "Sabedoria e serenidade da "nova crítica' ". Suplemento Literário, 9 de agosto de 1958, p. 1.

BRANCO, Frederico. "Nacionalismo \& literatura". Suplemento Literário, "Revista das revistas", 13 de setembro de 1958, p. 6.

MONTEIRO, Adolfo Casais. "A situação paradoxal da crítica”. Suplemento Literário, 15 de novembro de 1958, p. 2.

CANDIDO, Antonio. "Perenidade da biografia". Suplemento Literário, "Revista das revistas", 28 de fevereiro de 1959, p. 1.

MONTEIRO, Adolfo Casais. "Sociologia e crítica literária”. Suplemento Literário, 5 de setembro de 1959, p. 4.

BRITO BROCA, José. “A propósito de crítica militante”. Suplemento Literário, "Letras Francesas”, 19 de setembro de 1959, p. 1.

MONTEIRO, Adolfo Casais. "Ainda sobre a função universitária”. Sétimo Caderno, 6 de dezembro de 1959, [p. 1].

\section{Anos 1960}

LINHARES, Temístocles. "O desejo de ter uma literatura". $7^{\circ}$ Caderno, 7 de fevereiro de 1960, p. [1].

PERRONE-MOISÉS, Leyla. “Aspectos do 'Nouveau Roman' ”. Suplemento Literário, $1^{\circ}$ de abril de 1960, p. 2.

CHAMIE, Mário. “Literatura sem autor”. Suplemento Literário, 9 de julho de 1960, p. 2.

CARPEAUX, Otto Maria. "Críticos novos”. Suplemento Literário, 15 de outubro de 1960, p. 1.

MARTINS,Wilson. "Literatura comparada (?)". Suplemento Literário, 18 de fevereiro de 1961, p. 2. . “Impressionismo científico". Suplemento Literário, 20 de maio de 1961, p. 2.

"Instalado o Congresso de Crítica Literária". Primeiro Caderno, 25 de julho de 1961, p. 11.

"Apresentada a tese 'Crítica como síntese'”. Primeiro Caderno, 26 de julho de 1961, p. 8.

"Congresso de Crítica de Assis: imitação, contingência literária”. Primeiro Caderno, 27 de julho de 1961, p. 10.

"Críticos discutem a validade da poesia concreta". Primeiro Caderno, 28 de julho de 1961, p. 8.

"Congresso de Crítica: debate sobre o romance nordestino". Primeiro Caderno, 29 de julho de 1961, p. 7.

CARVALHO, Antônio Pinto de. "Literatura e Sociedade". Suplemento Literário, 12 de maio de 1962, p. 6.

MONTEIRO, Adolfo Casais. “Quem são os críticos?” Suplemento Literário, 14 de julho de 1962, p. 1.

“Edição dos Anais do Congresso de Crítica Literária”. Primeiro Caderno, 3 de setembro de 1963, p. 14.

MONTEIRO, Adolfo. "Palavras velhas para critérios novos". Suplemento Literário, 9 de novembro de 1963, p. 2.

MARTINS, Wilson. “A crítica sociológica I”. Suplemento Literário, 4 de janeiro de 1964, p. 2. 
"Dezoito pintores das mitologias cotidianas". Primeiro Caderno, 30 de agosto de 1964, p. 13.

LINHARES, Temístocles. “Ainda a crítica dos críticos”. Suplemento Literário, 15 de maio de 1965, p. 4.

MARTINS, Wilson. “A Nova Guarda”. Suplemento Literário, 13 de novembro de 1965, p. 6. . "A crítica sociológica". Suplemento Literário, 8 de janeiro de 1966, p. 2.

XAVIER, Lívio. "Para onde vai a crítica literária brasileira". Suplemento Literário, "Revista das Revistas", 7 de outubro de 1967, p. 2.

BIDERMAN, Maria Teresa Camargo. "Do estruturalismo linguístico". Suplemento Literário, 10 de fevereiro de 1968, p. 5.

PERRONE-MOISÉS, Leyla. "Os intelectuais e a revolução cultural”. Suplemento Literário, 10 de agosto de 1968 , p. 1.

"R. Jakobson visita São Paulo". Primeiro Caderno, 8 de setembro de 1968, p. 32.

“O Brasil, a cultura e a universidade". Primeiro Caderno, 13 de julho de 1968, p. 21.

MARQUES, Oswaldino. "Fenomenologia da obra literária". Suplemento Literário, 6 de setembro de 1969, p. 1.

. “Fenomenologia da obra literária III". Suplemento Literário, 20 de setembro de 1969, p. 3.

\section{Anos 1970}

LINHARES, Temístocles. "A Comichão estruturalista". Suplemento Literário, 31 de janeiro de 1970, p. 4.

"Linguística - Curso de linguística geral, de Ferdinand de Saussure". Suplemento Literário, "Lançamentos", 11 de abril de 1970, p. 2.

SÁFADY, Naief. “O Fim da literatura”. Suplemento Literário, 25 de abril de 1970, p. 4.

"Crítica Literária - Teoria da forma literária, de Kenneth Burke”. Suplemento Literário, "Lançamentos", 23 de maio de 1970, p. 2.

“Ensaio - Estruturalismo e Antropologia, de Dan Sperber". Suplemento Literário, "Lançamentos", 6 de junho de 1970, p. 2.

MARQUES, Oswaldino. "Estrutura das ignorâncias altamente especializadas". Suplemento Literário, 6 de junho de 1970, p. 3.

"Ensaio - Estruturalismo e Linguística, de Oswald Ducrot". Suplemento Literário, "Lançamentos", 13 de junho de 1970, p. 2.

"Ensaio - Estruturalismo e Poética, de Tzvetan Todorov". Suplemento Literário, "Lançamentos", 13 de junho de 1970, p. 2.

"Ensaio - Estruturalismo e Filosofia, de François Wahl”. Suplemento Literário, "Lançamentos", 20 de junho de 1970, p. 2.

"Ensaio - Estruturalismo e Psicanálise, Moustafa Safouxan". Suplemento Literário, "Lançamentos", 20 de junho de 1970, p. 2

GIACOMELLI, Eloah F. Resenha de Perspectives in contemporary criticism, organizado por Sheldon Norman Grebstein. Suplemento Literário, "Resenha Bibliográfica", 4 de julho de 1970, p. 2.

ILARI, Rodolfo. Resenha a Linguistique et enseignement du français, de Émile Genouvrier e Jean Peytard. Suplemento Literário, "Resenha Bibliográfica", 11 de julho de 1970, p. 2.

"Linguística - Linguística, poética, cinema, de Roman Jakobson". Suplemento Literário, "Lançamentos", $1^{\text {o }}$ de agosto de 1970, p. 2.

FREDERICO, Celso. Resenha de Sobre o trabalho teórico, de Louis Althusser. Suplemento Literário, "Resenha Bibliográfica", 5 de dezembro de 1971, p. 2. 
"Ensaio - Estruturalismo de Lévi-Strauss e marxismo de Louis Althusser, de Caio Prado Júnior". Suplemento Literário, "Lançamentos”, 2 de janeiro de 1972, p. 2.

SUCUPIRA Filho, Eduardo. Resenha a Estruturalismo de Lévi-Strauss e marxismo de Louis Althusser, de Caio Prado Júnior. Suplemento Literário, "Resenha Bibliográfica", 9 de janeiro de 1972, p. 2.

“Linguística - Introdução aos estudos linguísticos, de Francisco da Silva Borba”. Suplemento Literário, "Lançamentos", 25 de junho de 1972, p. 2.

"Estruturalismo - Chaves do estruturalismo, de Jean-Marie Auzias". Suplemento Literário, "Livros Novos", 13 de agosto de 1972, p. 2.

"Semiótica e filosofia, de Charles Sanders Peirce". Suplemento Literário, "Livros Novos", 10 de dezembro de 1972, p. 2.

"Semiologia e comunicação linguística, de Eric Buyssons". Suplemento Literário, "Livros Novos", 21 de janeiro de 1973, p. 2.

"O Sistema dos objetos, de Jean Baudrillard”. Suplemento Literário, "Livros Novos", 1 de abril de 1973, p. 2.

“Estilística estrutural, de Michel Riffaterre". Suplemento Literário, "Livros Novos”, 17 de junho de 1973, p. 2.

REIS, Edgard Pereira dos. "Formalistas em edição brasileira". Suplemento Literário, "Livros Novos", 6 de janeiro de 1974, p. 2.

"Semântica estrutural, de Algirdas Julien Greimas". Suplemento Literário, "Livros Novos", 6 de janeiro de 1974, p. 2.

"Os signos e a crítica, de Cesare Segre". Suplemento Literário, "Livros Novos", 14 de abril de 1974, p. 2.

“Introdução à semanálise, de Julia Kristeva". Suplemento Literário, "Livros Novos", 14 de abril de 1974, p. 2.

SANT'ANNA, Affondo Romano de. "Estrutura ou forma da narrativa?". Suplemento Literário, 15 de setembro de 1974, p. 5.

MERQUIOR, José Guilherme. "Teses para uma crítica antiformalista”. Suplemento Literário, 17 de novembro de 1974, p. 5.

SANT'ANNA, Affonso Romano de . "Por um novo conceito de literatura". Suplemento Literário, 17 de novembro de 1974 , p. 1.

PRETI, Dino. "Sociologia e Linguística". Suplemento Cultural, 19 de dezembro de 1976, p. 7.

STEINBERG, Martha. "A Ciência dos signos". Suplemento Cultural, 2 de janeiro de 1977, pp. 8-9.

ROCCO, Maria Thereza Fraga. "Linguística: ciência e deslumbramento". Suplemento Cultural, 30 de janeiro de 1977, p. 11.

WALDMAN, Berta. “A Evolução da crítica literária”. Suplemento Cultural, 28 de janeiro de 1979, pp. 15-16.

STEINBERG, Martha. "Os Trabalhos do Círculo de Praga". Suplemento Cultural, 25 de março de 1979, p. 10.

\section{Anos 1980 em diante}

KAKOWICZ, Moisés. "Quando o amor vira a cabeça”. Caderno 2, sábado, 4 de outubro de 1986, p. 1.

STYCER, Maurício. “Andar com fé eu vou, que a fé não costuma faiá”. Caderno 2, quinta-feira, 8 de janeiro de 1987, p. 1.

MARETTI, Eduardo. "Acadêmicos, entre a tese e o jornalismo". Caderno 2, "Leitura", quinta-feira, 2 de agosto de 1990, p. 4. 
"Universidade deve preparar público para fruição cultural”. Cultura, sábado, 24 de abril de 1993, p. 1.

CITELLI, Adílson Odair. "Cultura de massa marginaliza obras-primas". Caderno 2 Especial Domingo, 20 de fevereiro de 1994, p. D3.

CHIARELLI, Tadeu. "Jornais afastam-se da polêmica". Caderno 2/ Cultura, domingo, 4 de junho de 2000, p. D9.

PÉCORA, Alcir. "Análise literária requer pluralismo irredutível”. Caderno 2/ Cultura, "A Crítica hoje", domingo, 3 de dezembro de 2000, p. D6.

NÉSPOLI, Beth. "No palco, fragmentos de um triângulo amoroso". Caderno 2, "Teatro", sextafeira, $1^{\circ}$ de março de 2002, p. D6.

MEDEIROS, Jotabê. "Fragmentos de um discurso rigoroso". Caderno 2, "Política Cultural", sábado, 4 de janeiro de 2003, p. D3.

VILLAÇA, Alcides. "Ficção ou ciência exata". Caderno 2, "Literatura. Teoria", domingo, 7 de outubro de 2012, p. D7.

\section{Literatura comparada}

CARELLI, Mário. Culturas cruzadas. Intercâmbios culturais entre a França e o Brasil. Tradução de Nícia Adan Bonatti do original francês Cultures croisées - histoire des échanges culturels entre la France et le Brésil, de la découverte aux temps modernes (Paris : Éditions Nathan, 1993). Campinas (SP) : Papirus, 1994.

CARVALHAL, Tania Franco. O Próprio e o alheio. Ensaios de literatura comparada. São Leopoldo (RS): Editora da Universidade do Vale do Rio dos Sinos, 2003.

. Literatura comparada. São Paulo: Ática, 1992.

COUTINHO, Eduardo, CARVALHAL, Tania Franco (org.). Literatura comparada: textos fundadores. Rio de Janeiro: Rocco, 1994.

MACHADO, Álvaro Manuel; PAGEAUX, Daniel-Henri. Da Literatura comparada à teoria da literatura. Lisboa: Edições 70, 1988.

NITRINI, Sandra Margarida. Literatura Comparada: história, teoria e crítica. São Paulo: Editora da Universidade de São Paulo, 1997.

PIGLIA, Ricardo. "Memoria y tradición", Anais do II Congresso Internacional da ABRALIC, Belo Horizonte, UFMG, 1991, v. 2, pp. 60-66.

RIVAS, Pierre. Encontro entre literaturas: França/ Brasil/ Portugal. Tradução coordenada por Durval Ártico e Maria Letícia Guedes Alcoforado. São Paulo: Hucitec, 1995. . Diálogos interculturais. São Paulo : Hucitec, 2005.

\section{Teoria literária}

COMPAGNON, Antoine. Le démon de la théorie. Littérature et sens commun. Paris : Éditions du Seuil, 1998.

. La littérature, pour quoi faire? Paris : Collège de France/ Fayard, 2007.

. «XX $\mathrm{XX}^{\mathrm{e}}$ Siècle ». In TADIÉ, Jean-Yves (dir.). La littérature française: dynamique \& histoire II. Paris : Gallimard, pp. 543-832.

CUSSET, François. French theory. Foucault, Derrida, Deleuze \& Cie et les mutations de la vie intellectuelle aux Etats-Unis. Paris : Éditions de la Découverte, 2005 (2003). 
DURÃO, Fabio Akcelrud. Teoria (literária) americana: uma introdução crítica. Campinas (SP): Autores Associados, 2011.

. "Do Texto à Obra". In Alea, vol. 13, n 1, janeiro-junho 2011, pp. 67-81.

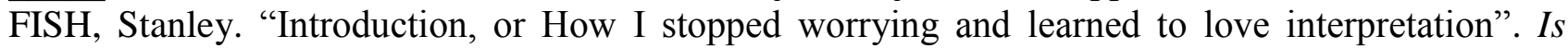
there a text in this class? The Authority of interpretive communities. Cambridge (Massachusetts), Londres: Harvard University Press, 1980, pp. 1-17.

JAUSS, Hans Robert. Pour une esthétique de la réception. Tradução de Claude Maillard. Paris : Gallimard, 1978.

LIMA, Luiz Costa. Estruturalismo e teoria da literatura: introdução às problemáticas estética e sistêmica. Petrópolis (RJ): Vozes, 1973.

MERQUIOR, José Guilherme. De Praga a Paris. Tradução de Ana Maria de Castro Gibson. Rio de Janeiro: Nova Fronteira, 1991.

MONTEIRO, Adolfo Casais. Estrutura e autenticidade como problemas da teoria e da crítica literárias. São Paulo, s.e., 1968.

PERRONE-MOISÉS, Leyla. Altas literaturas. Escolha e valor na obra crítica de escritores modernos. São Paulo: Companhia das Letras, 1998.

Quatre conférences sur la "Nouvelle critique”. Suplemento de Studi Francesi, n ${ }^{\mathrm{o}}$ 34, janeiro-abril de 1968. Turim: Società Editrice Internazionale, 1968.

SOUZA, Antonio Candido de Mello e. Formação da Literatura brasileira: momentos decisivos. Belo Horizonte: Editora Itatiaia Ltda, 2000 (1959), 2v.

. “A Literatura e a formação do homem”. Textos de intervenção. São Paulo: Duas Cidades/ Editora 34, 2002, pp. 77-92.

SULEIMAN, Susan R. "Introduction: Varieties of Audience-Oriented Criticism". In CROSMAN, Inge, SULEIMAN, Susan R. (org.). The Reader in the Text. Essays on Audience and Interpretation. Princeton (New Jersey): Princeton University Press, 1980, pp. 3-45.

THOMPSON, Ewa M. Russian Formalism and anglo-american New Criticism. A comparative study. The Hague: Mouton, 1971.

TODOROV, Tzvetan. La Littérature en péril. Paris: Flammarion, 2007.

WELLEK, René. Conceitos de crítica. Tradução de Oscar Mendes. São Paulo: Cultrix, [1979] (1963).

ZILBERMAN, Regina. Estética da recepção e história da literatura. São Paulo : Ática, 2004.

\section{Crítica literária}

ARRIGUCCI Jr., Davi. Entrevista a Luiz Jackson, Fernando Pinheiro Filho e Gustavo Sorá. Tempo Social - Dossiê Crítica Literária. São Paulo, vol. 23, n ${ }^{0}$ 2, novembro de 2011. Disponível em: $\quad$ http://www.scielo.br/scielo.php?pid=S0103-20702011000200007\&script=sci_arttext (consultado em 24 de maio de 2013).

BARBOSA, João Alexandre. A Tradição do impasse: linguagem da crítica e crítica da linguagem em José Veríssimo. São Paulo: Ática, 1974.

BAYARD, Pierre. Comment parler des livres que l'on n'a pas lus? Paris : Minuit, 2007.

BRITO BROCA, J. Letras francesas. Edição organizada e prefaciada por Francisco de Assis Barbosa. São Paulo: Conselho Estadual de Cultura, 1969.

COUTINHO, Afrânio. Por uma crítica estética. [Rio de Janeiro]: Ministério da Educação e Cultura, Serviço de Documentação, 1954.

. Da crítica e da nova crítica. Rio de Janeiro: Civilização Brasileira, 1957. 
. "Introdução". Correntes cruzadas. Questões de literatura. Rio de Janeiro: A Noite, 1953, pp.I-XXIII.

GONÇALVES, Lisbeth Rebollo (org.). Sérgio Milliet - 100 anos: trajetória, crítica de arte e ação cultural. São Paulo: ABCA/ Imprensa Oficial do Estado de São Paulo, 2004.

LAFETÁ, José Luiz. 1930: a crítica e o Modernismo. São Paulo: Duas Cidades/ Editora 34, 2000.

MAUREL, Anne. La critique. Paris: Hachette, 1998 (1994).

MERQUIOR, José Guilherme. O Estruturalismo dos pobres e outras questões. Rio de Janeiro: Tempo Brasileiro, 1975.

MILLIET, Sérgio. Diário crítico. São Paulo: Martins/ Editora da Universidade de São Paulo, 19811982, 10v.

PERRONE-MOISÉS, Leyla. Falência da crítica: um caso limite: Lautréamont. São Paulo: Editora Perspectiva, 1973.

PICARD, Raymond. Nouvelle critique ou nouvelle imposture. [Paris]: Jean-Jacques Pauvert Éditeur, 1965.

POULET, Georges (org.). Les chemins actuels de la critique. [Paris]: Union Générale d'Éditions, 1968.

ROCHA, João Cezar de Castro. Crítica literária: em busca do tempo perdido? Chapecó (SC): Argos, 2011.

ROGER, Jérôme. La critique littéraire. Paris: Armand Colin, 2007 (2005).

SANT'ANNA, Affonso Romano de. Análise estrutural de romances brasileiros. Petrópolis (RJ): Editora Vozes, 1973.

SOUZA, Antonio Candido de Mello. Literatura e sociedade: estudos de teoria e história literária. Rio de Janeiro: Ouro sobre Azul, 2008 (1965).

. "A Passagem do dois ao três. (Contribuição para o estudo das mediações na análise literária). Revista de História, ano 25, tomo 3, vol. 50, $\mathrm{n}^{\mathrm{O}}$ 100, São Paulo, outubro-dezembro de 1974, pp. 787-799.

TADIÉ, Jean-Yves. La critique littéraire au XX siècle. Paris: Pierre Belfond, 1987.

\section{Tradução}

CAMPOS, Haroldo de. "Da Tradução como criação e como crítica". In Metalinguagem \& outras metas. Ensaios de teoria e crítica literária. São Paulo: Editora Perspectiva, 1992, pp. 31-48.

EVEN-ZOHAR, Itamar. "The Position of translated literature within the literary polysystem". In Lawrence Venuti (org.), The Translation Studies Reader. Londres: Routledge, 2000, pp. 192197.

JAKOBSON, Roman. “Aspectos linguísticos da tradução”. In Linguística e comunicação. Tradução de Izidoro Blikstein e José Paulo Paes. São Paulo: Cultrix, 1995 (1969), pp. 63-72.

SCHNAIDERMAN, Boris. "Haroldo de Campos e a transcriação da poesia russa moderna". Fragmentos, n $^{\mathrm{o}}$ 25. Florianópolis, julho-dezembro de 2003, pp. 61-68.

. "Haroldo de Campos, poesia russa moderna, transcriação". Revista USP, n 59, São Paulo, setembro-novembro de 2003, pp. 172-180. 


\section{História literária}

ANDRADE, Mário. "Decadência da influência francesa no Brasil”. In Vida literária. São Paulo: Editora da Universidade de São Paulo, 1993, pp. 3-5.

ANDRADE, Carlos Drummond de. "Exorcismo". In Poesia e prosa. Rio de Janeiro: Nova Aguilar, 1979, p. 793.

BARBOSA, Nélson Luís. As Letras francesas no Suplemento Literário do jornal O Estado de S. Paulo: dois momentos, duas leituras. Dissertação de mestrado. São Paulo: Faculdade de Filosofia, Letras e Ciências Humanas da Universidade de São Paulo, 2001.

COMPAGNON, Antoine. Les Cinq paradoxes de la modernité. Paris: Seuil, 1990.

DOSSE, François. História do estruturalismo. Tradução de Álvaro Cabral, revisão de Márcia Mansor D’Alessio. Bauru (SP): Edusc, 2007, 2v.

ESCOBAR, Carlos Henrique (org.). O Método estruturalista. Rio de Janeiro: Zahar Editores, 1967.

FANINI, Ângela Maria Rubel. "Textos de Antonio Candido, Affonso Romano de Sant'Anna e Roberto Schwarz em torno de O Cortiço". Revista de Letras, v. 9, 2007, pp. 13-18. Disponível em:

http://www.dacex.ct.utfpr.edu.br/site_angela/Arquivos/Producao/Antonio_Candido_Affonso _Romano_e_Roberto_Schwarz_em_torno_de_O_Cortico.pdf (consultado em 24 de maio de 2013).

FARIA, Regina Lúcia de. “A Polêmica do estruturalismo ou 'Quem tem medo da teoria?' ’In Anais do XI Congresso Internacional da ABRALIC - Tessituras, Interações, Convergências, 13-17 de julho de 2008, São Paulo. São Paulo: Universidade de São Paulo, 2008. Disponível em: http://www.abralic.org.br/anais/cong2008/AnaisOnline/simposios/pdf/041/REGINA_FARIA .pdf (consultado em 24 de maio de 2013).

JEY, Martine. "Gustave Lanson et la réforme de 1902: défense d'une réforme, compromis et décalage". In Fabula, la recherche en littérature, publicado em 7 de outubro de 2005. Disponível em :

http://www.fabula.org/atelier.php?Gustave_Lanson_et_la_r\%26eacute\%3Bforme_de_1902 (consultado em 24 de maio de 2013).

LEITE, Rui Moreira. "Missão portuguesa no Brasil". In Pro-Posições, v. 17, n 3 (51), setembro a dezembro de 2006, pp. 71-79. Disponível em:

http://mail.fae.unicamp.br/ proposicoes/textos/51_dossie_leiterm.pdf (consultado em 24 de maio de 2013).

LEONE, Carlos. O Essencial sobre Adolfo Casais Monteiro. Lisboa: Imprensa Nacional/ Casa da Moeda, 2005.

LILTI, Antoine. "Querelles et controverses. Les formes du désaccord intellectuel à l'époque monderne". In Mil neuf cent 2007/1, n ${ }^{\circ}$ 25, pp. 13-28.

LORENZOTTI, Elizabeth. Suplemento Literário, que falta ele faz! : 1956-1974 do artístico ao jornalístico: vida e morte de um caderno cultural. São Paulo: Imprensa Oficial do Estado de São Paulo, 2007.

MONTEIRO, Adolfo Casais. Estrutura e autenticidade como problemas da teoria e da crítica literárias. São Paulo: s.e., 1968.

MORRISON, Donald. "In Search of lost time". In Time Magazine, número "The Death of French culture", 21 de novembro de 2007. Também disponível em:

http://www.time.com/time/magazine/article/0,9171,1686532,00.html (consultado em 24 de maio de 2013).

MORRISON, Donald, COMPAGNON, Antoine. Que reste-t-il de la culture française? suivi de Le Souci de la grandeur. Paris: Denoël, 2007. 
MOTTA, Leda Tenório da. Sobre a crítica literária brasileira no último meio século. Rio de Janeiro: Imago Editora, 2002.

NUNES, Benedito. “Ocaso da literatura ou falência da crítica ?” Língua e Literatura, n 24,1998, pp. 11-22.

PERRONE-MOISÉS, Leyla. "Por amor à arte". In Estudos Avançados, v. 19, n 55, setembrodezembro de 2005, pp.335-348.

PERRONE-MOISÉS, Leyla (org.). Do Positivismo à Desconstrução : ideias francesas na América. São Paulo: Editora da Universidade de São Paulo, 2004.

PERRONE-MOISÉS, Leyla. Entrevista a Alcino Leite Neto. In SCHWARTZ, Adriano (org.). Memórias do presente: 100 entrevistas do "Mais!": 1992-2002: Conhecimento das artes. São Paulo: Publifolha, 2003, pp. 280-288.

PONTES, Heloísa. Destinos mistos: os críticos do Grupo Clima em São Paulo (1940-68). São Paulo: Companhia das Letras, 1998.

RIVAS, Pierre. "Paris capital internacional". Diálogos interculturais. São Paulo: Hucitec, 2005, pp. 118-149.

ROMANO, Luís Antônio Contatori. A Passagem de Sartre e Simone de Beauvoir pelo Brasil em 1960. Campinas (SP): Mercado de Letras/ São Paulo: Fapesp, 2002.

SARTRE, Jean-Paul. L'Existentialisme est un humanisme. Paris: Les Éditions Nagel, 1968 (1946).

SÜSSEKIND, Flora. Literatura e vida literária: polêmicas, diários e retratos. Belo Horizonte: Editora UFMG, 2004.

\section{História}

CARDOSO, Irene R. A Universidade da comunhão paulista. São Paulo: Cortez Editora, 1992.

FERNANDES, Florestan. A Questão da USP. São Paulo: Editora Brasiliense, 1984.

HOLLANDA, Heloisa B. de; GONÇALVES, Marcos A. Cultura e participação nos anos 60. São Paulo: Brasiliense, 1982.

SALONE, Roberto. Irredutivelmente liberal: política e cultura na trajetória de Júlio de Mesquita Filho. São Paulo: Albatroz Editora, 2009.

\section{História: sítios da Internet}

Associação Nacional de Jornais: www.anj.org.br (consultado em 24 de maio de 2013).

Portal da Imprensa: http://portalimprensa.uol.com.br (consultado em 24 de maio de 2013).

Biblioteca Virtual (site do governo do Estado de São Paulo), mais precisamente:

http://www.bibliotecavirtual.sp.gov.br/saopaulo-historia.php (consultado em 24 de maio de 2013).

Enciclopédia Itaú Cultural: www.itaucultural.org.br, mais precisamente:

http://www.itaucultural.org.br/aplicexternas/enciclopedia_teatro/index.cfm?fuseaction=personalidad es biografia\&cd verbete $=92 \& c d$ item $=22$ (sobre a encenação de Fragmentos de um Discurso Amoroso) (consultado em 24 de maio de 2013). 
http://www.itaucultural.org.br/aplicexternas/enciclopedia_lit/definicoes/verbete_imp.cfm?cd_verbet $\underline{\mathrm{e}=8762 \& \mathrm{imp}=\mathrm{N}}$ (sobre Afrânio Coutinho) (consultado em 24 de maio de 2013).

http://www.itaucultural.org.br/aplicexternas/enciclopedia_ic/index.cfm?fuseaction=marcos_texto\&c $\underline{\mathrm{d} \text { verbete}=3760}$ (sobre a Exposição Nacional de Arte Concreta) (consultado em 24 de maio de 2013).

http://www.itaucultural.org.br/aplicexternas/enciclopedia_lit/index.cfm?fuseaction=definicoes texto $\underline{\& d} \_$verbete $=9594 \&$ lst_palavras $=($ sobre o Concretismo $)($ consultado em 24 de maio de 2013$)$.

Folha de São Paulo: $\underline{w w w . f o l h a . u o l . c o m . b r}$, mais precisamente:

http://www1.folha.uol.com.br/folha/conheca/historia.shtml (consultado em 24 de maio de 2013).

Jornal da USP edição de 2 a 8 de fevereiro de 2004:

http://www.usp.br/jorusp/arquivo/2004/jusp673/pag0809.htm (consultado em 24 de maio de 2013).

O Estado de S. Paulo: www.estadao.com.br, mais precisamente:

http://www.estadao.com.br/historico/index.htm (consultado em 24 de maio de 2013).

Dossiê sobre a censura sofrida pelo jornal no século XXI:

http://www.estadao.com.br/pages/especiais/sobcensura/ (consultado em 24 de maio de 2013).

Universidade de Campinas: $\underline{w w w . u n i c a m p . b r}$, mais precisamente:

http://www.unicamp.br/unicamp/a-unicamp/historia (consultado em 24 de maio de 2013).

Universidade Estadual Paulista: www.unesp.br, mais precisamente:

http://www.unesp.br/apresentacao/historico.php (consultado em 24 de maio de 2013).

Bienal Internacional do Livro:

http://www.bienaldolivrosp.com.br/Pages/Standard.aspx?id=6545 (consultado em 24 de maio de 2013).

Decreto-lei 972 (regulamentação da profissão de jornalista):

http://www.planalto.gov.br/ccivil_03/decreto-lei/del0972.htm (consultado em 24 de maio de 2013).

Sobre Ana Maria Machado:

http://www.anamariamachado.com (consultado em 24 de maio de 2013). 